\title{
Organizacja jako system sieci zintegrowanych relacji komunikowania
}


酱 


\section{Zarządzanie}

\section{Organizacja jako system sieci zintegrowanych relacji komunikowania}

Magdalena Zalewska-Turzyńska 
Magdalena Zalewska-Turzyńska - Uniwersytet Łódzki, Wydział Zarządzania, Katedra Zarządzania ul. Matejki 22/26, 90-237 Łódź

e-mail: magdalena.zalewska@uni.lodz.pl

RECENZENT

Wojciech Czakon, Stefan Lachiewicz, Kazimierz Zimniewicz

\author{
REDAKTOR INICJUJĄCY \\ Monika Borowczyk

\section{OPRACOWANIE REDAKCYJNE} \\ Monika Poradecka
}

SKŁAD I ŁAMANIE

Mateusz Poradecki
KOREKTA TECHNICZNA
Leonora Gralka

PROJEKT OKŁADKI

Katarzyna Turkowska

Zdjęcie wykorzystane na okładce: @ Depositphotos.com/sdecoret

Wydrukowano z gotowych materiałów dostarczonych do Wydawnictwa UŁ

(C) Copyright by Magdalena Zalewska-Turzyńska, Łódź 2018

(C) Copyright for this edition by Uniwersytet Łódzki, Łódź 2018

Wydane przez Wydawnictwo Uniwersytetu Łódzkiego

Wydanie I. W.08393.17.0.M

Ark. druk. 22,625

ISBN 978-83-8142-441-7

e-ISBN 978-83-8142-442-4

Wydawnictwo Uniwersytetu Łódzkiego

90-131 Łódź, ul. Lindleya 8

www.wydawnictwo.uni.lodz.pl

e-mail: ksiegarnia@uni.lodz.pl

tel. (42) 6655863 
nothing is as practical as a good theory

Lewin (1945, s. 129) 



\section{Spis treści}

Wprowadzenie

\section{Część I. Teoretyczna}

1. Komunikacja wewnątrzorganizacyjna 29

1.1. Istota komunikacji wewnątrzorganizacyjnej 29

1.2. Dotychczasowy stan wiedzy 32

1.3. Komunikacja jako zjawisko w środowisku organizacji 39

1.4. Komunikacja jako sposób na tworzenie organizacji 42

2. Ogólna teoria systemów jako nauka $\quad 53$

2.1. Podejście systemowe - wybór metody badawczej $\quad 55$

2.2. Wartość podejścia systemowego dla badaczy XXI wieku $\quad 71$

2.3. Zarys pojęć system i systemowość - perspektywa ogólna i organizacyjna

2.4. Systemowe pojęcie relacji i ich ujęcie w kontekście systemowym 85

\section{Część II. Metodologiczno-badawcza}

3. Metoda badawcza analizy i syntezy systemowej 97

3.1. Analiza klasyczna, analiza systemowa, analiza sieci społecznych 99

3.2. Analiza systemowa - metody i procedury badawcze organizacji 107

3.3. Analiza systemów złożonych - opis metody badania organizacji 123

3.3.1. Określenie systemu na obiekcie i jego przedstawianie 126

$\begin{array}{ll}\text { 3.3.2. O grupowaniu relacji wokół celu organizacji - model synkretyczny cyklu } & \\ \text { zarządzania } & 139\end{array}$

3.3.3. Analiza struktury organizacji i zachowania komunikacyjnego w systemie $\quad 146$

3.3.4. Projekt udoskonalenia lub poprawy systemu - etap tożsamy z budowaniem $\begin{array}{ll}\text { systemu } & 147\end{array}$

3.3.5. Warunki realizacji analizy systemów złożonych (ASZ) 148

\section{Część III. Konstrukcyjna}

4. Ogólne i szczegółowe zasady konstrukcji modelu organizacji jako systemu komunikowania $\quad 153$

4.1. Budowa modelu organizacji 156

4.1.1. Relacje organizacyjne pierwszego rzędu 168

4.1.2. Relacje organizacyjne drugiego rzędu $\quad 171$

4.1.3. Relacje organizacyjne trzeciego rzędu $\quad 174$ 
4.1.4. Relacja organizacyjna czwartego rzędu

4.1.5. Relacje organizacyjne samozwrotne z podsystemem zarządzania - drugiego, trzeciego, czwartego i piątego rzędu

4.2. Relacje komunikacyjne pierwszego stopnia

$\begin{array}{ll}\text { 4.2.1. Podsystem antropologiczny - relacje pierwszego stopnia } & 181\end{array}$

4.2.2. Podsystem społeczny - relacje pierwszego stopnia 192

4.2.3. Podsystem techniczno-technologiczny - relacje pierwszego stopnia 195

4.2.4. Podsystem ekonomiczny - relacje pierwszego stopnia 199

4.3. Sieć relacji komunikowania się 200

4.4. Model organizacji jako systemu sieci zintegrowanych relacji komunikowania $\quad 210$

5. Koordynacja w sensie ogólnym i szczegółowym 217

5.1. Koordynacja według klasyków teorii organizacji - Fayola i Le Chateliera 217

5.2. Koordynacja w ujęciu współczesnych autorów 222

5.3. Zorganizowanie - koordynowanie - sprawność. Dyskusja prakseologiczna 228

5.4. Model koordynacji: sprawne komunikowanie - efekt organizacyjny 238

5.5. Wskaźniki koordynowania według rodzajów 241

$\begin{array}{ll}\text { Zakończenie } & 271\end{array}$

$\begin{array}{ll}\text { Bibliografia } & 285\end{array}$

$\begin{array}{ll}\text { Załączniki } & 321\end{array}$

$\begin{array}{ll}\text { Abstract } & 353\end{array}$

$\begin{array}{ll}\text { Spis rysunków } & 357\end{array}$

$\begin{array}{ll}\text { Spis tabel } & 359\end{array}$

$\begin{array}{ll}\text { Od Redakcji } & 361\end{array}$ 


\section{Wprowadzenie}

Komunikowanie się jest najważniejszym procesem społecznym. Lon Luvois Fuller uznał, że „komunikowanie się ludzi warunkuje utrzymanie życia” (Fuller, 1969, w: Tokarczyk, 1980, s. 225). Przez komunikowanie się Fuller' rozumie „całą sieć wszystkich możliwych powiązań między ludźmi”, jest to „jądro i główny element wszystkich ludzkich dążeń" (Tokarczyk, 1980, s. 226). Związki komunikacji z utrzymaniem życia są wzajemne i dwustronne, jest to droga, na której ludzie dokonują „wymiany wartości, jakości i znaczeń”, a także proces wzajemnego wzbogacania ludzkich osobowości, realizacji i osiągania ludzkich celów (Fuller, 1969, w: Tokarczyk, 1980, s. 226). Dla Fullera komunikowanie i celowość są zatem wzajemnie powiązane - podobnie jak w organizacji. Celowość zakłada komunikowanie się, ponieważ „możliwość celowego działania ma miejsce dopiero przy istnieniu pełnego komunikowania się ludzi i po drugie - ponieważ komunikowanie się, dostarczając środków przenoszenia ludzkich osiągnięć, wzbogaca możliwość celowego działania” (Tokarczyk, 1980, s. 227). Zależność w drugą stronę prezentowana jest także przez podwójny argument - „bez celowej działalności dokonanej lub zamierzonej nie ma właściwie nic istotnego do zakomunikowania, po drugie - komunikowanie się zmierza zawsze do określonego celu" (Tokarczyk, 1980, s. 227).

Autorce tej książki bliska jest koncepcja Fullera w każdym wymiarze - komunikacji międzyludzkiej, jej istotności w życiu człowieka i wagi dla niego. Upodobanie do Fullerowskiej koncepcji zbieżności komunikowania i celowego działania, zwłaszcza działania organizacyjnego, jest uzasadniane na kolejnych kartach.

1 Fuller sformułował materialne prawo natury, którego podstawą jest triada normatywnych postulatów: chroń życie ludzkie, działaj celowo i komunikuj się. Postulaty te wynikają z potrzeb życia jednostki ludzkiej, potrzeb związków ludzkich i potrzeb ludzkości. Natomiast sama koncepcja komunikacji międzyludzkiej przypomina koncepcję „twórczej interkomunikacji znaczeń symbolicznych" Wiemana (1958, s. 22-24). 


\section{O genezie powstania pracy, czyli identyfikacja problemu}

W gospodarczym życiu i w działaniu organizacji ważna, jeśli nie najważniejsza, jest jej sprawność ${ }^{2}$. To ona decyduje o powodzeniu organizacji ${ }^{3}$, zadowoleniu klienta i ogólnym sukcesie firmy. Niesprawność stanowi więc problem.

Globalizacja powszechnie ogarniająca świat nauki (i nie tylko) prowadzi do szerokiego upowszechnienia wiedzy, a jednocześnie wprowadza w dyscyplinie zarządzania wąskie specjalizacje (np. Rokita, 2003; Mikuła, 2006; Zimniewicz, 2015; Jędrych, 2016; Listwan, 2017; Aguinis, 2018). Tymczasem perspektywa przekrojowa, obejmująca szerokie spektrum zagadnień, staje się bardziej adekwatna do potrzeb teorii i praktyki zarządzania, stąd obiecujące jest zwrócenie się ku integrowaniu zagadnień specjalistycznych na gruncie organizacji (Zimniewicz, 2014, s. 199-205; 2016, s. 6-7).

Wśród źródeł niesprawności organizacji zidentyfikowano znaczną liczbę przyczyn szczegółowych różnej skali - brak jasno określonego celu strategicznego, brak związku między nakładami a efektami ${ }^{4}$, brak zaufania wzajemnego przełożonych i podwładnych, przeciążenie obowiązkami zatrudnionych, niewłaściwy podział pracy, problemy z motywacją pracowników itd. Przyczyny te są różnie nazywane i klasyfikowane, jednak to niewłaściwa komunikacja w znacznym stopniu odpowiada za problemy organizacji, a poprawny proces komunikowania usprawniłby jej działanie we wskazanych obszarach. Z tego względu nie powinno się rozważać pojedynczo kolejnych punktów z długiej listy przyczyn niesprawności organizacji, ale należy spojrzeć na ten problem z szerszej i całościowej perspektywy komunikacyjnej.

W obszarze organizacji i zarządzania uznaje się ogólnie, że efektywna komunikacja to podstawa zarządzania przedsiębiorstwem, niezależnie od jego wielkości i branży. Szczegółowo wskazuje się także, że jest ona podstawą procesów podejmowania decyzji w zespołach zadaniowych, budowania zespołu, podziału

2 W pracy cecha sprawności jest rozumiana prakseologicznie, jako wielkość niemianowana efektu do nakładu, sytuująca swoją wartość na skali w przedziale zamkniętym <0; 1>, gdzie 0 świadczy o braku sprawności (niesprawności), 0,5 o sprawności przeciętnej - średniej, a 1 o najwyższym stopniu sprawności. Stąd „sprawność” i „niesprawność” to kategorie skrajne sytuowane na skali ciągłej.

3 W pracach koncentrujących się na człowieku jako kluczowym zasobie organizacji i skupiających się na sposobie realizacji ról organizacyjnych przez kreowanie możliwości i szans chodzi głównie o osoby charakteryzujące się wysoką efektywnością działań własnych i zespołowych (por. np. Czapla, 2011, s. 62-75).

4 Zjawisko to jest obserwowane wyłącznie w większych przedsiębiorstwach, gdzie centra kosztów zostały organizacyjnie odseparowane od centrów przychodów (Pasieczny, 2015, s. 535). 
kompetencji, motywowania do działania i oceny efektów wspólnej pracy (Repper, 2013, s. 109-116; Liao, Cheng, 2014; Bolman, Deal, 2017). Co więcej, należyta komunikacja wewnętrzna może poprawić poziom zadowolenia z pracy oraz wpływać korzystnie na atmosferę (Suter i in., 2009, s. 41-51; Ten Brummelhuis i in., 2012). Konieczny jest zatem wybór właściwych narzędzi i kanałów komunikacji, dopasowanych do specyfiki firmy, jej wielkości i struktury organizacyjnej. Natomiast wśród przyczyn niesprawności komunikowania wymienia się tylko niedostatki w umiejętnościach komunikacji interpersonalnej przełożonych oraz podwładnych (Lingard5 ${ }^{\mathrm{i}}$ in., 2004; Hersey, Blanchard, Johnson, 2007, s. 214-230; Morreale, Spitzberg, Barge, 2007).

Dla autorki jest to czubek "góry lodowej” problemu komunikacji wewnątrzorganizacyjnej. Kompetencje i umiejętności menedżerów i pracowników w zakresie komunikowania wpływają na efektywność działania organizacji (np. Singh, 2014, s. 36-39; Sharma, 2015, s. 91-96), niemniej czynników komunikacyjnych, od których zależy powodzenie organizacji, jest więcej. Skupienie na cechach nadawcy, odbiorcy oraz na właściwościach „technicznych” zaistnienia procesu nie wystarcza. Uwarunkowania organizacyjne komunikowania również wpływają na ocenę funkcjonowania organizacji, zarządzanie jako funkcja również wiąże się z procesem komunikacji (Stankiewicz, 2006, s. 14-15). Powstają zatem koncepcje, na przykład zarządzanie przez komunikację (management by communication) (Cornelissen, 2004), polegające na budowaniu systemu stałego informowania pracowników o głównych celach organizacji, jej problemach, zamierzeniach kierownictwa, a także o aktualnej i docelowej pozycji na rynku.

Nawet najlepsze kompetencje komunikacyjne odbiorców nie pomogą w sytuacji pogłębiającego się przeładowania komunikacyjnego (informacjami) (Simpson, Prusak, 1995; Edmunds, Morris, 2000; Cho, 2017; Stephens i in., 2017) lub niewłaściwego przepływu komunikatów wewnątrz organizacji (Hartano, Li, Na, Simpson, 2010; White, Vanc, Stafford, 2010). Według Heidi Bartoo i Patricii M. Sias (2004) otrzymywanie „dużej ilości informacji” nie jest konieczne, wystarcza bowiem

5 Wyjątkowo interesujące są badania dotyczące błędów komunikacyjnych na sali operacyjnej, przeprowadzone przez 94 przeszkolonych obserwatorów, którzy odnotowali 90 godzin obserwacji podczas 48 zabiegów chirurgicznych. Około 30\% wymian komunikatów kończyło się niepowodzeniem, a jedna trzecia z nich niosła skutki, które zagrażały bezpieczeństwu pacjentów. Zanotowano 421 zdarzeń komunikacyjnych, z których 129 zakwalifikowano jako awarie komunikacyjne. Obejmowały one: „okoliczności” (45,7\% przypadków), w których niewłaściwy był czas komunikacji, „treść” (35,7\%) - brak lub niedokładność informacji, „cel” (24\%) - nie rozwiązano problemu oraz „odbiorców” (20,9\%) - wykluczono ważne osoby. Z kolei 36,4\% niepowodzeń spowodowało widoczne skutki dla procesów systemowych, w tym nieefektywność, napięcie zespołu, marnotrawstwo zasobów, rozwiązania tymczasowe, opóźnienie, niedogodności dla pacjenta i błędy proceduralne (Lingard i in., 2004). 
„odpowiednia ilość informacji”, o ile zawiera „odpowiednie informacje”. Właściwa ilość jest jednak trudna do ustalenia - według badań Johna W. Haasa (2007) nawet jeśli wzrosła ilość komunikacji wewnętrznej w organizacji, pracownicy nadal pragnęli jej więcej.

Wydaje się, że rozumienie zależności komunikacyjnych w organizacji na gruncie teorii organizacji nadal jest jeszcze w dużej mierze intuicyjne, nie jest bowiem poddane rygorom stawianym teoriom (opis, wyjaśnienie, wskazówki utylitarne) (Czakon, 2017, s. 144-145; Samul, 2017, s. 51-61).

Autorka uznaje, że komunikowanie powinno być wymieniane wśród głównych, może nawet najważniejszych przyczyn, którym należy przypisać znakomitą większość problemów organizacji, a jednak jest mało uznanym czynnikiem niesprawności organizacji. Tutaj mieści się zatem luka poznawcza, na którą w toku pracy próbuje odpowiedzieć autorka, a jej celem jest wskazanie zależności między sprawnością organizacyjną a komunikacją.

Sprawność jest miarą poddającą się ocenom prakseologicznym, znaną już i opisaną w literaturze organizacji, jednak w ostatnich latach mało popularną, prawdopodobnie z powodu zawężenia rozumienia poszczególnych, rozmaitych definicji sprawności, jak się wydaje - wtórnie narzuconych przez propagatorów. Pierwotne konstrukty są bowiem znacznie szerzej zakreślone, niż je naukowcy obecnie stosują (Banajski, 2015). W toku poszukiwań właściwej metody badawczej dla wskazania zależności między sprawnością organizacyjną a komunikacją rozważano modelowanie za pomocą metafory wzorowanej na modelu organizacji jako przepływu i transformacji (Morgan, 1997, s. 272 i nast.). Jednak metoda posługiwania się metaforami 6 nie odpowiada rygorom badania prakseologicznego. Powstała zatem potrzeba poszukiwania teorii, metody badawczej i narzędzia, które potrafią połączyć zagadnienie prakseologii i komunikowania się.

Na potrzeby realizacji celu pracy rozważano zatem wstępnie szeroki katalog metod badawczych wykorzystywanych w badaniach społecznych, a szczególnie w badaniach nad organizacjami (np. Konecki, 2000; Perechuda, 2000a; Chełpa, 2002; Babbie, 2004; Adamkiewicz-Drwiłło, 2008; Czakon, 2009; Matejun, 2011). Wiele z nich prezentuje niedostatki w kontekście celu pracy - niedokładność i ograniczoną perspektywę. Jedną z możliwych propozycji ich niwelowania jest metoda triangulacji. Jej prekursorzy, Donald Campbell i Donald Fiske (1959, s. 83, 101), wskazali, że łączenie różnych metod w jednym projekcie badawczym pozwala zminimalizować błąd wynikający z konkretnej metody pomiaru i określonego rodzaju używanego narzędzia. Metoda triangulacji jest więc obecnie chętnie wykorzystywana

6 Metafora „nie jest jedynie ornamentem stylistycznym czy retorycznym. Przeciwnie, jest ona centralnym składnikiem codziennego posługiwania się językiem, a co więcej - wpływa na nasz sposób postrzegania, myślenia i działania" (Krzeszowski, 2010, s. 7). 
na potrzeby badania problemów organizacji (np. Furmanek, 2017, s. 23-42; Nadolna, 2017, s. 173-185). Każda konkretna, pojedyncza metoda będąca częścią triangulacji podaje wyniki z jednej, własnej perspektywy i jednocześnie jest obarczona błędem dla siebie specyficznym (Denzin, Lincoln, 1994, s. 1-7). Błędy eliminuje się przez połączenie metod (Hornowska i in., 2012, s. 72-83), co również rozszerza perspektywę badań. Trafność operacjonalizacji pojęcia teoretycznego, mierzonego na różne sposoby, powinna być określona przez część wspólną (por. np. Brzeziński, 2007, s. 525-532; Hornowska, 2009, s. 96) w postaci łączenia wyników badań za pomocą trzech różnych metod badawczych i korzystania $z$ różnych źródeł informacji. Wyniki powinny wzajemnie się potwierdzać. Tymczasem okazuje się, że dane pozyskane za pomocą różnych narzędzi często prowadzą do odmiennych wniosków, a to do znaczących nieporozumień (Hornowska i in., 2012, s. 72-83). Omawiane ograniczenie wynika ze statusu zjawiska, które jest przedmiotem badania.

Jeżeli jest to zjawisko traktowane statycznie, jednoprzyczynowo i niesystemowo, to poszukiwanie trafności zbieżnej za pomocą metody triangulacji wydaje się mieć sens. Natomiast gdy przedmiotem badania jest zjawisko ujmowane procesualnie, systemowo i uwarunkowane wieloprzyczynowo, to odwoływanie się do tak rozumianej triangulacji może prowadzić wręcz do tworzenia artefaktów. Poszukiwanie za wszelką cenę tego, co wspólne, będzie bowiem sprzyjać konstruowaniu pojęć teoretycznych bez empirycznego odniesienia (pozbawionych referencji egzystencjalnej) [...] (Hornowska i in., 2012, s. 75).

Ponieważ badane w tej pracy zjawisko zdecydowanie nie jest jednoprzyczynowe, należało odrzucić metodę triangulacji jako podstawę badawczą.

Zwrócono się zatem w kierunku teorii systemów jako podstawy badawczej. Daje ona w tym przypadku naukowe podstawy wnioskowania (procedurę naukową) i pozwala uniezależnić się od metafor niewspółgrających z mierzeniem sprawności w sensie prakseologicznym. Co więcej, pozwala na szerokie ujęcie zagadnienia niesprawności organizacji z perspektywy komunikacyjnej. Z kolei technicznie płaszczyzna systemowa daje możliwość budowy nie tylko modelu organizacji, ale także pozwala na wypracowanie metody analizy systemów złożonych ${ }^{7}$ dla osiągania sprawności organizacyjnej przez komunikowanie. Z przedstawionych wyżej powodów teoria systemów jako podstawa badawcza jest adekwatna do realizacji celu pracy.

$7 \quad$ Nazwa analiza systemów złożonych może sugerować zawężenie kategorii obiektów badanych w stosunku do analizy systemowej bez określnika. Zawężenie takie nie jest zamysłem autorki, stanowi jedynie zabieg językowy, który pozwoli na odróżnienie pierwowzoru od metody wypracowanej na gruncie niniejszej pracy, wszak każdy system - ex definitione - jest złożony. 
Cornell C. Chikere i Jude Nwoka napisali o teorii systemów, że:

[...] jest abstrakcyjną filozofią, która zawiera wysoce empiryczną i śledczą formę nauki o zarządzaniu. Teoria systemów sugeruje ewolucyjne wyjaśnienie dominacji zarządzania we współczesnym społeczeństwie. Wyjaśnia również rolę złożonych organizacji we współczesnym społeczeństwie; [...] Teoria zarządzania systemami we współczesnych organizacjach jest prawdziwym narzędziem naukowym dla świata akademickiego. Wspiera on dodatkową wiedzę z zakresu zarządzania w świecie biznesu, zwiększając w ten sposób wskaźniki przetrwania i rentowności tych organizacji (Chikere, Nwoka, 2015, s. 6).

\section{Uzasadnienie podjęcia problemu badawczego}

Istnieje wiele opracowań dotyczących społecznego komunikowania się, a znaczna większość z nich jest bezpośrednim przeniesieniem zagadnień komunikacji społecznej na płaszczyznę organizacji jako miejsca kontaktów międzyludzkich (rozdział pierwszy niniejszego opracowania). Organizacja ma jednak swoją specyfikę, polegającą na współdziałaniu ludzi dla osiągnięcia celu i korzyści, głównie majątkowych, lecz nie tylko. Antycypowanie treści komunikacji społecznej na potrzeby organizacji utrudnia wyodrębnienie specyfiki komunikacji organizacyjnej. Zadanie wskazania specyfiki komunikowania organizacyjnego jest wyjątkowo trudne ze względu na konieczność wyabstrahowania charakterystycznych elementów komunikacji, które występują w organizacji, a nie występują w komunikacji społecznej lub odwrotnie. Czynności mowy oraz akty komunikacji (obejmujące trzy poziomy - lokucyjny, illokucyjny, prelokucyjny - działanie komunikacyjne jako takie, cel i efekt, jaki przynosi komunikacja - Skudrzykowa, Urban, 2000, s. 10-13) występują przecież w obu przypadkach. Tak samo dzieje się w przypadku zachowań komunikacyjnych (obietnica, prośba, groźba ${ }^{8}$, przeproszenie, zaproszenie - Austin, 1993) i intencji aktów mowy (stwierdzenia, dyrektywy, komisywy, autoekspresje i deklaratywy - Searl, 1987). Być może różnicę stanowi natężenie określonego typu komunikatów, jest to jednak przypuszczenie, niestety, niepotwierdzone w badaniach przeprowadzanych w ciągu ostatnich 50 lat ${ }^{9}$.

8 Zasadniczo zastraszanie nie powinno występować ani w organizacji, ani w codziennym życiu. Niezależnie od założeń zdarza się jednak i w życiu, i w organizacji - tu w postaci patologii (np. mobbingu, bullyingu itp.).

9 Według najlepszej wiedzy autorki o stanie badań nad implementacją komunikacji społecznej do warunków wewnątrzorganizacyjnych. 
Funkcjonują także teorie - będące inspiracją dla niniejszego opracowania - według których komunikacja stanowi organizację, czyli konstytuuje ją (Tompkins, 1984; Luhmann, 2000). Kiedy kierownik przedstawia projekt (w postaci przekazu ustnego lub pisemnego), w zasadzie jednocześnie określa strukturę zespołu i inicjuje dalsze działania. W tym konstrukcie teoretycznym komunikacja jest odpowiednikiem organizacji, tworzy kontekst społeczny organizacji (Putnam, Phillips, Chapman, 1996; Tompkins, Wanca-Thibault, 2001). Komunikacja zostaje zdefiniowana jako siła konstruktywna (Miller, 2012) lub konstytutywna (Craig, 1999; Penman, 2000) organizacji.

Komunikacja wewnętrzna odgrywa ważną rolę w organizacji z uwagi na dowody, że firmy posiadające strategię właściwej komunikacji są zazwyczaj skuteczne, podczas gdy inne starają się wykazywać wydajność niższą od optymalnej (Argenti, Forman, 2002; Tourish, Hargie, 2004, s. xii-xxv). Komunikacja organizacyjna jest także traktowana jako podstawowy proces w organizacji.

W erze informacyjnej aktywa organizacji obejmują wiedzę i wzajemne relacje ludzi. Jej podstawowa działalność polega na wykorzystaniu informacji wejściowych, które przy użyciu twórczych i intelektualnych zasobów pracowników są przetwarzane, aby wytworzyć wartości. Komunikacja wewnętrzna jest rdzeniem (procesem podstawowym), dzięki któremu organizacja może tę wartość wytworzyć (Quirke, 2002, s. 21).

Równocześnie jednak występuje dysproporcja między postrzeganym znaczeniem komunikacji a rzeczywistą uwagą i zasobami skierowanymi na jej potrzeby (Argenti, Forman, 2002; Tourish, Hargie, 2004, s. 1-36). Christine Oliver (1997) wskazuje, że komunikacja jest rzadko rozpoznawana jako główna spośród wymaganych kompetencji. Stąd, paradoksalnie, mimo rosnącej świadomości dotyczącej znaczenia komunikacji w organizacjach jest ona rzadko przekładana na język praktyki, a wiedza w tym zakresie nie powoduje wzrostu umiejętności.

Niektórzy słusznie sądzą, że „istota i rola komunikacji (za) rzadko są przedmiotem badań i dyskusji”"10 (Kitchen, Daly, 2002, s. 49), ponieważ uważa się je za oczywiste (np. Tourish, Hargie, 2004, s. 1-16), a

10 Ana Tkalac Verčič, Dejan Verčič oraz Krishnamurthy Sriramesh (2012) uznają, że komunikacja wewnętrzna jest najszybciej rozwijającą się specjalizacją w ramach public relations i zarządzania komunikacją. Ten wzrost rozpoczął się w latach dziewięćdziesiątych w Stanach Zjednoczonych i później rozprzestrzenił się na Europę. Za jego przyczynę uznaje się „globalizacje, deregulacje, kryzysy ekonomiczne, które przyniosły permanentną restrukturyzację, downsizing, outsourcing, fuzje i przejęcia i inne przejawy bardziej lub mniej kreatywnej destrukcji. Wynikiem była drastyczna redukcja zaufania pracowników w stosunku do kierowników [...]" (Verčič, Verčič, Sriramesh, 2012, s. 223). W skrócie komunikacja wewnętrzna 
Świadomość znaczenia komunikacji w skutecznym zarządzaniu organizacjami jest wśród polskich menedżerów dość powszechna. Stosunkowo rzadko jednak podejmują oni działania mające na celu doskonalenie procesów komunikacyjnych (Czekaj, Ziębicki, 2008, s. 5).

Rola komunikacji w ramach organizacji jest nieuporządkowana, w użyciu jest duża lista terminów akademickich, która utrudnia ustalenie „wspólnego gruntu poznawczego" (termin wprowadzili Ikujiro Nonaka i Hirotaka Takeuchi, 1995, s. 14). Autorzy pytają, kim w zasadzie są ci, o których w środowisku akademickim i biznesowym mówi się „specjaliści od komunikowania”. Zarządzanie komunikacją wewnętrzną uznawane jest za domenę praktyków, tymczasem istnieją także znaczne luki w teorii komunikacji wewnętrznej - teoretycy wzywają do badań nad istotą, zakresem i ostrością tego pojęcia (Forman, Argenti, 2005, s. 262).

Komunikacja wewnętrzna jest jednym z najbardziej dominujących i ważnych działań w organizacji (Harris, Nelson, 2008), ponieważ wszelkie relacje w organizacji wywodzą się z komunikacji, a jej funkcjonowanie i przetrwanie opiera się na efektywnych relacjach między jednostkami i grupami. Jednocześnie w opracowaniach z zakresu komunikacji wewnątrzorganizacyjnej „Główna uwaga skupiana jest [...] przede wszystkim na poprawności komunikacji w wymiarze relacji interpersonalnej, z pominięciem najczęściej jej aspektów organizacyjnych, w tym zagadnień doskonalenia" (Czekaj, Ziębicki, 2006, s. 167-168). Możliwości organizacyjne są opracowane i wprowadzone przez procesy społeczne i komunikacyjne (Jones, Watson, Gardner, Gallois, 2004). Komunikacja pomaga jednostkom i grupom koordynować działania, aby osiągnąć cele, co jest ważne z perspektywy socjalizacji, podejmowania decyzji, rozwiązywania problemów i zmiany zarządzania procesami. Komunikacja wewnętrzna dostarcza pracownikom ważnych informacji na temat: siebie nawzajem, ich pracy i organizacji ochrony środowiska. Może pomóc motywować, budować zaufanie, tworzyć wspólną tożsamość i pobudzić zaangażowanie. Jest to sposób, aby wyrazić emocje, nadzieje i ambicje oraz świętować osiągnięcia. Komunikacja jest bazą dla osób i grup, aby nadać sens organizacjom, których są członkami, określić, czym są i co znaczą (Welch, Jackson, 2007, s. 180).

Komunikacja wewnętrzna odbywa się na wielu poziomach - komunikacja interpersonalna lub twarzą w twarz stanowi podstawową jej formę. Organizacje od lat starają się rozwijać umiejętności menedżerów w zakresie mówienia, pisania i prezentacji. Komunikacja na poziomie grupy występuje w zespołach, działach i grupach interesów, skupia się na wymianie informacji, dyskusji, koordynacji zadań, rozwiązywaniu problemów i osiąganiu konsensusu. Komunikacja organizacyjna

wyłoniła się jako kluczowa funkcja w organizacji, zasługująca na uznanie jako odrębnie wydzielona specjalność. 
w literaturze koncentruje się na takich kwestiach jak wizja i misja, strategia, nowe inicjatywy i wiedza organizacyjna oraz wydajność. Ta formalna komunikacja często następuje w postaci kaskadowej, jako konsekwencja hierarchicznej budowy struktury organizacyjnej. Wzorce komunikowania się w organizacji ulegają przekształceniom z powodu zmian struktury organizacyjnej, także technologia, której podstawą jest internet (np. media społecznościowe, komunikowanie na odległość) modyfikuje komunikację właśnie na poziomie organizacyjnym.

Inne argumenty, które przyczyniły się po powstania przedstawianej pracy, są związane z rozwojem teorii systemów Ludwiga von Bertalanffy'ego. Teoria systemów i metoda analizy systemowej skupiają się w szczególności na cechach konstrukcyjnych systemów (Bunge, 1979). Z tego powodu można uznać, że dążą one do przekroczenia głównie sztucznych barier utworzonych między różnymi dyscyplinami naukowymi. Mario Bunge uznaje, że teoria systemowa posiada dwie najważniejsze cechy charakterystyczne - istnieją koncepcje i zasady konstrukcyjne, które wydają się utrzymywać niezależnie od rodzaju systemu oraz istnieją „rozwiązania modelowe" (modelling strategies), które wydają się działać wszędzie. Ponadto według Bungego wykorzystywaniu podejścia systemowego przyświecają dwie motywacje - poznawcza i praktyczna. Motywacji poznawczej towarzyszy chęć odkrywania podobieństw między systemami wszelkiego rodzaju, mimo różnych kontekstów, w których powstają i funkcjonują. Praktyczna motywacja sprowadza się natomiast do konieczności radzenia sobie z rozbudowanymi i wielostronnymi systemami, które są charakterystyczne dla społeczeństwa przemysłowego (Bunge, 1979; 2000).

Metoda systemowa (także teoria, podejście, nurt i paradygmat - szczegółowego rozróżnienia dokonano w rozdziałach drugim i trzecim niniejszej pracy) daje szczególnie szerokie możliwości badawcze organizacji. Wynikają one z historii powstania podejścia systemowego i zainteresowania się naukowców ogólną teorią systemów (OTS). Warren Weaver (1948, s. 536-537) umieścił pojawienie się i zastosowanie OTS jako odcinek finalny ewolucyjnego przechodzenia nauki przez etapy. W pierwszym etapie badano przedmioty o charakterze prostym, jedno- lub kilkuelementowe, tak zwane obiekty o złożoności prostej (przykładem może być fizyka na etapie mechaniki). Wówczas, aby mieć pogląd o całości, wystarczało klasyczne podejście analityczne, czyli przebadanie poszczególnych elementów traktowanych statycznie. Etap drugi to badanie obiektów o charakterze złożoności niezorganizowanej (na przykład fizyka na etapie termodynamiki). Dla obiektów złożonych załamywało się proste podejście analityczne i konieczne stało się wykorzystanie statystyki. I wreszcie etap trzeci, który rozpoczął się od zagadnień prezentowanych w biologii (Ludwig von Bertalanffy, Walter B. Cannon, teoria homeostatu), językoznawstwie (Romuald Jacobs), psychologii postaci (Gestaltt - postać jako całość), dotyczył badania obiektów o właściwościach złożoności zorganizowanej. 
Ogólnie uznaje się, że von Bertalanffy stworzył podwaliny teorii systemowej (wątpliwości w tym zakresie przedstawiono w rozdziale drugim), jednak według najlepszej dostępnej autorce wiedzy nie podjął badań nad komunikacją i organizacjami. Natomiast w naukach o organizacji przyjmuje się już za pewnik, że organizacje są systemami. Istnieje kilka systemowych modeli organizacji, mających nazwy i charakter systemowy, jednocześnie autorzy tych modeli nie wskazują metody systemowej lub systemowego postępowania, według których modele takie zostały zbudowane - na przykład w popularnym modelu Leavitta ${ }^{11}$ podsystemy nie zostały uporządkowane hierarchicznie. Jest to kolejny powód, dla którego należy podjąć się systematycznej analizy organizacji metodą systemową.

Niektóre „odkrycia” mogą okazać się oczywiste, niemniej obecnie funkcjonują one w sferze przekonań i przeświadczeń - w niniejszej pracy zostaną zbadane systemową metodą naukową. Rozumienie zależności komunikacyjnych w organizacji na gruncie teorii organizacji nadal jeszcze jest w dużej mierze intuicyjne (Miles, 2012, s. 244), brakuje bowiem systematyki (Brown, Colville, Pye, 2015, s. 269), wykorzystywany jest przy tym język potoczny, niekoniecznie naukowy (Cornelissen $i$ in., 2008, s. 7-22).

Przeprowadzone przez zespół WAZO badania w zakresie komunikacji pokazują, że w organizacjach funkcjonują różne rozwiązania organizacyjne (z miażdżącą przewagą rozwiązań tradycyjnych ${ }^{12}$, a nie rozwiązań „przyszłości”, które występują tylko w 7,2\% polskich przedsiębiorstw - Kołodziejczak, 2016, s. 29-30). W ich ramach występują rozmaite rozwiązania komunikacyjne, także uznawane za najnowsze i przyszłościowe - w wszystkich typach organizacji odnaleziono 73,7\% takich sposobów komunikowania, a tylko 2,8\% tradycyjnych (Zalewska-Turzyńska, 2016b, s. 211-242). Dlatego proponowany model systemowy ma szansę odnosić się do wszystkich typów organizacji i sposobów komunikacji jednocześnie.

Ponadto autorka tej pracy stoi na stanowisku, że wiedza o strukturach organizacyjnych wyprzedziła wiedzę o komunikacji, a niesprawność określonych struktur organizacyjnych przypisywana jest innym przyczynom niż te, które leżą u źródła

11 Model powstał w wyniku zainteresowań autora implementacją zmian organizacyjnych. Oryginalny model Leavitta składa się z czterech elementów i sześciu powiązań między nimi, oznaczonych strzałkami o dwóch zwrotach. Model organizacji nie został wyodrębniony z otoczenia, nie posiada wejścia i wyjścia ani sprzężenia zwrotnego - elementów uznawanych za systemowe. Jego zadaniem było wskazanie na powiązania podczas wprowadzania zmiany w organizacji - zmiana w jednym z elementów implikuje zmianę w trzech pozostałych - i w tym znaczeniu model ten można uważać za „prekursora” modeli systemowych.

12 Szczegółowy opis tradycyjnych typów organizacji i sposobów komunikowania znajduje się w cytowanej publikacji. W dużym skrócie tradycyjna organizacja jest hierarchiczna, z podziałem zadań, a komunikacja przebiega zgodnie ze strukturą organizacyjną, bez użycia nowoczesnych urządzeń i programów, ogranicza się do komunikacji bezpośredniej twarzą w twarz lub z użyciem telefonu. 
- niedostatkom komunikacji. Istnieje zależność między wadliwym systemem komunikacji wewnątrzorganizacyjnej i niesprawną organizacją, czyli głównym czynnikiem sprawczym waloru sprawna/niesprawna organizacja jest sprawna/niesprawna komunikacja wewnątrzorganizacyjna.

\section{Cel pracy}

Celem naukowym jest opracowanie:

1) systemowego modelu organizacji z perspektywy komunikacji - „systemowego modelu sieci zintegrowanych relacji komunikowania” (SMSZRK),

2) naukowej metody analizy systemowej organizacji, prowadzącej do podniesienia sprawności organizacji przez komunikowanie wewnątrzorganizacyjne,

3) systemu wskaźników koordynacji systemowego modelu sieci relacji komunikowania w kierunku sprawności.

Cel aplikacyjny wyraża się w tym, że właściciel lub menedżer istniejącej organizacji może posłużyć się modelem, aby doskonalić zarządzanie (koordynowanie) organizacją i podnosić jej sprawność przez komunikację. Ponadto w przypadku tworzenia nowej firmy zastosowanie modelu pozwoli na zbudowanie organizacji optymalnej od strony komunikacyjnej.

Osiągnięcie tak postawionego celu wymaga realizacji prac na płaszczyźnie:

1) teoretycznej:

- interpretacji dotychczasowego dorobku w dziedzinie komunikacji wewnątrzorganizacyjnej,

- oceny dorobku teorii systemów w zakresie wykorzystywania w organizacji i zarządzaniu,

- krytycznej oceny opisanych w literaturze przedmiotu systemów społecznych (organizacji) ujmowanych systemowo oraz metod analizy systemowej,

2) metodycznej:

- wypracowania metodyki analizy systemów złożonych (ASZ) organizacji i stworzenia narzędzia badawczego,

- skonstruowania modelu organizacji z perspektywy komunikacyjnej,

- ustalenia wskaźników koordynacji organizacyjnej podnoszących sprawność działania organizacji i zbudowania modelu systemu organizacji osadzonego na idei komunikowania się - tak zwanego modelu koordynacji organizacyjnej (KO).

Podejmując próbę realizacji tak zdefiniowanego systemu celów, sformułowano główną tezę badawczą, zgodnie z którą podnoszenie sprawności organizacyjnej można osiągać przez poprawę komunikacji wewnątrzorganizacyjnej. 
W naukach o zarządzaniu istnieje luka poznawcza w zakresie metod doskonalenia sprawności organizacji przez komunikację wewnątrzorganizacyjną. Konieczne jest zatem opracowanie metody badawczej - metody AZS opartej na koordynacji komunikacji wewnątrz organizacji, co prowadzi do sformułowania tezy ogólnej, w postaci: istnieją pewne typy działań, które stosowane w określonej kolejności decydują o sprawności funkcjonowania organizacji - należą do nich komunikacja, integracja, koordynacja i organizacja (w znaczeniu czynnościowym).

Tak postawionej tezie ogólnej podporządkowano cztery tezy szczegółowe:

T1: Komunikowanie warunkuje integrowanie.

T2: Zintegrowanie warunkuje koordynowanie.

T3: Koordynowanie warunkuje zorganizowanie.

T4: Zorganizowanie warunkuje sprawność.

Przyjęto następujące założenia:

1) realizacja każdej czynności, każdego działania w organizacji i każdej funkcji (sic!) zarządzania odbywa się za pomocą komunikowania się - jest to proces inicjujący wszelkie działania (w organizacji nic nie może się wydarzyć bez procesu komunikowania się);

2) można stworzyć zintegrowany system sieci relacji komunikowania się (ZSSRK) - uporządkowany i scalający organizację;

3) koordynacja (integracja, zorganizowanie, sprawność) podlega mierzeniu i daje się zoperacjonalizować;

4) można stworzyć mierniki sprawnego koordynowania takiego systemu, czyli model;

5) struktura organizacyjna (rzeczowa) i struktura ZSSRK to przykład izomorfizmu (zmiana struktury = zmiana sieci komunikacji).

\section{Źródta i metody badawcze}

Rozkwit podejścia systemowego w Polsce przypadł na lata sześćdziesiąte-osiemdziesiąte ubiegłego wieku, dlatego znaczna cześć prezentowanej literatury z tego zakresu pochodzi z tamtego okresu i z powodu upływu lat jest wyjątkowo trudno dostępna. Niemniej w miarę możliwości starano się dotrzeć do pierwotnych publikacji. Poszukiwano także tekstów źródłowych i autorskich koncepcji. Z tej przyczyny często oprócz polskich publikacji przytaczane są także anglo- i rosyjskojęzyczne.

Obecnie w literaturze amerykańskiej zauważa się renesans zainteresowania systemami - ich filozofią, teorią i metodami badawczymi. Obserwuje się ożywione dyskusje dotyczące cech konstytutywnych systemów, warunków ich stosowalności w systemach złożonych, przedstawia się także szczegółowo systemowe pochodzenie teorii 
złożoności (np. cytowani w pracy Demetis, Lee, Mingers, Taylor, Jackobsen, Millett, Midgley, Wilby, Dekkers). Zagadnienia te mają odzwierciedlenie w niniejszej pracy.

Co więcej, zakorzeniła się już „moda” na określanie zagadnień mianem systemowe, co ma wskazywać na kompleksowe, całościowe podejście do zagadnienia (nawet jeśli nie dotyczy systemów jako takich). Zdarzają się także publikacje wydane w ostatnich latach, które traktują zagadnienia systemowe pobieżnie, do zarysowania perspektywy i ukierunkowania dalszych szczegółowych rozważań w wąskim kontekście prezentowanego zagadnienia. Prace te w małym stopniu rozwijają zagadnienia systemowych metod badawczych, częściej skupiają się na ontologii i epistemologii systemów, dlatego w tym zakresie nie są tutaj cytowane, natomiast przedstawia się te opracowania, które wniosły pewną jakość do rozwoju metod badania systemowego.

Teoretyczno-metodologiczny charakter pracy zdecydował o wyborze metod badawczych. W części teoretycznej wykorzystano metodę analizy i oceny krytycznej literatury przedmiotu, dedukcji i indukcji (w formie podstawowej jako opis uogólniający ${ }^{13}$ ) przez opis poszczególnych obserwowalnych faktów, zjawisk, zdarzeń - jest to bezpośrednia i najprostsza metoda przejścia od faktów do pojęć. Taka forma opisu stanowi początek badania naukowego. Źródłem rozważań jest ogólne zjawisko, które stopniowo prowadzi do szczegółowej analizy obszarów komunikacji i koordynacji organizacyjnej.

W części metodologiczno-badawczej i konstrukcyjnej zwrócono się w kierunku analizy systemowej jako metody badawczej. Powodem jej wyboru jest rozwój teorii organizacji, jaki odbył się na przestrzeni ostatniego półwiecza, ogromna liczba „wykrytych prawidłowości” występujących w organizacji, opracowana przez wielu autorów. Im więcej ujawnionych prawidłowości wykorzystuje się w modelu, tym staje się on prostszy, zmniejsza się też liczba nieskorelowanych obserwacji. Wraz ze wzrostem liczby wykrytych prawidłowości rośnie moc predykcyjna modelu. Część metodyczna oparta została na metodzie analizy i syntezy systemowej, analizie wskaźnikowej, eksperymencie myślowym i analizie abstrakcyjnej (A. Bogdanowa) ${ }^{14}$.

W pracy ogólnie na określenie podejścia badawczego do systemów używa się z terminu analiza systemowa. Jej zasadniczą cechą charakterystyczną (nie wchodząc

13 Polega na obserwacji faktów i grupowaniu ich w możliwie jednorodne zbiory według określonych kryteriów pozwalających na uchwycenie elementów o cechach wspólnych i powtarzających się. Metoda ta jest szeroko wykorzystywana w naukowej klasyfikacji zjawisk składających się na obszar badawczy danej dyscypliny (Pytkowski, 1985).

14 Zadaniem metody analizy abstrakcyjnej A. Bogdanowa jest „wykrycie prawidłowości przebiegu zjawisk, czyli budowa praw umożliwiających zarówno wyjaśnianie genetyczne przebiegu procesów organizacyjnych, jak również przewidywanie wystąpienia pewnych faktów organizacyjnych" (Perechuda, 1984, s. 33). Po zrealizowaniu celu poznawczo-teoretycznego można realizować cel praktyczny nauki o organizacji, polegający na kształtowaniu właściwego przebiegu zjawisk i optymalizacji oddziaływania. 
w szczegóły) jest badanie relacji między podsystemami, podejścia odmiennego od analizy klasycznej. Analizą systemową (AS) określa się także konkretną metodę badawczą należącą, obok inżynierii systemowej (SE) i badań operacyjnych (OR), do nurtu twardego myślenia systemowego, natomiast analiza systemów złożonych jest rekonstrukcją własną pierwotnej analizy systemowej, powstałą jako wynik prac metodologiczno-konstrukcyjnych. Przyjęto mówić o analizie systemowej jako metodzie badawczej, pomijając nazewniczo następujący po niej etap syntezy. Poprawność metodologiczna wymaga, aby każda analiza prowadziła do syntezy. To wyjaśnienie pozwala odróżnić analizę systemową jako metodę badawczą, która ma zastosowanie w perspektywie teoretyczno-metodologicznej, od analizy systemu jako etapu projektowania mającego charakter praktyczno-aplikacyjny.

\section{Korzyści płynące z pracy}

Efektem pracy jest model organizacji służący podnoszeniu jej sprawności przez komunikację. Komunikacja jest tutaj traktowana jako narzędzie. Model ${ }^{15}$ i towarzysząca mu teoria systemowa pozwalają na systematyczne wyjaśnienie zjawiska podnoszenia sprawności organizacji przez poprawę komunikacji.

Teoria to zbiór powiązanych ze sobą twierdzeń, które zapewniają systematyczne wyjaśnienie zjawisk. Teorie mają zatem trzy funkcje - starają się wyjaśnić zjawiska przez próbę określenia jego przyczyny, pozwalają na przewidywanie przyszłych stanów i zdarzeń, także w celu ich zmiany, i na koniec określają relacje między zmiennymi, dlatego są w stanie wyjaśnić zjawiska i przewidywać je. Teorie naukowe różnią się od naiwnego teoretyzowania (Czakon, 2017), są bardziej od niego użyteczne, ponieważ są obiektywne, oparte na obserwacjach w realnym świecie, nie powstały na podstawie przekonań, są sprawdzalne - naukowcy są w stanie sprawdzić prawdziwość teorii na przykład przez powtórzenie badania tą samą metodą.

Zalety zaprezentowanego w pracy modelu teoretycznego przedstawiono poniżej:

1) przedstawiony model naukowy jest opracowany zgodnie z metodą badawczą analizy i syntezy systemowej, prezentuje naukowe ujęcie tego, co do tej pory było przyjmowane intuicyjnie;

2) pozwala na wypracowanie metody analizy systemów złożonych, możliwej do wykorzystania na potrzeby systemowego badania zagadnień w organizacji, powstałych na innej płaszczyźnie (np. konflikt); jeśli zaistnieje potrzeba

15 Ze względu na użyteczność modele są: opisowe (deskryptywne), operacyjne (umożliwiające pomiar oraz prognozowanie) i funkcjonalne (określające relacje między częściami oraz odkrywające zależności). 
systemowego badania organizacji przez pryzmat konfliktu, należy postępować zgodnie ze wskazaną metodą;

3) pozwala doskonalić zarządzanie (koordynowanie) organizacją przez komunikację, podnoszenie jej sprawności - jest dostosowany do każdego typu organizacji;

4) jeśli powstaje nowa organizacja, model daje możliwość zbudowania „od razu” organizacji optymalnej od strony komunikacyjnej.

\section{Struktura pracy}

Pierwsza część pracy przedstawia dorobek z zakresu komunikowania wewnątrzorganizacyjnego z dwóch perspektyw - gdy komunikowanie „społeczne” odbywa się w środowisku organizacji oraz gdy komunikacja konstytuuje organizację. Oba podejścia powstały na gruncie nauk społecznych, a następnie zostały zaadaptowane do nauk o organizacji. Z jednej strony są to zatem podejścia niespecyficzne dla dyscypliny, ale uprawomocniają konstytutywną rolę komunikacji dla organizacji, choć nie pozwalają - z powodów metodologicznych - na operacjonalizację w kierunku sprawności organizacji. Gdyby jednak udało się przedstawić organizację jako komunikację, za pomocą innej metody, pozwalającej na taką operacjonalizację, możliwe stałoby się podnoszenie sprawności organizacji przez komunikację wewnątrzorganizacyjną. W pracy do celu operacjonalizacji wybrano metodę analizy i syntezy systemowej. Charakterystyka systemów i podejścia systemowego daje możliwość ujęcia organizacji z perspektywy podsystemów i relacji między nimi - zgodnie z charakterystyką procesu komunikowania się. $Z$ tego powodu w dalszej części pierwszego rozdziału przywołano dorobek nauki o systemach, a następnie przedstawiono analizę jego zawartości i krytyczną ocenę, co stanowi także szczegółową analizę luki poznawczej w tym zakresie. Skupiono się także na systemowym pojęciu relacji, komunikowanie się jest bowiem w tej pracy traktowane w sposób relacyjny, co więcej - teoria systemów wypracowała formalną postać zapisu relacji wewnątrzpodsystemowych. Przy konstrukcji relacyjnego modelu organizacji jako komunikacji odniesiono się do formy tego zapisu.

Część druga ma charakter metodyczno-badawczy. Rozpoczyna się wyjaśnieniem, w jakim zakresie analiza systemowa stanowi w niniejszej pracy przewage metodyczną nad analizą klasyczną oraz analizą sieci społecznych. W pierwszym przypadku jest to pominięcie elementu relacji, w drugim efekt, który powstaje tylko na podstawie kompletnych danych empirycznych (drobny brak w danych skutkuje niepoprawną analizą i niepełnym modelem organizacji). 
Przydatnym rozwiązaniem byłoby - w tym miejscu - zaadaptowanie funkcjonującego modelu organizacji jako systemu "gotowego” do dalszych prac. Niestety, jak wykazano, nie ma pewności, że którykolwiek z nich powstał jako efekt prac systemowych. Brak takiej pewności prowadzi do konieczności budowy modelu opartego na metodzie analizy systemowej jako metodzie badawczej. Przyjmując, że efekt prac może być podobny do modeli już istniejących, dla poprawności metodycznej podjęto się konstrukcji modelu. W dalszej kolejności w rozdziale trzecim przedstawiono rozmaite propozycje metod badawczych analizy systemowej oraz szczegółowe procedury w ramach metody, proponowane przez rozmaitych autorów (kluczem doboru jest nie tyle nazwa analiza systemowa, ile zawartość merytoryczna procedury, pozwalająca na badanie elementów i relacji między nimi). Procedury tego rodzaju, opracowane na potrzeby organizacji, ograniczały się do metodyki podejmowania decyzji lub metodyk naprawczych konkretnych funkcji - szerszego kontekstu procedur analizy systemowej nie odnaleziono. $\mathrm{Z}$ tego powodu autorka poszukiwała szerzej inspiracji do budowy własnej propozycji metody analizy systemów złożonych, wychodząc poza dyscyplinę i kierując zainteresowanie na ogólną teorię systemów. Inspirację taką znalazła u Jaroslava Habra i Jaromira Vepreka (1976), Petera Checklanda (2000) i Johna Mingersa (2014; 2017). Na koniec tego rozdziału zaprezentowano własną modyfikację metody analizy systemowej jako metody badawczej.

W rozdziale czwartym przedstawiono aplikację zaprojektowanej metody analizy systemów złożonych na podstawie obserwacji obiektów rzeczywistych organizacji różnego rodzaju. Wyodrębniono realne elementy systemu, uporządkowano je rzeczowo w podsystemy pierwszego stopnia i wyodrębniono relacje między nimi, następnie zidentyfikowano podsystemy drugiego stopnia (wyznaczając dwa konkretne podsystemy pierwszego stopnia, relacje wewnętrzne podsystemowe i relacje między dwoma podsystemami pierwszego stopnia) oraz relacje między nimi. Dalej konsekwentnie wyodrębniono podsystemy trzeciego i czwartego stopnia. Na wyodrębnionych relacjach podsystemów organizacyjnych odwzorowano relacje komunikacyjne charakterystyczne dla relacji rzeczywistych (czyli konkretne relacje rzeczywiste są w organizacji realizowane za pomocą określonych komunikatów). Komunikaty takie zostały wyodrębnione i powiązane w wiązki treściowe, które połączono funkcjonalnie w sieci, w ten sposób powstała podstawa modelu organizacji - siećl6 relacji komunikowania (pierwszego, drugiego, trzeciego

16 Sieci są wszędzie i w każdej skali. Mózg to sieć komórek nerwowych połączonych aksonami, komórki to sieci cząsteczek połączone reakcjami biochemicznymi. Społeczeństwa również są sieciami ludzi połączonych przyjaźnią, relacjami rodzinnymi i zawodowymi. W większej skali sieci pokarmowe i ekosystemy mogą być reprezentowane jako sieci gatunkowe. Ponadto sieci przenikają technologię: przykłady obejmują internet, sieci energetyczne 
i czwartego stopnia). Komunikaty podlegają następnie uporządkowaniu i zintegrowaniu ze względu na synkretyczny model cyklu zarządzania. Efektem prac przedstawionych w rozdziale trzecim jest model systemu sieci zintegrowanych relacji komunikowania (MSSZRK), który stanowi podstawę do dalszej pracy nad budową modelu koordynacji organizacyjnej w kierunku sprawności.

W rozdziale piątym w części konstrukcyjnej powstał model koordynacji komunikacyjnej na potrzeby sprawności organizacji jako systemu sieci zintegrowanych relacji komunikowania, przygotowanego w rozdziale czwartym. $\mathrm{W}$ niniejszym opracowaniu uznaje się funkcję koordynacji za nadrzędną funkcję zarządzania, dlatego integruje się relacje komunikowania się ze względu na funkcję koordynowania. Jest ona podstawą budowy modelu koordynacji organizacyjnej. Z tego powodu opracowanie modelu koordynacji zostało poprzedzone wyjaśnieniami dotyczącymi pojęcia koordynacja, które w klasycznych teoriach rozumiane było znacznie szerzej niż wśród autorów współczesnych. Obecne podejścia do koordynacji wskazują wachlarz ujęć szczegółowych, w tej pracy wykorzystanych do opracowania pięciu grup wskaźników koordynacji organizacyjnej (przez komunikowanie). Operacjonalizacja wskaźników koordynacji zainicjowała konieczność zwrócenia się ku płaszczyźnie prakseologicznej, która pozwala na mierzenie sprawności organizacji i osiąganie efektu organizacyjnego (przez koordynację komunikacyjną).

Te wyjaśnienia prowadzą do prezentacji trzydziestu jeden wskaźników koordynacji organizacyjnej dla sprawności komunikacji, podzielonych na pięć grup rodzajowych. Wskaźniki zaprojektowano konsekwentnie w taki sposób, aby ich wartość za każdym razem była w przedziale od 0 do 1, przy czym w miarę zbliżania się do wartości 1 rośnie koordynacja organizacji, a tym samym jej sprawność - wzrost wskaźnika jest tożsamy ze wzrostem sprawności organizacyjnej.

Pracę zamknięto zakończeniem, w którym wskazano kierunki dalszych badań i możliwości wykorzystania metody i modelu zaproponowanych w pracy.

i systemy transportowe. Nawet język używany do przekazywania myśli to sieć słów połączonych relacjami syntaktycznymi. Mimo wszechobecności sieci ich struktura i właściwości nie zostały jeszcze w pełni poznane. Nadal nie odnaleziono odpowiedzi na przykład na następujące pytania: „W jaki sposób interakcje kilku nieprawidłowo działających genów w złożonej sieci genetycznej prowadzą do raka?”, „Jak dyfuzja przebiega tak szybko przez niektóre sieci społeczne i komunikacyjne, prowadząc do epidemii chorób i wirusów (również komputerowych)?”, ,Jak działają niektóre sieci mimo awarii ogromnej większości ich węzłów?" (Barabási, 2007, s. 34). 



\section{Część I Teoretyczna}





\section{Komunikacja wewnątrzorganizacyjna}

Komunikowanie jest rozmaicie definiowane w zależności od płaszczyzny naukowej, na jakiej powstało - psychologii, socjologii, filozofii, ekonomii, teorii organizacji i zarządzania, historii, etnologii oraz biologii i cybernetyki. Na gruncie teorii systemów definicji komunikowania nie przedstawiono. W pracy zainteresowanie komunikowaniem zawężono, ogniskując je na rozważaniach dotyczących komunikacji wewnątrzorganizacyjnej.

\subsection{Istota komunikacji wewnątrzorganizacyjnej}

Istnieją różne interpretacje terminu komunikacja1. John Fiske (2003, s. 15) ocenia, że wszyscy go rozpoznają, ale niewielu potrafi pomyślnie zdefiniować. Najprostsza chyba definicja komunikacji to interakcja społeczna przez wiadomości (Bovée, Thill, 2000; Fiske, 2003; Tourish, Hargie, 2004). Wiele definicji komunikacji ma charakter ogólny, nieodnoszący się do organizacji, natomiast z czasem przystosowywano je do jej potrzeb - na przykład: komunikacja to proces zorientowany na osiąganie celów w określonych sytuacjach (Eisenberg, Goodall, 2004).

W literaturze anglojęzycznej spotyka się dwa określenia - communication i communications:

[...] interpretacje terminów mogą się nieznacznie różnić, jednak najbardziej powszechną praktyką jest rozważenie komunikacji (w liczbie pojedynczej) jako procesu społecznego, który zwykle występuje, gdy zachodzi osobista interakcja. Komunikacja (w liczbie mnogiej) jest używana w kontekście specyficznym do wskazania kanałów oraz środków technologicznych, które ułatwiają ten proces (Spence, 1994, s. 86).

$1 \quad$ Frank Dance i Carl Larson (1976) zgromadzili wszystkie ówczesne definicje komunikacji (w znaczeniu ogólnym) - ponad czterdzieści lat temu odnotowali ich więcej niż trzysta. 
Paul Argenti i Janis Forman (2002) rozróżniają komunikację korporacyjną (corporate communication(s)), gdzie liczba pojedyncza zarezerwowana jest dla procesu, a mnoga dla produktów komunikacji - na przykład notatek, stron internetowych i wiadomości e-mail. W języku polskim ta różnica nie jest widoczna.

Tabela 1. Sposoby definiowania komunikacji wewnętrznej

\begin{tabular}{|c|c|}
\hline Autor & $\begin{array}{l}\text { Definicje, w których autor expressis verbis odniósł definiens do definiendum } \\
\text { komunikacja wewnętrzna }\end{array}$ \\
\hline $\begin{array}{l}\text { P.A. Argenti } \\
(2003, \text { s. } 128)\end{array}$ & $\begin{array}{l}\text { Istotą jest stworzenie atmosfery szacunku dla wszystkich pracowników } \\
\text { w organizacji. Komunikacja od kierowników powinna przechodzić } \\
\text { bezpośrednio od jednego kierownika do następnego, a od przełożonego } \\
\text { do pracownika, ale wraz ze wzrostem wielkości firmy i jej złożoności często } \\
\text { staje się to bardziej utrudnione - stąd konieczność funkcji komunikacji } \\
\text { wewnętrznej. }\end{array}$ \\
\hline $\begin{array}{l}\text { C.L. Bovée, } \\
\text { J.V. Thill }(2000, \\
\text { s. } 7,4)\end{array}$ & $\begin{array}{l}\text { Wymiana informacji i pomysłów w obrębie organizacji. Sprawna komunikacja } \\
\text { ma miejsce, gdy uczestnicy „osiągają wzajemne zrozumienie, pobudzają } \\
\text { innych do działania i zachęcają ludzi do myślenia w nowy sposób”. }\end{array}$ \\
\hline $\begin{array}{l}\text { G. Cheney, } \\
\text { L. Christensen } \\
(2001, \text { s. 233) }\end{array}$ & $\begin{array}{l}\text { Relacje z pracownikami, oświadczenia dotyczące misji oraz rozwój } \\
\text { organizacyjny. }\end{array}$ \\
\hline $\begin{array}{l}\text { J. Cornelissen } \\
(2004, \text { s. 189) }\end{array}$ & $\begin{array}{l}\text { Wszystkie instrumenty wykorzystywane przez firmę do porozumiewania się } \\
\text { z pracownikami. }\end{array}$ \\
\hline $\begin{array}{l}\text { D. Cowan } \\
(2017, \text { s. } 7-8)\end{array}$ & $\begin{array}{l}\text { Nie jest „kaskadowaniem” informacji, bo ona oznacza komunikację } \\
\text { hierarchiczną i sugeruje przekazywanie informacji „na oślep” w dół. Potrzeba } \\
\text { bardziej dynamicznego sposobu komunikacji, pozwalającego rozpoznać, } \\
\text { jak udana jest komunikacja w górę, w dół i diagonalna oraz na każdym } \\
\text { poziomie organizacji. Autor nazywa ją „infuzją”. To słowo pokazuje potrzebę } \\
\text { wolnego przepływu informacji przekraczającej granice zawodowe wewnątrz } \\
\text { organizacji i angażuje strukturę organizacyjną w dót, w górę i diagonalnie. }\end{array}$ \\
\hline $\begin{array}{l}\text { K. DeMaria } \\
(2016, \text { s. } 70)\end{array}$ & $\begin{array}{l}\text { Oznacza pracowników komunikujących się ze sobą. Komunikacja } \\
\text { wewnętrzna może być także funkcją menedżerską, która pozwala } \\
\text { poszczególnym członkom zespołów skutecznie komunikować się ze sobą. } \\
\text { Komunikacja taka może odbywać się za pomocą tradycyjnych mediów lub } \\
\text { może także korzystać z nowszych platform, takich jak social networking. } \\
\text { Wewnętrzna komunikacja to podzbiór komunikacji strategicznej, odgrywa } \\
\text { integralną rolę w definiowaniu organizacji, bez względu na to, jak duża lub } \\
\text { rozpowszechniona jest organizacja. }\end{array}$ \\
\hline $\begin{array}{l}\text { M. Dunmore } \\
(2002 \text {, } \\
\text { S. } 133-134)\end{array}$ & $\begin{array}{l}\text { Proces wspierający wdrażanie strategii, szerzenie wartości oraz tworzenie } \\
\text { osobowości przedsiębiorstwa, odgrywający znaczącą rolę w tworzeniu } \\
\text { przewagi konkurencyjnej. }\end{array}$ \\
\hline $\begin{array}{l}\text { U. Gros }(1994, \\
\text { s. 69) }\end{array}$ & $\begin{array}{l}\text { Główny proces organizacyjny polegający na wymianie informacji między } \\
\text { różnymi uczestnikami, wiążący ze sobą jednostki organizacyjne firmy i firmę } \\
\text { z otoczeniem. }\end{array}$ \\
\hline $\begin{array}{l}\text { S. Jo, } \\
\text { S.W. Shim } \\
(2005 \text { p. } 278)\end{array}$ & $\begin{array}{l}\text { Powstający paradygmat public relations i zarządzanie relacjami sprawiają, } \\
\text { że konieczne jest ponowne zdefiniowanie komunikacji wewnętrznej jako } \\
\text { element budowania dobrych relacji między zarządem a pracownikami. }\end{array}$ \\
\hline
\end{tabular}




\begin{tabular}{|c|c|}
\hline Autor & $\begin{array}{l}\text { Definicje, w których autor expressis verbis odniósł definiens do definiendum } \\
\text { komunikacja wewnętrzna }\end{array}$ \\
\hline $\begin{array}{l}\text { H.K. Kalla } \\
(2005, \text { s. 306) }\end{array}$ & $\begin{array}{l}\text { Wszelkie akty komunikacji formalnej i nieformalnej mające miejsce } \\
\text { we wnętrzu organizacji, zachodzące na wszystkich jej poziomach. }\end{array}$ \\
\hline $\begin{array}{l}\text { A. Mazzei } \\
(2010, \text { s. 221) }\end{array}$ & Przepływ wiadomości między ludźmi w obrębie organizacji. \\
\hline $\begin{array}{l}\text { Z. Mikołajczyk, } \\
\text { K. Zimniewicz } \\
(2001, \text { s. 225) }\end{array}$ & $\begin{array}{l}\text { Określa komunikację wewnątrzorganizacyjną przez trzy role, jakie pełni } \\
\text { w zarządzaniu: } \\
\text { - umożliwia kierownikowi kontakty z podwładnymi, z przełożonymi } \\
\text { wyższych szczebli, z klientami i dostawcami itd., } \\
\text { - rola informacyjna polega na przekazaniu wiadomości podwładnym o ich } \\
\text { zadaniach i równocześnie na pozyskaniu od podwładnych informacji, } \\
\text { - rola decyzyjna polega na przekazaniu wiadomości o powziętych } \\
\text { postanowieniach i problemach występujących w zakładzie. } \\
\text { Służy również zbieraniu, segregowaniu i przetwarzaniu informacji } \\
\text { na potrzeby decyzji. }\end{array}$ \\
\hline $\begin{array}{l}\text { S. Oliver (1997, } \\
\text { s. 64) }\end{array}$ & $\begin{array}{l}\text { Wymiana pomysłów, faktów i emocji przez dwie lub więcej osób, z użyciem } \\
\text { słów, liter i symboli, w oparciu o problemy: techniczny (jak dokładnie } \\
\text { symbole mogą być przekazywane), semantyczny (jak właściwie symbole } \\
\text { przekazują żądane znaczenia), skuteczności (jak odbierane znaczenia } \\
\text { wpływają na zachowanie w pożądany sposób). }\end{array}$ \\
\hline $\begin{array}{l}\text { E. Scholes } \\
\text { (1997, s. xviii, } \\
21)\end{array}$ & $\begin{array}{l}\text { Profesjonalne zarządzanie interakcjami między wszystkimi ludźmi } \\
\text { posiadającymi interes lub udział w danej organizacji. Jest sercem organizacji. }\end{array}$ \\
\hline $\begin{array}{l}\text { M. Welch, } \\
\text { P.R. Jackson } \\
(2007, \text { s. } 193)\end{array}$ & $\begin{array}{l}\text { To komunikacja między strategicznymi menedżerami organizacji a jej } \\
\text { wewnętrznymi interesariuszami, mająca na celu promowanie zaangażowania } \\
\text { w organizację, poczucia przynależności do niej, świadomości zmieniającego } \\
\text { się środowiska organizacji i zrozumienie zmieniających się celów } \\
\text { organizacyjnych. }\end{array}$ \\
\hline
\end{tabular}

Źródło: opracowanie własne na podstawie wskazanej literatury.

Komunikacja w organizacji odnosi się do komunikacji i interakcji między pracownikami lub członkami organizacji. W literaturze występują następujące terminy na określenie komunikacji wewnętrznej w firmie - komunikacja wewnętrzna (Van Riel, Blackburn, 1995, s. 13; Forman, Argenti, 2002; Cornelissen, 2004, s. 189) i komunikacja organizacyjna² (Thomas, Stephens, 2015, s. 4), które oznaczają to samo i używane są zamiennie. Komunikacja wewnętrzna bywa również nazwana stosunkami wewnętrznymi (internal relations) (Grunig, Hunt, 1984, s. 240; Cutlip, Center, Broom, 2006) lub wewnętrznym public relations (internal public relations) (Jefkins, 1988, s. 287; Kreps, 1989; Wright, 1995, s. 182; Kennan, Hazleton, 2006). Spotyka się także określenia: komunikacja pracownicza (employee

2 Gail Fann Thomas i Kimberlie J. Stephens (2015, s. 4) wymieniają komunikację biznesową (business communication), komunikację menedżerską (managerial communication), komunikację korporacyjną (corporate communication) i komunikację organizacyjną (organizational communication). 
communication) (Argenti, 1996, s. 94; Smidts, Pruyn, van Riel, 2001, s. 1051), relacje pracownicze (employee relations) (Grunig, Hunt, 1984, s. 240; Argenti, 1996, s. 94; Quirke, 2002, s. 198) i wreszcie komunikacja załogi (staff communication) (Stone, 1995, s. 115). Dla ogólnej orientacji w tabeli 1 przedstawiono sposoby definiowania komunikacji wewnętrznej.

Jak widać, w literaturze występują dwie perspektywy definiowania komunikacji wewnętrznej. Najczęściej autorzy określają komunikację wewnętrzną bardzo ogólnie - jako „zjawisko, które istnieje w organizacji” (Deetz, Tracy, Simpson, 2000, s. 5; Welch, Jackson, 2007, s. 178). Drugie podejście postrzega komunikację wewnętrzną jako „sposób na opisanie i określenie organizacji” (Deetz, Tracy, Simpson, 2000, s. 5). Pierwsze określenie traktuje organizację jako płaszczyznę, na której „dzieje się komunikacja”, podczas gdy w drugim komunikacja jest głównym procesem, przez który pracownicy wymieniają informacje, tworzą relacje, nadają sens, „konstruują” kulturę i wartości organizacji. W procesie tym połączeni są ludzie, wiadomości, znaczenia, praktyki i cele organizacji (Shockley-Zalabak, 1995), jest to podstawa organizacji nowoczesnej (D’Aprix, 1996).

Pierwsze podejście dominuje ilościowo ${ }^{3} \mathrm{w}$ literaturze, ale drugie jest ciekawsze poznawczo, zyskuje szerszą akceptację praktyków, coraz więcej organizacji uznaje kluczową rolę komunikacji w przypadku, gdy musi poradzić sobie ze złożonymi zagadnieniami i szybkimi zmianami w burzliwym otoczeniu i na globalnych rynkach. Interesujące jest także to, iż niektórzy autorzy odróżniają pojęcia komunikacja i efektywna komunikacja (np. Bovée, Thill, 2000) (tabela 1), podczas gdy inni, mówiąc o komunikacji, zawsze odnoszą się do skutecznej komunikacji (np. S. Oliver, 1997).

\subsection{Dotychczasowy stan wiedzy}

Oprócz adaptowania zagadnień komunikacji (społecznej) na potrzeby organizacji nierzadkim zjawiskiem jest osadzanie badań nad komunikacją w organizacji tylko na jednej perspektywie badawczej, rozmaicie klasyfikowanej. Często wyróżniane są w tym kontekście paradygmaty ${ }^{4}$ : mechanistyczny, psychologiczny, interpretacyjno-symboliczny, systemowo-interakcyjny i krytyczny (Fisher, 1978; Krone, Jablin, Putnam, 1987; Littlejohn, 1992; Jablin, 2004, s. 732-818).

3 Na dzień 13 czerwca 2018 roku google scholar podawało 10800 wyników dla frazy communication in organization i tylko 78 dla communication as organization.

4 Bazując na dostępnych w literaturze teoriach organizacji, E. Griffin (2003, s. 263-264) zobrazowat rolę komunikowania się w przedsiębiorstwie na tle pięciu podejść: mechanistycznego, zorientowanego na relacje międzyludzkie, systemowego, kulturowego i politycznego. 
Tabela 2. Przegląd nurtów myślowych w kontekście ich zainteresowania komunikowaniem w organizacji

\begin{tabular}{|c|c|c|}
\hline Podejście & Badacze & $\begin{array}{c}\text { Szczegótowe zainteresowania badawcze nad } \\
\text { komunikowaniem się }\end{array}$ \\
\hline Klasyczne & $\begin{array}{l}\text { F.W. Taylor } \\
\text { H. Fayol } \\
\text { M. Weber } \\
\text { H.L. Le Chatelier } \\
\text { F. Bunker } \\
\text { G. i L. Gilbreth } \\
\text { K. Adamiecki }\end{array}$ & Nie występowało. \\
\hline $\begin{array}{l}\text { Human } \\
\text { relations }\end{array}$ & $\begin{array}{l}\text { E. Mayo } \\
\text { Ch. Bernarda) } \\
\text { McGregor }\end{array}$ & $\begin{array}{l}\text { 1. Znaczenie komunikacji formalnej i nieformalnej dla } \\
\text { organizacji. } \\
\text { 2. Komunikacja kluczem do współpracy. } \\
\text { 3. Zasady teorii X i Y uwidaczniają się w sposobie } \\
\text { komunikowania, głównie w obszarze treści } \\
\text { - nakazy, polecania, rozporządzenia lub zachęcanie, } \\
\text { pobudzanie, mobilizowanie. }\end{array}$ \\
\hline $\begin{array}{l}\text { Szkoła } \\
\text { stosunków } \\
\text { międzyludzkich }\end{array}$ & $\begin{array}{l}\text { M.R. Blake } \\
\text { i J. Mouton } \\
\text { R. Likert } \\
\text { F. Fiedler }\end{array}$ & $\begin{array}{l}\text { 1. Uznanie znaczenia komunikacji wewnętrznej } \\
\text { w organizacji, podkreślenie znaczenia komunikacji } \\
\text { twarzą w twarz. } \\
\text { 2. Nadal dominująca komunikacja w dół struktury } \\
\text { organizacyjnej, ale zauważono potrzebę odpowiedzi } \\
\text { pracowników (feedback), co wpływa na ich ocenę } \\
\text { satysfakcji z pracy. } \\
\text { 3. Zaczęto dodawać elementy społeczne do komunikacji } \\
\text { zorientowanej na zadania. } \\
\text { 4. Komunikacja menedżerska stała się mniej formalna, } \\
\text { ludzi zaczęto traktować jak zasób organizacji. } \\
\text { 5. Organizacje systemu IV Likerta, charakteryzowano } \\
\text { wielokierunkową komunikacją oraz partycypacyjny } \\
\text { styl i strukturę komunikacji, by pobudzać wzrost } \\
\text { wydajności i zmniejszać absencję i rotację. } \\
\text { 6. Podejście zasobowe: komunikacja staje się } \\
\text { wielokierunkowa i relacyjna. Feedback stymuluje } \\
\text { wymianę pomystów i wspomaga rozwiązywanie } \\
\text { problemów. Do treści społecznych i zadaniowych } \\
\text { dodano elementy innowacyjne - kwestie zaufania } \\
\text { i zaangażowania pracowników; organizacje zaczęły } \\
\text { dzielić się z pracownikami komunikatami dotyczącymi } \\
\text { podejmowania decyzji. }\end{array}$ \\
\hline Cybernetyka & $\begin{array}{l}\text { N. Wienerb) } \\
\text { L. von } \\
\text { Bertalanffy } \\
\text { K. Weick }\end{array}$ & $\begin{array}{l}\text { 1. Komunikacja jest „środkiem wiążącym system”, łączy } \\
\text { system z otoczeniem i różne podsystemy względem } \\
\text { siebie, co decyduje o przeżyciu i wzroście organizacji. } \\
\text { 2. Powiązanie podsystemów ułatwia wewnętrzną } \\
\text { stabilność i kontrolę organizacji. Powiązanie całego } \\
\text { systemu z otoczeniem zewnętrznym sprawia, } \\
\text { że komunikacja stymuluje wzrost organizacji } \\
\text { i osiąganie celów. }\end{array}$ \\
\hline
\end{tabular}


Tabela 2 (cd.)

\begin{tabular}{|c|c|c|}
\hline Podejście & Badacze & $\begin{array}{l}\text { Szczegółowe zainteresowania badawcze nad } \\
\text { komunikowaniem się }\end{array}$ \\
\hline Cybernetyka & $\begin{array}{l}\text { N. Wienerb) } \\
\text { L. von } \\
\text { Bertalanffy } \\
\text { K. Weick }\end{array}$ & $\begin{array}{l}\text { 3. Weick korzysta z teorii systemów do wyjaśnienia } \\
\text { zachowań organizacyjnych i procesu nadawania } \\
\text { sensu - „organizacje powołane są do tego, by ciągle } \\
\text { mówić do siebie po to, by dowiedzieć się, co myślą”. } \\
\text { Komunikacja jest procesem rdzennym w organizacji. } \\
\text { Przez informacje, jakie powstają w wyniku procesów } \\
\text { lub wzorów zachowań, systemy mogą poszerzyć swoją } \\
\text { wiedzę i zmniejszyć niepewność złożonego otoczenia, } \\
\text { w którym działają. } \\
\text { 4. Jest niezbędna do wymiany informacji } \\
\text { w podsystemach i między nimi, przez wielokierunkowe } \\
\text { kanały wykorzystywane do komunikacji wewnętrznej. } \\
\text { Proces sprzężenia zwrotnego (feedback) pomaga } \\
\text { systemom dostosować, zmienić i zachować kontrolę. } \\
\text { Powszechne stają się zbiorowe procesy decyzyjne oraz } \\
\text { wspólna odpowiedzialność za komunikację. }\end{array}$ \\
\hline $\begin{array}{l}\text { Podejście } \\
\text { sytuacyjne }\end{array}$ & $\begin{array}{l}\text { E. Schein } \\
\text { T. Deal } \\
\text { i A. Kennedy } \\
\text { Th. Peters } \\
\text { i R. Waterman } \\
\text { J.T. Larkin } \\
\text { i S. Larkin } \\
\text { K. Miller }\end{array}$ & $\begin{array}{l}\text { 1. Podkreślano znaczenie komunikacji twarzą w twarz } \\
\text { i komunikacji nadzoru podczas zmian kulturowych } \\
\text { i innych ważnych inicjatyw organizacyjnych (Larkin, } \\
\text { Larkin). } \\
\text { 2. Podejście opisowe do kultury skupia się na sposobach } \\
\text { komunikacji i interakcji, jakie mogą doprowadzić } \\
\text { do określenia sensu organizacji podzielanego przez } \\
\text { wszystkich jej uczestników. } \\
\text { 3. Komunikację i kulturę łączą wzajemne relacje. } \\
\text { Komunikacja pomaga w tworzeniu kultury i wpływa } \\
\text { na nią przez formalne i nieformalne kanały, historie, } \\
\text { wspólne doświadczenia i działania społeczne. Kultura } \\
\text { wpływa na komunikację, bo pracownicy współdziałają } \\
\text { przez wspólne ramy interpretacyjne kultury, np. przez } \\
\text { charakterystyczne słownictwo w firmie, uznane kanały } \\
\text { medialne oraz ustalone procedury i sposoby działania. }\end{array}$ \\
\hline $\begin{array}{l}\text { Nowe } \\
\text { perspektywy } \\
\text { w komunikacji }\end{array}$ & \multicolumn{2}{|c|}{ 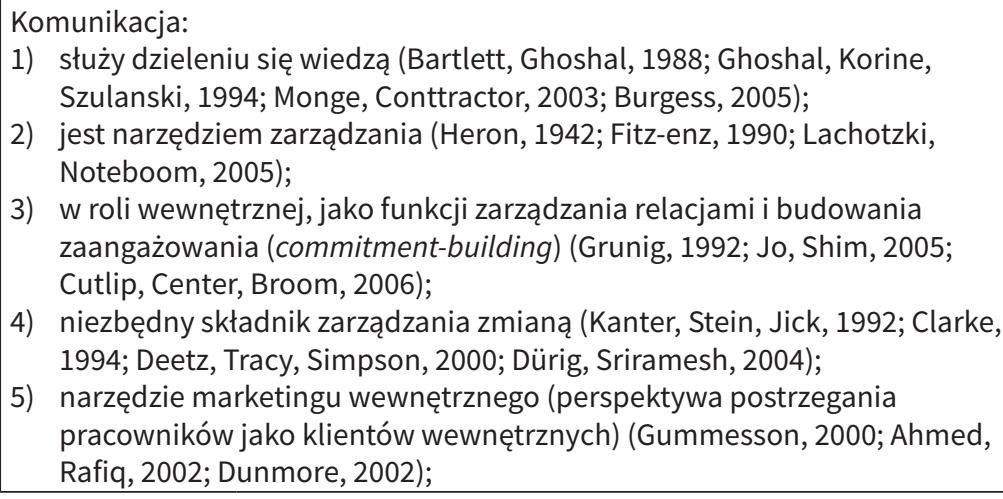 } \\
\hline
\end{tabular}




\begin{tabular}{|c|c|c|c|}
\hline Podejście & & Badacze & \\
\hline & 6) & \multicolumn{2}{|c|}{ 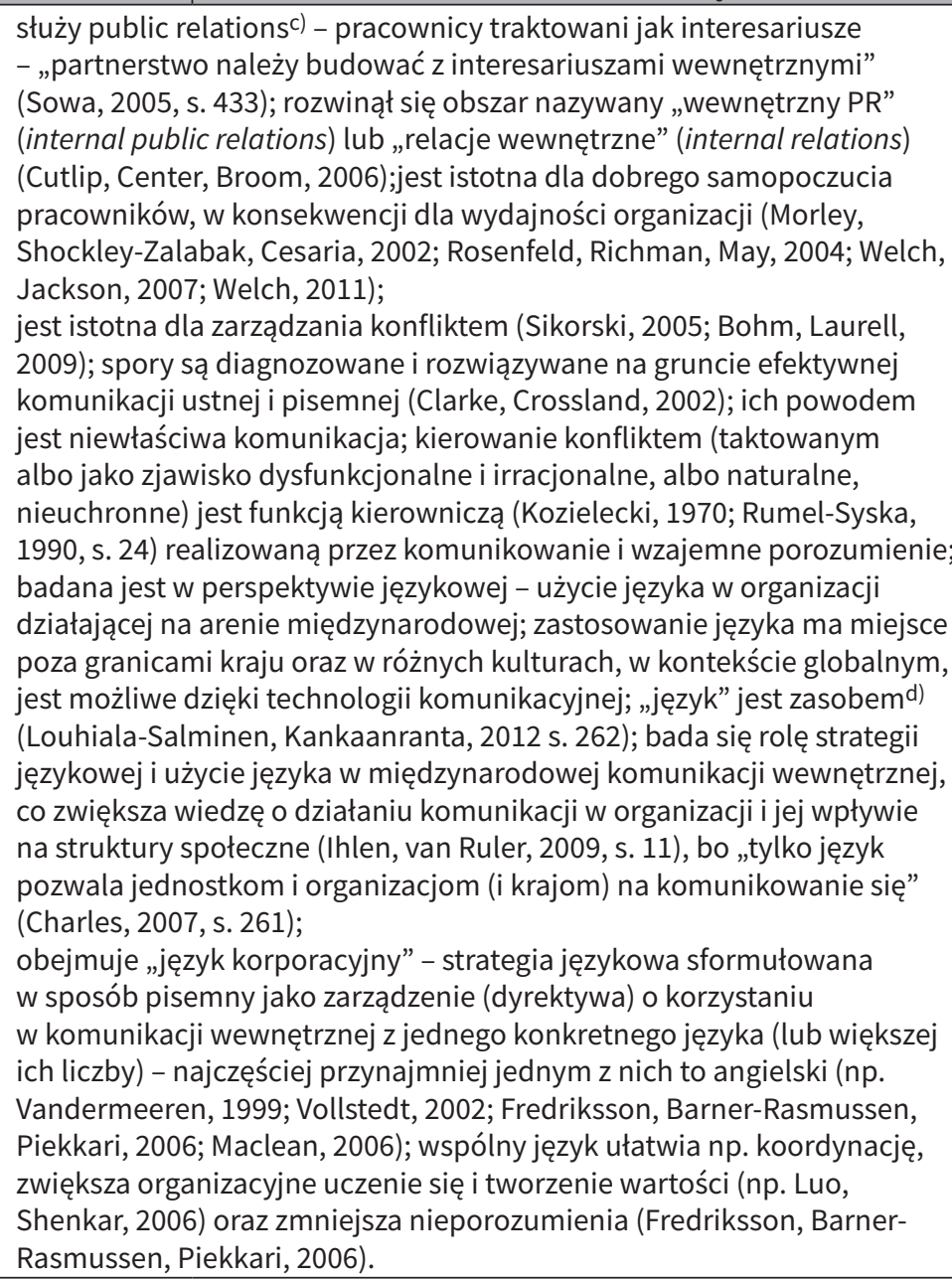 } \\
\hline
\end{tabular}

a) „Najbardziej uniwersalną formą współpracy człowieka i chyba najbardziej skomplikowaną jest mowa” (Barnard, 1938, w: Modaff, DeWine, Butler, 2008, s. 50); b) Praca N. Winera Cybernetyka, czyli sterowanie i komunikacja w zwierzęciu i maszynie (Cybernetics or Control and Communication in the Animal and the Machine) dała początek samodzielnej dyscyplinie naukowej. Tytuł pracy Wienera (1971) jest często traktowany jako pierwsza definicja cybernetyki, której podstawą jest sterowanie układami

(systemami) za pomocą komunikacji (informacyjnych sprzężeń zwrotnych); c) Jeśli istnieje różnica między public relation a corporate communication, to nie na polu komunikacji wewnętrznej (S. Oliver, 1997; Cornelissen, 2008); d) Niektóre wcześniejsze badania podkreślają znaczenie zarządzania językiem jako składnikiem majątku. Według niech rzeczywisty koszt bariery językowej nie może być mierzony w kategoriach tłumaczeń - pisemne i ustne, ale przez zniszczone relacje (Feely, Harzing, 2003).

Źródło: opracowanie własne na podstawie Wiener, 1948, 1961; von Bertalanffy, 1951; 1968; Blake, Mouton, Barnes, Greiner, 1964, s. 133-155; Likert, 1979, s. 147-156; Schein, 1985, 1996; Martyniak, 1993, s. 21-23, 42, 122; Brown, Starkey, 1994, s. 807-828; Larkin, Larkin, 1996, s. 95-104; Miller, 1996; Peters, Waterman, 2011; Modaff, DeWine, Butler, 2008 oraz odniesień wskazanych wewnątrz tabeli. 
W tabeli 2 przedstawiono fragmentaryczne ujęcia komunikacji wewnętrznej $\mathrm{w}$ organizacji w układzie dostosowanym do przedmiotu zainteresowania. W pierwszej fazie rozwoju nauki o organizacji ujęcia częściowe powstawały jako konsekwencja obowiązującego paradygmatu. W latach dziewięćdziesiątych ubiegłego wieku nastąpiło znaczne przyspieszenie rozwoju nauk, co spowodowało rozdrobnienie podejść do komunikacji wewnętrznej i zaowocowało szerokim spektrum perspektyw badawczych.

Obszar badań, jakim jest komunikacja wewnętrzna w organizacji, rozwija się w wyjątkowo szybkim tempie. Elementy wszystkich wskazanych wyżej podejść do komunikacji wewnętrznej w organizacji są w nim widoczne. Sposobów komunikacji w organizacji, a tym samym fragmentarycznych perspektyw badawczych powstało i powstaje wiele, wciąż pojawiają się nowe, koncentrujące się wokół rozmaitych zagadnień.

Początek XXI wieku przyniósł tendencję do szerokiego spojrzenia na komunikację organizacyjną i koncepcje podejścia zintegrowanego do komunikacji wewnątrzorganizacyjnej. Poniżej przedstawiono takie kompleksowe podejścia do komunikacji wewnętrznej.

Hanna Kalla (2005, s. 304-305) identyfikuje cztery dziedziny komunikacji wewnętrznej: komunikacji biznesowej (business communication) - dotyczącej umiejętności komunikacyjnych pracowników, komunikacji zarządczej (management communication) - koncentrującej się na rozwoju umiejętności komunikacyjnych i możliwości związanych z zarządem, komunikacji korporacyjnej (corporate communication) - zogniskowanej wokół komunikacji formalnej oraz komunikacji organizacyjnej (organizational communication) - zaadresowanej do filozofii i zagadnień teoretycznych. Zintegrowana komunikacja wewnętrzna łączy wszystkie cztery obszary, płaszczyzną integracji jest organizacja, natomiast sposobu integracji Kalla nie określa.

Mary Welch i Paul R. Jackson (2007, s. 185) także postrzegają zatrudnionych jako wewnętrznych interesariuszy. Z tej perspektywy komunikacja wewnętrzna jest badana w czterech wymiarach: wewnętrznej komunikacji menedżerów liniowych (internal line management communication), wewnętrznej komunikacji zespołów (internal team peer communication), wewnętrznej komunikacji projektowej (internal project peer communication), wewnętrznej komunikacji korporacyjnej (internal corporate communication).

Fraser Likely (2008, s. 15) przebadał artykuły opublikowane w „Strategic Communication Management” oraz w innych czasopismach zorientowanych na komunikację wewnętrzną, a także materiały konferencyjne i fora tematyczne. Wynikiem tych badań jest określenie pięciu ról, za pomocą których realizowana jest komunikacja organizacyjna: 
1) nadawca (reporter, moderator),

2) nauczyciel (trener, coach),

3) agent zmian,

4) konsultant komunikacyjny (doradca procesu konsultuje wyniki operacyjne),

5) strateg organizacyjny (menedżer relacji).

Badacze często rozróżniają wewnętrzną komunikację od zewnętrznej przez odwołanie się do granic organizacji. Traktują organizację jako system będący stale w interakcji z otoczeniem zewnętrznym (Goldhaber, 1993; Kitchen, 1997; Scholes, 1997; Argenti, Forman, 2002; Cutlip, Center, Broom, 2006). Niemniej, granice organizacyjne są niedokładnym kryterium w definiowaniu komunikacji wewnętrznej. Alessandra Mazzei (2010, s. 222) uważa, że jest prawie niemożliwe, aby odizolować wewnętrzną komunikację od zewnętrznej, bo wszyscy pracownicy są członkami społeczeństw zewnętrznych i odbierają wiadomości z kilkudziesięciu źródeł i kanałów jednocześnie. Pracownicy nie powinni być zaskakiwani, dlatego organizacje muszą przekazywać im komunikaty, zanim dowiedzą się o nich z ogólnego przekazu.

Candace White, Antoaneta Vanc i Gina Stafford (2010) twierdzą, że przewaga konkurencyjna strategicznej komunikacji wewnętrznej pochodzi nie tylko z jej zalet w postaci satysfakcji pracowników i wyższej wydajności, ale wynika również z pozytywnego udziału, jaki wnoszą dobrze poinformowani pracownicy na rzecz komunikacji zewnętrznej - public relations.

Ważne jest zatem, aby menedżerowie mogli oceniać komunikację wewnętrzną. Przeprowadzano badania, które potwierdziły pozytywny związek między komunikacją wewnętrzną a efektywnością organizacji (Hargie, Tourish, 1993; Dickson, Rainey, Hargie, 2003; Quinn, Hargie 2004; Robson, Tourish, 2005). Narzędzia powstałe w latach siedemdziesiątych XX wieku są nadal używane - na przykład Kwestionariusz Satysfakcji z Komunikacji (Communication Satisfaction Questionnaire - CSQ), Audyt Stowarzyszenia ICA (International Communication Association - ICA Audit), Audyt Rozwoju Komunikacji Organizacyjnej (Organisational Communication Development Audit) oraz Skala Komunikacji organizacyjnej (Organisational Communication Scale) (Clampitt, 2009, s. 58-61).

Janusz Czekaj i Bernard Ziębicki (2006, s. 167-175; 2008, s. 5-22) przedstawiają wybrane metody wspomagania audytu systemu komunikowania się w organizacji. Metodykę, którą podają za Calem W. Downsem, złożoną z ośmiu etapów, wzbogacają o dodatkowy etap pozwalający na zwiększenie stopnia obiektywności oceny. Przedstawiona diagnoza systemu komunikacyjnego sprowadza się do zestawienia niesprawności i błędów w procesach informacyjno-komunikacyjnych. Natomiast system komunikacyjny zorientowany jest na integrację procesów informacyjnych i decyzyjnych w organizacjach. Phillip G. Clampitt i Cal W. Downs (1993, s. 10-11) 
określili korzyści z audytu komunikacji organizacyjnej, które obejmują poprawę produktywności, obniżają absencję, podwyższają jakość usług i produktów, podnoszą poziom innowacji, ograniczają skłonność do strajków, obniżają koszty.

Kevin Ruck i Mary Welch (2012) analizowali różne audyty narzędzi komunikacji wewnętrznej, aby ustalić, w jaki sposób naukowcy oceniają komunikację wewnętrzną. Odkryli, że komunikacja odzwierciedla w większym stopniu skupienie na środowisku zarządzających niż nastawienie na pracowników. Pisali, że „możliwości zabierania głosu przez pracowników mogą być znacząco poprawione” (Ruck, Welch, 2012, s. 301). Wiele z obecnych metod oceny skuteczności komunikacji wewnętrznej polega jedynie na analizie treści wiadomości, a nie na jej roli w budowaniu relacji, wspieraniu dialogu i zaangażowaniu w organizacji. Inne badania wykazały, że wirtualne techniki komunikacji wewnętrznej mogą pomóc w pokonaniu tej luki i wspieraniu relacji wzajemnych, na przykład social networking może pomóc w „zapewnieniu ducha zespołu i utrzymaniu kultury niezależnie od miejsca na świecie" (Bennett, Owers, Pitt, Tucker, 2010, s. 139). Ali D. Akkirman i Drew L. Harris (2004) zaobserwowali, że wirtualni pracownicy biurowi wskazywali na wyższy poziom zadowolenia w zakresie osobistych informacji zwrotnych, klimatu komunikacyjnego i relacji z organami nadzoru, co prawdopodobnie spowodowane było dodatkowym wysiłkiem w tworzeniu sieci z odległymi pracownikami. Obowiązkiem firm jest podjęcie dodatkowego kroku i wykorzystywanie komunikacji wewnętrznej dla dobra pracowników, niezależnie, czy sprzyja ona relacjom, czy też zwiększa możliwości współpracy (DeMaria, 2016, s. 71). Liderzy biznesu odgrywają kluczową rolę w promowaniu komunikacji w swoich organizacjach. „Blogowanie umożliwia uczestnictwo w społeczności, które chcesz pielęgnować - niezależnie od tego, czy są to Twoi pracownicy, potencjalni pracownicy, klienci czy ktokolwiek inny" (Napoli, 2006, s. 1). W ten sposób skuteczna komunikacja wewnętrzna może również zwiększyć poziom zaufania pracowników do kadry kierowniczej, przez stworzenie bardziej otwartej i przejrzystej kultury firmy, a w otwartej kulturze, w której komunikowanie pomysłów nie jest moderowane ani ograniczane, najlepsze pomysły wybiją się naturalnie 5 . Kristen DeMaria (2016, s. 73) ustaliła, że narzędzia komunikacji wewnętrznej w badanych przez nią firmach różniły się, spójna była jednie idea otwartej komunikacji. Uczestnicy, zapytani o poziom kontroli sprawowany nad ich narzędziami komunikacyjnymi, opisywali środowisko z bardzo niewielkim nasileniem monitorowania urządzeń komunikacyjnych.

5 Philip M. Napoli (2006) stwierdzit, że teoria ta była częściej wykorzystywana w kontekście deregulacyjnym niż w kontekście proregulacyjnym, co sugeruje ruch w kierunku bardziej otwartych form komunikacji. 


\subsection{Komunikacja jako zjawisko w środowisku organizacji}

Komunikacja w organizacji jest szeroko i drobiazgowo opisywana w pracach o komunikacji w zarządzaniu, w których ogólny proces komunikowania między ludźmi jest dostosowany do warunków panujących w przedsiębiorstwie. Organizacja jest zatem traktowana jako kontekst, a jednocześnie jako środowisko, w którym dzieje się komunikowanie.

$\mathrm{W}$ pracach tych proces komunikowania definiowany jest w rozmaity sposób - jako „dynamiczny dwustronny proces” (Stankiewicz, 2006, s. 44), „porozumiewanie się ludzi” (Potocki, 2001, s. 10), „nadawca przesyła wiadomość do odbiorcy, na którym wywiera ona jakiś efekt” (Lasswell, 1948, s. 37), „wymiana informacji i przekazywanie znaczeń" (Katz, Kahn, 1979, s. 346). Z punktu widzenia celu tego opracowania na szczególną uwagę zasługuje definicja komunikowania Urszuli Gros (1994, s. 69): jest to „główny proces organizacyjny polegający na wymianie informacji między różnymi uczestnikami [...]” [podkr. M.Z.-T.]. Istotne są tutaj dwa warunki - komunikacja odbywa się między ludźmi6, a sprzężenie zwrotne ${ }^{7}$ występuje jako konieczny i niezbędny warunek istnienia procesu. W niniejszym opracowaniu przyjęto założenie, że spełnienie obu warunków pozwala taki proces nazywać komunikowaniem lub komunikacją.

Mimo rozmaitości definicji proces komunikowania, według tego podejścia, jest traktowany jako sui generis transmisja informacji, wiadomości (Kulczycki, 2011). Komunikację społeczną adaptuje się na potrzeby komunikowania wewnątrzorganizacyjnego, elementy procesu są zatem rozpatrywane osobno, w sposób liniowy i zawężane do potrzeb organizacji - przedstawia się takie elementy, jak nadawca, odbiorca, komunikat, kod, kanał, zakłócenia, luka informacyjna, sprzężenie zwrotne i układ odniesienia (Potocki, 2001, s. 11-22; Fiske, 2003, s. 47-49; Gros, 2003, s. 149-151; Potocki, Winkler, Żbikowska, 2003, s. 35-47; Sobkowiak, 2005, s. 112; Stankiewicz, 2006, s. 51-60; Morreale, Spitzberg, Barge, 2007, s. 31; Kozyra, 2008; Rozwadowska, 2011, s. 124-130; Ober, 2013) oraz kodowanie i dekodowanie (Gros, 1994, s. 70; Sikorski, 2005, s. 82). Stąd konsekwentnie nadawcą i odbiorcą jest przełożony i podwładny, zależnie od kierunku komunikacji (Gronbeck, German, Ehninger, Monroe, 2001, s. 27; Schulz, von Thun, 2001; Fiske, 2003, s. 60-61; Potocki, Winkler, Żbikowska, 2003, s. 36; Schulz, von Thun, Ruppel, Stratmann, 2004). Komunikat jest strukturą, na którą składają się znaczenie, znaki, symbole, forma;

6 „[...] komunikacja może mieć jedynie charakter relacji między jednostkami, bo tylko jednostka potrafi zakodować i odkodować wiadomość" (Sikorski, 2005, s. 82).

7 W literaturze w rozmaity sposób określa się pojęcia: komunikowanie, komunikowanie się i informowanie. Arkadiusz Potocki (2001, s. 10) uważa „komunikowanie” za proces jednostronny, a „komunikowanie się” za dwustronny, któremu przysługuje sprzężenie zwrotne. 
przyjmuje postać informacyjną i perswazyjną (Jowett, O’Donnell, 1989, s. 22; Szymanek, 2004, s. 228-234; Morreale, Spitzberg, Barge, 2007, s. 39). Kodowanie polega na przekształceniu wiadomości w symbole i obrazy, a nadawca stara się zapewnić podobieństwo znaczeń, dobierając je tak, aby jego zdaniem niosły tę samą treść dla odbiorcy (Knapp, Hall, 2000, s. 24-25; Potocki, Winkler, Żbikowska, 2003 s. 39-40). Istotne dla celu pracy staje się zatem rozróżnienie treści (ogólnego sensu tego, co jest przekazywane - np. przekazanie imperatywu do realizacji zadania) od formy przekazywanej treści (np. forma natężenia imperatywu: prośby, polecenia, rozkazu).

Dekodowanie polega na odebraniu komunikatu, a następnie jego interpretacji (Grzesiuk, 1988, s. 26; Grzesiuk, Korpolewska, 1988, s. 24; Baran, Davis, 2007, s. 31). Natomiast kanałem komunikacyjnym jest sposób porozumiewania się nadawcy i odbiorcy (Gros, 1993, s. 11), inaczej mówiąc - jest to „droga”, wszelkie środki techniczne wykorzystane do przekazywania komunikatu (Rozwadowska, 2011, s. 124-130).

Cel komunikacji społecznej to wymiana myśli, dzielenie się wiedzą, informacjami i ideami, wywołanie określonego skutku. Przeniesienie komunikacji społecznej na płaszczyznę organizacji powoduje „doprecyzowanie kontekstu” i narzuca odnoszenie wskazanych elementów i ich zawartości merytorycznej do płaszczyzny organizacji.

Z perspektywy społecznego komunikowania, zaadaptowanego na potrzeby organizacji (Czarniawska, 2010; Czakon, 2017), pojawia się wiele koncepcji, podziałów, wyróżnień i uporządkowań. W literaturze przedstawia się najczęściej pięć poziomów komunikacji - wewnątrzosobową, interpersonalną, grupową, międzygrupową i organizacyjną (Goban-Klas, 1999, s. 31-32; Nęcki, 2000, s. 94-96; Dobek-Ostrowska, 2004, s. 109-120; Singh, 2014). Przedstawia się podział komunikacji na formalną, zgodną ze strukturą organizacyjną, a dokładniej tożsamą z więziami zależności służbowej i funkcjonalnej w organizacjach o strukturze typu klasycznego, tradycyjnego lub zgodnie z przebiegiem podstawowego procesu, oraz komunikację nieformalną, występującą obok formalnej, ale nieprzestrzegającą takich zależności. Pojawia się także określenie - chyba bardziej oddające jej istotę - komunikacja rzeczywista. Stanowi ona połączenie obu poprzednich, struktury organizacyjne zmieniają się bowiem wolniej niż komunikacja między ludźmi w tych strukturach i organizacjach.

Specyficzne typy komunikacji z punktu widzenia organizacji to komunikowanie w dół, w górę, horyzontalne i diagonalne. Nie są one typami komunikowania społecznego odniesionego do płaszczyzny organizacji, ale są dla niej właściwe. Mają one bowiem odzwierciedlać szeroko rozumianą strukturę i typ organizacji. W tym kontekście często prezentowane są zatem sieci komunikacji wewnątrz organizacji, takie jak na przykład łańcuch, koło wozu, „Y”, każdy z każdym, okrąg8. Typ organizacji w zasadzie narzuca wykorzystywany typ sieci komunikacyjnej.

8 Wymienione wyżej sieci zostały wyodrębnione w latach pięćdziesiątych XX wieku. Alex Bavelas (1950, s. 725-730) badał pięcioosobowe zespoły, Keith Davis (1953a, s. 84-90; 1953b, 
Wskazuje się także na funkcje komunikatów przekazywanych w organizacji ${ }^{9}$. Popularny podział przedstawili Ramon J. Aldag i Timothy Stearns (1987, s. 490), kategoryzując komunikaty w podziale na funkcje jako informacyjne, motywacyjne, kontrolne i emotywne. Mehmet Altınöz (2008, s. 627-628) zaproponował podział ze względu na funkcje: dostarczenia informacji, przekonywania i wpływu, wspierania ${ }^{10}$ oraz unifikacji. Przytacza on także podział, którego autorami są Scott i Mittchel (bez stosownego odwołania), dzielący funkcje komunikacji w organizacji na kontrolną, motywacyjną, wyrażania emocji i przekazywania informacji (w zasadzie tożsame z propozycją Aldaga i Stearnsa).

Konsekwencją przyjętej definicji komunikacji jako procesu porozumiewania się ludzi lub jako przekazywania wiadomości, treści, wymiany znaczeń przeniesionych na płaszczyznę organizacji jest to, że proces komunikowania odnosi się wyłącznie do osób, żadna zatem, nawet najdoskonalsza maszyna ucząca się nie może w tym zakresie zastąpić człowieka jako podmiotu procesu. Ponadto proces ten jest relacją wzajemną, realizowaną przez przepływ komunikatów w obie strony (dwustronną, często mówi się o sprzężeniu zwrotnym jako warunku konstytuującym proces komunikacji, którego spełnienie gwarantuje właśnie wzajemność przekazu). Za sprawność procesu komunikowania w organizacji odpowiada poziom realizacji wzajemnych relacji między elementami procesu, nie zaś realizacji tych elementów w oderwaniu od siebie. Na koniec niezbędna jest także określona treść przekazu, jego zawartość merytoryczna odniesiona do środowiska organizacji (ważne jest także dołączenie do tej kategorii pytań - one również zawierają treść, bo pyta się o coś). Te trzy elementy - z perspektywy celu pracy - pozwalają na to, aby mówić o procesie komunikowania.

Transmisyjny charakter komunikacji, koncentrujący się na komunikacji jako przekazywaniu $^{11}$ znaczeń (informacji, wiedzy, uczuć), jest często opisywany

s. 301-312; 1969, s. 269-272) nie ograniczył liczby uczestników. Od tamtego czasu ich prace są cytowane przez rozmaitych autorów, w Polsce przez wtórne odwołanie do popularnego podręcznika Ricky'ego W. Griffina (2002, s. 563-565), nie zaś do ich pierwotnych opracowań (nazwisko Bavelas jest tam wymienione błędnie jako Vavelas). Inni autorzy (np. Mishra, 1990, s. 213-228) odnoszą się bezpośrednio do badań Davisa, popularyzując je bardziej niż rozwijając. Można przypuszczać, że od czasu wskazanych badań Bavelasa i Davisa nie przeprowadzono badań pogłębionych w tym obszarze. Przykład stanowić może Faris Alwzinani (2017).

9 Ta klasyfikacja odnosi się do organizacji. Istnieje wiele innych klasyfikacji podstawowych funkcji komunikatów - z punktu widzenia na przykład psychologii społecznej (Kurt Lewin), informacji i łączności (Claude Shannon i Warren Weaver), semiotyki (Roman Jacobsen) itp. (więcej o tym zob. Zalewska-Turzyńska, 2012, s. 63-84).

10 „Wspieranie” (communication for training) w jego koncepcji ma na celu ksztattowanie zachowań podwładnych, aby ich działania były spójne z celami organizacji (Altınöz, 2008, s. 628).

11 Za sztandarowe modele takiego stanowiska należy uznać na przykład modele Shannona-Weavera, Lasswella, Berlo itp. 
w literaturze z zakresu zarządzania - zwłaszcza w pracach Bogusławy Dobek-Ostrowskiej (2004), Henryka Mruka (2004), Janiny Stankiewicz (2006), Aleksego Pocztowskiego (2008) i innych. Takie podejście, rozpatrywane w kontekście organizacji, ułatwia analizę elementów procesu, kontekst jest bowiem ustalony - organizacja. Kontekst określa interpretację pozostałych elementów procesu - nadawcą może być zatem przełożony, podwładny lub współpracownik, tak samo jak odbiorcą. Niemniej jednak istnieją naukowcy, którzy dystansują się od takiego podejścia (Wendland, 201212, s. 139) - zarzucają oni głównie abstrahowanie od kontekstu sytuacyjnego (zanurzenie w kontekście społeczno-kulturowym w ładzie aksjonormatywnym) oraz brak „przeźroczystości”13 i neutralności medium (Kulczycki, 2011, s. 4). Powstaje zatem odmienny sposób opisu, analizy i badania komunikowania w organizacji, wskazany poniżej.

\subsection{Komunikacja jako sposób na tworzenie organizacji}

Według tej perspektywy „działalność komunikacyjna jest organizacją” (Weick, 1995, s. 75). W ostatnich latach pojawiła się znaczna liczba publikacji, które poważnie wspierają twierdzenie Karla E. Weicka, uznając konstytutywną rolę komunikacji w organizacji (CCO ${ }^{14}$ - communication constitutes organization - Cooren, Taylor, 1997; Ashcraft, Kuhn, Cooren, 2009; Putnam Nicotera, 2009; Cooren, Kuhn, Cornelissen, Clark, 2011; Brummans, Cooren, Robichaud, Taylor, 2014), oraz fakt, że komunikacja w zasadzie stanowi rzeczywistość społeczną (Craig, 1999). Zwolenników tej perspektywy teoretycznej jednoczy myśl, że organizacje są powoływane i utrzymywane w praktyce komunikacyjnej i przez nią (Cooren, Kuhn,

12 Michał Wendland (2012) oraz Emanuel Kulczycki (2011) piszą o komunikacji w kontekście „komunikologii” jako o samodzielnej dyscyplinie naukowej. Natomiast w niniejszej pracy komunikacja pełni rolę służebną w organizacji - jest narzędziem sprawnego zarządzania organizacjami. Jest narzędziem niezbędnym i ważnym, warunkującym powodzenie organizacji, jednak niezależnie jak ważnym - tylko narzędziem, co autorka pragnie w tym miejscu podkreślić.

13 „Rola środków przekazu (mediów) sprowadza się nie tylko do samego przekazywania treści, lecz przede wszystkim do zmian w obszarze form świadomości społecznej i sposobach funkcjonowania społeczeństw. W kontekście rozważań Waltera Onga, Harolda Innisa, Jacka Goody'ego czy Marshalla McLuhana ciężko przyjąć założenie o przeźroczystości środków przekazu" (Kulczycki, 2011, s. 5 przypis 3).

14 Koncepcja CCO (communication constitutes organization) jest jeszcze nieugruntowana w publikacjach polskich, dlatego w tym rozdziale skorzystano wyłącznie z piśmiennictwa anglojęzycznego. Z tego powodu dla potrzeb niniejszej pracy proponuje się tłumaczenie „komunikacja tworzy organizację” (KTO), najczęściej jednak używany jest oryginalny skrót, który jest rozpoznawalny w światowej literaturze. 
Cornelissen, Clark, 2011). Perspektywa CCO pochodzi z interdyscyplinarnego obszaru badań komunikacji organizacyjnej (Putnam, Nicotera, 2008).

Theresa R. Castor podkreśla, że:

[...] naukowcy zajmujący się komunikacją organizacyjną [...] stają się coraz bardziej zainteresowani komunikacją jako konstytutywną perspektywą organizacji (CCO), która uważa organizacje za skonstruowane społecznie poprzez komunikację (as socially constructed through communication) (Castor, 2005, s. 480).

Podejście CCO (np. Taylor, 2000; Kuhn, 2008) dotyczy jednego z najbardziej fundamentalnych pytań w badaniach organizacji: „Czym jest organizacja?”. Odpowiadając na nie uczeni CCO próbują radykalnie zmienić perspektywę. Odrzucają takie podejście, według którego organizacje są tworzone przez ich członków - „organizacje to przede wszystkim zbiór ludzi, a wszystko, co robią organizacje, robią ludzie” (Simon, March, 1958, s. 110). Zamiast tego przedstawiają płynne i procesowe pojęcia organizacji, które stanowią efemeryczne akty komunikacji: „Organizacja nie jest strukturą fizyczną - zbiorem ludzi (lub komputerów), połączonych przez istotne kanały komunikacji, ale konstrukcją powstałą z rozmowy" (Taylor, 1993, s. 22). Wynika z tego, że jeśli organizacje są rozumiane przede wszystkim jako zjawiska komunikacyjne, wiedza z badań nad komunikacją prawdopodobnie przyspieszy badania organizacji (Putnam, Phillips, Chapman, 1996).

Ogólnie rzecz ujmując, perspektywa CCO jest raczej niejednolitym teoretycznym przedsięwzięciem, chociaż jego główni zwolennicy przyjmują podstawę teoretyczną, że rzeczywistość jest konstytuowana komunikacyjnie (Craig, 1999; Cooren, 2012), co obejmuje również organizacje (Luhmann, 2000; McPhee, Zaug, 2000; Taylor, Van Every, 2000).

Karen Lee Ashcraft, Timothy R. Kuhn i Francois Cooren w 2009 roku przedstawili przegląd powstającej perspektywy CCO „szkoły montrealskiej” (np. Taylor, Van Every, 2000; Cooren, Taylor, Van Every, 2006) oraz teorii strukturyzacji (np. McPhee, Poole, 2001; McPhee, Zaug, 2008).

Pięć lat później, w 2014 roku, Boris H.J.M. Brummans, Francois Cooren, Daniel Robichaud, i James R. Taylor (2014, s. 174) wyodrębnili trzy szkoły: szkołę montrealską (the Montreal School of Organizational Communication) (np. Taylor, Van Every, 2000; 2011; Cooren, Taylor, Van Every, 2006), oparty na teorii strukturalnej Giddensa model czterech przepływów (Four-Flows Model) (McPhee, Zaug, 2000) i teorię systemów społecznych Luhmanna (Luhmann's Theory of Social Systems) (np. Luhmann, 2003; Seidl, Becker, 2005). Ashcraft, Khun i Coorin (2009) wymienili wiele innych prac jako „domyślnych” przedstawicieli perspektywy CCO (np. Monge, Contractor, 2003; Deetz, 2005), tym niemniej poniżej skoncentrowano się 
na tych trzech szkołach jako na głównych przedstawicielach tego, co ich autorzy nazywają „wyraźną” perspektywą CCO.

Mimo że trzy szkoły mają pewne założenia bazowe, na przykład o formatywnym charakterze używania języka, znacznie różnią się pod innymi względami - między innymi w kwestiach odpowiednich metod empirycznych oraz roli podmiotów ludzkich i pozaludzkich w CCO. Ponadto perspektywa CCO została skrytykowana za wydawanie zbyt śmiałych twierdzeń ontologicznych, które nie różnicują w wystarczającym stopniu rodzajów komunikacji u tworzących organizację (Bisel, 2010), a także za niejasne wskazanie, co odróżnia organizacje od innych podmiotów społecznych, takich jak „ruchy” czy „społeczności” (Sillince, 2010). W odpowiedzi na te krytyczne uwagi Dennis Schoeneborn, Steffen Blaschke, Robert D. McPhee, David Seidl oraz James R. Taylor (2014, s. 287) proponują zaangażowanie się w dalsze prace teoretyczne na przecięciach trzech głównych szkół myślenia CCO i wyznaczenie wspólnej płaszczyzny, na której można zbudować jednolitą perspektywę CCO.

Na szczególną uwagę, w kontekście podejścia prezentowanego przez autorkę w niniejszej pracy, zasługują trzy twierdzenia wybrane spośród prezentowanych według szkół CCO, dotyczące izomorfizmu, wytwarzania komunikacji i genezy zjawiska.

Przede wszystkim istotne jest założenie izomorficznego lub równoważnego związku między organizacją a komunikacją (Taylor, 1995), co pozwala traktować „komunikację i organizację jako jedność monastyczną lub jako to samo zjawisko, wyrażone w różny sposób. Oznacza to, że komunikowanie jest organizowaniem i organizowanie jest komunikowaniem: dwa procesy są izomorficzne” (Putnam, Philips, Chapman, 1996, s. 375).

Podstawowe rozróżnienie (po komunikacyjnej stronie równoważności) dotyczy modalności tekstu i rozmowy:

Wymiar tekstu odpowiada powtarzającym się, dość stabilnym i bezspornym aspektom komunikacji (tj. „powierzchni” organizacji - the organization's 'surface'), a wymiar konwersacyjny odnosi się do żyjącej i rozwijającej się ko-konstruktywnej strony komunikacji (tzn. „wnętrza organizacji” - the 'site' of organization)” (Ashcraft, Khun, Cooren, 2009, s. 20).

W społeczno-konstruktywistycznym rozumieniu organizacji Taylor i Cooren uznają, że organizacja to przemienny ciąg epizodów rozmowy (gdzie organizację osiąga się na miejscu) i tekstualizacji (gdzie organizacja jest „wcielona” jako rozpoznawalny aktor, tworząc oryginalne przedstawienia samego siebie). Ten radykalny pogląd jest związany z założeniem, że organizacja występuje wyłącznie 
na poziomie bieżących procesów konwersacji-tekstu, a zatem „nie ma innego istnienia niż dyskurs" (Cooren, Taylor, 1997, s. 429).

Jednak w tej konceptualizacji organizacji kluczowe pozostaje pytanie ${ }^{15}$ : „Jaka szczególna forma komunikacji sprawia, że komunikacja jest organizacyjna?” (Cooren, Taylor, 1997, s. 409). Odpowiedź na to pytanie sprawia, że konceptualizacja organizacji według szkoły montrealskiej została skrytykowana za swoją nieprecyzyjność. Krytykę taką podjęli przede wszystkim przedstawiciele perspektywy związanej z teorią strukturyzacji (np. McPhee, Poole, 2001; McPhee, Zaug, 2008).

Przeciwdziałając pojęciu izomorficznej równoważności między organizacją a komunikacją, opierają się oni na podstawowej metaforze wytwórczej, twierdząc, że organizacje wytwarzają komunikację i są wytwarzane przez komunikację (wzorowane na Giddensowskiej teorii dualności struktury i teorii agencji - Giddens, 1984, 2003; Jones, Karsten, 2008). Na przykład Robert D. McPhee i Marshall Scott Poole, wyrażając poparcie dla prac Taylora, piszą, że:

Jedno z ograniczeń podejścia Taylora i innych polega na tym, że próbuje ono używać pojęć komunikacyjnych mających zastosowanie do wszystkich interakcji, być może pod wpływem idei, że jeśli organizacja i komunikacja są równoważne, to każda komunikacja powinna być organizacyjna. Ponieważ te pojęcia muszą [...] mieć zastosowanie do małżeństw, tłumu i społeczności ${ }^{16}$, które komunikują się ze sobą, utrudnione jest znalezienie kluczowych pojęć wyjaśniających konkretnie pojęcie komunikacji organizacyjnej (McPhee, Poole, 2001, s. 534).

W podobnym tonie Robert D. McPhee i Pamela Zaug (2008) kwestionują ideę, że każda forma komunikacji ma nieodłączną konstytutywną zdolność do tworzenia organizacji. Proponują w zamian rozróżnienie czterech rodzajów komunikacji

15 W zasadzie powstają trzy pytania wzajemnie ze sobą powiązane. Jeśli sugeruje się koncepcję komunikacji jako niezbędny, ale ostatecznie niewystarczający warunek powstania organizacji (McPhee, Zaug 2008; Bisel, 2010), po pierwsze powstaje pytanie o to, co sprawia, że komunikacja jest organizacyjna. Po drugie, ściśle związane z pierwszym - jeśli organizacje są zdefiniowane jako składające się z czegoś tak ulotnego jak komunikacja, to w jaki sposób są ustabilizowane w czasie (Cooren, Fairhurst, 2008). I wreszcie, co odróżnia organizacje od innych form zjawisk społecznych, takich jak sieci, społeczności czy ruchy spoteczne (Sillince, 2010). Rozmaici autorzy prezentują obecnie szeroką wymianę myśli i polemik w celu odpowiedzi na zarysowane pytania (np. Bisel, 2010; Putnam, Nicotera, 2010; Sillince, 2010).

16 John A.A. Sillince (2010) twierdzi, że model czterech strumieni opracowany przez McPhee i Zaug (2008) może mieć zastosowanie do wszystkich tych form. Dlatego Sillince wzywa do sformułowania bardziej dokładnej definicji i określenia cech charakterystycznych dla organizacji. 
(także typów wiadomości, typów relacji i odbiorców - audiences) (McPhee, Zaug, 2008, s. 21) niezbędnych do utworzenia organizacji, nazywanych „przepływami”:

1) organizacje często wyraźnie rozróżniają swoich członków i nieczłonków, co pociąga za sobą nieustanne negocjacje przynależności (membership negotiation);

2) organizacje pociągają za sobą komunikacyjne procesy refleksyjnej samostrukturyzacji, co z kolei odróżnia je od luźnych form spotkań społecznych;

3) organizacje postępują zgodnie z co najmniej jednym wyraźnie określonym celem, który służy im jako „szablon” komunikacyjnych procesów koordynacji działań (activity coordination);

4) organizacje nie działają w próżni, ale są w całości włączone do społeczeństwa.

W ten sposób organizacje same również generują (a jednocześnie są kształtowane przez) złożone procesy komunikacyjne, instytucjonalne pozycjonowanie, dzięki którym negocjowany jest ciągle status organizacji przez interakcje z interesariuszami. Te cztery przepływy należy jednak traktować jako „miękki zestaw kryteriów, a nie jasną definicję tego, co czyni komunikację organizacyjną” (McPhee, Zaug, 2008; Schoeneborn, 2011, s. 673, 670-763).

Francois Cooren i Gail T. Fairhurst (2008), sympatycy szkoły montrealskiej, odpowiadają na powyższe zarzuty McPhee i Zaug (2008), twierdząc, że ich model czterech przepływów przyjmuje zbyt redukcyjne, odgórne stanowisko wobec organizacji:

Na przykład grupa osób może się zorganizować, aby osiągnąć wspólny cel (na przykład: „poruszać się”17) i rozwijać pewne wzorce interakcji, ale to niekoniecznie oznacza, że grupa ta stanowi oficjalną organizację (na przykład przemieszczająca się firma). Mogły po prostu być grupą przyjaciół, starającą się pomóc jednemu z nich w poruszaniu się (Cooren, Fairhurst, 2008, s. 121).

Cooren i Fairhurst (2008) proponują zastosowanie perspektywy oddolnej. Organizacja powinna być postrzegana jako zjawisko wschodzące, zakorzenione fundamentalnie w interakcjach lokalnych. Dlatego najważniejsze pytanie dotyczy tego, w jaki sposób lokalne i ulotne interakcje są przetwarzane w długotrwałe i stabilne formy organizacji: „To jest to źródło stabilności, które należy odsłonić” (Cooren, Fairhurst, 2008, s. 123). W odpowiedzi podkreśla się znaczenie tekstowej i pozaludzkiej agencji dla procesów organizacji. Podmioty nieludzkie są postrzegane tutaj jako czynniki zdolne do działania, ze względu na ich obecność

17 Użyte w oryginalnym tekście angielskie określenie moving oznacza „być w ruchu” lub „być aktywnym". W przedstawionym tłumaczeniu chodziło bardziej o oddanie sensu wypowiedzi niż o puryzm językowy. 
i szczególne konfiguracje. Podawane są następujące przykłady: „PDA przypomniała mi o spotkaniu” (Cooren, 2006, s. 84-85), oznaczenie na drzwiach restauracji, w której odbywa się impreza prywatna, które prawdopodobnie powstrzyma innych przed wejściem ${ }^{18}$ (Schoeneborn, 2011, s. 673).

Teoria systemów społecznych Niklasa Luhmanna19 $(1989 ; 1992 ; 1995 ; 2000)$ została zaadaptowana na potrzeby wyjaśnienia niedostatków szkoły montrealskiej (Bakken, Hernes, 2003; Hernes, Bakken, 2003; Nassehi, 2005; Seidl, Becker, 2005; 2006). Luhmann wyróżnia trzy podstawowe typy autopojetycznych ${ }^{20}$ systemów społecznych (Luhmann, 1986, s. 173):

1) interakcje - najmniejsza i najbardziej nieuchwytna forma spotkań społecznych na poziomie mikro;

2) organizacje jako bardziej sformalizowane i stabilne systemy społeczne na poziomie mezo;

18 Choć okoliczności mogą się różnić, podmioty pozostają stałe w czasie, ponieważ odrywają się od intencji ich twórców i kontekstu ich tworzenia. W odniesieniu do organizacji można by powiedzieć, że w efekcie organizacje powstają dzięki różnym formom agencji pozaludzkich (por. Latour, 1994), które umożliwiają zmianę miejsca, a tym samym utrwalenie jego istnienia. W tym kontekście perspektywa CCO kieruje uwagę na socjologię jako warunek stabilizacji organizowania (Cooren, 2006; Orlikowski, 2007). Zmiany w praktykach socjomaterialnych, na przykład wprowadzenie nowych mediów i rodzajów komunikacji organizacyjnej (Yates, Orlikowski, 1992), zasadniczo mają wpływ na utrwalenie organizacji. Cooren wyjaśnia powyższe w następujący sposób: „Różne typy agencji są zwykle tworzone i mobilizowane, aby realizować organizację (aby wymienić tylko kilka: wykresy organizacyjne, umowy, rejestry, kamery nadzoru, statusy, listy kontrolne, zamówienia, notatki itp.). [...] Organizowanie może być więc rozumiane jako zjawisko hybrydowe, które wymaga zmobilizowania podmiotów [...], które przyczyniają się do powstania i ustalenia formy organizacji” (Cooren, 2006, s. 83).

19 „Projekt życia” Luhmanna polegał na opracowaniu uniwersalnych ram teoretycznych, które można zastosować do wszystkich zjawisk społecznych i umożliwiających opisy spójne z teorią. Wyrażając swoje idee na temat systemów społecznych, Luhmann (1995) zaczyna od komunikacji jako podstawowego elementu domeny społecznej. Pod tym względem teoria systemów społecznych (TSS) prowadzi do intuicyjnego przekonania, że istoty ludzkie są częścią środowiska procesów komunikacyjnych (Luhmann, 1992, s. 30). Innymi słowy, Luhmann wprowadza wyraźne rozróżnienie między komunikacją („systemami społecznymi”) a poszczególnymi ludźmi („systemami psychicznymi”): „W związku z tym systemy społeczne nie obejmują osób i działań, ale komunikację" (Luhmann, 1989, s. 145). Mimo tego raczej bezosobowego rozumienia systemu społecznego jako komunikacji wzajemnej, Luhmann uważa, że procesy komunikacji i indywidualne procesy myślowe są wzajemnie zależne (Luhmann, 1992, s. 281).

20 Kluczem do zrozumienia komunikacji Luhmanna jest jego pojęcie autopojezy. Luhmann zakłada, że domena społeczna składa się z różnych systemów autopojetycznych, które reprodukują się samorzutnie na podstawie bieżących procesów komunikacyjnych: „społeczne systemy wykorzystują komunikację jako swój szczególny tryb reprodukcji autopojetycznej. Ich elementami są komunikacje, które są rekursywnie produkowane i reprodukowane przez sieć łączności, a które nie mogą istnieć poza siecią" (Luhmann, 1986, s. 174). 
3) całe społeczeństwo, które obejmuje wszystkie formy systemów społecznych na poziomie makroekonomicznym, które można dalej zróżnicować w różne podsystemy funkcjonalne, takie jak system polityczny, system gospodarczy, system prawny itd.

Organizacja, jak wszystkie systemy społeczne, składa się zasadniczo z komunikacji. W związku z tym jest ona konceptualizowana jako system autopojetyczny złożony z połączonych ze sobą wydarzeń komunikacyjnych. Dlatego organizacja istnieje tylko wtedy, gdy udaje się jej „wytwarzać” dalszą komunikację, która wymaga jeszcze „większej komunikacji”. Powstaje pytanie - „Jak organizacje utrzymują swoją egzystencję od jednego zdarzenia komunikacyjnego do następnego?”. Luhmann koncentruje się na decyzjach jako konstytutywnym elemencie organizacji wywodzącym się z wieloletniej tradycji w badaniach organizacji. Przypisuje decyzjom radykalny charakter komunikacyjny ${ }^{21}$ : „Luhmann sugeruje koncepcję decyzji jako konkretnej formy komunikacji. To nie decyzje są najpierw tworzone, a następnie przekazywane; decyzje to komunikacja" (Seidl, 2005, s. 39).

$\mathrm{W}$ tabeli 3 syntetycznie przedstawiono porównanie 22 trzech szkół perspektywy CCO.

Mimo że wymienione podejścia różnią się między sobą, przyświeca im najważniejsza dla treści niniejszej pracy idea, że komunikacja tworzy organizację. Czy powstanie jedna, spójna koncepcja - dziś trudno powiedzieć, różnice między poszczególnymi koncepcjami są bowiem znaczące. Tym niemniej podejście, w którym komunikacja konstytuuje organizacje, bliskie jest autorce niniejszego tekstu.

W tej pracy zdecydowano się jednak przyjąć inne narzędzie badawcze, zapożyczone nie z socjologii, ale z teorii systemów. Takiemu wyborowi przyświecały dwa powody. Po pierwsze, metoda systemowa jest najbardziej odpowiednia do badania organizacji, której siła tkwi we współdziałaniu, a kluczowa przewaga ujawnia się w perspektywie relacji wzajemnych członków organizacji, ich kompetencje wzmacniają się w efekcie współpracy.

21 Według Luhmanna organizacja powstaje, gdy akt mowy przyjmuje formę decyzji - na przykład najbardziej podstawowy typ decyzji organizacyjnych, czyli decyzje o członkostwie. Akty komunikacyjne reprezentatywne dla tego typu zawierają takie wyrażenia, jak „Zatrudniliśmy...” lub „Proszę, poznaj nowego kolegę”. To, co liczy się dla organizacji, to zakończona decyzja. Seidl (2005b, s. 158) opiera się na tym samym przykładzie, kiedy wyjaśnia, że to, co ma znaczenie dla organizacji, jest decyzją jako taką, a nie procesem, który doprowadził do tej decyzji.

22 Jest to wynik prac konferencji z marca 2012 roku, która odbyła się na Uniwersytecie w Hamburgu i zgromadziła część głównych przedstawicieli wszystkich trzech szkół myślenia CCO. W panelu dyskusyjnym wzięli udział przedstawiciele każdej z nich: François Cooren reprezentował szkołę w Montrealu, Robert D. McPhee model Four-Flows, a David Seidl teorię systemów społecznych Luhmanna. Moderatorem był Dennis Schoeneborn. 


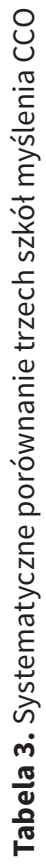

\begin{tabular}{|c|c|c|c|}
\hline 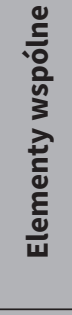 & $\begin{array}{l}\frac{\check{0}}{\overline{0}} \\
\end{array}$ & 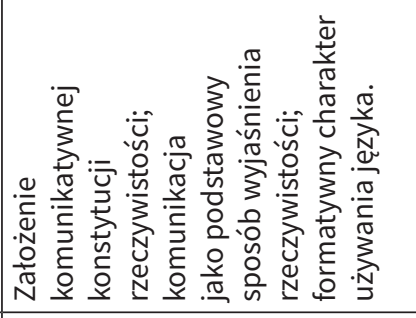 & $\begin{array}{l}\dot{\vec{\sigma}} \\
\frac{\pi}{\omega}\end{array}$ \\
\hline 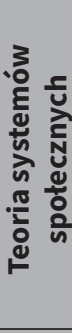 & 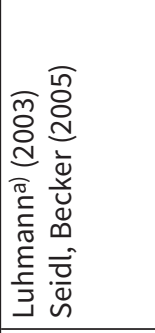 & 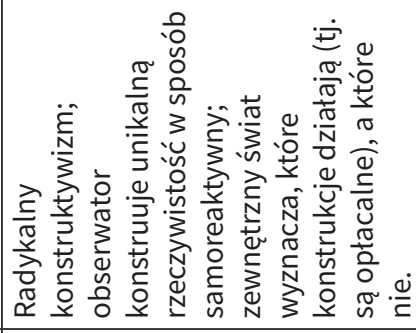 & 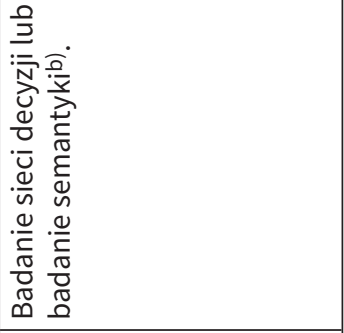 \\
\hline 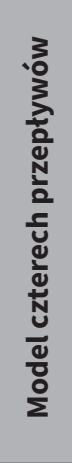 & 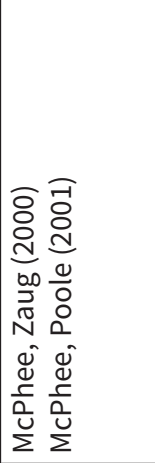 & 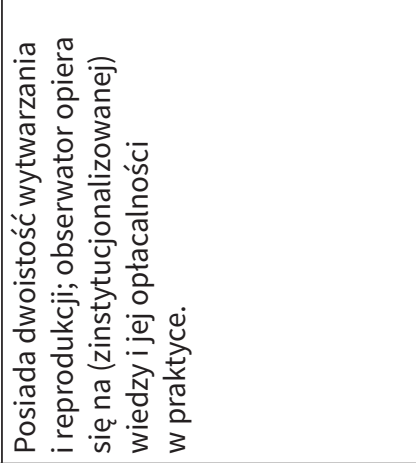 & 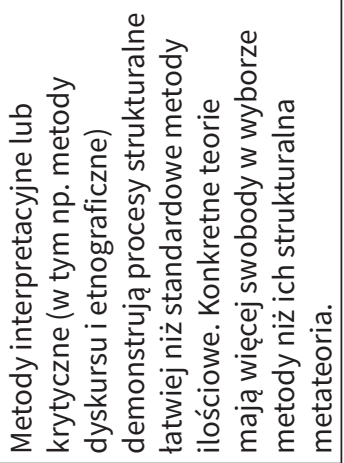 \\
\hline 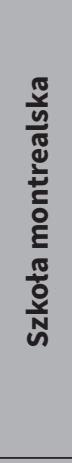 & 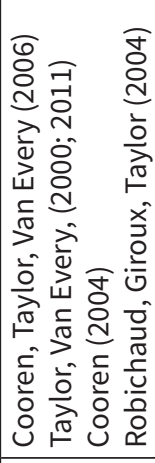 & 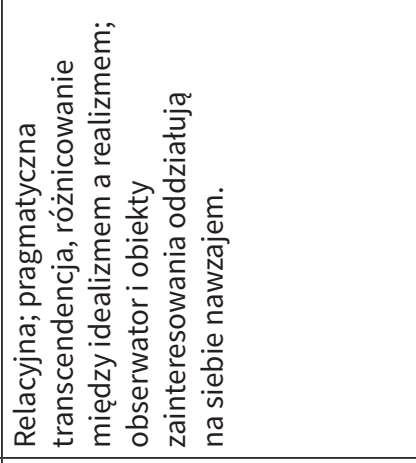 & 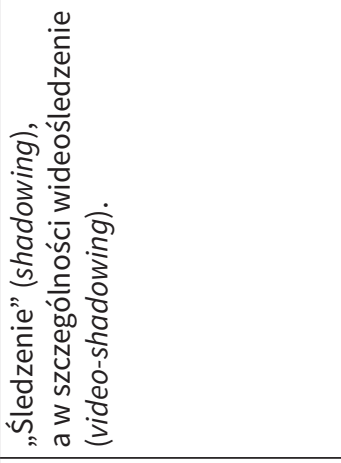 \\
\hline 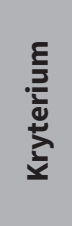 & 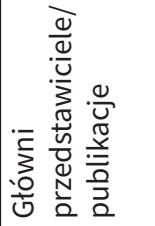 & 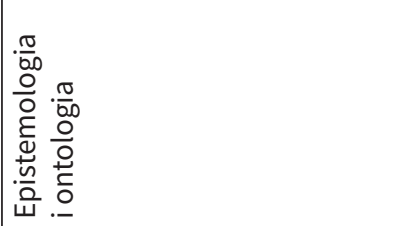 & 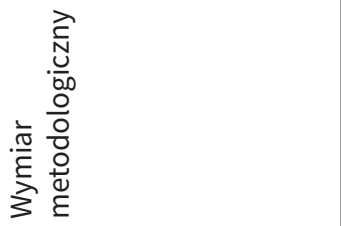 \\
\hline
\end{tabular}




\begin{tabular}{|c|c|c|}
\hline 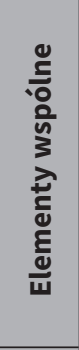 & 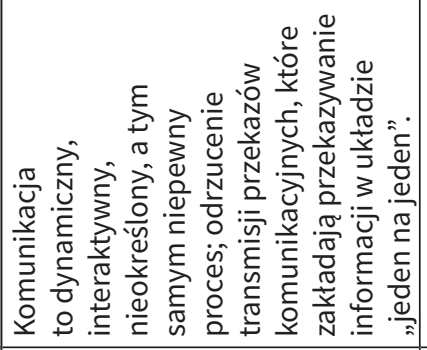 & 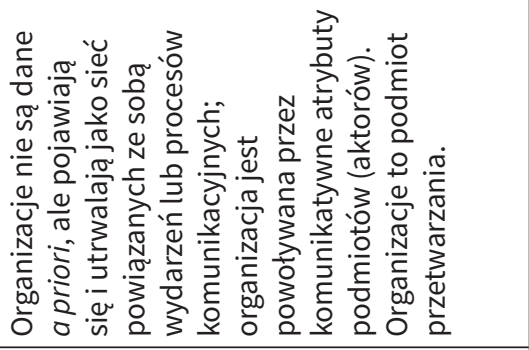 \\
\hline 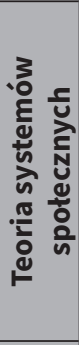 & 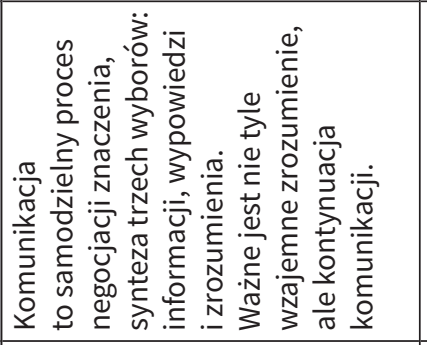 & 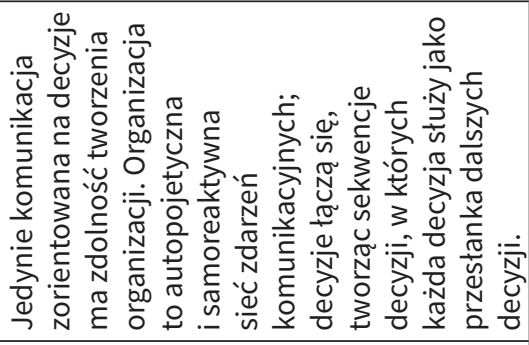 \\
\hline 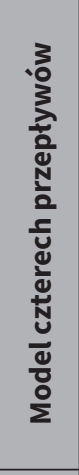 & 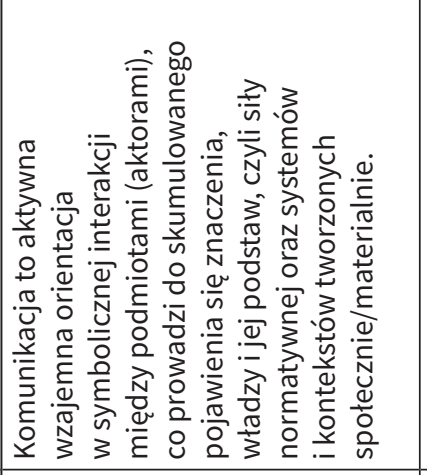 & 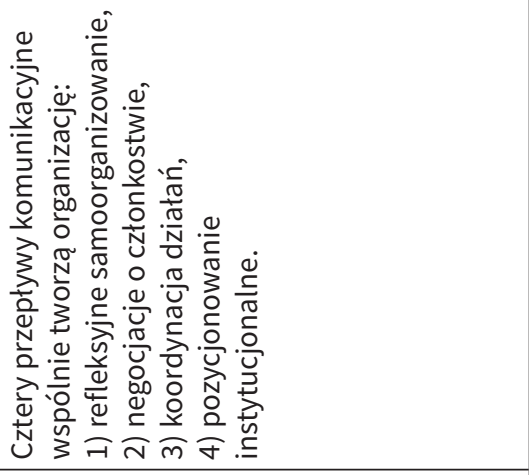 \\
\hline 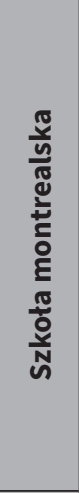 & 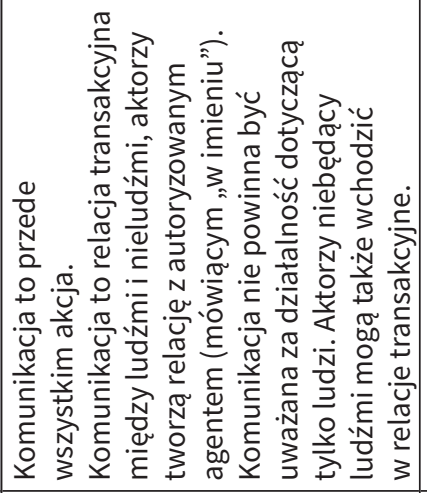 & 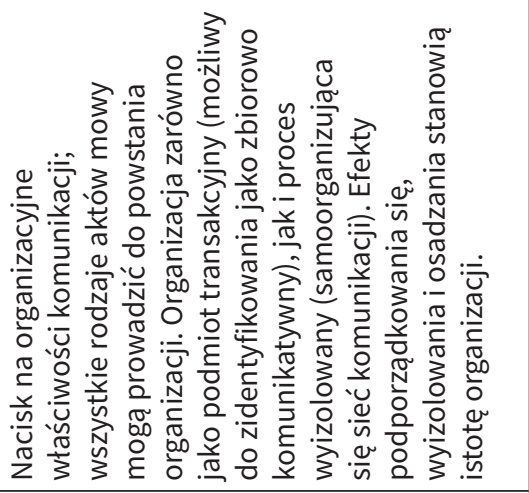 \\
\hline 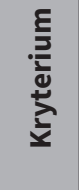 & 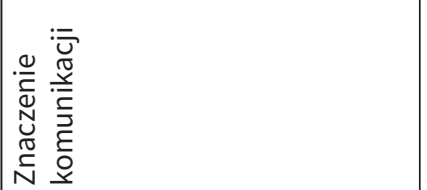 & 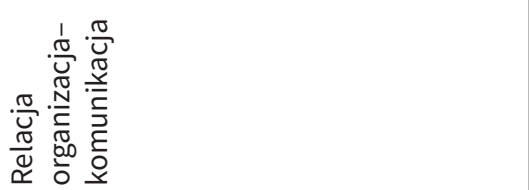 \\
\hline
\end{tabular}




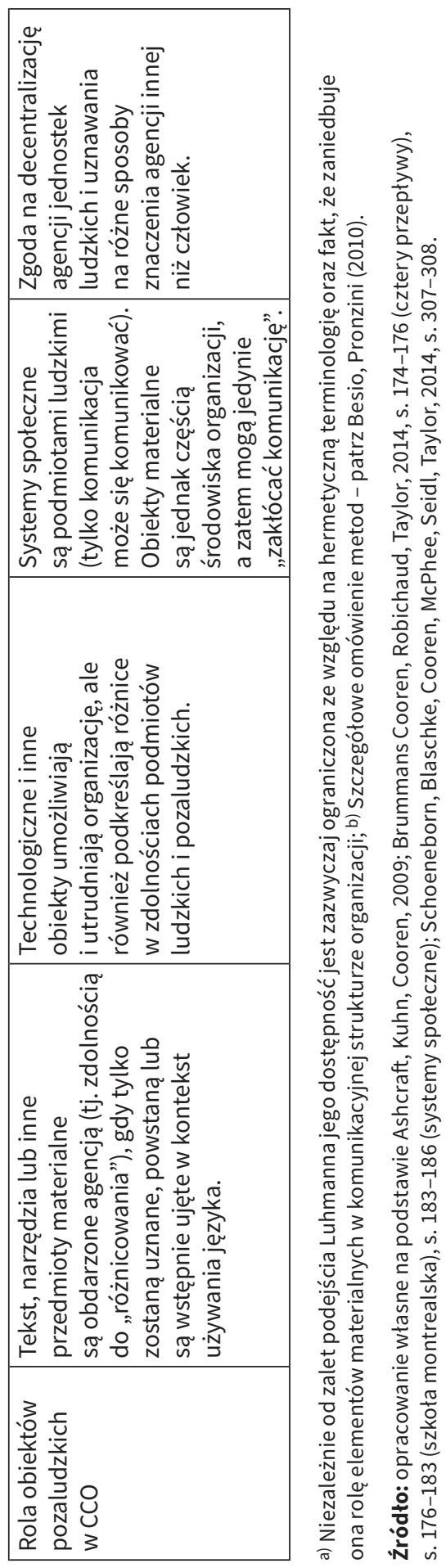


Po drugie, głównie Luhmann²3 (ale także inni przedstawiciele nurtu CCO przywołani powyżej) wypracowuje koncepcje komunikacji systemów społecznych, odwołując się do poziomu ogólnospołecznego, a następnie tę koncepcję aplikuje na potrzeby organizacji. Oznacza to, że jego podejście jest - co do metody - podobne do przypadku komunikowania społecznego, które także jest zawężane do potrzeb kontekstu organizacji.

W niniejszej pracy chodzi jednak o wypracowanie modelu i metody dedykowanych dla organizacji, a nie adaptowanie ich z szerszej perspektywy.

Wielość i rozmaitość ujęć i podejść do komunikacji wewnętrznej - zarówno teoretycznych, jak i badawczych - wskazuje, jak istotna, potrzebna, wręcz konieczna jest sprawna i skuteczna komunikacja wewnętrzna w organizacji.

Rozmaite przedstawione powyżej perspektywy są jednak fragmentaryczne lub wykazują zintegrowanie częściowe, wszelkie przedstawione podejścia do komunikacji wewnątrz organizacji nie gwarantują bowiem kompletnej, w pełni zadowalającej odpowiedzi na pytanie o sposób zapewnienia sprawności organizacji przez zapewnienie sprawnej komunikacji (przez integrację i koordynację zapowiedziane tezą pracy). Próba przedstawienia takiego sposobu jest przedmiotem kolejnych rozdziałów niniejszego opracowania.

23 Ogólnie, podstawowym elementem teorii systemu Luhmanna jest komunikacja. Wszystkie systemy społeczne - rozróżnia on interakcje, organizacje i systemy funkcjonalne, które razem budują społeczeństwo - składają się z pewnych czynności komunikacyjnych, a raczej z samooceny łączenia zdarzeń komunikacyjnych w czasie. Systemowość jego podejścia nie oznacza, że jakiekolwiek konkretne, szczególne zjawisko można rozumieć jako dedukowane z ogólnych zasad; nie jest też zainteresowany wykrywaniem przyczyn. Używa terminu system do pokazania, jak powstają pewne formacje społeczne, które są ustabilizowane przez wzajemne zależności, procesy sprzężenia zwrotnego i samokontrolowane procesy komunikacji. Interesuje się procesami komunikacyjnymi, które pozwalają własnym strukturom systemów wyłaniać się przez własne praktyki (Nassehi, 2005, s. 181; Groddeck, 2011, s. 71). 


\section{Ogólna teoria systemów jako nauka}

W pracy za podstawę przyjęto podejście systemowo-sytuacyjne. Wypracowywany w treści monografii model organizacji (systemowy) powstał jako konsekwencja tego wyboru, natomiast koordynowanie taką organizacją odbywać się będzie dzięki sytuacyjnym wskaźnikom. Przyjęcie takiej perspektywy poprzedzono analizą możliwości budowy modelu według funkcjonujących podejść (paradygmatów) w teorii organizacji. Po dokonaniu wyboru perspektywy systemowej, którego uzasadnienie znajduje się w tekście poniżej, w następnej kolejności przedstawiono narzędzie, które wypracowano na podstawie analizy dostępnych podejść występujących w ramach ujęć systemowych, dobranych ze względu na kryterium „poręczności” tego narzędzia do realizacji celu pracy, czyli do modelowania organizacji jako systemu złożonego, opartego na komunikacji wewnątrzorganizacyjnej.

Z perspektywy występujących w teorii organizacji ${ }^{1}$ nurtów czy szkół² ${ }^{2}$ ze względu na kryterium stosowanych w nich metod badania organizacji (jako przedmiotu badań), wymienić należy cztery zasadnicze podejścia, które kolejno dominowały i w których zmieniał się punkt ciężkości, jednak żadne z nich nie zostało definitywnie unieważnione. Ten ciąg podejść (czy też paradygmatów) można określić w następujący sposób: podejście inżynierskie, które uznawało one best way; systemowe, w którym całość oglądano przez pryzmat części; sytuacyjne, gdzie wyjaśnienie następowało przez kontekst i na koniec złożoność (czasem według niektórych autorów poprzedzona teorią chaosu, ważną ze względu na koncepcję granicy

1 W tym miejscu oddziela się teorie organizacji od teorii i koncepcji zarządzania nią. Istnieje znacznie więcej teorii, koncepcji, metod i technik zarządzania organizacjami niż teorii organizacji w znaczeniu rzeczowym. Czekaj i Ziębicki (2013, s. 49) dzielą rozwój teorii i koncepcji zrządzania na „dwa zasadnicze etapy” - etap uniwersalistyczny od około 1900 roku do lat siedemdziesiątych XX wieku oraz trwający od lat siedemdziesiątych etap o charakterze sytuacyjnym. W ramach tych dwóch etapów wyróżniają osiem teorii i koncepcji zarządzania.

2 Kwestię nurtów i szkół/kierunków wyróżnia się w pracy za Bielskim (2001, s. 28-43). Przyjmuje on koncepcję podziału na nurty (klasyczny i neoklasyczny, psycho-socjologiczny i systemowy), w ramach których wyznacza kierunki i szkoły (np. dla nurtu systemowego podaje: badania operacyjne, kierunek systemowy i cybernetyczny, rozważa kierunek sytuacyjny). 
porządku i chaosu), która jest nie do opanowania, jednak podejmuje się próby redukcji złożoności. Każde ${ }^{3}$ z tych podejść oferuje właściwy sobie zbiór hipotez, wyjaśnień oraz metod badawczych.

W przypadku one best way korzystano z metod naukowego badania i narzędzi inżynierskich. Podejście systemowe pozwalało na wyodrębnienie cech systemowych, na różnorodność w ramach uniwersalizmu - można opisać dowolną organizację za pomocą ustalonego katalogu cech o różnym ich natężeniu w różnych organizacjach. Podejście sytuacyjne rozszerzyło podejście systemowe. Pozwala ono na wyjaśnienie działania organizacji przez kontekst i jej reakcję na zmiany w dynamicznym otoczeniu. W tej perspektywie organizacja to obiekt o wysokiej reaktywności na otoczenie (Krupski, 2005), uzależniony od kontekstu, w jakim funkcjonuje. Wszystko stało się zmienne. Teoria złożoności (complexity theory) stała się naturalnym sukcesorem teorii systemów. W założeniu pozwala na zrozumienie złożonych systemów, których zachowanie - ze względu na ich złożoną naturę - jest trudne do określenia i przewidzenia (Mesjasz, 2004, s. 58-59). Rozwinęła się wśród modeli równoległych i rozproszonych systemów komputerowych, sieci komunikacyjnych o dużym zasięgu, sztucznej inteligencji, algorytmów ewolucyjnych i ekonomii (Brodbeck, 2002, s. 377-402). Reasumując, podejście one best way, przez swoje inżynierskie metody badawcze, nie jest obecnie w stanie wyjaśnić funkcjonowania organizacji, nie odzwierciedla rzeczywistych problemów i ich rozwiązań. Tymczasem teoria złożoności korzysta z wyrafinowanych metod, które są na tyle skomplikowane, że wykraczają poza technologiczne możliwości komputerów, taka złożoność jest nie do opanowania ${ }^{4}$ (Butler, 1990, s. 39), dlatego należy podejmować próby jej redukcji.

Z tego względu w tej pracy, nie odrzucając teorii złożoności ${ }^{5}$ (stosowne wyjaśnienie znajduje się w poniżej), zainteresowanie skierowano na podejście systemowo-sytuacyjne, co wiąże się z wprowadzeniem następujących założeń:

3 Wątpliwości niesie ze sobą teoria chaosu, która wprawdzie jest zbiorem hipotez, jednak w obszarze nauk społecznych nie przedstawia wyjaśnienia ani nie daje narzędzia badawczego organizacji. Jeśli jednak podejmowane są takie próby, wymagają one wyrafinowanej aparatury formalnej.

4 Zachowanie realnych systemów przypomina zachowanie systemów złożonych. Pojawiają się próby modelowania odrębnych zachowań organizacyjnych za pomocą matematycznych metod analitycznych, jednak modelowanie całości w skali makro za pomocą analitycznych metod nauk o złożoności wydaje się niemożliwe (Butler, 1990, s. 39).

5 „Na obecnym etapie rozwoju teorii i praktyki organizacji i zarządzania wykorzystanie teorii złożoności sprowadza się przede wszystkim do prób stosowania analogii i metafor. [...] Na poziomie epistemologicznym teoria złożoności ukazuje ograniczenia przewidywalności działania organizacji oraz stanów otoczenia. [...] Natomiast jeśli chodzi o tworzenie strategii organizacji, to teoria złożoności stanowi źródło analogii i metafor, które pozwalają 
1) podstawę stanowi idea podejścia systemowego (von Bertalanffy, 1984), której podstawowym założeniem jest traktowanie organizacji jako systemu otwartego, zbioru współgrających ze sobą elementów, zorientowanych celowo i charakteryzujących się złożonością;

2) relacje są pierwotne wobec elementów;

3) organizacje traktuje się jako systemy relacyjne otwarte (granice w graficznej postaci modelu organizacji o kształcie wieży Eiffla nie są zamknięte, istniejące kratownice oryginalnego budynku obrazują kanały komunikacyjne, jakimi przemieszczają się komunikaty w kierunku podsystemu zarządzania, dla ich koordynacji).

\subsection{Podejście systemowe - wybór metody badawczej}

Analizując zmiany zachodzące wewnątrz podejścia systemowego odniesionego głównie do metod badania organizacji, zauważa się nieustające poszukiwanie najlepszego sposobu odwzorowania lub modelowania organizacji na potrzeby zarządzania nią. W tym przypadku teoria systemów złożonych jest kolejnym wcieleniem teorii systemów, nazywanym (krócej) teorią złożoności.

Aby prześledzić wewnętrzne zmiany, jakim podlegało rozumienie systemów w ramach podejścia systemowego, a tym samym rozwój systemowych metod badawczych, skorzystano z systemu metodologii systemów (SOSM - System of Systems Methodologies) Michaela Jacksona i Paula Keysa (1984; Jackson, 2000; 2003). Konstrukcja ta oparta jest na siatce „typów idealnych”, składa się z dwóch wymiarów: sytuacji problemowych (systemów) i kontekstów problemowych (uczestników). Konstrukcję taką wypełniają rozmaite podejścia systemowe, z których każde korzysta z nieco innych metod badania systemowego. Poniżej przedstawiono szczegółowo ideę klasyfikacji, a następnie wskazano ewolucję systemowych podejść badawczych organizacji, które stały się inspiracją do zaproponowania autorskiej metody analizy systemów złożonych (Complex Systems Analysis), prezentowanej w niniejszej pracy.

Skala pionowa obejmuje kontinuum typów systemów - od prostych do złożonych. Proste systemy scharakteryzuje mała liczba podsystemów zaangażowanych w niewielką liczbę silnie ustrukturyzowanych interakcji, które nie zmieniają się z upływem czasu, są stosunkowo niewrażliwe na działania ich części lub wpływ środowiska. Systemy złożone charakteryzuje duża liczba podsystemów zaangażowanych w wiele luźno ustrukturyzowanych interakcji, których wynik nie jest 
z góry określony. Te systemy dostosowują się i ewoluują w miarę upływu czasu, ponieważ wpływają na nie ich własne, celowe części oraz burzliwe otoczenie.

Tabela 4. Podejścia systemowe związane z kontekstami problemowymi w systemie metodologii systemów

\begin{tabular}{|c|c|c|c|c|}
\hline & \multicolumn{3}{|c|}{ Udział uczestników } \\
\hline & & $\begin{array}{l}\text { Jednolity } \\
\text { (unitary) }\end{array}$ & \begin{tabular}{|l|} 
Pluralistyczny \\
(pluralist)
\end{tabular} & $\begin{array}{l}\text { Przymusowy } \\
\text { (coercive) }\end{array}$ \\
\hline \multirow[b]{2}{*}{ Systemy } & Proste & $\begin{array}{l}\text { Twarde myślenie } \\
\text { systemowe (OR, SE, SA) }\end{array}$ & \multirow{2}{*}{$\begin{array}{l}\text { Podejścia } \\
\text { systemów } \\
\text { miękkich }\end{array}$} & $\begin{array}{l}\text { Emancypacyjne myślenie } \\
\text { systemowe (emancipatory) }\end{array}$ \\
\hline & Złożone & $\begin{array}{l}\text { Dynamika systemów } \\
\text { Cybernetyka organizacji } \\
\text { Teoria złożoności }\end{array}$ & & $\begin{array}{l}\text { Postmodernistyczne myślenie } \\
\text { systemowe }\end{array}$ \\
\hline
\end{tabular}

Źródto: Jackson, Keys, 1984; Jackson, 2000, s. 35; 2003, s. 24; Adams, Mun, 2005, s. 503; Reynolds, Holwell, 2010, s. 11.

Oś pozioma klasyfikuje relacje, które istnieją między uczestnikami, osobami zainteresowanymi kontekstem problemowym. Występują w trzech rodzajach: „jednolite”, „pluralistyczne” i „przymusowe”. Uczestnicy pozostający w relacji jednolitej wyznają podobne wartości, mają podobne przekonania i zainteresowania oraz wspólne cele. Wszyscy, choć w rozmaity sposób, są zaangażowani w decyzje o sposobie realizacji uzgodnionych celów. Uczestnicy, których relacje uznaje się za pluralistyczne, zgadzają się tylko co do interesów głównych, jednak nie podzielają tych samych wartości ani przekonań, dlatego konieczna jest przestrzeń na prowadzenie debat, sporów, nawet konfliktów. Jeśli wszyscy uczestnicy czują zaangażowanie w proces decyzyjny, przystosowują się i idą na kompromisy. W ten sposób dochodzą do porozumienia co do produktywnych sposobów działania i przynajmniej tymczasowo działają w sposób zgodny z nim. Uczestnicy określani jako będący w związkach przymusowych mają niewiele wspólnych interesów i, jeśli mają swobodę wyrażania ich, trzymają się swoich, sprzecznych wartości i przekonań. Kompromis jest niemożliwy, a działań nie podejmuje się ze względu na wspólne cele. Decyzje podejmowane są przez tego, kto ma największą siłę, a przestrzeganie poleceń zapewnia się różnymi formami przymusu.

Połączenie wskazanych wyżej wymiarów „systemów” i „uczestników” prowadzi do wyodrębnienia sześciu typów idealnych. Przedstawione typy idealne to pewne skrajności logiczne, które można wykorzystać do konstruowania abstrakcyjnych modeli rzeczywistości. Jednocześnie siatka typów idealnych pomaga prześledzić rozwój podejścia systemowego i właściwych im metod badawczych używanych w ciągu ostatnich kilku dekad, a także uchwycić różnorodność prób podejmowanych przez naukowców i praktyków myślenia systemowego w celu rozwiązywania złożonych problemów. 
Jako prekursora myślenia systemowego i ogólnej teorii systemów podaje się Ludwiga von Bertalanffy’ego, który w 1954 roku założył Society for General Systems Theory. Stowarzyszenie to szybko zmieniło nazwę na Society for General Systems Research, a od 1988 roku do dziś funkcjonuje pod nazwą International Society for the Systems Sciences (ISSS). W 1956 roku stowarzyszenie rozpoczęło wydawanie rocznika „General Systems”, który ukazuje się do dziś. Przewodniczącym stowarzyszenia na lata 2017-2018 jest David Rousseau (http://www.isss.org/world/) ${ }^{7}$.

Niejednokrotnie początek podejścia systemowego wyznacza się na moment wydania przez von Bertalanffy’ego książki, w której propagował podejście i paradygmat systemowy w naukach - interdyscyplinarnie (von Bertalanffy, 1984, s. 24), a nie tylko w odniesieniu do zagadnień organizacji. Tymczasem koncepcja teoretyczna systemowości jest znacznie starsza i nie chodzi tu o wywodzenie źródła systemowości od wczesnej filozofii greckiej Arystotelesa (choć i takie opracowania można odnaleźć w naukach ekonomicznych) (Waszczyk, Szczerbicki, 2003, s. 6; Ostwald, 2009; Dobija, 2014, s. 126). Za prekursora podejścia systemowego należy uznać Aleksandra Aleksandrowicza Bogdanowa ${ }^{8}$, który wprowadził pojęcie systemu w trzytomowym dziele pod tytułem Tektologia9 (Walentynowicz, 1979, s. 7; Kotarbiński, 1982 s. 339, Perechuda, 1984, s. 15). Bogdanow jako pierwszy dostrzegł

6 Dziś nazywa się „International Journal of General Systems”. Publikuje się w nim opracowania dotyczące klasyków systemów oraz najnowsze rozwiązania (np. Liu, Alsaadi, Yin, Wang, 2015; Belohlavek, 2017).

7 Podczas kongresów i konferencji odbywają się dyskusje i wymiana doświadczeń między naukowcami i praktykami (np. 2014 MIT SDM Conference on Systems Thinking for Contemporary Challenges). Na szczególną uwagę zasłguje: What is Systems Thinking and why is it Important? Qi Van Eikema Hommesa oraz A New Era in Project Management: Viewing Projects as Systems Bryana R. Mosera.

8 Bogdanow to najczęściej używany pseudonim. Naprawdę nazywał się Aleksander Aleksandrowicz Malinowski. Korzystał także z innych pseudonimów: Rjadowoj, Jermow, Werner, Sergiusz Wasiliewicz. Urodził się 10(22).07.1873, zmarł 7.04.1928 (Perechuda, 1984, s. 11).

9 Tektologia wydawana była sukcesywnie. Tom pierwszy pt. Wseobszczeja organizacjonnaja nauka - tektologija ukazał się w Moskwie w 1913 roku (Kotarbiński, 1968 pisze, że w 1912 r.), drugi w 1917 (a według Kotarbińskiego w 1916). Pierwsze pełne wydanie wszystkich trzech tomów miało miejsce w 1922 roku. Następnie tomy ukazywały się kolejno w latach 1925, 1927 i 1929. Przekład niemiecki, dwutomowy, pt. Algemeine Organisationslehre (Ogólna teoria organizacji), wydano w 1926 i 1928 roku (Perechuda, 1984, s. 15) lub w latach 1924-1926 (Kotarbiński, 1982 s. 339). Ponieważ Perechuda szeroko cytuje teksty Bogdanowa, tłumacząc je z rosyjskiego, daty podane przez niego można uznać za bardziej prawdopodobne. Słowo tektologia jako pierwszy zastosował Ernst Haeckel (16.02.1834-9.08.1919, niemiecki zoolog, zwolennik ewolucji), ale w innym znaczeniu, choć także dotyczącym budowy. Podzielit on morfologię na dwie sekcje - tektologię, naukę o indywidualności organicznej oraz promorfologię, która ma na celu ustanowienie krystalografii form organicznych. „Tektologia bada cechy struktury jednostki organicznej, i kompozycji ciała z różnych części (komórek, tkanek, organów)" [tłum. M.Z.-T.] (Haeckel, 1904, s. 97). 
i opisał systemową budowę świata. Ponadto jako pierwszy przedstawił myśl o systemowym obrazie świata, tektologię określił mianem ogólnej nauki o organizacji, w sposób systematyczny wyznaczył cel, obszar i metodę badawczą, a także wypracował język opisu. Ustalił również reguły budowania i rozpadu systemu. Podstawowe twierdzenie Bogdanowa, że świat, w tym organizacje, są dynamicznym zbiorem procesów organizujących i dezorganizujących, nie zdezaktualizowało się. Niestety, trudny język, dziś już nieco archaiczny, złożony z nietypowych terminów, które Bogdanow zbudował na potrzeby nowatorskich wówczas rozważań systemowych (np. ingresja, dezingresja, egresja i degresja) (Bogdanow, 1968, s. 131; Przelaskowski, 1968, s. 153; Styczyński, 1990, s. 85-91) oraz rozległość i złożoność jego koncepcji10 spowodowały trudności w zrozumieniu treści i w konsekwencji doprowadziły do jej zapomnienia na prawie wiek. Po latach doceniono jednak jego wkład - Gerald Midgley (2003, s. xix) przedstawia wyciąg z prac Bogdanowa na temat tektologii i we wstępie do czterotomowego opracowania stwierdza, że praca Bogdanowa ma takie samo prawo do prekursorstwa jak dzieło von Bertalanffy’ego, mimo słabszego wpływu na późniejsze myślenie systemowe. Magnus Ramage i Karen Shipp (2009, s. 3, także: Forrester, 2007, s. 345-358; Hammond, 2010, s. 134) wymieniają Bogdanowa pośród myślicieli systemowych z pierwszej połowy XX wieku, którzy przyjęli linię holistyczną i omawiają swoje pracę w kategoriach systemu.

Zanim von Bertalanffy opublikował i spopularyzował podejście systemowe II wojna światowa narzuciła wojskowym konieczność posługiwania się myśleniem systemowym (Hitch, 1955; Enthoven, 1963; Fortuin, van Beek, van Wassenhove, 1996). Wówczas - niejako z konieczności - zainicjowano opracowywanie metodologii systemowych jako sposobu radzenia sobie z rzeczywistymi problemami. Powstały wtedy i rozwinęły się metodologie badań operacyjnych (operational research - OR), analiza systemów (system analysis - SA) oraz inżynieria systemów (system engineering - SE). Podobieństwo tych metod koncentrowało się wokół dążenia do optymalizacji działania systemów o jasno określonych celach. Nazwano je twardym myśleniem systemowym (hard systems thinking) (Checkland, 1981). Istotą było stosowanie systematycznej metodologii, która dzięki ustalonym celom pomagała zidentyfikować problemy stojące na drodze optymalizacji i rozwiązać je, wykorzystując modelowanie naukowe, racjonalne testowanie, procesy wdrażania i oceny. Twarde myślenie systemowe prezentowało założenie, że natura problemów jest prosta, jednostkowa, a wynikało to z uwarunkowań historycznych jego powstania - działania wojenne i powojenna odbudowa kraju uzasadniały przyjmowanie jednolitych założeń. Jednocześnie szukano rozwiązań rzeczywistych problemów,

10 Bogdanow określit, że „obszar badawczy tektologii obejmuje całe doświadczenie świata” (Perechuda, 1984, s. 23). Z tego powodu niektórzy komentatorzy jego prac określili je jako nowy etap w rozwoju filozofii, czemu Bogdanow stanowczo zaprzeczył. 
ale ich wprowadzenie było kosztowne i często uważane za nieetyczne, bo traktowane jako eksperyment na „żywych organizmach”. Z tego powodu tradycyjne metody eksperymentalne zastąpiono modelami, głównie matematycznymi - w literaturze identyfikuje się różne typy modeli twardego myślenia systemowego: ikoniczne, analogiczne, analityczne, symulacyjne, gier, oceny i koncepcyjne.

Rozwiązania proponowane przed wprowadzeniem twardego myślenia systemowego koncentrowały się raczej na częściach organizacji niż na całości, a optymalizacja tylko jednej części ma przecież konsekwencje w innych miejscach organizacji, czasem nawet szkodliwe dla całości (błąd „suboptymalizacji”). Oferowane niesystemowe panacea przynosiły niepowodzenia. Interwencje inżynierii procesowej zawiodły pod względem zapewnienia ogólnej poprawy. Benchmarking zachęcał do analizowania efektywności różnych części organizacji oddzielnie, ze względu na zewnętrzne wzorce, natomiast pomijano fakt, że jeśli nawet każda część jest zoptymalizowana, a części ze sobą nie współdziałają, to wydajność całej organizacji może być katastrofalna. Total Quality Management znacznie przyczyniło się do ulepszenia projektowania procesów, ale ignorowało szersze problemy strukturalne organizacji. Zrównoważona karta wyników obejmowała różne punkty widzenia na ocenę dokonań organizacji, czyli brała pod uwagę większą liczbę elementów do analizy, a jednocześnie wszystkie one postrzegała z tej samej perspektywy - oglądano różne elementy, ale w ten sam sposób (Jackson, 2000).

Przeniesione $\mathrm{z}$ wojska do organizacji twarde myślenie systemowe miało jednak ograniczenia. Wymagało obiektywnego opisu systemu, tak aby można było stworzyć model matematyczny i optymalne rozwiązanie problemu. Rzeczywistość, przed którą stoją dzisiejsi menedżerowie, jest złożona, podlega częstym zmianom, dlatego niemożliwe jest zredukowanie sytuacji problemowych do formy, która umożliwiłaby takie modelowanie. Innym ograniczeniem jest trudność w odwzorowaniu rzeczywistości w zadowalający sposób - podejście twarde wymaga, aby cel badanego systemu był znany lub ustalony przed rozpoczęciem analizy. Metoda badań operacyjnych (OR) wymaga sformułowania problemu w postaci celu do osiągnięcia. W sytuacjach organizacyjnych często samo uzgodnienie celu(ów) jest już podstawą problemu. A przecież różni interesariusze (np. właściciel, agent, pracownik) mają zróżnicowane opinie na temat natury systemu, w który są zaangażowani, i w konsekwencji rozmaitych jego celów. Sytuacje ekstremalnej złożoności i turbulencji otoczenia, w którym organizacje się znajdują, również utrudniają stosowanie systemów twardych. Jonathan Rosenhead i John Mingers (2001) wskazują obecne wykorzystanie metod twardego myślenia systemowego do podejmowania decyzji i rozwiazywania problemów.

Twarde myślenie systemowe, które wynikało z potrzeby praktyków, trafiło w latach sześćdziesiątych i siedemdziesiątych na uniwersytety. Zakładano 
wówczas, że ludzie w organizacjach podzielają wartości i przekonania, oraz że systemy są na tyle proste, że można je matematycznie modelować (rozwiązywano głównie problemy operacyjne, które dotyczyły przede wszystkim inwentaryzacji, kolejkowania, planowania - Keys, 1991; Cavaleri, Obloj, 1993). Rozszerzenie zakresu stosowania twardego podejścia systemowego napotkało trudności ze względu na własne ograniczenia - konieczności precyzyjnego określenia celu systemu w postaci konsensusu dla wszystkich zainteresowanych stron. Wysoka złożoność systemów spowodowała, że wytworzone modele matematyczne przedstawiały zniekształcony obraz nadmiernie uproszczonej rzeczywistości, często szybko dezaktualizujący się, co ograniczyło możliwość korzystania z nich. Znając ograniczenia podejścia systemowego, nie zarzucono prac nad nim, uważano bowiem, że do rozwiązania problemu metody systemowe są lepsze niż metody typu ad hoc.

Ewolucja systemów złożonych w dalszej kolejności opiera się na zrozumieniu natury systemu jako złożonej i adaptacyjnej, jego zdolności do poszukiwania celu i trwania w turbulentnym otoczeniu. Te cechy spowodowały powstanie trzech różnych podejść: „dynamiki systemu”, „cybernetyki organizacji” i „teorii złożoności” (Pava, 1986, s. 201-221; Jackson, 2003). Na tym etapie uważa się za niemożliwe matematyczne modelowanie relacji między wszystkimi zmiennymi zaangażowanymi w działanie systemu. Można jednak określić najważniejsze aspekty strukturalne (structural aspects), które umożliwią analitykowi rozpoznanie kluczowych cech systemu i nieprawidłowości w obecnym jego funkcjonowaniu, aby system mógł przetrwać i działać skutecznie w miarę upływu czasu przez nieustanne regulowanie (się) i samoorganizację oraz dostosowanie do warunków zewnętrznych.

Każde $\mathrm{z}$ trzech wyżej wskazanych podejść charakteryzuje się nieco odmienną charakterystyką i metoda badawczą. Jay W. Forrester (1958) i zespołem z Massachusetts Institute of Technology ustalili rygorystyczne zasady podejścia „dynamiki systemu”. Peter Senge spopularyzował to podejście w książce Piąta Dyscyplina (2014), w której promował dynamikę systemu (tytułową „piątą dyscyplinę”) jako klucz do stworzenia organizacji uczących się.

Metodyka badawcza opracowana przez Forrestera (1961; 1971) obejmuje cztery kroki:

1) ustala się granice systemu (identyfikacja zmiennych wpływających na problem);

2) konstruuje się model pętli sprzężeń zwrotnych, ujawniając zależności między zmiennymi; następnie przekształca się go w model matematyczny (za pomocą oprogramowania można przekształcić model w symulację komputerową) i waliduje przez porównanie zachowania modelu $z$ aktywnością organizacji w świecie rzeczywistym; 
3) po osiągnięciu zgodności przeprowadza się eksperymenty na modelu, aby ustalić, w jaki sposób alternatywne decyzje mogą poprawić wydajność;

4) na koniec przedstawia się zalecenia (wybór alternatyw decyzyjnych).

Ta metoda łączy badanie ilościowe i jakościowe - pozwala zrozumieć naturę systemu, a jednocześnie zaangażowanie elementów ilościowych umożliwia wdrożenie zaleceń do systemu (Wolstenholme, 1990).

Początkowo Forrester interesował się dynamicznym zachowaniem branż, zidentyfikował główne przepływy ludzi, materiałów i pieniędzy oraz sposoby ich kontrolowania dzięki sprzężeniom zwrotnym. Modelował je komputerowo za pomocą systemów równań różniczkowych, wyjaśniał dynamiczne zachowanie systemu w czasie (Forrester, 1993; 1994). Nowsze ujęcie metodologii dynamiki systemu, opracowane przez Kambiza E. Maaniego i Roberta Y. Cavanę (2000), uwzględnia potencjał edukacyjny proponowany przez Petera Senge’a (Senge, Sterman, 1994; Zimniewicz, 2003; Senge, 2014) i obejmuje pięć kolejnych etapów: konstrukcję problemu, modelowanie pętli przyczynowej, modelowanie dynamiczne, planowanie scenariuszy i modelowanie, wdrożenie i uczenie się organizacyjne. Dynamika systemu jest też obecnie wykorzystywana na poziomie mikro do badania „modeli mentalnych" (Lyneis, Cooper, Els, 2001; Zhang, Dilts, 2004; Nazareth, Choi, 2015; Abdelkafi, Täuscher, 2016).

W stosunku do metodyki systemów dynamicznych (Stacey, 2007) sformułowano podstawowy zarzut - redukowanie systemu do ograniczonej liczby modeli matematycznych. W tym zakresie uznano, że Senge powiela błąd Forrestera (Flood, Jackson, 1991; Keys, 1991; Jackson, 2000), sądząc, że kluczowe problemy związane z zarządzaniem można zbadać za pomocą zamkniętego zestawu „archetypów” zachowania systemu. Senge zastępuje rygorystyczną symulację komputerową Forrestera menedżerami uczącymi się przez relacje zwrotne. Drugim zarzutem jest ograniczona użyteczność modelów dynamiki systemów, spowodowana ich nieprecyzyjnością, niedokładnością prognoz dotyczących przyszłych stanów systemów. Ten argument staje się istotny zwłaszcza w kontekście spostrzeżeń teorii chaosu i złożoności w odniesieniu do „efektu motyla”.

W przypadku cybernetyki organizacji podstawą metod badawczych są prawa cybernetyczne wywiedzione z koncepcji czarnej skrzynki, informacji zwrotnej i różnorodności (Ashby, 1976). Metoda czarnej skrzynki, polegająca na kontrolowaniu systemu, jakim jest organizacja, przez monitorowanie wyjść i odpowiednie manipulowanie wejściami, nie dzieli systemu na części.

Stafford Beer $(1972 ; 1979)$, pracując jeszcze nad metodą badawczą systemów dynamicznych, przyjął za podstawę badań ciało ludzkie kontrolowane przez system nerwowy. Powstał z niego neurocybernetyczny model złożony z pięciu podsystemów, zidentyfikowany funkcjonalnie w mózgu i ciele. Beer oznaczył je jako: wdrażanie, 
koordynacja, kontrola operacyjna (w tym zarządzanie usługami), rozwój i polityka. Jest to podstawą Viable System Model (VSM), który znajduje zastosowanie także w organizacjach społecznych. Później Beer (1979) wywiódł ten sam model (składający się z pięciu podsystemów i odpowiednich pętli sprzężenia zwrotnego i przepływu informacji) z oryginalnych praw cybernetycznych. Co do zasady VSM uosabia cybernetykę organizacji. Ma on zastosowanie do dużych i małych organizacji - nawet w jednoosobowym przedsiębiorstwie wszystkie pięć funkcji jest nadal wykonywane, tyle że przez jedną osobę. VSM jest jednak bardziej modelem niż metodą. Może być stosowany w trybie projektowym i diagnostycznym. Tryb projektowy koncentruje się na planach nowych organizacji, tryb diagnostyczny polega na ocenie problemów rzeczywistej organizacji na podstawie wiedzy o jej możliwym „zdrowym” stanie.

Jednym z najważniejszych ustaleń metody cybernetyki organizacji jest to, że złożone systemy mają charakter „rekurencyjny” - istnieją w hierarchiach i forma organizacyjna systemów wyższego rzędu może być powtarzana w ich częściach. Druga cecha jest następstwem pierwszej - wszystkie systemy wykazują te same cechy organizacyjne. VSM respektuje rekurencyjny charakter systemów, a jego zastosowanie do różnych poziomów systemu pozwala na konstruowanie eleganckich reprezentacji organizacji (Jackson, 2000). Te same zasady można stosować do modelowania podsystemu organizacji, samej organizacji i jej suprasystemu (nadsystemu). Istnieją przykłady aplikacji tej metody systemowej (Beer, 1985; Espejo, Harnden, 1989; Epsejo, Schwaninger, 1993). Beer zaleca rygorystyczną procedurę naukową, aby wydobyć te cybernetyczne prawa.

W późniejszych dyskusjach na temat VSM Beer korzysta również z teorii autopojezy opracowanej przez Humberto Maturanę i Francisco Varela (1980). Systemy autopojetyczne są systemami samozasilającymi się, jednak, jak zauważa Beer, istotne jest, aby ta właściwość była zawarta jedynie w systemie jako całości i w jego kluczowych elementach operacyjnych. Jeśli bowiem wsparcie systemu stanie się autopojetyczne (np. stara się produkować dla własnej korzyści), wówczas w systemie pojawi się biurokracja. Tymczasem na przykład Raúl Espejo (Espejo, Harnden, 1989) proponował połączenie VSM i metody systemów miękkich jako sposób na złagodzenie wdrożeniowego problemu związanego z cybernetyką organizacji.

Inni, bardziej radykalni zwolennicy tego podejścia przyjęli „cybernetykę drugiego rzędu” (second-order cybernetics) ${ }^{11}$. Ta zmiana, z naciskiem na subiektywność, naśladuje to, co już zrobili myśliciele systemów miękkich w ogólnym myśleniu systemowym. Na przykład Roger Harnden (Espejo, Harnden, 1989) woli traktować VSM jako punkt skupienia do dyskusji na temat złożonych kwestii organizacyjnych wśród zainteresowanych obserwatorów, jednocześnie próbuje „uratować” VSM

11 Jest to cybernetyka systemu obserwacyjnego w przeciwieństwie do systemu obserwowanego. 
od paradygmatu funkcjonalistycznego. Beer (1974) napisał, że prawo Ashby'ego o wymaganej różnorodności było równie ważne dla menedżerów jak prawo względności Einsteina dla fizyków. Jest to podkreślenie właściwości systemów złożonych, które nie straciło na sile, jakkolwiek stało się podstawą dyskusji naukowych o jego implikacjach ${ }^{12}$, o czym mowa w dalszej części tekstu.

Model VMS jest uważany za niezwykle bogatą reprezentację organizacji, integruje wyniki około pięćdziesięciu lat pracy w teorii organizacji (Jackson, 2000). Model wnikliwie traktuje relacje między organizacjami i środowiskiem. Organizacja jest postrzegana jako zdolna do wpływania na otoczenie oraz do przystosowywania się do niego. Jest także podstawą do projektowania systemów informacyjnych w organizacjach, kładzie nacisk na identyfikację kluczowych elementów operacyjnych i klarowność roli niezbędnych funkcji wspomagających. VSM przedstawia również naukowe uzasadnienie empowermentu i demokracji w organizacjach. Części muszą uzyskać autonomię, aby mogły odpowiedzieć na ogromną różnorodność środowiska, która w przeciwnym razie przekroczyłaby możliwości zarządzania. Kładzie nacisk na koordynację i audyt, a nie kontrolę hierarchiczną.

Tradycyjnie „twarde” nauki systemowe poczyniły założenia dotyczące zachowania systemów, które zaczęły zawodzić, co doprowadziło do powstania najpierw teorii chaosu, a później teorii złożoności (Gare, 2000; Fioretti, Visser, 2006; Ioannides, 2012; Woodside, 2014; Hsiao, Jaw, Huan, Woodside, 2015; De Roo, Hillier, 2016).

Popularyzator teorii złożoności, James Gleick (1987), dowodził, że nauka XX wieku zostanie zapamiętana ze względu na teorię względności, mechanikę kwantową i teorię chaosu. Naukowcy powinni porzucić mechanistyczne i deterministyczne założenia leżące u podstaw światopoglądu Newtona i przyjąć perspektywy, które rozpoznają związki (relacje), nieokreśloność oraz mają holistyczny charakter. Badanie chaosu - w formie teorii złożoności - ma największy wpływ na myślenie o zarządzaniu (Gleick, 1987). Wcześniejsze modele organizacji postrzega jako kładące nacisk na porządek i regularność kosztem niekonsekwentnych i nieciągłych. Teoria złożoności skupia uwagę na tych aspektach życia organizacyjnego, które często przeszkadzają menedżerom - nieporządku, nieprawidłowości i przypadkowości. Akceptuje się niestabilność, zmianę i nieprzewidywalność oraz oferuje odpowiednią poradę, jak postępować.

Meteorolog Edward Lorenz jest uznawany za pioniera rozwoju teorii chaosu (Gleick, 1987). Pracował nad problemem długoterminowych prognoz pogody, korzystając z prostej symulacji komputerowej, opartej zaledwie na dwunastu równaniach. Studiował dłużej jedną, konkretną sekwencję pogody i w pośpiechu ponownie wprowadził warunki początkowe, ale wykorzystał trzy, zamiast sześciu miejsc

12 Innym obliczem tego podejścia jest ekoregionalne podejście do zrównoważonego rozwoju (Espinosa, 2002). 
po przecinku. Różnicę stanowiła jedna tysięczna, założył zatem, że nowe szacowanie powieli stare, tymczasem nowy wzorzec pogodowy szybko oddzielił się od poprzedniego i w ciągu przewidywanych kilku miesięcy wszystkie podobieństwa zostały utracone. Lorenz odkrył, że niewielkie zmiany w stanie początkowym złożonego systemu mogą znacznie zmienić długoterminowe zachowanie - ta zależność stała się znana jako „efekt motyla”. Lorenz opublikował swoje wyniki w czasopiśmie meteorologicznym w 1963 roku. W kolejnej dekadzie inni naukowcy odkryli podobne zjawiska w innych dziedzinach. Zbadano zachowanie złożonych systemów w matematyce, chemii i biologii i stwierdzono, że charakteryzuje się ono nieprzewidywalnością, chociaż wydawało się, że można je opisać za pomocą kilku prostych równań. W wielu przypadkach jednak ta nieprzewidywalność wydawała się podlegać pewnemu porządkowi. Ponadto systemy stale prowadzą wymianę z otoczeniem, nie tylko dostosowują się do niego, ale również z nim współpracują. Stąd zmiany systemowe i środowiskowe w odpowiedzi na siebie nawzajem ewoluują łącznie.

Synteza różnych dyscyplin, możliwa dzięki powszechnej akceptacji nowego paradygmatu, najlepiej wyraża się w teorii chaosu i złożoności. Właśnie dzięki tej nauce wiele pomysłów opracowanych w wyniku „rewolucji systemów” zostało dopracowanych do idei i koncepcji wystarczająco rygorystycznych, aby wesprzeć prawdziwą „ogólną teorię systemów” w sensie von Bertalanffy’ego. Gleick (1987) wymienia sześć podstawowych nurtów w teorii złożoności: „zależność wrażliwa od warunków początkowych” (sensitive dependence on initial conditions), „dziwne atraktory”13 (strange attractors) (Lorenz, 1963), „samopodobieństwo” (self-similarity), „samoorganizacja” (self-organization) (Prigogine, Stengers, 1990), „krawędź chaosu” (edge of chaos) (Packard, 1988; Langton, 1990) i „krajobraz przydatności” (fitness landscape) (Kauffman, 1995). Ogólnie metody teorii złożoności wymagają zaakceptowania zmiany myślenia, przyjęcia, że organizacje i ich otoczenie charakteryzują się nieliniowymi sprzężeniami zwrotnymi, wrażliwymi na małe różnice warunków początkowych, a ich zachowanie jest nieprzewidywalne, planowanie długookresowe jest zatem niemożliwe. Inaczej rzecz ujmując, planowanie długoterminowe, sztywne struktury, precyzyjne definiowanie zadań i skomplikowane reguły, które często im towarzyszą, są niebezpieczne, bo mogą „naprawić” organizację według określonej wizji, podczas gdy dynamiczne otoczenie wymagać będzie

13 Lorenz postulował, że istnieje porządek leżący u podstaw pozornego chaosu. Systemy pogodowe z nieco odmiennymi warunkami początkowymi mogą nie powtarzać tego samego zachowania w czasie, ale wykazywać podobne wzorce, na przykład zachowanie koła wodnego, gdy zostało naniesione na wykres, nigdy się nie powtórzyło, ale pozostało w określonym wzorcu zachowań. Lorenz nazwał ten obraz „atraktorem Lorenza”. Takie atraktory (attractors) nazywa się teraz „dziwnymi atraktorami” (strange attractors). Utrzymują one nieprzewidywalną trajektorię, która jednocześnie jest w granicach określonego wzorca. 
elastycznych reakcji. Z tego powodu podstawowe znaczenie mają relacje z otoczeniem, reagowanie i dostosowywanie się oraz gotowość do wykorzystania szans.

Gareth Morgan (1997) sugeruje, że metoda wdrożenia teorii złożoności do systemu może mieć trzy etapy. Etap pierwszy polega na zrozumieniu wzoru atraktora określającego bieżące zachowanie organizacji i powodów, dla których jest dominująca. Jeśli wzór nie jest pożądany z punktu widzenia organizacji, należy dokonać zmiany, aby system przeszedł na inny schemat. Etap drugi to wprowadzanie zmian. Etap trzeci wymaga ustabilizowania nowego wzoru atraktora, jednocześnie zapewnia, że nie „zablokuje” organizacji w dłuższej perspektywie w rutynowe formy działania. Kluczem do etapów pierwszego i trzeciego jest zatem próba uchwycenia „wzoru” na głębszym poziomie, tak aby wydobyć porządek leżący u podstaw chaosu. Jeśli uda się uchwycić wzorzec wywołujący złożone, dynamiczne zachowanie, wówczas uzyska się pewien wgląd w to, co się dzieje i można zacząć podejmować rozsądne decyzje. Jest to łatwiejsze, jeśli pamięta się o tym, że takie wzory są często konstruowane na podstawie prostych struktur fraktalnych.

Zgodnie z siatką systemów metodologii systemy ewoluowały w kierunku rozwiązań pluralistycznych. Peter Checkland (2000) opracował miękkie metody systemowe (Soft Systems Methods - SSM) (Mingers, 2017, s. 67). SSM to metodologia interwencyjna (wspierana przez fenomenologiczna teorię społeczną - Husserl, 1964) sprawdzająca się w przypadku źle ustrukturyzowanych sytuacji problemowych, w których utrzymywanie relacji jest co najmniej tak samo ważne jak poszukiwanie celu, i wskazuje, co i jak należy zrobić.

Badacze systemów miękkich porzucili pogląd, że cele organizacji są łatwo identyfikowalne i uzgodnione, i można je wykorzystać do obiektywnego przedstawienia systemu. Nauka o zarządzaniu była niewolnikiem paradygmatu „szukania celu" (np. prace noblisty Herberta Simona). Checkland (1981; 1999) uznał ten paradygmat za nieodpowiedni w odniesieniu do faktycznej praktyki zarządzania, w zamian - za Geoffreyem Vickersem (1965; 1970) - przyjął za podstawę „utrzymywanie relacji”. SSM prezentuje system jako siedmiostopniowy, cykliczny, uczący się (Checkland, 1981). Później nazwano ją cyklem uczenia się (The learning cycle of Soft Systems Methodology). Wymaga realizacji następujących kroków:

1) uznanie sytuacji za problem,

2) wyrażenie sytuacji problemowej,

3) stworzenie podstawowych definicji odpowiednich celowych systemów,

4) stworzenie modeli pojęciowych odpowiednich systemów (holonów) wymienionych w definicjach podstawowych,

5) porównanie modeli i świata rzeczywistego,

6) wprowadzenie zmian systematycznie pożądanych z punktu widzenia kultury,

7) podjęcie działań, aby naprawić sytuacje problemowe. 
Pracując z tym modelem, Checkland uznał, że siedmiostopniowy cykl jest zbyt ograniczony, ponieważ cykl uczenia się można przecież rozpocząć na dowolnym etapie, czyli wykorzystuje się go elastycznie i iteracyjnie, tymczasem siedmiostopniowy model przyczynia się bardziej do systematycznego niż systemowego zrozumienia procesu. Powstał zatem „dwupasmowy model” (The two-strands model of SSM), przedstawiony w pracy Soft Systems Methodology in Action (Checkland, Scholes, 1990). Dwa pasma modelu SSM to „strumień analizy kulturowej” oraz „strumień analizy oparty na logice” - ten, który zdominował siedmiostopniową, pierwotną wersję.

SSM ostatecznie zajmuje się „zarządzaniem mitami i znaczeniami”, mają one podstawowe znaczenie dla funkcjonowania organizacji - jako środek, dzięki któremu jednostki mogą zrozumieć swoją sytuację. Wzmocniona analiza kulturowa przyjmuje postać trzech rodzajów badań, zwanych analizami 1, 2 i 3. Analiza pierwsza uwzględnia interwencję oraz rolę klienta, rolę rozwiązującego problemy oraz rolę właściciela problemów. Analiza druga to analiza systemu społecznego, w której patrzy się na role, normy i wartości. Analiza trzecia obejmuje politykę sytuacji problemowej oraz sposób uzyskiwania i wykorzystywania władzy. Analiza może być jawna lub ukryta i opiera się na rozmaitych elementach, które mają wpływ na organizację, jak na przykład zarządzanie środkami, umiejętności zawodowe, talent i osobowość. Analizy 1, 2 i 3 nie muszą być wykonywane jednorazowo, ale wyniki są przechowywane do użycia w badaniu systemowym i istotne jest, aby były stale aktualizowane.

Badania prowadzi się za pomocą czterech narzędzi: bogatych obrazów (rich pictures), definicji głównych (root definitions), modeli koncepcyjnych (conceptual models) i porównania (comparison). Pierwszy pomiar prowadzi się z kulturowym strumieniem analizy, drugi i trzeci ze strumieniem opartym na logice, a czwarty zapewnia połączenie między nimi.

Bogaty obraz jest przedstawiany dzięki rysunkom, które pokazują postrzegane w danej chwili różne cechy sytuacji problemowej. Nie ma reguł ich rysowania - niektóre z nich są sformalizowane, inne z natury przypominają kreskówki, zależą od umiejętności i celów osób je wykonujących. Aby uniknąć selektywności bogatego obrazu, uwzględnia się sytuacje problemowe pod względem struktur, procesów i klimatu.

„Definicje główne” to zwięzła informacja o zawartości systemu teoretycznego w jego fundamentalnej formie. Definicja jest podstawą modelu, stąd musi mieć w swoim rdzeniu proces transformacji $(\mathrm{T})$ - gdzie dowolne wejście zmienia się na wyjściu w nowy stan lub formę, musi także określać kontekst (światopogląd), który nadaje transformacji znaczenie. Dobrze sformułowana definicja to taka, która może dać użyteczny model pojęciowy, często wskazuje również, kto może 
przeprowadzić transformację, a kto ją powstrzymać, kto ma z niej skorzystać oraz jakie są jej ograniczenia. Poprawna definicja ma spełnić kryteria określone przez skrót CATWOE (C - customers, A - actors, T - transformation, $\mathrm{W}$ - world view, $\mathrm{O}$ - owners, E - environmental constraints).

Na definicję składa się dokładny opis tego, czym jest system. Poprawne sformułowanie pozwala zbudować model koncepcyjny, który określa działania podejmowane w celu przeprowadzenia transformacji. Modele koncepcyjne nie są modelami czegoś w rzeczywistym świecie; są celowymi „holonami”, skonstruowanymi do ułatwienia dyskusji o sytuacji problemowej i wszelkich pożądanych zmianach. Dlatego powinny one być rozwijane wyłącznie z odpowiednich definicji głównych, bez odniesienia do rzeczywistości (powinny być abstrakcyjne). Model koncepcyjny powstaje przez przemyślenie i zapisanie minimalnej liczby działań, które wydają się konieczne do przeprowadzenia transformacji w sposób zdefiniowany w definicji głównej. Ponieważ są to „systemy działań ludzi”, będą zawierały czasowniki określające rzeczywiste czynności podejmowane przez ludzi. Zazwyczaj na pierwszym etapie jest to zwykle około siedmiu czynności, które są logicznie uporządkowane pod względem interakcji i ukazują wzajemne zależności. Właściwe ich monitorowanie i kontrola w niewielkim stopniu zależą od określenia kryteriów efektywności (np. ilość produkcji podzielona przez ilość wykorzystanych zasobów) i skuteczności („czy to działa?”, „czy transformacja spełnia cel długoterminowy?”). Checkland sugeruje, że można dodać inne kryteria.

Debata na temat ewentualnych zmian w sytuacji problemowej dokonywana jest przez „porównania” między modelami pojęciowymi a zawartością wyrażaną w bogatych obrazach. Checkland (1981) wymienia cztery sposoby na porównania:

1) nieformalną dyskusję na temat głównych różnic między modelami obecnymi i przyszłymi;

2) formalne zakwestionowanie głównych różnic, na przykład przez wypełnienie tabeli z pytaniami;

3) pisanie scenariuszy w oparciu o teoretycznie funkcjonujący system działalności człowieka, wskazujących, jak postępować w przyszłości;

4) próbę modelowania rzeczywistości za pomocą tej samej struktury co w modelu koncepcyjnym, podkreślenie znaczących różnic prowokujących dyskusję.

SSM określa zasady stosowania metod, a jednocześnie nie ogranicza sposobu ich wykorzystania, jest w stanie zapewnić inną odpowiedź w każdej sytuacji, w zależności od użytkownika i natury sytuacji. SSM nie wymaga, aby wszystkie metody (bogate obrazy, główne definicje, modele pojęciowe i porównania) były używane, lub używano ich w ten sam sposób w każdej interwencji. Właśnie ta elastyczność zapewnia trafność SSM w tak wielu sytuacjach zarządczych. 
Kolejne przejście wzdłuż poziomej osi siatki kontekstów problemowych prowadzi do przymusowych sytuacji problemowych. W systemach miękkich dominuje nastawienie, że można osiągnąć konsensus, a przynajmniej ugodę między różnymi interesariuszami. Praktycy systemów zauważyli także potrzebę sformułowania podejść systemowych opartych na założeniu, że sytuacje problemowe mogą być przymusowe.

„Heurystyka systemów krytycznych” Ulricha pozwala zadawać pytania o to, kto czerpie korzyści z konkretnych projektów systemów i stara się wzmocnić pozycję osób, na które wpływają decyzje zarządcze, a które nie biorą w nich udziału. „Synergia zespołowa” Beera ma na celu określenie płaszczyzny i procedur umożliwiających wszystkim zainteresowanym stronom demokratyczną debatę nad problemami, z którymi się stykają. Wreszcie istnieją systemowcy, którzy zastanawiają się, czy jakakolwiek metodologia systemów może zagwarantować uogólnioną poprawę. Opowiadają się oni za postmodernistyczną praktyką w obliczu ogromnej i nieprzeniknionej złożoności i przymusu.

Postmoderniści ${ }^{14}$ atakują oświecenie (Smith, 2006), a zatem systemowy i krytyczny modernizm ${ }^{15}$. Odrzucają szczególnie wiarę w racjonalność, prawdę i postęp. Zaprzeczają, że nauka może zapewnić dostęp do obiektywnej wiedzy, a więc pomóc kierować organizacjami i społeczeństwami w obliczu złożoności (Smith,

14 Postmodernizm powstał, by zerwać z tradycją oświeceniową zaproponowaną przez Friedricha Nietzschego i kontynuowaną przez Martina Heideggera (Brocklesby, Cummings, 1996). Nietzsche zakwestionował nacisk kładziony przez filozofów oświeceniowych (np. Immanuela Kanta) na istotę ludzką i indywidualną racjonalność, podważał myśl, dzięki której ludzkość poczyniła „postęp”. Jaźń dla Nietzschego to przygodny produkt różnych sił fizycznych, społecznych i kulturowych. Aby być wolnym, jednostka musi zmienić siebie przez krytyczne kwestionowanie wszystkich otrzymanych opinii i przyjętych sposobów postępowania, do tego potrzebuje siły, dlatego "wolę władzy” należy celebrować. Heidegger inspirował się Nietzschem, ale podążał własną drogą, podważał zachodnią tradycję filozoficzną i przeorientowat filozofię wokół studium bycia, koncentrując się szczególnie na wyjątkowości „bycia w świecie” każdej osoby.

15 Jean-François Lyotard (1984) rozpoznaje dwa główne przejawy modernizmu, które nazwa - za Robertem Cooperem i Gibsonem Burrellem (1988) - modernizmem systemowym (systemic modernism) i modernizmem krytycznym (critical modernism). Modernizm systemowy koncentruje się na zwiększeniu „wydajności” systemów pod względem miar wejście-wyjście oraz na radzeniu sobie z niepewnością otoczenia. Metody naukowe mają wspomóc odkrycie tego, co jest logiczne i uporządkowane na świecie oraz wskazać technologię wspomagającą przewidywanie i kontrolę. Ta forma modernizmu wyraża się w relacjach z twardym myśleniem systemowym dynamiką systemu, cybernetyką organizacji i teorią złożoności. Natomiast zadaniem krytycznego modernizmu jest postępowe urzeczywistnianie powszechnej emancypacji człowieka. Zależy od tego, czy język jest „przezroczysty” (nienacechowany), aby mógł działać jako środek, dzięki któremu ludzie osiągają porozumienie w sprawie celów, które chcą realizować. Taką formę modernizmu można rozpoznać w myśleniu systemów miękkich i w pracy myślicieli systemów emancypacyjnych. 
2005). Negują również, że język jest przejrzysty i może funkcjonować jako regulująca zasada konsensusu. Podkreślają natomiast, że trzeba nauczyć się żyć z niewymiernością, akceptować różne interpretacje świata i być tolerancyjnym wobec różnorodności. Co więcej, chcą zapewnić różnorodność i pobudzać kreatywność przez odnawianie konfliktów i dawanie posłuchu marginalnym głosom. Postmodernizm oferuje niewielkie bezpieczeństwo, raczej rozwija się na niestabilności, zakłóceniach, chaosie, przygodności, paradoksie i nieokreśloności.

Prace Friedricha Nietzschego i Martina Heideggera promujące emancypację stanowią alternatywę dla tradycji oświeceniowej, nakreślonej przez Immanuela Kanta, Georga Wilhelma Friedricha Hegla i Jürgena Habermasa, zaangażowanych w poszukiwanie powszechnej lub zbiorowej emancypacji człowieka. Ta alternatywa okazała się szczególnie atrakcyjna dla różnych, głównie francuskich filozofów - Michela Foucaulta, Jacquesa Derridy, Jeana-François Lyotarda i Jeana Baudrillarda, którzy byli oponentami strukturalizmu dominującego w latach sześćdziesiątych i siedemdziesiątych XX wieku. Strukturalizm dąży do odkrycia związków przyczynowych, postrzeganych jako ukryte powody sposobu zachowania się systemu (analiza dynamiki systemu i cybernetyka organizacji). Nowa grupa francuskich filozofów, nazywanych poststrukturalistami lub postmodernistami (bez szczegółowego ich rozróżniania w tym miejscu), odrzuciła myśl, że istnieją takie determinujące struktury, które socjologowie mogą odkryć w sposób obiektywny.

Istnieją olbrzymie trudności z dopasowaniem podejścia systemowego i myślenia postmodernistycznego. Co więcej, niespójne z filozofią postmodernizmu jest to, aby przedstawiać usystematyzowaną metodologię i aby stworzyć uporządkowaną metodę przekształcania teorii w praktykę. Tym niemniej poniżej wskazano (Brocklesby, Cummings, 1996) pewne możliwości w tym zakresie.

Ann R. Taket i Leroy White (2000), przyjmując postawę postmodernistyczną w naukach o zarządzaniu, oferują - jak ją nazywają - „książkę kucharską”, która przedstawia niektóre przepisy (główne cechy postmodernistyczne), a następnie zachęca do zmiany i innowacji „w gotowaniu”. Autorzy ci nadają wytycznym akronim PANDA (Participatory Appraisal of Needs and the Development of Action) - partycypacyjna ocena potrzeb i rozwój działania ${ }^{16}$. Jest to praca holistyczna i pragmatyczna, zajmująca się różnorodnością i niepewnością występującą w warunkach wieloagencji i w nowoczesnych organizacjach. PANDA odrzuca teorie totalizujące, a zachęca do mieszania różnych perspektyw, akceptowania

16 PANDA składa się dziewięciu czynności pogrupowanych w cztery kategorie: 1) Deliberation I: Selecting participants, Defining purpose/objectives, Exploring the situation; 2) Debate: Identifying options, Researching options (which could include consulting on options), Comparing options; 3) Decision: Deciding action, Recording decisions; 4) Deliberation II: Monitoring/Evaluating. 
sprzeczności, rozpoznawania i kształtowania różnorodności oraz przyjmowania otwartej postawy.

Inna możliwość „współpracy” myślenia systemowego i postmodernizmu wiąże się z przeformułowaniem niektórych idei postmodernistycznych w metody stosowane do systemów. Takie możliwości dają prace Foucaulta, Derridy i Lyotarda. Diagnostyka systemów wiedzy to postmodernistyczna metoda zaczerpnięta z wczesnych prac Foucaulta (2002) o „archeologii wiedzy”. Warren Kent Topp (1999) opracował metodę odkrycia systemu kształtowania (formative system) organizacji, stanowi on system produkcji wiedzy „drugiego rzędu” i umożliwia regulację tego, co aktorzy organizacji myślą i wyrażają. Zmiana organizacyjna staje się zatem kwestią nie tyle przesuwania poszczególnych perspektyw, ile zmieniania matrycy wiedzy, która rządzi organizacją i wyznacza, co ludzie mogą powiedzieć. Metodą na zrozumienie systemu kształtowania jest zadanie serii krytycznych pytań. Późniejsze dzieło Foucaulta (2009) na temat genealogii koncentruje się na zdemaskowaniu cech dyskursów totalizujących, co pozwala jednostkom zrozumieć, do jakiego stopnia są one uzależnione od istniejących struktur władzy i wiedzy oraz uchwycić niektóre mechanizmy utrzymywania obecnego porządku. Oferuje też narzędzia i techniki, aby podważyć status quo. W celu osiągnięcia powszechnej emancypacji jednostki muszą zaakceptować dominację różnic i niemożność postępowania w oparciu o konsensus. Inna metoda to „dekonstrukcja” Derridy (1993). Jest to potężne narzędzie, które ma na celu zgłębienie wartości lub głębokiej struktury tekstu (dla Derridy wszystko można postrzegać jako tekst). Stosuje się różne strategie ${ }^{17}$ do testowania tekstów pod kątem sprzeczności i ambiwalencji. Praca Lyotarda sugeruje natomiast „rozmowę generatywną” jako postmodernistyczną metodę prowadzącą do pojawienia się nowych koncepcji, systemowych pomysłów i tematów, które mogą stać się wyznacznikami przyszłych działań w organizacjach. W rozmowach generatywnych chodzi o zamianę jednej „gry językowej" na inną w celu tworzenia nowej wiedzy. Jedyną regułą jest to, że każda nowa fraza w rozmowie musi zawierać link do poprzedniej frazy, co zapobiega powtarzaniu się zwrotów.

Akceptacja myślenia systemowego wśród postmodernistów jest relatywnie nowym podejściem (np. Taket, 2002; Ormerod, 2003). Mimo przedstawionych powyżej prób trudno połączyć postmodernistyczne i systemowe metody badawcze.

Osobnym rozważaniom, według autorki, powinien podlegać przymusowy charakter uczestnictwa w organizacji, tu jedynie zarysowany (nie stanowi przyczynku do realizacji celu pracy). Na przestrzeni lat zmienił on swoje znaczenie w porównaniu z przymusem pracy zarobkowej końca XIX i początku XX wieku. Wprawdzie

17 Cynthia Mathis Beath i Wanda J. Orlikowski (1994) oraz Ann R. Taket (2002) podają rozmaite przykłady strategii dekonstrukcyjnych. 
praca (najemna) dla większości ludzi jest koniecznością (utrzymanie się), jednak pracownik ma wolność wyboru pracodawcy - w przypadku niezadowalającej współpracy może pracodawcę zmienić (nawet się przeprowadzając). Pracownik może także zmienić zawód, a rozszerzanie kwalifikacji lub ich zmiana stały się obecnie normą. Istnieje także elastyczność pod względem formy świadczenia pracy - praca najemna w wielu przypadkach może być zamieniona na prowadzenie działalności na własny rachunek. $Z$ tych względów przymusowość uczestnictwa w organizacji wymaga dalszych pogłębionych studiów.

W kolejnych pracach nad metodą analizy systemów złożonych skorzystano z inspiracji, jakie dają nieprzymusowe metody systemowe. W porównaniu z pierwotną analizą systemową przyjęto konieczność określenia celu systemu przed przystąpieniem do analizy, jednak znacznie ją zliberalizowano, każda z nieprzymusowych metod badania systemowego w różny bowiem sposób wykorzystuje w swoich procedurach krok określania celu. Uznaje się zatem dynamikę formułowania celu w czasie (zmienność), łagodzi konieczność tworzenia modelu matematycznego organizacji (tylko) do optymalnego rozwiązania konkretnego problemu. W ten sposób unika się zniekształcenia obrazu organizacji w wytworzonych modelach matematycznych z powodu nadmiernego uproszczenia rzeczywistości - sprzyja mu podniesienie waloru abstrakcyjności modelu.

Główne inspiracje nowej metody analizy systemów złożonych wywodzą się z poszczególnych metod systemowych - z dynamiki systemów pochodzi zorientowanie na relacje (zwrotne) w systemie, które również w metodologii systemów miękkich stanowi podstawę, ważniejsze jest bowiem utrzymanie relacji w systemie od poszukiwania celów. SSM wnosi do nowej metody konstrukcje modelu pojęciowego i abstrakcyjnego modelu koncepcyjnego. Cybernetyka uwypukla wagę koordynacji, sprzężenia zwrotnego i przepływu informacji, model VSM daje możliwość jego przeznaczenia do celów projektowych oraz diagnostycznych, a także konstruowania eleganckich modelowych reprezentacji organizacji. Ponadto złożone systemy pozwalają położyć nacisk na „rekurencyjny” charakter systemów (możliwość powtarzanie systemów wyższego rzędu w ich częściach). Szczegółowa procedura metody analizy systemów złożonych zostanie opisana w podrozdziale 3.3.

\subsection{Wartość podejścia systemowego dla badaczy XXI wieku}

Potrzeba stosowania nowej analizy systemowej w badaniach jest bezsporna, jeśli przeanalizuje się poniższe fakty. Po pierwsze, nawet najlepsze rozwiązania cząstkowe (stosowane pojedynczo lub zbiorowo) dotyczące systemu niejednokrotnie nie zapewniają dobrych wyników systemu jako całości - suma optimum podsystemów nie musi 
równać się optimum systemu (Demetis, Lee, 2017, Witczak, 2018, s. 26-37). Przyczyną jest pominięcie relacji między częściami systemu. Po drugie, globalizacja i technologia wprowadziły zmiany dotyczące podstawowych zadań stawianych przed organizatorami (kierownikami) na wszystkich poziomach ich realizacji. Dziś odpowiedzi na pytania o możliwość realizacji zadania, jego opłacalność lub zyskowność oraz potrzebne zasoby są łatwo osiągalne. Szybki postęp wewnątrzdyscyplinowy, jaki nastąpił w XXI wieku, spowodował przeniesienie punktu ciężkości w przypadku problemów rozwiązywanych systemowo w kierunku określenia zadań cząstkowych w taki sposób, aby ich lista i zakres pozwalały na optymalną realizację całości przedsięwzięcia.

W przeszłości w naukach o zarządzaniu nastąpiło odejście od metod systemowych na rzecz sytuacyjnych, w zakresie całej koncepcji, nie tylko metody badawczej. Wówczas pośród przyczyn zmiany dominującego paradygmatu wymieniano abstrakcyjność podejścia, brak możliwości wypracowania wspólnego języka opisu (zakładano, że mogłaby to być matematyka nieilościowa, umożliwiająca aksjomatyczno-dedukcyjny opis rzeczywistości), a także specyfikę systemów społecznych, która „nie znajduje odpowiednika na poziomie systemów biologicznych i fizycznych" (Koźmiński, 1984, s. 12). Ostatni zarzut ma swoje konsekwencje metodologiczne - rozwiązania badawcze poszukujące swoistej wyjątkowości sytuacji organizacyjnych nie pozwalają na modelowanie organizacji za pomocą metod formalnych ani analizy statystycznej (Mingers, White, 2010).

Interesującą dyskusję naukową, między innymi na temat korzystania $\mathrm{z}$ dorobku ogólnej teorii systemów, w jej pierwotnej postaci, na potrzeby budowania teorii organizacji i jej systemów informacyjnych oraz nad ograniczeniami OTS, rozpoczęli w 2016 roku Daniel Robey i Christine Abdalla Mikhaeil (2016) oraz Dionysios S. Demetis i Allen S. Lee $(2016 ; 2017)$ na łamach czasopisma „Information and Organization”. W 2017 roku do dyskusji dołączyli także John Mingers (2017) i Ulrike Schultze (2017).

Demetis i Lee ${ }^{18}$ (2016, s. 118-119) zwrócili uwagę na trudności empiryczne dla OTS oraz wyrazili podejrzenia dotyczące przydatności „wielkiej teorii”. Prace empiryczne muszą być zgodne z konwencjonalnymi praktykami, które redaktorzy, recenzenci i czytelnicy rozumieją i potrafią ocenić. Biorąc pod uwagę złożoność systemów w OTS, wczesne studia nad systemami często sięgały poza metody symulacyjne w celu weryfikacji lub wykazania zasad teorii systemów (Forrester, 1968, s. 398-415). Symulacja jest pod wieloma względami cennym narzędziem, jednak trafność badań symulacyjnych ostatecznie zależy od trafności założeń leżących u podstaw jej modeli matematycznych (Robey, Mikhaeil, 2016, s. 128).

18 Demetis i Lee ilustrują rozważania przykładem dotyczącym roli technologii informacyjnej w przeciwdziałaniu praniu brudnych pieniędzy - do tego przykładu aplikują epistemologię systemową. 
Teoria systemów może jednak przynieść dodatkową wartość interakcjom między naukowcami a praktykami (rozwój teorii systemów był napędzany przez wiele różnych dyscyplin). Aby pomóc w syntezie, którą teoria obiecała, jej leksykon ewoluował w taki sposób, aby obejmował interdyscyplinarność, w wyniku czego teorię systemów można obecnie zrozumieć w różnych dziedzinach, ponieważ wykracza ona poza fizykę, chemię, informatykę, biologię, socjologię, politykę, sztukę, ekonomię i inne dyscypliny (Demetis, Lee, 2017, s. 166). Sformułowania systemowe zagościły już na stałe w literaturze fachowej rozmaitych dyscyplin, a nawet w języku potocznym (np. sprzężenie zwrotne/feedback). Język nie stanowi już problemu.

Być może bardziej istotny powód „zaniedbywania”19 teorii systemów wyrastał z ogólnego powątpiewania w wartość „wielkiej teorii”. Nauki o organizacji generalnie unikają „wielkiej teorii” na rzecz teoretyzowania w perspektywie teorii „średniej” albo ugruntowanej, które są uważane za bardziej praktyczne i łatwiejsze w stosowaniu w badaniach (Robey, Mikhaeil, 2016, s. 128). Tymczasem ogólna teoria systemów, kwalifikowana jako „wielka teoria”, zaprojektowana była do unifikacji nauki i określenia natury systemów na różnych poziomach analizy, co może jednak łatwo doprowadzić uczonych do zainteresowania się badaniami praktycznych problemów określonego typu. Dotyczy to głównie interpretatorów, którzy zwykle stosują jakościowe metody badawcze do generowania szczegółowych i „zniuansowanych analiz złożonych sytuacji lokalnych” (Robey, Mikhaeil, 2016, s. 128), z ograniczonymi aspiracjami do uogólnienia (idea teorii ugruntowanej dla odmiany sugeruje, że teorie powinny być konstruowane z obserwacji empirycznych, a nie a priori - Robey, Mikhaeil, 2016, s. 128).

Ogólna teoria systemów oferuje uporządkowany, wysoce teoretyczny pogląd na świat. Ponieważ problemy w naukach stosowanych, takich jak studia nad organizacjami, są zwykle podejmowane w celu rozwiązania problemów w świecie rzeczywistym, teorie „średniego zasięgu” i „lokalne” są częściej wybierana niż „wielka teoria”. Teoria systemów nie kwalifikuje się jako teoria oparta na danych, ale raczej stanowi propozycję ogólnych właściwości systemu i ich dynamiki (Robey, Mikhaeil, 2016, s. 128). Jednocześnie dominujące podejście do teoretyzowania na poziomie średnich zakresów, polegające na wyznaczaniu „łatwych do stosowania”, specyficznych opisów, doprowadziło do ogromnej złożoności teoretycznej, która w rzeczywistości stała się niewykonalna. Stworzyło to asymetrię, która staje się

19 Demetis i Lee (2017, s. 165) przekonują, że nauka systemowa ożywiła inne dziedziny. Przykładem jest biologia systemów, która opiera się (częściowo) na wczesnych zasadach systemowych (Wiener, 1948; Wiener, Schadé, 1965; Ashby, 1976). Doprowadzito to najlepsze instytucje akademickie do podjęcia takich programów studiów. Harvard Medical School oferuje na przykład Wydział Biologii Systemów z kursami, w których teoria systemów dynamicznych jest wykorzystywana jako narzędzie do zrozumienia biologii molekularnej i komórkowej. Podobne oferty mają uniwersytety w Oksfordzie i Cambridge. 
nieproduktywna. Przykładem (Demetis, Lee, 2017, s. 166-167) jest model akceptacji technologii (technology acceptance model - TAM), dla którego Dirk S. Hovorka i Kai Larsen „szacują, że opublikowano tysiące prac naukowych, z których większość jest niepowiązana, nie odnosi się wzajemnie do siebie, ani nie jest cytowana. Oznacza to, że podczas gdy podstawowe pojęcia pozostają takie same, każda praca dodaje inne konstrukty" (Hovorka, Larsen, 2017, s. 5710). Te rozszerzenia modelu akceptacji technologii, które Hovorka i Larsen szacują na około 5000 deklarowanych „oryginalnych wkładów”, stwarzają znaczne zapotrzebowanie na integrację teorii. Ten argument dotyczy epistemologii i metodologii teorii systemów i jest zbieżny z oceną autorki tego opracowania.

Robey i Mikhaeil (2016, s. 128) doceniają zakres, w jakim niektóre koncepcje systemów podstawowych wprowadzono w obszary zarządzania (w tym w teorię organizacji i zachowania organizacyjne), socjologii (w tym w teorię instytucjonalną) i inżynierii. Mimo „spadku zainteresowania naukami systemowymi, koncepcje OTS weszły do badań nad organizacjami i tam pozostają" (Mingers, 2017, s. 67). Na przykład podejścia teoretyczne oparte na systemach socjotechnicznych i na socjomaterialności (Leonardi, 2013), teoria strukturyzacji (Orlikowski, Robey, 1991) oraz teoria złożoności (Braa i in., 2007) wywodzą się z nauk o systemach. Myślenie systemowe jest głęboko zakorzenione w projektowaniu i metodologii teorii organizacji, co z kolei kształtuje sposób pojmowania organizacji. Robey i Mikhaeil (2016, s. 129) argumentują, że wiele kluczowych wniosków z ogólnego myślenia systemowego stało się częścią leksykonu organizacji. Mimo że częściowo zaniedbano połączenia z OTS jako źródła tych pomysłów, i tak wzbogacają one teorię organizacji dzięki przyjęciu i absorpcji wielu zasad.

Teoria systemów jest wciąż obecna w dyskursie naukowym teorii organizacji, gdyż nauka ogólnie rozumiana jest już od czterdziestu lat głęboko przesiąknięta myśleniem systemowym i badaniami nad systemami, ale pierwotne sformułowania, charakterystyczne dla OTS, wymagają innowacyjności metodologicznej, a to bywa postrzegane jako ryzykowne. Robey i Mikhaeil (2016, s. 129) twierdzą, że „można uzyskać o wiele więcej, ponownie angażując się w naukę systemową". Konstatacja ta stanowi inspirację dla autorki niniejszej pracy do podjęcia się tego zadania.

Demetis i Lee (2017, s. 167) sądzą, że nauka systemowa może służyć badaczom organizacji mimo obciążenia poznawczego (związanego z abstrakcyjnością). Ci, którzy chcą ponownie zaangażować naukę o systemach w badania nad organizacjami, mogą stosować podstawowe pojęcia i generować nowe spostrzeżenia, które dotyczą problemów napotykanych w organizacjach. Ustalone wcześniej metody analizy systemowej jako metody badawczej w ówczesnej postaci są nadal wykorzystywane w praktyce organizacyjnej, chociaż samą metodę analizy systemowej uznano za trudną (Demetis, Lee, 2017; Mingers, 2017, s. 67). 
Do głównych dyscyplin teorii systemowych należy ogólna teoria systemów i cybernetyka (Mingers, 2017, s. 68), natomiast do zastosowań systemowych - które są rozważane w niniejszej pracy - należą badania systemowe, analiza i synteza systemowa, inżynieria systemów, programowanie systemowe, a także analiza operacyjna, uważana za prekursorkę zastosowań systemowych (w swojej pierwotnej postaci). Do zastosowań należy także przedstawiana tutaj metoda badawcza w postaci analizy systemów złożonych. Główna różnica między wymienionymi zastosowaniami systemowymi polega na możliwości ich bezpośredniego, praktycznego wykorzystania.

Na analizę systemową traktowaną jako badanie wpływ w ostatnich latach miały cztery główne nurty - naukowe zarządzanie, inżynieria przemysłowa, psychologia inżynieryjna oraz badanie operacyjne. Dyscypliny te korzystały i nadal korzystają z metod analizy systemowej (Mingers, 2017). Debora Hammond (2010), która prześledziła ewolucję teorii systemów w swojej pracy nad historią teorii systemów, nazwała cały wysiłek nauką o syntezie. W takim duchu realizowana jest także niniejsza praca.

\subsection{Zarys pojęć system i systemowość - perspektywa ogólna i organizacyjna}

Termin system tradycyjnie można wyprowadzić z łaciny (Bobrowski, 1905; Jougan, 1958, s. 670, 1530, za: Maryniarczyk, 1989-1990, s. 291) - systema, -atis, pierwotnie oznaczał interwał muzyczny, w łacinie średniowiecznej i nowożytnej określano nim uniwersum (kosmos) lub corpus artykułów wiary. Grecki odpowiednik $\sigma v ́ \sigma \tau \eta \mu \alpha$, - $\alpha \tau o \varsigma$ oznaczał całość zorganizowaną, ukształtowanie, uporządkowanie.

Nie istnieje Słownik pojęć systemowych (ale istnieje Mały słownik cybernetyczny pod redakcją Marii Kempisty). Pewne prowizorium można odnaleźć u Tadeusza Pszczołowskiego w Małej encyklopedii prakseologii i teorii organizacji. Słownik jezyka polskiego PWN podaje wiele znaczeń na określenie systemu. Jest to pewna całość - układ; system zorganizowania czegoś - zasada; filozoficzny, etyczny - teoria; sposób działania - metoda; system społeczno-polityczny - ustrój; system nerwowy, krwionośny - układ. Natomiast Wielki słownik języka polskiego bezpośrednio nie podaje definicji systemu, uprzedza natomiast, że hasło system ma wiele znaczeń i wymienia ich listę - planetarny, alarmowy, immunologiczny, filozoficzny, działania, totalitarny, dziesiętny oraz w komputerze.

Kategorię „system” odnaleźć można w słowniku dziedzinowym wielu nauk - na przykład biologii, geografii, psychologii, socjologii, cybernetyki i zarządzania itp., co już daje przyczynek do wielowariantowych podstawowych definicji. 
Jednak termin ten jest niejednoznaczny nawet w obszarze pojedynczej dyscypliny. Taki stan rzeczy nie powinien dziwić, jest naturalną konsekwencją pierwotnie rozdzielnego, dziedzinowego traktowania przedmiotu badań, jakim jest system, a także specyficznych prób opisu i analizy na poszczególnych gruntach naukowych. Stąd różnice w określeniu pojęcia system uwarunkowane są przez charakter badania systemowego (Sadowski, 1978, s. 90). Na gruncie ogólnej teorii systemów (OTS) von Bertalanffy'ego zainicjowano zintegrowanie podejść dyscyplinowych. Jednak od lat osiemdziesiątych XX wieku nie rozwijano koncepcji systemów w tej postaci na gruncie OTS ${ }^{20}$. Zagadnienie systemów pojawia się za to w poszczególnych dyscyplinach, oczywiście z odniesieniem do dorobku ogólnosystemowego, jednak prace kontynuowane są dla oddzielnych płaszczyzn dyscyplinowych (Stowarzyszenie, http://isss.org/world/). Stąd, nawet jeśli próbuje się wprowadzić definicję systemu w znaczeniu ogólnym, rezultat okazuje się charakterystyczny dla klasy rzeczy, które właśnie podlegają badaniu - w niniejszej pracy jest to organizacja (treść tej pracy również nie ustrzegła się temu ograniczeniu).

Interdyscyplinarna natura pojęcia system i jednocześnie jego partykularne modyfikacje dziedzinowe są dwoma powodami, dla których nie sposób dokonać racjonalnej i przemyślanej analizy ewolucji tego pojęcia, na gruntach różnych nauk kształtowało się ono bowiem rozmaicie - $\mathrm{w}$ różnych kierunkach, a ponadto niejednoczasowo i w różnym tempie. Można natomiast historycznie prześledzić ewolucję podejść systemowych na gruncie jednej dyscypliny - najbardziej uzasadniona naukowo jest analiza ogólnej teorii systemów (von Bertalanffy, 1976, s. 27-47; 1984, s. 39-45), wykracza ona jednak poza obszar teorii organizacji. Z tego względu skorzystano z drugiej możliwości, jaką jest przedstawienie ewolucji metody analizy systemów na gruncie teorii organizacji (zaprezentowanej w kolejnym podrozdziale). Wcześniej jednak należy wprowadzić definicję pojęcia system.

Przeglądy definicji systemów funkcjonują już w literaturze przedmiotu organizacja i zarządzanie od lat siedemdziesiątych XX wieku. Najpełniejsze zestawienie definicji systemów w postaci listy trzydziestu czterech pozycji (autorów lub współautorów) zawierającej czterdzieści określeń przedstawił Vadim Sadowski (1978, s. 106-112). Definicyjne rozważania w ramach dyscyplin - biologii, chemii i psychologii, organizacji i innych - przygotowali Igor Viktorovich Blauberg, Vadim Sadowski i Erik Grigor'evič Judin (1973, s. 9-40). Funkcjonują zatem różne określenia definicyjne systemu - od tolerancyjnych do restrykcyjnych.

20 Pogodzenie potrzeb ontologicznych i epistemologicznych dyscyplin społecznych i technicznych okazało się wyjątkowo trudne, jeśli nie niemożliwe. Jak pisał von Bertalanffy w liście do Alexis de Tocqueville: Amerykanie „poświęcają się naukom praktycznym, mają awersję do idei ogólnych i odkryć teoretycznych” (Hammond, 2010, s. 107). 
Ponieważ znaczna część przytoczonych tutaj rozważań jest już szczegółowo opisana w literaturze i powszechnie znana, dlatego zrezygnowano ze szczegółowej analizy tego zagadnienia na rzecz innej, niewyeksploatowanej jeszcze naukowo perspektywy - pierwszeństwa pojęcia elementu lub pierwszeństwa pojęcia relacji w definiowaniu systemu. Definicje systemu - ogólnie zbioru oddziałujących na siebie elementów - koncentrują się głównie wokół elementów jego budowy oraz relacji między nimi. Naukowcy zajmujący się systemami, definiując pojęcie system, kładą nacisk albo na elementy, albo na relacje, zależnie od przyjętej perspektywy badawczej.

Większość definicji powstała na podstawie podejścia, w którym system traktowany jest jako rzecz - reprezentanci takiego spojrzenia to na przykład Russell Lincoln Ackof, Ludvig von Bertalanffy, Marian Mazur, Vadim Sadowski i Awiner I. Ujemow. Dla nich system to „zbiór elementów pozostających we wzajemnych relacjach” (von Bertalanffy, 1984, s. 86) lub też „zbiór elementów i zachodzących między nimi relacji” (Mazur, 1976, s. 45) albo „zbiór uporządkowanych w określony sposób elementów powiązanych wzajemnie ze sobą i tworzących pewną całość” (Sadowski, 1978, s. 112).

Ujemow (1973b, s. 62) określił system jako zbiór obiektów, między którymi zachodzi określona relacja o ustalonych cechach.

Każdy system jest przede wszystkim przedmiotem. Przedmiot pojedynczy [...] (Piłka) będzie systemem wówczas, gdy przedstawimy ją jako zespół jej części lub jako zespół jej cech. Zespół można przedstawić jako przedmiot wraz z pewną relacją wewnętrzną, tzn. taką, której wszystkie korelaty należą do danego przedmiotu (Ujemow, 1973b, s. 60).

Proponował on nawet, aby niektóre relacje rozważać jako przedmioty.

Elementy systemu to zatem pewien zbiór rzeczowy lub abstrakcyjny, na który nie nałożono żadnych ograniczeń, z jednym wyjątkiem - rzeczy te są dla danego systemu niepodzielne. Niepodzielność jest względna. To, co jest niepodzielnym elementem systemu, może w ramach innego systemu ulegać podziałowi, czyli składać się z kolejnych niepodzielnych elementów. Elementy posiadają określone właściwości, które nie są tożsame $z$ właściwościami całego systemu. Jednak aby mówić o systemie, nie wystarczy po prostu zbiór elementów.

Według innych autorów pojęcie system to zbiór pewnych relacji - powstały definicje relacyjne (np. Halla, Mesarovicia). Systemem jest „zbiór obiektów wraz z relacjami istniejącymi pomiędzy tymi obiektami oraz pomiędzy ich własnościami” (Hall, 1968, s. 93). Mihajlo Mesarović sformalizował pojęcie systemu na płaszczyźnie matematycznej w taki sposób: 
Punktem wyjścia jest pojęcie (ogólnego) systemu jako relacji między abstrakcyjnymi zbiorami

$$
S \subset \times\left\{V_{i}: i \in I\right\}
$$

gdzie $\times$ oznacza iloczyn kartezjański, a I jest zbiorem indeksów. Gdy I jest zbiorem skończonym, powyższe można zapisać w sposób prostszy

$$
S \subset V_{1} \times \ldots \times V_{n}
$$

Składniki tej relacji, $V_{i}$, określone są jako obiekty (systemu). Obiekt przedstawia tu cechę lub charakterystykę, za pomocą których system jest opisywany. Zbiór $V_{i}$ przedstawia wszystkie sposoby, w jakie odpowiednia cecha jest postrzegana czy doznawana (Mesarović, 1973, s. 49-50).

Relacje to zatem pewne powiązania i sprzężenia, jakie występują między elementami systemu, konstytuując go w całość. Wszystkie elementy systemu, każdy $z$ osobna, są powiązane $z$ innymi elementami. Ponadto własności systemu nie są po prostu sumą własności poszczególnych elementów składowych, są określone przez istnienie i specyfikę relacji między elementami, to one „konstytuują się jako integrujące własności systemu jako całości” (Sadowski, 1978, s. 96). W teoriach relacyjnych system jest definiowany przez związki między cechami. Podkreślane są związki scalające części składowe w ramach konkretnej konstrukcji systemu. Relacje scalające system to grupa tak zwanych relacji systemotwórczych - „Z reguły sprzężenia i relacje systemotwórcze to sprzężenia i relacje wewnętrzne danego systemu"21 (Sadowski, 1978, s. 97).

Wydaje się, że polemika prymatu elementów lub relacji w systemie pozostanie na razie bez rozstrzygnięcia, relacje konstytuują bowiem system i stanowią o jego właściwościach, jednak bez elementów nie powstałyby relacje. Inaczej mówiąc, elementy bez uwzględnienia relacji nigdy nie tworzą systemu, z drugiej zaś strony systemu nie tworzą także relacje rozpatrywane w oderwaniu od elementów. Dla realizacji celu szczegółowego tej pracy, w postaci budowy modelu relacyjnego organizacji (za pomocą relacji komunikowania), przyjęto prymat relacji nad elementami, uwzględniając wewnętrzne, systemotwórcze relacje merologiczne oraz relacje oddziaływania (szczegóły w kolejnym podrozdziale).

Istnieje jeszcze trzecie oblicze systemów, według którego są one definiowane jako całości przeciwstawiane środowisku. Na przykład Ashby kładzie nacisk

21 Sadowski wymienia pojęcia relacje i sprzężenia obok siebie, jak gdyby reprezentowały one ten sam poziom ogólności, jednak sprzężenie jest jedną z możliwych form relacji. 
na specyficzny charakter stosunków między systemem a otoczeniem (podstawa idei homeostazy) i efektywnego badania sprzężeń w systemie: „System - dowolny zespół zmiennych, który obserwator wybiera spośród zmiennych właściwych «maszynie» rzeczywistej" (Ashby, 1976, s. 82).

System jest traktowany jako całość, jest względnie odosobniony od pozostałego świata, otoczenia. Podczas wzajemnego oddziaływania systemu z otoczeniem system tworzy i przejawia swoje własności ${ }^{22}$. Poziom otwarcia i zamknięcia systemu również podlega szerokim dyskusjom (von Bertalanffy, 1984, s. 69-71). Oprócz wewnętrznych relacji i sprzężeń łączących elementy systemu występuje także szereg zewnętrznych relacji i sprzężeń. Wszystko to, co znajduje się poza granicami systemu ${ }^{23}$, stanowi jego otoczenie i ono też może być traktowane jako osobny system. Z tego wynika, że system zawsze istnieje w otoczeniu, a elementy wchodzące w skład jednego systemu mogą stanowić równocześnie składniki otoczenia innego systemu (który również jest zbiorem elementów i relacji) (Mazur, 1976, s. 46). Wyodrębnienie systemu z otoczenia jest więc zawsze w jakimś sensie umowne i relatywne 24 . Jeśli określony system podlega badaniu, wówczas to obserwator ustala jego granice - czyli określa, co należy do systemu, a co do niego już nie należy. Wynika to z ontologii systemów -

[...] obiektu rozpatrywanego bez uwzględnienia celu jego badania nie można w sposób bezwzględny zaklasyfikować do systemów lub niesystemów. I przeciwnie, ten sam (pod względem ontologicznym) obiekt może w zależności od postawionego problemu być badany jako systemowy lub niesystemowy (Judin, Sadowski, w: Ujemow, 1973b, s. 62-63).

Wyjątkiem są obiekty niesystemowe, na przykład proste, jednoelementowe.

22 Określenie właściwość przysługuje przedmiotom abstrakcyjnym, cecha to określenie prakseologiczne, przysługujące przedmiotom materialnym i osobom. Określenie własność jest nadrzędne wobec dwóch pozostałych (Pszczołowski, 1978, s. 110-117).

23 Guido Fioretti i Bauke Visser (2004, s. 16) uważają, że koncepcja systemów zakłada, że granice między organizacją a jej otoczeniem są wyraźne. Manuel Castells (1996, s. 167; 2007) twierdzi jednak, że ustalenie granic systemu i transformacji nie jest łatwe, zwłaszcza w przypadkach, gdy organizacje mają wiele węzłów interakcyjnych (multiple nodes of interactions) i linii komunikacyjnych. W burzliwym środowisku, gdy zadania i składy grup są zmienne, teoria systemów otwartych nie daje szybkiej odpowiedzi na pytanie, jak organizacje mają sobie radzić w tak złożonych sytuacjach (Clippinger, 1999, s. 21). Terence J. Sullivan (2004, s. 45) oraz T. Wang (2004, s. 395) proponują, aby zmodyfikować model systemów otwartych w sytuacjach, w których szybkość dokonywania wyborów i ich zakres przeważają nad stabilnością i przewidywalnością. Jest to zatem możliwe.

24 Na schematach cybernetycznych nie zaznacza się otoczenia, uważając jego istnienie za oczywiste (Mazur, 1976, s. 46). 
Z tego powodu system łatwiej opisać przez jego własności ${ }^{25}$. Oprócz wcześniej wymienionych - elementów, relacji (złożoności) i otoczenia (w kontekście związanej z otoczeniem cechy otwartości i zamkniętości systemu) - wymienia się także inne. Wielu autorów przygotowywało własne listy właściwości systemów, począwszy od von Bertalanffy'ego, który zaproponował następujące:

[...] całościowość, addytywność, centralizacja, różnicowanie, część przewodnia, system zamknięty i otwarty, finalność, ekwifinalność, wzrost w czasie, wzrost względny, rywalizacja [...] (von Bertalanffy, 1984, s. 128).

Właściwości systemów proponowane przez von Bertalanffy’ego są nadal szeroko dyskutowane (Demetis, Lee, 2016, s. 128; 2017 s. 167). Na przykład cecha addytywności, określana stwierdzeniem:

[...] że dany zespół można zbudować krok po kroku, składając pierwsze oddzielne elementy i na odwrót - cechy zespołu można całkowicie rozłożyć na cechy oddzielnych elementów. Odnosi się to do tych zespołów, które można nazwać „stosami”, takimi jak stos cegieł lub sterta luźnych przedmiotów [...]. Nie odnosi się to do tych systemów, które w języku niemieckim nazywają się Gestalten ${ }^{26}$ (von Bertalanffy, 1984, s. 98-99),

doczekała się dyskusji w pracach Sadowskiego - który stwierdził, że:

W ramach ogólnej teorii systemów addytywność oznacza, że zmiana dowolnego elementu systemu zależy tylko od tego elementu. W rezultacie zmiana całego systemu jest sumą zmian jego elementów niezależących od siebie wzajemnie (wzajemne oddziaływanie elementów w tym przypadku równe jest zeru i w rzeczywistości mamy do czynienia z systemem zdegenerowanym) (Sadowski, 1981, s. 297).

Własność całościowości oznacza, że systemy są określonymi przez obserwatora całościami i - jako „coś niepodzielnego” - łącznie podlegają badaniu. Centralizacja definiowana jest niejasno w opozycji do indywidualizacji, jako „nabieranie

25 Tyson R. Browning (2001, s. 292) podaje, że klasyczne podejście do zwiększenia rozumienia złożonego systemu polega na jego modelowaniu, zazwyczaj przez: 1) rozkładanie go na podsystemy, o których wiadomo stosunkowo więcej; 2) odnotowanie zależności (integracji) między podsystemami, które są powodem określonych zachowań systemu;3) odnotowanie wejścia i wyjścia oraz ich wpływu na system.

26 System Gestalten jest to psychologia postaci, według której jaźń jest pewną całością i nie może być rozbijana na elementy. Za jego prekursorów uważa się Laurę i Fritza Perlsów, a za popularyzatora Kurta Koffkę (2013). 
scalonego, coraz bardziej niepodzielnego charakteru” (von Bertalanffy, 1984, s. 103). Pojęcie różnorodności określa, z ilu rozróżnialnych elementów składa się zbiór części systemu. Systemy zamknięte to systemy, „o których sądzi się, że są odizolowane od swojego środowiska" (von Bertalanffy, 1984, s. 69), także posiadają otoczenie, ale nie występują połączenia z nim, dlatego w tym przypadku otoczenie nie wpływa na stan lub zachowanie systemu. Systemy otwarte wykazują połączenia z otoczeniem, w wyniku których otoczenie wpływa na stan lub zachowanie systemu i odwrotnie. Oddziaływanie otoczenia na system odbywa się za pomocą wejść i wyjść z otoczenia systemu (von Bertalanffy, 1984, s. 69-71). Systemy otwarte zachowują się inaczej niż zamknięte, bo do tego samego stanu końcowego można dotrzeć, wychodząc od innych warunków wyjściowych i różnymi drogami. „To właśnie nazywamy ekwifinalnością” (von Bertalanffy, 1984, s. 70). Ponadto występuje wzrost złożoności systemu.

To przechodzenie do wyższego ładu wymaga zasilania w energię, a energia jest do systemu dostarczana w sposób ciągły tylko wtedy, kiedy jest to system otwarty, pobierający energię z otoczenia (von Bertalanffy, 1984, s. 101).

Część z przedstawionych właściwości ewoluowała w pracach innych autorów. Sadowski (1973, s. 338-339) pracował nad określeniem własności systemów, uporządkował cechy formalne systemów, jakie scharakteryzował i opisał von Bertalanffy, i przedstawił je w formie listy. Należą do nich: integralność - zmiana dowolnego elementu wpływa na wszystkie pozostałe elementy systemu i prowadzi do zmian całego systemu i odwrotnie; addytywność - zmiana dowolnego elementu zależy tylko od niego samego, a zmiana całego systemu jest sumą zmian niezależnych od siebie jego elementów (oddziaływanie wzajemne w tym przypadku równe jest zeru); mechanizacja to proces przejścia systemu zintegrowanego w system addytywny, współczynniki oddziaływania wzajemnego poszczególnych elementów zmniejszają się przy tym, a przy $t \rightarrow \infty$ dążą do zera. Kolejna własność to centralizacja, czyli proces zwiększania współczynników oddziaływania wzajemnego w pewnej części lub elemencie systemu, co w rezultacie prowadzi do nieznacznych zmian części wiodącej systemu i istotnych zmian całego systemu; organizacja hierarchiczna systemu, która oznacza, że poszczególne elementy systemu stanowią systemy rzędu niższego i (lub) system rozpatrywany występuje jako element systemu wyższego rzędu.

Sadowski, pracując nad koncepcją systemów von Bertalanffy'ego, przyjął część określeń własności zaproponowanych przez niego, z częścią dyskutował, ale także wypracował kolejne propozycje własności, wśród których wymienił: budowę hierarchiczną, uporządkowanie, organizację i strukturę (Sadowski, 1978, s. 95-100). Budowa hierarchiczna to własność związana $\mathrm{z}$ „podzielnością systemu” oraz 
istnieniem różnorodnych sprzężeń i relacji. Podzielność obiektów pozwala na rozważanie ich jako szczególnych systemów, a sprzężenia i relacje mogą być rozłożone na bardziej elementarne. W rezultacie dowolny system jest złożonym tworem o charakterze hierarchicznym, w którym wyodrębnia się różne poziomy i różne typy sprzężeń wzajemnych między różnymi poziomami, bo:

[...] system jest z natury swojej hierarchiczny; każdy jego składnik z kolei może być rozpatrywany jako system, a sam system badany stanowi tylko jeden ze składników systemu szerszego. Na tej podstawie można sformułować zasadę hierarchiczności dowolnego systemu - obiekt jest rzeczywiście badany jako system tylko pod warunkiem opracowania środków analizy każdego jego podsystemu jako określonego systemu i każdego systemu (włączając w to rozważany wyjściowy obiekt jako całość) jako podsystemu pewnego systemu szerszego (Sadowski, 1981, s. 294).

Uporządkowanie to ustalenie istnienia w systemie określonego porządku elementów, relacji i sprzężeń w budowie i funkcjonowaniu systemu.

Uporządkowanie sprowadza się do relacji [...] Tam, gdzie zbiór, poczynając od dwuelementowego, a kończąc na nieskończonym, jest tym samym pojęciem zbioru, tam już jest uporządkowanie (Kuhn, 1962, s. 14).

Organizacja systemu ustala nie tylko własność uporządkowania jego elementów i relacji, ale także specyficzne dla każdego systemu wzajemne stosunki między podsystemami. Struktura natomiast to charakterystyka uogólniona specyficznych własności systemowych w formie abstrakcyjnej, ustalająca elementy, relacje systemu, ich uporządkowanie i organizację (Sadowski, 1978, s. 98). Sadowski wymieniał także systemy samoorganizujące się i samorozwijające - są to systemy zachowujące się aktywnie, w których prymat wiodą wewnętrzne prawa zachowania, a otoczenie odgrywa rolę podrzędną.

Inny katalog właściwości zaproponował Artur D. Hall (1968, s. 99-103): niezależność (addytywność) i spójność (koherentność). Systemy spójne ${ }^{27}$ zachowują się jak jedna całość, a zmiana w jednym elemencie wywołuje zmianę we wszystkich pozostałych. Podział progresywny oznacza zmiany w czasie prowadzące do stopniowego przejścia od spójności do niezależności. Integracja progresywna, czyli przeciwieństwo podziału progresywnego, prowadzi do spójności. Centralizacja pozwala jednemu z podsystemów odgrywać decydującą rolę (podsystem kierujący).

27 Dla Halla spójność i niezależność są skrajnymi przypadkami tej samej miary: „Spójność (koherentność) i niezależność (addytywność) nie są dwoma różnymi własnościami, lecz skrajnymi przypadkami tej samej" (Hall, 1968, s. 100). 
Kolejną listę siedmiu cech systemów przygotował Ujemow (1973b, s. 67-68) - są to: jednorodność, elementarność, minimalność, niezupełność, uporządkowanie, immanentność i autonomiczność elementów. System jednorodny to taki, który składa się z jednorodnych elementów, elementarny to taki, którego żaden element nie jest w danym systemie rozpatrywany jako system, minimalny to taki, który przestaje być systemem po zlikwidowaniu choćby jednego elementu, niezupełny to taki, który po dołączeniu nowego elementu nie przekształca się w inny system, a zupełny nie pozwala na przyłączenie nowych elementów. System immanentny to taki, w którym relacja systemotwórcza może występować tylko między elementami danego systemu, relacja systemotwórcza systemów nieimmamentnych może występować także między elementami nienależącymi do danego systemu.

Podstawowe pojęcia określające system według Johna Mingersa (2017, s. 68) obejmowały: części, całości, podsystemy, układ, granice, środowisko, strukturę, proces, właściwości wyodrębniające (emergent properties), hierarchię systemów, pozytywne i negatywne informacje zwrotne, informacje i sterowanie, systemy otwarte, holizm i obserwatora. Własności systemów (identyfikujące wspólne wzorce i procesy - Bausch, 2002, s. 421; Capps, Hazen, 2002, s. 309) wpływają na możliwości ich klasyfikowania i podziału ${ }^{28}$. Poniżej przestawiono celowy wybór właściwości i klasyfikacji systemów, dostosowany do celów pracy - ze względu na konstrukcję metody systemowej analizy organizacji złożonych i konsekwentnie związaną z tą metodą konieczność budowy relacyjnego modelu organizacji jako systemu komunikacji organizacyjnej. Można już teraz powiedzieć, że system budowany za pomocą metody systemowej jest abstrakcyjny, sztuczny, złożony, koherentny i otwarty. Pozostałe właściwości systemu należy ustalić w toku prac nad nim. Metoda klasyfikacji systemów pozwala przeprowadzić badania na wybranych systemach i uogólnić wyniki na całą grupę systemów z tej samej klasy, a więc posiadających te same lub podobne właściwości.

Według kryterium realności występują systemy rzeczywiste, istniejące realnie i nierzeczywiste, abstrakcyjne (Tien, Berg, 2003, s. 23-24). Kryterium powstania systemu dzieli je na naturalne, powstałe w wyniku działania sił przyrody i sztuczne, stworzone przez człowieka. Kryterium złożoności wyznacza systemy proste, złożone z niewielkiej liczby elementów oraz systemy złożone, składające się z wielu elementów i więzi wewnętrznych i zewnętrznych. Istnieją także systemy złożone w takim stopniu, że przy obecnym stanie wiedzy ich badanie nie jest w pełni możliwe. Kryterium hierarchii elementów jest odnoszone do centralizacji i decentralizacji. W systemach scentralizowanych jeden $\mathrm{z}$ obiektów przyjmuje centralną pozycję, w zdecentralizowanych podsystem kierujący nie występuje. Kryterium

28 Wyjaśnienie pochodzenia stabilności i ewolucji systemów - por. Montuori (2000, s. 65); Alter (2007, s. 36). 
siły sprzężeń wewnętrznych (Stewart, Ayres, 2001, s. 85; Yoon, Kuchinke, 2005, s. 19) pozwala wyodrębnić różne stopnie spójności systemów, przy czym systemy spójne (koherentne) to takie o silnych więziach wewnętrznych, że zmiana w jednym pojedynczym elemencie wywołuje zmianę we wszystkich pozostałych. Kryterium działania wyodrębnia systemy statyczne i dynamiczne ${ }^{29}$ (Ackoff, 1973). W systemach statycznych nie odbywają się procesy przetwarzania (np. kamieńn ${ }^{30}$ ), a ewentualne zmiany są wynikiem działania czynników zewnętrznych, w dynamicznych następują procesy przetwarzania energii, materii i informacji. Kryterium przewidywalności wyznacza systemy deterministyczne i probabilistyczne. Deterministyczne systemy reagują na bodźce zewnętrzne w sposób przewidziany (prawdopodobieństwo wysokie lub pewność); systemy probabilistyczne charakteryzują się niepewnością działania i reakcji na bodźce. Kryterium współpracy z otoczeniem określa systemy otwarte i zamknięte (Fioretti, Visser, 2004, s. 16; Wang, 2004, s. 396; Amagoh, 2008, s. 2). Otwarte wymieniają energię, materię i informacje, wpływają na otoczenie i ulegają wpływowi. Systemy zamknięte pozostają izolowane, hermetyczne. Powyższe rozważania zebrano w tabeli 5.

Tabela 5. Klasyfikacja systemów

\begin{tabular}{|l|l|l|}
\hline \multicolumn{1}{|c|}{ Kryterium } & \multicolumn{2}{|c|}{ Rodzaje systemów } \\
\hline Realność & $\begin{array}{l}\text { Systemy rzeczywiste - istniejące } \\
\text { realnie }\end{array}$ & $\begin{array}{l}\text { Systemy nierzeczywiste } \\
\text { - abstrakcyjne }\end{array}$ \\
\hline $\begin{array}{l}\text { Powstanie } \\
\text { (geneza) systemu }\end{array}$ & $\begin{array}{l}\text { Naturalne, powstałe w wyniku } \\
\text { działania sił przyrody }\end{array}$ & Sztuczne, stworzone przez człowieka \\
\hline Złożoność & $\begin{array}{l}\text { Proste, złożone z niewielkiej liczby } \\
\text { elementów }\end{array}$ & $\begin{array}{l}\text { Systemy złożone, składające } \\
\text { się z wielu elementów i więzi } \\
\text { wewnętrznych i zewnętrznych }\end{array}$ \\
\hline Hierarchia & $\begin{array}{l}\text { Zcentralizowane, gdzie jeden } \\
\text { zobiektów przyjmuje centralną } \\
\text { pozycję }\end{array}$ & $\begin{array}{l}\text { Zdecentralizowane, gdy podsystem } \\
\text { kierujący nie występuje }\end{array}$ \\
\hline
\end{tabular}

29 Przyjmując za podstawę krytykę lana Beesona i Chrisa Davisa (2000, s. 181), perspektywa systemowa zakłada, że zarządzanie jest tatwo identyfikowane z centrum sterowania, a w podejściu systemowym centralną rolę przypisuje się zarządzaniu, co powoduje przecenianie roli zarządzania w organizacji jako centrum kontrolującego zdarzenia i działania, atrakcyjne wydaje się więc rozważenie koncepcji dynamicznych systemów nieliniowych na gruncie teorii złożoności (Morel, Ramanujam, 1999, s. 278; Styhre, 2002, s. 345; Price, 2004, s. 42).

30 Przyjmując, że system składa się z elementów (i ich cech) statycznych i dynamicznych oraz relacji stałych i zmiennych, taka kombinacja pozwoliła na zbudowanie ośmiostopniowej hierarchicznej skali Bouldinga (Boulding, 1956, s. 197-208). Oryginalna koncepcja, obejmująca hierarchię złożoności, nie przebrzmiała i jest nadal cytowana (np. Martinelli, 2001, s. 72-74; Stewart, Ayres, 2001, s. 83; Bausch, 2002, s. 418). Doczekała się także rozwinięcia do dziewięciu poziomów (np. Ashmos, Huber, 1987, s. 609; Beeson, Davis, 2000, s. 182; Sullivan, 2004, s. 48; Yoon, Kuchinke, 2005, s. 17). 


\begin{tabular}{|l|l|l|}
\hline \multicolumn{1}{|c|}{ Kryterium } & \multicolumn{2}{c|}{ Rodzaje systemów } \\
\hline $\begin{array}{l}\text { Siła sprzężeń } \\
\text { wewnętrznych }\end{array}$ & $\begin{array}{l}\text { Spójne (koherentne) to takie } \\
\text { o silnych więziach wewnętrznych }\end{array}$ & O słabych więziach wewnętrznych \\
\hline Działania & Systemy statyczne & Systemy dynamiczne \\
\hline Przewidywalnośćć & $\begin{array}{l}\text { Systemy deterministyczne reagują } \\
\text { na bodźce zewnętrzne w sposób } \\
\text { przewidziany (prawdopodobieństwo } \\
\text { wysokie lub pewność) }\end{array}$ & $\begin{array}{l}\text { Systemy probabilistyczne } \\
\text { charakteryzują się niepewnością } \\
\text { działania i reakcji na bodźce }\end{array}$ \\
\hline $\begin{array}{l}\text { Współpraca } \\
\text { zotoczeniem }\end{array}$ & Otwarte & Zamknięte \\
\hline
\end{tabular}

Źródto: opracowanie własne.

Reasumując, system jest w założeniu tworem idealnym, bo „Co to jest system? [...] jakiś system to jakiś sposób patrzenia na świat” (Weinberg, 1979, s. 70). Inaczej mówiąc, systemy - jako takie - nie występują w świecie realnym, a są tworzone przez naukowców, badaczy, planistów, projektantów itp., traktujących obiekty jak systemy. Jest to rzeczywistość przetransponowana w model systemu na potrzeby myślenia, badania, rozumienia, projektowania (Weinberg, 1979, s. 70).

\subsection{Systemowe pojęcie relacji i ich ujęcie w kontekście systemowym}

Ze względu na sposób ujęcia głównego problemu pracy - założenie tożsamości organizacji jako systemu relacyjnego - systemowe pojęcie relacji będzie poniżej szczególnie wnikliwie rozważane.

Potocznie słowo relacja rozumiane jest dwojako - jest to na przykład raport lub sprawozdanie i to znaczenie nie będzie rozpatrywane w niniejszej pracy. Znaczenie drugie oscyluje wokół kwestii wzajemnego związania, jest synonimem takich określeń jak: stosunek, związek, wpływ, zależność lub też współzależność, więź, korelacja, odniesienie oraz układ, sprzężenie i stycznośćs1.

Tytułem uporządkowania toku myślenia należy w tym miejscu wskazać, że relacje są statyczne i dynamiczne, „procesy to ciąg relacji” (Lipiec, 1979, s. 67). Podejście to budzi wątpliwość, ponieważ proces jest ciągiem zdarzeń, a to znaczy, że jest dynamiczny, jednak relacje bywają także statyczne.

31 Nie wymieniono tutaj szeregu określeń, które intuicyjnie kojarzą się z pojęciem relacji, ale stanowić mogą jej typ szczegółowy. Przykładem może być określanie oddziaływanie, jest to bowiem jeden z możliwych typów relacji i stanowi zawężenie pojęcia. Zakłada ono działanie jednej ze stron na drugą, relacja nie musi wypływać z działania, może nią być na przykład tożsamość budowy lub podstawowych funkcji (por. Ujemow, 1973a, s. 57). 


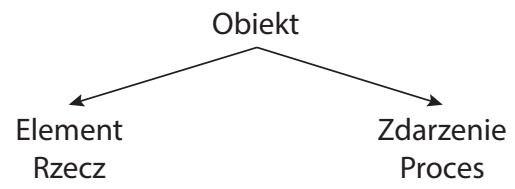

Ujęcie statyczne Ujęcie dynamiczne

Rysunek 1. Ujęcie statyczne i dynamiczne obiektu

Źródto: opracowanie własne.

Dotychczasowa dość obszerna literatura z zakresu podejścia systemowego charakteryzuje się brakiem zgodności sądów i opinii oraz wielowątkowością - zawiera różnorodne aspekty ujęcia systemowego. Występuje wiele różnic nawet w zasadniczych punktach widzenia, dotyczących istoty i metod ujęcia systemowego. W kolejnych akapitach przedstawiono różne ujęcia systemów, wypracowane na podstawie rozmaitych punktów wyjściowych. Wybór przedstawionych teorii jest podyktowany celem niniejszego opracowania - określeniem organizacji jako systemu relacyjnego.

Pojęcie relacji jest rozmaicie definiowane na gruncie różnych dyscyplin naukowych. Używane jest w znaczeniu powiązań, więzi, zależności, podporządkowania, podległości, związku między przynajmniej dwoma elementami, a także jako stosunek lub względność (Wojciechowski, 2013, s. 27).

Matematycy i logicy na gruncie teorii mnogości i logiki matematycznej definiują relacje jako podzbiory iloczynu kartezjańskiego zbiorów ${ }^{32}$.

Jeżeli $R \subseteq X \times Y$, to $R$ jest relacją. Jeżeli $R$ jest relacją, to istnieją takie zbiory $X$ i $Y$, że $R \subseteq X \times Y$. Relacja ${ }^{33} n$-argumentowa ${ }^{34}$ to zbiór $R \subseteq X_{1} \times X_{2} \times \ldots \times X_{n}$.

Zbiór $X_{1} \cup X_{2} \cup \ldots \cup X_{n}$ nazywany jest polem relacji. Jeśli $X_{1}=X_{2}=\ldots=X_{n}=X$, to mówi się o relacji w zbiorze $X$. Relacja w sensie matematycznym określona jest zawsze w pewnym z góry zadanym zbiorze, dlatego mówiąc na przykład

32 Iloczyn kartezjański dwóch zbiorów jest to ogół wszystkich par (uporządkowanych zbiorów dwóch elementów), z których pierwszy należy do pierwszego zbioru, a drugi do drugiego: $A \times B=\{(a, b) ; a \in A$ i $b \in B\}$.

33 Wielu autorów unika nazwy relacja, mówiąc o „symbolach pierwotnych” lub „symbolach relacyjnych" itp. Jednak na gruncie uogólnionej teorii relacji, w której skład wchodzą relacje między zbiorami (np. „zawieranie się”) oraz między zbiorem a elementem (np. „należy do...") nie da się utworzyć iloczynu kartezjańskiego bez pojęcia zbioru wszystkich zbiorów.

34 Występują także przypadki szczególne, gdy: $n=1$, wtedy $R \subseteq X$, taka relacja jednoczłonowa jest podzbiorem zbioru $X ; n=2$, to $R \subseteq X \times Y$ nazywana jest relacją binarną, dla której stosuje się dwa równoważne zapisy: $R \subseteq X \times Y(x, y) \in R$ oraz $x R y$ (zapis taki czyta się jako: $x$ jest w relacji $R$ z elementem $y$ ). 
o dwuargumentowej ${ }^{35}$ relacji większości między liczbami, trzeba określić, na jakim zbiorze liczb.

Takie relacje definiuje się jako:

1) zaprzeczenie relacji $R: x \not R y \Leftrightarrow \neg x R y$;

2) dziedzina relacji $R$ to zbiór: $\operatorname{dom} R=d_{R}:=\{x \in X: \exists y \in Y x R y\}$;

3) przeciwdziedzina relacji $R$ to zbiór: $d_{R}^{-1}:=\{y \in Y: \exists x \in X x R y\}$;

4) relacja odwrotna do $R$ to relacja: $R^{-1}:=\{(y, x) \in Y \times X:(x, y) \in R\}, y R^{-1} x \Leftrightarrow x R y$, $d_{R-1}=d_{R}^{-1}, d_{R^{-1}}^{-1}=d_{R}$

5) złożenie relacji $R$ i $S$ : jeśli $R \subseteq X \times Y, S \subseteq Y \times Z$, to $S \circ R=U \subseteq X \times Z$ $x U z \Leftrightarrow \exists y \in Y(x R y \wedge y S z)$. Składanie relacji nie jest przemienne, ale jest łączne, to znaczy: $R \circ(S \circ T)=(R \circ S) \circ T$.

Występują również relacje szczególne, określane jako relacja pełna, pusta oraz relacja identyczności. Relacje te przedstawiono poniżej:

1) relacja pełna (każdy $x$ jest w relacji z każdym $y) R=X \times Y$;

2) relacja pusta (żadne elementy nie są w relacji) $R=\emptyset \subseteq X \times Y$;

3) relacja identyczności (równości) $I_{X}=i d_{X}: I_{X} \subseteq X \times X, x I_{X} y \Leftrightarrow x=y, R^{-1} \circ R=I_{X}$, $R \circ R^{-1}=I_{Y}, R \circ I_{X}=R$.

Szczegółowy przegląd rodzajów relacji pozwala ustalić znaczną ich rozmaitość (Kuratowski, Mostowski, 1978, s. 76; Turzyński, 2003, s. 42-71; Guzicki, Zakrzewski, 2007, s. 153-240) - relacja może być symetryczna, asymetryczna (antysymetryczna), niesymetryczna, tranzytywna (przechodnia), atranzytyna (aprzechodnia), nontranzytywna (nieprzechodnia), zwrotna, azwrotna (przeciwzwrotna), nonzwrotna, spójna, aspójna, nonspójna oraz identyczności, większości, mniejszości, podzielności. Poniżej wskazano podstawowe własności relacji określone w matematyczny sposób. $\mathrm{O}$ relacji $R \subseteq X \times Y$ mówi się, że jest:

1) zwrotna $\Leftrightarrow \forall x \in X \quad x R x$;

2) przeciwzwrotna $\Leftrightarrow \forall x \in X \quad \neg x R x$;

3) przechodnia $\Leftrightarrow \forall x, y, z[(x R y \wedge y R z) \Rightarrow x R z]$;

4) symetryczna $\Leftrightarrow \forall x, y \quad(x R y \Rightarrow y R x)$;

5) (słabo) antysymetryczna $\Leftrightarrow \forall x, y \quad[(x R y \wedge y R x) \Rightarrow x=y]$;

6) silnie antysymetryczna $\forall x, y \quad(x R y \Rightarrow \neg y R x)$;

7) spójna $\Leftrightarrow \forall x, y \quad(x R y \vee y R x \vee \mathrm{x}=y)$.

Symbole sumy i iloczynu zbiorów, oznaczenie zbioru pustego, odnaleźć można również w pracach przygotowywanych na gruncie nauk społecznych, jednak wtedy autorzy stosują głównie słowny opis operacji - na przykład „ogół wszystkich osobników należących do badanych populacji” zamiast oznaczenia sumy

35 Relacją dwuargumentową nazywa się dowolny zbiór złożony z par uporządkowanych. Konsekwentnie występują również relacje $n$-argumentowe. 
„mnogościowej” badanej populacji. Stosowanie powszechnie znanych symboli36 jest ścisłe, jednoznaczne i skraca zapis formuł.

Teoria mnogości pozwoliła na opisanie systemów w sposób matematyczny. Teoria systemów według Mesarovicia (1976, s. 246-262) prezentuje wysoki stopień „matematyzacji”. Własności i zachowanie systemu badane są metodami ścisłymi, co pozwala na zastosowanie tej teorii w systemach podejmowania decyzji, sterowania oraz w systemach opisywanych przez wejścia i wyjścia. Mesarović (1976, s. 247) zakłada, że teoria systemów zajmuje się objaśnianiem zjawisk lub struktur pojęciowych w kategoriach przetwarzania informacji i procesu podejmowania decyzji, istotny jest sposób przekazywania informacji oraz osiągania celów postawionych systemowi.

Do opisu badanego systemu proponuje on wykorzystanie następującej dwuetapowej metody formalizacji:

1) sformułowanie słownej definicji systemu, zgodnej z intuicyjnym znaczeniem, odniesionej do odpowiednich dziedzin zastosowań (pojęcie ma być proste, eleganckie, ogólne i matematycznie ścisłe);

2) zdefiniowanie przyjętego pojęcia systemu aksjomatycznie przy użyciu minimalnej struktury matematycznej.

Zaletą formalizacji jest możliwość badania systemów złożonych (wielkich) jako złożonych z wielu podsystemów. System definiowany jest jako relacja określona na zbiorze abstrakcyjnym iloczynu kartezjańskiego (Mesarović, 1976, s. 248):

$$
S \subset \times\left\{V_{i}: i \in I\right\}
$$

przy czym $\times$ oznacza iloczyn kartezjański, a I jest zbiorem indeksów. W przypadku gdy $I$ jest zbiorem skończonym, wówczas postać zapisu systemu może być prostsza:

$$
S \subset V_{1} \times V_{2} \times \ldots V_{i} \times \ldots V_{n}
$$

składniki relacji $V_{i}$ nazywane są obiektami systemu. Obiekt przedstawia cechę lub charakterystykę systemu opisaną w kategoriach, w jakich opisywany jest badany system.

Według Mesarovicia system to zbiór, ale szczególnego rodzaju - jest to relacja. Zbiór ten jest zespołem wszystkich poprawnych kombinacji składników. Zbiór-relacja wraz z dodatkowymi danymi zawiera informację o rzeczywistym

36 Podstawowe symbole mnogościowe to: $\varnothing$ - zbiór pusty; $A \subset A, A \subseteq B, B \supset A, B \supseteq A$ - zbiór $A$ jest podzbiorem zbioru $B ; A \cup B$ - suma mnogościowa dwóch zbiorów; $A \cap B$ - iloczyn mnogościowy dwóch zbiorów; $A-B(\operatorname{rzadziej} A \backslash B)$ - różnica zbiorów. 
„mechanizmie”. Konieczność takiego definiowania podyktowana jest przyjęciem matematyki jako języka tej teorii. Opis systemu jest często przedstawiany jako równania zapisane tak, że każdej zmiennej odpowiada obiekt reprezentujący zakres danej zmiennej, natomiast relacja jest określona tak, że każda kombinacja elementów należących do obiektów (wartości odnośnych zmiennych) spełnia dany układ zależności.

Koncepcja Mesarovicia polega na tym, aby określić relacje na pewnym wyjściowym zbiorze elementów. Taka definicja systemu daje możliwość wykorzystania aparatu teorii mnogości, formalnej dla badań systemowych. Ograniczeniem takiego podejścia - które widzi także Mesarović - jest jego szeroka lub nawet krańcowa ogólność, granicząca z trywialnością. Dlatego Mesarović odnosi swoje rezultaty do systemów abstrakcyjnych, które wypełniają szereg dodatkowych warunków i w takiej postaci dają się opisać matematycznie (Mesarović, 1976, s. 246-262).

Do opisu formalnego systemu Mesarović proponuje dwie metody:

1) metodę opisu przez „wejście-wyjście” (opis terminalny, przyczynowy lub opis bodziec-reakcja),

2) metodę opisu przez „dążenie do celu” (opis przez proces podejmowania decyzji, opis przez rozwiązywanie problemów lub opis teleologiczny).

Przy zastosowaniu metody przez „dążenie do celu” nadal rozróżnia się wejścia i wyjścia, ale zachowanie systemu opisuje się w kategoriach procesu dążenia do celu. Metoda „wejście-wyjście” wymaga podania procedury określającej związek między bodźcami i reakcjami (wejściami i wyjściami). Mesarović uważa, że w zasadzie każdy system można opisać przez wejście-wyjście albo przez proces dążenia do celu. W ten sposób próbuje godzić kolidujące ze sobą koncepcje - na przykład behawioryzm Skinnera i strukturalizm Chomskiego ${ }^{37}$.

Natomiast Ujemow poszukuje złotego środka między nadmiernie szerokim określaniem systemu a koniecznością nadmiernego zawężenia. Problem widzi w odpowiednim stopniu ogólności klasy relacji. Określenie wszystkich zbiorów obiektów odnoszących się do systemu nie gwarantuje sukcesu, w przyszłości może bowiem się okazać, że jakaś klasa obiektów nie została tu ujęta. Rozwiązaniem według Ujemowa może być powiazanie systemotwórczego charakteru relacji z rolą, jaką relacja odgrywa w określeniu systemu (nie z typem relacji samej w sobie). Każdą relację uważa się za systemotwórczą, ponieważ posiada z góry ustalone

37 Rozbieżność między Skinnerem a Chomskim polega na tym, że behawioryści w dociekaniach badawczych unikają analizowania procesów zachodzących wewnątrz „czarnej skrzynki” (myśli, uczuć, motywów postępowania), właściwa metoda badawcza to opis czynności faktycznie wykonanych przez człowieka. 
własności. Dowolne zbiory, w których uzewnętrzniają się relacje zaliczane do systemotwórczych, traktuje się jako systemy (Ujemow, 1973a, s. 92-93):

$$
(R(m)) \dot{P},(R(m)) \ddot{P},(R(m)) \ddot{P} \text { itd. }
$$

gdzie:

$R$ - relacja (wartość zmienna),

$m$ - zbiór (wartość zmienna),

$P$ - kolejne własności, z odpowiednią liczbą kropek: $\dot{P}, \ddot{P}, \ddot{P}$ (wartości stałe).

Stałe własności $P$ odnoszą się do zmiennych relacji $R$, a relacje do zbioru $m$. Uogólnienie powstaje w przypadku zamiany symbolu stałej własności, mającej charakter systemotwórczy, na symbol zmienny. W takim przypadku „system to zbiór obiektów, w którym zachodzi relacja posiadająca z góry zadane własności” (Ujemow, 1973a, s. 93).

Ujemow zaproponował sposób na „ogólność” Mesarovicia. Korzysta z tych samych pojęć co Mesarović - element (u niego rzecz), relacja, własność, zbiór, ale zmienia kolejność posługiwania się tymi kategoriami. Różnica podejścia Ujemowa widoczna jest w tym, że określa on zbiór obiektów jako system, odmiennie niż Mesarović, który określa system jako zbiór relacji. Ujemow proponuje drogę od własności do relacji, posiadającej określoną własność, a następnie do obiektów, na które te własności się rozciągają. „Każdy system jest przede wszystkim przedmiotem” (Ujemow, 1973b, s. 60). System to zbiór rzeczy, w którym realizowana jest wcześniej określona relacja charakteryzująca się konkretnymi własnościami, ewentualnie jest to zbór rzeczy z określonymi własnościami i ustalonymi między nimi relacjami (Ujemow, 1973b, s. 53-69).

Rozumienie systemu przez Mesarovicia i Ujemowa jest, co do zasięgu, tożsame, ich koncepcje generują bowiem tę samą klasę systemów, czyli dowolny system Mesarovicia będzie także systemem dla Ujemowa i odwrotnie. Różnica polega na tym, że:

[...] jako punkt wyjściowy powinniśmy przyjąć te relacje i własności, które zostały określone w zbiorze elementów wykorzystywanych dla określenia systemu przez Mesarovicia. Następnie powinniśmy, co jest zawsze możliwe, znaleźć ten właśnie zbiór elementów, a to da nam system wg Ujemowa (Sadowski, 1978, s. 104).

U Ujemowa relacje i własności są zadane, co ułatwia rozgraniczanie, co jest systemem, a co nim nie jest - w niektórych zbiorach można, a w innych nie można doszukać się relacji posiadających własność $P$. Na dowolnym zbiorze elementów Mesarovicia zawsze można odnaleźć pewne relacje i własności, dzięki którym zbiory 
te mogą być badane jako systemy, stąd brakuje granicy dla odróżnienie systemów od niesystemów ${ }^{38}$.

Sposobem na uniknięcie trudności związanych z określeniem systemu jako zbioru elementów z występującymi między nimi relacjami jest wykorzystanie określonej cechy systemu - na przykład „całościowości”, „sprzężenia”, „struktury”, organizacji” itp. Posługując się wymienionymi cechami systemowymi, można otrzymać opisy treściowe systemów bardziej rozwinięte i szczegółowe niż w przypadku teorii Ujemowa i Mesarovicia. Jednak takie opisy nie są wystarczające w przypadku potrzeby rozwiązywania zadań praktycznych w ujęciu systemowym (Sadowski, 1978, s. 104).

Ujemow wprowadza pojęcie parametr systemowy, ze względu na który można wyodrębniać systemy. Dwuwartościowe parametry systemowe (np. homogeniczność) stanowią podstawę dychotomicznego podziału pojęcia system, wielowartościowe (np. prostota) prowadzą do wyodrębnienia teoretycznie nieskończenie wielu klas systemów. W wyniku badań empirycznych Ujemow (1973a, s. 95) uzyskał „kilka dziesiątków ogólnosystemowych praw o charakterze empirycznym”. Niestety, autor podał tylko jeden przykład spośród sygnalizowanych praw - „ani jeden minimalny system nie jest elementarno-autonomiczny” (Ujemow, 1973a, s. 85).

Wyodrębnia on także kategorię pomiaru, stosowaną również w naukach humanistycznych, rozumianą jako „poznawczy proces, w którym ustala się stosunek jednej (mierzonej) wielkości do innej jednorodnej wielkości (przyjętej za jednostkę miary)" (Ujemow, 1973a, s. 100) i konsekwentnie wyodrębnia dwa istotne momenty w procedurze pomiaru, wyraźnie zaznacza, że pierwszy jest celem, a drugi środkiem (Ujemow, 1973a, s. 100):

1) otrzymanie modelu liczbowego, który może zastąpić badanie samego obiektu;

2) ustalenie stosunku jednej wielkości do drugiej.

Ujemow podkreśla prymat celu nad środkiem, co pozwala mu uogólnić pojęcie pomiaru do dowolnej procedury, w wyniku której otrzymuje się model liczbowy obiektu, a to z kolei pozwala obyć się bez wzorca ${ }^{39}$. Jest to podejście diametralnie odmienne od kolejnego - według Roberta Orcharda. Przedstawił on inne matematyczne ujęcie systemu - dla niego:

System ogólny jest w istocie rzeczy modelem abstrakcyjnym jakiegoś już istniejącego systemu (materialnego lub pojęciowego), w którym znajdują odbicie (w stopniu, w jakim sobie tego życzymy) wszystkie główne lub podstawowe cechy systemowe oryginału (Orchard, 1976, s. 204).

38 Takie rozwiązanie sugeruje teoria mnogościowa systemu, która akcentuje pojęcie zbioru - według teoriomnogościowej koncepcji badania systemu (Mesarović, 1976, s. 247-251).

39 Skale bezwzorcowe są najczęściej stosowane w socjologii. Skala Beauforta oraz termometry pieców hutniczych posługują się skalą bezwzorcową (Ujemow, 1973b, s. 100). 
Klir wyróżnia sześć klas systemów zhierarchizowanych epistemologicznie, uściślonych przez kryteria metodologiczne. Na najniższym poziomie - oznaczonym 0 - system definiuje jako zbiór zmiennych, zbiór możliwych stanów zadeklarowanych dla każdej zmiennej i pewną postać opisu znaczenia zmiennych i ich stanów. Ten poziom Klir nazywa systemem źródłowym. Na wyższych poziomach epistemologicznych definiowane systemy różnią się między sobą zakresem wiedzy dotyczącym zmiennych odpowiedniego systemu źródłowego (kolejny poziom uzupełniany jest o kolejny element). I tak, poziom 1 definiuje się przez dane, poziom 2 przez ogólny związek, na poziomie 3 ogólny związek uzupełnia się zbiorem relacji (te systemy Klir nazywa strukturowymi). Na wyższych poziomach dopuszcza się zmianę systemu strukturowego w czasie, przestrzeni i ze względu na zbiór innych parametrów, w ramach którego definiuje się zmienne. Poziom 4 pozwala na opisywanie tych zmian przez pojedynczą procedurę - takie systemy Klir nazywa metasystemami. Na poziomie 5 dopuszcza się zmianę procedury względem pewnego zbioru parametrów, zgodnie z procedurą lub metaprocedurą wyższego poziomu (Klir, 1981, s. 127-128).

Kryteria metodologiczne - uzupełniające, odnoszą się do zmiennych lub relacji objętych opisem własności systemu. Klir wymienia zmienne nazwowe, porządkowe, skali metrycznej (określone lub rozmyte) itp. W celu formalizacji systemu Klir proponuje trzystopniowe postępowanie:

1) zdefiniowanie systemu $S_{1}$ na obiekcie będącym przedmiotem badań (z przyjętego przez badacza punktu widzenia),

2) określenie systemu ogólnego $S_{2}$ na podstawie tej samej definicji (lub innej $\mathrm{z}$ proponowanych $\mathrm{w}$ teorii),

3) dokładne sprecyzowanie jednoznacznej transformacji $T$ składników systemu $S_{1}$ w system $S_{2}$.

Klir proponuje odpowiedni zapis za pomocą symboli matematycznych. Jednak na koniec wypowiada wnioski odmienne od Mesarovicia i Ujemowa, dla których badanie modelu może zastąpić badanie obiektu:

[...] jedynie słusznym punktem widzenia na metodologię ogólnosystemową jest taki, który uznaje, iż nie ma ona bezpośredniego znaczenia w kategoriach świata rzeczywistego. Rozumie się przez to, iż znaczące interpretacje wymagają wiedzy specjalnej, którą można osiągnąć jedynie przez intensywne badania przeprowadzane nad rozważanymi obiektami (Klir, 1981, s. 132).

Inni autorzy wyróżniają rozmaite typy relacji, nie zawsze osadzone na gruncie teorii systemów. Jerzy Kisielnicki (1986, s. 190) przyjął za podstawę rozważania Józefa Lipca $(1972 ; 1979)$ i wyróżnił: 
1) relacje typu „część-całość” - „Jest to relacja niesymetryczna i nieprzechodnia, która opisuje zależności określane często jako hierarchiczne. Można je przedstawić w postaci grafu; węzły są nazwami wskaźników, a łuki - operatorami relacji. Kierunek strzałki wskazuje ten wskaźnik, którego jest częścią";

2) relacje typu „przyczyna-skutek” - „Do jej określenia niezbędny jest opis analityczny, pozwalający wydzielić ze zbioru te wskaźniki, które są poprzedzające, czyli powodują określone skutki. Relacja tego typu ma zastosowanie w opisie i analizie zjawisk społeczno-ekonomicznych";

3) relacje typu „różne aspekty tego samego obiektu” - występuje „[...] gdy grupujemy informacje z punktu widzenia określonych cech obiektu badań, przy czym informacje o nim pochodzą z rożnych zbiorów lub też źródeł”;

4) relacje typu „kojarzenie przez procedurę” - „Do opisu danego obiektu należy korzystać z określonych procedur, które pozwalają na selekcję, grupowanie itp. wskaźników zgodnie z określonymi kryteriami formalnymi”;

5) relacje typu „leksykalnego” - „[...] gdy w różnych nazwach wskaźników lub ich identyfikatorach występują identyczne jednostki leksykalne jedno- lub wielowyrazowe. Bardzo często spotykana w systemach informacji ekonomicznej, niezależna od sposobu wykorzystania wskaźników, aspektów semantycznych, jak też pragmatycznych systemu informacji”.

W przedstawionej typologii relacji Kisielnickiego za systemowe w sensie teorii systemów można uznać, ze względu na definicję, relacje części do całości, relacje aspektowe tego samego obiektu, kojarzenia przez procedurę i leksykalne. Relacji typu „przyczyna-skutek” nie można traktować jako systemowej z powodu różnoczasowości występowania wskaźników.

Oprócz wskazanych powyżej kategorii lub typologii pojęcia relacja występują w literaturze także inne koncepcje pełne, niezawężone, interesujące z punktu widzenia budowy systemów, a jednak bezpośrednio nieoparte na teorii systemów i do niej nienawiązujące, $\mathrm{z}$ tego powodu także pominięte $\mathrm{w}$ niniejszym opracowaniu.

Powyżej wskazano rozmaite opisowe i analityczne ujęcia pojęcia relacja, ograniczone do podejść systemowych. Konstruowana w ramach niniejszej pracy systemowa procedura badawcza oraz towarzyszący jej komunikacyjny system organizacji oparte są właśnie na podejściu relacyjnym. Stąd tak istotne dla powodzenia dalszych konstrukcji jest naukowe uzasadnienie relacyjności systemu organizacji na gruncie teorii systemów. Ponadto istotnym elementem jest wskazanie podstawy do matematycznego zapisu pojęcia relacji, co w konsekwencji pozwala na formalizację i zostanie wykorzystane w dalszej części opracowania. 
W powyżej przedstawionym zestawieniu świadomie pominięto wiele spośród „teorii systemów społecznych” powstałych na gruncie nauk społecznych (np. Niklasa Luhmanna, Petera Senge, Anthony'ego Giddensa, Garetha Morgana, Talcotta Parsonsa, Floriana Znanieckiego ${ }^{40}$ ). Pojęcie systemów jest w niniejszej pracy rozważane z perspektywy ideowo-pojęciowej oraz teoretyczno-metodologicznej. Systemowe modele stworzone na gruncie nauk społecznych nie wydają się odpowiednie do analizy systemowej organizacji, ponieważ są ideowe, a nie metodologiczne. Ewentualne badania organizacji jako systemu na gruncie nauk społecznych mogą być prowadzone w sposób analityczny (klasyczny), niesystemowy, co utrudnia operacjonalizację i pomiar (sprawności) organizacji.

W celu wyjaśnienia tego stanowiska w kolejnym rozdziale przedstawiono ideę badania systemowego organizacji w postaci metody analizy systemów (złożonych). Wskazano sposób ujmowania systemów w perspektywie nurtów badawczych, kładąc nacisk na metody systemowe, rozumiane jako analityczne narzędzie badawcze. Pokazano także różnice między metodą analizy klasycznej a systemowej i metodą systemów sieci. Wskazano także na rozróżnienie między określeniem system a układ, stosowanym przez cybernetyków. Rozważania te rozwijano, analizując istniejące w literaturze opisy metod analizy systemowej, odnoszone głównie do systemów organizacji. Wykazano także, że procedury czy metody (nazewnictwo zależy od autora) prezentowano wyłącznie jako opisy metod, bez podania przykładów zastosowania albo też nie dotyczą one całości organizacji. Ich autorzy ograniczają się do sformułowania wytycznych przy wdrażaniu metody. Natomiast jeśli pokazują zastosowanie metody analizy systemowej, to na przykładzie, który nie dotyczy całej organizacji - jest to między innymi proces podejmowania decyzji wewnątrzorganizacyjnej. Konsekwencją wykazanych niedostatków analiz szczegółowych metod analizy systemowej stała się konstrukcja własna autorki w postaci procedury analizy systemów złożonych jako metody badawczej systemu organizacji.

40 Szczegółowe opracowanie dotyczące różnic podejścia systemowego i społecznego do systemu organizacji, a także doniesienie o publikacjach z tego zakresu znajduje się w: Zalewska-Turzyńska, 2016a, s. 397-407. 


$$
\begin{array}{r}
\text { Część ll } \\
\text { Metodologiczno-badawcza }
\end{array}
$$





\section{Metoda badawcza analizy i syntezy systemowej}

Teoria systemów pozwala patrzeć na świat z perspektywy (Encyklopedia powszechna PWN, 1987, s. 356):

1) filozoficzno-metodologicznej (np. von Bertalanffy, Boulding, Rapoport, Sadowski),

2) aksjomatyczno-formalnej (np. Meserović, Zadeh, Ashby, Lange),

3) analityczno-systemowej (Habr, Veprek).

Teoria systemów wyjaśnia rzeczywistość na trzech poziomach ogólności¹. Od najogólniejszego są to: poziom ontologiczny - wówczas „wszystko jest systemem", istnieją obiekty złożone, więc systemy istnieją; poziom epistemologiczny - jako kategoria poznawcza, w której odbiór rzeczywistości, czasu i przestrzeni nie rozstrzyga, czy systemy istnieją, czy nie (być może nie istnieją), ale na pewno łatwiej patrzy się na rzeczywistość jak na systemową całość (Laszlo, 1978). Te dwa poziomy ogólne nie są podstawą rozważań w niniejszej pracy, podstawę taką stanowi trzecia płaszczyzna - narzędziowa. System jest zatem narzędziem badania obiektów złożonych (Rokita, 2011). Metoda systemowa jest więc w tej pracy rozumiana jako analityczne narzędzie badawcze (nurt analityczno-systemowy i metodologia badań systemowych).

Dalsza część pracy obejmuje rozważania dotyczące analizy systemowej jako metody badawczej, inaczej mówiąc - dotyczy tylko metody badawczej nazywanej analizą

1 Możliwości kategoryzacji jest wiele. George Klir (1976, s. 23) uznaje ogólną teorię systemów za: teorię formalną (Mesarović, 1973; 1976; Wymore, 1967), metodologię (Ashby, 1976; 1991; Klir, 1981), sposób myślenia (von Bertalanffy, 1984; Churchmann, 1968), sposób spojrzenia na świat (Weinberg, 1976; 1979), poszukiwanie optymalnego uproszczenia (Ashby, 1991; Weinberg, 1976), metodykę nauczania (Boulding, 1953; Klir, 1981; Weinberg, 1976; 1979), metajęzyk (Löfgren, 1988), zawód (Klir, 1981). Stefan Ziemba, Władysław Jarominek, Robert Staniszewski (1980, s. 15) jako trzeci - najmniej ogólny - poziom wyróżniają „,podstawę systemową jako metodologię". Jurij Czerniak (1978, s. 7) oraz Igor Viktorovich Blauberg, Vadim Sadowski i Erik Grigor'evič Judin (1973, s. 25-28) dzielą je na cztery typy. Niezależnie od podziałów i rozróżnień dotyczących podejść do systemów i teorii systemów w każdej z nich wymienia się kategorię „metoda systemowa”. 
systemów złożonych. Metoda systemowa może pomóc w stawianiu pytań, aby prawidłowo sformułować problem, wskazać zadania do wykonania albo najskuteczniejsze $\mathrm{z}$ wielu możliwych sposoby ich realizacji. Skoro w XXI wieku problemu nie stanowi już rozwiązanie zadania (pomija się kwestię kosztu tego rozwiązania), łatwo jest wygenerować kilka jego sposobów. Problemem stało się obecnie wyodrębnienie wszystkich kroków cząstkowych w realizacji przedsięwzięcia, orientacja w nich lub znalezienie optymalnej kombinacji najkorzystniejszych rozwiązań przy określonych ograniczeniach. Stąd potrzeba zastosowania podejścia systemowego w planowaniu i realizacji przedsięwzięć. W obszarze organizacji metoda analizy systemowej pozwala przede wszystkim na kompleksowe ${ }^{2}$ badanie organizacji - ustalenie wiązki celów organizacji (pozwalających osiągać efekt dla niej optymalny, zamiast maksymalnego w poszczególnych obszarach ${ }^{3}$ ), wyznaczanie głównych dziedzin decyzyjnych, ich analiza i określanie potrzeb - w zakresie informacji - do podejmowania decyzji. Ponadto metoda badawcza w postaci analizy systemowej pozwala na zaprojektowanie kanałów przepływu informacji, a następnie na zgrupowanie obszarów w celu obniżenia obciążenia kanałów komunikacyjnych i wreszcie na optymalne uporządkowanie struktur organizacyjnych. Badania na obiektach pozwalają wysuwać propozycje sposobu modyfikacji organizacji systemu na potrzeby optymalizowania i doskonalenia go jako całości. Tak szerokie możliwości badania daje analiza systemowa jako metoda badawcza. Podejście systemowe do tych zagadnień dotychczas uznawano za trudne, jednak obecne techniczne możliwości obliczeniowe i obszarowe przygotowanie merytoryczne nie stanowią już przeszkody do podjęcia badań metodą analizy systemów złożonych.

Podobne wątpliwości i ograniczenia towarzyszyły naukowcom z powodu podejmowania szeroko pojętych badań naukowych i rozwojowych. Koszty badań są wysokie, efekty nie zawsze współmierne do nakładów, a dodatkowo „starzeją się” w dramatycznie szybkim tempie. Specjalizacja w obszarach wydaje się niezbędna do osiągnięcia wysokiej jakości wyników, jednak utrudnia koordynację prac nad kompleksowymi i długoterminowymi programami. Utrudnione jest

2 Kompleksowość jest tu w zasadzie rozumiana jako połączenie dwóch uprzednio stosowanych paradygmatów badawczych w naukach o organizacji - tradycyjnego (klasycznego), skupionego na rzeczowych i ekonomicznych elementach organizacji, z behawioralnym (neoklasycznym), traktującym tak zwany element ludzki za podstawę organizacji. Jeden i drugi paradygmat przeceniat rolę swojego kluczowego czynnika sukcesu. Kompleksowość ma polegać na braniu pod uwagę obu czynników, i co ważniejsze - na badaniu relacji między nimi (Kurnal, 1970, s. 34-60; Martyniak, 1979, s. 61-97; Koźmiński, 1983, s. 5-14; Bielski, 2001, s. 26-43). Więcej o tym w rozdziale czwartym niniejszej pracy.

3 Maksymalizacja zysku wygenerowanego przez organizację versus rozwój, na przykład technologiczny organizacji. Badania obszarowe w tym zakresie prowadzą między innymi: Paul Krugman (1979, s. 253-266), Stephen LeRoy, Jon Sonstelie (1983, s. 67-89), Philipe Aghion i in. (2015), Luc Laeven, Ross Levine, Stelios Michalopoulos (2015, s. 1-24). 
także skoordynowanie wykorzystania wyników badań podstawowych i stosowanych. Systemowe rozwiazywanie problemów badawczych za pomocą metody analizy systemów złożonych mogłoby wpłynąć pozytywnie na usprawnienie przepływu i wymiany informacji.

W szeroko zakreślonej literaturze systemowej oraz z zakresu organizacji na przestrzeni ostatnich stu lat ${ }^{4}$ występuje wiele definicji i innych określeń opatrzonych określnikiem systemowy. Powstaje pytanie, które elementy składają się na naukę systemową, a które na metodę systemową (metodę badań systemowych). Ponieważ z założenia nauki systemowe mają charakter kompleksowy i interdyscyplinarny, trudno jest zastosować ostry i kategoryczny w ocenie podział. Natrafia się jednak na takie próby rozróżnień. Według nich wyodrębnić można teorie systemowe i zastosowania systemowe.

\subsection{Analiza klasyczna, analiza systemowa, analiza sieci społecznych}

Niniejszy podrozdział poświęcono możliwościom analizy systemowej jako metody badawczej. Istnieje różnica między analizą tradycyjną jako metodą badawczą a analizą systemową w tym samym znaczeniu oraz analizą sieci społecznych, którą przedstawiono poniżej.

Emanuel Kant (1957, s. 69) określał analizę jako „rozkładanie na czynniki pojęć, które już posiadamy o pewnych podmiotach”. Główną zasadą nauki klasycznej (Galileusz, Kartezjusz) jest rozczłonkowanie obiektu i badanie każdego z elementów podstawowych, „atomowych” z osobna. Sposób opisu postępowania analitycznego jest rozmaity - w zależności od obiektu i obszaru zainteresowań badawczych.

Zgodnie z drugą regułą Rozmowy o metodzie Kartezjusza, należało podzielić „każ-

dy problem na tyle oddzielnych prostych elementów, na ile to było tylko możliwe” (Klir, 1976, s. 29).

Konsekwencją analizy jest synteza - scalenie elementów, „formułowanie twierdzeń ogólnych na podstawie uznanych za prawdziwe zdań cząstkowych, uogólnienie" (Pszczołowski, 1978, s. 236). Jeśli całość można rozłożyć na części, to można

4 Powstanie ogólnej teorii systemów datuje się na 1954 rok (Klir, 1976, s. 34). Jednak na początku lat trzydziestych powstawały już podstawy nauki systemowej, chociaż pojęcie systemowy jeszcze nie było używane, a jeśli spojrzeć na wydaną w 1912 roku Tektologię Bogdanowa, można mówić już o stuletniej perspektywie systemowej. 
potem z tych części ponownie złożyć całość. Procedura taka według klasyków jest możliwa zarówno w sensie materialnym, jak i konceptualnym ${ }^{5}$. Niestety, nie zawsze taki sposób wykonywania badań prowadzi do prawidłowego poznania całego obiektu, a poznanie elementów obiektu nie musi przesądzać o całym obiekcie, może okazać się podejściem redukcjonistycznym. Prawidłowe rozwiązanie zbioru zadań cząstkowych niekoniecznie prowadzi do rozwiązania problemu jako całości. Klasyczna procedura analityczna pomija wzajemne oddziaływania między częściami. Badanie obiektów daje poprawne rezultaty, gdy relacje między elementami nie występują lub jeśli ich natężenie jest na tyle słabe, aby można je było pominąć. W takim przypadku można rozczłonkować obiekt, zanalizować go (pod względem logicznym lub matematycznym), a następnie ponownie złożyć w całość. Drugim wyjątkiem jest przypadek, w którym relacje opisujące zachowanie części są liniowe - wtedy zachowany jest warunek sumowalności części (równanie opisujące zachowanie części ma taką samą postać jak równanie opisujące zachowanie całości). W obszarze organizacji istnieją przykłady takich wyjątków podlegających z sukcesem analizie klasycznej - na przykład analiza elementarnych ruchów roboczych - therblingów (Martyniak, 1982, s. 40) lub badanie procesu roboczego Taylora (Martyniak, 1976, s. 33). W tym przypadku metoda odnosi sukcesy, rozpoznane działania elementarne charakteryzują się bowiem relacjami liniowymi, co pozwala na ich skuteczną syntezę.

Jeśli jednak badane są obiekty o relacjach nieliniowych - obiekty dynamiczne charakteryzujące się rozmaitymi i zmiennymi interakcjami, wówczas klasyczna metoda analityczna nie pozwala wychwycić zależności między częściami. Rezultat takiego badania daje niepełny obraz obiektu. Pojawia się konieczność opisu nieliniowych relacji - ich występowania na przykład za pomocą równań różniczkowych (von Bertalanffy, 1984, s. 86), złożoności (von Bertalanffy, 1984, s. 64), siły (Rapoport, 1983) lub rodzaju (charakter nietrywialny - Simon, 1962). Klasyczna

5 Podejście sytuacyjne wprowadziło pojęcie kontekstu do analizy tradycyjnej. Pod wpływem filozofii pragmatycznej (Austin, 1993) uznano, że komunikowanie to pewien typ działania społecznego, analizowany w kontekście sytuacji społecznej. Analizie podlega kontekst językowy (znaczenie słów) i społeczny (sytuacja, w jakiej komunikowanie ma miejsce) (Field, 2005). Problemem w przypadku kontekstu językowego jest: trudność wyznaczenia granicy między tekstem a kontekstem - „Mowa jest systemem zorganizowanym hierarchicznie, a zatem to, co jest tekstem w jednym przypadku, staje się kontekstem w innym. [...] ten sam tekst może funkcjonować w różnych kontekstach językowych, np. dyskursach czy rejestrach. Teksty mogą podlegać procesom dekontekstualizacji (oderwania od kontekstu pierwotnego) i następnie rekontekstualizacji, umieszczenia w nowym kontekście" (Bielecka-Prus, 2012, s. 21), a w przypadku kontekstu społecznego: „np. umiejscowienie w czasie i w przestrzeni, typ działań komunikacyjnych podejmowanych przez uczestników (np. wykład, kłótnia), język ciała, statusy uczestników komunikacji itd. Lista ta jest bardzo długa i być może nie da się jej zamknąć". Elementy zmienne i akcydentalne w wyodrębnianiu kontekstu zamykają możliwość operacjonalizacji modelu systemu zbudowanego na ich podstawie. 
metoda analizy redukuje takie charakterystyki i właśnie z tego powodu nie wystarcza ona do badania obiektów dynamicznych, jakimi są systemy. Jeśli organizacje, jako obiekty dynamiczne, w badaniach traktowane są w sposób mechanistyczny, to nie ujawniają kompletu swoich cech - analizowanie organizacji jako prostej sumy ich części powoduje pominięcie ich istotnych relacji funkcjonalnych.

Analiza systemowa jako metoda badawcza pozwala na analizowanie elementów oraz relacji między nimi, a także na „rozczłonkowanie” systemu, jednak nie do poziomu atomowego, ale w granicach wyznaczonych przez podsystem podstawowego rzędu, to jest złożonego z przynamniej dwóch elementów i relacji między nimi. Na potrzeby niniejszej pracy taki podstawowy element analizy systemowej nazwano systentem. Analiza systemowa z założenia nie zatraca możliwości badania relacji między systentami. Jej efektem jest pełne badanie obiektu - elementów, właściwości elementów, relacji oraz właściwości relacji. W dalszej części opracowania przedstawiono procedurę takiej systemowej analizy na obiekcie organizacji złożonej (rozdział czwarty).

Metoda badawcza w postaci analizy systemowej nie stanowi definiens złożonego ze słów analiza oraz system; systemowa jest określnikiem wskazującym na rodzaj lub typ analizy - całościowej, a nie na przedmiot analizowany, choć w zasadzie i tak się dzieje. Analizę systemową jako metodę badawczą można klasyfikować jako „metodę systemową, którą można rozumieć jako wyrażenie explicite procedur przedstawienia (opis, objaśnienie, przewidywanie, konstruowanie itd.)" (Sadowskij, 1973, s. 31). Może ona występować w różnych formach: „od empirycznego na wpół intuicyjnego opisu cząstkowych procedur badań systemowych do ściśle matematycznego formułowania ogólnosystemowych procedur i metod" (Sadowskij, 1973, s. 31).

Poniżej przedstawiono słownikowe sformułowania definicyjne z zakresu metodologii badania naukowego. Analiza systemowa to:

[...] metoda badawcza polegająca na:

1) ujmowaniu opisywanych obiektów nie jako elementów niezależnych, lecz jako części składowych określonego systemu;

2) przyjęcie tezy, że badanie systemu jest niemożliwe bez uwzględnienia ogółu warunków, w jakich on działa i w ramach których istnieje;

3) założeniu, że cechy charakterystyczne całego systemu wynikają nie tylko z cech jego elementów, lecz również ze struktury sprzężeń między nimi (Encyklopedia Powszechna PWN, 1987, s. 357).

Analiza systemowa w tym znaczeniu i według tego źródła znajduje zastosowanie przy badaniu systemów technologicznych, ekonomicznych, ekologicznych oraz społecznych. 
Mały słownik cybernetyczny (Kempisty, 1973; Pekalis, 1974) nie zawiera hasła przedmiotowego analiza systemowa. Ponadto cybernetycy nie używają określenia system, traktując obiekt badania jako „układ” (układ nie jest systemem). Jednak w niniejszej pracy wyraźnie rozróżnia się podejście systemowe (korzystające z określenia system) oraz cybernetyczne (wykorzystujące określenie układ). Założenia i koncepcja przedmiotu badania dla systemu i układu są inne. Różnicę w ich rozumieniu przedstawiono na rysunkach i wyjaśniono.

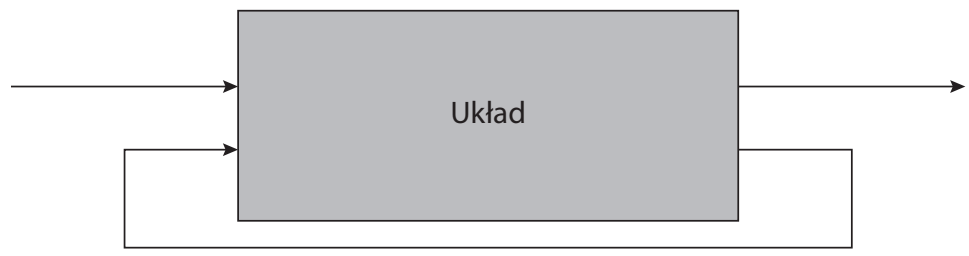

Rysunek 2. Model układu

Źródto: opracowanie własne.

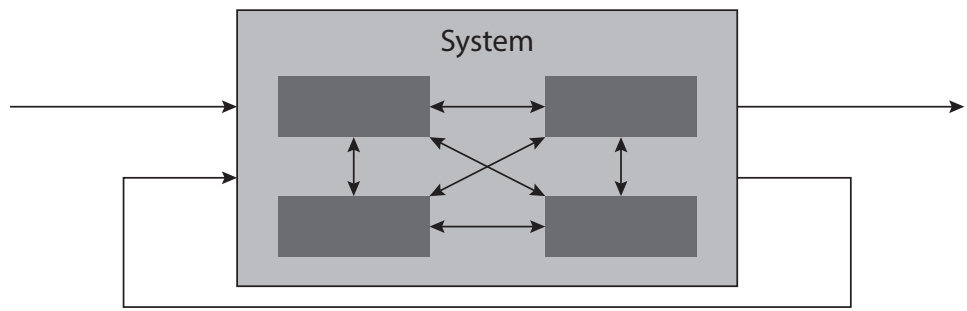

Rysunek 3. Model systemu

Źródto: opracowanie własne.

W podejściu systemowym obiekt traktowany jest jako mniej lub bardziej zwarta całość, różniąca się od swojego otoczenia stopniem powiązań jego elementów (Mynarski, 1981, s. 7). Całość ta jest celowo wyodrębniona, złożona z części, powiązań (relacji) między nimi oraz między każdą częścią i całością. W układzie natomiast elementy nie składają się na całość, jakościowo różnią się od nich samych. Cybernetycy traktują układ jako tak zwaną czarną skrzynkę, której wnętrza się nie bada. Układ w tym znaczeniu jest systemem zamkniętym, graficznym przedstawieniem funkcjonowania mechanizmu sprzężenia zwrotnego. Bada się wyłącznie sterowanie i regulowanie ${ }^{6}$ układu (z zewnątrz), nie ma tu miejsca na analizę systemową, ponieważ wnętrze układu nie jest przedmiotem zainteresowania badaczy.

6 Różnica między sterowaniem i regulowaniem omówiona będzie szczegółowo w następnym podrozdziale. 
Obiekty traktowane jako systemy są natomiast otwarte. Ważne jest ich wewnętrzne zorganizowanie, które może podlegać badaniu, w tym analizie systemowej. Ludwig von Bertalanffy ustalił następujące typy regulacji w systemach:

1) oddziaływanie elementów na siebie nawzajem i na całość systemu,

2) spełnianie funkcji ekwifinalności,

3) systemy $z$ regulacją typu sprzężenie zwrotne.

Badanie w postaci analizy systemowej pozwala zatem rozpatrywać obiekt jak system, co oznacza wnikanie do jego wnętrza. W tabeli 6 przedstawiono porównanie metod analizy klasycznej i systemowej.

Tabela 6. Porównanie metod analizy klasycznej i systemowej

\begin{tabular}{|c|c|c|}
\hline Kryterium & Analiza klasyczna & Analiza systemowa \\
\hline $\begin{array}{l}\text { Co jest } \\
\text { pierwotne? }\end{array}$ & Części składowe & Całość \\
\hline $\begin{array}{l}\text { Gtówne } \\
\text { „prawo” }\end{array}$ & Całość to suma części. & Całość to więcej niż suma części. \\
\hline $\begin{array}{l}\text { Geneza } \\
\text { powstania }\end{array}$ & $\begin{array}{l}\text { Podejście mechanistyczne: części } \\
\text { składa się w całość. }\end{array}$ & $\begin{array}{l}\text { Częściowe odrzucenie podejść } \\
\text { mechanistycznego i witalistycznego } \\
\text { (pierwotna całość, na którą działają } \\
\text { siły metafizyczne) i pozostawienie } \\
\text { z nich: } \\
\text { 1) pierwotna jest całość, } \\
\text { 2) badanie za pomocą analizy, ale } \\
\text { całości - systemowej. }\end{array}$ \\
\hline $\begin{array}{l}\text { Metoda } \\
\text { poznania } \\
\text { (badawcza) }\end{array}$ & $\begin{array}{l}\text { Rozłożenie obiektu na czynniki } \\
\text { elementarne, badanie każdego z nich } \\
\text { z osobna, a następnie sumowanie } \\
\text { wyników poszczególnych części. }\end{array}$ & $\begin{array}{l}\text { Analiza systemowa - najpierw } \\
\text { określane są ogólne zarysy całości, } \\
\text { potem dopiero rozróżnianie } \\
\text { „szczegółów”. } \\
\text { Nie rozkłada się podsystemów } \\
\text { na czynniki elementarne, pozostaje } \\
\text { się na poziomie podsystemu } \\
\text { „elementarnego” (systentu) } \\
\text { - minimum dwa elementy i relacja } \\
\text { między nimi. }\end{array}$ \\
\hline Efekt & $\begin{array}{l}\text { Drobiazgowy opis i analiza } \\
\text { elementów, w zasadzie brak } \\
\text { możliwości analizy relacji między } \\
\text { elementami. }\end{array}$ & $\begin{array}{l}\text { Pełny obraz funkcjonowania obiektu } \\
\text { jako całości, być może niebyt } \\
\text { szczegółowy opis jego elementów } \\
\text { składowych. }\end{array}$ \\
\hline $\begin{array}{l}\text { Niedostatki } \\
\text { metody }\end{array}$ & $\begin{array}{l}\text { Niemożność dostrzeżenia relacji } \\
\text { między elementami. } \\
\text { Obiekt po rozłożeniu i ponownym } \\
\text { złożeniu nie jest tożsamy z obiektem } \\
\text { pierwotnym. }\end{array}$ & $\begin{array}{l}\text { Rozpatrywanie złożonych systemów } \\
\text { z pewną doza naiwnej prostoty. }\end{array}$ \\
\hline
\end{tabular}


Tabela 6 (cd.)

\begin{tabular}{|c|c|c|}
\hline Kryterium & Analiza klasyczna & Analiza systemowa \\
\hline $\begin{array}{l}\text { „Przykład } \\
\text { żaby” }\end{array}$ & $\begin{array}{l}\text { Badanie żaby - po rozczłonkowaniu } \\
\text { i zbadaniu elementów nie uda się } \\
\text { już złożyć ich w całość bez zmiany } \\
\text { właściwości całości żaby. }\end{array}$ & $\begin{array}{l}\text { Być może niezbyt szczegółowo } \\
\text { zbadane zostaną poszczególne } \\
\text { elementy, ale właściwości żaby jako } \\
\text { całości będą zbadane - opisane } \\
\text { i zanalizowane. }\end{array}$ \\
\hline Przeznaczenie & $\begin{array}{l}\text { Szczegółowe, drobiazgowe, } \\
\text { pogłębione badanie elementu. }\end{array}$ & $\begin{array}{l}\text { 1. Ulepszanie procesu myślenia. } \\
\text { 2. Studiowanie określonych } \\
\text { systemów. } \\
\text { 3. Tworzenie nowych praw, } \\
\text { udoskonalanie dawnych } \\
\text { (Weinberg, 1979, s. 62). }\end{array}$ \\
\hline $\begin{array}{l}\text { Dążenie } \\
\text { w myśleniu }\end{array}$ & Porządek pierwszego stopnia (prawo). & $\begin{array}{l}\text { Porządek drugiego stopnia (prawo } \\
\text { o prawach). }\end{array}$ \\
\hline Badanie & $\begin{array}{l}\text { Badanie praw w dyscyplinie, } \\
\text { traktowanie ich jako szczególnych } \\
\text { przypadków w dyscyplinie. }\end{array}$ & $\begin{array}{l}\text { Badanie praw w dyscyplinie, } \\
\text { poszukiwanie podobieństw w innej } \\
\text { - formułowanie prawa ogólnego. }\end{array}$ \\
\hline
\end{tabular}

Źródto: opracowanie własne.

Metoda analizy systemowej daje szerokie możliwości badawcze i obiecuje efekty, których nie można osiągnąć za pomocą klasycznej metody analizy. Zabawnym przykładem różnicy między analizą klasyczną a systemową jest przedstawiona przez A. Rapoporta (1983, s. 54) dziecięca zagadka: „a i b na kominie siedziało, a upadło, b przepadło, co zostało?”. Odpowiedź: zostało „i”. W zasadzie jest to kwintesencja różnicy między tymi dwoma typami metod badawczych.

Innym typem analizy, konkurencyjnym w stosunku do metody analizy systemów jest analiza sieci społecznych (System Network Analysis - SNA7). Jest to narzędzie do badania skomplikowanych, wieloelementowych i wielopoziomowych struktur relacji między różnego rodzaju podmiotami społecznymi, narzędzie zakorzenione na przykład w matematyce, socjologii, antropologii, statystyce itp. Wraz z rozwojem odpowiedniego oprogramowania SNA stała się ważnym narzędziem badawczym wykorzystywanym nie tylko w nauce, lecz również w biznesie. Specjalne oprogramowanie analityczne pozwoliło na rozwój i popularyzację metody oraz sieciowego podejścia w badaniach społecznych (O metodzie..., http:// www.episteme.com.pl/obszary-wiedzy/SNA/o-metodzie). Wartość tego typu badań społecznych obniża fakt, że skupiają się one głównie na analizie zdarzeń post factum.

Podobieństwa SNA i analizy systemowej dotyczą kompleksowości podejścia, podstawy budowania modelu - komunikowania, oceny efektywności/sprawności

7 Głównymi twórcami i popularyzatorami SNA są: Stanley Wasserman, Steve Borgatti, Philippe Bonacich, Berry Wellman, Linton C. Freeman, Valdis E. Krebs, Mark Granovetter, David Knoke czy Rob Cross. 
komunikacji dla organizacji, możliwości wykorzystania modelu do projektowania i modyfikowania organizacji. (O metodzie..., http://www.episteme.com. pl/obszary-wiedzy/SNA/o-metodzie). Różnice między tymi metodami, stosowanymi na potrzeby organizacji (i do niej zawężonych) zostały przedstawione w tabeli 7.

Tabela 7. Porównanie analizy systemowej i analizy systemów społecznych w obszarze modelowania organizacji

\begin{tabular}{|c|c|c|}
\hline Kryterium & Analiza systemowa & Analiza sieci społecznych \\
\hline $\begin{array}{l}\text { Podstawa } \\
\text { powstania } \\
\text { metody }\end{array}$ & Teoria systemów & $\begin{array}{l}\text { Wywodzi się między innymi } \\
\text { z matematycznej teorii grafów, } \\
\text { algebry macierzowej oraz statystyki } \\
\text { (Stępka, Subda, 2009) }\end{array}$ \\
\hline $\begin{array}{l}\text { Powstanie } \\
\text { metody } \\
\text { - uwarunkowanie }\end{array}$ & $\begin{array}{l}\text { Rozwój myśli teoretycznej oraz } \\
\text { dyscyplinowo rozwój praktyki }\end{array}$ & $\begin{array}{l}\text { Wraz z rozwojem odpowiedniego } \\
\text { oprogramowania (O metodzie..., } \\
\text { http://www.episteme.com.pl/ } \\
\text { obszary-wiedzy/SNA/o-metodzie) }\end{array}$ \\
\hline $\begin{array}{l}\text { Metoda } \\
\text { pozyskania } \\
\text { modelu }\end{array}$ & $\begin{array}{l}\text { Teoretyczna } \\
\text { Metoda naukowa }\end{array}$ & $\begin{array}{l}\text { Empiryczna } \\
\text { Metoda badawcza (Kawa, 2014, } \\
\text { S. 41) }\end{array}$ \\
\hline Model & Dla dowolnej organizacji - ogólny & $\begin{array}{l}\text { Dla jednej konkretnej organizacji } \\
\text { - szczegółowy }\end{array}$ \\
\hline Typ modelu & $\begin{array}{l}\text { Model deterministyczny } \\
\text { (organizacja istniejąca) oraz } \\
\text { prognostyczny (organizacja } \\
\text { projektowana) }\end{array}$ & $\begin{array}{l}\text { Model deterministyczny - tylko dla } \\
\text { organizacji istniejącej }\end{array}$ \\
\hline $\begin{array}{l}\text { Szczegółowość } \\
\text { danych } \\
\text { wejściowych } \\
\text { do modelu }\end{array}$ & $\begin{array}{l}\text { Wystarcza znajomość części } \\
\text { systemu do antycypowania całości } \\
\text { (por. system Mendelejewa) }\end{array}$ & $\begin{array}{l}\text { Potrzebne pozyskanie kompletnych } \\
\text { danych o relacjach między } \\
\text { podmiotami danej sieci (Kawa, } \\
\text { 2014, s. 42) }\end{array}$ \\
\hline $\begin{array}{l}\text { Relacje występują } \\
\text { między... }\end{array}$ & $\begin{array}{l}\text { Systentami (elementy systemowe } \\
\text { - dwie osoby i relacja między nimi) } \\
\text { Procesami, zdarzeniami } \\
\text { Podsystemami kolejnych rzędów }\end{array}$ & $\begin{array}{l}\text { Węzłami/ludźmi (O metodzie..., } \\
\text { http://www.episteme.com.pl/ } \\
\text { obszary-wiedzy/SNA/o-metodzie, } \\
\text { Kawa, 2013, s. 73) }\end{array}$ \\
\hline $\begin{array}{l}\text { Interpretacja } \\
\text { mierników }\end{array}$ & Precyzyjna, wskazana w pracy & $\begin{array}{l}\text { Ma charakter „techniczny” i jest } \\
\text { „otwarta” (Fuks, Kawa, Pierański, } \\
\text { 2014, s. 52) }\end{array}$ \\
\hline $\begin{array}{l}\text { Obszar } \\
\text { zainteresowań }\end{array}$ & $\begin{array}{l}\text { Makro (cała sieć relacji } \\
\text { w organizacji) }\end{array}$ & $\begin{array}{l}\text { Mikro (rola poszczególnych } \\
\text { pracowników w organizacji) } \\
\text { Mezo (podsieci organizacji) } \\
\text { Makro (cała sieć relacji } \\
\text { w organizacji) } \\
\text { (Stępka, Subda, 2009) }\end{array}$ \\
\hline
\end{tabular}


Tabela 7 (cd.)

\begin{tabular}{|l|l|l|}
\hline \multicolumn{1}{|c|}{ Kryterium } & \multicolumn{1}{|c|}{ Analiza systemowa } & \multicolumn{1}{c|}{ Analiza sieci społecznych } \\
\hline $\begin{array}{l}\text { Typ/rola } \\
\text { wskaźników }\end{array}$ & $\begin{array}{l}\text { Dotyczy cech „organizacyjnych”, } \\
\text { wyrażanych w komunikatach } \\
\text { w sposób treściowy i funkcjonalny }\end{array}$ & $\begin{array}{l}\text { Dotyczą cech „technicznych”, stanu } \\
\text { sieci komunikacji: }\end{array}$ \\
& & $\begin{array}{l}\text { 1) gęstości, } \\
\text { 2) współczynnika grupowania, } \\
\text { 3) efektu małego świata, } \\
\text { 4) średnicy, } \\
\text { 5) liczby podmiotów (węzłów), } \\
\text { 6) liczby relacji bezpośrednich } \\
\text { (połączeń). } \\
\text { (Fuks, Kawa, Pierański, 2014, } \\
\text { s. 52) }\end{array}$ \\
\hline $\begin{array}{l}\text { Podmioty relacji } \\
\text { w organizacji } \\
\text { odniesione do }\end{array}$ & Wszystkich uczestników organizacji & $\begin{array}{l}\text { Pracowników (Stępka, Subda, 2009; } \\
\text { Komunikacja wewnętrzna, http:// } \\
\text { www.episteme.com.pl/uslugi/ } \\
\text { media-i-komunikacja/komunikacja- } \\
\text { wewnetrzna) }\end{array}$ \\
\hline
\end{tabular}

Źródto: opracowanie własne.

Być może efekt w postaci modelu wypracowanego metodą systemową będzie tożsamy z modelem empirycznym wypracowanym metodą SNA, co wzajemnie potwierdzi prawidłowość modeli. Co więcej, te dwie metody można traktować jako uzupełniające się - aby powstał model SNA, konieczny jest komplet informacji o wszystkich węzłach i połączeniach do stworzenia obrazu sieci komunikacyjnej organizacji (Frontczak, sine dato). Brak któregoś węzła lub relacji fałszuje obraz organizacji. W tym miejscu model systemowy może posłużyć do wskazania miejsc w organizacji, w których należy poszukiwać brakujących danych. Ponadto zmiana jednego elementu w modelu SNA pociąga za sobą zmianę całego modelu, tymczasem model systemowy ulega zmianie w przypadku zmiany systemu. Niestety, nieustanne zmiany, jakim podlegają organizacje i towarzysząca im potrzeba dynamicznej modyfikacji obrazu organizacji, dotyczą w równym stopniu obu przypadków modelowania.

Przewaga badania w postaci analizy systemowej nad klasyczna analizą rozmaitych obiektów oraz empiryczna proweniencja analizy systemów społecznych stały się głównymi powodami, które przesądziły o wyborze i zastosowaniu metody analizy systemowej jako metody badawczej w niniejszej pracy. W następnej kolejności przedstawiono podejścia do analizy systemowej jako metody badawczej organizacji przygotowane przez rozmaitych autorów. Przedstawione metody zawierają ujęcia definicyjne oraz - jeśli występują - wskazówki dotyczące celu, jaki powinna osiągnąć analiza systemowa w kolejnych etapach procedury. 


\subsection{Analiza systemowa - metody i procedury badawcze organizacji}

O metodzie naukowej ${ }^{8}$ mówi się:

[...] gdy stosuje się ją systematycznie, wielokrotnie przy badaniu różnych problemów, wykorzystując wyniki tych badań do tworzenia teoretycznych uogólnień lub empirycznego zweryfikowania założonych hipotez (Mikołajczyk, 1997, s. 38).

Metoda naukowa stanowi ogólny tryb postępowania badawczego (Pytkowski, 1985):

[...] które powinno obejmować bardziej precyzyjne wzorce, czyli techniki postępowania w stosunku do poszczególnych fragmentów lub ogólnego stanu analizowanej rzeczywistości. Wzorce te stanowią „narzędzia” badawcze, przy stosowaniu których należy się kierować pewnymi zasadami postępowania, o ile pragnie się osiągnąć zamierzone cele (Mikołajczyk, 1997, s. 38).

W niniejszej pracy określenia metoda i narzędzie stosowane są zgodnie ze wskazaną definicją. W obszarze organizacji poszczególne techniki zawierające się w metodzie systemowej często nazywane są przez ich autorów mianem procedura.

Poniżej wskazano szczegółowe metody i procedury analizy systemowej. Przedstawione propozycje ograniczono do kręgu zainteresowania nauk o organizacji i odniesiono do obiektu organizacja. Zaprezentowany katalog jest możliwie kompletny według obecnej wiedzy autorki. Przy prezentacji korzystano z ich nazw własnych, stąd duża dowolność nazewnicza - zostały one jednak dobrane ze względu na zawartość merytoryczną i w tym zakresie pozostają metodami, bez względu na ich oryginalną nazwę. Ponadto w wyniku analizy przedstawionych metod wskazano ich niedostatki z punktu widzenia podejścia systemowego, co w dalszej kolejności prowadzi do przedstawienia autorskiej propozycji analizy systemów złożonych jako metody badawczej.

Teoria systemów i analiza systemowa posiadają różne poziomy ogólności, różnią je także ich poziomy abstrakcji. Teoria systemowa jest zorientowana przede wszystkim na określenie praw rządzących systemami, tworzenie modeli i aparatu pojęciowego. Analiza systemowa zorientowana jest na procedurę i metodę systemowego badania - opis, objaśnienie, przewidywanie, konstruowanie itd. (Sadowskij, 1973, s. 31). Postawę przyjętą za obowiązującą w tym opracowaniu - podejście

8 Tadeusz Kotarbiński (1982, s. 524) podkreśla „systematyczność stosowania” metody, a Andrzej K. Koźmiński i Andrzej Zawiślak (1982, s. 51) powtarzalność „z racji swojej skuteczności”. 
systemowe - wprowadza się z powodu „wygody metodologicznej” i jest ona równoznaczna z wyznaczeniem narzędzia badania, pozwalającego na szersze poznanie organizacji, co jest niemożliwe, jak wyjaśniono wyżej, w przypadku przeprowadzania tradycyjnego badania analitycznego lub analizy systemów społecznych.

Założenia metody analizy systemowej jako metody badawczej są następujące: obserwator (badacz) powołuje system ze względu na określone zadanie. Istnieje obiekt w postaci zbioru podobiektów stanowiących pewną całość. Istnieje także podmiot badający - obserwator, oraz zadanie - określane jako stosunek obserwatora do obiektu, który to stosunek stanowi kryterium, klasyfikacji obiektów i ich własności. Takie założenia mają swoje konsekwencje - zależnie od obserwatora realizującego określone zadanie, ale stosującego odmienne kryteria, wynik może być inny (inne kryteria badawcze może przyjąć drugi obserwator dla tego samego obiektu ze względu na to samo zadanie - np. organizacja badana ze względu na jej optymalność przez inżyniera i psychologa).

Z punktu widzenia stopnia sformalizowania analiza systemowa jako metoda może występować w postaci opisowej lub algebraicznej (algebraiczny zapis grafów). Metody drugiego typu pozwalają zakwalifikować analizę systemową do metod formalnych. W tych ramach analizy systemowej jako metody badawczej znajdować się będzie metoda projektowana w niniejszej pracy.

Metodę badań systemowych Sadowski opisuje jako:

[...] wyrażenie explicite procedur przedstawiania obiektów jako systemów i sposobów ich systemowego badania (opis, objaśnienie, przewidywanie, konstruowanie itd.). [...] podejście systemowe może [...] ucieleśniać się [...] - od empirycznego na wpół intuicyjnego opisu cząstkowych procedur badań systemowych do ściśle matematycznego formułowania ogólnosystemowych procedur i metod (Sadowski, 1973, s. 31).

Określa on także zadania systemowych badań naukowych jako:

1) opracowanie środków przedstawiania badanych obiektów jako systemów;

2) budowanie ogólnych modeli systemu oraz modeli różnych klas i cech systemów, włączając modele dynamiki systemów, ich ukierunkowanego zachowania, rozwoju historycznego, budowy hierarchicznej, procesów sterowania w systemach itd;

3) badanie konceptualnej struktury teorii systemowych.

Taka lista zadań badania systemowego odstaje pod względem poziomu ogólności od metody analizy systemowej jako metody badawczej. Propozycję tę przedstawiono jako systemową metodę prowadzenia badań naukowych, różni się ona od szczegółowych teorii systemowych poziomem ogólności i specyfiką przedmiotu 
badań, a zatem mniej lub bardziej ścisłym odniesieniem do świata rzeczywistego. W przypadku powyższej procedury występuje luźniejsze odniesienie do rzeczywistości.

Istnieją także inne, mniej abstrakcyjne podejścia do metody analizy systemowej, czasami nawet skrajnie konkretne - zdarza się, że w procedurach analizy systemów podkreślane są cechy wspólne z badaniami operacyjnymi ${ }^{9}$ Różnica polega na tym, że:

[...] analiza systemowa ma do czynienia z problemami bardziej złożonymi o większym stopniu niepewności, a ponadto cele i kierunki działania, które są założeniami w badaniach operacyjnych, w analizie systemowej są przedmiotem badań (Gasparski, Lewicka, 1973, s. 15).

Według Edwarda Quade’a na proces analizy systemowej składa się:

1) wyjawienie celu polegające na wskazaniu sposobów mierzenia jego osiągnięcia przy różnych wariantach rozwiązania,

2) określenie alternatywnych sposobów osiągania celu (mogą to być polityka, strategia, specyficzne działania czy środki),

3) określenie nakładów dla każdej z alternatyw,

4) zbudowanie modelu stanowiącego aproksymację rzeczywistości,

5) określenie kryterium, które jest prawidłem porządkującym alternatywy ze względu na ich efektywność (Gasparski, Lewicka, 1973, s. 15).

W powyższym przykładzie analiza systemowa służy zmianie, a nie poznaniu. Publikacja zatytułowana Analiza systemowa organizacji autorstwa Andrzeja Koźmińskiego zawiera wiele elementów poznawczych, opisowych, w tym opis procedury analizy systemowej stosowanej w przypadku sytuacji problemowej:

Analiza systemowa organizacji jest metodą rozwiązywania problemów związanych z doskonaleniem organizacji (podnoszeniem skuteczności działania), polegającą na wykorzystaniu podejścia systemowego (Koźmiński, 1979, s. 35).

Definicja ta, niemalże w takim samym brzmieniu, znajduje się w Encyklopedii organizacji i zarządzania (ze względu na tego samego autora). Jest ona rozszerzona o sformułowanie: „czyli na potraktowaniu organizacji jako systemu” (Encyklopedia organizacji i zarządzania, 1981, s. 31).

$9 \quad$ Na szczęście nie wszędzie - w Małej encyklopedii prakseologii i teorii organizacji badania operacyjne są wyraźnie tożsame z analizą sieciową (planowaniem sieciowym), a nie z analizą systemową (Pszczołowski, 1978, s. 15). 
Niestety, definicja w prezentowanym brzmieniu nie wyjaśnia istoty analizy systemowej. Jest ona obarczona błędem typu petitio principii. Brakuje bowiem charakterystyki ontologicznej, nie wyjaśniono, czym rzeczywiście jest analiza systemowa, w zamian wskazano jej cel, wyjaśniono do czego służy (do doskonalenia organizacji). Niezależnie od braków tej definicji odnaleźć można pewne zalecenia, sformułowane w postaci listy kroków czy etapów, określanych mianem procedury analizy systemowej. Należy się im przyjrzeć w sposób szczegółowy i zastanowić, czy możliwe jest ich zastosowanie do badania organizacji (złożonej) jako całości w sposób systemowy.

Procedura metody badawczej analizy systemowej według Koźmińskiego obejmuje cztery kroki, które mogą być wielokrotnie i cyklicznie powtarzane. Etap sformułowania problemu polega na szczegółowym i możliwie pełnym opisie zadań i celów do osiągnięcia i wykonania. Zawiera także „określenie istotnych zmiennych i opis związków zachodzących między nimi” (Koźmiński, 1979, s. 41). Zasadne staje się także określenie kryteriów oceny wyznaczonych uprzednio celów działania.

Etap badania obejmuje poszukiwanie nowych, odkrywczych propozycji pomysłów i kierunków działania oraz argumentów przemawiających za i przeciwko nim. Na tym etapie szacuje się także koszty związane $z$ analizowanymi wariantami przyszłego działania (Koźmiński, 1979, s. 41-43).

Następnie należy przystąpić do etapu eksplanacji, w którym buduje się model upraszczający zbyt złożoną rzeczywistość, aby uchwycić te jej aspekty, które badacz uważa za ważne. W modelu powinny być określone czynniki wpływające na realizację celów oraz ich wartości, a także relacje zachodzące między tymi czynnikami wraz z ich charakterystykami. Modele te mogą mieć charakter analityczny (skwantyfikowany), opisowy, być hybrydą poprzednich lub zestawem modeli. Na podstawie zbudowanego modelu dokonuje się analizy wrażliwości i przechodzi do ostatniego etapu - interpretacji uzyskanych wyników - który polega na ocenie wyników analizy ze względu na rzeczywiste warunki. Podstawowe pytanie dotyczy tego, czy zastosowany model nie stanowi nadmiernego uproszczenia rzeczywistości. Jak pisze Koźmiński: „Duże znaczenie na tym etapie ma intuicja, doświadczenie i ogólna znajomość przedmiotu analizy przez badacza [...]” (Koźmiński, 1979, s. 42-43).

Analiza systemowa dokonywana za pomocą procedury przedstawionej przez Koźmińskiego jest uważana za proces iteracyjny - przybliżający do rozwiązania przez wielokrotne powtarzanie przedstawionego cyklu czynności poznawczych. W tym modelu badanie przerywane jest, gdy intuicja, doświadczenie i ogólna wiedza o przedmiocie badania dają wynik zadowalający. Co więcej, autor wskazuje, że badanie przerywa się, "gdy wyczerpany zostanie przeznaczony na nie budżet lub jego koszty osiągną ekonomicznie uzasadnioną granicę" (Koźmiński, 1979, s. 43). 
Sytuacja problemowa

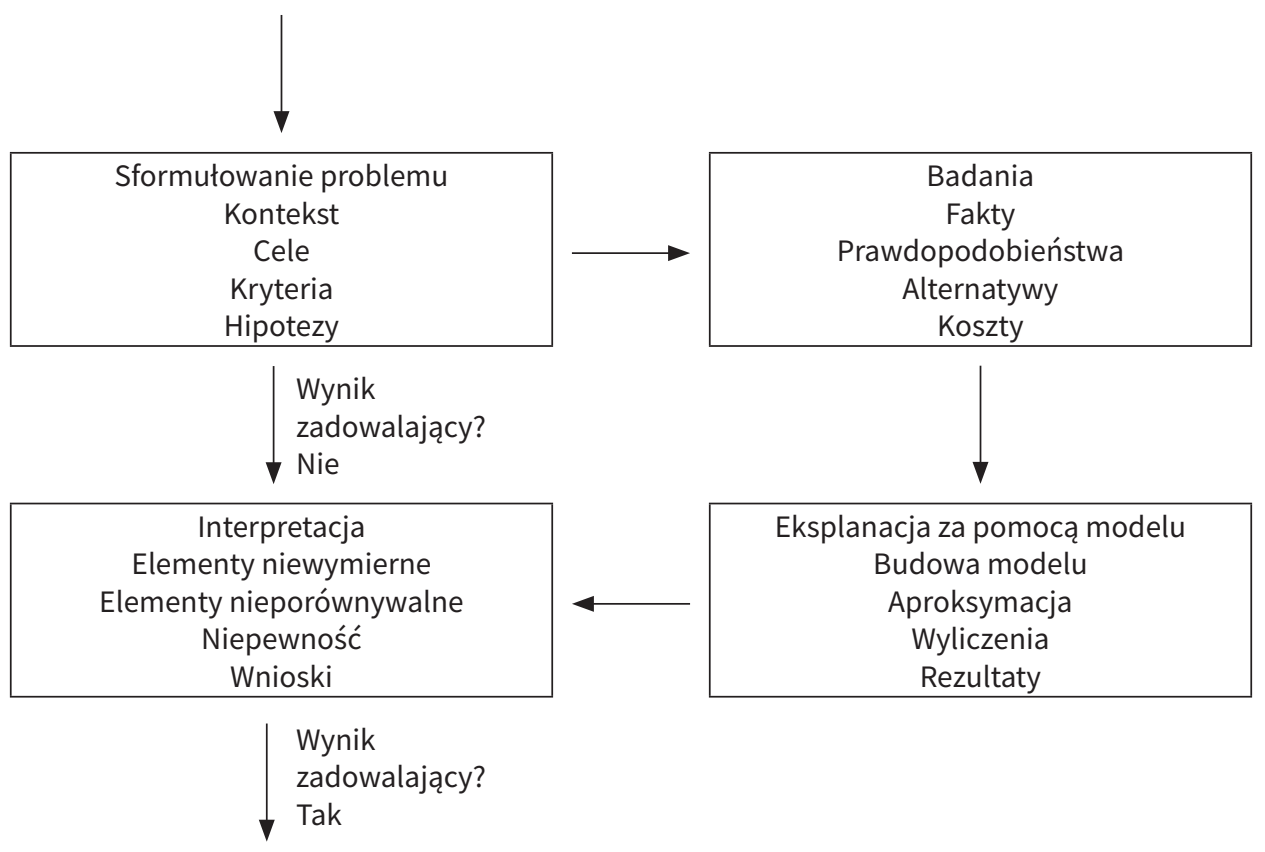

Sugestie działania

Rysunek 4. Procedura analizy systemowej według Quade’a

Źródto: Quade, 1963, s. 40.

Przedstawiona metoda analizy systemowej organizacji dotyczy problemów zaistniałych wewnątrz organizacji (nie jej samej), jest procesem iteracyjnym, który zostaje przerwany, gdy wyczerpią się fundusze na niego przeznaczone. Do celów analizy przeprowadzanej w niniejszym opracowaniu potrzeba innego ujęcia.

Badanie literatury z zakresu analizy systemowej organizacji prowadzi do wniosku, że wielu autorów korzysta $z$ tej nazwy i nadaje swoim pracom miano analiz systemowych, jednak nie są one oparte na podstawowych założeniach analizy systemowej jako metody badawczej - określenia części i relacji między nimi. Słowo system w pracach naukowych bywa używane zasadniczo w trzech kontekstach znaczeniowych. Po pierwsze, jako synonim całościowego podejścia lub też wynik działań porządkujących, systematyzujących. Drugie równie często używane znaczenie dotyczy transformacji: wejście - przetwarzanie - wyjście (np. system rachunkowości lub powyżej przedstawiona koncepcja Koźmińskiego). Trzeci kontekst to naukowe, właściwe dla tej pracy, znaczenie słowa system, używane na określenie obiektu złożonego z elementów i relacji między nimi.

Za przykład użycia słowa system w pierwszym znaczeniu może posłużyć książka pod tytułem Pełna analiza systemowa (Robertson, Robertson, 1994), w której 
analiza systemowa definiowana jest jako „Sztuka poznawania i określania systemów drogą budowania modeli” (Robertson, Robertson, 1994, s. 551). Analiza systemowa jest tutaj tożsama z projektowaniem i zarządzaniem projektami - „Jednym z celów analizy systemowej jest dostarczenie kierownictwu [...] lepszej i bardziej skutecznej informacji” (Robertson, Robertson, 1994, s. 79), natomiast „Wyzwaniem dla dzisiejszej analizy systemowej jest tworzenie złożonych systemów spełniających oczekiwania użytkowników” (Robertson, Robertson, 1994, s. 141). Nie jest to opinia odosobniona (np. Gasparski, 1978; Dorosiński, Gasparski, Wrona, 1981; Gasparski, 1988; Gasparski, Miller, 1990), a jednocześnie podejście takie nie spełnia założeń systemowych przyjętych w niniejszym opracowaniu.

Inne ujęcie analizy systemowej organizacji wypracował Gerald Nadler w postaci konstrukcji systemu idealnego. Koncepcja ta wywarła wpływ na współczesną metodologię badań organizatorskich, sugerowała bowiem, aby w pierwszej kolejności poszukać kompletnego rozwiązania:

[...] właściwej koncepcji efektywnego zorganizowania rozpatrywanego procesu pracy, wychodząc od koncepcji idealnej, a potem stopniowo zbliżając się do koncepcji spełniającej warunki ograniczające (Martyniak, 1976, s. 66).

Koncepcję systemu idealnego przedstawia się graficznie za pomocą trójkąta (rysunek 5).

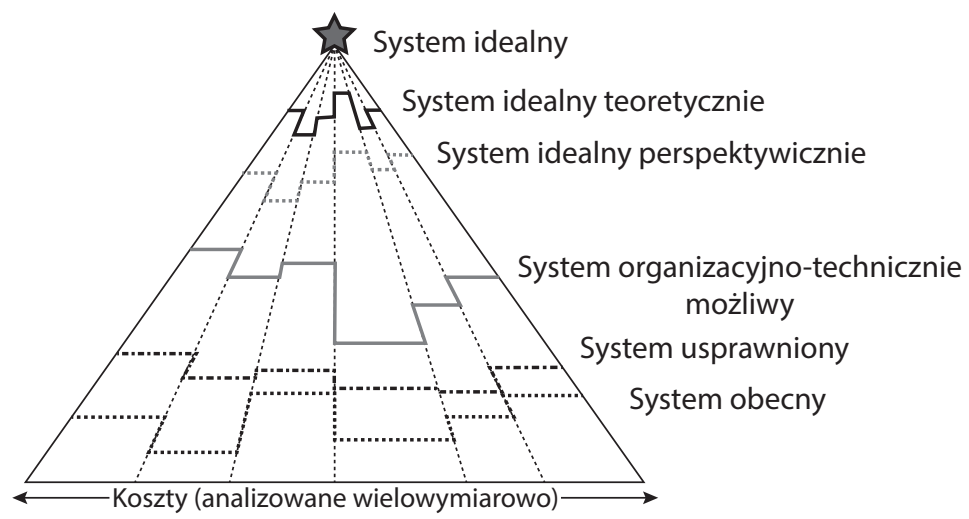

Rysunek 5. System idealny według Geralda Nadlera

Źródto: Martyniak, 1976, s. 70.

System idealny teoretyczny jest nieosiągalny, ale stanowić ma swego rodzaju układ odniesienia, który pozwala wyobrazić sobie rozmaite możliwe 
rozwiązania oraz inspiruje podczas tworzenia koncepcji systemu. System idealny perspektywiczny (praktyczny) zakłada idealne warunki funkcjonowania oraz ukształtowania jego współzależnych cech, zgodnie z najnowszymi osiągnięciami nauki i techniki. System idealny realizowany technologicznie uwzględnia najnowocześniejsze i najefektywniejsze rozwiązania organizacyjno-techniczne dostępne w skali świata, z zastrzeżeniem, że brane pod uwagę są rozwiązania wdrożone $\mathrm{z}$ wynikiem pozytywnym, a nie takie $\mathrm{w}$ stadium pomysłu. System proponowany jest „pogorszeniem” koncepcji systemu idealnego realizowanego technologicznie, nie każdy bowiem projekt systemu organizacyjnego opartego na sumie najlepszych rozwiązań jest wdrażany w konkretnym przedsiębiorstwie. Trzeba zatem uwzględniać wszystkie ograniczenia i specyfikę warunków przedsiębiorstwa.

Etapy postępowania organizatorskiego w podejściu funkcjonalno-wzorującym Nadlera, służące do ustalenia i wdrożenia systemu, są zatem następujące (Martyniak, 1976, s. 70-71):

1) ustalenie funkcji (celu),

2) wprowadzenie systemu idealnego,

3) zebranie informacji,

4) sugerowanie wariantów,

5) wybór systemu zalecanego,

6) sformułowanie systemu,

7) rewizja systemu,

8) testowanie systemu,

9) instalowanie systemu,

10) kontrola funkcjonowania systemu.

Metoda analizy systemowej organizacji w ujęciu Nadlera spełnia kryteria systemowości w sposób niezupełny z punktu widzenia metody przyjętej w niniejszym opracowaniu. System traktowany jest jako całość poddawana transformacji, nie wskazano odniesień do struktury systemu w postaci elementów i relacji między nimi. Wskazane etapy analizy to kolejne, sekwencyjnie po sobie zachodzące fazy analizy pewnej określonej całości, bez odniesień do jej struktury wewnętrznej. Ponadto Nadler używa innego języka niż teoria systemów lub teoria organizacji i zarządzania. W ten sposób ujawnia się odmienne ukierunkowanie specjalistyczne. Określenie sformułowanie systemu (nie konceptualizacja, konstrukcja) sugeruje, że chodzi tutaj o urządzenie. Jak większość przedstawionych w tym podrozdziale procedur analizy systemowej, również ta jest efektem pracy inżynierów, informatyków lub inżynierów systemów. Jej treść jest poświęcona głównie problematyce ulepszania systemów informatycznych. Warstwa językowa nie jest dostosowana do języka organizacji. 
Metodyka budowy i analizy modeli produkcyjno-gospodarczych, jaką zaproponował Jay Wright Forrester (1993, s. 26, w: Martyniak, 1979, s. 88-89), obejmuje następujące etapy:

1) sformułowanie problemu techniczno-ekonomicznego;

2) opisowe sformułowanie podstawowych zależności charakteryzujących strukturę badanego systemu;

3) budowę modelu strukturalnego przy użyciu specjalnego języka symulacyjnego;

4) modelowanie systemu na EMC;

5) modyfikowanie modelu pod kątem zapewnienia zgodności między zachowaniem modelu a zachowaniem badanego systemu;

6) znajdowanie zmian w parametrach modelu wpływających na poprawę jego zachowania oraz przetłumaczenie tych zmian na język rzeczy wistego systemu.

Forrester uważał jednak, że opracowana przez niego metoda nie jest jeszcze doskonała, zaznaczył bowiem, że symulacji nie można uważać za metodę prognozowania określonych zdarzeń w określonym momencie lub traktować jej jako gwarancję prawidłowości jakiejś konkretnej decyzji.

Istnieje także inna „metodologia analizy systemowej stosowanej w celu określenia rozwiązań ulepszających” (Findeisen, Quade, 1985, s. 86). U wskazanych autorów analiza systemowa w najprostszym ujęciu jest identyczna $\mathrm{z}$ tradycyjnym schematem decyzyjnym składającym się z następujących elementów (Findeisen, Quade, 1985, s. 88-91): celów, wariantów, kosztów, miar jakości działania, kryteriów wyboru oraz modeli. Jest to iteracyjna metoda analizy problemu, realizowana najczęściej komputerowo. Iteracje są w tym przypadku traktowane wyłącznie pozytywnie - jako możliwość modyfikacji i ulepszania oraz eliminowania elementów zbędnych.

Mimo złożoności sprzężeń uzależniających (iteracji) procedurę analizy systemowej podzielono na trzy stadia (Findeisen, Quade, 1985, s. 97):

1) formułowania problemu,

2) badań, obejmujące:

- tworzenie i badanie wariantów,

- określenie skutków,

- prognozowanie stanu otoczenia,

3) ocen (porównywania i uszeregowania wariantów). 

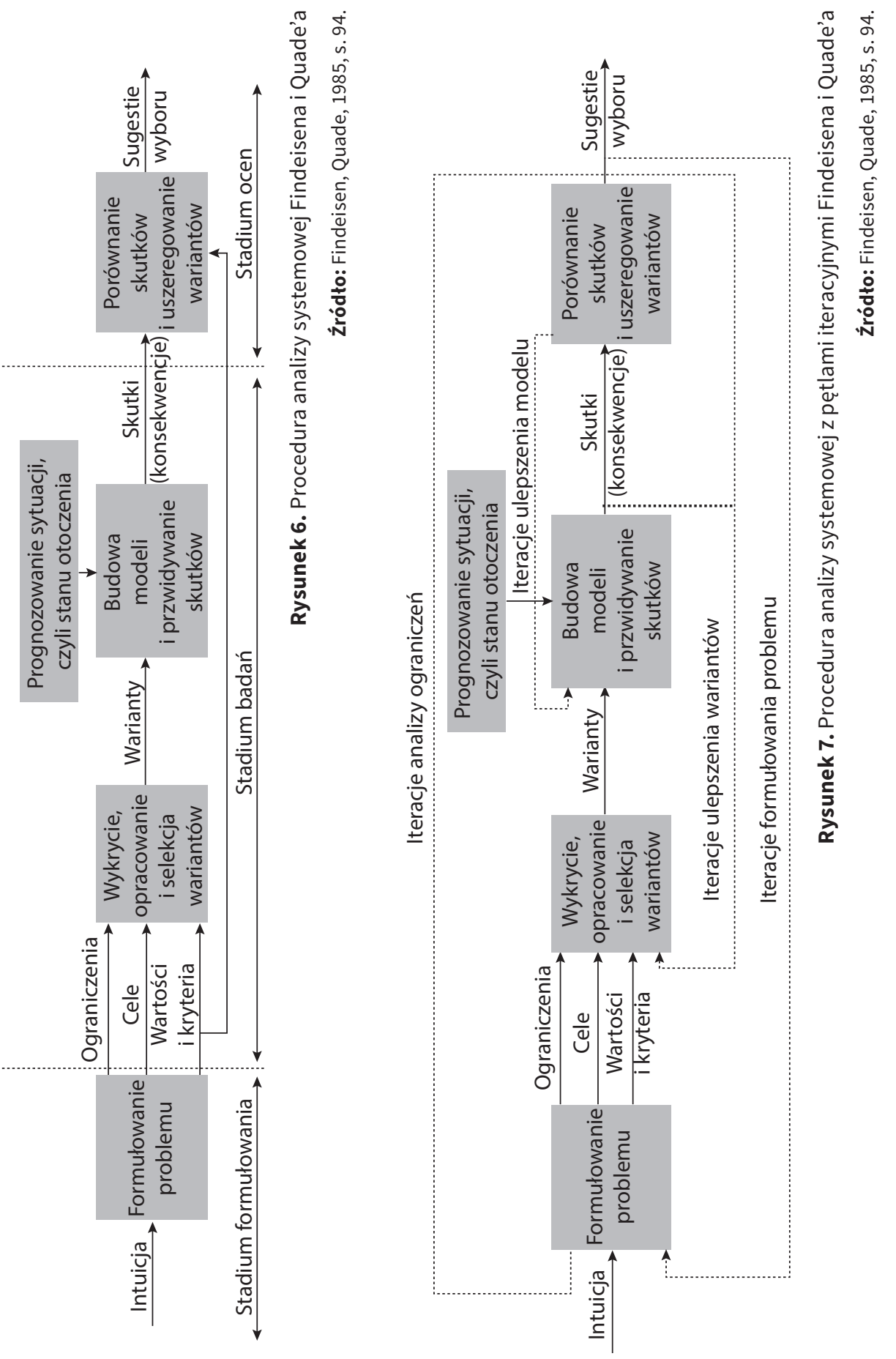
Autorzy zastrzegają, że taka analiza systemowa wspomagająca podjęcie decyzji jest sztuką, ponieważ „Sposób podejścia, dający w przypadku jednego analityka wynik pożyteczny, może w przypadku innego prowadzić do błędnych lub mylnych wniosków” (Findeisen, Quade, 1985, s. 93). W niniejszym opracowaniu dąży się do stworzenia „stabilnej” procedury, która będzie uniezależniona od osoby decydenta. Ponadto w procedurze systemowej Findeisena i Quade’a obszar analizy systemowej jest wieloznaczny w tym sensie, że zależy od tego, czego dotyczą decyzje podejmowane przez organizację - czy decyzje dotyczą zagadnień i problemów jej samej (tzw. decyzje wewnątrzorganizacyjne), czy dotyczą rozwiązań międzyorganizacyjnych lub też obejmują decyzje organizacji w stosunku do jej otoczenia. Stąd, z powodu kontekstu i zawartości podejmowanych decyzji, nie w każdym z wyżej określonych przypadków metoda analizy systemowej może obejmować organizację jako taką. Dlatego o tej metodzie należy pamiętać, może być ona wsparciem lub inspiracją przy tworzeniu właściwej metody analiz systemowej organizacji.

Jak widać z powyższej analizy metod, analiza systemowa poszczególnych komórek organizacyjnych przedsiębiorstwa lub procesów - pojedynczych lub też ich grup - jest zaawansowana. Jednak systemowa analiza organizacji złożonej i modelowanie przedsiębiorstwa jako całości jest, w ramach badań szkoły systemowej, przedmiotem mniej lub bardziej udanych prób i doświadczeń. Podobny wniosek wyciągali inni autorzy w latach siedemdziesiątych (Mesarović, Takahara, 1975). Zwrócenie się w kierunku teorii złożoności prowadzi do tego samego wniosku (Mesjasz, 2004).

Derda (Habr, Veprek, 1976, s. 163-165) mówi o systemowym kształtowaniu organizacji. Jako podstawę do rozważań przyjął system informacyjny, jednak jednocześnie dąży do rozwiązania zagadnień kompetencji, podporządkowania oraz przyporządkowania pracowników do poszczególnych stanowisk kierowniczych systemu. Podsystemy określa mianem agend. Wypracował algorytm metody, który osadził na 16 grupach czynności (tzw. blokach), przedstawionych syntetycznie na rysunku 8. Jak widać, przedstawiona metodyka obejmuje szereg cykli, pozwalających na przykład na poprawienie czynności kierowniczych, uzupełnienie ewentualnie brakujących czynności, skorygowanie modelu na podstawie wskazanej metody analitycznej itp. Według tej metodyki systemowe kształtowanie organizacji ${ }^{10}$ składa się z trzech etapów: Z1 dotyczy modelowania agend kierowniczych, Z2 budowy modelu organizacyjnego ${ }^{11}$, Z3 powoływania ludzi na stanowiska funkcyjne (Habr, Veprek, 1976, s. 166-169).

10 Wkradła się tu pewna nieścisłość - metody analityczne nie mogą być stosowane do syntezy.

11 Z2 (etap budowy modelu organizacyjnego) od punktu 12 staje się modelem rekrutacji, co zawęża perspektywy budowy organizacji i jak się wydaje powinno być umieszczone w etapie 


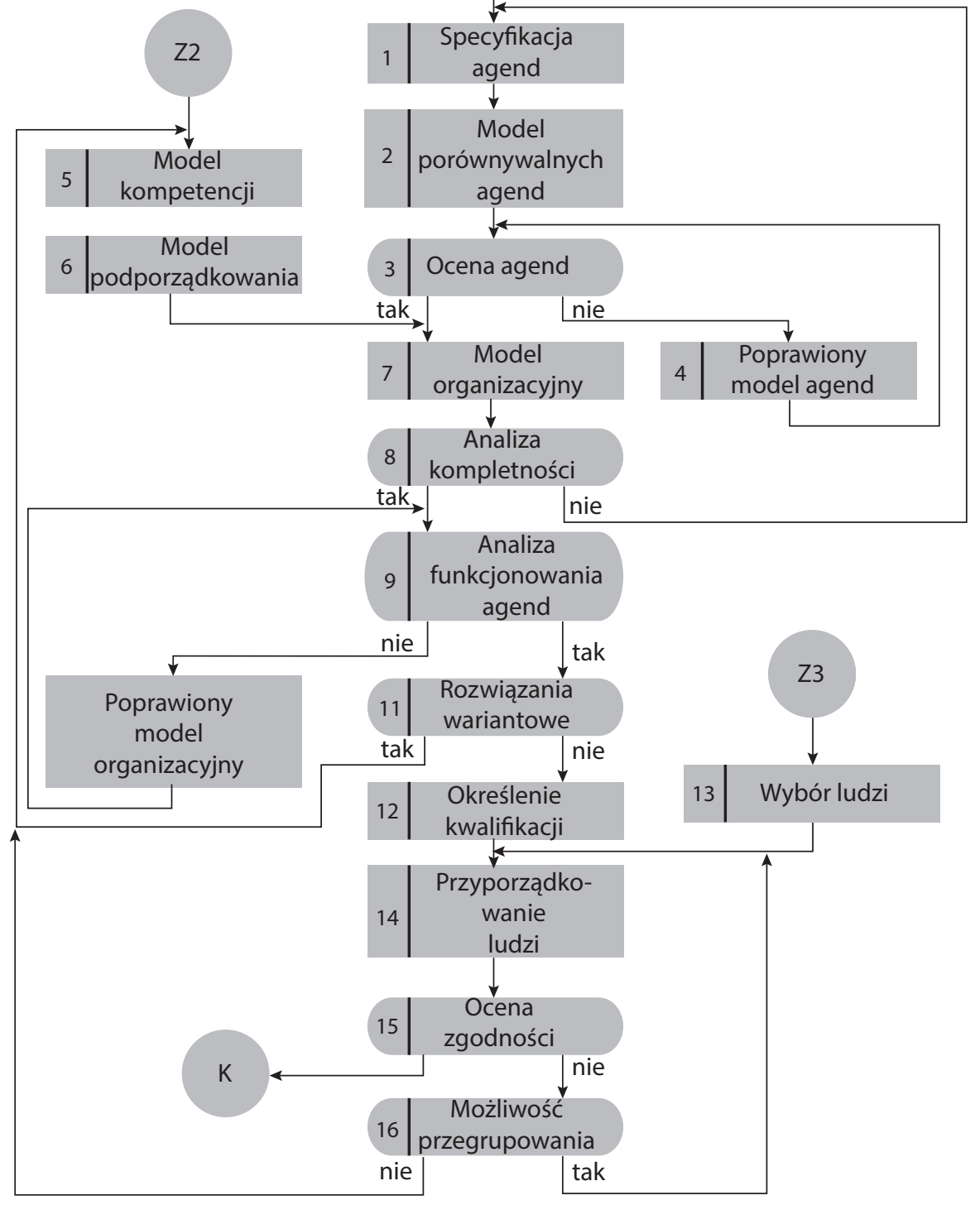

Rysunek 8. Algorytm systemowego opracowania organizacji

Źródto: Habr, Veprek, 1976, s. 168.

Z3 (powoływania ludzi na stanowiska funkcyjne), być może wówczas opatrzonym nazwą o szerszym zakresie znaczeniowym. 
Model ten jest propozycją interesującą, wcześniej niespotykaną, chyba pierwszą próbą systemowego podejścia do analizy organizacji jako całości. Pewne wątpliwości w kontekście niniejszej pracy budzi blok 2. Należy w nim porównywać agendy, a także przedstawić aktualny stan zarządzania podsystemami wyszczególnionymi w bloku 1 w procesie porównawczym. Porównanie ma się odbywać w stosunku do porównywalnego procesu albo do porównywalnego przedsiębiorstwa. Pojawiają się tu założenia, że istnieje materiał do porównań w postaci podobnego podsystemu lub innego systemu, który jest elementem normującym, wzorzec ${ }^{12}$ nie jest tutaj bowiem konstruktem myślowym spełniającym maksymalne wartości oczekiwanych parametrów. Stąd też nie można określić jakości wzorca.

Dalsze poszukiwanie ujęć analizy systemowej w kontekstach organizacyjnych przyniosło efekt w postaci systemowej analizy systemów zarządzania (Habr, Veprek, 1976). Zajmuje się ona „[...] badaniem wyodrębnienia systemu zarządzania, jego struktury, jego zachowania oraz poszukiwaniem sposobów udoskonalenia działania tego systemu" (Habr, Veprek, 1976, s. 177). Zasadne staje się zatem rozszerzenie tej metody na organizację, nie ograniczając jej wyłącznie do podsystemu zarządzania i - po wprowadzeniu modyfikacji - traktowanie jako systemowej metody analizy systemu organizacyjnego.

Według Habra, Vepreka (1976, s. 178-179) podstawowe etapy systemowej analizy systemów zarządzania to:

1) określenie systemu na obiekcie ${ }^{13}$ i jego prezentacja,

2) analiza struktury i zachowania systemu,

3) projekty udoskonaleń lub poprawek systemu oraz ich wdrożenie (wprowadzenie).

Autorzy wskazują, że dwa pierwsze kroki obejmują działania analityczne, jednak trzeci zawiera element syntezy. Zauważają, że niekiedy wprowadza się rozróżnienie między analizą systemowa i syntezą systemową (Habr, Veprek, 1976, s. 179). Na potrzeby niniejszego opracowania jako analizę systemową rozumie się kompletny przebieg procesu wraz z syntezą stanowiącą etap zamykający i podsumowujący rozważania

12 Pojęcie wzorca (normy) jest nierozerwalnie związane ze sterowaniem i regulowaniem systemu. W przypadku regulowania norma (cel) jest narzucona z zewnątrz i regulator nie ma prawa zmienić aktualnie obowiązującej normy. W przypadku sterowania organizator - obiekt sterujący - ma prawo do dokonywania zmian poziomu dotychczas obowiązującej normy sterującej (więcej: Kempisty, 1973, s. 365, 420; Zalewska-Turzyńska, 2013, s. 295-298). Inaczej mówiąc, sterowanie odbywa się przez zdolność do zmiany celu działającego układu, a regulacja oznacza zdolność do niwelowania odchyleń funkcjonowania odbiegających od danego celu.

13 Wypada w tym miejscu przypomnieć, że system nie jest tożsamy z organizacją (obiektem) w tym sensie, że system jest teoretyczną reprezentacją organizacji (lub jakiegoś jej aspektu), stąd określenie stosowane przez Habra i Vepreka. 
analityczne. Należy mieć jednak na względzie fakt, że poszczególne czynności przedstawionego procesu myślowego nie mają tak gładkiego, sukcesywnego przebiegu, jak przedstawiono poniżej. Procedura obarczona jest licznymi sprzężeniami zwrotnymi, interakcjami, przebiegami wielokrotnymi, a także przebiegami równoległymi.

Opis kolejnych etapów ${ }^{14}$ (zbiorów czynności myślowych) systemowej analizy systemów przedstawiono poniżej.

\section{Etap 1 - Określenie systemu na obiekcie i jego przedstawianie}

Etap ten składa się z następujących czynności (Habr, Veprek, 1976, s. 179, 182):

1) sprawdzenie prawidłowości sformułowania celu systemu,

2) wybór (wyodrębnienie) elementów systemu,

3) wybór (wyodrębnienie) elementów otoczenia systemu,

4) wybór (wyodrębnienie) istotnych sprzężeń między elementami systemu oraz między systemem i jego otoczeniem,

5) stworzenie graficznej postaci systemu, macierzowej postaci systemu lub innych sposobów prezentacji.

\section{Etap 2 - Analiza struktury i zachowania systemu}

Analizę można przeprowadzać bezpośrednio lub pośrednio. Do przeprowadzenia analizy bezpośredniej wykorzystuje się postać graficzną, macierzową lub inną, poszukując zakłóceń przede wszystkim w strukturze systemu. Do analizy pośredniej wykorzystuje się zbiór testów - zewnętrznych i wewnętrznych - do badania zarówno struktury, jak i zachowania systemu. W testach zewnętrznych system jest traktowany jak „czarna skrzynka” i bada się przede wszystkim jego zachowanie. Podczas przeprowadzania testów wewnętrznych bada się zachowanie podsystemów lub elementów systemów, strukturę, charakter i jakość sprzężeń (Habr, Veprek, 1976, s. 181).

\section{Etap 3 - Projekt udoskonalenia lub poprawy systemu}

Na podstawie przeprowadzonej w poprzednim etapie analizy systemu należy opracować:

[...] projekty zmian w strukturze systemu lub zmian we właściwościach transformacji elementów systemu, mających doprowadzić do poprawienia funkcjonowania systemu jako całości. Główne metody wykorzystywane do poprawienia działalności systemu są oparte na metodach analizy operacyjnej, symulacji lub podejściu heurystycznym (Habr, Veprek, 1976, s. 181-182).

14 Można rozpoznać tu fazy sformalizowanych podejść do rozwiązywania problemu - konstrukcja, obliczenie, interpretacja, wdrożenie. 
Udoskonalenie systemu dokonywane jest głównie na trzech płaszczyznach:

1) opracowywania programów uczących dla systemu,

2) wykorzystywania zmian celów i relacji wartościowych,

3) opracowywania całej strategii, zmierzającej do udoskonalenia działalności systemu.

Autorzy przyznają, że:

Do chwili obecnej mamy niewielkie doświadczenia w tej fazie analizy systemowej. Możemy się jednak spodziewać, że zostanie ona bardzo szybko rozpracowana, jak tylko uda się pomyślnie opanować pierwszy etap analizy systemowej (Habr, Veprek, 1976, s. 182).

\section{Warunki realizacji analizy systemowej}

Habr i Veprek (1976, s. 180) sugerują konieczność rozwiązania na kolejnych etapach następujących, istotnych - według nich - zagadnień:

1) decyzja dotycząc tego, czy za elementy systemu uważa się czynności, czy też jednostki organizacyjne,

2) wybór szczebla abstrakcji,

3) wyodrębnienie w prezentowanym systemie podsystemów i określenie, które $\mathrm{z}$ nich są krytyczne dla funkcjonowania systemu,

4) stwierdzenie, w których elementach systemu przebiega proces decyzyjny, a w których proste przekształcanie informacji,

5) wybór metod uproszczenia odpowiednich dla systemu: bezpośrednich czy pośrednich,

6) decyzja dotycząca tego, jaki sposób prezentacji będzie bardziej korzystny: schemat blokowy czy graf przepływów.

Wskazana powyżej metoda stanowi solidną podstawę do wypracowania nowej metody badawczej analizy i syntezy systemowej.

Poszukiwania metod systemowych odniesionych do organizacji doprowadziły także do pozycji Metody systemowe Jerzego Kisielnickiego, wydanej w serii „Metody i Techniki Organizatorskie”. Autor zebrał tutaj imponującą liczbę (36) metod systemowych dotyczących „rozwiązywania określonego problemu w ujęciu całościowym" (Kisielnicki, 1986, s. 12).

Przedstawione metody zostały pogrupowane według kryterium celu zastosowania na metody analizy i identyfikacji, określania celów działania, badania zachowania, rozwoju, oceny działalności i metody ogólnosystemowe. Te ostatnie - grupa sześciu metod, jako przedmiot szczególnego zainteresowania niniejszego opracowania - zostały poddane szczegółowej analizie. Są nimi analiza systemowa w ujęciu cybernetycznym, analiza systemowa w ujęciu J. Grahama, analiza 
usprawnieniowa i projektowanie organizacji przedsiębiorstw RAPPOS, dynamika systemów, matematyczna analiza systemów ${ }^{15}$ oraz technika systemowa w ujęciu Ch. Zangenmeistera i R. Haberfellnera (Kisielnicki, 1986, s. 14-15). Wskazane przez Kisielnickiego metody ogólnosystemowe służą odpowiednio podejmowaniu decyzji, projektowaniu systemu informatycznego do celów zarządzania, kompleksowemu usprawnieniu organizacji w przedsiębiorstwie, badaniu dynamiki rozwoju (np. handlu, nowych produktów, a nawet społeczeństwa), opracowaniu modeli rozwoju społeczno-gospodarczego (Kisielnicki, 1986, s. 33, 40, 46, 80, 119).

Jest to zbiór inspirujących metod służących rozwiązywaniu mniej lub bardziej konkretnych problemów występujących w organizacji w sposób systemowy. W kontekście analizy systemowej jako metody badawczej organizacji interesująca jest metoda RAPPOS ${ }^{16}$.

Przyjęto w niej trzy podstawowe zasady:

1. „Przedmiotem badania, przekształcania, tworzenia, usprawnienia i zarządzania jest funkcjonowanie systemu roboczo-organizacyjnego.

2. Przedmiotem badania jest projektowanie, organizowanie, zarządzanie i usprawnianie organizacji systemów roboczo-organizacyjnych.

3. Metodą badawczą są teoretyczne podstawy marksistowsko-leninowskiego materializmu dialektycznego zastosowane do sfery dyscyplin systemowych i humanistycznych (Kisielnicki, 1986, s. 46-47).

Szczegółowe dyrektywy tej metody przedstawił Franciszek Liptak (1980, s. 130) jako jedenaście następujących po sobie kroków:

15 Wiesław Sadowski (nie Vadim) w artykule pt. O matematycznej teorii organizacji (1966, s. 5-19) przedstawia prosty przykład o charakterze ilustracyjnym, dotyczący wyznaczenia optymalnej struktury organizacyjnej. Za podstawę przyjmuje dwie zmienne, czyli ogranicza system do iloczynu dwóch relacji - każda osoba dysponuje na ogół różnym zasobem informacji oraz każda z osób ma na ogół inny zakres podejmowania decyzji. Wprowadza także warunki - cele osób są identyczne z celami grupy, a grupy z celami organizacji (s. 9). W ten sposób metoda eliminuje wpływ bodźców, motywacji i grup nieformalnych na projektowaną strukturę. Autor jest świadomy ograniczeń metody, wywód przeprowadza w sposób przemyślany i rzetelny. Mimo znacznego postępu technologicznego umożliwiającego skomplikowane obliczenia, dokonując oceny tej metody, należy pamiętać o narzuconych w niej ograniczeniach - najbardziej dokuczliwe to traktowanie organizacji zgodnie z paradygmatem mechanicznym z pominięciem elementów ekonomicznych, socjologicznych i psychologicznych.

16 Nieznana szerzej na świecie czechosłowacka autorska koncepcja Liptaka - „racionalizacna analyza a projektowanie pracovno-organizacnych systemov”. Prace Liptaka publikowane były w Polce na przełomie lat siedemdziesiątych i osiemdziesiątych (np. Program usprawniania organizacji lub Systemowa organizacja pracy). 
Krok 1: Gdzie? - charakterystyka badanego systemu.

Krok 2: Co? - diagnostyka poziomu funkcjonowania systemu organizacyjnego - syntetyczna, wszechstronna ocena systemu, ustalenie problemów ogólnych oraz problemów specyficznych wymagających rozwiązań priorytetowych.

Krok 3: Dlaczego? - ocena problemów do rozwiązania.

Krok 4: Za pomocą czego? - rozwiązywanie problemów według zadań.

Krok 5: Jak? - modelowanie organizacji.

Krok 6: Za ile? - optymalizacja.

Krok 7: Co - kiedy? - opracowanie projektu usprawnień organizacji.

Krok 8: Realizacja - wprowadzenie zmian.

Krok 9: Co to daje? - ocena skutków zmian.

Krok 10: Co jeszcze? - wprowadzenie zmian korygujących.

Krok 11: Kontrola funkcjonowania systemu w nowej strukturze.

Jak widać, omawiana technika w sposób przejrzysty prowadzi etapami do rozwiązania problemów występujących w organizacji i do jej usprawnienia, jeśli już istnieje. Krok drugi wyraźnie wskazuje na orientację problemową metody, przewiduje nawet hierarchizację problemów - na bardziej i mniej priorytetowe.

Janusz Czekaj (2000) przedstawia kilka metod ${ }^{17}$ rozwiązywania problemów zarządzania informacją w przedsiębiorstwie. Wszystkie one są interesujące w kontekście niniejszej pracy, część z nich odnosi się bezpośrednio do systemów informatycznych, inne do systemu informacyjnego. Na szczególną uwagę w kontekście niniejszej monografii zasługuje metoda analizy systemu komunikacji KSS (Czekaj, 2000, s. 93-95), która opiera się na założeniu, że jakość i przepływ informacji w przedsiębiorstwie wiąże się ściśle z jego strukturą organizacyjną i systemem zarządzania. Metoda ma na celu udoskonalenie istniejącego systemu informacyjnego, aby zapobiegać powstawaniu luki informacyjnej.

17 Oprócz wymienionej metody analizy systemu komunikacji KSS Czekaj (2000) przedstawia także listę innych inspirujących metod dotyczących informacji w przedsiębiorstwie. Są to: OiM (organizacja i metody - s. 76-77), metoda analizy i projektowania systemu informacyjnego W. Bocchino (s. 78-80), metoda analizy i projektowania systemów informacyjnych SADT (s. 81-83), metoda inwentaryzacji kompleksowej systemu informacyjnego (IKSI - s. 83-84), metoda opisu macierzowego (s. 85-86), metoda analizy i projektowania systemu informacyjnego BISAD (s. 86-87), metoda HIPO hierarchii wejście-proces-wyjście (s. 88-89), metoda analizy i projektowania systemu informacyjnego ISAC (s. 89-90), metoda ASTEX, znajdująca zastosowanie w restrukturyzacji systemu informacyjnego (s. 91-92), metoda planowania informatycznej infrastruktury zarządzania BSP (s. 96), metoda analizy funkcjonalnej systemu informacyjnego FAOR (s. 97-99), metoda analizy struktury komunikacji KSA (s. 101-103), metoda projektowania zintegrowanego systemu informacyjnego ARIS (s. 104-106). 
Procedura ta składa się z pięciu etapów:

1) wstępne rozpoznanie przedsiębiorstwa, obejmujące cele, strukturę organizacyjną, system zarządzania oraz procesy informacyjne,

2) zbieranie informacji, które sprowadza się do rozpoznania nieprawidłowości występujących w sferze zarządzania informacją,

3) diagnoza systemu informacyjnego, rozpoczynająca się od opracowania i analizy wyników wywiadów,

4) projektowanie systemu, którego celem jest integracja procesów informacyjnych i decyzyjnych w organizacji,

5) wdrożenie projektu, rozpoczynające się od opracowania instrukcji organizacyjnych oraz harmonogramu wprowadzania zmian w poszczególnych podsystemach i całej organizacji.

Jak widać - mimo iż nazwa metody odnosi się do komunikacji - procedura ograniczona jest do procesów informacyjnych i decyzyjnych w organizacji. Podobnie jak we wcześniej przedstawionych modelach wymieniono kolejne etapy postępowania, nie opisano zaś szczegółowego sposobu postępowania.

Reasumując, przeprowadzone na szeroką skalę poszukiwania procedury analizy systemowej jako metody badawczej organizacji doprowadziły do identyfikacji wielu metod systemowych, adaptowanych niekiedy dla organizacji, ale powstałych na gruncie innych nauk. Natomiast metody dedykowane organizacji wydają się mieć na celu poprawę stanu istniejącej firmy. W wielu „budowa i doskonalenie” stanowi deklaratywny postulat właśnie w zakresie budowy. Niemniej wszystkie przedstawione powyżej konstrukty zostały szczegółowo przeanalizowane i (po wzbogaceniu ich o celowo dobrane elementy innych ujęć systemowych) doprowadziły do powstania propozycji procedury analizy systemów złożonych jako metody badawczej do budowy i optymalizacji organizacji, przedstawionej poniżej.

\subsection{Analiza systemów złożonych - opis metody badania organizacji}

Poniżej przedstawiono autorski opis procedury badawczej analizy systemowej powstały na podstawie koncepcji Habra i Vepreka (1976) z uzupełnieniami według Checklanda (2000) i Mingersa (2017):

1. Określenie systemu na obiekcie i jego przedstawianie:

1.1) negocjacje sformułowania celu systemu,

1.2) identyfikacja ${ }^{18}$ podsystemów systemu,

1.3) identyfikacja istotnych sprzężeń (relacji) między podsystemami systemu,

18 Habr i Veprek $(1976$, s. 179, 182) proponują określenie wybór, które nie wydaje się właściwe. Chodzi tu o ustalenie „odpowiedniości” kwalifikującej dowolny element jako niezbędny 
1.4) grupowanie relacji wokół celu organizacji,

1.5) graficzna postać systemu.

2. Analiza struktury i zachowania systemu.

3. Projekt udoskonalenia lub poprawy systemu.

Procedura została wypełniona treścią powstałą na potrzeby realizacji celu niniejszej pracy - efekty przedstawiono poniżej.

Przed szczegółowym opisem kolejnych etapów analizy systemów złożonych jako metody badawczej należy przedstawić przyjęte założenia wraz ze stosownymi wyjaśnieniami.

Po pierwsze, przedmiotem badań jest nie tylko organizacja istniejąca (Habr i Veprek), co może sugerować trzeci etap procedury - udoskonalenia i poprawy systemu, którego nie uda się wykonać na systemie nieistniejącym. Brak możliwości analizy nieistniejącego obiektu wydaje się logiczny. A jednak można analizować sytuację i potrzeby prowadzące do budowy nowego systemu (Checkland). Z tego powodu analiza systemowa jako metoda badania ma zastosowanie również dla nowo powstających organizacji (Mingers, 2017, s. 68). Stąd postulat stosowalności metody systemowej do organizacji istniejących i nowo budowanych.

Po drugie, należy odróżnić analizę komunikowania, jaka odbywa się w istniejącej organizacji, i analizę komunikowania dla organizacji nowo budowanej. Przy budowie nowego systemu to komunikacja warunkuje strukturę. Projektowanie organizacji należy zaczynać od projektowania komunikacji i na tych relacjach komunikowania dopiero osadzać strukturę. W przypadku analizy istniejącej organizacji struktura warunkuje komunikację. Po upływie czasu, w przypadku wolno zmieniającej się struktury organizacyjnej (dowolnego typu), może ona stać się elementem ograniczającym komunikację (zwłaszcza formalną) przez jej nieadekwatność do potrzeb organizacji i jej uczestników. Organizacja i otoczenie podlegają ciągłym zmianom, stąd komunikacja w organizacji jest procesem bardziej dynamicznym niż procesy zmian strukturalnych i to właśnie jest główną przyczyną wskazywanego tutaj dysonansu, jaki z upływem czasu może powstawać między komunikacją i strukturą organizacji. Komunikację, zmierzającą do powstania organizacji (komunikacja genezą organizacji) należy charakteryzować inaczej niż taką, która odbywa się w już funkcjonującej organizacji. Stąd rysują się dwie perspektywy czy też dwa kryteria, ze względu na które odbywa się badanie systemowe. Mogą one przyjmować dwa stany - pierwsze kryterium dotyczy stanu organizacji - nowa lub istniejąca - który warunkuje inne podejście do badania, projektowanie lub diagnozę organizacji; drugie kryterium to pierwszeństwo komunikacji lub struktury nad tą drugą. W ujęciu systemowym poprawa „kawałka systemu” jest tożsama

składnik podsystemu, a nie o dowolne wybranie elementów ze względu na jakieś przyjęte kryterium. 
z przebudową (rekonstrukcją) całego systemu, a nawet budową systemu od nowa - i tak rozumiany jest trzeci etap procedury analizy systemów złożonych jako metody badawczej w niniejszym opracowaniu. Zmiana wprowadzona w dowolnym podsystemie lub dowolnej relacji wpływa na resztę systemu - na podsystemy i relacje między nimi. Co więcej, jeśli zmiana nie została poprzedzona analizą systemową, to nie będzie znany jej efekt $w$ innych podsystemach i relacjach niż tylko te, które podlegają zmianie. Efekt staje się nieprzewidywalny i może być niekorzystny. To podstawowy powód przeprowadzania pełnych badań systemowych.

Do istniejącej organizacji można także zastosować metodę budowania organizacji „od nowa”. Organizacja istniejąca jest projektowana od nowa, na podstawie jej potrzeb, wówczas projekt jest traktowany jako wzorzec. Istotne są wtedy odchylenia istniejącej niesprawnej organizacji od zaprojektowanej. W takim przypadku istniejące organizacje w trakcie analizy poddaje się dekompozycji systemowej - wyodrębnia się pewne całości z systemu, stąd „rozcinanie” systemu na podsystemy i relacje kolejnych rzędów. Granicą dekompozycji są podsystemy (systenty), a nie elementy. Podsystemy, składające się z elementów i relacji międzyelementowych, nie są konstruktami wyłącznie uproszczonymi, abstrakcyjnymi i „pustymi wewnętrznie” (ich zawartość wewnętrzna jest złożona - por. podrozdział 4.2 niniejszej pracy). Tym niemniej elementy traktuje się w pracy ogólnie, gdyż - na potrzeby realizacji celu monografii - nie są tak ważne jak podsystemy. Główne zainteresowanie w pracy skoncentrowano na zachowaniach systemu oraz jego podsystemów w relacjach $\mathrm{z}$ innymi podsystemami oraz podsystemów w relacji z podsystemem zarządzania.

Porównując faktyczny (rzeczywisty) przebieg komunikatów ze wzorcowym, należy dążyć do takich zmian w organizacji rzeczywistej, które pozwolą wyeliminować lub przynajmniej ograniczyć rozbieżności między nimi. W organizacji istnieje tak zwana komunikacja nieformalna (lub pozaformalna, przybiegająca kanałami poza strukturą organizacyjną) - nie chodzi tu o jej wyeliminowanie, ale o to, aby komunikaty nieformalne, które dotyczą realizacji zadań i działania organizacji, włączyć do wiązek komunikatów funkcjonujących w organizacji.

Przedstawione powyżej założenia wpływają na kolejność kroków analizy, w której najpierw określa się relacje organizacyjne, a następnie nakłada się na nie relacje komunikowania. Temu założeniu podporządkowano konstrukcję kolejnych części pracy. Konsekwentnie, najpierw wskazano relacje występujące ogólnie (relacje organizacyjne), a następnie na nie nałożono odpowiednie relacje komunikowania w postaci form i treści przekazu (czyli komunikatów zawierających określoną treść). Relacje komunikowania są następnie kanalizowane w sieci według zaproponowanego w tej pracy cyklu zarządzania. Taka konstrukcja modelu i tekstu wynika z potrzeby syntezy następującej jako konsekwencja analizy. 
W budowanej tutaj organizacji, prezentowanej jako system relacyjny, podstawową jednostką rozważań są podsystemy, dalsza dekompozycja może się koncentrować na relacjach wewnątrzpodsystemowych. Stąd, ze względu na przyjęty cel pracy, pojawia się potrzeba, aby obok wskazania niezbędnych podsystemów, uwidocznić także relacje między nimi, a także między elementami każdego podsystemu a tym systemem.

Ze względu na analizę relacyjną komunikowania wewnątrzorganizacyjnego świadomie skoncentrowano się na relacjach wewnątrzorganizacyjnych, zaznaczono miejsce analizy relacji system-organizacja-otoczenie, jednak nie koncentrowano się na tym zagadnieniu, nie jest ono bowiem celem niniejszego opracowania. Stanowi ono interesujące zagadnienie i zasługuje na osobne opracowanie. Poniżej w sposób szczegółowy przedstawiono kolejne kroki pierwszego etapu procedury analizy systemowej.

\subsubsection{Określenie systemu na obiekcie i jego przedstawianie}

Poniżej omówiono etapy procedury badawczej analizy systemów złożonych.

\section{Negocjacje formułowania celu systemu}

Klasyczna analiza systemowa przyjmuje, że cel jest ustalony wcześniej, poza organizacją. „Pierwszym zadaniem każdego właściciela organizacji czy też pracującego w niej menedżera jest określenie jej celu i misji” (Kisielnicki, 2001, s. 52). Wówczas sprawdzenie prawidłowości sformułowania celu systemu obejmuje stwierdzenie, czy został on już określony i czy wyznaczona definicja celu może być nadal wykorzystana. Jeśli weryfikacja jest negatywna, należy dokonać poprawek. Jeśli istnieje konieczność uwzględnienia kilku celów, należy także wyjaśnić zależności między nimi ${ }^{19}$.

Obecnie często burzliwe otoczenie organizacji (technologie komunikacyjne wspierane internetem) w znacznym stopniu wpływa na zmienność celów. Dotyczy ona kryterium czasu (jak często i na jak długo cele się zmieniają), zakresu (czy zmiany są szerokie, czy wąskie, głębokie czy powierzchowne) oraz siły zmiany (wywołują rewolucję czy stanowią płynną ewolucję). Każda zmienność celów może zostać określona, a dany moment w czasie opisany celem. Ponadto otoczenie może wpływać także na sposób określania celów - szczegółowy lub ramowy. Mając na uwadze te kryteria, pozwalające na elastyczne ujmowanie celu organizacyjnego, jego ustalenie jest niezbędne, organizacje powstają bowiem $\mathrm{z}$ inspiracji teleologicznej, co z kolei stanowi podstawę koncentracji zespołów wewnątrzorganizacyjnych. Powód, czy

19 Należy tu pamiętać, że w analizie systemowej istnieją trzy rodzaje celów lub ich zbiorów: cel obiektu, cel systemu stworzonego na tym obiekcie oraz cel przeprowadzanej analizy (Habr, Veprek, 1976, s. 180, 199-200). 
motywacja ustalenia celu są - z punktu widzenia procedury analizy systemów złożonych - nieistotne ${ }^{20}$. Nie jest również ważne, czy osoba ustalająca cel może go zrealizować, czy też powstał on przez działanie czynników zewnętrznych. Istotny jest efekt w postaci sformułowania celu.

Jeśli cel wyznaczony przez zewnętrznego zleceniodawcę nie jest ustalony w sposób systemowy, podobnie gdy cel jest zinstytucjonalizowany (np. w normach ISO serii 9000), bywa określany niekonkretnie w sposób mglisty (opatrzony wówczas określeniem ramowy), niedokładny (bez podania parametrów), niewyważony (w listę celów dużych wplątane są cele małe). W konsekwencji zespół pracuje nad rozwiązaniem, które nie likwiduje istoty problemu. Niedostatki sformułowania celu obarczone są znaczącymi konsekwencjami, dlatego też rozsądne wydaje się włączenie stadium ustalania celu jako integralnego etapu procedury analizy systemowej. W takim przypadku cel powinien być formułowany w sposób systemowy, po pogłębionych konsultacjach i negocjacjach z interesariuszami (zleceniodawcami i wykonawcami). Od sposobu sformułowania celu zależy bowiem kształt później zbudowanego systemu oraz metody i sposobu jego osiągania.

Cel bywa formułowany jako maksymalizacja lub minimalizacja jakiegoś parametru (ogólnie np. maksymalizacja efektów, zysku, minimalizacja kosztów, nakładów), wówczas zakłada się osiągnięcie pewnej skrajności. Od strony formalnej są to pojęcia jednoznaczne, dlatego pasują do celów operatywnych. Wątpliwości pojawiają się z perspektywy rzeczowej, bo osiągnięcie ekstremum zakłada korzystanie z jednego tylko kryterium. Wprowadzenie kolejnych kryteriów często prowadzi do sprzecznych stanowisk - osiąganie pewnych ekstremów może stać w opozycji do innych. Stąd propozycja wprowadzania rozwiązań kompromisowych w postaci rozwiązań optymalnych. „Optymalny” nie oznacza jednak - jak w przypadku programowania matematycznego - ogólnego określenia na ekstrema - minimum lub maksimum - zależnie od punktu widzenia. Tu chodzi o odnalezienie takiego poziomu wskaźnika znajdującego się między ekstremami, który jest zadowalają$c y^{21}-\mathrm{w}$ medycynie jest on nazywany poziomem referencyjnym.

20 Wymagania teorii systemów dotyczące poszukiwania celu i autopojezy dodatkowo wzmacniają widoczną stabilność systemów/podmiotów i ich granic. Czynią to przez nasycenie systemów intencjonalnością, wolnością i tożsamością. W ten sposób zarówno systemy, jak i ich komponenty/podsystemy są nie tylko esencjalizowane, ale również powstaje możliwość, że one (np. osoby, technologie, struktury społeczne) działają pod własną władzą. Stwarza to obraz systemów jako sieci zależności wejściowych/wyjściowych i hierarchicznych, w ramach których zmotywowane, samoregenerujące się i racjonalne komponenty realizują własne programy (Schultze, 2017, s. 63, ponadto Kołodziejczak, Zalewska, 2006, s. 27-36; Krzakiewicz 2013, s. 109-117).

21 Por. ograniczenie poznawcze racjonalności (March, Simon, 1976) i remedium w postaci racjonalności względnej. „W większości przypadków [...] chodzi o wykrycie i wyselekcjonowanie 
Skomplikowanie i złożoność celów przejawia się w postaci braku aparatu pojęciowego $\mathrm{w}$ dziedzinie opisywanych zjawisk i procesów ekonomicznych i zarządzania, a także różnych poziomów, na których cele występują. Dla badacza najwygodniej sformułowany cel to cel w postaci sformalizowanej (Zieleniewski, 1964, s. 182-187, Martyniak, 1976, s. 33-35). Część problemów trudno jest przedstawić w sposób formalny (np. matematyczny), pojawiają się nawet trudności w werbalnym (słownym) ich określeniu. Powodem tego są niedostatki terminologiczne, a omówienie opisowe nie zawsze jest wystarczające, bo jest narażone na konieczność ich wyjaśniania. Powierzchownie określone cele mogą być następnie niedokładnie interpretowane. Systemowe podejście do formułowania celów pozwala utrzymać proces myślowy formułowania celów na określonym, jednolitym poziomie abstrakcji. Kategoryzacja celów przebiega zatem z zachowaniem ich szczebli koncepcyjnych. Dzięki temu możliwa jest także agregacja celów - istnieje bowiem pełna rozpiętość szczebli i dotyczących ich celów, które podlegają kaskadowaniu, regule skalarnej i addytywnej.

Występuje także grupa problemów „o złej strukturze” - są to problemy ekonomiczne, trudne do ujęcia w kategoriach ilościowych, wyrażane zazwyczaj w formie opisowej przez ustalone kategorie pojęciowe. Przeważają w nich aspekty jakościowe $^{22}$ (np. popularna obecnie kwestia jakości życia w pracy).

Reasumując, formułowanie celu jest samo w sobie problemem, istnieje bowiem wiele danych, z których badacz musi wybrać najistotniejsze, bywa także, że brakuje danych lub ich jakość jest wątpliwa. Jednocześnie istnieje także wiele możliwości formułowania celu spośród identycznego materiału wyjściowego. Zadaniem badacza jest poprawne sprecyzowanie zadania.

\section{Identyfikacja podsystemów i relacji (sprzężeń23) między nimi}

Pojęcia relacji jest $\mathrm{w}$ niniejszej pracy używane w szerokim rozumieniu definicji słownikowej, zakres pojęcia stosowany jest elastycznie - na przykład jako powiązania, oddziaływania, warunkowanie (zarówno w znaczeniu merologicznym, jak i w znaczeniu oddziaływania). Jako przykład można przytoczyć rozmaity charakter wyodrębnianych relacji: funkcjonalne, przyczynowe, komunikowania, współpracy, konfliktu. W pracy relację stanowią wszelkiego rodzaju powiązania między dwoma podsystemami, określane w zależności od problemu i stosowane elastycznie.

alternatyw zadowalających; jedynie w wyjątkowych przypadkach chodzi o wykrycie i wyselekcjonowanie alternatyw optymalnych" (March, Simon, 1976, s. 216).

22 Taka struktura problemu prowadzi do wykorzystania metod heurystycznych, które nie stanowią głównego nurtu zainteresowań badawczych w niniejszym opracowaniu.

23 Sprzężenie to zawężenie pojęcia relacje. „Te oddziaływania mogą mieć rozmaitą naturę” (Ziemba, Jarominek, Staniszewski, 1980, s. 11-12). 
Identyfikowanie podsystemów i relacji systemu rozpoczyna ujęcie istoty problemu (celu) (Mingers, 2017), które ułatwia uchwycenie czynników świata rzeczywistego, ważnych dla rozwiązywania problemów. Określenie charakteru problemu - ekonomicznego, technicznego, społecznego itp. - pomaga redukować czynniki świata realnego, bo „zredukowanie ilości najistotniejszych czynników jest najważniejszym wkładem metodycznym podejścia systemowego" (Mingers, 2017, s. 67-68; podobne stanowisko prezentują Habr, Veprek, 1976, s 300). Ponadto „Nie trzeba wymieniać wszystkich elementów i wszystkich relacji, aby ustalić system” (Ujemow, 1973b, s. 62). Na przykład Dmitrij Mendelejew w trakcie przygotowywania układu (systemu) okresowego pierwiastków posiadał niekompletny ich zbiór i nie znał wszystkich relacji między nimi, jednak wiedział, że cechy relacji ${ }^{24}$ zmieniały się według prostego prawa, dlatego wykroczył poza znany mu zbiór pierwiastków i dzięki systematyzacji przewidział istnienie nowych. Określenie systemu na obiekcie wymaga w tym miejscu etapu polegającego na identyfikowaniu relacji między podsystemami systemu.

Na tym etapie należy zebrać „materiał budowlany do dalszej działalności, tj. do tworzenia modelu” (Habr, Veprek, 1976, s. 300). Materiał ten musi być kwantyfikowalny, zebrany nie dowolnie, ale na podstawie danych empirycznych, przeglądu literatury, modeli antycypowanych itp. Dopuszcza się także wyobrażenia intuicyjne, ponieważ ten materiał (tzw. surowy) w następnej kolejności zostanie poddany opracowaniu. Zbieranie materiału pozwala poruszać się badaczowi na niskim poziomie abstrakcji, operować pojęciami realnymi, aby później w procesie opracowywania przenieść koncepcję na wyższy poziom abstrakcji. Ustalony uprzednio cel wyznacza perspektywę lub kryterium „zbierania” materiałów rzeczywistych, które zostaną wykorzystane do budowy w modelu.

Materiały rzeczywiste (elementy) pogrupowane według kryterium rzeczowego prowadzą do wyodrębnienia podsystemów. Istotna jest tu także analiza relacji wewnątrzpodsystemowych oraz międzypodsystemowych. Podsystemy wchodzące w skład systemu wykazują dwa typy cech - własne i takie, które ujawniają się $\mathrm{w}$ kontakcie z innymi cechami systemu. W tym miejscu stosowna jest analogia systemu do chóru, wskazująca główną cechę systemów wykorzystywaną w analizie systemowej. Solista ujawnia walory swojego głosu przez dowolny dobór repertuaru - na miarę swojego głosu. Gdy jednak dołącza kolejna osoba - tworząc tym samym duet - każda z osób nie powinna prezentować własnych walorów wokalnych w najwyższym stopniu, a tylko takie, które odsłaniają swoje piękno w duecie - i jednocześnie konstytuują go. Pozostałe umiejętności - choćby najwyższej próby

24 „Jeśli oprócz relacji między samymi obiektami będziemy rozpatrywać także relacje między cechami obiektów, to otrzymamy dwa różne systemy obiektów o różnych relacjach" (Ujemow, 1973a, s. 57). 
- nie są ujawniane, bo nie wspierają walorów wokalnych duetu. Jeśli do duetu dołącza kolejna osoba, tworząc tercet, ujawniane są inne umiejętności wokalne niż w przypadku duetu. Dokładając kolejne osoby-elementy tworzy się chór, którego niezaprzeczalnym walorem jest wielość dopasowanych do siebie głosów - one jednak oderwane od całości nie potrafią zachwycać, w taki sposób jak w całości. Stąd jakakolwiek zmiana w dowolnej części systemu wpływa na pozostałe jego części. I odwrotnie, zmiana systemu pociąga za sobą zmiany pojedynczych systentów, które połączone są wzajemnymi relacjami (przyczyny jego całościowego charakteru $\left.{ }^{25}\right)$. Ta cecha narzuca sposób badania systemów.

Dlatego całościowość, czyli niesumatywność ${ }^{26}$ (czy też nieaddytywność ${ }^{27}$ ), staje się najważniejszą z cech systemowych ujawniających się w procesie analizy i syntezy systemów złożonych jako metody badawczej. Jeśli obiekt zachowuje się nieaddytywnie, wówczas jest systemem, inaczej jest zbiorem niezależnych części. Dodatkowo system rozpatrywany całościowo nabywa takich własności, jakich nie posiada żadna z jego części.

Co więcej, system:

[...] jest określoną całością, z czego w szczególności wynika zasadnicza niemożność sprowadzenia jego własności do sumy własności jego elementów składowych i niemożność wyprowadzenia z tych ostatnich własności całości (Sadowski, 1981, s. 294).

25 „W przeciwieństwie do addytywności całościowość obiektu oznacza, że zmiana dowolnego elementu systemu ma wpływ na inne elementy systemu i prowadzi do zmiany całego systemu. A także na odwrót, zmiana dowolnego elementu zależy od zmian wszystkich innych elementów systemu" (Sadowski, 1981, s. 297).

26 Addytywność jest określeniem pochodzenia tacińskiego: additio - 'dodawanie'; addere - 'dodawać', dlatego korzystając z języka polskiego, cechę tę można określać jako sumatywność. Addytywność jest pierwotnie matematycznym określeniem na własność funkcji przypisującej wartości liczbowe dowolnym obiektom - funkcja jest addytywna, gdy jej wartość dla dowolnego obiektu jest równa sumie jej wartości dla części, na jakie obiekt został podzielony: $f(x+y)=f(x)+f(y)$ (Encyklopedia PWN, 2013).

27 „W ramach ogólnej teorii systemów addytywność oznacza, że zmiana dowolnego elementu systemu zależy tylko od tego elementu. W rezultacie zmiana całego systemu jest sumą zmian jego elementów nie zależących od siebie wzajemnie (wzajemne oddziaływanie elementów w tym przypadku równe jest zeru i w rzeczywistości mamy do czynienia z systemem zdegenerowanym)" (Sadowski, 1981, s. 297). Niektórzy autorzy nie są kategoryczni w określaniu systemów jako nieaddytywnych, dla przykładu: „Dla systemów otwartych charakterystyczne jest przechodzenie od stanu addytywności (w tym lub innym stopniu) do stanu całościowości. Proces ten można nazwać systematyzacją [...]. Proces przeciwny - mechanizacja - przejście od stanu całościowości do stanu addytywności [...]" (Robey, Mikhaeil, 2016, s. 128). 
W spójnym systemie zmiana jednego elementu lub jego własności pociąga zatem za sobą zmianę innych elementów lub ich własności. Jeśli natomiast zmiany jednego elementu nie wpływają na inne elementy systemu, to takie elementy są niezależne, a przemiany w nim zachodzą w sposób addytywny (von Bertalanffy, 1984, s. 99).

Dla opisania cechy nieaddytywności von Bertalanffy (jako pierwszy) skorzystał $z$ układów symultanicznych równań różniczkowych, w których $Q_{i}$ oznacza pewną miarę elementów. Przy założeniu, że istnieje skończona liczba elementów, otrzymuje się (von Bertalanffy, 1984, s. 87):

$$
\begin{aligned}
& \frac{d Q_{1}}{d t}=f_{1}\left(Q_{1}, Q_{2}, \ldots, Q_{n}\right) \\
& \frac{d Q_{2}}{d t}=f_{2}\left(Q_{1}, Q_{2}, \ldots, Q_{n}\right) \\
& \frac{d Q_{n}}{d t}=f_{n}\left(Q_{1}, Q_{2}, \ldots, Q_{n}\right)
\end{aligned}
$$

Oznacza to, że zmiana jakiejkolwiek miary $Q_{i}$ jest funkcją wszystkich pozostałych miar $Q$ - od $Q_{1}$ do $Q_{n}$ i na odwrót - zmiana jakiejkolwiek miary $Q_{i}$ pociąga za sobą zmianę wszystkich pozostałych miar oraz systemu jako całości.

Zasadę systemowej całościowości von Bertalanffy wyprowadzał przez rozwinięcie równań (1) w szereg Taylora:

$$
\frac{d Q_{1}}{d t}=a_{11} Q_{1}+a_{12} Q_{2}+\ldots+a_{1 n} Q_{n}+a_{111} Q_{1}^{2}+\ldots
$$

Z powyższego wzoru wynika wyraźnie, że zmiana jakiejkolwiek wielkości $Q_{i}$ jest funkcją wszystkich pozostałych elementów od $Q_{1}$ do $Q_{n}$, natomiast zmiana dowolnego $Q_{i}$ powoduje zmianę wszystkich pozostałych elementów, a także całego systemu.

Przystosowując powyższy zapis do celu niniejszej pracy i mając na względzie systenty ${ }^{28}$ jako podstawowe jednostki budowy systemu, należy stwierdzić co następuje: podsystem posiada swoje własne cechy. Badając systent

28 Dla przypomnienia - jest to nazwa wytworzona na potrzeby tej pracy, oznaczająca najmniejszy podsystem systemu wyższego rzędu, złożony z dwóch elementów i relacji między nimi. W przypadku organizacji jest to podsystem złożony z przełożonego i podwładnego oraz relacji między nimi. 
$p_{1}$ podsystemu $P$ w izolacji, dostrzega się jego cechy własne i sposób, w jaki zachowuje się on poza systemem (niejako w oderwaniu od systemu). Jeśli bada się relację $\left(p_{1} \rightarrow p_{2}\right)$, wówczas ujawniają się cechy systemowe w relacji. Im więcej systentów $p_{n}$ wchodzi $\mathrm{w}$ relację z badanym $p_{1}$, w tym większym stopniu nasilenia przejawiają się $\mathrm{w}$ jego zachowaniu konstytutywne cechy systemowe. Jeśli $p_{1}$ jest wkomponowany we wszystkie systenty podsystemu, wówczas redukcji ulegają jego cechy własne, autonomiczne, konstytuujące jego podmiotowość, a ujawniają się wyłącznie cechy systemowe. Jest to kluczowa i najważniejsza właściwość systemów, stanowiąca istotną podstawę przedstawionego w pracy toku rozumowania oraz bazę dla przeprowadzanej procedury analizy systemów złożonych. Poniżej dokonano autorskiej próby zapisu symbolicznego tej procedury:

1. Badanie relacji ${ }^{29}$ wewnętrzpodsystemowych podsystemu $P$ złożonego $\mathrm{z}$ systentów $p_{1}$ oraz $p_{2}$, czyli $P=\left\{p_{1} ; p_{2}\right\}-$ na potrzeby tej pracy określonych jako relacje pierwszego stopnia.

Analiza $P=\left\{p_{1}+p_{2}+p_{1} \rightarrow p_{2}+p_{1} \leftarrow p_{2}\right\}$.

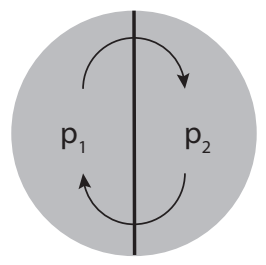

Rysunek 9. Relacje pierwszego stopnia

Źródto: opracowanie własne.

Oznacza to, że w badaniu należy uwzględnić cechy lub zachowania $p_{1}$ i $p_{2}$ $\mathrm{w}$ odosobnieniu, a następnie cechy lub zachowania $p_{1} \mathrm{w}$ relacji (pod wpływem) $p_{2}$ i odwrotnie $-p_{2}$ pod wpływem $p_{1}$.

2. Badanie relacji międzypodsystemowych podsystemów $P$ i $D$, złożonych odpowiednio z systentów $P=\left\{p_{1} ; p_{2}\right\}$ oraz $D=\left\{d_{1} ; d_{2}\right\}$ - na potrzeby tej pracy określonych jako relacje drugiego stopnia.

29 Relacja $p_{1} \leftrightarrow p_{2}$ nie zawsze jest równoważna, jest bowiem zwrotna, ale może być symetryczna lub niesymetryczna albo przechodnia, ponadto zwykle nie jest identyczna. 


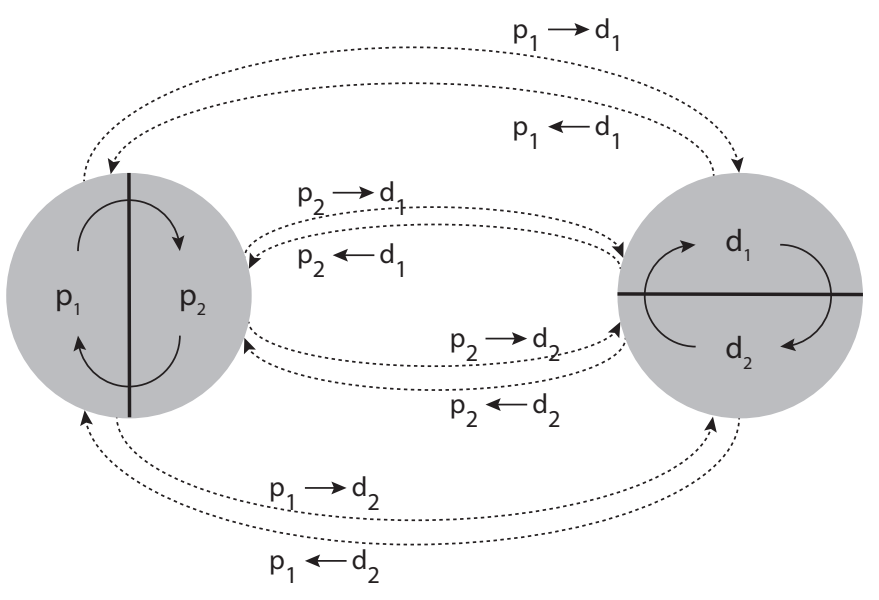

Rysunek 10. Relacje drugiego stopnia

Źródto: opracowanie własne.

Podsystem $P-D=P\left(p_{1}, p_{2}\right)+D\left(d_{1}, d_{2}\right)=P\left(p_{1}\left(p_{1} \rightarrow p_{2}\right)\right)+\left(p_{1}\left(p_{1} \rightarrow d_{1}\right)\right)+$ $\left(p_{1}\left(p_{1} \rightarrow d_{2}\right)\right)+\left(p_{2}\left(p_{1} \leftarrow p_{2}\right)\right)+\left(p_{2}\left(p_{2} \rightarrow d_{1}\right)\right)+\left(p_{2}\left(p_{2} \rightarrow d_{1}\right)\right)+D\left(d_{1}\left(p_{1} \leftarrow d_{1}\right)\right)$ $+\left(d_{1}\left(p_{2} \leftarrow d_{1}\right)\right)+\left(d_{1}\left(d_{1} \rightarrow d_{2}\right)\right)+\left(d_{2}\left(p_{1} \leftarrow d_{2}\right)\right)+\left(d_{2}\left(p_{2} \leftarrow d_{2}\right)\right)+\left(d_{2}\left(d_{1} \leftarrow d_{2}\right)\right)$ $\mathrm{W}$ badaniu należy uwzględnić cechy lub zachowania podsystemów $p_{1}$ i $p_{2}$ oraz $d_{1} \mathrm{i} d_{2}$ w odosobnieniu, a następnie cechy lub zachowania każdego z podsystemów $p_{1}, p_{2}, d_{1}$ i $d_{2}$ w relacji (pod wpływem) pozostałych trzech podsystemów z osobna (dwanaście relacji).

3. Badanie relacji międzypodsystemowych podsystemów $P, D$ i $Q$, złożonych odpowiednio z systentów $P=\left\{p_{1} ; p_{2}\right\}, D=\left\{d_{1} ; d_{2}\right\}$ oraz $Q=\left\{q_{1} ; q_{2}\right\}-$ na potrzeby tej pracy określonych jako relacje trzeciego stopnia.

Podsystem $P-D-Q=P\left(p_{1}, p_{2}\right)+D\left(d_{1}, d_{2}\right)+Q\left(q_{1}, q_{2}\right)=P\left\{\left(p_{1}\left(p_{1} \rightarrow p_{2}\right)\right)+\right.$ $\left.\left.\left(p_{1}\left(p_{1} \rightarrow d_{1}\right)\right)+\left(p_{1}\left(p_{1} \rightarrow d_{2}\right)\right)+p_{1}\left(p_{1} \rightarrow q_{1}\right)\right)+p_{1}\left(p_{1} \rightarrow q_{2}\right)\right)+\left(p_{2}\left(p_{1} \leftarrow p_{2}\right)\right)+$ $\left.\left(p_{2}\left(p_{2} \rightarrow d_{1}\right)\right)+\left(p_{2}\left(p_{2} \rightarrow d_{1}\right)\right)+\left(p_{2}\left(p_{2} \rightarrow q_{1}\right)\right)+\left(p_{2}\left(p_{2} \rightarrow q_{2}\right)\right)\right\}+D\left\{\left(d_{1}\left(p_{1} \leftarrow d_{1}\right)\right)+\right.$ $\left(d_{1}\left(p_{2} \leftarrow d_{1}\right)\right)+\left(d_{1}\left(d_{1} \rightarrow d_{2}\right)\right)+\left(d_{1}\left(d_{1} \rightarrow q_{1}\right)\right)+\left(d_{1}\left(d_{1} \rightarrow q_{2}\right)\right)+\left(d_{2}\left(p_{1} \leftarrow d_{2}\right)\right)+$ $\left.\left(d_{2}\left(p_{2} \leftarrow d_{2}\right)\right)+\left(d_{2}\left(d_{1} \leftarrow d_{2}\right)\right)+\left(d_{2}\left(d_{2} \rightarrow q_{1}\right)\right)+\left(d_{2}\left(d_{2} \rightarrow q_{2}\right)\right)\right\}+$ $Q\left\{\left(q_{1}\left(q_{1} \leftarrow p_{1}\right)\right)+\left(q_{1}\left(q_{1} \leftarrow p_{2}\right)\right)+\left(q_{1}\left(q_{1} \leftarrow d_{1}\right)\right)+\left(q_{1}\left(q_{1} \leftarrow d_{2}\right)\right)+\right.$ $\left(q_{1}\left(q_{1} \rightarrow q_{2}\right)\right)+\left(q_{2}\left(q_{2} \leftarrow p_{1}\right)\right)+\left(q_{2}\left(q_{2} \leftarrow p_{2}\right)\right)+\left(q_{2}\left(q_{2} \leftarrow d_{1}\right)\right)+\left(q_{2}\left(q_{2} \leftarrow d_{2}\right)\right)+$ $\left.\left(q_{2}\left(q_{2} \leftarrow q_{1}\right)\right)\right\}+P D\left\{\left(p d\left(p d \rightarrow q_{1}\right)\right)+\left(p d\left(p d \rightarrow q_{2}\right)\right)+P D\left\{\left(p_{1} d_{1}\left(p_{1} d_{1} \rightarrow q_{1}\right)\right)+\right.\right.$ $\left(p_{1} d_{1}\left(p_{1} d_{1} \rightarrow q_{2}\right)\right)+\left(p_{1} d_{2}\left(p_{1} d_{2} \rightarrow q_{1}\right)\right)+\left(p_{1} d_{2}\left(p_{1} d_{2} \rightarrow q_{2}\right)\right)+\left(p_{2} d_{1}\left(p_{2} d_{1} \rightarrow q_{1}\right)\right)+$ $\left(p_{2} d_{1}\left(p_{2} d_{1} \rightarrow q_{2}\right)\right)+\left(p_{2} d_{2}\left(p_{2} d_{2} \rightarrow q_{1}\right)\right)+\left(p_{2} d_{2}\left(p_{2} d_{2} \rightarrow q_{2}\right)\right)+\left(p_{1} d_{1}\left(p_{1} d_{1} \leftarrow q_{1}\right)\right)+$ $\left.p_{1} d_{1}\left(p_{1} d_{1} \leftarrow q_{2}\right)\right)+\left(p_{1} d_{2}\left(p_{1} d_{2} \leftarrow q_{1}\right)\right)+\left(p_{1} d_{2}\left(p_{1} d_{2} \leftarrow q_{2}\right)\right)+\left(p_{2} d_{1}\left(p_{2} d_{1} \leftarrow q_{1}\right)\right)+$ $\left.\left(p_{2} d_{1}\left(p_{2} d_{1} \leftarrow q_{2}\right)\right)+\left(p_{2} d_{2}\left(p_{2} d_{2} \leftarrow q_{1}\right)\right)+\left(p_{2} d_{2}\left(p_{2} d_{2} \leftarrow q_{2}\right)\right)\right\}+P Q\left\{\left(p q\left(p q \rightarrow d_{1}\right)\right)+\right.$ $\left(p q\left(p q \rightarrow d_{2}\right)\right)+P Q\left\{\left(p_{1} q_{1}\left(p_{1} q_{1} \rightarrow d_{1}\right)\right)+\left(p_{1} q_{1}\left(p_{1} q_{1} \rightarrow d_{2}\right)\right)+\left(p_{1} q_{2}\left(p_{1} q_{2} \rightarrow d_{1}\right)\right)+\right.$ 


$$
\begin{aligned}
& \left(p_{1} q_{2}\left(p_{1} q_{2} \rightarrow d_{2}\right)\right)+\left(p_{2} q_{1}\left(p_{2} q_{1} \rightarrow d_{1}\right)\right)+\left(p_{2} q_{1}\left(p_{2} q_{1} \rightarrow d_{2}\right)\right)+\left(p_{2} q_{2}\left(p_{2} q_{2} \rightarrow d_{1}\right)\right)+ \\
& \left(p_{2} q_{2}\left(p_{2} q_{2} \rightarrow d_{2}\right)\right)+\left(p_{1} q_{1}\left(p_{1} q_{1} \leftarrow d_{1}\right)\right)+\left(p_{1} q_{1}\left(p_{1} q_{1} \leftarrow d_{2}\right)\right)+\left(p_{1} q_{2}\left(p_{1} q_{2} \leftarrow d_{1}\right)\right)+ \\
& \left(p_{1} q_{2}\left(p_{1} q_{2} \leftarrow d_{2}\right)\right)+\left(p_{2} q_{1}\left(p_{2} q_{1} \leftarrow d_{1}\right)\right)+\left(p_{2} q_{1}\left(p_{2} q_{1} \leftarrow d_{2}\right)\right)+\left(p_{2} q_{2}\left(p_{2} q_{2} \leftarrow d_{1}\right)\right)+ \\
& \left.\left(p_{2} q_{2}\left(p_{2} q_{2} \leftarrow d_{2}\right)\right)\right\}+D Q\left\{\left(d q\left(d q \rightarrow p_{1}\right)\right)+\left(d q\left(d q \rightarrow p_{2}\right)\right)+D Q\left\{\left(d_{1} q_{1}\left(d_{1} q_{1} \rightarrow p_{1}\right)\right)+\right.\right. \\
& \left(d_{1} q_{1}\left(d_{1} q_{1} \rightarrow p_{2}\right)\right)+\left(d_{1} q_{2}\left(d_{1} q_{2} \rightarrow p_{1}\right)\right)+\left(d_{1} q_{2}\left(d_{1} q_{2} \rightarrow p_{2}\right)\right)+\left(d_{2} q_{1}\left(d_{2} q_{1} \rightarrow p_{1}\right)\right)+ \\
& \left(d_{2} q_{1}\left(d_{2} q_{1} \rightarrow p_{2}\right)\right)+\left(d_{2} q_{2}\left(d_{2} q_{2} \leftarrow p_{1}\right)\right)+\left(d_{2} q_{2}\left(d_{2} q_{2} \leftarrow p_{2}\right)\right)+\left(d_{1} q_{1}\left(d_{1} q_{1} \leftarrow p_{1}\right)\right)+ \\
& \left(d_{1} q_{1}\left(d_{1} q_{1} \leftarrow p_{2}\right)\right)+\left(d_{1} q_{2}\left(d_{1} q_{2} \leftarrow p_{1}\right)\right)+\left(d_{1} q_{2}\left(d_{1} q_{2} \leftarrow p_{2}\right)\right)+\left(d_{2} q_{1}\left(d_{2} q_{1} \leftarrow p_{1}\right)\right)+ \\
& \left.\left(d_{2} q_{1}\left(d_{2} q_{1} \leftarrow p_{2}\right)\right)+\left(d_{2} q_{2}\left(d_{2} q_{2} \leftarrow p_{1}\right)\right)+\left(d_{2} q_{2}\left(d_{2} q_{2} \leftarrow p_{2}\right)\right)\right\} .
\end{aligned}
$$

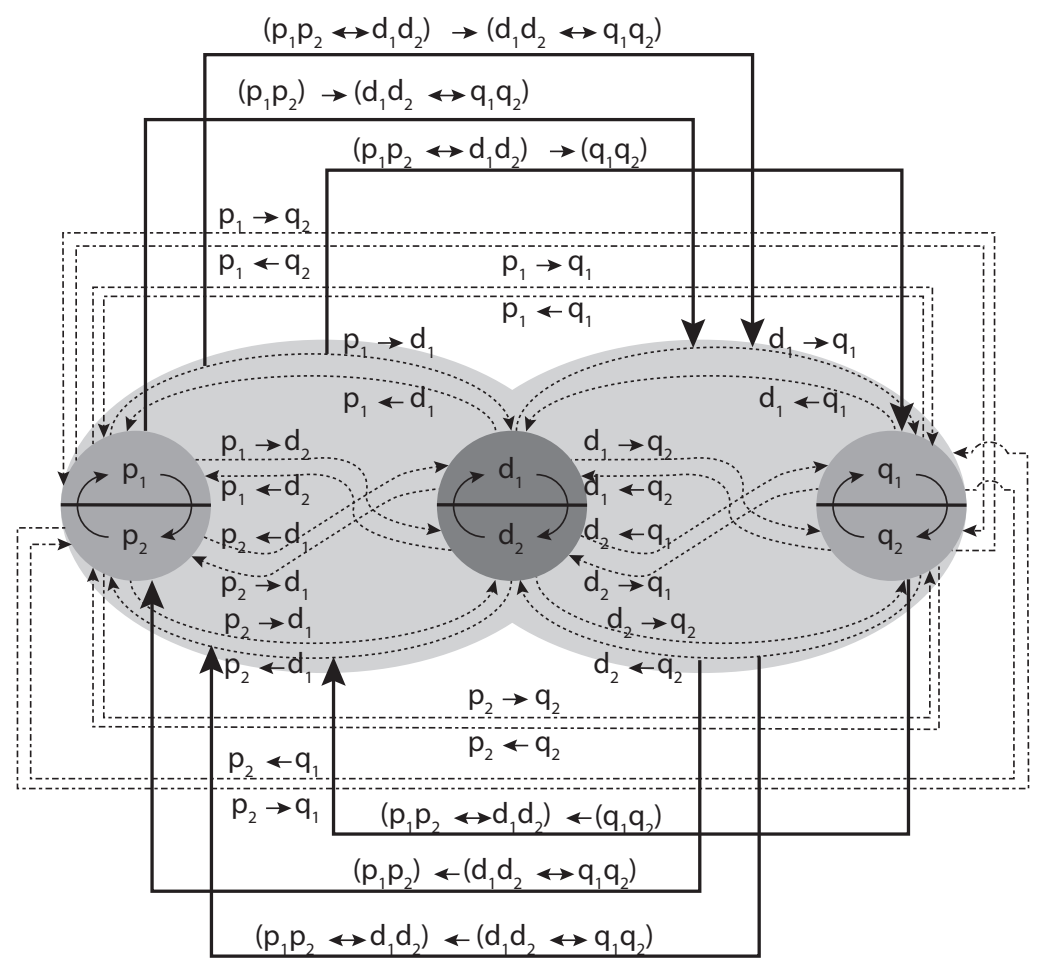

Rysunek 11. Wybrane relacje trzeciego stopnia

Źródto: opracowanie własne.

$\mathrm{W}$ badaniu należy uwzględnić cechy lub zachowania podsystemów $p_{1}$ i $p_{2}, d_{1}$ i $d_{2}$ oraz $q_{1}$ i $q_{2}$ w odosobnieniu (sześć relacji), a następnie cechy lub zachowania każdego z podsystemów $p_{1}, p_{2}, d_{1}$ i $d_{2}, q_{1}, q_{2}$ w relacji (pod wpływem) pozostałych pięciu podsystemów $z$ osobna (dwanaście relacji), a w dalszej kolejności podsystemów pierwszego stopnia $p_{1}$ i $p_{2}, d_{1}$ i $d_{2}$ oraz $q_{1}$ i $q_{2}$ w relacji do podsystemów drugiego stopnia $p_{1} d_{1}, p_{1} d_{2}, d_{1} q_{1}, d_{1} q_{2}, q_{1} p_{1}, q_{1} p_{2}$, oraz $p_{2} d_{1}, p_{2} d_{2}, d_{2} q_{1}, d_{2} q_{2}, q_{2} p_{1}$, $q_{2} p_{2}$. Na końcu bada się relacje kolejnych podsystemów drugiego stopnia na siebie, na przykład $p_{1} p_{2} \leftrightarrow d_{1} d_{2}$ w kolejnych kombinacjach. 
Na szczególną uwagę w przepadku relacji kolejnych stopni zasługuje wzrost poziomu złożoności i skomplikowania relacji, jakie niesie ze sobą wzrost liczby podsystemów w badanym systemie o jeden, zgodnie ze wzorem $n(n-1)^{2}$, gdzie $n$ oznacza liczbę systentów w systemach sumarycznie (każde $p_{n}, d_{n}, q_{n}, \ldots, x_{n}, \ldots$ jest liczone oddzielnie). W przypadku badania relacji międzypodsystemowych trzeciego stopnia systemu złożonego z trzech podsystemów, z których każdy składa się tylko z dwóch systentów, liczna relacji wynosi siedemdziesiąt dwa. Z tego powodu na rysunku 11 zaznaczono wszystkie relacje pierwszego stopnia oraz przykładowe relacje drugiego stopnia (oznaczone tutaj liniami przerywanymi, a w modelu głównym na rysunku 19 kolorem zielonym) i trzeciego stopnia (oznaczone liniami ciągłymi i kolorem czerwonym w modelu) oraz dwa z trzech podsystemów drugiego rzędu (linia przerywana i kolor zielony).

Wyodrębnione w organizacji relacje (dla odróżnienia nazywane organizacyjnymi) identyfikuje się w następnej kolejności z występującymi w organizacji relacjami komunikowania - jest to izomorficzne nałożenie relacji na siebie, w sposób tożsamościowy. Inaczej mówiąc, określone relacje organizacyjne realizowane są przez tożsame z nimi relacje komunikowania.

\section{Ustalenie granic systemu (otoczenie systemu) - etap niekompatybilny ze względu na określony cel pracy}

Każdy system znajduje się w otoczeniu.

Wyodrębnienie jednego systemu jest równoznaczne z podziałam całej rzeczywistości na dwa systemy [wyróżnienie - M.Z.-T.), z których jednym jest system rozpatrywany, drugi zaś resztą rzeczywistości, określaną jako otoczenie rozpatrywanego systemu (Ziemba, Jarominek, Staniszewski, 1980, s. 12).

W zasadzie wyodrębnienie systemu powoduje, że cała reszta może być traktowana jako osobny system-otoczenie, nie jest potrzebne dzielenie rzeczywistości na dwie części lub wyodrębnianie dwóch systemów. Podejście systemowe pozwala wyodrębnić system z całości i traktować resztę także jako system (otoczenie lub nadsystem). W niniejszej pracy przy wyodrębnianiu systemu skorzystano z tej właściwości. System i jego nadsystem można traktować jako supersystem.

O zakwalifikowaniu danego elementu do systemu lub do otoczenia „decyduje przedmiot badania, konkretny obiekt oraz cel badania” (Ziemba, Jarominek, Staniszewski, 1980, s. 12). Wyodrębnienie systemu pozwala zatem ograniczyć złożoność etapów prac. Ze względu na arbitralność podczas wyodrębniania granic systemu ten etap jest uznawany za trudny (Robey, Mikhaeil, 2016, s. 128). Istnieją także ograniczenia dotyczące wyznaczenia systemu do rozwiązywania konkretnego 
problemu w postaci technicznych możliwości zbadania ram problemu oraz efektywności ekonomicznej rozwiązania (Mingers, 2017).

W warunkach zintegrowanych działań i współpracy granice między organizacjami $^{30}$ zamazują się, a działania przenikają. Jeśli cele przedsiębiorstwa zorientowane są na zewnątrz, a granice samodzielnie konstytuowane, to system ma możliwość ich modyfikacji. Systemowe postrzeganie organizacji jako układu względnie odosobnionego, oddziałującego wzajemnie z otoczeniem, ma swoje konsekwencje również w sposobie określania granic organizacji. Związek otoczenia z systemem polega na tym, że wpływa ono w sposób bezpośredni lub pośredni na funkcjonowanie systemu i odwrotnie (Bielski, 2001, s. 126-127). Jest to określenie o tyle trafne, co ogólne. Granice są zatem dynamiczne, stale zmieniają się, są trudne do uchwycenia. W przypadku organizacji granice są „, raczej umowne niż naturalne i dotyczą raczej procesów i zachowań ludzi niż obiektów fizycznych" (Bielski, 2001, s. 127).

Stopień otwartości granic organizacji jest odwrotnością stopnia izolacji organizacji (czyli jej podsystemów) od otoczenia, w niewielkiej części zależy od decyzji kierownictwa, bardziej jest związany z typem otoczenia (zmienne, złożone), w jakim przyszło jej funkcjonować.

Istnieje wiele sposobów na określenie (elementów) otoczenia ${ }^{31}$ organizacji - począwszy od wąskich, na przykład jako linia demarkacyjna, pozwalająca na identyfikację zasobów będących własnością organizacji w zbiorze zasobów otoczenia (Helfat w: Cyfert, 2012, s. 20), po szerokie, systemowe - jako mechanizm wydzielenia organizacji z otoczenia, zapewniający możliwość postrzegania jej jako pewnego rodzaju całości (Liewellyn w: Cyfert, 2012, s. 20), a także cybernetyczno-systemowe w postaci:

Granice organizacji są wyznaczane przez procesy wymiany i mechanizmy alokacji materii, energii oraz informacji w organizacji. Definiowanie granic obejmuje działania związane z diagnozowaniem wejść i wyjść oraz określeniem przepustowości i wydajności systemu (Katz, Kahn za: Cyfert, 2012, s. 20).

Na potrzeby tego opracowania uznaje się, że granice określa się (i w konsekwencji także mierzy) zasięgiem i siłą relacji komunikowania (w) organizacji ${ }^{32}$.

30 W teorii organizacji otoczenie systemu to takie elementy rzeczywistości pozasystemowej, których zachowanie ma wpływ na zachowanie systemu i odwrotnie. Jeśli te elementy znajdują się w „dalszym” oddaleniu - takim, że relacja wpływu nie zachodzi - wówczas tych elementów nie nazywa się otoczeniem systemu (Zieleniewski, 1964, s. 137, 140-141).

31 Szczegółowe studium pojęcia granic organizacyjnych przygotował Szymon Cyfert (2012, szczególnie s. 20 i nast.).

32 Zagadnienia dotyczące cech granic, ich przepuszczalności i sterowania przepływami informacji między organizacją a otoczeniem w kontekście wyznaczonego celu niniejszej pracy 


\section{Stąd konsekwentnie zasięg jest szerszy niż relacje wewnątrzorganizacyjne, a siła mniejsza. Poziom obu parametrów powinien być ustalony dla każdej organiza- cji z osobna w toku badań empirycznych.}

Wytyczanie granic przez organizację z perspektywy systemowej jest w tym sensie powtarzalne, że ustalane na zasadzie regulowania systemu przez sprzężenie zwrotne oraz dzięki procesom uczenia się (dynamika systemów). Zasięg granic organizacji ulega zmianie wraz z jej wzrostem i rozwojem, przy czym konieczne jest zachowanie długookresowej sprawności organizacji. Mając powyższe na uwadze, w tej pracy pomija się etap wyznaczania elementów otoczenia organizacji. Wyodrębnia się jeden system - organizację - i traktuje ją jako całość podlegającą badaniu - pozostała „reszta” to otoczenie, a granica między nimi ulega ciągłym zmianom.

\section{Model - graficzna postać systemu}

Zasadniczo wszystkie modele są błędne,
ale niektóre są przydatne

(Dekkers, 2017, s. 62)

Metodą badawczą uprawnioną w analizie systemowej organizacji jest modelowanie w3. $^{33}$.

Modele są przedstawieniami stanów, przedmiotów lub zdarzeń. Są one wyidealizowane w tym sensie, że są mniej złożone niż rzeczywistość i stąd łatwiejsze w użyciu do celów badawczych. Modelami łatwiej jest się posługiwać i manipulować niż przedmiotami rzeczywistymi. Prostota modeli w porównaniu z rzeczywistością wynika stąd, ze uwzględniają one tylko te własności i rzeczywistości, które są w danym przypadku istotne (Ackoff, 1969, s. 143).

Modele tworzone są jako reprezentacja zmiennej rzeczywistości, oglądanej przez określonego badacza, z wyznaczonej przez niego perspektywy, w określonym czasie. Jednocześnie model konstruowany jest, aby osiągnąć cel postawiony i realizowany przez badacza.

pozostają poza obszarem zainteresowań. Wyłącznie sygnalnie można stwierdzić ich pełną przepuszczalność - model organizacji przedstawiony w podrozdziale 4.4 opiera się na otwartej strukturze kratownic konstrukcyjnych, które nie ograniczają możliwości przepływu komunikatów organizacja-otoczenie. Problem stanowi nadmiar komunikatów, wyodrębnienie przydatnych, koszt przetwarzania tego nadmiaru.

33 Modelowanie i modele mogą być zarówno systemowe, jak i niesystemowe - modele utworzone w oparciu o na podstawie innego podejścia badawczego niż systemowe to na przykład transakcyjne modele komunikowania się (Berne, 2013). 
Nie można zatem oprzeć się wrażeniu, że systemowe modele są uzyskiwane w wyniku analogii do konstruowania metafory organizacyjnej, są bowiem obciążone subiektywnością badacza w postaci jego możliwości badawczych i osobistych preferencji. Różnica polega jednak na wprowadzanej procedurze badawczej (sformułowanie problemu, badanie, eksplanacja za pomocą modelu i interpretacja) oraz iteracyjnym charakterze podejścia systemowego (więcej o tym: Checkland, 1990; 2000; Adams, Mun, 2005, s. 502-508). Zakres, obszar czy rozległość modelu wyznacza badacz i są one dostosowane do celu badania, dlatego dla jednego zjawiska może powstać kilka niewykluczających się, ale uzupełniających i równie trafnych modeli, osadzonych na różniących się od siebie (innych) założeniach - „badacze tworzący modele pozwalają odkrywać aspekty rzeczywistości nieoczywiste dla innych" (Silvert, 2001, s. 26). Model konstruuje się w celu poznania organizacji lub wprowadzania w niej zmian, czyli jej doskonalenia - przez podnoszenie skuteczności jej działania, sprawnego lub sprawniejszego zarządzania nią. Nie konstruuje się modeli systemowych tylko w celach poznawczych, systemowe modele są użytkowe (Gasparski, Lewicka, 1973; Reynolds, Holwell, 2010, s. V), modele organizacji są narzędziami, mają spełniać określone zadania w danych warunkach i w tym celu są tworzone (Koźmiński, 1983, s. 85; Reynolds, Holwell, 2010, s. 17).

Budowa modelu pozwala w zasadzie na ominięcie etapu identyfikowania systemu podczas formułowania problemu. Przyjęło się kojarzyć model z jego postacią graficzną, jednak „Może nim być jakakolwiek konstrukcja myślowa na dostatecznym szczeblu abstrakcji” (Habr, Veprek, 1976, s. 304). W analizie systemów modele mogą mieć charakter zarówno skwantyfikowany, jak i opisowy, model jest zatem narzędziem poznawczym i skutecznym środkiem rozwiązywania nawet najbardziej złożonych i szeroko zarysowanych problemów. Powinien stanowić izomorficzną reprezentację obiektu - konieczna jest tożsamość modelu i systemu modelowanego na płaszczyźnie analogii, morfologii, struktury oraz tożsamości funkcjonalnej.

O modelu nie można mówić, że jest „prawdziwy” albo „fałszywy” (kategorie poznawcze), ani wyrokować czy jest „dobry”, czy „zły” (kategorie etyczne), można jedynie oceniać, czy jest „dostatecznie użyteczny” - gdy pozwala osiągnąć cel w stopniu zadowalającym badacza. Stąd wynika pewna podwójna perspektywa dla tej metody badawczej - po pierwsze: abstrakcyjność modelu jako konstrukcji myślowej oraz po drugie: orientacja praktyczna modelu, który powstaje, by kształtować wyobrażenie o rzeczywistości (a nie wyłącznie ją odwzorować w celach poznawczych). Skoro więc metoda systemowa zakłada konfrontację modelu z empiryczną rzeczywistością, to wprowadzanie modelu nazbyt uproszczonego jest mało użyteczne, nie sprawdza się podczas rozwiązywania konkretnych problemów praktycznych. 
Podejście systemowe w swojej idei czerpie inspiracje z różnych nauk - najczęściej z matematyki lub cybernetyki - co odbija się w stosowanym języku. Dlatego zdarza się pewien brak spójności w nazewnictwie - pod określoną nazwą różni autorzy rozumieją rozmaite rzeczy i zjawiska albo tym samym rzeczom i zjawiskom nadają odmienne nazwy. Niniejsza praca powstała na podstawie teorii organizacji i nauk o zarządzaniu, dlatego słownictwo powstałe na tym gruncie jest tutaj dominujące. Zostało ono jednak (w przypadku pewnych braków) uzupełnione określeniami teoriosystemowymi, cybernetycznymi i prakseologicznymi, wybranymi stosownie do celu pracy.

\subsubsection{0 grupowaniu relacji wokót celu organizacji - model synkretyczny cyklu zarządzania}

Istnieją dwie główne możliwości grupowania komunikatów - według przebiegu procesów organizacyjnych oraz według funkcji.

Stanowisko niektórych autorów bywa bezkompromisowe, jeśli chodzi o wagę procesów dla organizacji: „Zaryzykować możemy stwierdzenie, że proces jest podstawowym i najważniejszym przejawem działania przedsiębiorstwa” (Skrzypek, Hofman, 2010, s. 13). Szczegółowe zapoznanie się z ideą procesu organizacyjnego ${ }^{34}$ prowadzi do wniosku, że procesowy sposób grupowania komunikatów wiązałby się z połączeniem w jedną wiązkę różnorodnych treściowo komunikatów, ponieważ procesy w swojej istocie przebiegają przez całą organizację (relacje komunikowania realizują bowiem relacje organizacyjne). Stąd w przypadku orientacji procesowej rozmaite grupy treści są konieczne do realizacji zadań wchodzących w skład jednego procesu.

W literaturze omawia się pojedyncze procesy oraz systemy procesów, mając na myśli „współpracujące ze sobą procesy, których zadaniem jest tworzenie wartości dodanej dla klienta" (Skrzypek, Hofman, 2010, s. 17). Oznacza to, że system procesów organizacji obejmuje wszystkie procesy w niej występujące oraz zależności między tymi procesami, przez wskazanie relacji wzajemnych, zachodzących na wejściach i wyjściach poszczególnych procesów. Porządkowanie relacji komunikowania

34 Klasycy zarządzania procesowego są w zasadzie zgodni co do definicji procesu - jest to zestaw, sekwencja, wiązka działań realizowanych wewnątrz przedsiębiorstwa (Hammer, Champy, 1996) (w szerszym kontekście uznaje się także działania równoległe, nie tylko sekwencyjne, a także działania zewnętrzne - Skrzypek, 2002, s. 146), których realizacja zwiększa wartość (Porter, 1985, s. 3), a celem jest tworzenie lub dostarczanie klientowi produktu lub usługi (Rummler, Brache, 2000, s. 75). Kluczowe jest zatem „kreowanie wartości, która przyciągnie i zatrzyma klientów docelowego segmentu rynku oraz zapewni spełnienie oczekiwań akcjonariuszy odnośnie wyników finansowych organizacji" (Kaplan, Norton, 2001, s. 43). Jest to „zbiór działań wzajemnie powiązanych lub wzajemnie oddziałujących, które przekształcają wejścia w wyjścia” (ISO 9000: 2000, s. 5). 
w jednorodne wiązki treściowe w jednym procesie uznaje się za trudne ze względu na różne treści konieczne do realizacji jednego procesu - efektem byłaby duża liczba rozmaitych wiązek wspierających jeden proces i wobec tego przypisana do jednego procesu. Takie porządkowanie dla systemu procesów wprowadziłoby chaos w miejsce uporządkowania, wielość wiązek zostałaby zmultiplikowana przez liczbę procesów, bez gwarancji na brak powtórzeń treściowych w ramach wiązek w poszczególnych procesach. Thomas H. Davenport uznaje, że:

[...] w praktyce gospodarczej należy dokonać wyboru 10-20 procesów, a jako podstawowy motyw postępowania należy przyjąć liczbę procesów zależnych od celu, do którego wykorzystujemy je (Davenport, 1993, s. 28).

Podana liczba procesów może wskazywać na poziom skomplikowania wzajemnego uporządkowania wiązek treściowych komunikatów.

Istotne miejsce w procesie i w systemie procesów zajmuje komunikowanie - każdy proces, niezależnie czy podstawowy, czy uzupełniający ${ }^{35}$, wymaga koordynacji wewnętrznej przez komunikację. Stąd szczególne miejsce w zarządzaniu procesami przysługuje komunikacji, gdyż obok „rozumienia przez pracowników roli, jaką spełniają procesy” (Skrzypek, Hofman, 2010, s. 13) w organizacji komunikacja wewnętrzna zachodząca między uczestnikami organizacji zapewnia efektywne działanie przedsiębiorstwa (Kolman, 1992, s. 29; Hofman, Skrzypek, 2010, s. 13). Zaburzenia komunikowania powodują rozmaite nieciągłości w procesach organizacyjnych, a te z kolei wpływają na spadek wydajności oraz efektywności organizacji jako całości. Procesy - licznie występujące w organizacji - muszą być wzajemnie uzgodnione przy udziale komunikowania, aby mogły być realizowane w sposób płynny. Dla perspektywy procesowej konieczne jest wyznaczenie innego niż treściowe kryterium porządkowania komunikatów w wiązki ${ }^{36}$.

35 Elżbieta Skrzypek i Mariusz Hofman (2010, s. 13) wymieniają procesy podstawowe zależnie od typów przedsiębiorstw, na przykład system procesów przedsiębiorstwa produkcyjnego obejmuje procesy „związane z obsługą klienta i przyjmowaniem zamówień, procesy związane z projektowaniem produktu, procesy technicznego przygotowania produkcji, procesy planowania i organizacji produkcji, procesy wytwarzania, procesy magazynowania i wysyłki do klienta, procesy sprzedaży. Dodatkowo [...] są realizowane procesy utrzymania ruchu i inwestycji, procesy kontroli jakości, procesy zaopatrzenia, procesy zarządzania zasobami ludzkimi, procesy zarządzania aktywami finansowymi”. Część z tych procesów Lee J. Krajewski i Larry P. Ritzmann wymieniają jako procesy wspomagające: alokację kapitału, budżetowanie, rekrutowanie i zatrudnianie, ocenę i rekompensatę, wsparcie i rozwój zasobów ludzkich, zgodność z przepisami, systemy informacyjne, zarządzanie przedsiębiorstwem i funkcjonalnością.

36 Pominięto rozważania dotyczące procesowych modelów organizacji, dlatego że procesy są tutaj rozważane jako kryterium grupowania komunikatów wewnątrzorganizacyjnych, ponadto przy ich tworzeniu korzystano z innej niż systemowa metodyki. 
Drugim sposobem jest grupowanie komunikatów według ich funkcji37. Podsystemy kolejnych rzędów „kumulują się” w celu organizacji - sposób ten zostanie wyjaśniony poniżej. Pośrednikiem porządkowania staje się zaproponowany na potrzeby realizacji celu pracy synkretyczny model cyklu zarządzania (SMCZ) w postaci zintegrowanych koncepcji cyklu działania zorganizowanego Henriego Le Chateliera oraz funkcji zarządzania Henriego Fayola.

Zorganizowane działanie człowieka odbywa się według pewnego, jednolitego schematu, który jest jednocześnie zbiorem właściwości charakteryzujących organizację działania. Najpełniejsze chyba ujęcie tych właściwości w ramy schematu można odnaleźć u Le Chateliera w postaci cyklu działania zorganizowanego lub cyklu organizatorskiego. Według niego każde działanie zorganizowane obejmuje pięć etapów „mniej lub bardziej rozwiniętych zależnie od wypadku, jednak zawsze chociażby w zarodku istniejących" (Le Chatelier, 1926, s. 14-15). Są nimi kolejno: postawienie jasnego i ściśle określonego celu, zbadanie środków i warunków do jego osiągnięcia, przygotowanie środków i warunków, wykonanie zamierzonej czynności i wreszcie kontrola otrzymanych wyników oraz wyciągnięcie z nich wniosków. Podkreśla się achronologiczność cyklu (Zieleniewski, 1969, s. 202) i istotność fazy preparacji (pojęcie wprowadzone przez Kotarbińskiego) - często przez rozbicie jej na trzy etapy ${ }^{38}$ - jako pierwszy i niezbędny etap cyklu, bez którego nie można przejść do etapów kolejnych i niemożliwe jest osiągnięcie celu działania. Etapy te muszą następować po sobie płynnie, w sposób zharmonizowany, skoordynowany.

Fayol jako pierwszy wyodrębnił czynności administracyjne z całości działań wykonawczych realizowanych w organizacji. Były to wszelkie czynności kierownicze. Wówczas sformułowano je jako: przewidywanie, organizowanie, rozkazywanie, koordynowania i kontrolowanie (Fayol, 1947, s. 37). Tych pięć pierwotnych funkcji administracyjnych podlegało (i podlega) rozmaitym autorskim ${ }^{39}$ modyfikacjom. Ponadto są one nadal stosowane w praktyce biznesowej.

37 Metodyka ARIS służy do analizy i modelowania procesów gospodarczych, prowadzi do stworzenia w przedsiębiorstwie zintegrowanego systemu przetwarzania informacji. Istotą tego podejścia jest badanie łańcucha procesów w organizacji (uporządkowanie, usprawnienie i wdrożenie nowych procesów), a nie proces komunikowania się między ludźmi. Z tego powodu nie może służyć jako metoda do porządkowania komunikatów.

38 Co więcej, może się wydawać, że Zieleniewski zażegnał spory dotyczące liczby etapów, napisał bowiem: „W gruncie rzeczy jest też mało istotną okolicznością, ile takich kolejnych faz się wyróżni. Można ich liczbę dość dowolnie pomniejszać, łącząc je w większe całości, lub zwiększać, dzieląc je na mniejsze fragmenty. Ważne jest w tym tylko, aby nie zapomnieć o żadnym istotnym elemencie i zrozumieć racjonalne związki między nimi” (Zieleniewski, 1969, s. 202) Wydaje się to - co do zasady - być istotą podejścia systemowego.

39 Louis Allen i George Terry proponowali wprowadzenie funkcji motywowania (1958, s. 13). Harold Koontz i Cyril O’Donnel wyróżnili planowanie, organizowanie, politykę kadrową, kierowanie i kontrolę (1969, głównie s. 460). Chester Bernard proponował utrzymanie 
Funkcje zarządzania i cykl działania zorganizowanego wykazują podobieństwo pod względem klasyfikacji rodzajowej, rozważane są ze względu na kryjące się za nazwami określone czynności, występujące - zależnie od organizacji - w rozmaitych zestawieniach i proporcjach. Mają one charakter uniwersalny, występują bowiem w każdej organizacji, bez względu na jej branżę czy wielkość. Istnieje wyraźna tożsamość zawartości treściowej w zakresie trzech elementów - planowania działania, organizacji (lub realizacji) oraz kontroli.

Fayolowską funkcję przewidywania (rozumianą wówczas jako badanie przyszłości i ustalanie działania stosownie do niej) zinterpretowano współcześnie jako planowanie, zubożając w ten sposób jej zakres, należy więc przywrócić „przewidywanie" jako etap początkowy. Obecnie najnowsze technologie, metody badawcze i symulacje wspomagają ten etap ${ }^{40}$.

W modelu synkretycznym cyklu zarządzania jako pierwszy etap uznaje się zatem etap planowania, poprzedzony przewidywaniem i rozszerzony o elementy preparacyjne w postaci określenia celu, doboru niezbędnych środków i warunków materialnych, a także ich pozyskanie i przygotowanie. Etap drugi i trzeci cyklu działania zorganizowanego Le Chateliera, w postaci zbadania i przygotowania środków i warunków niezbędnych do realizacji zamierzonego celu, mogą także obejmować zatrudnienie odpowiednich specjalistów, właściwych do realizacji celu oraz motywowanie zatrudnianych w ramach przygotowania środków i warunków społecznych. $Z$ tego względu etap motywowania może być traktowany jako preparacyjny. Pozostawiono jednak jego odrębność nazewniczą (wyróżniając spośród przygotowania środków do realizacji celów), podkreślając w ten sposób i wyróżniając zagadnienia społeczne, tak obecnie uwypuklane w naukach o zarządzaniu. Organizowanie to etap realizacji przygotowanego działania, a etap kontroli zamyka pełen cykl działania celowego.

komunikacji wewnętrznej, politykę kadrową i formułowanie celów i zadań (1958, s. 215). Adam Stabryła używał zamiennie określeń motywowanie - pobudzanie (1983, s. 14) oraz proponował identyfikację, decydowanie rozkazodawcze, organizowanie, kontrolę (1983, s. 17).

40 O narzędziach do przewidywania przyszłości do potrzeb organizacji pisze się wiele, określa się zmiany zachodzące w organizacjach (np. Benschop, Holgersson, Van den Brink, Wahl, 2015, s. 553-574; Bolman, Deal, 2017; Church, Burke, 2017, s. 14-22; Cerdin, Brewster, 2018 s. 279-294). Liczba prognoz przygotowanych w ostatnich latach rośnie, ludzie mają ogromną potrzebę przewidywania i prognozowania, chcą znać przyszłość. Określa się zatem bieżące lub przyszłe stany makroekonomiczne, w jakich przyjdzie funkcjonować organizacjom (Konchitchki i in., 2016, s. 1-36). Ponieważ świat zmienia się coraz szybciej, jest bardziej złożony niż kiedykolwiek wcześniej, to również algorytmy są coraz bardziej złożone (Bowles, Kirman, Sethi, 2017, s. 215-230; Schwertner, 2017, s. 389-398), różna jednak jest ich przewidywalność. Dlatego skraca się horyzont czasowy dla „dobrych” prognoz. 


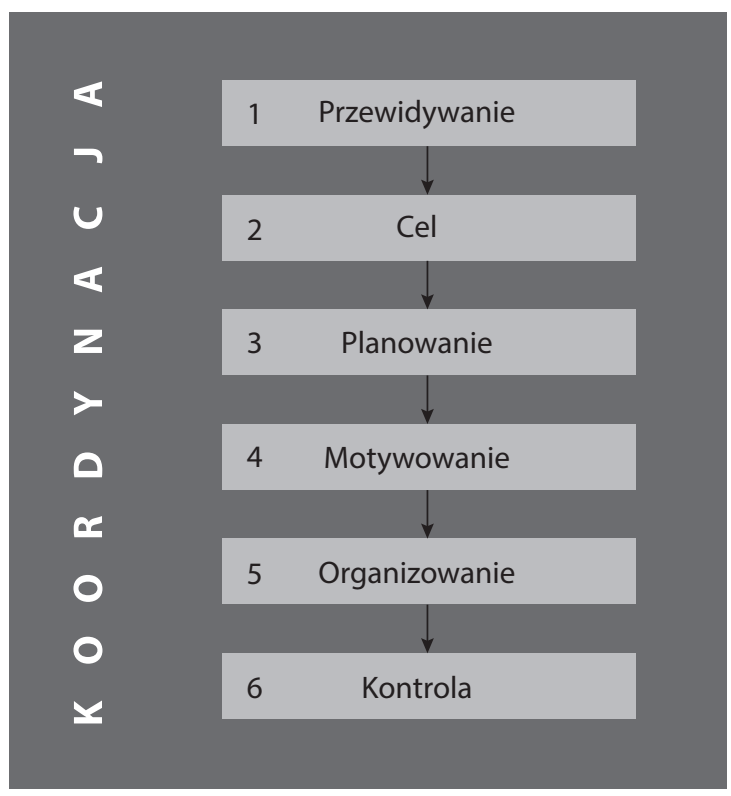

\section{Objaśnienie:}

1. Według Le Chateliera

2. Według Le Chateliera

3. Według Le Chateliera I Fayola

4. Według Fayola (oryginalnie rozkazodawstwo)

5. Według Le Chateliera i Fayola

6. Według Le Chateliera i Fayola

\section{Uwaga:}

Koordynacja jest nadrzędna wobec wskazanych funkcji. Realizacja całego cyklu zapewnia jej spełnienie w odniesieniu do całości.

Rysunek 12. Synkretyczny model cyklu zarządzania

Źródto: opracowanie własne.

Reasumując, proponowany tutaj synkretyczny model cyklu zarządzania obejmuje:

1) przewidywanie rzeczywistości (jakie będą warunki działania organizacji?),

2) określenie celu (wraz z określeniem kryteriów i mierników celu),

3) planowanie i dobór niezbędnych środków i warunków materialnych (pozyskiwanie zasobów materialnych),

4) planowanie i dobór niezbędnych „zasobów” ludzkich (motywowanie),

5) organizowanie - realizację,

6) kontrolę.

W rezultacie relacje podsystemów „kumulują się” w cyklu zarządzania prowadzącym do realizacji celu działania organizacji. Oznacza to, że relacje organizacyjne i tożsame z nimi relacje komunikowania należy pogrupować w wiązki, 
a następnie grupy wiązek zgodnie z elementami synkretycznego modelu cyklu zarządzania, traktowanymi jako kryteria.

Ze względu na funkcje wyróżnia się relacje:

1) przewidywania,

2) określania celu,

3) planistyczne,

4) organizacyjne,

5) motywacyjne,

6) kontrolne.

W ramach funkcji występują relacje tematyczne:

1) antropo-społeczne,

2) antropo-techniczne,

3) antropo-ekonomiczne,

4) społeczno-technologiczne,

5) społeczno-ekonomiczne,

6) techniczno-ekonomiczne.

Według kategoryzacji logiczno-językowej wyróżnia się:

1) pytania,

2) odpowiedzi (informacje),

3) prośby, nakazy, rozkazy,

4) zobowiązania, obietnice,

5) ostrzeżenia,

6) decyzje,

7) rady, instrukcje (i wyrażenie ich zrozumienia),

8) propozycje,

9) mianowania (powołania na stanowisko),

10) zwalniania (odwołania ze stanowiska),

11) ocenę i osąd (przedstawianie sądu),

12) wyrażanie emocji (radowanie się, smucenie itp.),

13) akceptację,

14) odmowę,

15) gratulowanie,

16) życzenia (chcenie i zamierzanie),

17) inne. 


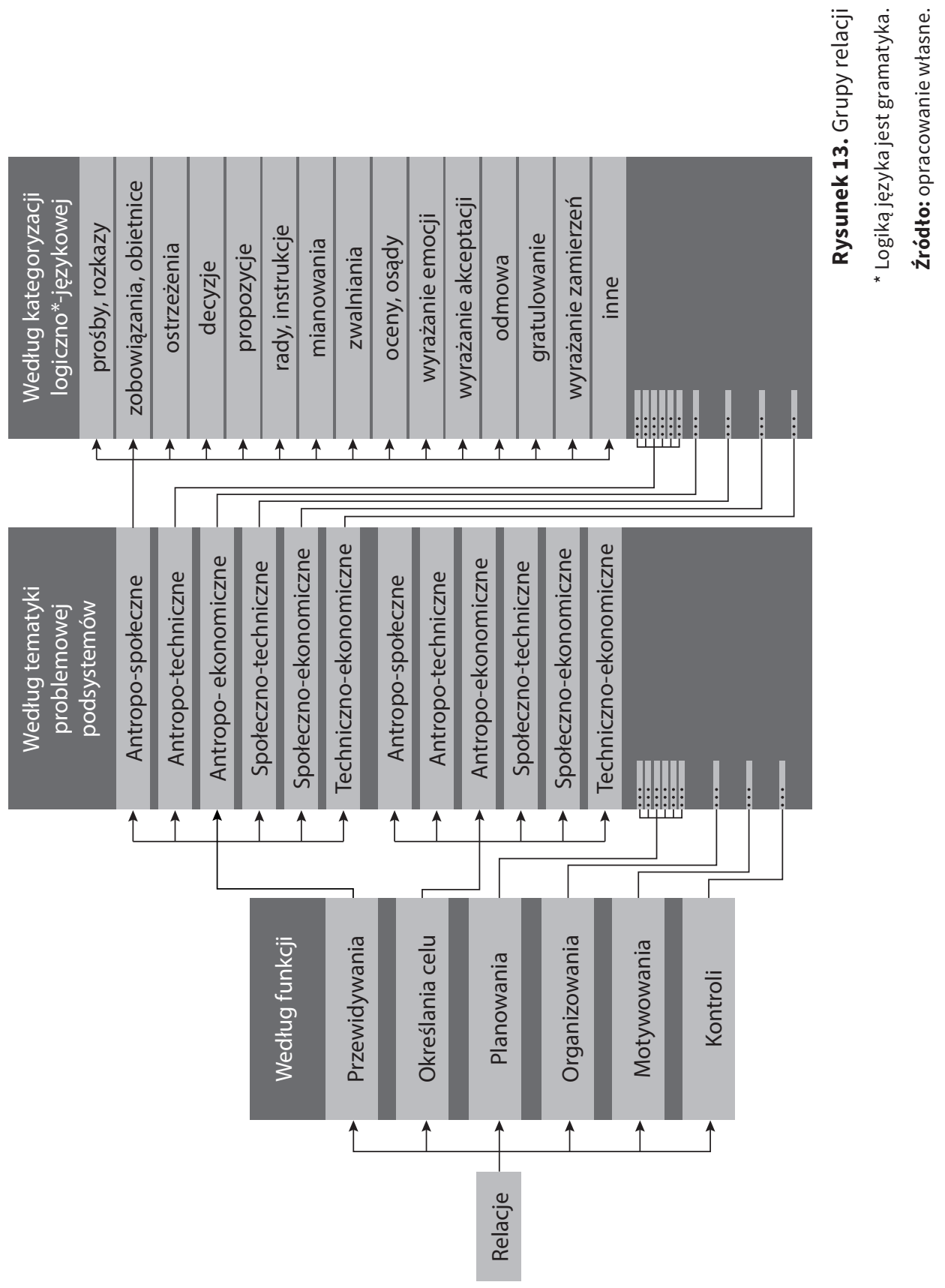




\subsubsection{Analiza struktury organizacji i zachowania komunikacyjnego w systemie}

Analizę systemową można przeprowadzać bezpośrednio lub pośrednio. Do analizy bezpośredniej wykorzystuje się postać graficzną, macierzową lub inną, poszukując zakłóceń przede wszystkim w strukturze systemu. Do analizy pośredniej wykorzystuje się zbiór testów - zewnętrznych i wewnętrznych - zarówno do badania struktury, jak i zachowania systemu. W testach zewnętrznych system jest traktowany jak „czarna skrzynka” i bada się przede wszystkim jego zachowanie. Podczas przeprowadzania testów wewnętrznych bada się zachowanie podsystemów lub elementów systemów, strukturę, charakter i jakość sprzężeń.

Na potrzeby niniejszego opracowania uwzględniono konieczność analizy bezpośredniej wewnętrznej struktury systemu jako całości. Określone podsystemy organizacji w układzie relacyjnym (kolejnych rzędów) tworzą określoną strukturę złożoności organizacji. Relacje między elementami są zaznaczone przez strzałki (rysunek 14).

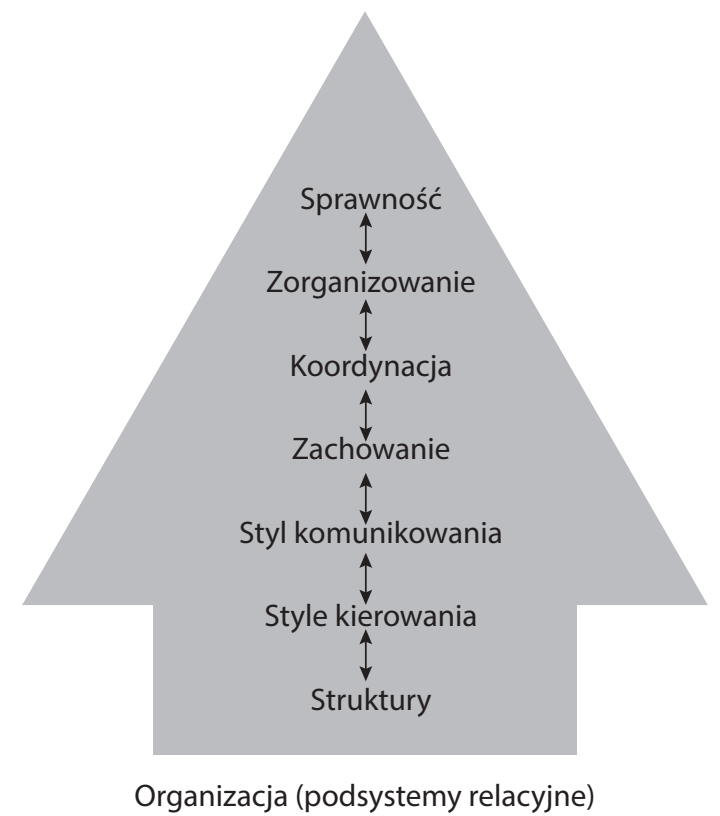

Rysunek 14. Schematyczna przykładowa struktura systemu jako całości

Źródto: opracowanie własne.

Rodzaj struktury wpływa bezpośrednio na styl kierowania organizacją (upraszczając: struktury hierarchiczne narzucają autokratyczny sposób kierowania w większym 
stopniu niż na przykład struktury typu zadaniowego). Styl kierowania jest bezpośrednio związany ze stylem komunikowania i jednocześnie dzięki niemu najłatwiej rozpoznawalny. Styl komunikowania wpływa na zachowanie ludzi w organizacji (np. różnice w zachowaniu po usłyszeniu polecenia i prośby), a ono z kolei wpływa na stopień koordynacji wewnątrzorganizacyjnej. Organizacje koordynowane posiadają wysoki poziom zorganizowania, co wpływa na wysoką sprawność organizacji.

\subsubsection{Projekt udoskonalenia lub poprawy systemu - etap tożsamy z budowaniem systemu}

Na podstawie przeprowadzonej w poprzednim etapie analizy systemu należy opracować:

[...] projekty zmian w strukturze systemu lub zmian we właściwościach transformacji elementów systemu, mających doprowadzić do poprawienia funkcjonowania systemu jako całości. Główne metody wykorzystywane do poprawienia działalności systemu są oparte na metodach analizy operacyjnej, symulacji lub podejściu heurystycznym (Habr, Veprek, 1976, s. 181-182).

Doskonalenie systemu następuję głównie na trzech płaszczyznach:

1) opracowywania programów uczących dla systemu,

2) wykorzystywania zmian celów i relacji wartościowych,

3) opracowywania całej strategii prowadzącej do udoskonalenia działalności systemu.

Habr i Veprek przyznają, że:

Do chwili obecnej mamy niewielkie doświadczenia w tej fazie analizy systemowej. Możemy się jednak spodziewać, że zostanie ona bardzo szybko rozpracowana, jak tylko uda się pomyślnie opanować pierwszy etap analizy systemowej (Habr, Veprek, 1976, s. 182).

Mimo że powstały informatyczne programy uczące się, to w zasadzie zarzucono opracowywanie systemowych udoskonaleń całego systemu. Często wprowadza się udoskonalenia fragmentaryczne, co jest ewidentnym błędem ze stanowiska metodologii podejścia systemowego, które nie zakłada samodzielnej obecności w systemie jakichkolwiek odrębnych „fragmentów”, jedynie poza wyróżnionymi podsystemami i ich relacjami. Nie możne uznać za punkt interwencji systemowej naprawy drobnego fragmentu całości. Trzeba naprawiać cały system, aby ulepszyć działanie choćby jednej jego części. 
Przedstawiany projekt zastosowania analizy systemowej ma na celu zaprojektowanie systemu sieci zintegrowanych relacji komunikowania się. Usprawnienia fragmentaryczne, ze względu na przyjętą metodologię badania systemowego (analizy i syntezy systemowej), wykluczają możliwość zmiany lokalnej bez uwzględnienia potrzeby zmiany organizacji jako całości. Jeśli występuje potrzeba poprawy w organizacji, dotyczy ona całości. Stąd etap poprawy włączony zostaje tym samym w projektowanie całości organizacji.

\subsubsection{Warunki realizacji analizy systemów złożonych (ASZ)}

Warunki realizacji ASZ:

1. W niniejszym opracowaniu przyjęto kryterium organizacji (w odróżnieniu od kryterium funkcji), punktem wyjścia jest najmniejszy obiekt struktury organizacyjnej, którym jest komórka organizacyjna licząca co najmniej dwie osoby oraz relację między nimi (w celu spełnienia kryterium hierarchizacji jest to zwierzchnik i podwładny, aby zapewnić element kierowniczy). Tak określonej jednostce organizacyjnej nadano nazwę systent (termin własny) - jest to najmniejszy element systemu, stanowiący elementarną płaszczyznę systemu komunikowania.

2. Metoda analizy systemowej nie wyznacza jednego, określonego szczebla abstrakcji ${ }^{41}$, tak samo nie uznaje jednego poziomu szczegółowości. Analiza obejmuje zarówno poziom systentów, jak i poziom całej organizacji.

3. Proces decyzyjny w tym opracowaniu nie stanowi podstawowego kryterium analizy, nacisk położony jest na procesy komunikacyjne w organizacji.

4. Konieczne upraszczanie rozpoczyna się od rozeznania możliwości zmniejszenia różnorodności warunków, czynności i rozwiązań.

5. Schemat blokowy to narzędzie, w którym „elementy systemu przedstawione są jako wierzchołki, sprzężenia zaś między elementami jako łuki” (Habr, Veprek, 1976, s. 189). W grafie przepływów lub grafie skierowanym „wierzchołki wykresu oznaczają zmienne, natomiast łuki grafu - transformacje” (Habr, Veprek, 1976, s. 191).

Graficzne przedstawianie pełnego systemowego modelu organizacji nastręczać będzie pewnych trudności. Uwzględnienie na rysunku wszystkich relacji (jako strzałek) spowodować może nieczytelność modelu. Natomiast pominięcie części z nich lub sumaryczne ich przedstawienie prowadzi do trywialności

41 W tym miejscu określenie szczebel abstrakcji dotyczy tego, jak szczegółowego typu elementy będą badane. Nie chodzi tu o poziom abstrakcji badań, dla którego ASZ jako metoda badawcza plasuje się dwa szczeble poniżej teorii systemów, zaraz za teorią systemów dla obszaru organizacja. 
modelu. Przedstawianie modelu graficznego jest zatem „żeglowaniem między Scylla a Charybdą", tym niemniej podjęto taką próbę w dalszej części tekstu (rozdział czwarty).

W niniejszym rozdziale zaprezentowano autorską wersję przebiegu analizy systemów złożonych jako metody badawczej. Przedstawiono kolejne etapy prac konstrukcyjnych i badawczych wraz z ich opisem i wytycznymi. Tytułem podsumowania powyżej wskazanych etapów ASZ jako metody badawczej oraz warunków realizacji badania można przytoczyć określone zasady, sformułowane przez Wojciecha Gasparskiego i Witolda Kieżuna do badania istniejącej rzeczywistości przy podejściu systemowo-strukturalnym. Wymagają oni ich bezwzględnego stosowania:

[...] po pierwsze, konstruowanie modelu (systemu in abstracto), w którym określane są własności i relacje między własnościami, czyli struktura systemu oraz indywidua (rzeczy) dysponujące tymi własnościami; po wtóre, traktowanie systemu jako całości i to nie w sensie sumatywności jego składowych, lecz ich zintegrowania; po trzecie, badanie przedmiotu ze względu na spełnianą przezeń funkcję, a więc w aspekcie teleologicznym. Jest to sposób traktowania badanego obiektu jako całości specyficznie wyodrębnionej, tak mianowicie, by możliwa była jego analiza prowadząca do dekompozycji na elementy składowe, oraz synteza elementów składowych, czyli ich kompozycja, w komplementarną całość (Gasparski, Kieżun, 1973, s. 170). 



\section{Część III Konstrukcyjna}





\section{Ogólne i szczegółowe zasady konstrukcji modelu organizacji jako systemu komunikowania}

Organizacja jest jednym z najistotniejszych pojęć w naukach o zarządzaniu. W zależności od sposobu definiowania organizacji i przyjętego paradygmatu naukowego buduje się określoną reprezentację modelową, z natury rzeczy uproszczoną, aby umożliwiła analizę wszystkich części systemu organizacji, a w dalszej perspektywie pozwoliła optymalizować jej działanie. W niniejszej pracy przyjęto perspektywę systemową. Na przestrzeni lat w literaturze przedstawiono wiele modeli wspierających analizę organizacji, których budowę oparto na rozmaitych kryteriach. W tej monografii do dalszych prac konieczny jest systemowy model organizacji, zbudowany na podstawie zasad analizy i syntezy systemowej. Zaadaptowanie opracowanego wcześniej modelu ułatwiłoby pracę, dlatego przeprowadzono poszukiwania systemowego modelu organizacji, opracowanego zgodnie z zasadami metody systemowej. Poszukiwania obejmowały modele, które zostały nazwane „systemowymi” przez ich autorów lub propagatorów, oraz takie, których budowa wyraźnie wskazuje na systemowe inspiracje. Te rozwiązania modelowe okazały się ułomne z różnych, przedstawionych w tabeli 8 powodów.

Tabela 8. Przyczyny „niesystemowości” modeli systemowych

\begin{tabular}{|c|c|}
\hline Nazwa modelu/autor & Zarzuty niesystemowości \\
\hline $\begin{array}{l}\text { Systemowy model organizacji } \\
\text { - Harold J. Leavitt* (1965/2013, } \\
\text { s. 1687-1688) }\end{array}$ & $\begin{array}{l}\text { Zarzuty: hipostazy }{ }^{\star *} \text { (Krzyżanowski, 1999, s. 29) arbitralnego } \\
\text { uznania czterech abstrakcyjnych kategorii za możliwe } \\
\text { do rozłącznego rozróżnienia (Jemielniak, Latusek, 2005, } \\
\text { s. 17), niewłaściwe umiejscowienie niektórych podsystemów } \\
\text { (Krzyżanowski, 1999, s. 29-35; Bielski, 2002, s. 38), brak } \\
\text { uporządkowania hierarchicznego, niezbędnego w modelach } \\
\text { systemowych, brak wskazań wyodrębnienia systemu } \\
\text { z otoczenia. }\end{array}$ \\
\hline
\end{tabular}


Tabela 8 (cd.)

\begin{tabular}{|c|c|}
\hline Nazwa modelu/autor & Zarzuty niesystemowości \\
\hline $\begin{array}{l}\text { Model organizacji według } \\
\text { Fremonta Ellswortha Kasta } \\
\text { i Jamesa Erwina Rosenzweiga } \\
(1973, \text { s. 313) }\end{array}$ & $\begin{array}{l}\text { Brak wskazanego warsztatu - w autorskim tekście Kast } \\
\text { i Rosenzweig (1972, s. 461; Johnson, Kast, Rozenzweig, 1967) } \\
\text { zaprezentowali wyniki pracy w postaci modelu, nie wskazali } \\
\text { warsztatu badacza). } \\
\text { Koźmiński (1983, s. 285-287) umiejscawia model w „szkole } \\
\text { sytuacyjnej”, co sugeruje stosowanie sytuacyjnych metod } \\
\text { badawczych - głównie eklektycznych: hybrydy koncepcji } \\
\text { szkoły astońskiej, systemowej i socjologicznej. }\end{array}$ \\
\hline $\begin{array}{l}\text { Model organizacji Marcina } \\
\text { Bielskiego }(2001, \text { s. } 81)\end{array}$ & $\begin{array}{l}\text { Brak osobnych typów wejść i wyjść - zasileniowych } \\
\text { i informacyjnych, bezpośrednich połączeń między } \\
\text { podsystemami a otoczeniem organizacji, wyłącznie } \\
\text { połączenie między organizacją jako całością a jej } \\
\text { otoczeniem. Relacje ujęte holistycznie, bez wąskiego } \\
\text { rozumienia (Bielski, 2001, s. 81-85; 2002, s. 38). }\end{array}$ \\
\hline $\begin{array}{l}\text { Model socjo-techniczny grupy } \\
\text { Tavistock (Trist, Baumforth, } \\
\text { 1951; Emery, 1959; Herbst, } \\
\text { 1974; Cummings, 1978, } \\
\text { s. 625-634; Emery, Triest, 1981; } \\
\text { Trist, 1981; Trist i in., 1995, } \\
\text { s. 567-569) }\end{array}$ & $\begin{array}{l}\text { Model do projektowania struktury organizacyjnej dla } \\
\text { optymalizacji podsystemów - najlepsze dopasowanie } \\
\text { między elementami społecznymi i technicznymi (Daft, 2016, } \\
\text { s. 291). }\end{array}$ \\
\hline $\begin{array}{l}\text { Model organizacji Tadeusza } \\
\text { Pszczołowskiego (1978, } \\
\text { s. } 151-153)\end{array}$ & $\begin{array}{l}\text { Wyróżniono rdzeń (jądro) organizacji oraz krąg wewnętrzny } \\
\text { i zewnętrzny. Brak struktury rdzenia - model typu „czarna } \\
\text { skrzynka”. }\end{array}$ \\
\hline $\begin{array}{l}\text { Model Daniela Katza i Roberta } \\
\text { Louisa Kahna }(1979, \text { s. } 67-80)\end{array}$ & $\begin{array}{l}\text { Użyty systemowy język opisu, brak odniesienia do analizy } \\
\text { i syntezy systemowej. }\end{array}$ \\
\hline $\begin{array}{l}\text { Model Henry'ego Mintzberga } \\
(1979, \text { s. } 215-297 ; 1981, \\
\text { s. } 103-116)\end{array}$ & $\begin{array}{l}\text { Traktowany jako rozwiązanie pośrednie między modelem } \\
\text { systemowym a modelem Katza i Kahna. }\end{array}$ \\
\hline $\begin{array}{l}\text { Model organizacji według } \\
\text { Leszka J. Krzyżanowskiego } \\
(1999, \text { s. } 37,240)\end{array}$ & $\begin{array}{l}\text { Model ideologiczny, nie ujawniono systemowej procedury } \\
\text { powstania modelu. }\end{array}$ \\
\hline $\begin{array}{l}\text { S McKinseya, Thomasa Petersa } \\
\text { i Roberta Waterman (Peters, } \\
\text { Waterman, 2011, s. 48; Peters, } \\
\text { Waterman, Phillips, 2011, s. 18) }\end{array}$ & $\begin{array}{l}\text { Brak wyodrębnionego elementu technologii (na wzrost jej } \\
\text { znaczenia w świecie XXI w.), pominięcie otoczenia. Sukces } \\
\text { organizacji jest możliwy w drodze integracji elementów } \\
\text { „miękkich” i „twardych”b) (Cyfert, Krzakiewicz, 2006, } \\
\text { s. 10), ale nie istnieje uniwersalne rozwiązanie (Peters, } \\
\text { Waterman, 2011, s. 25-26). Systemy (systems) w modelu } \\
\text { są definiowane jako procedury i procesy w organizacji, } \\
\text { używane do kontrolowania i wykorzystywania zasobów, } \\
\text { wskazujące na sposób realizacji określonych czynności } \\
\text { i zadań (Peters, Watermann, 2011, s. 48), system nie może } \\
\text { być częścią systemu. }\end{array}$ \\
\hline
\end{tabular}




\begin{tabular}{|c|c|}
\hline Nazwa modelu/autor & Zarzuty niesystemowości \\
\hline Najnowsze modele organizacji & $\begin{array}{l}\text { Powstają modele oparte na najnowszych trendach } \\
\text { funkcjonujących w dyscyplinie; mają one za zadanie } \\
\text { odpowiadać na potrzeby gospodarki opartej na wiedzy, } \\
\text { szybko rozwijającej się technologii i przemian społecznych. } \\
\text { Mają być użytecznie, nie musza być systemowe. } \\
\text { „Chaosowe” myślenie systemowe (van Eijnatten, 2004). } \\
\text { Model organizacji wirtualnej (Chen, Liao, Fang, 2012). } \\
\text { Model organizacji sieciowej (Yassa, Hassan, Omara, 2012). } \\
\text { Model organizacii kwantowej (Kałuski, 2012). }\end{array}$ \\
\hline
\end{tabular}

a) Prace propagujące model Kasta i Rozenzweiga i inne źródła wtórne tym bardziej nie zawierają informacji na temat warsztatu badaczy i metody wypracowania modelu. Można jedynie, po dokładnym przeanalizowaniu literatury, powołać się na opinie innych autorów, na przykład: „[Książka] Opowiada o teorii systemów, gdyż mówi o motywacji, osobowości lub teorii ról. Rzeczywiście, większość książki mówi o czymś, zamiast wyjaśniać to do głębi”. Taką opinię wyrazili J. Dale Taliferro

i Howard Baumgartel na łamach „Personel Psychology” (1970, s. 615) na temat książki: F.E. Kasta i J.E. Rosenzweiga, Organization and Management: A Systems Approach; b) Przy tym powodzenie organizacji w większym stopniu zależy od elementów „miękkich”, które mogą rekompensować niedostatki w elementach „twardych”. Przyczyna może być banalna - elementów „miękkich” jest więcej, ale może też świadczyć o tym, że autorzy modelu bardziej cenili sobie element ludzki (czy też zależny od ludzi) niż struktury, strategie czy procedury (systemy). * Model ten powstał w wyniku zainteresowania Leavitta zagadnieniem zmiany organizacyjnej. Znamienny jest tytuł pracy, w której model przedstawiono po raz pierwszy (1965): Applied organizational change in industry: structural, technical and humanistic approaches. W założeniu jego autora miał on wskazywać obszary organizacji, w których ujawnia się wprowadzana zmiana organizacyjna. Jeśli dokonywana jest zmiana w jednym

z wymienionych przez Leavitta obszarów, konsekwencje będą ponoszone w pozostałych trzech

obszarach. Jak się wydaje, ten sens wzajemnej współzależności - zmiana w jednym elemencie pociągająca zmianę we wszystkich pozostałych - dał podstawę do określania tego modelu mianem systemowego. Model ten nie powstał w wyniku metody badawczej analizy systemowej i w oryginalnej wersji, oprócz cechy współzależności, nie wykazuje żadnej innej cechy systemowej. ** Leszek Krzyżanowski pisze na temat systemowego modelu organizacji Leavitta: „I właśnie zobrazowanie [...], w szczególności zaś ich interpretacja, budzi najpoważniejsze zastrzeżenia, gdyż obarczona jest kardynalnym błędem logicznym, który polega na hipostazie, czyli na przypisywaniu realnego istnienia konstruktom myślowym, a więc pojęciom. Czymże bowiem innym są owe podsystemy organizacji, jeśli nie wytworami intelektu, między którymi żadne realne więzi nie mogą przecież zachodzić" (Krzyżanowski, 1999, s. 29). Więzi i podsystemy (podstawa metody systemowej)

są tak samo wytworem intelektu - konstruktem myślowym, a skoro wytworzono je na potrzeby wskazanego modelu, to mają w nim prawo zachodzić. Zarzut jest zatem chybiony, przypisuje bowiem systemom konstrukcję obiektów realnych, tymczasem są one konstrukcją modelową, myślową.

Źródto: opracowanie własne.

Powyżej przedstawione modele organizacji nazywane są modelami systemowymi organizacji, bo tak nazwali je albo ich autorzy, albo (nawet częściej) ich propagatorzy. „Systemowość” tych modeli budzi uzasadnione wątpliwości ze względu na podstawę ich wypracowania - $\mathrm{w}$ drodze syntezy (systemowej) poprzedzonej kompleksową analizą systemową, odniesioną do rzeczywistego, treściowego i wreszcie formalnego opisu obiektu badania. Niezachowanie poprawności metody budowy systemu utrudnia dostosowanie modelu do konstruktu myślowego przeprowadzanych eksperymentów myślowych. Model jest reprezentacją 
rzeczywistości w granicach tym modelem opisanej, stąd trafność modelu zależy od definicji i desygnatu. W niektórych przywołanych modelach stosowano wyrażenie system, zaczerpnięte z systemowego języka opisu, ale to nie wystarcza, aby stwierdzić, czy ich autorzy poprzedzili konstrukcję modelów jakąkolwiek wersją badania systemowego (analizy i syntezy). Są to podstawowe powody, dla których w tym opracowaniu nie wykorzystano ich do dalszych prac konstrukcyjnych.

\subsection{Budowa modelu organizacji}

W niniejszej pracy przyjęto dwie zasadnicze, ogólne przesłanki budowy modelu - reizm i kategorię relacji. Obowiązującą doktryną ontologiczną w dalszej części pracy jest reizm ${ }^{1}$ - zgodnie z którym istnieją tylko rzeczy (Kotarbiński, 1961, s. 501; Lipiec, 1979, s. 54). Podstawą konstrukcji modelu, do którego prowadzą niniejsze rozważania, są zatem rzeczy mające odniesienie ontyczne - do bytów realnych, gdyż:

Leibniz powiada, że wszelkie cierniste kwestie metafizyczne upadną natychmiast, skoro będziemy przestrzegali tej zasady, by w wypowiadaniu twierdzeń umieć używać tylko nazw konkretów (Kotarbiński, 1961, s. 503).

Rzeczami ${ }^{2}$ są zatem obiekty o względnie trwałej strukturze, która zapewnia pewien rodzaj niezmienności (np. elementów zawartości, związków między nimi). Określona rzecz, niezależnie w jaki sposób opisywana, wyróżnia się trwałością, która zapewnia jej zachowanie tożsamości nawet przy braku pełnej takożsamości (Lipiec, 1979, s. 58).

Podejście do człowieka jest w reizmie proste: „świat obiektów jest tożsamy ze światem rzeczy lub osób” (Kotarbiński, 1961, s. 498). Stąd wniosek, że można w sensie ontycznym traktować ludzi jak obiekty/rzeczy. Człowiek jest uzupełnieniem

1 W Sporze o istnienie świata Roman Ingarden (1960, s. 213-271) rozróżnia trzy postaci bytu zasadniczo niesprowadzalne do siebie - rzeczy, zdarzenia i procesy, gdzie podstawą ontyczną są odpowiednio rzeczy, które trwają w czasie, zdarzenia/zjawiska/stany rzeczy, które dokonują się w czasie i procesy, które rozpościerają się w czasie. Występują także ich kombinacje (Lipiec, 1979, s. 54). Istnieją różne szkoły filozoficzne biorące za podstawę swoich rozważań określone kategorie ontyczne - są to reizm (Kotarbiński, 1961, s. 501), ewentyzm (Russel, Wittgenstein) i procesualizm (Bergson).

2 Rzeczą jest każdy konkretny przedmiot realny, określony czasowo, przestrzennie i fizycznie. Rzeczą w tym sensie jest także człowiek. W prakseologii i na potrzeby tej pracy terminy rzecz, przedmiot, obiekt używane są zamiennie, jednak na gruncie filozofii termin przedmiot jest używany w znaczeniu szerszym, natomiast rzecz to tylko materialny przedmiot (Pszczołowski, 1978, s. 216). 
maszyny, ważna jest jego energia wytwórcza, czynniki fizyczne, biologiczne, które przyczyniają się do efektywności organizacji. Ta niezbyt elegancka konstatacja nie jest poglądem odosobnionym - teoria organizacji wypracowała przecież pojęcie zarządzanie zasobami ludzkimi, stawiając człowieka na równi z pozostałymi czynnikami wytwórczymi - pracą, kapitałem i ziemią. Od organizacji jednak zależy, czy zasób ten jest traktowany podmiotowo, czy przedmiotowo.

Ponieważ kategoria rzeczy nie wystarczy do opisu rzeczywistości - „Bytu znanego nam z doświadczenia nie można bowiem złożyć z samych rzeczy” (Lipiec, 1979, s. 63-64), to aby określić złożoność i zmienność świata realnego, należy do opisu dołożyć kategorię relacji. Dopiero obie kategorie „rzeczy” i „relacji” współtworzą obraz rzeczywistości. Rzeczy mają odniesienie do relacji wewnętrznych i zewnętrznych z innymi bytami. Dlatego rzeczy są pojęciami bazowymi, natomiast relacje mają charakter relatywny, bo są odnoszone do tych pierwszych. Relacje są realne, efektywne i bezpośrednie - zachodzące związki zależą od właściwości rzeczy, między którymi zachodzą (Lipiec, 1979, s. 65).

W ogólnej teorii organizacji w ujęciu systemowym wyróżnia się trzy perspektywy „organizacji” - rzeczowe ${ }^{3}$, atrybutowe i czynnościowe (Mreła, 1968, s. 27-28; Kotarbiński, 1969, s. 74; Zieleniewski, 1976, s. 49-51, 52-53). Są one popularne, osadzone w teorii na tyle, że nie wymagają szczegółowego definiowania. W związku z tym poniżej jedynie wyjaśniono, w jakim zakresie te perspektywy są wykorzystywane w niniejszej pracy.

Pierwsze i drugie znaczenie - organizacja jako rzecz oraz organizacja jako cecha rzeczy i procesów - nazywane jest rezultatowym, rzeczy i czynności nabywają bowiem cechę „zorganizowania” w rezultacie określanego procesu - ciągu zdarzeń. Ponadto organizacje to rzeczy istniejące realnie w przestrzeni i w czasie, dlatego aby w pełni poznać je, widzieć je „konkretnie”, Zieleniewski postuluje określenie tego:

[...] jakie są, jakie mają cechy, jakie stosunki zachodzą między ich częściami, jak i to: co się w nich i z nimi dzieje, jakie procesy w nich zachodzą, jakie spotykają je zdarzenia (Zieleniewski, 1969, s. 268).

3 W rzeczowym rozumieniu organizację ludzkiego działania charakteryzują: 1) posiadanie celu - całość działania jest świadomie skierowana na jego osiągnięcie; 2) wyodrębnienie wyróżnionej całości w stosunku do innych całości działań; 3) złożoność wyróżnionej całości z części, które ją tworzą; 4) powiązanie części w jedną wyróżnioną całość działania (Kurnal, 1970, s. 102-104). Trudno oprzeć się wrażeniu, że jest to wczesna definicja tak zwanych nowoczesnych struktur organizacyjnych. Mimo upływu lat, zmieniającego się otoczenia i zmian następujących w organizacjach (także w strukturze) nadal spełniają one wszystkie cztery kryteria definicji Jerzego Kurnala. 
Będzie to podstawa do prac prowadzonych w dalszej części monografii. Nie ma tu znaczenia, na jaki czas powołane zostały instytucje - na przykład burzliwe otoczenie i prakseologia nie stawiają im warunku trwałości. W świecie XXI wieku - zglobalizowanym i nieustannie on-line - trudno mówić o stałości i niezmienności.

Budowany na potrzeby pracy model powstaje na podstawie relacji ${ }^{4}$ natury komunikacyjnej. Sposób powiązania człowieka z rzeczowymi środkami działania i warunkami może charakteryzować właściwość ścisłości i trwałości powiązania oraz częstości jego występowania. Stąd „występuje zależność powiązania celu i rodzaju działania” (Kurnal, 1970, s. 179). Relacje mogą charakteryzować następujące kryteria: ich liczba, częstotliwość, trwałość, ścisłość i rodzaj (fizyczne, duchowe). Charakter więzi pochodzi jednak od charakteru elementów - podsystemów.

W niniejszym opracowaniu konkretyzacja odbywać się będzie na trzech poziomach:

1) rzeczowa konkretyzacja w modelu organizacji dotyczy określenia rzeczy/ przedmiotów (w tym człowieka - zgodnie z zasadą reizmu) wchodzących w skład systemu organizacji i sposobu ich uporządkowania (wewnętrznej struktury systemu);

2) konkretyzacja czynnościowa pozwala wyodrębnić przebiegi komunikacji między częściami systemu - miejsce ich występowania, składniki, między którymi występują; relacje w poniższym modelu wyodrębnione będą w ujęciu przedmiotowym - ze względu na treść relacji komunikacyjnej zachodzącej między określonymi podsystemami;

3) atrybutowa konkretyzacja pozwala określić typy wcześniej wyodrębnionych relacji, tak aby modelować przebiegi komunikacyjne w kierunku sprawności.

Budowany model ma się odnosić do dowolnego typu organizacji, których w literaturze przedmiotu wyróżnia się wiele, zależnie od przyjętego kryterium, na przykład według:

1) typu relacji między ludźmi a organizacją (rodzaju władzy): organizacje przymusowe, utylitarne, normatywne (Etzioni za: Bielski, 2001, s. 92-93);

2) celów do spełnienia: instytucje polityczne (wykonywanie władzy państwowej), gospodarcze (wytwarzanie i wymiana dóbr materialnych), społeczne

4 Na płaszczyźnie organizacji relacje to „sposób połączenia części w jedną całość - jest istotnym elementem cechy organizacyjności, czyli sposobu zorganizowania całości organizacyjnej” (Kurnal, 1970, s. 177). „Stosownie do postawionego celu człowiek dobiera części i łączy je ze sobą w jedną wyodrębnioną całość [...]. Sposób połączenia części może przy tym przybierać różne konkretne kształty. Może to być podzielenie jakiegoś działania na powiązane ze sobą chronologicznie części czasowe [...] [albo - przyp. M.Z.-T.] podzielenie jakiegoś działania na powiązane ze sobą w jedną całość części przestrzenne [...] Może to być wreszcie połączenie człowieka, a ściślej biorąc, jego sił fizycznych i duchowych z rzeczową aparaturą działania" (Kurnal, 1970, s. 178-179). 
(zaspokajanie potrzeb ludzi w różny sposób - np. instytucje naukowe, oświatowe, ochrony zdrowia itp.), rodzinne (związane $\mathrm{z}$ „procesem reprodukcji życia społecznego") (Kurnal, 1970, s. 164-168);

3) funkcji genotypowej: produkcyjne (gospodarcze, dostarczanie dóbr i usług), scalające (podtrzymywanie porządku społecznego, socjalizowanie ludzi), adaptacyjne (rozwój społeczny i gospodarczy przez rozwijanie wiedzy), polityczne (instytucje państwa wraz z aparatem przymusu oraz partie polityczne, związki zawodowe itp.) (Katz, Kahn, 1979, s. 176-178), lub według funkcji genotypowej albo celu zewnętrznego: organizacje gospodarcze, użyteczności publicznej, administracyjne: państwowe i samorządowe, militarne i policyjne, społeczne oraz organizacje religijne (Bielski, 2002, s. 35).

Jak widać, istnieje wiele typów organizacji i wiele organizacji wewnątrz wskazanych typów. Można przytaczać kolejne - mniej lub bardziej udane - typologie, jednak Marcin Bielski stwierdził, że:

[...] ważniejsze od sformułowania pełnej i użytecznej praktycznie typologii organizacji jest opracowanie kryteriów analizy porównawczej, poszukiwanie podobieństw i różnic między organizacjami i ich podsystemami oraz formułowanie sytuacyjnych dyrektyw praktycznych (Bielski, 2001, s. 94).

Takie podejście jest wprowadzane w toku niniejszej rozprawy. Ponieważ budowany model ma odnosić się do każdego typu organizacji - fabryki, warsztatu, banku, uczelni, biura rachunkowego, firmy projektującej strony internetowe etc. - punktem wyjścia do dalszych rozważań jest model społeczno-techniczny organizacji, a relacje mają charakter komunikacyjny.

Przechodząc do konkretyzacji modelu sieci i systemu sieci zintegrowanych relacji komunikowania poniżej przedstawiono proces budowania modelu. Jego etapy są zgodne z przedstawionymi w podrozdziale 2.5 etapami procedury analizy systemów złożonych organizacji.

\section{Etap I - określenie systemu na obiekcie i jego przedstawianie}

\section{Cel systemu ${ }^{5}$}

Celem przeprowadzanej procedury analizy systemowej jest budowa relacyjnego modelu organizacji z perspektywy komunikacji.

Zbudowany model posłuży do doskonalenia organizacji przez usprawnienie działania na drodze ułatwienia koordynowania organizacji przez komunikowanie.

5 Cel systemu nie jest tożsamy z celem badania systemu - na przykład celem systemu może być przetrwanie, celem badania systemu sposoby, w jaki osiąga cel. 


\section{Zidentyfikowanie problemu}

Należy przedstawić organizację, pojmowaną przez optykę procesu komunikowania się, w postaci relacyjnego modelu systemu organizacji osadzonego na idei komunikowania się.

Konieczne będzie rozpoznanie podsystemów i relacji komunikowania wpływających na proces koordynacji wewnątrzorganizacyjnej.

\section{Identyfikacja systemu}

Na potrzeby rozwiązania tak zidentyfikowanego problemu nie można wykorzystać istniejącego modelu, ponieważ opracowane modele organizacji określane jako systemowe - jak już stwierdzono uprzednio - nie powstały jako efekt metody systemowej. Punktem wyjścia i inspiracją do budowy przedstawionego modelu relacyjnego organizacji stały się zatem głównie dwa modele: Leavitta (także Bielskiego) oraz model socjotechniczny. Poddano je analizie i syntezie oraz przemyśleniom własnym i wyodrębniono poszczególne podsystemy. Z tego powodu poniżej zaprezentowano ugruntowane już w nauce organizacji i zarządzania słownictwo i pojęcia naukowe, a także określenia nowe, wypracowane dla organizacji na gruncie teorii systemów, potrzebne do osiągnięcia założonego celu pracy.

Celem badania jest stworzenie metodą systemową uniwersalnego relacyjnego modelu organizacji w perspektywie komunikacyjnej. Model ten ma być stosowalny do każdego typu organizacji rzeczywistej. Z tego powodu za podstawę badań nie może służyć jedna konkretna, rzeczywista organizacja, występująca w stanie naturalnym w postaci realnej (firma XY, z nadanym numerem regon, której właścicielem jest określona osoba lub grupa osób), ani nawet konkretny zestaw obiektów rzeczywistych tożsamych co do typu działalności (firma produkcyjna, usługowa, bank czy uczelnia). Podstawą do badań jest zatem „obraz pojęciowy organizacji”, integrujący wszystkie jej typy i rodzaje - w zakresie rzeczowym. W konsekwencji tak szerokiego materiału empirycznego powstaje (1) model opisowy organizacji, na podstawie którego buduje się następnie (2) model formalny, przeznaczony do dalszych etapów badań. Taka wieloetapowa procedura jest konieczna ze względu na fakt, że model opisowy jest nieoperacyjny, natomiast model formalny poddaje się już procedurze badawczej. Model opisowy stanowi jednak badanie systemowe samo w sobie - gdyż „Najprostszy rodzaj badania [systemowego - przyp. M.Z.-T.] to opis cech obiektu" (Ujemow, 1973b, s. 65). Poniżej przedstawiono zatem kolejne etapy budowy modelu - model opisowy organizacji, który następnie przekształcony zostanie w opis formalny, a ten posłuży dalszemu badaniu.

System ustala się ze względu na cel badania, co więcej - dla przypomnienia - aby ustalić system, nie jest konieczne wymienianie wszystkich elementów i/lub wszystkich relacji. Jest to niewątpliwa zaleta metody systemowej, ponieważ z pewnością nie wyróżniono tu wszystkich możliwych składowych. Elementy są dobrane 
ze względu na cel - wybrano takie, które mają znaczenie dla komunikowania się w organizacji. Z tego powodu model przybiera wskazaną poniżej postać.

Ponadto należy w tym miejscu przypomnieć, że w podejściu systemowym przyjmuje się ontyczny prymat całości wobec elementów, które są wtórne i poza systemem pozbawione samodzielności bytowej. Dlatego poniżej wyodrębniono części systemu z całości organizacyjnej.

\section{Części systemu}

Mając powyższe na względzie, zgodnie z procedurą z całości organizacyjnej wyodrębniono najpierw realnie występujące części, mające odniesienie ontyczne do realnych składników bytu w rzeczywistości organizacyjnej, wchodzące w skład obiektu organizacja. Posłużono się analizą literatury teoretycznej i praktycznej, a także obserwacją rozmaitych organizacji dostępnych dla badacza. Budowany tutaj systemowy model organizacji ma w swojej istocie odzwierciedlać rozmaite typy działalności organizacyjnej (firmy produkcyjne i usługowe, banki, urzędy, przychodnie). Każdy $\mathrm{z}$ badanych typów organizacji wykazuje istnienie podstawowych rzeczowych części wchodzących w skład systemu organizacji, z których powstały trzy kategorie: ludzie, maszyny - technika i technologia (według kategorii ich funkcjonowania) oraz majątek trwały i ruchomy organizacji, kategoryzowany w walorach finansowych (ekonomika). Odnośne charakterystyki przedmiotowe podsystemów przedstawiono poniżej.

Następnie rozpoznano i określono cechy obiektów na podstawie analizy literatury oraz obserwacji empirycznych. W rezultacie powstała długa lista właściwości opisujących trzy wskazane rodzaje obiektów. Lista nie jest zamknięta. Wskazane właściwości obiektów przedstawiono w układzie „surowym”. W grupowaniu właściwości dotyczących podsystemu „ludzie” uwzględniono dwie ich grupy - takie, które dotyczą człowieka jako jednostki ${ }^{6}$, są w zasadzie jego immanentną charakterystyką, bez względu na otoczenie, w jakim przebywa (perspektywa psychologiczna i aksjologiczna), i takie cechy człowieka, których powstanie lub poziom występowania jest zależny od grupy ${ }^{7}$, w której przebywa (perspektywa socjologiczna

6 Na przykład jego potrzeby (fizjologiczne, bezpieczeństwa i przynależności itd.), postawy, aspiracje, typ osobowości, motywacje, kwalifikacje, kompetencje, wiedza, wykształcenie, doświadczenie, umiejętności, predyspozycje, możliwości (w tym możliwości uczenia się), kreatywność, realizowany przez niego styl kierowania, ale także myślenie, emocje, afekty, wola, wyznawane wartości osobiste.

7 Na przykład współpraca, kooperacja, style komunikacji, zespoły - ich konstrukcja, dobór członków, działanie, awanse, przeniesienia, degradowanie, zwolnienia; sposób rozpoznawania problemów i podejmowania decyzji, przestrzegane wartości grupowe, ujawniające się w grupie ambicje, motywacje, powstała kultura organizacyjna, lojalność i zaufanie w grupie, przestrzegane standardy etyczne, ale także powstała nieformalna hierarchia, autorytet, władza, przywództwo, konkurencja i rywalizacja. 
i antropologiczna). Z tego powodu przedstawiono człowieka z perspektywy jednostkowej i kulturowej ${ }^{8}$ oraz jako składową szerszej grupy społecznej - zadaniowej, i takie też wyznaczono podsystemy w organizacji.

Poniżej przedstawiono „surowe” składowe systemu, uporządkowano w (zasadzie oczywiste) podkategorie, które są tożsame z wyodrębnionymi później podsystemami. Wymieniono je również w celu zobrazowania złożoności obiektu, wielości elementów składowych rzeczywiście możliwych do zaobserwowania i wyróżnienia ich w obiektach realnych, jakimi są organizacje.

\section{Podsystem: Człowiek}

Cechy opisu: Siła głosu, siła fizyczna, wydajność wysiłkowa, produktywność osoby, pracowitość, chęć do działania, determinacja, zmęczenie, znużenie, radzenie sobie ze stresem w pracy, wielozadaniowość, strach o pracę (jej utrzymanie) lub brak strachu, umiejętność przekonywania, postawy (ich mierzenie), przekonania, myślenie, emocje, afekty, wola, system wartości, autorytet osobisty, satysfakcja (poziom, podstawa), pochodzenie społeczne, status społeczny, środowisko kulturowe (z nich wynikają: normy, wyznawane wartości, stereotypy, uprzedzenia, preferencje), motywy/ motywacje wewnętrzne, zadowolenie z pracy, cechy osobowości ${ }^{9}$ (rozumiane jako zespół cech, pod względem których jednostki różnią się między sobą), typ osobowości (kategoria klasyfikacyjna cech osobowości), temperament, etyka osobista, skłonność do agresji, skłonność do posłuszeństwa (polecenia, nakazy, rozkazy), ambicje, aspiracje, odpowiedzialność, możliwości umysłowe i intelektualne człowieka - wiedza, doświadczenie, wykształcenie, umiejętności, zdolności do pracy i kompetencje in potentia, kwalifikacje, możliwości (skłonność do) uczenia się, zainteresowania, uzdolnienia, predyspozycje, możliwości i potencjał (w tym możliwości uczenia się, kreatywność, talent, zdolność), inteligencja (IQ, EQ), sposoby podejmowania decyzji, potrzeby i oczekiwania, postrzeganie siebie, cele indywidualne.

\section{Podsystem: Grupy ludzi}

Cechy opisu: Podział pracy: współpraca, kooperacja, rywalizacja, konkurencja, konflikt, walka, cele grupowe (organizacyjne), konstrukcja zespołu, dobór członków, działanie, awanse, przeniesienia, degradowanie, zwolnienia; role w grupie,

8 Warstwa kulturowa przynależna jednostce, na przykład pochodzenie środowiskowe, społeczne, wyniesione z domu nawyki pracy.

9 Cecha wyodrębniona jest na podstawie analizy czynnikowej (koncepcja menedżerskich cech osobowościowych podlega nadal żywym dyskusjom wśród naukowców - patrz następny rozdziat). Nurt psychometryczny - Cattell (16 czynników), Eysenck (3 PEN). Nurt leksykalny - Costa, McCrae (pięćdziesięcioczynnikowa koncepcja), Allport (5 kategorii, 18000 cech). Nurt badawczy - Tupes i Christal; Norman; Goldberg; Angleitner i Hofstee (Strelau, 2004a, s. 525-560). 
kultura grupowa/organizacyjna, ujawniające się w grupie ambicje, motywacje, atmosfera (w) pracy, wielkość grupy, spójność grupy, hierarchia, lojalność i zaufanie w grupie, jednorodność/różnorodność, rozproszenie odpowiedzialności, próżniactwo społeczne, różnice w postawach i wartościach w różnych kulturach - założenie: ta sama kultura, zachowanie grupowe, stanowczość zachowań (np. owczy pęd) w organizacjach formalnych, złożonych, struktura grup formalnych, sposób projektowania zespołów roboczych, autorytet, władza, przywództwo, konkurencja i rywalizacja, przestrzegane/odrzucane wartości grupowe, tożsamość społeczna (uformowanie się „my”), zachowania organizacyjne/stosunki międzyludzkie, sposób rozpoznawania problemów i podejmowania decyzji na poziomie grupy, etyka grupowa, wgląd w otoczenie pracy (społeczne), dynamika grup.

\section{Podsystem: Ekonomika}

Cechy opisu: Widziane w bilansie: aktywa (majątek) materialne (rzeczowe - budynki, hale, maszyny), aktywa niematerialne (patenty, licencje, np. na programy komputerowe, bazy danych), aktywa finansowe (np. akcje, obligacje, środki pieniężne), pasywa, zobowiązania (wobec dostawców, pracowników, Skarbu Państwa) i przychody.

Widziane we wskaźnikach ekonomicznych: wartość wykonywanej pracy, poziom produkcji, liczba zamówień, oczekiwania produkcyjne odbiorców/rynku, minimalizowanie kosztów przez wielkość dostaw oraz termin dostaw materiałów (surowców, półproduktów, środków obsługi), koszt poziomu zatrudnienia, strategia, zadania, cele, środki, wartość ekonomiczna przedsiębiorstwa.

\section{Podsystem: Technika i technologia}

Cechy opisu: Maszyny i urządzenia (komputery, linie produkcyjne, wyposażenie transportowe) - energooszczędność versus czasochłonność pracy maszyn, sprawność produkcyjna, sposób wytwarzania towarów (metody), wydajność pracy maszyn, produktywność, jakość, struktura pracy (metody na określonym stanowisku), złożoność technologii, sposób tworzenia sieci dostaw, niezależność przepływu pracy, rodzaj systemów informacyjnych (programy informatyczne), sposób przetwarzania danych.

\section{Podsystem: Zarząd (właściciel)}

Cechy opisu: Osoba lub grupa osób bezpośrednio podejmujących decyzje i wydających polecenia, zlecających pracę innym, polecających uregulowanie wynagrodzenia za pracę (ewentualnie regulujących samodzielnie), korzystających z technologii do kierowania i dysponowania finansami całej organizacji, decydujących o ich przeznaczeniu i alokacji. 
Chodzi tutaj o podmiot zlecający pracę (postać zlecenia jest dowolna: ściśle określone zadania, ogólnie określone funkcje, wymagane efekty pracy lub wyznaczający kierunek i ramy działań) i odpowiedzialny za regulowanie należności za to zlecenie. Forma prawna lub organizacyjna nie jest istotna w tych rozważaniach. Podsystem „zarząd” - w tym sensie - abstrahuje od problemów teorii agencji: mocodawca zleca pracę agentowi, agent zleca pracę pracownikom. Konflikt mocodawca-agent umiejscawia się w podsystemie antropologicznym w przypadku niezgodności celów i pragnień między mocodawcą i agentem oraz ich odmiennej skłonności do ryzyka.

Powyżej przedstawiono kategorie w postaci pogrupowanych obserwowalnych składowych rzeczywistych, zgodnie z procedurą metody analizy systemów złożonych. Atrybuty obiektu „człowiek” określane są z perspektywy psychologicznej, fizjologicznej, fizycznej, antropologicznej, aksjologicznej oraz ekonomicznej. Dlatego powstała w tym miejscu trudność nazewnicza. W modelach organizacji wszelkie elementy lub podsystemy związane z człowiekiem uzyskują głównie nazwę psychologiczny (samodzielnie lub w złożeniach leksykalnych). Jednak wyodrębnienie na potrzeby pracy przedmiotowych składników podsystemu pokazało ogrom płaszczyzn oceny człowieka, na tyle szerokich, że określenie to wydaje się nieadekwatne, zawężające. Określenie człowiek wydawałoby się zatem najlepsze - ujmuje istotę podsystemu i jest usankcjonowane w oryginale Leavitta. Spostrzega się jednak problem leksykalny, jaki pojawiać się będzie przy nazewnictwie podsystemów kolejnych rzędów (w kolejnych złożeniach nazewniczych). Z tego względu zdecydowano się na określenie podsystemu jako „antropologiczny”10 - nie jest to jednak określenie doskonałe, stanowi kompromis między zbyt wąskim „psychologiczny” a trudno odmienianym, choć całościowym, „człowiek”.

Atrybuty obiektu „ludzie (grupa)” określa się na podstawie wyżej wymienionych perspektyw (częściej społecznych niż psychologicznych), z tą różnicą, że wyniki takiej analizy będą inne niż w przypadku perspektywy jednostkowej. Atrybuty obiektu „maszyny” to cechy techniczne, ekonomiczne. Środki finansowe ocenia się na przykład ze względu na ich wysokość, pochodzenie.

Zgodnie z założeniem metody systemowej, jak wiadomo, nie jest konieczne wyodrębnienie wszystkich elementów systemu. Do dalszej analizy jako cechy przykładowe wybrano te, które w literaturze oceniane są jako najbardziej charakterystyczne lub występują najczęściej w opisie danego obszaru. Wybrano je również z powodu ich dopasowania do struktury relacyjnej - obrazowo pokazują występowanie i funkcjonowanie relacji. Często także inni autorzy tak zwanych modeli

10 Przemawia za tym szerokie ujmowanie zagadnień związanych z człowiekiem na płaszczyźnie antropologicznej (por. Cackowski, 1979; Nowak, 1984; Kopczyński, Siciński, 1990). 
systemowych (np. Bielski, Krzyżanowski, Leavitt) uznali je za ważne. Wyżej wyodrębnione kategorie będą dalej nazywane podsystemami (lub zamiennie subsystemami) autonomicznymi.

Analiza wyodrębnionych podsystemów autonomicznych w odniesieniu do modeli organizacji (wyróżnionych w poprzednim rozdziale), będących jednocześnie inspiracją i powodem powstania systemowego modelu relacyjnego, wymaga komentarza. W modelu, który powstaje, występują bowiem wyraźne zmiany w stosunku do istniejących już modeli organizacji (uznawanych za systemowe) i odejście od pewnego, już ustalonego standardu.

W modelach określanych jako systemowe wyodrębnia się podsystem celów i wartości. Jednak cele i wartości nie są podsystemem wyabstrahowanym w organizacji. Wydaje się, że zostały one w innych modelach zintegrowane, mimo iż są ontologicznie niespójne - wartości (aksjologia) są bowiem związane z człowiekiem w sensie jego psychiki (ludzie o określonych wartościach odnajdują się lub nie w określonych organizacjach; jeśli się nie odnajdują, coraz częściej zmieniają pracę, szukając miejsca dla nich odpowiedniego; jeśli mimo niedopasowania pozostają w organizacji ${ }^{11}$, to „odchorowują” pozostanie w niej - „stres w pracy”, choroby psychosomatyczne). Wartości grupowe i organizacyjne powstają jako wypracowane w grupie, w zespole. Inaczej rzecz ma się z celami organizacji - one nie podlegają ocenie aksjologicznej, są związane z poziomem kompetencji (czy organizacja ma właściwy „zasób ludzki”, aby wykonać zadanie, czy zatrudnieni są właściwi ludzie), ekonomii (czy to się opłaci), czasu (czy firma zdąży). Cele zależą zatem od decyzji kierownika lub grupy. Ludzie ustalają cele i je realizują (lepiej lub gorzej - to zależy od sposobu sformułowania celu, kompetencji realizatorów itp., od tego, czy wskazane elementy są wzajemnie dopasowane). Cel ustalają ludzie (także zarząd, właściciel, agent), biorąc pod uwagę możliwości techniczne (posiadane lub możliwe do pozyskania), ludzi, których zatrudniają albo mogą zatrudnić.

Z przedstawionego wyżej powodu rozdzielenie podsystemów celu i wartości jest zasadne - przy czym cele organizacyjne (bo nie indywidualne, te jako właściwości jednostki są domeną podsystemu antropologicznego) to składowa podsystemu wyższego rzędu - nadrzędnego podsystemu zarządzania. Natomiast wartości indywidualne i grupowe są składowymi podsystemu antropo-społecznego, a wartości organizacyjne podsystemu zarządzania.

Struktura organizacyjna w nowo projektowanym modelu organizacji przynależy do systemu nadrzędnego w stosunku do wymienionych podsystemów (zarządzania).

11 Jest to wynikiem ich własnej decyzji. Często inny czynnik jest w takim przypadku wartościowany jako bardziej ważny. Nieprzymusowe przystępowanie do systemu organizacji omawiano częściowo już w podrozdziale 2.1. 
Przedstawione elementy wyodrębniono ze względu na ich przedmiotowość - kryterium rzeczowe. Natomiast struktura organizacyjna jest elementem funkcjonalnym organizacji, nawet wersja statyczna jest trudna do uchwycenia z perspektywy rzeczowej. Dlatego w powstającym autorskim relacyjnym systemie organizacji podsystem struktury - tak jak go rozumie Bielski ${ }^{12}$ - staje się częścią składową nadrzędnego podsystemu zarządzania, bo jest narzędziem realizowania zarządzania. Dlatego nie jest podsystemem równoznacznym poziomem ogólności z innymi, jak u Leavitta ${ }^{13}$. W organizacji na poziomie nadrzędnego podsystemu zarządzania ustala się (często transakcyjnie ${ }^{14}$ ) cel działania, który następnie jest realizowany w określonej strukturze - jedne struktury sprzyjają, inne przeszkadzają realizacji pewnych zadań (nietrafiona struktura do realizacji celu działania). Nadrzędny podsystem zarządzania łączy i spaja pozostałe podsystemy, co więcej - integruje i koordynuje ich działanie.

12 Dla Bielskiego (2002, s. 41-42) natomiast podsystem struktury stanowi łącznik podsystemów technicznego i psychospołecznego na poziomie nadsystemu zarządzania, czyli jest to łącznik systemów - odpowiednio - deterministycznego i probabilistycznego. O ile można zgodzić się z przekonaniem Bielskiego dotyczącym zachowań ludzi, które nigdy nie dadzą się w pełni przewidzieć lub zaprogramować, to trudno obecnie zgodzić się z przekonaniem o wysokim poziomie stabilności i niezmienności techniki i technologii w organizacji. Co więcej, wątpliwe jest także twierdzenie o stałości struktury jako płaszczyzny określającej podział zadań, zależności wynikające z podziału władzy, przebieg procesów pracy. W znaczeniu statycznym w krótkim czasie założenia te są oczywiście możliwe do przyjęcia, jednak ujęcie dynamiczne (np. struktura zespołów projektowych) nie wytrzymuje konfrontacji z rzeczywistością. Ponadto struktura formalna nie jest w stanie objąć (opisać) wszystkich relacji między podsystemami organizacji, jest zawsze uzupełniana przez sieć stosunków nieformalnych. Kompletny opis gwarantuje nadsystem zarządzania. Stąd rozważania dotyczące struktury organizacyjnej jako podsystemu odłączonego od ludzi w nią „wpisanych” wydają się sztuczne.

13 Dla Leavitta struktura „oznacza systemy komunikacji, systemy władzy (lub inaczej ról) i systemy przepływu pracy" (1965/2013, s. 1687). W niniejszym opracowaniu komunikacja stanowić będzie podstawę budowy systemu, jest więc płaszczyzną integrowania organizacji jako całości. Władza natomiast jest przynależna zachowaniom grup i zespołów w organizacji jako jej immanentny i integralny element, stąd lokuje się w nadsystemie zarządzania, jeśli bowiem nie została wyznaczona w sposób formalny, to z pewnością ustali się niezależnie w sposób nieformalny. I wreszcie przepływ pracy (workflow), rozumiany jako zalgorytmizowany zespół czynności (Davenport, 1993; Thomson, 1995; Hammer, Champy, 1996; Basu, Blanning, 2000, s. 17-36) przyczyniających się do osiągnięcia celu organizacji, jest składnikiem podsystemu technologicznego jako metoda pracy. Jeśli natomiast przepływ pracy jest rozumiany bardziej nowocześnie jako przepływ dokumentów (wspomagany oprogramowaniem na potrzeby pracy grupowej) (Khoshafian, Buckiewicz, 1995, s. 207-258; Marschak, 1995), jest wówczas zlokalizowany w nadsystemie zarządzania.

14 Ustalenia dotyczące celu organizacji mogą oczywiście być odgórnie narzucone przez zarząd, częściej jednak (z powodu zmian w organizacjach w kierunku ich uelastycznienia) są wyznaczane w sposób relacyjny - inaczej mówiąc - formułowane są przez „porozumienie” nadsystemu zarządzania z kolejnymi podsystemami w zakresie możliwości wykonania zadania i dostępności zasobów. Ustalenia te gwarantują w pewnym sensie wykonalność zadań, co nie zmienia odpowiedzialności podsystemu zarządzania za realizację wyznaczonych celów. 
Reasumując, uporządkowanie elementów rzeczowych zaobserwowanych w organizacjach prowadzi do wstępnej konstrukcji modelowej i przyjmuje postać pokazaną na rysunku 15.

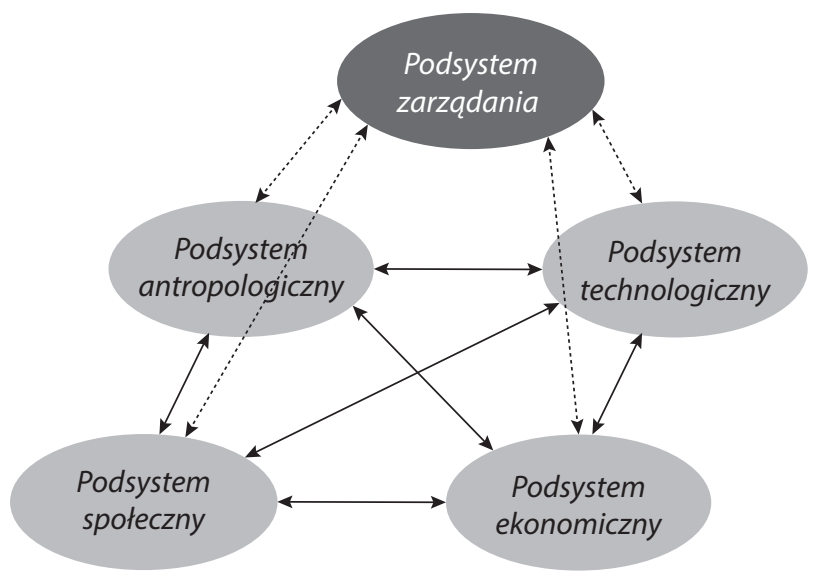

$\longleftrightarrow$ Relacje między-podsystemowe drugiego stopnia

(a...-...-.) Relacje samozwrotne drugiego stopnia między podsystemami a nadrzędnym podstystemem zarządania

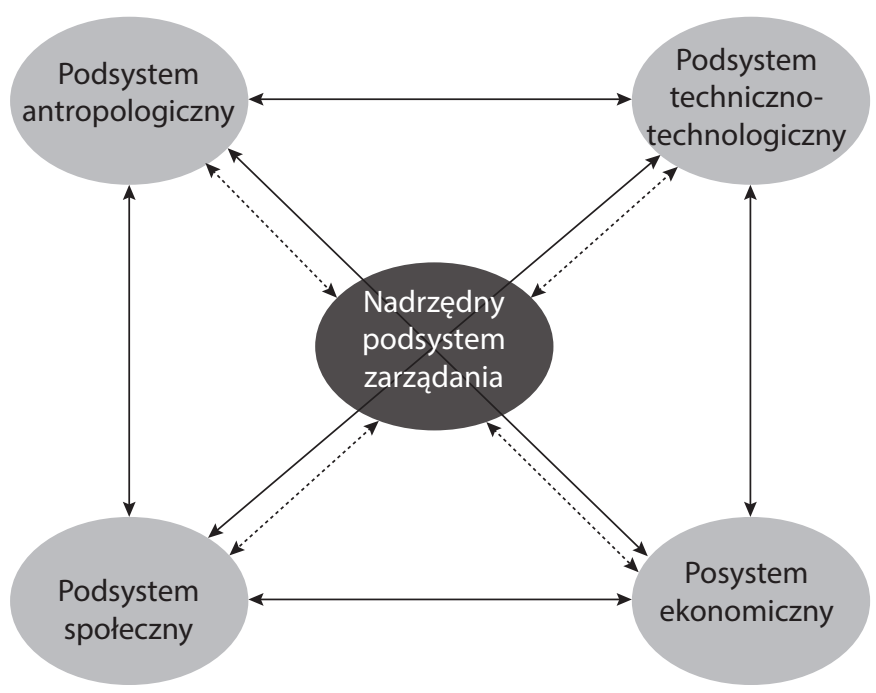

Rysunek 15. Wstępny model organizacji na etapie uporządkowania elementów (wersja przestrzenna na płaszczyźnie i uproszczona wersja „płaska”)

Źródto: opracowanie własne. 
W dalszej części tego podrozdziału analizie poddane zostaną relacje między podsystemami (usytułowane w modelu na tej samej płaszczyźnie). Tytułem przykładu wymienione zostały poniżej tylko niektóre cechy wewnątrzpodsystemowe.

\subsubsection{Relacje organizacyjne pierwszego rzędu}

W rzeczywistości podsystemy antropologiczne, społeczne, techniczne i ekonomiczne oraz ich wzajemne relacje są znacznie bogatsze niż przedstawione poniżej. Z punktu widzenia realizacji celu pracy nie ma jednak potrzeby wprowadzania drobiazgowych rozważań wewnątrzpodsystemowych, z systemowego punktu widzenia istotne są bowiem podsystemy oraz relacje między nimi. Dlatego do konstrukcji modelu relacyjnego $\mathrm{w}$ dalszej części pracy posłużą wyodrębnione w tym miejscu podsystemy autonomiczne. Niektóre składowe subsystemów autonomicznych będą się - z natury rzeczy - powtarzały, charakteryzują one bowiem więcej niż jeden subsystem, jednak wraz ze zmianą optyki konsekwentnie zmieniają się opisujące je własności.

\section{Podsystem antropologiczny}

(A) ( T) Obejmuje pojedyncze jednostki ludzkie, niejako autonomiczne, ale w przestrzeni organizacji. Tutaj akcent położony jest na indywidualne cechy uczestników organizacji. Obejmuje cele indywidualne i wynikające z nich motywy działania, jakimi osoby kierują się w swoich zachowaniach (w tym także, a w zasadzie głównie, w zachowaniach organizacyjnych). Chodzi tutaj o indywidualne systemy wartości wniesione do organizacji, oczekiwania i aspiracje. Jednocześnie ważne są kwalifikacje poszczególnych osób.

Podstawą subsystemu antropologicznego jest opisanie cech osobniczych człowieka jako podmiotu systemu organizacyjnego. Zainteresowaniu podlegają jego dyspozycje, zdolności i kompetencje in potentia do pracy i współpracy w organizacji. Stąd, dla przypomnienia, szeroka płaszczyzna rozważań obejmująca cechy aksjologiczne, kulturowe, antropologiczne, intelektualne, symboliczne, biologiczne (w tym fizyczne) itp. jednostki.

Przykładowe cechy tego podsystemu:

PF - dyspozycje psychofizyczne człowieka (pracownika, przełożonego) oraz jego

umiejętności manualne, (wiek, płeć, staż pracy, przekonania, własna hierarchia wartości czy prestiż/autorytet).

C - cechy osobowościowe (charakter).

I - możliwości umysłowe i intelektualne człowieka, zdolność do wykonania powierzonych zadań, kompetencje, wykształcenie, poziom wiedzy ogólnej i specjalistyczno-zawodowej.

$\mathrm{P}$ - potrzeby jednostki. 


\section{Podsystem społeczny}

(A) T $\urcorner$ Obejmuje grupy ludzi zaangażowane w działanie w organizacji i we wza(S) jemne interakcje. Dotyczy podziału pracy ${ }^{15}$ i wynikającego z niego po[ (S) E ! działu ról w zespole, stosunków władzy, dynamiki grup, wpływów w organizacji. Ważna jest tu wytworzona w organizacji kultura oraz formalna struktura, w jakiej ludzie funkcjonują, odgrywają swoje organizacyjne role.

Przykładowe cechy tego podsystemu:

$\mathrm{S}$ - stanowisko (B - kadra zarządzająca; N - pracownicy operacyjni).

F - forma zatrudnienia: umowa o pracę, zlecenie, przez agencję pracy tymczasowej, a także straż pracy.

K - konstrukcja zespołu - dobór członków, działanie, awanse, przeniesienia, degradowanie, zwolnienia.

F - funkcjonowanie w zespole, tożsamość społeczna (uformowanie się „my”), przestrzegane/odrzucane wartości grupowe, przestrzegane standardy etyczne, role w grupie.

\section{Podsystem techniczno-technologiczny}

(A) T Ten podsystem należy rozumieć jako technikę i technologię używaIS E I I ną w organizacji w procesach transformacji organizacyjnej tworzywa, surowców na wytwory przydatne użytkowo - rozumianą jako narzędzia i sposób ich użycia. Obejmuje zatem wiedzę (techniczną) niezbędną do realizacji celów organizacji, wyposażenie techniczne w postaci maszyn i urządzeń (aparatura). Ponadto zawiera środki produkcji (lub usług), na których przebiega transformacja przy udziale techniki (narzędzi) i technologii (sposobu). Ostatnim składnikiem są w zasadzie „niezauważalne”16 części wyposażenia materialnego i obsługi organizacji, konieczne do realizacji podstawowego celu organizacji, ale niestanowiące podstawowych narzędzi w podstawowym procesie organizacji. Każda struktura techniczna czy finansowa ożywiana jest przez człowieka. Powiązanie człowieka z każdym podsystemem organizacji ma charakter społeczny i stanowi treść relacji, o które chodzi w niniejszym opracowaniu.

Przykładowe cechy tego podsystemu:

$\mathrm{M}$ - maszyny, urządzenia.

Me - metody (know-how).

Śr - środki produkcji - materiały, surowce.

W - materialne wyposażenia organizacji (np. środki czystości).

15 W tym podsystemie zawarto także podsystem struktury Leavitta i Bielskiego, uznając brak konieczności jego autonomicznego występowania.

16 Na przykład krzesła w poczekalni do lekarza, które nie służą realizacji podstawowego zadania - leczenia ludzi, jak aparat EKG lub tomograf. Jednak występują w organizacji, ponadto są potrzebne. 


\section{Podsystem ekonomiczny}

(A) (T) Wyodrębnienie tego podsystemu jest konieczne, stanowi bowiem płasz(5) czyznę, na gruncie której dokonuje się pomiaru działalności przedsię! S E E ! biorstwa. Organizacje funkcjonują po to, aby generować przychody. Ponadto konsekwencje istnienia tego podsystemu dla organizacji są takie, że następuje ciągła koncentracja działań na zasobach, które generują największy efekt. Struktura składników materialnych, niematerialnych, prawnych, finansowych i rzeczowych wpływa na podejmowanie i prowadzenie działalności gospodarczej przez przedsiębiorcę. Jego źródłem jest człowiek zaangażowany w procesy organizacyjne.

Przykładowe cechy tego podsystemu:

A - aktywa organizacji (budynki, należności).

PA - pasywa organizacji (kapitał i zobowiązania - także wobec pracowników).

$\mathrm{K}-$ koszty.

$\mathrm{PR}-$ przychody.

Model organizacji tworzony na potrzeby relacyjnego ujęcia organizacji składa się z czterech podstawowych podsystemów, nazywanych dalej autonomicznymi (pierwszego rzędu) - antropologicznego, społecznego, techniczno-technologicznego oraz ekonomicznego. Następnie wyróżnia się subsystemy drugiego rzędu, są to tak zwane subsystemy skojarzone, powstałe na podstawie relacji zewnątrzpodsystemowych subsystemów autonomicznych. Występuje sześć relacyjnych subsystemów skojarzonych: antropo-społeczny, antropo-techniczny, antropo-ekonomiczny, społeczno-techniczny, społeczno-ekonomiczny oraz techniczno-ekonomiczny. Powstał zatem społeczno-techniczny model organizacji z podsystemami ujętymi w tabeli 16 . Widać tu podobieństwo do modelu socjo-technicznego grupy Tavistock (Cummings, 1978, s. 625-634; Emery, Triest, 1981; Emery, 1997, s. 885-931; Emery, 2000). Jednak przedstawiony poniżej model nie jest ani jego modyfikacją, ani rozwinięciem, powstał bowiem w wyniku badania metodą analizy systemów złożonych, stanowi etap w badaniu systemowym organizacji i należy go traktować jako podstawę dalszych etapów procedury analizy systemów złożonych.

Poniżej zostaną przedstawione relacje między wskazanymi podsystemami - drugiego, trzeciego i czwartego rzędu - występujące odpowiednio między dwoma, trzema i czterema podsystemami. Na tym etapie prac relacje te są umownie określane mianem relacji organizacyjnych, w odróżnieniu od przedstawionych w następnej kolejności relacji komunikacyjnych. Ponadto w tworzonym systemie wskazano przykładowe typy relacji, uwzględniając wyłącznie takie, które „wiążą system”17.

17 Na przykład relacje odległości fizycznej między obiektami (np. maszynami) - jako niewiążące systemu - zostaną pominięte w niniejszym modelu. 


\begin{tabular}{|l|l|}
\hline \multicolumn{1}{|c|}{ Podsystem antropo-społeczny (ludzie) } & \multicolumn{1}{|c|}{ Podsystem techniczno-ekonomiczny } \\
\hline $\begin{array}{l}\text { Podsystem ludzi jako jednostek } \\
\text { (antropologiczny) }\end{array}$ & $\begin{array}{l}\text { Podsystem techniki i technologii } \\
\text { (materiały, narzędzia i metody, instalacje, } \\
\text { urządzenia) }\end{array}$ \\
\hline Podsystem grup społecznych (społeczny) & $\begin{array}{l}\text { Podsystem zasobów materialnych/ } \\
\text { ekonomiczny }\end{array}$ \\
\hline
\end{tabular}

Rysunek 16. Podsystemy modelu społeczno-technicznego organizacji

Źródto: opracowanie własne.

\subsubsection{Relacje organizacyjne drugiego rzędu}

Następnym etapem działań jest określenie relacji organizacyjnych między dwoma podsystemami systemu „organizacja”. Relacje drugiego rzędu to takie relacje, które występują w subsystemach drugiego rzędu. Poniżej przedstawiono przykładowe opisy podsystemów i relacji określonych podsystemów modelu relacyjnego, które można w sposób uproszczony przedstawić za pomocą wzoru:

$$
r_{m n} \subset E_{1} \times E_{2}
$$

gdzie:

$r_{m n}$ - relacja organizacyjna,

$E_{1}$ - pierwszy podsystem,

$E_{2}-$ drugi podsystem.

\section{Podsystem antropo-społeczny}

(A) 7 (

(S) cję odwrotną.

(5) E) $\quad r_{11}-$ działania grupy, które zaspokajają potrzeby indywidualne (np. przynależności, uznania, autorytetu) i odwrotnie; poziom zadowolenia jednostki z uczestnictwa w organizacji;

$r_{12}$ - konformizm, zmiana postawy jednostki pod wpływem grupy (i odwrotnie); $r_{13}$ - facylitacja społeczna/zahamowanie (wzrost/spadek poziomu wykonania zadania wywołany obecnością innych);

$r_{14}$ - ujawniające się ambicje jednostek w grupie;

$r_{15}$ - potrzeba uznania człowieka w grupie (potrzeba a oczekiwania w grupie);

$r_{16}$ - forma zatrudnienia a cechy osobowościowe - QoWL - pewność lub niepewność pracownika (istnieją jednostki, które cenią sobie niezwiązanie z pracodawcą, natomiast inni czują się niepewnie w sytuacji braku stabilności zatrudnienia). 


\section{Podsystem antropo-techniczny}

A $\mathrm{T}$ । Podsystem antropo-techniczny obejmuje relację między dowolnym

(S) pracownikiem lub przełożonym a operatorem maszyny (produkcyjnej, (S _ _ usługowej), a także operatorem technologii komunikowania.

$r_{21}$ - dyspozycje psychofizyczne oraz intelektualne pracownika, operatora maszyny, jakie mają odpowiadać wymogom obsługi danego typu urządzenia (relacja pracownik-maszyna); ergonomia;

$r_{22}$ - dyspozycje psychofizyczne oraz intelektualne pracownika, jakie mają odpowiadać użytym metodom pracy, człowiek proponuje usprawnienia w metodach pracy na własnym stanowisku; ergonomia;

$r_{23}$ - dyspozycje psychofizyczne oraz intelektualne pracownika, jakie mają odpowiadać użytym środkom produkcji, pracownik modyfikuje środki produkcji (w określonym zakresie);

$r_{24}$ - osobowość a maszyna (np. użytkownik/pakowacz spędzający długie godziny nad monotonnym zadaniem);

$r_{25}$ - osobowość a metoda (np. człowiek cierpliwy a potrzebujący szybkiego efektu); $r_{26}$ - potrzeba człowieka do wygodnego miejsca pracy (ergonomia miejsca, narzędzi);

$r_{27}$ - dyspozycje osobnicze dotyczące urządzeń wykorzystywanych do komunikowania się w organizacji;

$r_{28}$ - dyspozycje osobnicze dotyczące metod wykorzystywanych do komunikowania się w organizacji.

\section{Podsystem antropo-ekonomiczny}

(A) (T) Podsystem antropo-ekonomiczny obejmuje relację między jednostI ką a osobami zajmującymi się zasobami ekonomicznymi organizacji I S E (w skrócie nazywanymi tutaj finansistami).

$r_{31}$ - człowiek jako zasób organizacji, jako kapitał intelektualny (człowiek intelektualnie i psychofizycznie - aktywa organizacji);

$r_{32}$ - zobowiązania wobec pracownika, na przykład z tytułu odpraw emertytalnych, programów pracowniczych, np. ochrony zdrowia (człowiek - pasywa);

$r_{33}$ - wynagrodzenia pracownicze (człowiek i koszty);

$r_{34}$ - przychody z tytułu świadczenia pracy (człowiek - przychody);

$r_{35}$ - potrzeba zaspokojenia wynagrodzeniem potrzeb życiowych.

\section{Podsystem społeczno-techniczny}

(A) (T) Podsystem społeczno-techniczny obejmuje relacje między grupami zatrudnionych a operatorami maszyn (znów nie tylko związanymi z głównym procesem organizacji, ale także z komunikowaniem). 
$r_{41}$ - grupa zawodowa posługująca się określoną metodą pracy, maszynami oraz środkami produkcji (np. pracownicy call-center);

$r_{42}$ - wzajemne dostosowanie możliwości maszyn i możliwości ludzi (projekt techniczny dostosowany do potrzeb ludzi - ergonomia); ergonomia - optymalne przystosowanie środowiska pracy, urządzeń technicznych, narzędzi pracy, maszyn, środków transportu i łączności do możliwości psychofizycznych człowieka;

$r_{43}$ - materialne parametry środowiska pracy: oświetlenie, wilgotność, hałas;

$r_{44}$ - warunki techniczne pracy przekładają się na wydajność pracy i jakość pracy (QWL);

$r_{45}$ - urządzenia techniczne, narzędzia pracy, maszyny, środki produkcji są coraz bardziej złożone, co zwiększa wymagania wobec pracowników - możliwości i ograniczenia człowieka w pracy (adaptacyjność organizmu);

$r_{46}$ - forma zatrudnienia wpływa na techniczny poziom wykonania pracy.

\section{Podsystem społeczno-ekonomiczny}

(A) (T) Podsystem społeczno-ekonomiczny obejmuje relacje między grupami (S) E ludzi a grupami osób odpowiedzialnych za gospodarowanie finansami I S E

$r_{51}$ - ustalanie poziomu wynagrodzenia (dany poziom w strukturze organizacyjnej, dana grupa pracownicza otrzymuje wynagrodzenie zasadnicze na tym samym poziomie);

$r_{52}$ - grupy pracowników odchodzących na emeryturę, kwalifikujące się do odpraw (socjo-pasywa, rezerwa, wypłata: koszty);

$r_{53}$ - wypłata wynagrodzeń (socjo-koszty);

$r_{54}$ - zakup dostosowanych ubrań roboczych (socjo-koszty);

$r_{55}$ - produktywność ludzi $=$ produkcja/jednostka zasobu (ludzie);

$r_{56}$ - opłacalność (zyskowność) - zatrudniony człowiek zarobi/wygeneruje zysk dla organizacji;

$r_{57}$ - forma zatrudnienia pracowników generuje odmienne obciążenia finansowe dla organizacji.

\section{Podsystem techniczno-ekonomiczny}

(A) (T) Podsystem techniczno-ekonomiczny obejmuje relacje między grupami (S) operatorów a grupami finansistów.

(5) (E) $r_{61}$-zasoby, z których organizacja czerpie korzyści (nie musi ich posiadać, ale sprawuje kontrolę - np. zasoby IT);

$r_{62}$ - wartość ekonomiczna metody (wartości niematerialne i prawne, know-how, patenty, licencje); 
$r_{63}$ - koszty i rodzaje techniczne materiałów zużywanych do procesu produkcji, na przykład ubrania robocze;

$r_{64}$ - ekonomiczność = zyski(wyniki)/nakład; wariant oszczędnościowy (const/ min) i wydajnościowy (max/const):

- oszczędność (obniżenie kosztów z powodu zmiany technologii metody, materiałów i środków),

- $\quad$ wydajność wyposażenia, kapitału, energii => wydajność planowana/rzeczywista $=$ produkcja/czas (godziny pracy maszyny, praca na jednostkę inwestycyjną, kWh, energię, litr paliwa), wydajność w stosunku do zapotrzebowania $\mathrm{W}>\mathrm{Z}$, zapas; $\mathrm{W}<\mathrm{Z}$, niezaspokojony popyt, koszt: utrata klientów;

$r_{65}-$ produktywność $=$ produkcja/jednostka zasobu (czas, pieniądz);

$r_{66}$ - korzystność;

$\mathrm{r}_{67}$ - opłacalność (zyskowność), koszt inwestowanych środków do kosztu sprzedaży;

$r_{68}$ - oszczędność energii - taniej/drożej techniką niż np. człowiekiem.

Powyżej przedstawiono przykładowe relacje międzypodsystemowe, czyli relacje między dwoma podsystemami. Kolejne przykładowe relacje trzyczłonowe - czyli trzeciego rzędu - wskazano poniżej.

\subsubsection{Relacje organizacyjne trzeciego rzędu}

Subsystemy trzeciego stopnia to trzyczłonowe relacje rzeczowe, przedstawione szczegółowo poniżej. Ze względu na czytelność i przejrzystość tekstu podczas wyróżniania kolejnych poziomów relacji zdecydowano się na pokazanie przykładowych relacji.

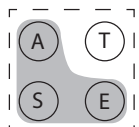

Podsystem antropo-społeczno-ekonomiczny obejmuje relacje między jednostkami a członkami grup i grup finansistów.

$r r_{11}$ - wyznaczenie kierunków i celów działalności organizacji (zależnie od rodzaju kierownictwa: jednoosobowego, zespołowego);

$r r_{12}$ - wyznaczenie norm opisu realizacji celów działalności organizacji;

$r r_{13}$ - „kontrola” grupowa jednostek dotycząca sprawiedliwych wynagrodzeń.

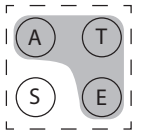

Podsystem antropo-techniczno-ekonomiczny obejmuje relacje między jednostkami a grupami operatorów (grupy techników).

$r r_{21}$ - wyznaczenie sposobów realizacji celów organizacji (potrzebnych w szerokim znaczeniu- kwalifikacji, narzędzi i finansów);

$r r_{22}$ - potrzeby techniczno-ekonomiczne jednostki (pracownika/kierownika). 
(A) (T) Podsystem antropo-społeczno-techniczny obejmuje relacje między (S) jednostkami a grupami ekonomistów, finansistów.

$r r_{31}$ - wyznaczenie określonej technologii dla grup pracowniczych ze względu na poziom kompetencji poszczególnych pracowników;

$r r_{32}$ - poziom technicznego zaawansowania określonych jednostek na tle grupy; $r r_{33}$ - „kontrola” grupowa dotycząca umiejętności technicznych poszczególnych członków zespołu.

(A) ( T) Podsystem społeczno-techniczno-ekonomiczny obejmuje relacje (S) (E) między jednostkami a grupami operatorów (grupy techników). $r r_{41}$ - wyznaczenie i realizacja strategii organizacji;

$r r_{42}$ - wyznaczenie środków realizacji celów organizacji;

$r r_{43}$ - obniżanie kosztochłonności działania, metod i wyposażenia dla określonego zespołu.

\subsubsection{Relacja organizacyjna czwartego rzędu}

Subsystem czwartego stopnia to czteroczłonowa relacja rzeczowa. Różni się od całościowego ujęcia organizacji, ponieważ relacja nie dotyczy powiązań z nadrzędnym podsystemem zarządzania.

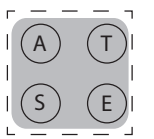

Podsystem antropo-społeczno-techniczno-ekonomiczny obejmuje relacje między jednostkami a grupami operatorów i ekonomistów. $r r r_{11}$ - relacje członków grupy (jednostek) na tle grupy w zakresie techniczno-ekonomicznym;

$r r r_{12}$ - wpływ grupy na jednostki w zakresie techniczno-ekonomicznym.

Każda z powyższych relacji organizacyjnych określonego stopnia - drugiego, trzeciego i czwartego - jest realizowana za pomocą tożsamej z nią relacji komunikowania (przedstawionych w podrozdziale 4.3), zgodnie z głównym założeniem pracy o istnieniu komunikacji jako warunku podstawowym działania organizacji. Wskazane relacje w kolejnym kroku ulegną grupowaniu (zintegrowaniu), ze względu na ich treść, na określone wiązki, które następnie zostaną zebrane, złożone w odnośne sieci zintegrowanych relacji.

Zanim jednak pokazane zostaną kolejne etapy budowania systemu, należy wskazać miejsce podsystemu zarządzania w całości konstrukcji modelu - o czym poniżej. 


\subsubsection{Relacje organizacyjne samozwrotne z podsystemem zarządzania - drugiego, trzeciego, czwartego i piątego rzędu}

Relacje kolejnych podsystemów z nadrzędnym podsystemem zarządzania w organizacji, zgodnie z podstawami ujęcia systemowego, mają dwojaką naturę - obejmują relacje bilateralne podsystemu zarządzania $\mathrm{z}$ każdym z podsystemów z osobna oraz relacje podsystemu zarządzania ze wszystkimi podsystemami jednocześnie.

Podstawą wyróżnienia podsystemów kolejnych rzędów jest obowiązkowe w sferze wiedzy systemowej stwierdzenie, że każdy podsystem uzależnia swoje zachowanie od podsystemów, z którymi pozostaje $\mathrm{w}$ relacjach, a zmiana relacji wzajemnych wpływa na zmianę zachowania systemu. Podsystem antropologiczny zachowuje się inaczej w relacjach z podsystemem zarządzania, a inaczej wówczas, gdy jego relacje dotyczą jednocześnie podsystemu technicznego oraz podsystemu zarządzania. Wzajemny wpływ kolejnego podsystemu zmienia bowiem jakość cech konstytutywnych systemowych. Ta cecha systemów jest podstawą do wykreowania systemowego modelu w postaci relacji komunikowania kolejnych rzędów (od pierwszego do piątego włącznie). Jest to jednocześnie uzasadnienie konieczności podziału na relacje kolejnych stopni.

W przedstawianym modelu istnieją relacje między nadrzędnym podsystemem zarządzania a poszczególnymi podsystemami. Te relacje są wymienione w tym miejscu włącznie dla porząaku toku myślowego, ponieważ w zasadzie wszystkie są relacjami drugiego rzędu - jako relacje kolejnych podsystemów z ich nadrzędnym podsystemem zarządzania (np. relacje: antropo-zarządzanie, antropo-społeczny-zarządzanie, antropo-społeczno-techniczny-zarządzanie itp.). Relacje między podsystemem zarządzania a pozostałymi podsystemami organizacji (różnych stopni) są relacjami innego typu (niż te, które powstają między nimi), są mianowicie samozwrotne i z definicji mają charakter integracyjny, w pewien sposób kumulacyjny, harmonizujący i koordynujący pozostałe działania wewnątrzorganizacyjne. Ponieważ relacje z systemem zarządzania mają inną naturę, nie nazywa się ich relacjami międzypodsystemowymi.

W tym miejscu należy przypomnieć, że pojęcie zarządu jest w niniejszej pracy rozumiane szeroko. Może on mieć jednoosobową postać właściciela lub może to być rozbudowane gremium osób (organ wieloosobowy), albo też przybierać postać agencji. W innych typach organizacji - tak zwanych organizacjach bez szefów (charakteryzujących się samozarządzaniem), w zwinnych organizacjach ${ }^{18}$, holakra-

18 Zasady określone w Manifesto for Agile Software Development (2017): ludzie i interakcje ponad procesami i narzędziami, działające oprogramowanie ponad obszerną dokumentację, współpraca z klientem ponad formalne ustalenia oraz reagowanie na zmiany ponad dziataniem zgodnym z planem. 
cji ${ }^{19}$ czy na przykład tak zwanych organizacjach turkusowej ${ }^{20}$, charakteryzujących się szerokim delegowaniem uprawnień dla pracowników (Ziębicki, 2017, s. 80-81), istnieje ktoś, kto te uprawnienia deleguje. Osoba taka lub grupa osób jest w niniejszej pracy rozumiana jako zarząd. Stąd na potrzeby niniejszego opracowania scharakteryzowano zarząd ogólnie, nie przez osoby, ale przez główne czynności jakie on wykonuje, a mianowicie przez:

1) delegowanie uprawnień,

2) zlecanie zadań na poziomie ogólnym - inicjowanie głównych procesów organizacyjnych,

3) polecanie uregulowania pracownikom należności za wykonane zadania (niekoniecznie samodzielne dokonywanie płatności, ale wydawanie poleceń jej wykonania) i regulowanie innych należności organizacji,

4) inicjowanie zakupów technologii dla funkcjonowania organizacji,

5) koordynowanie i pośredniczenie w komunikacji ${ }^{21}$.

Wracając do kwestii podsystemu zarządzania, poniżej wyjaśnione zostały relacje podsystemów kolejnych rzędów z nadrzędnym podsystemem zarządzania.

Relacje organizacyjne (w konsekwencji także relacje komunikacyjne) każdego podsystemu kolejnego rzędu z osobna są kumulowane w wiązki, przyjmowane, a następnie kwalifikowane i grupowane według synkretycznego modelu funkcji zarządzania. W uporządkowanej postaci trafiają do nadrzędnego podsystemu zarządzania, skąd - po przegrupowaniu - skoordynowane trafiają zwrotnie

19 Tak zwana organizacja zwinna (holacracy). Autorstwo koncepcji (datowanej na rok 2006) przypisuje się Brianowi Robertsonowi, który jest także autorem manifestu holakracji, określającego formalne zasady funkcjonowania takiej organizacji (Robertson, 2015, s. 28). Koncepcja nie była szeroko opisywana w literaturze przedmiotu. Nieliczne źródła literaturowe to głównie opracowania popularno-naukowe, przedstawiające doświadczenia praktyczne związane z jej stosowaniem. Podstawowym elementem w organizacji typu holakracja są autonomiczne kręgi (circle), odpowiedniki holonów. Pracownicy o różnych kompetencjach, którym zostają przypisane role, tworzą kręgi, a te z kolei stanowią elementy większych całości - kręgów nadrzędnych (kręgów departamentów, pionów czy kręgu całej firmy). Kręgi tworzone są zależnie od potrzeb. Część kręgów ma charakter stały, część istnieje jedynie do czasu osiągnięcia celu, jaki przyświecał ich utworzeniu (Ziębicki, 2017, s. 86). Podstawą zarządzania pracą kręgu są kolektywne uzgodnienia w ramach zebrań - zarządczych oraz taktycznych.

20 Autorem koncepcji datowanej na 2014 rok jest Belg Frederic Laloux. Wskazuje on modele ewolucji organizacji, opierając je na perspektywie sposobu myślenia człowieka. W zasadzie nie nadaje nazw kolejnym typom organizacji - odnosi je do kolorów: czerwone, bursztynowe, pomarańczowe, zielone i turkusowe właśnie. Turkusowe organizacje tworzone są na podstawie samozarządzania, wartości, zaufania, współpracy, partnerstwa, oraz stworzenia możliwości samorealizacji (Laloux, 2015, s. 49-51).

21 Lead link organizacji holakracyjnej jest często utożsamiany z liderem („szefem”) zespołu, rozumianym jako pośrednik i koordynator w komunikacji między i z innymi kręgami (Robertson, 2015, s. 28) - ta koncepcja jest wyraźnie spójna z prezentowaną w niniejszej pracy. 
do podsystemów modelu kolejnych rzędów, dla których są dedykowane i przeznaczone.

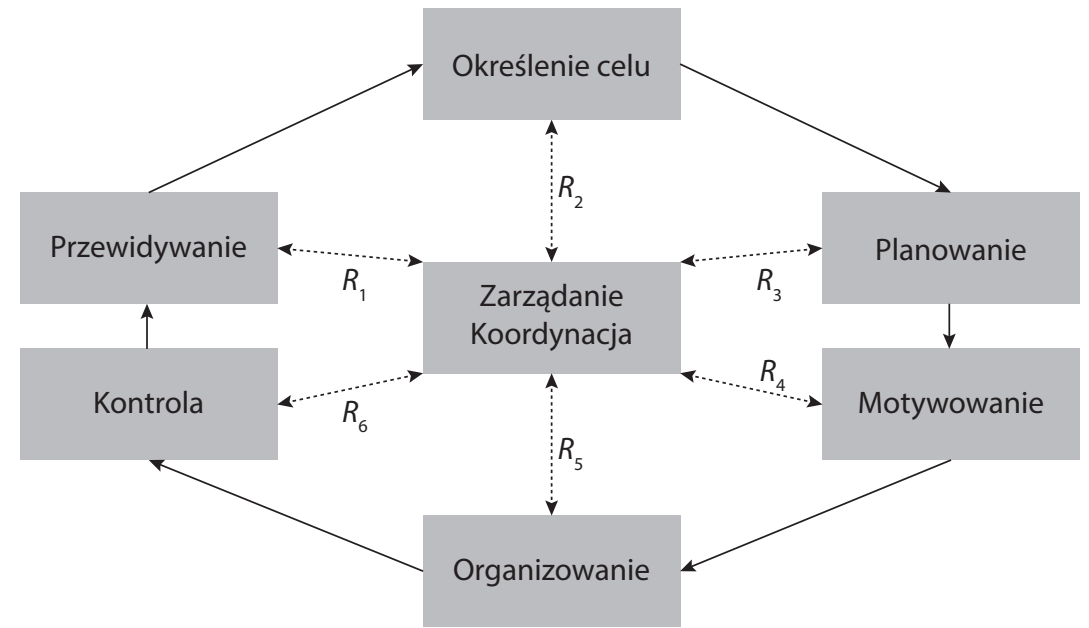

Rysunek 17. Przykład relacji zarządzania zakwalifikowanych według synkretycznego modelu cyklu zarządzania

$R_{n}$ - kolejny typ relacji zaliczany do określonej funkcji zgodnie z synkretycznym modelem cyklu zarządzania

Źródto: opracowanie własne.

Poniżej wskazano przykładowe relacje organizacyjne zgodne z SMCZ.

Relacje organizacyjne typu $R_{1}$ zaliczane do funkcji przewidywanie:

1) rozpoznanie otoczenia biznesowego;

2) analiza kierunków zmian.

Relacje organizacyjne typu $R_{2}$ zaliczane do funkcji wyznaczanie celu:

1) ustalanie kierunków i celów działalności organizacji (zależnie od rodzaju kierownictwa: jednoosobowego, zespołowego);

2) ustalanie norm opisu celów działalności organizacji i kryteriów oceny realizacji celów.

Relacje organizacyjne typu $R_{3}$ zaliczane do funkcji planowanie:

1) ustalanie strategii realizacji celów organizacji;

2) ustalanie sposobów realizacji celów organizacji;

3) ustalanie środków realizacji celów organizacji.

Relacje organizacyjne typu $R_{4}$ zaliczane do funkcji zarządzania organizowanie:

1) formowanie personelu, kształtowanie zespołu efektywnie realizującego przypisane mu zadania;

2) rozmieszczenie ludzi na stanowiskach pracy, aby w pełni wykorzystać ich potencjał, wiedzę i doświadczenia; 
3) integrowanie (tworzenie więzi między pracownikami, inaczej mówiąc, kształtowanie zespołu) i doskonalenie personelu (które stanowi swoiste dopełnienie funkcji formowania kadr).

Relacje organizacyjne typu $R_{5}$ zaliczane do funkcji zarządzania motywowanie:

1) zrozumienie motywów i potrzeb podwładnych;

2) tworzenie atmosfery wymiany wiedzy (zawodowej, umiejętności i odczuć osobistych, ambicji, planów i porażek);

3) zrozumienie zachowań pracowników i pobudek/bodźców tych zachowań.

Relacje organizacyjne typu $R_{6}$ zaliczane do funkcji zarządzania kontrolowanie:

1) demonstracja obiektywizmu (równe traktowanie wszystkich ocenianych członków organizacji);

2) zapoznanie pracowników z normami, poleceniami i zaleceniami, które będą oceniane podczas kontroli (w sposób dla nich zrozumiały); weryfikowanie wykonanych zadań zgodnie z podanymi uprzednio normami.

Wskazane wyżej relacje organizacyjne zaliczane do funkcji składowych modelu SMCZ będą realizowane przez odniesione do nich relacje komunikacyjne, odpowiadające im treściowo.

Reasumując, przedstawione wyżej relacje, będące podstawą funkcjonowania podsystemów kolejnych rzędów w organizacji, nazywane są tutaj relacjami organizacyjnymi. Stanowią one podstawę realizowanych w organizacji relacji komunikacyjnych - w ślad za określonym typem relacji organizacyjnej najczęściej idzie kilka typów relacji komunikowania realizujących tę pierwszą. Relacje komunikowania szczegółowo przedstawiono w następnym podrozdziale. Co więcej, wskazane wyżej relacje międzypodsystemowe wymagają rozpoznania właściwych im relacji komunikowania, a następnie pogrupowania ich, skumulowania i zintegrowania (relacji komunikowania) w wiązki w synkretycznym modelu cyklu zarządzania ze względu na treść (zawartość merytoryczną) komunikatów, co zostało przedstawione poniżej.

\subsection{Relacje komunikacyjne pierwszego stopnia}

Szczegółowa analiza systemowa elementów wchodzących w skład organizacji pozwoliła na podzielenie ich na cztery kategorie tematyczno-obszarowe, klasyfikowane jako podsystemy - podsystem antropologiczny, obejmujący jednostki w organizacji; podsystem społeczny, przyjmujący za podstawę zespoły zadaniowe; podsystem techniczno-technologiczny, obejmujący metody i urządzenia potrzebne do podstawowego działania organizacji, a także osoby zajmujące się produkcją 
lub usługami w organizacji. Podsystem ten zawiera również technikę i technologię używaną do komunikowania się. Ostatni podsystem - ekonomiczny - obejmuje ekonomikę, to jest zasilenie finansowe.

Zagadnienie struktury organizacyjnej, podobnie zresztą jak kultury organizacyjnej oraz celu i wyników organizacji (sprawności w sensie kumulatywnym), to elementy systemu „organizacja” znajdujące się w nadrzędnym podsystemie zarządzania wyżej w stosunku do wskazanych czterech podsystemów. Są to obszary bardziej ogólne, a jednocześnie mające wpływ na wszystkie cztery podsystemy. Określając lub negocjując cele, organizacja (bez względu na postać zarządu jako naczelnego kierownictwa lub właściciela - Kotey, Meredith, 1997, s. 37-64; Casidy, Nyadzayo, 2017) rozpatruje, czy jest w stanie podołać zadaniu, czy posiada stosowne zasoby do jego realizacji - w postaci kompetencji ludzi (jednostek i zespołów) i zasobów ekonomiczno-technicznych. Struktura pozwala realizować cel organizacji za pomocą zasobów, jakimi dysponuje organizacja, w postaci pracowników (jednostek i zespołów), technologii i finansów. Kultura organizacyjna wpływa na podsystemy (np. na wyznaczanie technologii wykorzystywanej w organizacji, elektroniczne, a nie papierowe przesyłanie danych), widoczna jest w doborze ludzi „pasujących” do zespołów - o odpowiednich kompetencjach i światopoglądach.

Poniżej przedstawiono cztery podsystemy pierwszego stopnia (rzędu). Są one interesujące - $\mathrm{z}$ punktu widzenia modelu organizacji tworzonego $\mathrm{w}$ niniejszej pra$\mathrm{cy}-\mathrm{z}$ dwóch powodów. Ze względu na systemowe ujęcie modelu w nich również zachodzą relacje wewnątrzpodsystemowe (są one opisywane i analizowane przez naukowców w szczegółowych badaniach tematycznych). Drugim powodem jest treściowa odrębność reprezentacji podsystemów przez wydawane przez nie komunikaty - inaczej rzecz ujmując: $z$ charakterystyki podsystemu wynika typ komunikatów, jaki jest z niego wydawany (czego dotyczą komunikaty, sposób w jaki są przekazywane). W konsekwencji po tych typach komunikatów rozpoznaje się rodzaj podsystemu. Dla dalszego konstruowania modelu organizacji jest to fragment systemu najbardziej wierny opisowi empirycznemu organizacji. W tym modelu podsystemy same w sobie stanowią bazę tematyczną dla wydawanych przez nie charakterystycznych treściowo komunikatów, łączonych następnie w wiązki w postaci relacji komunikowania.

Przykładowe elementy wewnątrzpodsystemowe, które podlegają relacjom wewnątrzpodsystemowym poszczególnych podsystemów pierwszego stopnia, zostały przedstawione w tabelach w załączniku. 


\subsubsection{Podsystem antropologiczny - relacje pierwszego stopnia}

Podstawą podsystemu antropologicznego jest człowiek - jednostka (Galton, 2004). Istnieje wiele rozmaitych płaszczyzn badawczych w tym zakresie, prace badawcze dotyczące człowieka w organizacji stanowią bowiem rozległą wiedzę, istotną dla organizacji. Tu w modelu jest miejsce na wiedzę zgromadzoną przez lata badań o człowieku w organizacji oraz o komunikowaniu się człowieka jako jednostki w organizacji. Komunikację traktuje się szeroko, jako sposób na „wydobycie” z człowieka informacji o nim samym - potrzebach, oczekiwaniach, celach, kompetencjach itp., dlatego poniżej w sposób ogólny zarysowuje się obszary tematyczne związane z jednostką w organizacji, które charakteryzują podsystem antropologiczny i uwidaczniają się w postaci komunikatów wychodzących z tego podsystemu (są wydawane przez przełożonych, podwładnych lub współpracowników, zależnie od pełnionych ról, jednak pełnione role ujawniają się w grupie, a to już element podsystemu społecznego).

Organizacje są płaszczyznami, na których jednostki mogą się realizować22, zaniedbanie tej perspektywy jest krótkowzroczne dla funkcjonowania organizacji (Świątek-Barylska, 2017a, s. 34-35; 2017b). Ludzie to jednostki skomplikowane, dlatego spostrzeżenia dotyczące ich zachowania mogą być badane przez wiele dyscyplin naukowych, w ramach rozmaitych perspektyw badawczych - źródła ich zachowań są głęboko zakorzenione w ekonomii, organizacji, socjologii, psychologii, filozofii, medycynie, prawie, prakseologii, cybernetyce i pedagogice. Stąd perspektywa jednostki jest na płaszczyźnie organizacji i zarządzania opisywana na rozmaite sposoby ${ }^{23}$, w dowolnych konfiguracjach, niezależnie jednak od wielości ująć teoretycznych sposobem poznania człowieka i jego potrzeb jest komunikacja, interakcja z drugim człowiekiem lub grupą ludzi (np. Sullivan, 2013).

22 Edwin A. Locke (1991, s. 288) zauważyt, że pracownicy zaniepokojeni tym, czy w trakcie wykonywania pracy zdołają wypełnić swoje potrzeby, niepokój ten wyrażają w codziennej rozmowie, zarówno werbalnie, jak i niewerbalnie. Nie wszystkie indywidualne potrzeby są istotne dla funkcjonowania organizacji, ale wszystkie są oznajmiane w procesie komunikacji. W określeniu potrzeb pomocne są rozmaite teorie motywacji - np. Abrahama Maslowa (1970) i Fredericka Herzberga (1982), Davida McClellanda (1965, s. 321-333; 1985), Richarda deCharmsa (1976; 1983, s. 391-398).

23 Człowieka w organizacji opisuje się na przykład przez pryzmat osobowości, wartości, podejmowania decyzji, postaw, motywacji, emocji i nastrojów (Robbins, Judge, 2011) albo osobowości, inteligencji (także emocjonalnej), charakteru, emocji, kompetencji i motywacji oraz decyzji i wyborów (Kuc, Moczydłowska, 2009, cz. I). 
Różnice indywidualne opisujące człowieka są przedmiotem zainteresowania rozmaitych badaczy ${ }^{24}$, nie istnieje taka cecha fizyczna (Jastrzębowski, 1997), forma zachowania, ani taka właściwość 25 psychiczna, pod względem której ludzie nie różniliby się26 (Strelau, 2004a, s. 654).

W kontekście tej pracy różnice indywidualne jednostek są rozpatrywane jako właściwości człowieka ujawniające się w procesie komunikowania na płaszczyźnie, jaką jest organizacja w znaczeniu rzeczowym. Różnice indywidualne ujawniają się w postaci zachowań komunikacyjnych i dopiero przez interakcje z drugim człowiekiem. Płaszczyzną, kontekstem, ramą ${ }^{27}$ dla komunikacji jest w tym przypadku środowisko

24 Już w starożytności występowała potrzeba klasyfikowania cech człowieka, postały zatem klasyczne podziały, na przykład typologia temperamentów Hipokratesa-Galena, zdolności umysłowe człowieka według Platona, pojęcie inteligencji określanej przez Cycerona jako właściwość umysłu, pod względem której ludzie różnią się między sobą, a także zróżnicowane osobowości według Teofrasa z Eresos oraz typologia właściwości fizycznych Hipokratesa (powiązanych z psychicznymi przez Kretschmera i Sheldona).

25 Część naukowców uznaje, że w latach pięćdziesiątych XX wieku upadła koncepcja cech osobistych przywódców. Pomiary okazały się niedokładne, co nie pozwoliło na wyizolowanie cech przywódczych. Teorię cech zamieniono na teorię zachowań przywódczych (w 1958 r. Robert Tannenbaum i Warren Schmidt opublikowali model przywództwa, wyjaśniający sposoby interakcji liderów z podwładnymi). Jako alternatywy teorii cech funkcjonują także teorie ról organizacyjnych (np. Mintzberga), teorie sytuacyjne (np. Herseya i Blanchard, 2007, s. 41-56) lub model Fiedlera (1965, s. 116; Fiedler, Chemers, 1974, s. 80), koncepcje kompetencji menedżerskich (Czapla, 2011). Nadal jednak bada się cechy osobowościowe w związku z zarządzaniem organizacjami, na przykład związki osobowości menedżera z jakością atmosfery w miejscu pracy. Wyniki wskazały na wysoką korelację cech osobowościowych z negatywnymi zachowaniami, na przykład wybuchami złości, krzykami, bezpodstawnym oskarżaniem innych, nadmiernym kontrolowaniem pracowników, ciągłym poczuciem zagrożenia, opornością na negatywny feedback, niechęcią do przyznawania się do błędów itd. (Hogan, Hogan, 2001, s. 40-51). Łatwo także znaleźć wyniki polskich badań dotyczących cech menedżerskich - na przykład Krystyna Kubik (2012) bada pożądane cechy (osobowości) menedżera, mające decydujący wpływ na sukces organizacji, a Adam Skrzypek (2013, s. 76) prezentuje wyodrębnione w toku badania cechy menedżera wiedzy. W ciągu ostatniej dekady ruch pozytywnej psychologii ponownie zainteresował się cechami i stanami psychologicznymi, podkreślono potrzebę masowych badań nad ludzkimi zaletami (Seligman, Csikszentmihalyi, 2000, s. 8; także Peterson, Seligman, 2004). Widoczne są implikacje pozytywnej psychologii dla zachowań organizacyjnych, świadczy o tym rozwój obszaru badań określanych jako pozytywne zachowania organizacyjne (Positive Organization Behavior - POB) pola badań z dziedziny zarządzania (Cameron, Dutton, Quinn, 2003). Na tym polu badawczym określane są mocne strony jednostek, zdefiniowane w kontekście POB jako cechy, które pozwalają jednostkom na osiąganie dobrych wyników lub na ich własne, możliwie najlepsze wyniki (Wood, Linley, Maltby, Kashdan, Hurling, 2011).

26 Scott A. Snell, Mark A. Shadur, Patrick M. Wright (2001) sugerują, że pracownicy mają psychologiczny kontrakt z firmą, oparty na zaangażowaniu, współpracy, wydajności i zgodności z nią. Im intensywniejszy kontrakt psychologiczny, tym wyższy stopień przyczyniania się do sukcesu ich firmy i wyższa aktywność zachowań komunikacyjnych.

27 Więcej o ramowaniu u George'a Lakoffa (2014). „Rama to struktura umysłowa, która kształtuje nasze cele, plany, metody działania, postrzeganie świata” (Lakoff w: Wężyk, 2014), 
pracy. Człowiek w organizacji zajmuje pozycję przełożonego lub podwładnego albo jest elementem zespołu, ale rozważany jest w tym podsystemie jako jednostka.

Wskazane elementy ogólne odnajduje się w środowisku pracy przez komunikację: inteligencję człowieka obserwuje się przez sposób jego wysławiania się, dobór słów, zasób słownikowy lub sposób konstrukcji zdań. Zdolności (np. pożądane w organizacji do uczenia się - Aguinis, 2018) będą obserwowalne przez szybkość rozumienia komunikatów, instrukcji, poleceń oraz liczby koniecznych powtórzeń komunikatów, zanim pracownik osiągnie biegłość w powierzonym zadaniu. Osobowość i temperament można dostrzec na przykład w tempie mówienia i mowie ciała, oszczędnej lub bogatej gestykulacji, a style poznawcze w sposobie zadawania pytań.

Ze względu na odmienną perspektywę poznawczą (czyli psychologię ogólną, a nie psychologię środowiska pracy) powyższy katalog pomija kilka istotnych aspektów badania jednostki w środowisku pracy - na przykład jego motywacji, stresu w pracy (np. wynikającego z niedopasowania czynników pracy do człowieka), jakości życia w pracy (Quality of Work-Life) (Maslach, Leiter, 2016) czy wzbogacenia pracy zawodowej i życia rodzinnego (Work Family Enrichment) (Greenhaus, Powell, 2006, s. 72-92).

Style zarządzania przełożonych wiązane są z ich stylem komunikacji - przykładowo Lewin, Likert i Bales, Blake i Mouton, Reddin, Hersey i Blanchard, Tannenbaum i Schmidt lub Goleman wyodrębnili rozmaite style, które odzwierciedlają się w typach (treści) komunikatów i sposobie (formie) komunikowania przełożonego.

Jednostki w organizacji działają również na podstawie własnych przekonań - ogólnego rozumienia świata, widocznego w zachowaniu i co ważne: wypowiadanego (Nespor, 1987, s. 317-328). Przekonania odgrywają kluczową rolę w motywowaniu ludzi do działania.

Określa się również przyczyny odniesionych sukcesów i porażek jednostek podczas realizowania zadań (Weiner, 1986; 1994a; 1994b; 2010; Kanfer, 1990, s. 75-170; Graham, 1991, s. 5-39), zwłaszcza gdy wynik jest ważny lub nieoczekiwany (Stipek, 1993). Ujawniają się one w komunikatach wydawanych przez ludzi (np. „udało mi się” versus „napracowałem się”).

Zagadnienia zmiany przekonań na temat własnych możliwości jednostki bada się za pomocą perswazji słownej (Bandura, 1986; Gist, 1987, s. 472-485; Wood, Bandura, 1989, s. 361-84) oraz przez poprawę samopoczucia fizycznego (Gist, 1987, s. 472-485; Wood, Bandura, 1989, s. 361-384; Schunk, Pintrich, Meese, 2008). Słowna perswazja jest powszechnie stosowana, aby namówić ludzi, przekonać ich, że mają zdolność osiągania tego, czego chcą. Innym sposobem modyfikowania

według Lakoffa bowiem „Słowa odzwierciedlają jedynie nasze rozumienie świata, nie rzeczywistość". 
przekonania jednostki na własny temat jest zwiększenie jej dobrego samopoczucia fizycznego i zmniejszenie stresu.

W kontekście motywacji wewnętrznej jednostki cele są zawsze zogniskowane w osobie, chociaż są one często określane na podstawie informacji i komunikatów kontekstowych (Ford, 1992, s. 112-115). Teoria wyznaczania celów sugeruje, że konkretne i trudne, ale osiągalne cele mogą zwiększać motywację jednostki i często to robią. Komunikaty o postępach w osiąganiu celów (rozmowy, raporty) wspierają wysiłek i wytrwałość jednostki lub dostarczają informacji do ponownego określania strategii lub jej modyfikacji dla zwiększenia skuteczności (Pinder, 1998; Latham, 2000; Fried, Slowik, 2004, s. 404-422; Locke, Latham, 1990; 2002; 2005; 2009; Ordonez, Schweitzer, Galinsky, Bazerman, 2009, s. 82-87). Jednostka potrzebuje znać sens swoich działań oraz ocenić rozbieżność między stanem obecnym a pożądanym, a ocena skłania do analitycznego myślenia i poprawy wydajności (Bandura, 1993, s. 117-148).

Charakterystyki człowieka (psychologiczna, antropologiczna, związane z wychowaniem itp.) są również obserwowalne przez komunikaty jednostki (zarówno treść, jak i forma). W tym zakresie prowadzono badania stylu komunikowania jednostek, pierwotnie najczęściej na gruncie lingwistyki, psychologii, w terapii małżeństw, a następnie podejmowano próby ich implementacji do środowiska organizacji. Wnioski z tych badań mają ograniczone zastosowanie w komunikacji wewnątrzorganizacyjnej, dają jednak obraz złożoności zagadnienia, wskazują rozmaitość ujęć oraz pozwalają sformułować wskazówki pomocne w pewnych warunkach do rozwiazywania problemów komunikacyjnych w organizacji.

Przykładem metody na określenie stylu poznawczego osoby są wypracowane na gruncie lingwistyki wskaźniki stylów mówienia Suitberta Ertela 28 (1986). Oblicza się częstość występowania pewnych określonych klas form wyrazowych $\mathrm{w}$ analizowanym komunikacie $\mathrm{w}$ porównaniu z częstością pojawiania się form wyrazowych należących do klas skontrastowanych pod jakimś względem z tymi pierwszymi. Zakłada się, iż wyodrębnione w ten sposób wskaźniki stylów mówienia są behawioralnym przejawem charakterystycznego dla danej osoby stylu poznawczego (Obrębska, Obrębski, 2011, s. 189). Język jest narzędziem rozpoznawania nastawienia do dokonywania zmian, prymatu działania lub przeżywania i analizowania. Nastawienie na zmienianie świata i jego przekształcanie przekłada się na bardziej dynamiczne i „działaniowe” formułowanie komunikatów, co język odzwierciedla nagromadzeniem czasowników. Jednocześnie mniejsze znaczenie

28 Ertel posłużył się w swoich badaniach następującymi wskaźnikami stylów mówienia: wskaźnikiem nieosobistych odniesień, wskaźnikiem mnogości, wskaźnikiem klasyfikacji, wskaźnikiem nominalizacji, wskaźnikiem abstrakcyjności i wskaźnikiem dogmatyzmu. Szczegółowy opis poszczególnych wskaźników por. Obrębska, Obrębski, 2011, s. 189-190. 
mają inne osoby, rzeczy i ich właściwości, a także wszystko to, co jest statyczne i niezmienne, co język obrazuje zaniżonym poziomem rzeczowników i przymiotników. Ertel uważa, że posługiwanie się rzeczownikami wymaga przetwarzania złożonej, zwartej (condensed) informacji, czasowniki zaś są strukturami zdecydowanie prostszymi poznawczo 29 (Ertel, 1986, s. 139-163).

Paul Watzlawick, Janet Helmick Beavin i Don D. Jackson uznają, że każda wiadomość ma dwa wymiary: sprawozdanie i polecenie (report, command):

Aspekt sprawozdawczy komunikatu przekazuje informacje i dlatego jest synonimem w komunikacji międzyludzkiej, w której wiadomość niesie treść. Wiadomość może być o czymkolwiek, co jest komunikowalne, niezależnie od tego, czy dana informacja jest prawdziwa, czy fałszywa, ważna, nieważna, nierozstrzygalna. Aspekt polecenia, z drugiej strony, odnosi się do tego, w jaki sposób należy traktować wiadomość (jaki jest jej rodzaj), a co za tym idzie, ostatecznie odnosi się do relacji między komunikującymi się (Watzlawick, Beavin, Jackson, 1967, s. 50-51).

Tak więc zarówno wymiar treści, jak i relacji to istotne części komunikacji. Praca cytowanych autorów przyczyniła się do prowadzenia szeregu badań, w tym także Roberta W. Nortona ${ }^{30}$, nad tymi wymiarami, a konkretnie ocenami sposobu przekazywania składnika relacyjnego.

Norton (1978) zidentyfikował dziewięć wymiarów stylu osoby komunikującej31 - stylu nadawcy ${ }^{32}$, które nazywał także konstruktami szczegółowymi

29 Podobne wnioski w badaniach uzyskali Dawid Pablo Boder (1927, s. 328-329) w obszarze języka angielskiego - wprowadził wskaźnik przymiotników-czasowników (AVQ - Adjective-Verb Quotient) oraz Władysław Jacek Paluchowski (2010, s. 66): ,intensywność używania czasowników wskazuje na aktywny, dynamiczny, niespokojny, emocjonalny i niekiedy mało refleksyjny styl mówienia, a wysoka ich proporcja wśród przymiotników jest wskaźnikiem poziomu skoncentrowania na sobie, podczas gdy niska wskazuje na orientację na otoczenie".

30 Praca Watzlawicka, Beavin i Jacksona wpłynęła także na późniejsze badania Nortona z 1983 roku. Norton uznał, że styl jest „funkcją dającą formę treści” (s. 19). „Oznacza to, że sygnały tworzą oczekiwania lub dostarczają wskazówek, co należy zrobić ze znaczeniem dosłownym” (s. 20). Ponadto zaproponowat, że styl jest „funkcją konsekwentnie powtarzających się stowarzyszeń komunikacyjnych” (s. 19), co wyjaśnit: „Tutaj styl nie tylko pociąga za sobą pierwszą funkcję, ale jest stosunkowo trwałym wzorem oddziaływania człowieka, związanym z osobą" (s. 19).

31 Nazwał je Comunicator Style - styl osoby komunikującej/komunikującego. Dosłowne tłumaczenie polskie jest wyjątkowo niezgrabne. W niniejszym opracowaniu przyjęto zatem tłumaczenie styl nadawcy.

32 Badania Nortona w zakresie stylu nadawcy zainspirowały wielu naukowców i doprowadziły do kolejnych badań nad komunikacją w kontekście interpersonalnym, na przykład styl komunikowania w terapii (Pettegrew, 1977), styl komunikacji menedżera (Bradley, Baird, 1977; Bednar, 1982; Infante, Gorden, 1991; Myers, Rocca, 2000), styl komunikacji małżeńskiej 
(subkonstruktami ${ }^{33}$ ), oraz dziesiąte kryterium, subkonstrukt zależny, czyli obraz nadawcy (communicator image) definiujący jego styl. Dominujący (dominant) nadawca mówi często, przejmuje odpowiedzialność w sytuacjach społecznych, jest silny i kontroluje nieformalne rozmowy. Dramatyczny (dramatic) nadawca manipuluje, wyolbrzymia, fantazjuje, przedstawia opowieści, metafory, pracuje rytmem, głosem i innymi narzędziami stylistycznymi w celu podkreślenia lub zbagatelizowania treści. Kłótliwy (contentious) nadawca wymienia argumenty, prowadzi spory. Ożywiony (animated) nadawca zapewnia częsty i trwały kontakt wzrokowy, często korzysta z mimiki (prezentuje rozmówcy wiele wyrazów twarzy) i gestów. Pozostawiającego wrażenie (impression leaving) zapamiętuje się z powodu odwzorowywań - podkreśla to, co mówi i sposób, w jaki mówi. Nadawca zrelaksowany (relaxed) jest spokojny i spójny, nawet pod presją nie jest podenerwowany i nie przejawia nerwowych zachowań. Uważny nadawca (attentive) naprawdę lubi słuchać innych, wyraża zainteresowanie tym, co ktoś inny ma do powiedzenia i celowo reaguje w taki sposób, aby druga osoba wiedziała, że on słucha. Otwarty nadawca (open) łatwo ujawnia osobiste informacje o sobie, łatwo wyraża uczucia i emocje, nie jest skryty, zdystansowany, jest szczery. Przyjazny nadawca (frien$d l y$ ) zachęca ludzi, docenia wkład innych, otwarcie wyraża zachwyt i ma tendencję do bycia taktownym. Styl nadawcy (communicator image) charakteryzuje osobę posiadającą wizerunek dobrego nadawcy, łatwość rozmowy z obcymi, z małymi grupami i osobami płci przeciwnej. Aby zmierzyć te style, Norton (1978) opracował ${ }^{34}$ miernik stylu nadawcy, w którym dziewięć wymiarów (odejmowanie wrażeń, kontrowersyjne, otwarte, dramatyczne, dominujące, odprężone, przyjazne, uprzejme i animowane) pełni funkcję predykatorów, które łączą się w celu określenia odczuwanego obrazu nadawcy jako zmiennej kryterialnej.

Norton (1983) badał komunikację wśród lekarzy przez pryzmat sposobu przekazu (nie zawartości merytorycznej komunikatu). W rezultacie zaproponował następujące style komunikacji: wyluzowany (relaxed), otwarty (open), dominujący (dominant), dramatyczny (dramatic). Te badania implikują w zasadzie jeden styl - empatyczny, ciepły i przyjazny - jako najbardziej skuteczny styl komunikowania.

(Honeycutt, Wilson, Parker, 1982) i styl komunikowania nauczycieli (Norton, 1977; Norton, Nussbaum, 1980).

33 Wiele ze zmiennych zostało przyjętych z badań wcześniej przeprowadzonych przez takich autorów jak: Timothy Leary (1957), William C. Schutz (1958), Richard Mann, Graham Gibbard i John Hartman (1967), Robert Bales (1970), Morton Lieberman, Irvin Yalom, Matthew Miles (1973) oraz Robert W. Norton (1983).

34 Przeprowadzone przez niego badania są znacznie bardziej skomplikowane - dziewięć wymiarów podzielił na pięć klastrów, później zmodyfikowanych do sześciu klastrów dla określenia profili stylu. Styl komunikującego i profil stylu mają być spójne pod względem kontekstu, sytuacji i czasu (Norton, 1983). 
To uogólnienie jest jednak zbyt uproszczone (Milmoe, Rosenthal, Blane, Chafetz, Wolf, 1967; Hall, Roter, Rand, 198135).

Sytuacyjna teoria publiczności pozwala analizować różne postawy jednostek wobec komunikacji (Grunig, 1978; Grunig, Hunt, 1984). Ludzie mogą biernie przetwarzać otrzymane informacje lub aktywnie szukać, interpretować i rozpowszechniać je, aby następnie angażować się w działania. Aktywne lub pasywne zachowania komunikacyjne wynikają z ich poziomu świadomości (przełożeni i podwładni) na temat sytuacji, ze sposobu postrzegania przeszkód, które prowadzą do naprawienia sytuacji i z ich zaangażowania w danej sytuacji. Osoby bardziej świadome i zaangażowane są aktywniejsze, natomiast ci, którzy sami wierzą, że są bezsilni, wykazują tendencję do biernych zachowań komunikacyjnych (Mazzei, 2010, s. 222-224). Badania terenowe, w których zastosowano teorię, Jamesa Gruniga wykazały, że aktywne zachowania komunikacyjne pracowników organizacji różnią się od pasywnych tym, że aktywni pracownicy angażują się w komunikację międzyludzką poziomą i cross-funkcjonalną, zasięgają informacji z różnych źródeł, rozmawiają z innymi specjalistami i osobami ze środowiska oraz poszukują informacji zorientowanych na zarządzanie, pracę i zadanie (Grunig, Hunt, 1984).

Konsekwencją różnic indywidualnych jednostek jest rozpoznanie stylów komunikacji ${ }^{36}$, rozumiane jako zawartość treściowa typów (kategorie), na które można podzielić ludzi ze względu na sposób, w jaki funkcjonują w procesie komunikacji (Pankiewicz, 2007, s. 41). Te cechy ujawniają się w kontakcie, w rozmowie z innymi ${ }^{37}$. Style są konstruowane na podstawie rozmaitych kryteriów. Najprostsze kategoryzacje proponują dwie graniczne postawy. Inne proponują dwa wymiary, które skrzyżowane ze sobą prowadzą do czterech typów. Jeszcze inne wprowadzają kategorie pośrednie, prowadząc do sześciu lub ośmiu propozycji. Wszystkie one stanowią zbiór typów idealnych - w zasadzie niewystępujących w rzeczywistości w sposób bezpośredni (czysty), niemniej stanowiących przyczynek do uporządkowania złożonej rzeczywistości. Przykłady przedstawiono poniżej - w kolejności od najprostszych.

Kierując się kryterium aktywności słownej, Zbigniew Nęcki (1996) wyróżnił aktywny i pasywny styl komunikacyjny. Styl aktywny charakteryzuje osoby z dużą gotowością do komunikowania się, znacznym wkładem komunikacyjnym

35 W tych badaniach stwierdzono, że pacjenci pozytywniej postrzegają werbalne wyrażenie obawy związane z wokalnym gniewem lub niepokojem. Jednocześnie nie preferują lekarzy dominujących (Hall, Roter, Rand, 1981).

36 Istnieje wiele sposobów określania komunikacji. Tutaj chodzi wyłącznie o takie, których zastosowanie jest możliwe i zasadne na gruncie organizacji.

37 Definicja stylu komunikacyjnego uznawana w lingwistyce to „syndrom określonych zachowań werbalnych, który ujawnia się w rozmowie i odzwierciedla stosunek rozmówców do siebie" (Grzesiuk, Trzebińska, 1978, s. 106). Definicja ta ogranicza styl do komunikacji werbalnej. 
w postaci skłonności do rozpoczynania rozmowy i jej podtrzymywania oraz znaczną siłą przebicia. Pasywny styl komunikacyjny charakteryzuje mała gotowość do komunikowania się, manifestująca się oczekiwaniem, że ktoś inny rozpocznie rozmowę i będzie dbał o jej przebieg, występuje mały wkład komunikacyjny oraz mała siła przebicia.

Lidia Grzesiuk badała zachowania, które ujawniają się w procesie komunikacji. Za kryterium podziału przyjęła punkt koncentracji jednostki podczas interakcji i wskazała na trzy kategorie stylów komunikowania (Grzesiuk, 1979, s. 32):

1) allocentryczny - jednostki koncentrują się zwykle na osobie partnera, przypisują partnerowi pozycję wyższą niż sobie;

2) egocentryczny - prezentują go osoby mające wzgląd przede wszystkim na siebie, przypisujące sobie pozycję wyższą niż partnerowi; styl allocentryczny i egocentryczny są stylami niepartnerskimi i częściej prowadzą do konfliktów;

3) styl partnerski prezentują osoby skoncentrowane podczas interakcji zarówno na własnej osobie, jak i na osobie partnera, przypisujące sobie i partnerowi pozycje równorzędne.

James Hawkins, Carol Weisberg i Dixie Ray przyjmują kryterium stopnia otwartości w ujawnianiu uczuć oraz rodzaju komunikacji między partnerami ${ }^{38}$. Wyodrębnili oni cztery podstawowe style komunikacji: styl w pełni otwarty - partnerski, styl konwencjonalny, kontrolujący oraz spekulatywny (Hawkins, Weisberg, Ray, 1980; Ryś, 1993, s. 46-47). Partnerski styl komunikacji polega na dialogu, umiejętności słuchania, bezpośrednim i otwartym ujawnianiu uczuć i myśli, odczuć wywołanych zachowaniem partnera, na wyznaczaniu i realizowaniu wspólnych celów. Osoby komunikujące się w ten sposób respektują przeżycia i odczucia partnera, dlatego nie narzucają sobie nawzajem zdań, wyrażają swoje prawdziwe intencje, nie dążą do jednomyślności, chyba że w kwestiach istotnych dla związku. Styl konwencjonalny charakteryzuje się niskim poziomem wzajemnej otwartości, nieujawnianiem uczuć, myśli, przeżyć i poglądów. Taka komunikacja zmierza do unikania rozwiązywania problemów, które ujawniłyby się w otwartych rozmowach małżonków. W stylu kontrolującym jeden z partnerów zmierza do podporządkowania sobie drugiego. Komunikacja często jest tutaj manipulacyjna. Nadawca z reguły nie ujawnia prawdziwych zamiarów, a jeżeli - to tylko w formie niewerbalnej. Styl spekulatywny charakteryzuje się pośrednim sposobem wyrażania odczuć i myśli.

Stylami komunikowania się w sytuacjach konfliktowych i błędami w komunikacji w rodzinie (Bradshaw, 1994) zajmowała się kolei Virginia Satir ${ }^{39}$. Badając in-

38 Badania i wnioski dotyczyły małżeństw i relacji komunikacyjnych między małżonkami. Wyniki antycypowane także na grunt organizacji.

39 Model powstał na podstawie podejścia do terapii rodzinnej w zakresie terapii jako procesu jednoczesnego tworzenia rzeczywistości, użycia języka i narracji oraz roli terapeuty jako 
terakcje konfliktowe oraz sposób zachowania się ludzi, wyróżniła i opisała cztery wadliwe typy komunikacji i jeden prawidłowy. Wadliwe style ${ }^{40}$ (Satir, Banmen, 1991) to:

1) oskarżający (blaming) - jednostka chce sprawiać wrażenie osoby silnej i niezależnej; w komunikacji jest nastawiona na krytykowanie innych; komunikat przekazywany w organizacji to: „Ty nic dobrego nie zrobiłeś, nie pomogłeś w tym projekcie, i zawsze mi przeszkadzasz";

2) uległy (placating) - osoba, która robi wszystko, aby nie zdenerwować ludzi w jej otoczeniu, jest uległa, bezustannie przepraszająca; przekazuje komunikat: „Zrobię jak chcesz, żebyś był zadowolony”;

3) superracjonalny (being super-reasonable) - nikłe okazywanie uczuć przez jednostkę, sztywna postawa, brak kontaktu wzrokowego z rozmówcą, używanie skomplikowanych sformułowań, niezrozumiałych słów; przykładowy komunikat to: „Wychodząc z finalnego aspektu i dochodząc do kontrowersji można zauważyć, że zaistniało pewne drobne nieporozumienie. Należałoby się zastanowić nad konsekwencjami takiego postępowania”;

4) rozkojarzony (being irrelevant), który stara się rozładować napiętą sytuację przez zwracanie uwagi na rzeczy nieistotne, niezwiązane $z$ tematem rozmowy; komunikat: „A te faktury miały jakieś znaczenie? Och, nic się nie stało, a w jakim kolorze zrobić prezentację?".

Natomiast prawidłowa komunikacja występuje, gdy dochodzi do prawdziwego kontaktu między dwiema osobami. Każdy ma prawo w pełni się wypowiedzieć i czuje, że może to zrobić (Satir, Banmen, 1991).

Lidia Jabłonowska (2012, s. 74-77) przedstawiła style komunikowania, łącząc dwa wymiary o skrajnych charakterystykach: dominacja - nienarzucanie się oraz ekspansywność - powściągliwość. Połączenie tych wymiarów w macierz pozwala wyróżnić cztery podstawowe style: wspierający, promujący, analityczny i kontrolujący. W procesie komunikacji każdy jej uczestnik:

[...] bez względu na pozycję i rolę, świadomie bądź nie, dokonuje tego rodzaju oceny innych, poprzez obserwacje ich zachowania względem siebie. Nie jest to obiektywne postrzeganie właściwości budowanych relacji, np. pracownik-pracownik, pracownik-menedżer, czy obiektywne postrzeganie tendencji osobowościowych (cech) konkretnego członka organizacji, a jedynie ich subiektywna ocena (Jabłonowska, 2012, s. 51).

uczestnika-moderatora.

40 John Bradshaw (1994) używa określeń: styl zjednywacza, obwiniacza, komputerowo-racjonalny, mąciciela. 
Wiele koncepcji stylów komunikowania powstało na podstawie teorii osobowości. Harry Sullivan podkreślał, że osobowość powstaje ze zdarzeń interpersonalnych, a nie wewnątrzpsychicznych, jest to „względnie trwały układ powtarzających się sytuacji interpersonalnych, charakterystycznych dla życia danego człowieka” (Hall, Lindzey, 1998, s. 172). Dodawał również, że osobowość jest tworem teoretycznym i nie można jej obserwować i badać w oderwaniu od momentów, w których jednostka wchodzi w relacje z innymi ludźmi, gdy zachowuje się w jakiś sposób w stosunku do innego człowieka lub grupy ludzi, bo osobowość przejawia się w kontaktach interpersonalnych. Stąd koncepcja stylu komunikowania oparta na procesach poznawczych wymienia trzy hierarchicznie zależne rodzaje doświadczeń (Sullivan): prototaktyczne - rejestracja pobudzeń płynących z organizmu (noworodki, niemowlaki), stanowiące warunek pojawienia się pozostałych typów; parataktyczne - polegające na dostrzeganiu związków przyczynowo-skutkowych między zdarzeniami występującymi w podobnym czasie, ale logicznie ze sobą niezwiązanymi (np. przesądy: gdy czarny kot przebiegnie przez drogę, to...); syntaktyczne - procesy związane z mową, umożliwiające logiczne uporządkowanie doświadczeń i pozwalające na porozumiewanie się.

Tabela 9. Zachowania charakterystyczne dla stylów komunikacyjnych wedtug Lidii Jabłonowskiej

\begin{tabular}{|l|l|}
\hline $\begin{array}{l}\text { Styl komuni- } \\
\text { kacyjny }\end{array}$ & \multicolumn{1}{c|}{ Zachowania } \\
\hline $\begin{array}{l}\text { Wspierający } \\
\text { NE }\end{array}$ & $\begin{array}{l}\text { Przyjazny, pomocny, empatyczny, ostrożny, życzliwy, wartościujący, sprawia } \\
\text { wrażenie osoby miłej, sprawdza się w tworzeniu dobrej atmosfery, dyplomata, } \\
\text { nastawiony na proces (proces = efekt), impulsywny, uczucia przygłuszają fakty }\end{array}$ \\
\hline $\begin{array}{l}\text { Analityczny } \\
\text { NP }\end{array}$ & $\begin{array}{l}\text { Logiczny, uporządkowany, dokładny, cierpliwy, nieustępliwy, metodyczny, } \\
\text { konsekwentny, szczegółowy, obiektywny, buduje struktury, systemy, } \\
\text { wymagający, przewidywalny, nie ulega wybuchom emocji, stabilny, } \\
\text { przywiązany do zasad }\end{array}$ \\
\hline $\begin{array}{l}\text { Promujący } \\
\text { DE }\end{array}$ & $\begin{array}{l}\text { Innowacyjny, z pomysłami, entuzjastyczny, wizjoner, refleksyjny, oryginalny, } \\
\text { towarzyski, otwarty na przyjmowanie i dawanie informacji zwrotnych, nagina } \\
\text { zasady, lubi błyszczeć, toleruje niedomówienia }\end{array}$ \\
\hline $\begin{array}{l}\text { Kontrolujący } \\
\text { DP }\end{array}$ & $\begin{array}{l}\text { Pragmatyczny, dynamiczny, preferuje działanie, zorientowany na zadanie, } \\
\text { domaga się konkretów, konkurencyjny, ryzykowny, niecierpliwy, } \\
\text { zorganizowany, stanowczy, nastawiony na cel, rezultat, efekt }\end{array}$ \\
\hline
\end{tabular}

Źródto: Jabłonowska, 2012, s. 75-76.

Koncepcja stylów interpersonalnych J.S. Wigginsa (Lorr, Strack, 1990, s. 423-425) oparta jest na teorii osobowości Sullivana. Wiggins stworzył ${ }^{41}$ okrągłą, dwuwymiarową skalę określoną przez osiem punktowych ocen - skalę

41 Timothy Leary jest z kolei jednym z autorów odkrycia, że zmienne określające relacje interpersonalne tworzą uporządkowaną kołową strukturę. 
międzypersonalnych przymiotników (Interpersonal Adjective Scales - IAS). Podstawowe dwa wymiary to miłość (LOV), rozumiana jako ciepło kontaktu i przyznawanie sobie i innym podmiotowości i wartości w relacjach, i dominacja (DOM), wiążąca się z dominacją i przyznawaniem sobie i innym statusu i ważności. Sposób komunikowania zależny jest od rodzaju relacji interpersonalnych, podzielonych na osiem rodzajów uporządkowanych w strukturę kołową, ze względu na wskazane dwa kryteria. Wyróżnione typy to: pewny siebie - dominujący (PA), towarzyski - ekstrawertywny (NO), ciepły - zgodny (LM), niezarozumiały - szczery (JK), skromny - uległy (HI), powściągliwy - introwertywny (FG), zimny - nieczuły (DE) oraz arogancki - wyrachowany (BC) (Yarnold, Grimm, Lyons, 1987, s. 185-196).

Podobną strukturę kołową wykorzystano, prezentując hierarchię komunikacyjnych potrzeb pracowników (rysunek 18).

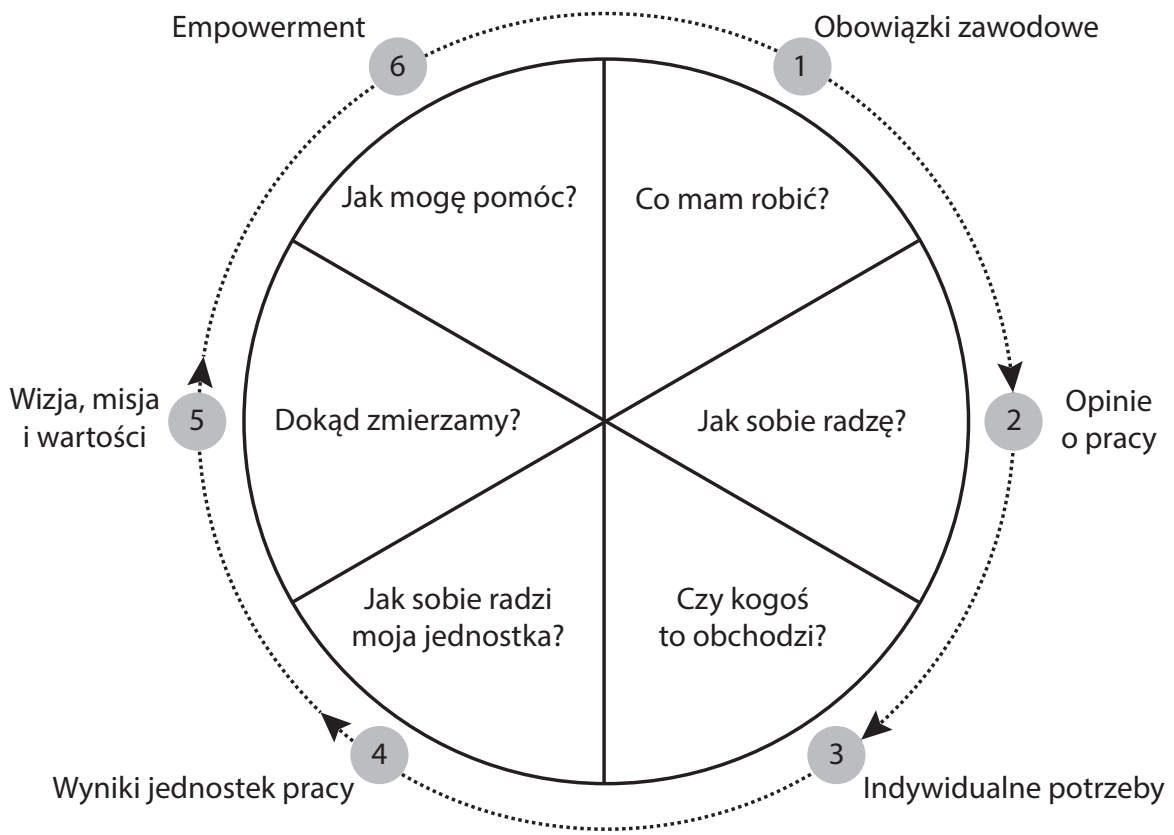

Rysunek 18. Hierarchia komunikacyjnych potrzeb pracowników Źródto: D’Aprix, 1996, w: Tariszka-Semegine, 2012, s. 91.

Jednostkę charakteryzuje jej sposób komunikowania, tak samo na płaszczyźnie organizacji, jak i w życiu codziennym, jednak w obszarze organizacji istnieje niedosyt badań w tym zakresie. Najczęściej prowadzone badania, dotyczące stylów i sposobów komunikowania jednostki, obejmują w zasadzie komunikację lekarzpacjent, nauczyciel-uczeń oraz komunikację między małżonkami. „Oczywistość” 
komunikacji w organizacji sprawia, że przyjmuje się ją za pewnik. Powyżej przedstawiono nieliczne opracowania dotyczące komunikacji jednostki w organizacji, ponieważ zwykle dotyczą one grupy lub zespołu.

\subsubsection{Podsystem społeczny - relacje pierwszego stopnia}

Grupy, aby realizować swoje zadania, muszą się komunikować ${ }^{42}$. Komunikacja jest niezbędna na każdym etapie tworzenia grupy i na każdym etapie prac wykonywanych przez grupę. W podsystemie społecznym podstawowym elementem zainteresowań są grupy i zespoły zadaniowe, ich wewnętrzne relacje i oddziaływania między grupami.

Naukowcy koncentrują się na jednostkach pracy (work units) i zespołach pracy (work teams) (Cummings, Worley, 2009), a w literaturze polskiej używają odpowiednio określeń zespoły i grupy (robocze, zadaniowe). Zespoły (jednostki pracy) składają się z osób związanych z wysoką współzależnością (np. tradycyjną linią montażową, określonym urzędem), korzystają z efektu synergii dzięki koordynacji wysiłków. W punkcie 4.2.2 (inaczej niż w kolejnych) pojęcia grup i zespołów w zasadzie traktuje się w sposób tożsamy, ich rozróżnienie nie jest tu bowiem konieczne, a określenia stosowane są zamiennie.

Mała grupa ${ }^{43}$ nie oznacza zebrania diad komunikacyjnych w jednym miejscu. W komunikacji interpersonalnej „utrata jednej jest utratą wszystkich” (Wilmot, 1987, s. 19), ponieważ zanika zdolność do nawiązania relacji. Utrata elementu lub jego pozyskanie w małej grupie znacząco zmienia liczbę interakcji i współzależność, a także komunikację między członkami. Grupy stosują zasady, role i koncepcje niezbędne do zrozumienia organizacji. Kiedy nowa osoba dołącza do organizacji, początkowo wpływ mają na nią współpracownicy tworzący grupę bezpośrednią. Funkcja informacyjno-komunikacyjna na wczesnych etapach zaangażowania pracownika jest znaczna (nowy pracownik dowiaduje się, jakie

42 Różnicę między komunikacją interpersonalną a grupową można przedstawić za pomocą dziewięciu kryteriów stanowiących jednocześnie elementy definicji. Komunikacja w małych grupach to: (1) komunikacja twarzą w twarz, (2) wśród niewielu osób (3-20, w zależności od badacza), (3) mających wspólny cel, (4) posiadających poczucie przynależności do grupy i (5) poczucie współzależności, (6) tworzących i egzekwujących normy i wspólne standardy, (7) wywierających wpływ na siebie nawzajem (8) przez pewien określony czas, (9) za pomocą pewnych wzorców strukturalnych (Harris, Sherblom, 2005). Czyli uczestnicy tączą się umyślnie w dążeniu do osiągnięcia pewnego wspólnego celu lub celów, przy wykorzystaniu pewnych standardów.

43 W zasadzie wszystkie grupy to sieci, ale nie wszystkie sieci to grupy. Sieć może obejmować dwie osoby lub może rozciągać się w całej organizacji. Szczególnie interesujące są koncepcje sprzężenia i powiązania. Gdy podsystemy (np. członkowie zespołu badawczo-rozwojowego) stają się silnie współzależni, są ściśle powiązani. Większość małych grup doświadcza silnego sprzężenia, gdy koncentrują się na zadaniu lub interakcji społecznej. 
panują zasady w organizacji, po prostu pytając o nie), maleje z czasem spędzonym w organizacji. Podczas transformacji w pełnoprawnego członka organizacji pracownik staje się mniej zależny od interpretacji i komunikatów innych członków grupy, a bardziej polega na własnej percepcji i interpretacji rzeczywistości (McShane, Von Glinow, 2000). „Nowicjusze” nie są w pełni świadomi oczekiwań grupy lub standardowych procedur operacyjnych.

Komunikacja w grupie, w organizacji służy przekazywaniu informacji, wyrażaniu emocji, motywacji i kontroli. Jest realizowana przez przekazywanie danych i wskazówek koniecznych do pracy i działań organizacyjnych, do podejmowania decyzji, oceny proponowanych rozwiązań, poprawy sprawności działań w organizacji. John F. Cragan i David W. Wright ${ }^{44}$ (1991) wyróżnili cztery płaszczyzny identyfikacji rozmów grupowych wewnątrz organizacji - rozwiązywanie problemów, role, podnoszenie świadomości grupowej oraz spotkania. Jeżeli płaszczyzny Cragana i Wrighta są realizowane w organizacji za pomocą wzajemnej komunikacji członków grupy, to element „spotkanie” jest narzędziem realizacji trzech pozostałych, bez względu na sposób realizacji spotkania - rzeczywisty lub wirtualny. A jednak spotkanie nie jest niezbędne do wzajemnego komunikowania się członków zespołu i skutecznego realizowania działań - na przykład asynchroniczne sposoby komunikowania nie spełniają kryterium spotkania, a pozwalają na skuteczne rozwiązywanie problemów, pełnienie ról w grupie, osiąganie celu grupowego, a także podnoszenie świadomości grupowej.

Edwin A. Locke i Gary P. Latham (Locke, 1968, s. 157-189; Baron, 1998, s. 275-294; Latham, 2000, s. 107-119; Locke, Latham, 2005, 2009, s. 17-23) rozpoczęli badania nad istotą ustalania celów w kontekście teorii motywacji. Ustalili cztery warunki ich osiągania (Locke, Latham, 1990) - cele muszą być konkretne, trudne, osiągalne i pracownicy muszą być zaangażowani w ich realizację. Spełnienie tych warunków jest skutecznym sposobem na zwiększenie motywacji i wydajności (Mento, Locke, Klein, 1992, s. 395-405; Wright i in., 1994, s. 795-803; Latham, 2000, s. 107-119; Locke, Latham, 2002, s. 705-717). Pracownik chętniej godzi się na rozwiązania, w doborze których brał udział. Cele ustalane wspólnie są od razu znane pracownikom, a ustanawiane odgórnie wymagają ogłoszenia - na zebraniu, w rozmowie bezpośredniej, e-mailem itp.

44 Cragan i Wright (1991, s. 9) zdefiniowali małą grupę jako „Kilka osób zajmujących się komunikacją i interakcją w czasie, zazwyczaj w kontaktach bezpośrednich, osoby te mają wspólne cele i normy oraz opracowały wzór komunikowania, aby osiągnąć swoje cele w sposób zależny od siebie nawzajem". 
Wartości grupowe decydują na przykład o tym, czy pracownicy dzielą się informacjami, czy też nie, określają poziom i zakres zaufania ${ }^{45}$ do współpracowników. Istotne w pracy jest to, czy przełożony ma do pracownika zaufanie, że wykona on pracę dobrze. Jednocześnie można nie mieć zaufania, że wykona ją na czas, lub też można mieć zaufanie, że dobrze wykona pracę (np. obetnie mi włosy), ale nie mieć zaufania do tej osoby ogólnie. Wartości grupowe są także połączone w rodzajem przywództwa stosowanego w zespole - czy zespół jest budowany na życzliwości, czy na strachu. Grupy są skuteczniejsze w rozwiązywaniu problemów niż pojedyncze osoby (Berko, 1996). Nawet jeśli proponowane rozwiązanie powstaje w długim czasie, „spotkania grupowe często służą jako główny punkt wspierania morale grupowego i motywowania pracowników do wyższego poziomu wydajności” (Cragan, Wright, 1991, s. 239).

Pełnione w zespole role, a także rodzaj przywództwa i sprawowanej władzy można rozpoznać po komunikatach, ich zawartości merytorycznej oraz sposobie przekazywania - konstrukcji wypowiedzi, tonie głosu, postawie podczas przekazu, a także po elementach komunikacji niewerbalnej (Rowe, Boulgarides, 1992, s. 29).

Podsystem społeczny obejmuje także zagadnienia związane z konfliktem, które są konstruktywne lub destruktywne, ale zawsze nieuniknione (Tjosvold, Wong, Feng Chen, 2014, s. 546) - niezależnie, czy traktowane jako zjawisko niechciane (Schotter, Beamish, 2011; Deutsch, Coleman, Marcus, 2014; Van Gramberg i in., 2017), czy nieuniknione (Mazanowska, 2015, s. 55-57). Ich źródło, przebieg, postępowanie w kierunku rozwiązania wymaga artykulacji (De Dreu, Weingart, 2003; Tjosvold, 2007; Gibson, Callister, 2010; Miron-Spektor, Gino, Argote, 2011; Nash, Hann, 2017) oraz zapobiegania powstawaniu konfliktów w przyszłości (Mackey, Perrewé, McAllister, 2017). Jednak konflikt może nawet zwiększać efektywność grupy (Gilin-Oore, Leiter, LeBlanc, 2015). Przyczyną konfliktów mogą być po prostu trudności językowe, nieporozumienia i szum komunikacyjny (Rahim, 2017), a niedostateczna komunikacja hamuje współpracę i wywołuje nieporozumienia.

Konflikty ujawniają się w procesie komunikacji - pracownicy otwarcie wskazują na przyczynę konfliktu, formułując na przykład skargi, zażalenia, zwołując strajki, albo uwidaczniają je pośrednio - przez plotki, anonimy, donosy. Komunikacja jest jednocześnie narzędziem rozwiązania - na przykład dokument „wypowiedzenie z pracy” jest skrajnym przykładem rozwiązania konfliktu.

45 Ludzie żyją w społeczeństwie, w którym zaufanie jest ograniczone - zamykają domy, mieszkają na osiedlach zamkniętych, ustawiają hasło na wszystkich kontach (nie tylko finansowych), pilnują dzieci 24 godziny 7 dni w tygodniu i w każdym obcym widzą podejrzanego, dopóki nie udowodni, że jest inaczej. 


\subsubsection{Podsystem techniczno-technologiczny - relacje pierwszego stopnia}

Podsystem techniczny jest w pewnym sensie ułomny, jeśli chodzi o komunikację. Jego istotą są maszyny i technologie, które w procesie produkcyjnym lub usługowym mogą przekazywać sobie informacje w postaci impulsów (np. informują o ukończeniu zadania i możliwości przesłania półproduktu do kolejnego etapu procesu produkcyjnego realizowanego za pomocą kolejnej maszyny). Jest to wydawanie sygnałów przez maszyny - reakcja na nie jest dokonywana najczęściej również przez maszyny, zgodnie $\mathrm{z}$ uprzednim ich zaprogramowaniem. Jest to zatem cybernetycznie rozumiana wymiana informacji. Komunikowanie polega natomiast na wzajemnej wymianie informacji, jednak podmiotami procesu są ludzie. Jeśli proces jest realizowany z jednej strony przez człowieka, z drugiej przez maszynę, nadal jest to proces informowania ${ }^{46}$. Inicjatorem procesu wymiany informacji może być zarówno człowiek, jak i maszyna - na przykład człowiek rozpoczyna pracę maszyny za pomocą włącznika i uruchamia w ten sposób proces produkcyjny, albo zaprogramowana maszyna daje znak (dowolnie: dźwiękowy, świetlny, tekstowy - w postaci odczytu parametrów albo werbalny - nagrana wiadomość) o usterce, inicjując tym samym działanie operatora, mające na celu usunięcie przeszkody. W obu wymienionych przypadkach „reakcji na sygnał" nie można mówić o komunikowaniu, a wyłącznie o informowaniu.

O procesie komunikowania mówi się zatem, gdy oboje uczestnicy interakcji - nadawca oraz odbiorca - to ludzie oraz gdy ich wzajemna relacja jest dwustronna, dwukierunkowa, co bezwzględnie oznacza występowanie sprzężenia zwrotnego. Oczywiście na proces komunikowania składają się jeszcze inne elementy.

Można się spierać co do wzajemnej relacji procesu komunikacji i nowoczesnych technologii, ponieważ trudno ustalić jej kierunek i siłę. Nowoczesne narzędzia technologiczne, oprócz wspomagania realizacji głównego procesu organizacji

46 Jednocześnie człowiek uprzednio zaprogramował maszynę. Szybkie sieci komórkowe typu 4G i rozwój sieci piątej generacji wpływają na szybkość komunikacji - na przykład rozwiązania chmurowe pozwalają prowadzić konferencje z uczestnikami z całego świata. Technologia zaspokaja także rozmaite potrzeby, na przykład aplikacje (głównie mobilne) dostarczają rozrywki, informacji, dają możliwość porównywania, dokonania transakcji, obniżania kosztów komunikacji itd. Powstaje obecnie trudne do rozstrzygnięcia pytanie o wpływ (wielkość i sitę) wykorzystania technologii mobilnych w pracy w organizacjach i radykalne zwiększenie adaptacji technologii internetowych do sposobu komunikowania się w organizacji. Istnieje natomiast wiele dowodów na zależność wzajemną technologii i przepływu informacji (z definicji przekaz informacji charakteryzuje się tym, że po obu stronach przekazu nie stoi człowiek). Przykłady można mnożyć - dostęp w czasie rzeczywistym do informacji o statusie nadanej paczki; podłączanie do sieci wielu urządzeń (np. kuchenek, rolet itd. z gatunku Internet of Things), sterowanie nimi, gromadzenie danych i ich analiza. Kolejny wątek mylony z komunikowaniem to mobile comerce - klienci (smart shoppers) wyszukują informacji głównie wspierającej zakupy w sieci, chcą mieć wszystkie dostępne „od ręki” - wyróżnia ich specyficzne podejście do informacji (Sobolewska, 2016, s. 134), której samodzielnie poszukują w internecie, a najważniejsze są szybkość wyszukiwania i kreatywne podejście do sposobów dotarcia do nich. 
(rdzeń techniczny ${ }^{47}$ - Parsons, 1972), wpływają na proces komunikacji ${ }^{48}$, a nawet wymuszają zmianę w nim - inny styl, zwiększona jej szybkość i liczba przekazywanych komunikatów, ułatwiony dostęp do rozmówców, nowoczesny sposób komunikowania. Dla autorki tej pracy technologia nie wpływa na sedno procesu - bez względu na postępującą technologię warunkiem zaistnienia procesu komunikowania jest zaangażowanie w proces nadawcy i odbiorcy - ludzi.

W nowoczesnym komunikowaniu treść komunikatu zmienia się w sensie sposobu jego sformułowania (przekazy często są krótsze lub przedstawione w inny niż werbalny sposób - np. wizualny), ale zawartość merytoryczna, inaczej mówiąc sedno (tzw. content - prośba, polecenie, zaproszenie) pozostają bez zmian. Zmienić się może forma komunikatu. Modyfikacji ulegają także kanały komunikacyjne (choć ludzie nadal korzystają z komunikacji ustnej i pisemnej, tyle że często za pomocą urządzeń). Różnice te można zobrazować analogią do książki - te same informacje mogą być przekazywane za pośrednictwem publikacji wykonanej w formie tradycyjnej, papierowej, elektronicznie za pomocą tekstu „przewijanego” na ekranie albo w interfejsie aplikacji komputerowych digital flip books, formatu książkowego dostosowującego się do wymiarów wyświetlacza (tzw. responsywnego) (Eppink, 2014, s. 298-306; Sugianto i in., 2017, s. 101-116). Tym samym wiązki komunikatów - powstające do celów zintegrowania relacji komunikowania w modelu - abstrahują od poziomu zaawansowania technologii ${ }^{49}$.

Dokonawszy wyjaśnienia, w jaki sposób w niniejszym opracowaniu rozumiana jest relacja technologii i komunikacji, można skierować uwagę na relacje wewnątrzpodsystemowe w podsystemie techniczno-technologicznym.

W organizacji oczekiwania wobec technologii sprowadzają się często do płaszczyzn czasu (Gleick, 2003; Burlita, 2015, s. 25-37), wysiłku i pieniądza (Peters,

47 Talcott Parsons (1972) zaproponowat rozróżnienie trzech poziomów organizacji - technicznego, zarządczego (menedżerskiego) i instytucjonalnego. Poziom techniczny lub rdzeń techniczny jest systemem działalności organizacyjnej, w której wytwarzane są rzeczywiste „produkty” organizacji.

48 Istnieją branże, w których metody i narzędzia rdzenne i komunikacyjne (komputery) mogą być tożsame - na przykład według przewidywań Gartner Inc. do 2020 roku na świecie będzie ponad 20 miliardów urządzeń z kategorii internetu rzeczy (Internet of Things) (http://www. gartner.com/newsroom/id/3165317). Producenci instalują moduły Wi-Fi nawet $w$ drobnym AGD, np. LG zapowiedziało, że wszystkie urządzenia z kategorii premium będą połączone z Wi-Fi i intuicyjnie obsługiwane przez użytkownika z poziomu smartfona.

49 Poziom zaawansowania technologii jest taki, że maszyny potrafią znaleźć bardziej skomplikowane wzorce zależności ukryte w analizowanych danych niż ludzie. Istnieją takie przypadki, w których twórca algorytmu nie do końca rozumie, jak on działa (tzw. problem czarnej skrzynki). Przykładem był program Deep Patient, w którym algorytm analizował karty pacjentów szpitala Mount Sinai Hospital w Nowym Jorku i nauczył się wykrywać osoby chore na schizofrenię. Nikt do końca nie wie, w jaki sposób (Miotto i in., 2016). 
Van der Lippe, 2007, s. 430-447). Element kosztowy rozpatrywany jest w podsystemie ekonomicznym. Oczekuje się, że dzięki technologii można produkować szybciej (w krótszym czasie), wyręczając się maszyną przy cięższych, bardziej skomplikowanych i nużących pracach oraz ponosząc niższe koszty (osobowe, ale także koszty za połączenie). Członek społeczeństwa konsumpcyjnego i społeczeństwa informacyjnego to coraz częściej „człowiek pośpiechu: człowiek, któremu brakuje czasu, który jest więźniem przymusu” (Nydhal, 2011, s. 36). Nie dziwi zatem powszechne „oczarowanie technologią” i traktowanie jej jako środka na oszczędność czasu, przyspieszenie działań i ułatwienie komunikacji - na przykład media społecznościowe zmieniają praktyki wewnętrznej komunikacji korporacyjnej50 (Matthews, 2010, s. 22).

Kwestię czasu badacze organizacji rozważają jeszcze w kontekście czasu poświęcanego na komunikację (spotkania, czat, e-mail) w stosunku do czasu poświęcanego na bezpośrednie wykonywanie czynności związanych z pracą (Ten Brummelhuis, Bakker, Hetland, Keulemans, 2012). Technologia pozwala także na pracę zdalną, poza siedzibą firmy, co jest ważne dla organizacji nie tylko w kontekście oszczędności czasu (Sanchez i in., 2007, s. 42-64; Kelliher, Anderson, 2008, s. 419-431). Pozwala - w zasadzie bez oczekiwania - na natychmiastową komunikacje z rozmówcą przebywającym w dowolnym miejscu na świecie (Spiegelman, Detsky, 2008, s. 1179-1181).

Komunikacja przenika każdy aspekt życia organizacyjnego, przełożeni i podwładni spędzają większość swojego czasu pracy na komunikowaniu ${ }^{51}$ (Gronn, 1983, s. 1-21). Istnieje wiele wyjaśnień doboru sposobów, w jaki menedżerowie wybierają media do komunikacji w konkretnej sytuacji organizacyjnej (Webster, 1998, s. 257-286). Obejmują one bogactwo mediów (Lengel, Daft, 1984), obecność społeczną (Short, Williams, Christie, 1976) multimedia (Muk, Chung, 2015), fizyczny dostępu do medium oraz konkretną dostępność do nich w czasie i przestrzeni (Reinsch, Beswick, 1990; Mehralizadeh, Shahi, Sharify, 2014), a także model

50 Systemy informacyjne przedsiębiorstwa (Enterprise Information Systems - EIS) wspomagane informatycznie obejmują szereg systemów jedno- lub wielodziedzinowych, na przykład systemy planowania zasobów przedsiębiorstwa (Enterprise Resource Planning - ERP), systemy do zarządzania relacjami z klientami (Customer Relationship Management - CRM), wspomaganie zarządzania projektami itd.

51 Frank van Massenhoven - dyrektor urzędu skarbowego wprowadził następujące rozwiązania w miejscu pracy: pracownicy z rocznika 1984 i młodsi mogą do 3 dni w tygodniu wykonywać pracę w sposób zdalny. W Ministerstwie Finansów występują zmienne stanowiska pracy, pracownik nie ma własnego biurka. Zatrudnieni mogą w godzinach pracy dowolnie korzystać z portali społecznościowych, aby swobodne wypowiadać się w internecie. Van Massenhoven mówi, że w urzędzie „stawiają na przejrzystość wiarygodność, szczerą komunikację i zaufanie" (http://www.jandezutter.be/home/Interview_met_Frank_Van_Massenhove.html). 
zamknięcia zadania (Straub, Karahanna, 1998) oraz połączenie użyteczności i norm (Kraut, 2016).

Technologia wpływa na to, jak ludzie się komunikują, a także na to, co komunikują (Te’eni, 2001, s. 251). Badacze skupiają się na sposobach projektowania technologii w organizacji w ramach systemu wspierającego komunikację, aby wspomóc jej efektywność, czyli to, jak zmienić medium i cechy wiadomości w tym celu.

Nowoczesna technologia umożliwia i wspomaga komunikację bezpośrednią, pośrednią, synchroniczną i asynchroniczną. Kryterium miejsca i czasu pozwala na wyróżnienie trzech rodzajów komunikacji zespołowej za pomocą nowoczesnych technologii informatycznych (Ellis, Gibbs, Rein, 1991, s. 41):

1) bezpośredni - nadawca i odbiorca znajdują się w tym samym miejscu i czasie, ich komunikowanie jest wspomagane informacjami zawartymi na nośniku elektronicznym (teksty i wykresy na ekranie, prezentacje, wizualizacje komputerowe) (Romero, Vernadat, 2016, s. 3-13);

2) synchroniczny - w tym samym czasie nadawca i odbiorca mogą znajdować się $\mathrm{w}$ innym miejscu, na swoim stanowisku pracy (np. telefon, wideokonferencje - Skype, NetMeeting, rozmowy w czasie rzeczywistym - IRC i ICQ, chat) (Spiegelman, Detsky, 2008, s. 1179-1181);

3) asynchroniczny - interakcja taka jest rozłożona w czasie, nie ma pewności natychmiastowej odpowiedzi (Rennecker, Godwin, 2005, s. 247-266); członkowie zespołu wprowadzają informację do sieci, tam jest ona przechowywana, w dowolnym czasie można się z nią zapoznać, uzupełnić ją, skomentować; od członków zespołu nie wymaga się przebywania w tym samym miejscu lub czasie; w razie potrzeby konkretni członkowie zespołu uzgadniają spotkanie w celu komunikacji bezpośredniej (np. Skype w wersji pisanej, poczta elektroniczna - e-mail, grupy dyskusyjne, nośniki pamięci52, centra danych - i-cloud, dropbox, nośniki przechowywania danych i archiwizacji - CD, pen-drive, dyski twarde) (Mazmanian, Orlikowski, Yates, 2005, s. 337-344; Derks, Bakker, 2010).

Badacze organizacji poruszają także kwestię bezpieczeństwa w sieci - organizacyjna płaszczyzna komunikacji w zasadzie wyklucza anonimowość rozmówców i niebezpieczeństwo kontaktów z osobami, które podają się za kogoś innego. Członkowie zespołu ${ }^{53}$ mogą nie znać się osobiście, ale współpracują ze sobą, wówczas rozpoznają

52 Znaki wykute w kamieniu przetrwają wieki, książki około stu lat, nośniki DVD do piętnastu lat, jeśli nie będą narażone na działanie światła i wilgoci, pamięć cyfrowa do pięciu lat - konieczna jest zatem ciągła konserwacja i przenoszenie danych.

53 W niniejszym opracowaniu zespół rozumiany jest raczej jako złożony z osób jednonarodowych, choć mogą one także pochodzić z różnych krajów, mieć różną kulturę, światopogląd, podejście do czasu itp. 
wzajemnie sposób komunikowania się (DeSanctis, 1993, s. 100-102; Orlikowski i in., 1995, s. 425; Olesen, Myers, 1999, s. 323-325). Bezpieczeństwo w sieci obejmuje także przesyłanie, analizowanie i archiwizowanie danych oraz przesyłanie innych informacji elektronicznie (np. załączniki do e-maili) (El-Gazzar, Hustad, Olsen, 2016, s. 64-84).

Reasumując, podsystem techniczno-technologiczny obejmuje w niniejszym opracowaniu ludzi obsługujących technikę i technologię (maszyny, metody, know-how), jaką wykorzystuje się w działalności organizacji - osoby i komunikaty zajmujące się tak zwanym rdzeniem technicznym organizacji oraz technikę i technologię stosowaną do komunikacji wewnątrzorganizacyjnej, obsługującej główny proces organizacji i działanie całej organizacji. Podmiotami procesu są więc ludzie.

\subsubsection{Podsystem ekonomiczny - relacje pierwszego stopnia}

Podsystem ekonomiczny obejmuje wszelkie zasoby organizacji. Nie są one jednak bytami oderwanymi od człowieka, nie mogą funkcjonować oddzielnie od niego. Aby zaistniały w organizacji i były wykorzystywane, człowiek musi nimi obracać, musi je nabyć, używać, sprzedać. Dlatego podsystem ekonomiczny jest w tej pracy rozważany z dwóch perspektyw: jako koszt komunikacji i jako komunikacja międzyludzka prowadzona w sprawach ekonomicznych. Wszelkie transakcje finansowe i pozafinansowe wymagają nie tylko aktywności, działania człowieka, ale także jego komunikowania się - na przykład przelew bankowy realizowany w okienku bankowym wymaga rozmowy z kasjerką, natomiast realizowany przez internet wymaga wyrażenia woli w postaci czynności komunikacyjnych z bankiem - logowania, wpisania numeru konta odbiorcy, zatwierdzenia.

W podsystemie ekonomicznym należy także uwzględnić koszty komunikacji - opłatę za rozmowę za pomocą połączenia telefonicznego, za dostęp do internetu, umożliwiający rozmaite formy komunikacji, ponadto koszty sprzętu (hardware) i programów (software) do komunikacji - np. koszt komunikatorów ${ }^{54}$.

Innym rodzajem kosztu jest na przykład koszt oczekiwania na odpowiedź (w przypadku komunikacji asynchronicznej) lub koszt braku natychmiastowej odpowiedzi (sytuacje kryzysowe) w porównaniu do wydatków na komunikację synchroniczną, podczas której odpowiedź jest udzielana natychmiastowo. Powodem utrudnień w uzyskaniu natychmiastowej odpowiedzi może być nie tylko wysoki

54 Koszty dotarcia do klientów za pomocą internetu w porównaniu z metodą tradycyjną są niższe, a sposoby łatwiejsze do zastosowania (głównie przez brak ograniczeń terytorialnych). Istnieje wiele możliwości komunikacji w sieci, niemalże z każdym na świecie możliwy jest satysfakcjonujący kontakt i wyczerpująca rozmowa. 
koszt jej uzyskania, ale utrudnienia, jakie w komunikacji synchronicznej mogą powodować różne strefy czasowe.

Kolejny rodzaj kosztów, jaki ponosi organizacja na komunikację, to koszty zabezpieczenia danych osobowych rozmówców, zabezpieczenia rozmów (uwzględniając treści wrażliwe). Komunikacja w tym podsystemie obejmuje pracowników finansowych i dotyczy obsługi finansowej organizacji - wydatków, kosztów, spodziewanych zysków, ich przeznaczenia (ile, na co, dlaczego i z jakim skutkiem).

Przedstawione relacje komunikacyjne pierwszego stopnia są relacjami wewnątrzpodsystemowymi. Stanowią one podstawę do tego, aby w kolejnym kroku budowy modelu wskazywać relacje komunikacyjne międzypodsystemowe drugiego i kolejnych rzędów (zgodnie z metodyką badań systemowych), z których tworzone są sieci. Wyodrębnione w podrozdziale 4.1 relacje organizacyjne kolejnych stopni będą w rozdziale 4.3 przedstawione za pomocą relacji komunikowania wraz z przykładami. Należy w tym miejscu zaznaczyć, że wyodrębnione relacje organizacyjne stanowią rodzaj kanałów komunikacyjnych, dzięki którym określone podmioty (pełniące rozmaite obowiązki) powinny komunikować się między sobą. Wyodrębnione relacje komunikacyjne pomogą określić rodzaj przekazywanych dzięki nim komunikatów i stypizować je według funkcji ich przeznaczenia. Wyodrębnienie relacji komunikacyjnych między podsystemami drugiego i następnych rzędów pozwala na wyznaczenie określonych kanałów tematycznych zaspokajających potrzeby zarządzania w organizacji. Stąd typizacja komunikatów przebiega według zmodyfikowanego modelu funkcji zarządzania (SMCZ) omówionego w punkcie 3.3.2.

\subsection{Sieć relacji komunikowania się}

Dla funkcji komunikatu nie ma znaczenia, czy są one ustne, czy pisemne - ma to znaczenie z perspektywy ewidencji komunikatów lub ich przepływu, ewentualnie jest związane $\mathrm{z}$ upodobaniami nadawcy lub odbiorcy.

W skład modelu komunikacji - tak samo jak modelu organizacji - wychodzą te same podsystemy, wyróżnione w podrozdziale 4.2. Relacje komunikacyjne wyodrębniono konsekwentnie między wskazanymi podsystemami, bazując na relacjach organizacyjnych tam wyróżnionych. Jest to zatem konsekwentne odwzorowanie relacji organizacyjnych $w$ relacje komunikowania, które realizują te pierwsze ${ }^{55}$.

55 „Odwzorowanie” nie oznacza „tożsamości”. W niniejszej pracy podstawę stanowi metoda badań systemowych, dająca możliwość mierzenia i zarządzania sprawnością organizacji. Inne płaszczyzny badawcze, na których stawia się tezę o tożsamości relacji organizacyjnych 
Komunikacja jako proces zachodzący między ludźmi występuje w sposób naturalny „po lewej stronie” modelu w podsystemach antropologicznym i społecznym, a także w relacji między nimi. Relacje komunikacyjne lewej strony modelu z prawą wydają się być naturalne o tyle, że realizowane są przez ludzi w zakresie obszarów zasileniowych - ekonomicznego i technicznego. Wyjaśnienia wymaga podmiotowość relacji komunikacyjnych po prawej stronie modelu - po stronie zasileniowej.

Z powodu specyficzności podsystemu techniczno-technologicznego komunikowanie wewnątrzsystemowe dotyczyć będzie wymiany informacji między operatorami maszyn i użytkownikami technologii. Podmiotami procesu są zatem ludzie posługujący się maszynami.

Drugim nie mniej ważnym aspektem podsystemu techniczno-technologicznego są urządzenia i metody służące komunikowaniu się między ludźmi. Chodzi tu o wszelkie urządzenia technologiczne wspomagające proces komunikowania, niezależnie od tego, czy komunikowanie to odbywa się synchronicznie (np. telefon, Skype) czy asynchronicznie (mail), bezpośrednio lub pośrednio. Konsekwentnie podmiotami podsystemu ekonomicznego będą ludzie dysponujący finansami - sami lub w imieniu i na rzecz osoby trzeciej. Z natury rzeczy po lewej - zasileniowej, technicznej, stronie modelu wystąpi mniej relacji niż po prawej - społecznej.

Zgodnie z założeniami metody analizy systemowej do zbudowania systemu wystarcza wskazanie przykładowych relacji, nie ma konieczności wyróżniania ich wszystkich (jak w komputerowej metodzie analizy sieci społecznych). Dlatego w poniżej przedstawionym modelu wskazano przykładowe relacje, które wybrano ze względu na kryterium popularności ich występowania w organizacji. Ponadto w niniejszej pracy zakłada się, że komunikaty wydawane wewnątrz organizacji są niemanipulacyjne, szeroko związane z celami i funkcjonowaniem organizacji. Komunikaty, na przykład podnoszące spójność zespołu, mieszczą się również w tej kategorii.

Relacje w modelu wypracowywanym w dalszej części pracy wyodrębnione są w ujęciu przedmiotowym - ze względu na treść relacji komunikacyjnej zachodzącej między określonymi podsystemami. Poniżej została przedstawiona charakterystyka treściowa komunikatów w podziale na podsystemy. Formy i treści przeka$\mathrm{zu}$ - tak zwane relacje komunikacyjne - zostały nałożone na relacje organizacyjne.

i komunikowania się, takiej możliwości nie dają - szczegółowe rozważania na ten temat przedstawiono w podrozdziale 1.4 (podejście społecznego konstruktywizmu - (Czarniawska, 2010) oraz nadawania znaczeń (Weick, 1979a), w którym dyskurs tworzy organizację, a nie tylko ją odzwierciedla (Jørgensen, Jordan, Mitterhofer, 2012)). Tym niemniej zauważalna tożsamość prezentowanej tezy z tezami przytoczonych tu autorów stanowi z perspektywy triangulacji pewne potwierdzenie prawidłowości wyników badań i wyciąganych wniosków - jednak inną metodą (Wei, Lin, 2017). 
W następnej kolejności relacje komunikacyjne zintegrowano w wiązki relacji komunikowania, które wyznaczono ze względu na treść komunikatów, a później wiązki połączono funkcjonalnie w sieci.

W toku prac nad niniejszą metodą i modelem rozważano porządkowanie relacji komunikowania $\mathrm{w}$ wiązki na podstawie wybranego modelu komunikowania, na przykład według Lasswella (dodając brakujący w nim element sprzężenia zwrotnego). Model ten składa się z elementów ułożonych liniowo w postaci: nadawca, komunikat, kanał, odbiorca, efekt. Towarzyszą mu pytania: „Kto mówi?”, „Co mówi?”, „Za pośrednictwem jakiego kanału mówi?”, „Do kogo mówi?”, „Z jakim skutkiem?". Badanie elementów tego i innych modeli komunikowania się społecznego prowadzi do zawężenia analizy - nadawcą i odbiorcą są zawsze pracownicy organizacji - przełożeni i podwładni. Różnicujące są komunikaty (ich zawartość), kanał (forma) i efekt (funkcja). Stąd wyróżniono typy komunikatów przedstawione w tabelach w załącznikach. Zestawienie szczegółowych komunikatów zamieszczone w kolejnych załącznikach ${ }^{56}$ może unaocznić drobiazgowość analizy przeprowadzonej na potrzeby pracy.

Relacje drugiego stopnia oznaczono na zielono w modelu głównym pracy (rysunek 19).

\section{Relacje komunikowania realizowane w podsystemie antropo-społecznym}

(A) (T) Wiązki relacji antropo-społecznych komunikowania obejmują wyjątkowo szerokie spektrum komunikatów. Zestawienie przykładowych rodzajów komunikatów realizujących określony typ relacji organizacyjnej przedstawiono w tabeli w załączniku 1.

Na przykład wyodrębniona wcześniej w podsystemie antropo-społecznym relacja organizacyjna $r_{11}$ - „Zaspokajanie potrzeb indywidualnych i zespołowych” - jest realizowana przez szereg relacji komunikacyjnych. Są to relacje określone symbola$\operatorname{mi}$ od $k_{11 \mathrm{~A}}$ do $k_{11 \mathrm{i}}$ i oznaczające odpowiednio: $k_{11 \mathrm{~A}}$ - komunikaty inicjujące proces produkcji, usług lub dotyczące konieczności wykonania zadania; $k_{11 \mathrm{~B}}$ - uzgadnianie działań poszczególnych wydziałów, wydawanie poleceń; $k_{11 \mathrm{C}}-$ komunikaty pracowników potwierdzające przyjęcie zadania i szczegółów jego wykonania (termin, liczba, rodzaj); $k_{11 D}$ - pytania i odpowiedzi o stan faktyczny w trakcie realizacji procesu pracy; $k_{11 \mathrm{E}}$ - komunikaty typu sprawozdawczego - dotyczące realizacji procesu pracy (poziomu, zaawansowania), subiektywnej i obiektywnej jego oceny; $k_{11 \mathrm{~F}}-$ diagnozowanie i rozwiązywanie problemów i konfliktów między pracownikami w zespołach;

56 Metoda analizy systemów złożonych wymaga systematycznej realizacji każdego etapu badania - co może być nużące dla czytelnika, dlatego autorka zdecydowała się przenieść te drobiazgowe rozważania do załączników. Ten zabieg zastosowano dla podniesienia czytelności pracy. 
$k_{11 \mathrm{G}}$ - komunikaty o zmianach - informowanie o ich wprowadzeniu, zmniejszanie oporów (np. wypowiedzenia); $k_{11 \mathrm{H}}$ - komunikaty potwierdzające zwrócenie uwagi na współpracowników; $k_{11 I}$ - pokazywanie zrozumienia przez empatię. Szczegółowy wykaz relacji komunikacyjnych realizujących określony $\left(r_{1 n}\right)$ typ relacji organizacyjnych w podsystemie antropo-społecznym znajduje się w załączniku 1.

Wskazane relacje komunikowania połączono w wiązki treściowe, czyli: ostrzeżenia, pytania, odpowiedzi, prośby-polecenia, zobowiązania-obietnice, oczekiwania, informacje, decyzje, rady-instrukcje, mianowanie-zwalnianie, negocjacje, ocenianie-osądzanie i wyrażanie emocji. Dla przykładu wiązka treściowa „ostrzeżenia" zawiera komunikaty o niedostatkach (np. brak obsady), o negatywnych skutkach podejmowanych decyzji lub o negatywnych skutkach niedostosowania się do klimatu panującego w zespole. Relacje $k_{11 \mathrm{D}}, k_{12 \mathrm{~B}}, k_{12 \mathrm{D}}$ są uprawnione do realizowania tej wiązki treściowej. Funkcje im przeznaczone, zgodnie z synkretycznym modelem cyklu zarządzania, to organizowanie i motywowanie, ponadto wiązka treściowa „ostrzeżenia” może być realizowana w formie pisemnej, ustnej lub za pomocą technicznych środków przekazu (brak w tym zakresie ograniczeń). Wiązki komunikatów wyodrębnionych w podsystemie antropo-społecznym szczegółowo wskazano w załączniku 2.

\section{Relacje komunikowania realizowane w podsystemie antropo-technicznym}

(A) (T) Wiązki relacji komunikacyjnych antropo-technicznych zawierają ko(S) E I munikaty, które dotyczą zadań realizowanych przez człowieka na stanowisku pracy w zakresie metody, maszyn i szeroko rozumianych środków produkcji i dotyczą rdzenia działalności organizacji (proces główny). Jednocześnie obejmują także komunikaty dotyczące technicznych środków komunikacji, urządzeń (maszyn) i metod komunikowania obsługujących całe przedsiębiorstwo, wszystkie podsystemy, nie tylko techniczno-technologiczny.

Na przykład wyodrębniona wcześniej w podsystemie antropo-technicznym relacja organizacyjna $r_{21}$ - „dyspozycje pracownika względem maszyny” - jest zaspokajana w tym przypadku przez dwie relacje komunikacyjne. Są to relacje określone symbolami $k_{21 \mathrm{~A}}$ i $k_{21 \mathrm{~B}}$ i oznaczające odpowiednio: $k_{21 \mathrm{~A}}$ - komunikaty dotyczące sposobu (metody) realizacji celu, wskazówki, wytyczne, sposoby realizacji zadania przekazywane przez kierownika podwładnym (dyrektywy zadaniowe); $k_{21 \mathrm{~B}}-$ komunikaty typu: „uruchomić maszynę”, „zatrzymać”, instrukcje obsługi. Wykaz relacji komunikacyjnych realizujących określony typ relacji organizacyjnych $\left(r_{2 n}\right)$ w podsystemie antropo-technicznym znajduje się w załączniku 3.

Szczegółowa lista wiązek treściowych obejmuje pytania, odpowiedzi, prośby-polecenia, zobowiązania-obietnice, oczekiwania, ostrzeżenia, informacje, decyzje, rady-instrukcje i negocjacje. Dla przykładu: typ treściowy „ostrzeżenia” zawiera 
komunikaty o skutkach korzystania z określonych metod, narzędzi i sposobów działania (BHP) lub na przykład o tempie pracy maszyny i jest realizowany przez relacje komunikowania $k_{21 \mathrm{~B}}$ oraz $k_{24 \mathrm{~A}}$. Funkcje im przeznaczone (SMCZ) to planowanie i organizowanie, brak ograniczeń w zakresie formy realizowania tej wiązki komunikacyjnej (pisemnie, ustnie lub za pomocą elektronicznych środków komunikacji). Wiązki komunikatów wyodrębnionych w podsystemie antropo-technicznym szczegółowo wskazano w załączniku 4.

\section{Relacje komunikowania realizowane w podsystemie antropo-ekonomicznym} (A) T) Relacje komunikacyjne antropo-ekonomiczne obejmują komunika- (S) (E) ty, które dotyczą finansowania zadań realizowanych przez człowieka na stanowisku pracy oraz spraw finansowych zatrudnionego.

Na przykład wyodrębniona wcześniej w podsystemie antropo-ekonomicznym relacja organizacyjna $r_{31}$ - „człowiek jako zasób organizacji” - jest realizowana przez relację komunikacyjną określoną symbolem $k_{31 \mathrm{~A}}$, oznaczającą komunikaty określające „wartościowość” danego pracownika dla organizacji (np. umiejętności pracownika, które przekładają się na zysk dla firmy). Wykaz relacji komunikacyjnych realizujących określony $\left(r_{3 n}\right)$ typ relacji organizacyjnych w podsystemie antropo-technicznym znajduje się w załączniku 5.

Szczegółowa lista wiązek treściowych obejmuje pytania, prośby-polecenia, zobowiązania-obietnice, oczekiwania, informacje-odpowiedzi, decyzje, mianowanie-zwalnianie, negocjacje, ocenianie i wyrażanie emocji. Dla przykładu: typ treściowy „pytania” zawiera komunikaty dotyczące kosztów podnoszenia kwalifikacji (w kontekście zysku $z$ nich) i jest realizowany przez relacje komunikowania $k_{34 \mathrm{~B}}$. Funkcje im przeznaczone (SMCZ) to organizowanie i motywowanie, realizowane w formie pisemnej, ustnej lub za pomocą elektronicznych środków komunikacji (brak ograniczeń w zakresie formy realizowania tej wiązki komunikacyjnej). Wiązki komunikatów wyodrębnionych w podsystemie antropo-ekonomicznym szczegółowo wskazano w załączniku 6.

\section{Relacje komunikowania realizowane w podsystemie społeczno-technicznym}

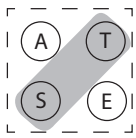

Relacje komunikacyjne społeczno-techniczne zawierają komunikaty, które wpływają na wzrost lub spadek poziomu wykonania zadania wywołany obecnością innych (facylitacja społeczna lub zahamowanie).

Na przykład wyodrębniona wcześniej w podsystemie społeczno-technicznym relacja organizacyjna $r_{41}$ - „grupa w pracy (metoda pracy, maszyny, środki)” - jest realizowana przez relację komunikacyjną określoną symbolem $k_{41 \mathrm{~A}}$, oznaczającą rozmowę grupy posługującej się określoną metodą pracy, maszynami oraz środkami produkcji na ich temat (np. pracownicy call-center o doskonałości/zawodności podstawowych urządzeń 
do pracy). Wykaz relacji komunikacyjnych realizujących określony $\left(r_{4 n}\right)$ typ relacji organizacyjnych w podsystemie społeczno-technicznym znajduje się w załączniku 7.

Szczegółowa lista wiązek treściowych obejmuje pytania, prośby-polecenia, oczekiwania, ostrzeżenia, informacje-odpowiedzi, decyzje i rady-instrukcje. Dla przykładu: typ treściowy „pytania” zawiera komunikaty dotyczące uzupełnienia luk informacyjnych w zakresie technicznym (przełożeni i podwładni) albo zapytania o charakterze doradztwa w działaniu pracowników i jest realizowany przez relacje komunikowania $k_{44 \mathrm{~B}}$ oraz $k_{45 \mathrm{~B}}$. Funkcje im przeznaczone (SMCZ) to planowanie, organizowanie i kontrola, realizowane w formie pisemnej, ustnej lub za pomocą elektronicznych środków komunikacji (brak ograniczeń w zakresie formy realizowania tej wiązki komunikacyjnej). Wiązki komunikatów wyodrębnionych w podsystemie społeczno-technicznym szczegółowo wskazano w załączniku 8.

\section{Relacje komunikowania realizowane w podsystemie społeczno-ekonomicznym}

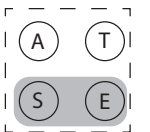

Komunikaty wydawane w podsystemie społeczno-ekonomicznym obejmują sprawy finansowe dotyczące grup zadaniowych.

Na przykład wyodrębniona wcześniej w podsystemie społeczno-ekonomicznym relacja organizacyjna $r_{51}$ - „ustalanie poziomu wynagrodzenia” - jest realizowana przez relacje komunikacyjne określone symbolami $k_{51 \mathrm{~A}}, k_{51 \mathrm{~B}}$ oraz $k_{51 \mathrm{C}}$ ) i oznaczające odpowiednio: $k_{51 \mathrm{~A}}$ - ustalanie poziomu wynagrodzenia dla grupy pracowników według na przykład stażu pracy, kwalifikacji, trybu pracy - dniówkowy, akordowy, zadaniowy; $k_{51 \mathrm{~B}}$ - komunikaty i negocjacje dotyczące rodzaju zabezpieczania społecznego grupy pracowniczej - na przykład dostęp do lekarzy wykupiony dla pracowników przez firmę; $k_{51 C}-$ ujawniające się w komunikatach ambicje ekonomiczne grup zawodowych. Wykaz relacji komunikacyjnych realizujących określony $\left(r_{5 n}\right)$ typ relacji organizacyjnych w podsystemie społeczno-ekonomicznym znajduje się w załączniku 9.

Szczegółowa lista wiązek treściowych obejmuje pytania, prośby-życzenia, zobowiązania, oczekiwania, ostrzeżenia, informacje-odpowiedzi, decyzje, rady-instrukcje i negocjacje. Dla przykładu: typ treściowy „pytania” zawiera komunikaty dotyczące zabezpieczenia społecznego grupy pracowniczej oraz kosztów wyposażenia pracowników (grupy zawodowej) na określonych stanowiskach i jest realizowany przez relacje komunikowania $k_{51 \mathrm{~B}}$ oraz $k_{54 \mathrm{~A}}$. Funkcje im przeznaczone (SMCZ) to organizowanie i motywowanie, realizowane w formie pisemnej, ustnej lub za pomocą elektronicznych środków komunikacji (brak ograniczeń w zakresie formy realizowania tej wiązki komunikacyjnej). Wiązki komunikatów wyodrębnionych w podsystemie społeczno-ekonomicznym szczegółowo wskazano w załączniku 10. 


\section{Relacje komunikowania realizowane w podsystemie techniczno-ekonomicznym}

(A) (T) Tutaj podstawą są komunikaty osób (operatorów technologii i finansistów, rachunkowców) związanych z techniką i ekonomią, dotyczące doboru środków do celu - metod, technologii i maszyn ze względu na koszt rozwiązań.

Na przykład wyodrębniona wcześniej w podsystemie techniczno-ekonomicznym relacja organizacyjna $r_{61}$ - „zasoby, z których organizacja czerpie korzyści” - jest realizowana przez relacje komunikacyjne określone symbolami $k_{61 \mathrm{~A}}$ oraz $k_{61 \mathrm{~B}}$ i oznaczające odpowiednio: $k_{61 \mathrm{~A}}$ - komunikaty dotyczące zasobów, z których organizacja czerpie korzyści - koszt do wyniku; $k_{51 \mathrm{~B}}$ - komunikaty dotyczące kosztu maszyn. Wykaz relacji komunikacyjnych realizujących określony $\left(r_{6 n}\right)$ typ relacji organizacyjnych w podsystemie techniczno-ekonomicznym znajduje się w załączniku 11.

Szczegółowa lista wiązek treściowych obejmuje pytania, oczekiwania, ostrzeżenia, informacje-odpowiedzi, decyzje i rady-instrukcje. Dla przykładu: typ treściowy „pytania” zawiera komunikaty dotyczące zasobów, z których organizacja czerpie korzyści (koszt do wyniku), kosztu maszyn, kosztu metod (rozwiązań) oraz wartości ekonomicznej metody (wartości niematerialne i prawne, know-how, patenty, licencje itp.) i jest realizowany przez relacje komunikowania $k_{61 \mathrm{~A}}, k_{61 \mathrm{~B}}, k_{62 \mathrm{~A}}$ oraz $k_{63 \mathrm{~A}}$. Funkcje im przeznaczone (SMCZ) to planowanie i kontrola, realizowane przede wszystkim w formie pisemnej lub za pomocą elektronicznych środków komunikacji w wersji pisemnej (w zakresie formy realizowania tej wiązki komunikacyjnej wprowadza się obostrzenie w postaci unikania formy ustnej, występuje potrzeba rejestracji pisemnej tych komunikatów). Wiązki komunikatów wyodrębnionych w podsystemie techniczno-ekonomicznym szczegółowo wskazano w załączniku 12.

\section{Złożone subsystemy trzeciego rzędu}

Kolejne poziomy relacji (kolejnego stopnia) budowane są w postaci relacji trzyelementowej, na przykład antropo-społeczno-ekonomicznej, a następnej - konsekwentnie - czteroelementowej. Jednak takie powiązania zagęszczają sieć relacji.

Subsystemy trzeciego rzędu obejmują wiązki relacji komunikowania trzech podsystemów i występują w postaci podsystemów: antropo-społeczno-technicznego, antropo-społeczno-ekonomicznego, antropo-techniczno-ekonomicznego oraz społeczno-techniczno-ekonomicznego.

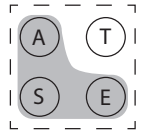

Podsystem antropo-społeczno-ekonomiczny obejmuje relacje komunikowania między jednostkami i członkami grup oraz grup finansistów.

Na przykład wyodrębniona wcześniej w podsystemie antropo-społeczno-ekonomicznym relacja organizacyjna $r r_{11}$ - „kierunki i cele działalności organizacji” 
- jest realizowana przez relacje komunikacyjne określone symbolami $k k_{11 \mathrm{~A}}$ oraz $k k_{11 \mathrm{~B}}$ i oznaczające odpowiednio: $k k_{11 \mathrm{~A}}$ - komunikaty dotyczące wprowadzania innowacji, rozwijania działalności, rozbudowy firmy; $k_{51 \mathrm{~B}}$ - komunikaty konformistyczne - powodujące zmiany ekonomicznej postawy jednostki pod wpływem grupy - na przykład grupa wpływa na zachowanie jednostki w organizacji w sprawie podejścia do wydawania pieniędzy firmy - skrajnej oszczędności lub rozrzutności. Wykaz relacji komunikacyjnych realizujących określony $\left(r r_{1 n}\right)$ typ relacji organizacyjnych w podsystemie antropo-społeczno-ekonomicznym znajduje się w załączniku 13.

Szczegółowa lista wiązek treściowych obejmuje pytania, odpowiedzi, prośby, zobowiązania, negocjacje, decyzje, rady-instrukcje, propozycje, oceny (osądy), wyrażanie emocji, postrzeganie i wyobrażenie. Dla przykładu: typ treściowy „pytania” zawiera komunikaty dotyczące ustalania możliwości wprowadzania innowacji, rozwijania działalności, rozbudowy firmy i jest realizowany przez relacje komunikowania $k k_{11 \mathrm{~A}}$. Funkcje im przeznaczone (SMCZ) obejmują przewidywanie, planowanie, organizowanie, motywowanie i kontrolę. Są realizowane w dowolnej formie - ustnej, pisemnej lub za pomocą elektronicznych środków komunikacji (brak ograniczeń formy komunikatów). Wiązki komunikatów wyodrębnionych w podsystemie antropo-społeczno-ekonomicznym szczegółowo wskazano w załączniku 14.

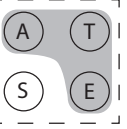

Podsystem antropo-techniczno-ekonomiczny obejmuje relacje między jednostkami a grupami operatorów (grupami techników).

Na przykład wyodrębniona wcześniej w podsystemie antropo-techniczno-ekonomicznym relacja organizacyjna $r r_{21}$ - „sposoby realizacji celów organizacji - kwalifikacje, narzędzia i finanse” - jest realizowana przez relacje komunikacyjne określone symbolem $k k_{21 \mathrm{~A}}$, który oznacza komunikat odnoszący się do kosztu technicznych i kompetencyjnych wymagań. Człowiek realizujący zadanie posiada (lub nie) umiejętności, kwalifikacje i kompetencje do jego realizacji, ale konieczny jest także dostęp do kosztownego wyposażenia/sprzętu (np. potrafię wykonać to zadanie, ale przy użyciu kosztownego sprzętu). Szczegółowy wykaz relacji komunikacyjnych realizujących określony $\left(r r_{2 n}\right)$ typ relacji organizacyjnych w podsystemie antropo-techniczno-ekonomicznym znajduje się w załączniku 15.

Szczegółowa lista wiązek treściowych obejmuje pytania, odpowiedzi, zobowiązania, informacje, decyzje, oceny (osądy) i wyrażanie emocji. Dla przykładu: typ treściowy „pytania” zawiera komunikaty dotyczące wyposażenia technicznego dla jednostki - zakupu lub możliwości korzystania i jest realizowany przez relacje komunikowania $k k_{21 \mathrm{~A}}$. Funkcje im przeznaczone (SMCZ) obejmują planowanie, organizowanie i motywowanie. Są realizowane w dowolnej formie - ustnej, pisemnej lub za pomocą elektronicznych środków komunikacji (brak ograniczeń formy 
komunikatów). Wiązki komunikatów wyodrębnionych w podsystemie antropo-techniczno-ekonomicznym szczegółowo wskazano w załączniku 16.

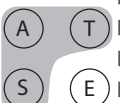

Podsystem antropo-społeczno-techniczny obejmuje relacje między jednostkami a grupami ekonomistów, finansistów.

Na przykład wyodrębniona wcześniej w podsystemie antropo-społeczno-technicznym relacja organizacyjna $r r_{31}$ - ,wyznaczenie technologii dla grup pracowniczych ze względu na poziom kompetencji poszczególnych pracowników" - jest realizowana przez relacje komunikacyjne określone symbolem $k k_{31 \mathrm{~A}}$, który oznacza komunikaty generowane na przykład przez koordynatora, mówiące, że zespół jest lub nie jest w stanie wykonać zadania za pomocą technologii, jaką ma do dyspozycji („nasz zespół nie jest w stanie wykonać tego zadania na komputerach, jakie mamy do dyspozycji"). Wykaz relacji komunikacyjnych realizujących określony $\left(r r_{3 n}\right)$ typ relacji organizacyjnych w podsystemie antropo-techniczno-ekonomicznym znajduje się w załączniku 17.

Szczegółowa lista wiązek treściowych obejmuje prośby-nakazy, ostrzeżenia, informacje, rady, mianowanie i oceny (osądy). Dla przykładu: typ treściowy „prośby” zawiera komunikaty dotyczące dostosowania wyników jednostkowych pracy do standardu grupy przez zmianę metody pracy lub też prośby do określonych jednostek o pomoc w realizacji działań w ramach zespołu i jest realizowany przez relacje komunikowania $k k_{32 \mathrm{~A}}$ i $k k_{33 \mathrm{~B}}$. Funkcje im przeznaczone (SMCZ) obejmują organizowanie, motywowanie i kontrolę. Są realizowane w dowolnej formie - ustnej, pisemnej lub za pomocą elektronicznych środków komunikacji (brak ograniczeń formy komunikatów). Wiązki komunikatów wyodrębnionych w podsystemie antropo-społeczno-technicznym szczegółowo wskazano w załączniku 18.

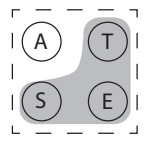

Podsystem społeczno-techniczno-ekonomiczny obejmuje relacje między jednostkami a grupami operatorów (grupami techników).

Na przykład wyodrębniona wcześniej w podsystemie społeczno-techniczno-ekonomicznym relacja organizacyjna $r r_{41}$ - „wyznaczenie technologii dla grup pracowniczych ze względu na poziom kompetencji poszczególnych pracowników" -jest realizowana przez relacje komunikacyjne określone symbolem $k k_{41 \mathrm{~A}}$, który oznacza komunikaty generowane na przykład przez koordynatora, mówiące, że zespół jest lub nie jest w stanie wykonać zadania za pomocą technologii, jaką ma do dyspozycji („nasz zespół nie jest w stanie wykonać tego zadania na komputerach, jakie mamy do dyspozycji”). Wykaz relacji komunikacyjnych realizujących określony $\left(r r_{4 n}\right)$ typ relacji organizacyjnych w podsystemie społeczno-techniczno-ekonomicznym znajduje się w załączniku 19. 
Szczegółowa lista wiązek treściowych obejmuje zobowiązania, ostrzeżenia, informacje, decyzje, rady, propozycje i oceny (osądy). Dla przykładu: typ treściowy „zobowiązania” zawiera komunikaty typu misja, wizja, strategia (zobowiązania organizacji wobec interesariuszy) lub obietnice zakupu sprzętu dla zespołu (zobowiązania wobec podwładnych) i jest realizowany przez relacje komunikowania $k k_{41 \mathrm{~A}}$ i $k k_{41 \mathrm{~B}}$. Funkcje im przeznaczone (SMCZ) obejmują przewidywanie, planowanie, organizowanie, motywowanie i kontrolę. Są realizowane w formie pisemnej lub za pomocą elektronicznych środków komunikacji (ograniczenie co do formy ustnej komunikatów wynika z wagi zobowiązań). Wiązki komunikatów wyodrębnionych w podsystemie społeczno-techniczno-ekonomicznym szczegółowo wskazano w załączniku 20.

\section{Subsystem czwartego rzędu - antropo-społeczno-techniczno-ekonomiczny}

Podsystem czwartego rzędu jest jednocześnie pierwszym etapem konstrukcji systemu. Relacje między podsystemami są oparte na kryterium rzeczowym (przedmiotowym).

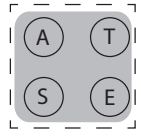

Podsystem antropo-społeczno-techniczno-ekonomiczny obejmuje relacje komunikowania między jednostkami a grupami operatorów i ekonomistów.

Na przykład wyodrębniona wcześniej w podsystemie antropo-społeczno-techniczno-ekonomicznym relacja organizacyjna $r_{r r}{ }_{11}$ - „relacje członków grupy (jednostek) na tle grupy w zakresie techniczno-ekonomicznym” - jest realizowana przez relacje komunikacyjne określone symbolem $k k k_{11}$, który oznacza komunikaty odnoszące się do pracy jednostki w grupie przy użyciu konkretnej technologii, za konkretne wynagrodzenie (np. pytanie jednostki: ,jak długo będę pracował na tym stanowisku, przy tej maszynie, za te pieniądze i w tym zespole?”). Wykaz relacji komunikacyjnych realizujących określony $\left(r r r_{11}\right)$ typ relacji organizacyjnych w podsystemie antropo-społeczno-techniczno-ekonomicznym znajduje się w załączniku 21.

\section{Relacje komunikacyjne samozwrotne z podsystemem zarządzania - drugiego, trzeciego, czwartego i piątego rzędu}

W nadrzędnym podsystemie zarządzania znajduje się funkcja integracyjna modelu. Podsystemy kolejnych rzędów (piętnaście podsystemów), każdy z osobna, generują rozmaite pod względem treściowym komunikaty dotyczące rozmaitych spraw. Te pojedyncze relacje komunikowania łączone są w jednorodne wiązki tematyczne. Relacje te wychodzą w miarę potrzeb organizacji ze wszystkich podsystemów kolejnych rzędów i do nich wracają po przegrupowaniu. 
Następnie wiązki relacji komunikowania (wiązki tożsame treściowo) łączą się w sieci - ze względu na kryterium funkcjonalne zgodnie z synkretycznym modelem cyklu zarządzania (SMCZ). W rezultacie powstają różnotematyczne i różnofunkcjonalne sieci komunikowania, które są integrowane w podsystemie zarządzania w celu sprawnego zarządzania organizacją.

Podstawą modelu są relacje komunikowania. Wiązki to połączone pojedyncze relacje komunikowania, jednorodne pod względem tematycznym, wydane przez jeden z piętnastu podsystemów organizacji dowolnego rzędu. Każdy podsystem może wygenerować wiele relacji komunikowania - zależnie od tematyki, której dotyczy. Natomiast na sieci komunikowania składają się wiązki jednorodnych tematycznie relacji komunikowania (wydawane przez różne podsystemy), pogrupowane funkcjonalnie ze względu na synkretyczny model cyklu zarządzania. Inaczej mówiąc, każdy komunikat wydawany w organizacji przynależy treściowo do określonej relacji komunikowania, tworząc wiązkę tematyczną wewnątrz tej relacji komunikowania, a jednocześnie za pośrednictwem relacji komunikowania funkcjonalnie przynależy do określonej sieci.

Podsystem zarządzania pełni rolę integratora systemu sieci relacji komunikowania dla potrzeb koordynowania organizacji i w celu zarządzania nią. W rezultacie organizacja stanowi system zintegrowanych sieci relacji komunikowania. Powstały w efekcie system sieci komunikowania jest zintegrowany do potrzeb koordynowania, w celu podnoszenia sprawności organizacyjnej.

Z tego względu samozwrotne relacje komunikowania realizowane przez podsystem zarządzania mają inny charakter niż pozostałe relacje realizowane przez pozostałe podsystemy. Wymieniane dotąd podsystemy kolejnych rzędów mają charakter przedmiotowy - podsystem zarządzania ma natomiast charakter funkcjonalny. $Z$ tego powodu, przez funkcje, nadrzędny podsystem zarządzania zmienia charakter pozostałych podsystemów, ich stan (dotyczy rzeczy) i zachowanie (dotyczy ludzi). Taka budowa organizacji wskazuje złożoność systemu (Simon, 1991, s. 457-476; Weick, 2010).

\subsection{Model organizacji jako systemu sieci zintegrowanych relacji komunikowania}

Konceptualny model organizacji jako systemu sieci zintegrowanych relacji komunikowania ma charakter modelu wielosegmentowego. Dla graficznego przedstawienia modelu wybrano kształt wieży Eiffla, konstrukcji przestrzennej, nieograniczonej ścianami i odpowiadającej swoim kształtem systemowej budowie organizacji, wskazującej złożoność. 


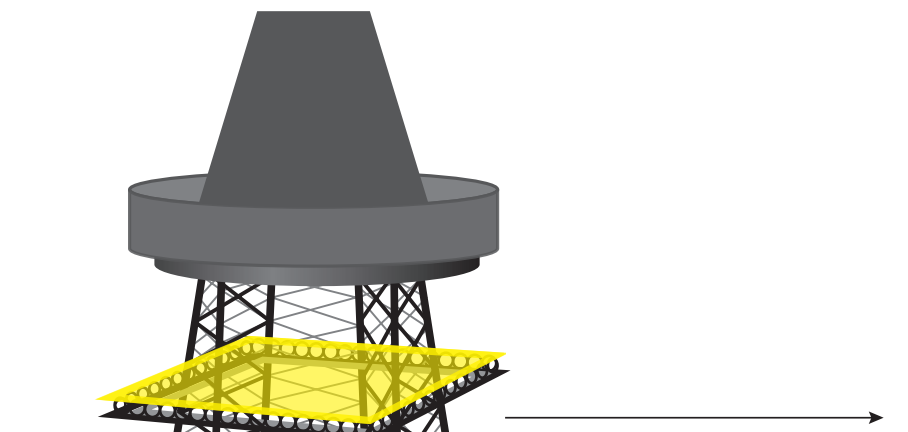

告

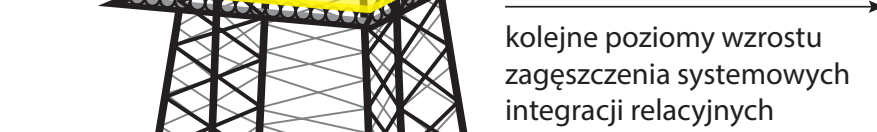
integracji relacyjnych

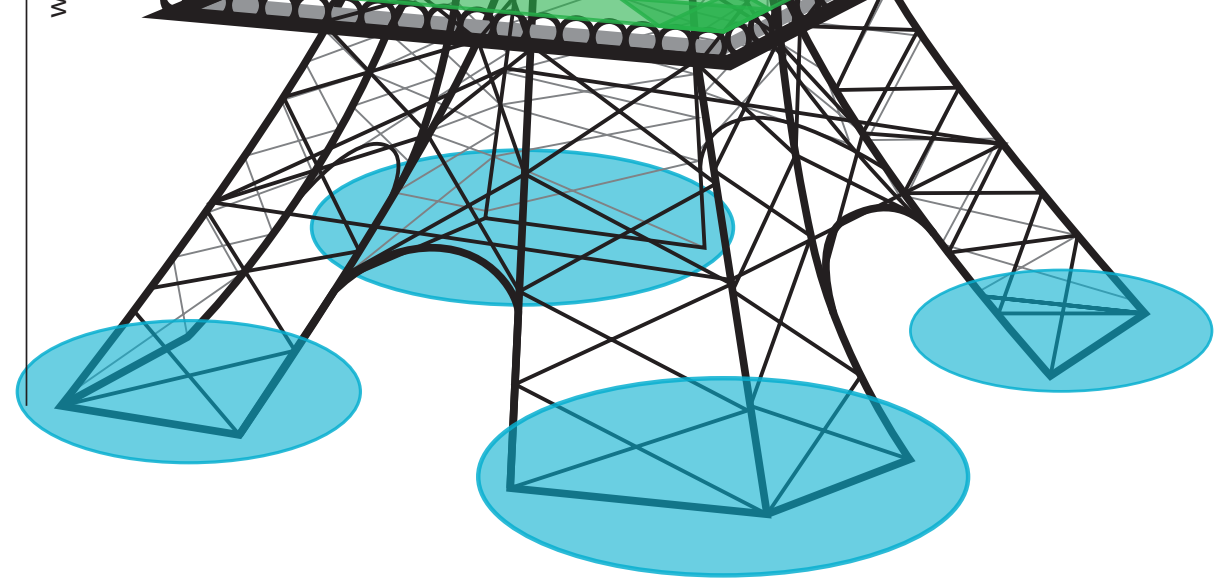

Rysunek 19. Model organizacji jako system sieci zintegrowanych relacji komunikowania Źródto: opracowanie własne. 
Poziom 1
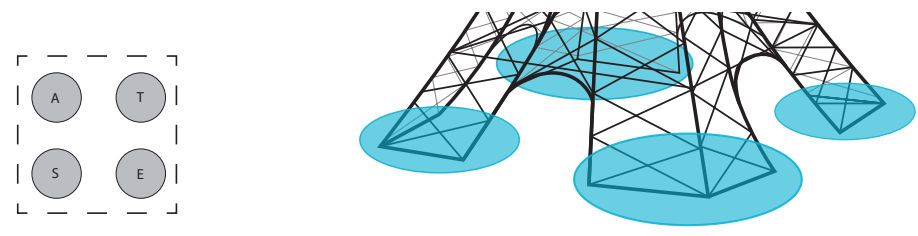

Poziom 2
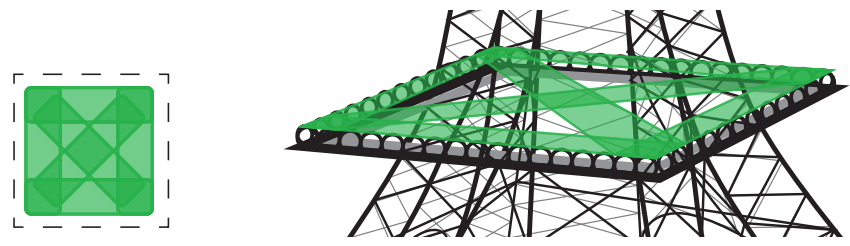

Poziom 3
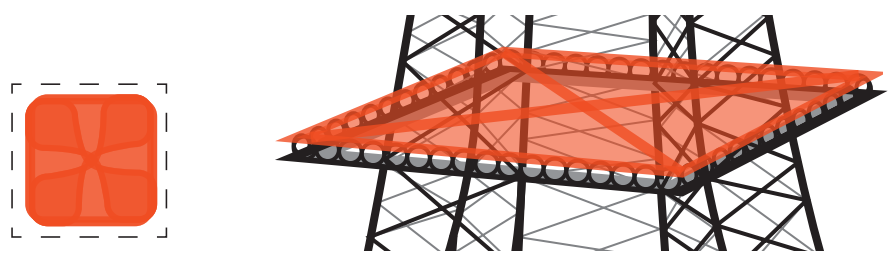

Poziom 4
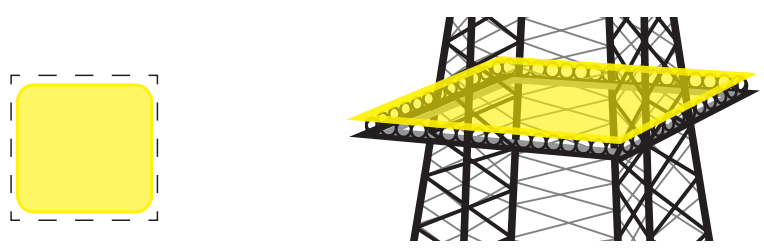

Poziom 4
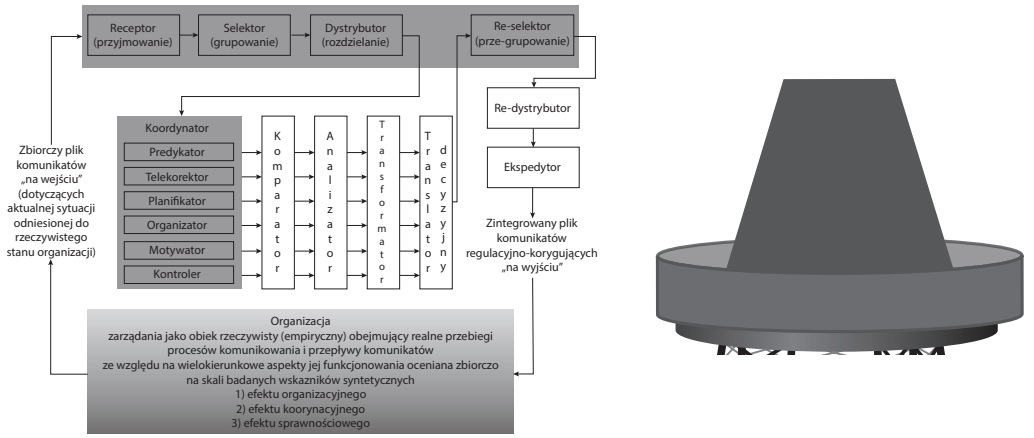

Rysunek 20. Szczegółowe poziomy modelu organizacji jako systemu sieci zintegrowanych relacji komunikowania

Źródto: opracowanie własne. 


\section{Segment 1}

Segment pierwszy składa się z podsystemów czterech kolejnych rzędów (umieszczonych na czterech kolejnych poziomach) oraz podsystemu zarządzania. Rodzaje podsystemów ułożone są w sposób systemowy, hierarchiczny.

Pierwszy rodzaj podsystemów jest umieszczony na poziomie pierwszym i oznaczony kolorem niebieskim. Obejmuje cztery autonomiczne podsystemy pierwszego rzędu: antropologiczny, społeczny, techniczny i ekonomiczny.

Drugi rodzaj podsystemów wchodzących w skład modelu organizacji to podsystemy drugiego rzędu, podsystemy skojarzone, umieszczone na poziomie drugim (oznaczone kolorem zielonym). Na tym poziomie występują podsystemy: antropologiczno-społeczny, antropologiczno-techniczny, antropologiczno-ekonomiczny, społeczno-techniczny, społeczno-ekonomiczny i techniczno-ekonomiczny.

Trzeci rodzaj to występujące na poziomie trzecim podsystemy trzeciego rzędu (oznaczone kolorem czerwonym). W jego skład wchodzą podsystemy: antropologiczno-społeczno-techniczny, antropologiczno-społeczno-ekonomiczny, antropologiczno-techniczno-ekonomiczny oraz społeczno-techniczno-ekonomiczny.

Kolejny, czwarty rodzaj, to podsystem czwartego rzędu - antropologiczno-społeczno-techniczno-ekonomiczny (oznaczony kolorem żółtym), umieszczone na poziomie czwartym.

Na samej górze, z racji swojej nadrzędnej roli, umieszczony został podsystem zarządzania (oznaczony kolorem fioletowym).

Kierunek wertykalny wzrostu stopnia integracji systemu relacji komunikowania, w aspekcie informacyjnym, jest zbieżny z procesem ograniczania autonomicznej różnorodności treści informacyjnej przesyłanych komunikatów na rzecz wzrostu uporządkowania ich systemowej jednorodności.

\section{Poziom 2}

Segment drugi modelu obejmuje system relacji komunikacyjnych wewnątrzpodsystemowych i międzypodsystemowych podsystemów kolejnych stopni. Relacje mają charakter dialogiczny, występują między nadawcą i odbiorcą. Na rysunku 19 reprezentują je czarne linie konstrukcyjne.

\section{Poziom 3}

Segment trzeci składa się z wiązek relacji komunikacyjnych połączonych w grupy tematyczne i uporządkowane przedmiotowo-problemowo-tematycznie według synkretycznego modelu cyklu zarządzania (przewidywanie, ustalanie celu, planowanie, organizowanie, motywowanie i kontrola). Wiązki te są jednorodne pod względem zawartości merytorycznej (treści), są także pochodnymi podsystemów rozmieszczonych na różnych poziomach - od pierwszego do czwartego. 


\section{Poziom 4}

Segment czwarty obejmuje sieci zbudowane z różnorodnych tematycznie relacji komunikowania, uprzednio w segmencie trzecim złożonych w wiązki jednorodnych tematycznie relacji komunikowania. Każda z sieci stanowi zgrupowanie określonego typu wiązek zbieranych ze wszystkich poziomów tego systemu.

\section{Poziom 5}

Segment piąty to nadrzędny podsystem zarządzania w funkcji integratora sieci relacji komunikowania. Funkcja integracyjna jest ciągła i nieprzerwana. Obieg cyklu komunikowania aktualizuje adekwatność relacji komunikowania do konkretnej, zaistniałej sytuacji. Ze względu na treść komunikatu, sposób grupowania i możliwości ich wykorzystania korekcie podlegają zarówno dotychczas realizowane procesy komunikowania, ze względu na ich ewentualne własne wady, jak i procesy komunikowania związane ze zmianą celu (telekorektor) indukowaną wpływami otoczenia (doskonalenie i aktualizowanie).

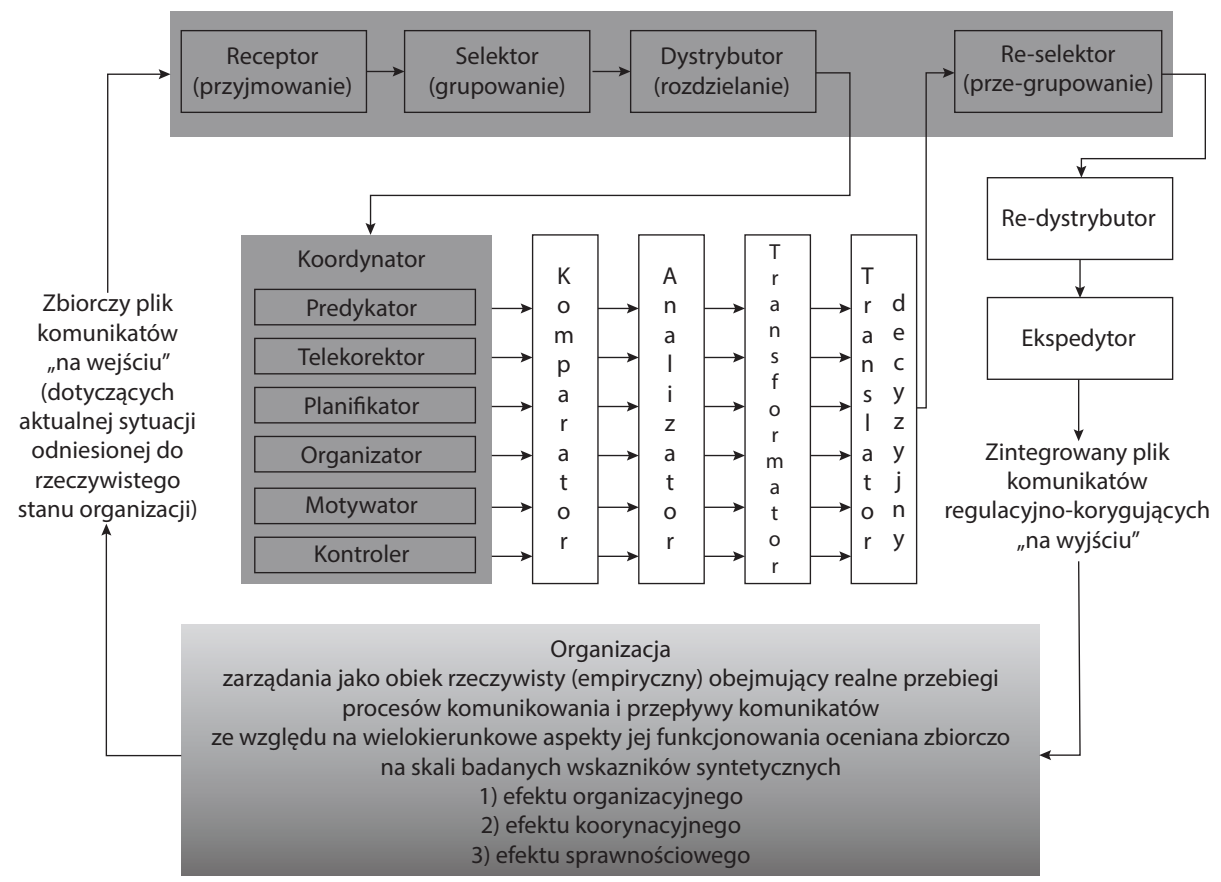

Rysunek 21. Model zarządzania (z selektywną eksplikacją jego funkcji i procesów) - w roli integratora relacji komunikowania wewnątrzorganizacyjnego

Źródto: opracowanie własne. 
Zbiorczy plik komunikatów dotyczących aktualnej sytuacji rzeczywistej organizacji trafia do nadrzędnego podsystemu zarządzania, w którym sieci komunikacyjne są przyjmowane i grupowane. W tym miejscu następuje weryfikacja i kontrola poprawności uprzedniego grupowania relacji komunikowania w sieci, a następnie ich rozdzielenie ze względu na treści związane $\mathrm{z}$ funkcjami koordynacyjnymi (predyfikator - przewidywanie, telekorektor - korekta celu, który podlegać może nieustannym zmianom, planifikator - planowanie, organizator - organizowanie, motywator - motywowanie i wreszcie kontroler - kontrolowanie). Są one wzajemnie porównywane (komparator), analizowane (analizator), przetwarzane (transformator) i dopasowywane do potrzeb decyzyjnych (translator decyzyjny). Sekwencja wskazanych działań na odebranych komunikatach prowadzi do przegrupowania komunikatów, aby mogły być redystrybuowane do tych podsystemów organizacji, w których występują potrzeby komunikacyjne w określonych zakresach. Komunikaty są następnie wysyłane do właściwych odbiorców (ekspedytor), zgodnie z potrzebami (rysunek 21).

Zbudowany model organizacji jako systemu sieci relacji komunikowania się prezentuje wyższą użyteczność dla osiągnięcia celów pracy niż inne modele komunikowania się obecne w literaturze, ponieważ:

1) powstał jako efekt badania systemowego, jest zatem pewne, że jest systemowy;

2) jako model w pełni systemowy może podlegać dalszemu badaniu systemowemu;

3) może być używany do zarządzania/koordynowania w kierunku sprawności. 



\section{Koordynacja w sensie ogólnym i szczegółowym}

Systemowy model organizacji zbudowany w poprzednim rozdziale na podstawie sieci relacji komunikowania podlega dalej koordynacji w kierunku sprawności. Klasycy uznawali ważność funkcji koordynacji na równi z zarządzaniem, jednak z biegiem czasu badania nad koordynacją ograniczono do jej wąskich aspektów. Klasyczne ujmowanie koordynacji daje podstawę do matematycznego jej zapisu i wskazuje reguły jej stosowalności. Nowoczesne podejście do zagadnienia koordynowania pozwala usytuować jej zakres i związać ją bezpośrednio z poszczególnymi funkcjami zarządzania (Jessop, 2007), a ich szczegółowa analiza stanowi podstawę do wyodrębnienia przedstawionego w pracy systemu koordynacji w postaci pięciu grup wskaźników według rodzajów.

W niniejszym opracowaniu za podstawę rozważań o koordynacji przyjęto perspektywę wewnątrzorganizacyjną. Ogólnie koordynowanie oznacza „uzgodnione, uporządkowane współdziałanie elementów pewnej całości” (Jarzębowski, 1981, s. 231),

\subsection{Koordynacja według klasyków teorii organizacji - Fayola i Le Chateliera}

Potrzebę koordynowania określił Henry Fayol przez sformułowanie funkcji administrowania. Według niego koordynować, to „łączyć, jednoczyć i harmonizować1 wszystkie czynności i wszystkie wysiłki” (Fayol, 1947, s. 37). Z późniejszych wersji funkcji kierowniczych czy też funkcji zarządzania koordynowanie zostało expressis verbis usunięte i utożsamiano je z ogólnym pojęciem zarządzania.

Na zarządzanie należy patrzeć jako na zespół działań lub proces mający na celu koordynację i integrację użytkowania zasobów dla osiągnięcia celu organizacyjnego (wydajności i satysfakcji) przez ludzi przy użyciu informacji w zorganizowanych strukturach (Koźmiński, 1987, s. 352).

1 Technika kreślenia harmonogramów jest przykładem narzędzia koordynacji, synchronizacji działań ludzkich w pracy zespołowej. 
Włączono je też do etapu organizowania, uznając, że można je:

[...] stosować zamiennie z ogólnym znaczeniem zarządzania, albo też można je utożsamiać z funkcją organizowania, a taki jest w istocie sens nadany przez Fayola funkcji koordynowania (Stabryła, 1983, s. 11).

Istnieją jednak różnice w rozumieniu tych pojęć.

Marry Parker Follett także przywiązywała zasadnicze znaczenie do koordynacji jako funkcji zarządzania. Martyniak (2002, s. 175-176) podaje ${ }^{2}$, że koordynacja według Follett wymaga kontaktów bezpośrednich i indywidualnych, powinna być prowadzona od samego początku realizacji przedsięwzięcia, uwzględniać wszystkie czynniki wpływające na sytuację (włącznie z czynnikami psychologicznymi) oraz powinna być ciągła i permanentna.

Henri Le Chatelier (1926, s. XX) traktuje koordynację w zasadzie nie jako etap cyklu działania zorganizowanego, ale jako podstawę działania organizacji i funkcję nadrzędną. Pisze, że „Koordynacja ich [robotników - przyp. M.Z.-T.] pracy jest koniecznością nieuniknioną [...]”, gdyż „Aby wytwarzać, nie dość jest mieć dobre maszyny, doskonałych robotników, wykształconych i inteligentnych inżynierów; trzeba jeszcze absolutnej koordynacji ich wysiłków" (Le Chatelier, 1926, s. 71). Koordynacja jest nadrzędna wobec wszelkich działań wewnątrz organizacji, tożsama z zarządzaniem - ta perspektywa konieczności koordynacji działań wewnątrzorganizacyjnych jest do dziś aktualna ${ }^{3}$, choć zmieniły się formy i sposoby jej przeprowadzania.

Za czasów Le Chateliera panowało przekonanie, że podział pracy trzeba posunąć

[...] aż do ostatnich granic [...]. Człowiek i maszyna nie pracują oddzielnie; aby otrzymać jakikolwiek wynik użyteczny, trzeba skoordynować ich czynności elementarne (Le Chatelier, 1926, s. XXVI).

Chodziło bowiem o zapewnienie rytmu wszystkich operacji. Dlatego w konsekwencji zadanie koordynacji rozdzielono na poszczególne szczeble - koordynowanie ogólnego biegu fabryki należało do dyrekcji, niższe szczeble miały koordynować przygotowanie robót w poszczególnych działach.

Le Chatelier (1926, s. XXVI) odnosił działanie skoordynowane do trzech rodzajów „stosunków” między ludźmi, które miały je zapewnić: współdziałania,

2 Martyniak niestety nie podaje odnośnika do żadnej z oryginalnych prac Follett, w całym rozdziale jej poświęconym opiera się wyłącznie na pracach wtórnych.

3 Le Chatelier (1926, s. 71) pisze: „Taylor nie wymyślił koordynacji, ale zbadał ją, podobnie jak inne czynniki produkcji, z całą starannością, stosując zawsze swoją maksymę: rozważ przedtem, zanim zaczniesz działać". 
nauczania i kierowania. Współdziałanie rozumiał jako pracę we wspólnym porozumieniu, nauczanie skupiało się na przekazywaniu wiadomości ${ }^{4}$ i obejmowało głównie metody pracy, a kierowanie wiązało się z wydaniem lub otrzymaniem polecenia w odpowiednim czasie (to jest „przed zaczęciem swojej roboty” - s. XXVII).

Harmonizacja Karola Adamieckiego 5 (1924/1972) - jako podstawa koordynacji - powstała w wyniku inspiracji ${ }^{6}$ pracami Le Chateliera. Przeprowadzone badania empiryczne doprowadziły między innymi do określenia podstawowego powodu problemów w organizacji pracy zespołów robotniczych, jaką jest zharmonizowanie ${ }^{7}$ poszczególnych jej części (organów) między sobą. Adamiecki sformułował w tym kontekście dwa prawa - harmonii doboru (w ustroju organizmu) i harmonii działania organów pracy zbiorowej. Te dwa rodzaje harmonii dotyczą wszystkich czynników pracy zbiorowej - maszyn, urządzeń ${ }^{8}$ i ludzi, stąd traktując organizację jako całość, uznawał harmonię w układzie społecznym - ludzi między

4 Le Chatelier zdawał sobie sprawę, że proces komunikacji nie jest obojętny, „[...] powinien więc być zbadany. Za pomocą jakiego sposobu instruktor powinien objaśniać wykonawcę? Czy ta komunikacja powinna odbywać się ustnie, czy też na piśmie? W jaki sposób powinny być redagowane kartki instrukcyjne, opisujące sposoby fabrykacji? W jakie szczegóły powinny wchodzić, a jakie powinny być pozostawione inicjatywie robotnika? Jakie symbole mają być używane? Może to, oczywiście, zmieniać się zależnie od rodzaju przemysłu. Taylor zbadał szczegółowo te zagadnienia w warsztatach mechanicznych; ale nie można tak samo postępować z artystą dekoratorem w sewrskiej fabryce porcelany, jak z zamiataczem ulic w Paryżu. Trzeba także wziąć pod uwagę rachunek wydatków, jaki pociąga za sobą pisanina w porównaniu z korzyścią jej zastosowania [...]" (Le Chatelier, 1926, s. XXVII).

5 „Adamiecki wybiegał swą prekursorską myślą o wiele dalej w przyszłość: ku podejściu systemowemu, które zaczęło dominować w skali światowej dopiero w 30 lat po jego śmierci" (Martyniak, 1995, s. 1).

6 Adamiecki był tłumaczem prac Le Chateliera. Jako profesor Politechniki Warszawskiej przetłumaczył pozycję pt. Filozofia systemu Taylora wydaną w roku 1926. W przedmowie do tego wydania Adamiecki wyraża się z podziwem o profesorze Le Chatelier słowami: „Co do zasad Taylora, to wśród komentatorów jest tylko jeden [...] [który] ujął główną ideę przewodnią Taylora lepiej nawet, niż sam autor. Jest nim sławny profesor, Henry Le Chatelier, który na gruncie europejskim pierwszy zrozumiał doniosłość zastosowania nauki do organizacji [...]" (Adamiecki, $1926 \mathrm{~s}$. VI).

7 „W jednej ze swych prac Adamiecki pisat, że «organizacja w ogóle powinna być wprowadzana stopniowo - etapami. Najpierw skoordynowanie poszczególnych czynności, czyli harmonizacja bez zmiany w sposobie ich wykonania i bez zmiany w urządzeniach technicznych, a potem dopiero dalsze etapy organizacji - badanie szczegółów i ich ulepszanie [...] Rozpoczynanie [...] od ulepszania szczegółów organizacji może nawet niekiedy wprowadzić zamęt i trudności [...]» (Adamiecki, 1926). To ostatnie zdanie brzmi tak, jak by było zaczerpnięte ze współczesnego podręcznika na temat podejścia systemowego w organizowaniu" (Martyniak, 1995, s. 1-2).

8 „Aby więc osiągnąć sprawność wzorcową pod względem ekonomicznym, [...] trzeba dobierać organy zgodnie z ich charakterystycznymi wykresami i następnie trzeba, aby te organy działały w ścisłym ze sobą związku, tak aby każda czynność odbyła się w swoim czasie" (Adamiecki, 1924; Martyniak, 1995, s. 2). 
sobą oraz technicznym - między ludźmi a rzeczowymi warunkami i środkami ich pracy (Adamiecki, 1972, s. 422).

Klasyczna literatura na temat organizacji uznaje, że najważniejszą funkcją organizacji jest koordynacja majątku fizycznego i zasobów ludzkich w celu wytworzenia dobra lub usługi (Barnard, 1938; Schein, 1985; Chisholm, 1989). Koordynacja zdefiniowana była szeroko, na przykład „Koordynacja jest [...] uporządkowanym układem wysiłków grupowych, zapewniającym jedność działania w dążeniu do wspólnego celu" (Mooney, 1947, s. 5), mimo że w tym zakresie była tożsama ze współpracą. Mooney twierdzi także, że koordynacja jest pierwszą zasadą organizacji i że wszelkie inne zasady organizacyjne „są po prostu zasadami, za pomocą których działa koordynacja, a tym samym staje się skuteczna" (Mooney, 1947, s. 5). James D. Thompson (1967, s. 56-59) wyróżnił problemy związane z koordynacją, na przykład standaryzację, planowanie lub wzajemne dostosowanie. Potrzebę koordynacji wzajemnego dostosowania podkreślali także Herbert Alexander Simon i James March (1958). Koordynacja odgrywała również główną rolę w myśleniu o zasobach wewnętrznych organizacji (Becker, Murphy, 1992; Milgrom, Roberts, 1992), historii organizacji biznesowych (Lamoreaux, Raff, 1995, s. 5), w strategii biznesowej, wzajemności i legitymizacji w ewolucji organizacyjnej, makroekonomii (Cooper, John, 1988) i innych dziedzinach.

Zupełnie inaczej, z powodu matematycznej konkretyzacji swoich rozważań, opisywali zasadę koordynacji Mihajlo Mesarović, Donald Maćko i Yasuhiko Takahara (2000, s. 98-106). Przedstawili ją na podstawie dwupoziomowego systemu kierowania (Mesarović, Maćko, Takahara 2000, s. 113). Zasada określa optymalne działanie „centrum decyzyjnego" w warunkach występowania interakcji między podsystemami (nazywanymi przez nich układami wykonawczymi).

Dana jest hierarchiczna struktura kierowania, a w niej $N$ podsystemów wykonawczych, wówczas zasadę można określić wzorem funkcji:

$$
P_{n}: D_{n} \times U_{n} \rightarrow Y_{n}, n=\{1, \ldots, N\}
$$

gdzie:

$P_{n}$ - funkcja procesu $P$,

$D_{n}$ - zbiór decyzji $n$-tego podsystemu kierownika lokalnego,

$U_{n}$ - zbiór interakcji związanych z procesem $P_{n}$,

$Y_{n}$ - zbiór wyników $n$-tego procesu wytwórczego.

Przy czym dana jest funkcja $\xi_{n}: D \rightarrow U_{n}, D=D_{1} \times D_{2} \times \ldots \times D_{n}$.

Mesarović, Maćko i Takahara zakładają, że globalnym celem systemu $F$ jest minimalizacja funkcji: 
$F: D \times Y \times V \rightarrow E$,

gdzie:

$D$ - zbiór decyzji,

$Y$ - zbiór wyników procesu wytwórczego,

$V$ - zbiór decyzji koordynujących,

$E$ - zbiór wartości efektów działania

oraz przy ograniczeniu danym przez funkcję $P$, takim że lokalnym celem podsystemów $f$ jest minimalizacja funkcji

$$
f: D \times Y \rightarrow E \text { dla dowolnej decyzji nadrzędnej } v \in V \text {, }
$$

czyli wybór optymalnych wartości $\left(d_{n}{ }^{*}(v), u_{n}{ }^{*}(v)\right)$ - działanie koordynacyjne centralnego decydenta (zwane równowagą sprzężeń) wymaga, by każdy lokalny decydent podejmował taką decyzję, aby:

$$
u_{n}^{*}(v)=u_{n}{ }^{*}(v), u_{n}^{*}(v)=\xi_{n}\left(d^{*}(v)\right), d \in D .
$$

Jeżeli zatem istnieje taka decyzja koordynacyjna $v \in \mathrm{V}$, że równowaga jest osiągana, to system daje się skoordynować za pomocą zasady równowagi sprzężeń.

Przedstawiony zapis zasady koordynacji w języku matematyki za pomocą funkcji daje wrażenie jakości trudnej, złożonej. Tymczasem zasada ta jest prosta, a nawet trywialna, co więcej - obarczona jest pewnym błędem logicznym - circulus vitiosus ${ }^{9}$, na podstawie tego co powyżej, składając oba warunki, można bowiem powiedzieć, że system daje się skoordynować za pomocą działania koordynacyjnego.

Ponadto wprowadzone przez autorów ograniczenia funkcji powodują, że jest ona stosowalna w zawężonym zakresie do systemów dwupoziomowych, w innym przypadku postać funkcji staje się na tyle skomplikowana, że utrudnia lub uniemożliwia skorzystanie w aparatu matematycznego (por. uwagi o teorii i metodzie systemów złożonych - podrozdział 3.3). Mając na względzie to ograniczenie, należy jednak docenić ideę, jaka przyświecała autorom przy konstrukcji zasady koordynacji. Mianowicie przedstawiona koncepcja łączy koordynację wyłącznie $z$ relacjami. Ten model matematyczny wskazuje możliwy maksymalny poziom koordynacji (równej 1 przy uwzględnieniu wszystkich możliwych relacji, w organizacji relacje typu „każdy z każdym”), odchylenie od poziomu maksymalnego wskazuje pewien niedobór w zakresie koordynacji, stąd zakres wskaźnika od 0 do maksymalnego możliwego 1. Centralny układ decyzyjny - w niniejszej

9 Błędne koło - jako „błąd polegający na definiowaniu jakiegoś terminu za pomocą tego samego terminu" (Podsiad, Więckowski, 1983, s. 37). Szersza kategoria tego błędu to petitio principii - błąd niedostatecznego uzasadnienia. 
pracy rozumiany jako ogniwo koordynacyjne - traci swoją obiektywność, którą ma w koncepcji Mesarovicia, Maćko i Takahary, i staje się arbitralny, bo"

[...] dla danego działania koordynującego $v$ centralny układ decyzyjny przewiduje wartość interakcji $\tilde{u}(v)$. Wtedy wartość błędu prognozy dla danego $v$ wyniesie $\varepsilon=\tilde{u}(v)-u(d(v))$. Wynika stąd, że nowa decyzja koordynująca powinna uwzględniać wielkość popełnionego błędu, czyli $v^{\prime}=v+T(\varepsilon)$, gdzie $T$ jest zadanym operatorem (Sienkiewicz, 1988, s. 137).

Przedstawiona zasada koordynacji (i jej matematyczna postać) jest użyteczna do celu i konstrukcji niniejszej pracy w następujących aspektach. Po pierwsze, wartość liczbowa prezentowanej funkcji koordynacji może być ustalona wyłącznie w badaniach empirycznych konkretnego systemu - dostępne są dowolne wartości z przedziału $<0 ; 1>$. Po drugie, funkcja opisuje - z punktu widzenia rodzajów koordynacji wskazanych szczegółowo w tym rozdziale - niespecyficzny rodzaj koordynacji, jest bowiem uzależniony od liczby relacji (w sztukach), a nie od ich typu lub rodzaju. W niniejszej pracy relacje odnoszone są do relacji komunikowania pogrupowanych w określone wiązki (typy). I wreszcie, odniesienie do liczby relacji w zasadzie może być utożsamiane koncepcyjnie ze wskaźnikiem zorganizowania z grupy strukturalnych wskaźników koordynacji, przedstawionych w dalszej części tego podrozdziału, określającym stosunek liczby faktycznie używanych relacji do liczby możliwych do wystąpienia (maksymalnie). Gdyby zaistniała potrzeba określania jednego, niesyntetycznego, niespecyficznego wskaźnika koordynacji, przyjąłby on następującą postać:

koordynacja = liczba używanych relacji/liczba wszystkich relacji możliwych do wyróżnienia w danym systemie.

\subsection{Koordynacja w ujęciu współczesnych autorów}

Koordynacja jest istotą zarządzania i jest nieodłączna we wszystkich jego funkcjach. Inaczej mówiąc, jest konieczna w sprawnej realizacji każdej z funkcji zarządzania (np. Ćwiklicki, 2010, s. 211) (zależność jest w zasadzie wzajemna, kolejne funkcje zarządzania ułatwiają koordynację, w niniejszym opracowaniu przyjęto nadrzędność koordynacji wobec pozostałych funkcji). Koordynacja jest istotą zarządzania.

Pojęcie koordynacji stało się jednak pewnym aksjomatem w obecnej literaturze z zakresu organizacji i zarządzania. Autorzy korzystają z niego, w zasadzie nie wyjaśniając jego istoty lub wyjaśniając je przez nie samo: 
Problem koordynacji jest jednym z podstawowych zagadnień nauk ekonomicznych oraz nauk o zarządzaniu. Zmierza bowiem do wyjaśnienia przyczyny istnienia firmy, jako zorganizowanej i biurokratycznej formy koordynacji działania podmiotów na rynku (Czakon, 2011, s. 5).

Koordynację zauważa się zwykle wówczas, gdy jej brakuje (Malone, Crowston, 1994, s. 90).

Wiele z bieżących opracowań koncentruje się na zagadnieniach koordynacji międzyorganizacyjnej, czyli koordynacji relacji organizacji z innymi organizacjami z otoczenia sektorowego (Szczerski, 2005; Czakon, 2011; Koźmiński, Latusek-Jurczak, 2011; Borowiecki, Rojek, 2012), zwanej perspektywą koordynowania sieci (Czakon, Latusek-Jurczak, 2011). Ta perspektywa jest odmienna od przyjętej w pracy orientacji wewnątrzorganizacyjnej, dlatego nie będzie dalej rozwijana.

Mimo upływu czasu, pojawienia się nowych form organizacji przedsiębiorstw i sposobów zarządzania nimi, definicja koordynacji, a jeszcze bardziej konieczność jej praktycznego stosowania nie straciły na aktualności. Sam proces jest jeszcze bardziej istotny dla praktyków i naukowców ze względu na globalizację i hiperturbulentne otoczenie organizacyjne oraz związaną z nim transformację typów organizacji i procesów organizacyjnych, które często są rozproszone geograficznie i wymagają koordynacji.

Współczesny kontekst pojęcia koordynacji w piśmiennictwie rozmaitych autorów został zredukowany przede wszystkim do współdziałania ${ }^{10}$. Na przykład wyróżnia się trzy główne formy koordynacji ${ }^{11}$ złożonych wzajemnych współzależności: koordynację ex post przez wymianę ${ }^{12}$, koordynację ex ante przez imperatywne władztwo (przykładem jest hierarchiczna firma, organizacja lub państwo) oraz

10 Zidentyfikowane różnice między koordynacją a współdziałaniem odnoszą się do kilku płaszczyzn: znaczenia - koordynacja przebiega jako realizowane funkcje zarządzania, podczas gdy współpraca obejmuje nieprzymuszoną pomoc wzajemną. Koordynacja jest zatem realizowana przez kierowników, jest potrzebna w realizacji zadań organizacji bez względu na typ organizacji, podczas gdy współpraca, jeśli występuje, jest realizowana na dowolnym szczeblu organizacji i stanowi przejaw emocji osób zaangażowanych w tym sensie, że jest zależna od chęci i woli wspólnie pracujących. Koordynacja jest niezbędna, jest planowana, a jej realizacja jest powierzana organowi centralnemu, ale ma pełne wsparcie ze strony różnych osób pracujących na różnych poziomach organizacyjnych, podczas gdy współpraca zależy od chęci i woli osób, i w tym sensie nie jest konieczna, współpraca bez koordynacji jest bezowocna.

11 Koordynacja działań zbiorowych jest także nazywana governance (Jessop, 2007) albo corporate governence (Samborski, 2012). W nurcie zarządzania strategicznego i ekonomii instytucjonalnej pojęcie to wiąże się z nadzorem korporacyjnym i relacjami w układzie: akcjonariusze-rada nadzorcza-zarząd korporacji.

12 Jessop (2007) podaje przykład anarchii rynku. 
refleksyjną samoorganizację (przykładem jest heterarchia podtrzymywana przez wynegocjowane porozumienie w kwestii rozwiązywania złożonych problemów w ramach korporatystycznego ładu lub horyzontalnych sieci umożliwiających koordynację kompleksowego podziału pracy) (Jessop, 2007, s. 9). Autor nie wyjaśnia, co rozumie pod pojęciem koordynacji ex ante i ex post, gdzie je lokuje i względem czego. Na potrzeby pracy interpretuje się je w następujący sposób. Koordynacja typu ex ante dotyczy fazy i funkcji planowania. Koordynowanie realizowane przez funkcję organizowania można konsekwentnie nazwać koordynowaniem in tractu, które oznacza bieżące doregulowanie. Natomiast koordynowanie ex post jest realizowane przez funkcje kontrolowania, po zakończeniu wykonywania określonego działania. Koordynowanie ex post może być także wykorzystywane jako narzędzie doregulowania systemu w przyszłych realizacjach. Takie rozumienie koordynacji ex ante, in tractu i ex post lokowane jest na osi czasu związanej z wykonywaniem określonego działania i bezpośrednio odnosi się do funkcji zarządzania. Ponadto zagadnienia procesu koordynacji dotyczyć mogą zarówno koordynacji organizacji powstającej, działań organizacyjnych na etapie tworzenia organizacji (zmierzających do jej powstania), jak i koordynacji doraźnej, regulującej, obejmującej bieżące działania kierownictwa organizacji już istniejącej. Bardziej interesujące wydają się działania koordynacyjne zmierzające do zapewnienia przetrwania organizacji - nie są to jednorazowe ciągi działań, a jednocześnie niekoniecznie powtarzalne.

Badania dotyczące koordynacji wewnątrzorganizacyjnej często przeprowadzane są w kontekście sieci jako struktury społecznej, organizacyjnej (Perechuda 2007, Dwojacki, Nogalski 1998). Badano koordynację heterogenicznych struktur sieci społecznych w ujęciu statycznym (Buskens, Snijders, 2005), w których heterogeniczność odniesiono do osób mających różne pozycje w sieci, co dla badaczy wiązało się z trudnością $\mathrm{w}$ postaci niekoniecznie takiej samej liczby relacji między uczestnikami (model matematyczny niesymetryczny). Ponieważ sieci tworzone przez ludzi zmieniają się w czasie (Flap, 2004), potrzebne jest podejście dynamiczne do koordynacji.

Największy wkład w uporządkowanie zagadnienia koordynacji prezentują prace Thomasa W. Malone'a i Kevina Crowstona (1994; Crowston, 1997). Charakteryzują one teorię koordynacji13 jako wciąż rozwijającą się „teorię, o tym jak koordynacja może występować w różnych systemach" (Malone, Crowston, 1994, s. 87). Według tej teorii aktorzy w organizacji stają przed problemami koordynacji, które powstają z powodu uzależnień (zależności) i ograniczeń w sposobie wykonywania

13 Teorie koordynacyjne oceniają wzorce wzajemnych interakcji między aktorami, którzy mają różne cele i biorą udział w wykonywaniu czynności wymagających różnorodnych zasobów (Malone, Crowston, 1994). 
zadań14. Przezwyciężeniu problemów służy mechanizm koordynacyjny ${ }^{15}$ - różny w różnych typach organizacji. Wymieniają uzależnienia typu zadanie-zadanie, zadanie-zasób i zasób-zasób, oraz typizują właściwe mechanizmy koordynacji w postaci (Crowston, 1997, s. 160):

1) eliminowania duplikacji zadań, łączenia zadań lub wyboru jednego, dostrzegania sprzeczności (konfliktu) i korzystania z zasobów według harmonogramu, porządkowania zadań, zapewnienia użyteczności wyniku, zarządzania przekazywaniem zasobów, a także

2) zidentyfikowania niezbędnych i dostępnych zasobów, wybrania określonego ich zestawu i właściwego ich przydzielenia i wreszcie

3) identyfikowania i zarządzania zależnościami.

Rozważania o funkcjonalnej (zadanie) i zasobowej płaszczyźnie koordynacji będą szczegółowo omawiane dalej.

Idea koordynacji jest także rozwijana w kontekście wiedzy - ani jednostki, ani zespoły nie są bowiem w stanie posiadać pełnej wiedzy, najważniejszy staje się nie tylko dostęp do zasobów sieci wiedzy zespołu (ogólnie nazywanej kapitałem społecznym), ale także skuteczna koordynacja wiedzą (Šmite, Moe, Šāblis, Wohlin, 2017). Powstały także prace o koordynacji z perspektywy podejmowania decyzji (Dutta, Jackson, 2003; Newman, Barabási, Watts, 2006). Konkretne modele gier koordynacyjnych wykorzystywanych w sieciach dynamicznych badali Brian Skyrms i Robin Pemantle (2009), Matthew O. Jackson i Alison Watts (2002), Sanjeev Goyal i Fernando Vega-Redondo (2005) oraz Siegfried Berninghaus i Bodo Vogt (2006), a strukturę koordynacji sieci Vincent Buskens, Rense Corten i Jeroen Weesie (2008). O koordynacji zadań związanych z rozwojem oprogramowania pisali Sandeep Krishnamurthy (2002), Pankaj Setia, Viswanath Venkateshi i Supreet Joglekar (2013), James Howison i Kevin Crowston (2014) oraz James Herbsleb16

14 „Np. dwa składniki systemu, które wzajemnie oddziałują na siebie, ograniczają możliwości zmian, jakie można dokonać w pojedynczym składniku bez ingerencji w funkcjonowanie drugiego" (Crowston, 1997, s. 159). W perspektywie systemowej zmiana jednego składnika bez wpływu na drugi jest w zasadzie niemożliwa.

15 Na przykład częstym problemem koordynacyjnym jest dopasowanie do określonego zadania wyspecjalizowanych umiejętności pracownika, który może je wykonać. Ta zależność między czynnością i osobą pojawia się w różnej formie w prawie każdej organizacji. Teoria koordynacji sugeruje zatem zidentyfikowanie i przeanalizowanie najczęstszych zależności i związanych z nimi mechanizmów koordynacyjnych w szerokiej różnorodności typów organizacji (Crowston, 1997, s. 159).

16 W publikacjach z obszaru koordynacji (jak zresztą i w innych obszarach) często zdarza się, że tytuł publikacji jest obiecujący, np. Building a socio-technical theory of coordination: why and how (outstanding research award) (Herbsleb, 2016). Jednak treść artykułu zredukowano do rozpoznania trudności rozwoju wielozadaniowego, globalnego oprogramowania typu open source (global software development - GSD). Natomiast sygnalizowana w tytule 
(2016). Koordynacja jest zagadnieniem rozpatrywanym w kontekście zarządzania projektami - związana jest z presją czasową prowadzonych tymczasowych projektów, oddzielnie lub w trwałych organizacjach. Podnoszone są zagadnienia presji czasowej związanej ze zbliżaniem się terminów ostatecznych (Gersick, 1988; Lim, Murnighan, 1994; Waller, Zellmer-Bruhn, Giambatista, 2002; Janicik, Bartel, 2003; Sydow, Lindkvist, DeFillippi, 2004; van Berkel, Ferguson, Groenewegen, 2016), a także koordynacja projektów tymczasowych z departamentami (działami), organizacjami lub sieciami, w których są one osadzone (Sydow, Lindkvist, DeFillippi, 2004) i wynikające z presji czasu konflikty (Ancona i in., 2001; Dille, Söderlund, 2011). Badania te są bardzo szczegółowe, wręcz drobiazgowe, zatraciły charakter uniwersalny i szeroką perspektywę koncepcji koordynacji.

Koordynację określa się także jako zarządzanie współzależnościami między czynnościami wykonywanymi przez jednego lub więcej pracowników, które są niezbędne, aby osiągnąć cel najczęściej, choć niekoniecznie, uznawany za wspólny (Malone, Crowstone, 1994). W przypadku gdy kilka osób dzieli ten sam cel, autorzy mówią o koordynowaniu wspólnych działań. Rozróżniają dwa rodzaje zależności do koordynowania: dzielenie zasobów i zależności czasowe (równoczesność i pierwszeństwo). Zoubida Afoutni, Roger Martin-Clouaire, Remy Courdier i François Guerrin (2010, s. 25), niekiedy dodają trzeci rodzaj koordynacji - zależność przestrzenną.

Panujące rozdrobnienie definicyjne ${ }^{17}$ pozwala na przedstawienie rozmaitych definicji cząstkowych tego pojęcia, gdyż:

[...] cechą charakterystyczną pojęć definiowanych [...] cząstkowo jest to, że żadna liczba definicji cząstkowych nie daje w sumie definicji pełnej. Zakres takiego pojęcia pozostaje otwarty (Pawłowski, 1978, s. 192).

Otwartość zakresowa pojęć wiąże się z pytaniem, czy pewne przedmioty są desygnatem tego pojęcia (należą do zakresu pojęcia). Pytanie jest permanentne

społeczno-techniczna teoria koordynacji (STTC) określa „zależności pomiędzy decyzjami inżynieryjnymi, które są postrzegane jako określające problem zadowolenia związanego z ograniczeniami, organizacja może je rozwiązać na wiele sposobów" (Herbsleb, 2016, s. 2), których nie podano.

17 Definicja pełna (niecząstkowa) podaje pełne znaczenie pojęcia definiowanego - dlatego jego zakres zostaje wyczerpany, ma ono charakter pojęcia zamkniętego. „Jeżeli z kolei, definicja zbudowana jest tak, że definiens pojęcia definiowanego zawiera jedynie opis cech tego pojęcia, albo też tylko zakres jego stosowalności - to taka definicja jest cząstkowa [...] nie jest ona definicją równościową i uniemożliwia operacje zastępowalności. Definicja cząstkowa «ustala warunek jedynie wystarczający lub jedynie konieczny [...]»" (Pawłowski, 1978, s. 192, w: Sobczyk, 2007, s. 155). 
i jednocześnie nierozstrzygalne, sytuacja nieostrości pojęć jest „w pełni adekwatna dla charakterystyki obszaru językowo-pojęciowego TOiZ (teorii organizacji i zarządzania)" (Sobczyk, 2007, s. 155).

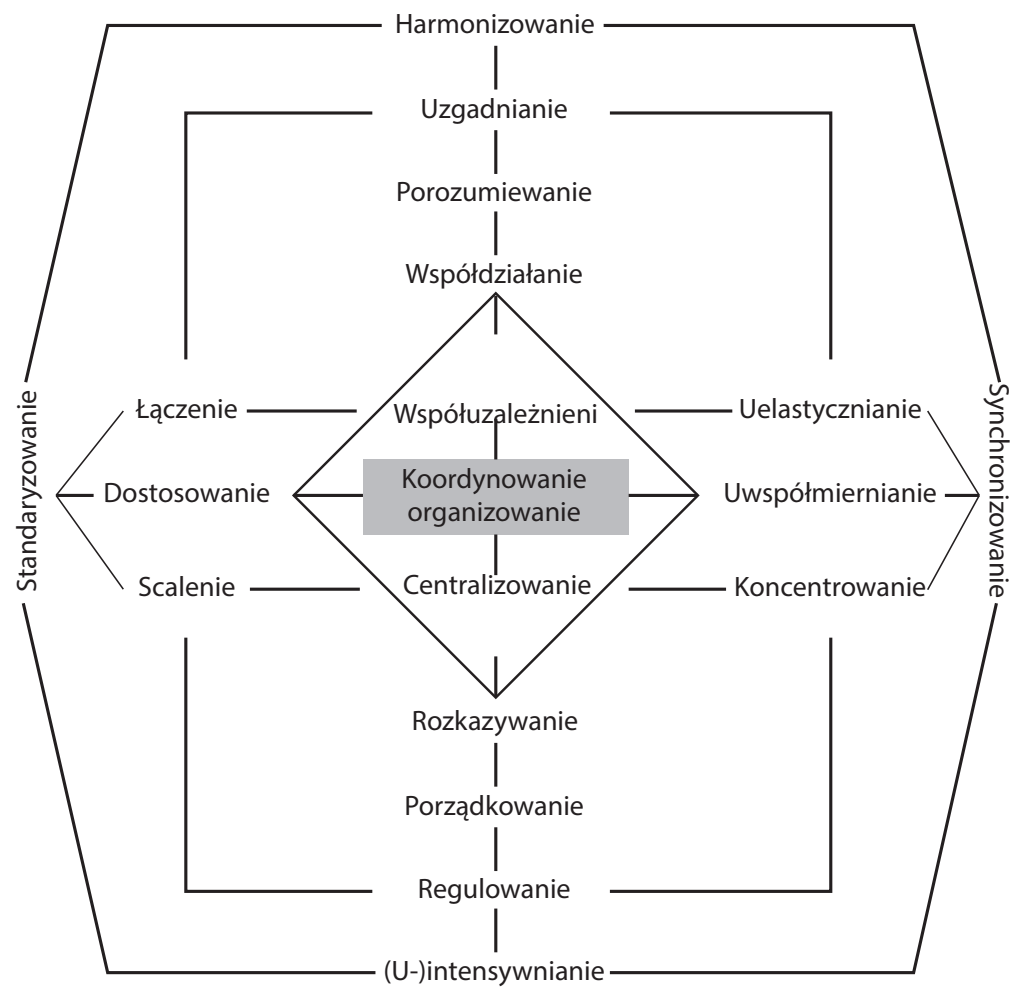

Rysunek 22. Schemat „obszaru pojęciowego” pojęcia koordynacji i koordynowania zakreślonego siecią relacji wokót wyodrębnionego centrum „koordynacja - organizacja”

Źródto: Sobczyk, 2007, s. 159.

W literaturze dotyczącej teorii organizacji odnajduje się przeprowadzone badania leksykalne nad zakresem definicji pojęcia koordynacja. Janusz R. Sobczyk (2007) przebadał około pięćdziesiąt definicji prezentowanych na przestrzeni co najmniej trzydziestu lat poprzedzających jego opracowanie. Przedstawił wykaz czynności koordynujących i przedmiotów koordynowania oraz wykaz częstotliwości ich występowania w badanych definicjach, dokonany w układzie systematyzacyjnym L. Urwicka (segmenty budowy morfologicznej tabeli Urwicka - Sobczyk, 2007, s. 156-158). Efektem drobiazgowych prac jest zakreślenie obszaru pojęciowego dla koordynacji i koordynowania. Wynikiem jego badań jest przedstawiony poniżej schemat zawierający obszar pojęciowy i relacje innych określeń wobec podstawowych koordynowanie 
i organizowanie. Im terminy położone są bliżej rdzenia, tym ściślejsza jest relacja pojęciowa między nimi a podstawowym terminem koordynacji.

Rozważając pojęcie koordynacja, należy dokonać także rozróżnienia na sens czynnościowy i rezultatowy. Koordynacja w znaczeniu czynnościowym obejmuje wszelkie działania koordynujące kierownictwa. Sens rezultatowy koordynacji nadaje pewien stan organizacji, która jest skoordynowana lub cechy skoordynowania nie posiada. Stąd znaczenie czynnościowe powinno leksykalnie przybrać formę koordynowanie, a znaczenie rezultatowe koordynacja, czyli stan uzyskany jako efekt koordynowania. W niniejszej pracy występuje relacja członu koordynującego przez zintegrowaną sieć relacji komunikowania z członem koordynowanym, jakim są ludzie, zasoby materialne, warunki i otoczenie fizyczne człowieka.

Ze względu na zawężone rozumienie pojęcia koordynacji we współczesnej nauce organizacji i zarządzania i jednocześnie w powodu ogromnego rozproszenia płaszczyzn definicyjnych pojęcia koordynacja lub koordynowanie w niniejszym opracowaniu zwrócono się ku prakseologii jako perspektywie badawczej i płaszczyźnie porządkującej.

\subsection{Zorganizowanie - koordynowanie - sprawność. Dyskusja prakseologiczna}

Prakseologia nierozłącznie wiąże się z pojęciem sprawności, dlatego w niniejszym podrozdziale wyjaśniono powód, dla którego skoncentrowano się na sprawności rezultatowej (wywód poprzedzony jest wyjaśnieniem różnic między różnymi typami sprawności) i określono wzajemne powiązanie sprawności rezultatowej i waloru koordynacji. Dalej wskazano, w jaki sposób efekt organizacyjny zależy od właściwej koordynacji, co prowadzi do konieczności wyróżnienia wcześniej już zasygnalizowanych typów koordynacji, teraz omówionych w sposób szczegółowy. I wreszcie wskazano na procesy komunikowania jako podstawę koordynowania procesów wewnątrzorganizacyjnych.

Mimo świadomości istnienia różnych sposobów rozumienia pojęcia sprawności w niniejszej pracy skoncentrowano się wyłącznie na jej prakseologicznym znaczeniu, przyjętym na gruncie teorii sprawnego działania. Podejście prakseologiczne gwarantuje bowiem płaszczyznę opisu i możliwość pomiaru - w tym zakresie korzysta się z jego dorobku w niniejszej pracy. Pośród występujących w literaturze prakseologicznej określeń sprawności odnaleźć można kilka jej rodzajów - sprawność manipulacyjną i metodyczną (ich nazwy nie budzą wątpliwości), a także sprawność syntetyczną, generalną, kolektywną, ogólną, uniwersalną i dystrybutywną, które w znacznej części są synonimiczne.

Wyróżniona tutaj sprawność manipulacyjna ma charakter formalny, niekoniecznie związany z meritum podejmowanej tutaj problematyki. Polega na „wysokiej 
umiejętności wykorzystania narzędzi lub wykonania prac manipulacyjnych. Często jest określana jako zręczność [...]” (Kotarbiński, 1973, s. 127; Piłejko, 1976, s. 134). Obejmuje ona umiejętności manualne jednej osoby, dlatego często jest wyłączona z rozważań prakseologicznych. Ponadto jest kategorią bardziej szczegółową niż pozostałe wymienione typy sprawności. Natomiast sprawność metodologiczna:

[...] polega na umiejętności wykorzystania wszystkich znanych metod i sposobów w celu podniesienia sprawności. Podstawą uzyskiwania tej sprawności jest posiadanie całej dostępnej w danych warunkach wiedzy i osiągnięć nauki, by zapewnić maksymalną sprawność, jakiej można byłoby oczekiwać przy odpowiedniej staranności poczynań (Piłejko, 1976, s. 132-135).

Pośród prakseologów panuje zgodność w zakresie przytoczonych wyżej definicji sprawności manipulacyjnej i metodologicznej, inaczej rzecz ma się z pozostałymi wymienionymi tutaj typami sprawności. Twórca prakseologii - Tadeusz Kotarbiński - posługiwał się pojęciami sprawności uniwersalnej, syntetycznej i manipulacyjnej (Kotarbiński, 1973, s. 127). Tadeusz Pszczołowski, który dokonał benedyktyńskiej pracy, zbierając i porządkując pojęcia prakseologiczne w postaci encyklopedii (Mała encyklopedia prakseologii i teorii organizacji) dokonał uporządkowania pojęć sprawności w postaci kolektywnej i dystrybutywnej (Pszczołowski, 1978, s. 227). Jan Zieleniewski posługiwał się określeniami - ogólna, uniwersalna i syntetyczna postać sprawności (Zieleniewski, 1969, s. 232-236), a Konstanty Piłejko - propagator prakseologii - rozróżnił „sprawność w znaczeniu syntetycznym, uniwersalnym, manipulacyjnym i metodologicznym” (Piłejko, 1976, s. 132). Porządkując definiens i definiedum wymienionych typów ${ }^{18}$ sprawności, obserwuje się, że znaczenia kolektywne, ogólne, generalne i syntetyczne są tożsame, tak samo jak pojęcia sprawności dystrybutywnej i uniwersalnej.

Kolektywne rozumienie sprawności:

[...] to ogół walorów praktycznego działania, razem wziętych: działa się tym sprawniej, im działaniu bliższe jest posiadanie w sobie wszystkich walorów dobrej roboty i to w jak najwyższym wymiarze (Kotarbiński, 1973, s. 127).

18 Sprawność w sensie dystrybutywnym uniwersalnym jest „,nazwą ogólną każdego z walorów praktycznych, a więc dokładność jest jakąś sprawnością, wydajność też, prostota takoż itd. [Natomiast - przyp. M.Z.-T.] Syntetycznie rozumiana sprawność - to ogół tych walorów razem wziętych: działa się tym sprawniej w tym rozumieniu, im działanie bliższe jest posiadania w sobie wszystkich walorów dobrej roboty, i to w jak najwyższym wymiarze" (Kotarbiński, 1973, s. 127). 
Dystrybutywne rozumienie sprawności „obejmuje różne, szczegółowe postacie sprawnego działania, każdy z walorów sprawności z osobna” (Piłejko, 1976, s. 134). Sprawnością „nazywa się każdy z walorów dobrej roboty z osobna, tj. sprawnością jest skuteczność, sprawnością jest korzystność, sprawnością jest ekonomiczność itd." (Pszczołowski, 1978, s. 227).

W niniejszej pracy przyjęto określenia za Pszczołowskim - kolektywne i dystrybutywne - jako najbardziej czytelne. Znaczenie dystrybutywne - uniwersalne - stanowi podstawę rozważań w dalszej części tej pracy ${ }^{19}$ jako ogół walorów praktycznych działania, czyli ocenianych pozytywnie jego cech. W tym sensie, porównując między sobą dwa działania, można łatwo ocenić, które z nich jest bardziej sprawne, jeśli zastosuje się następującą miarę:

Działanie A jest sprawniejsze od działania B, jeżeli działaniu A przysługuje więcej takich ocen szczegółowych albo, w przypadku tego samego kompletu ocen, jeżeli w działaniu A są one wyższego stopnia, tzn. sprawne działanie w tym znaczeniu jest zarazem bardziej skuteczne, korzystne, ekonomiczne (oszczędne i wydajne), racjonalne itd. [...] (Pszczołowski, 1978, s. 227).

Za podstawowe cechy sprawności działania w znaczeniu dystrybutywnym powszechnie uważa się skuteczność ${ }^{20}$, ekonomiczność, korzystność ${ }^{21}$, które w tej postaci do literatury wprowadził Jan Zieleniewski (1969, s. 223-236). W trakcie prac nad koncepcją sprawności naukowcy poszukiwali wymiarów najbardziej odpowiedniej definicji analitycznej, panowała zgodność co do intuicyjnego rozumienia tej cechy. Kotarbiński proponował wówczas taką wersję ${ }^{22}$ : „sprawnym

19 Łatwiej jest analizować poszczególne cechy sprawności działania w znaczeniu dystrybutywnym, niż analizować sprawność działania jako całości (Zieleniewski, 1966, s. 75).

20 „[...] skutecznym nazwiemy takie działanie, które prowadzi do skutku zamierzonego jako cel” (Kotarbiński, 1982, s. 104). Tym różni się skuteczność od często, niestety, zamiennie z nią stosowanej cechy efektywności, że działania skuteczne były zamierzone (efektywne zamierzone i niezamierzone). Ponadto efektywność jest oceniana ze względu na uprzednio określone potrzeby. Jeżeli wyniki są zgodne z uprzednimi potrzebami i celami, działanie było nie tylko efektywne, lecz również skuteczne. Stąd zakres pojęcia skuteczność obejmuje: cel, środek działania i rezultat, a zakres pojęcia efektywność w stosunku do skuteczności poprzedza element potrzeby (więcej o tym por. Zalewska-Turzyńska, 2012, s. 127-130).

21 Działanie skuteczne może być niekorzystne, gdy cel zamierzony został osiągnięty, ale wynik działania jest mniejszy od kosztów. Działanie nieskuteczne może być ekonomiczne, gdy zamierzony cel nie został osiągnięty, ale wskaźnik ekonomiczności $W / K>1$. Gdy cel został osiągnięty, ale wskaźnik $W / K<1$, działanie może być skuteczne, ale nieekonomiczne.

22 Interesujące staje się w tym miejscu uzasadnienie, jakiego użył Kotarbiński do wyboru walorów sprawności i określenia, dlaczego odrzucił skuteczność, a w to miejsce przyjął energię (działanie energiczne), korygując tym samym pierwsze wydanie Traktatu o dobrej robocie (1955). „Wolimy wymieniać w ich gronie celowość, a nie skuteczność, choć byłoby to też 
nazywamy wszelkie takie działanie i tylko takie działanie, które jest zarazem celowe, energiczne i ekonomiczne” (Kotarbiński, 1966, s. 144), stąd „tym dane działanie jest sprawniejsze, im jest bardziej celowe, energiczne i ekonomiczne”, bo te walory podlegają stopniowaniu. Oprócz tych trzech podstawowych walorów (walorem nazywa się cechę działania rozumianą pozytywnie) wyróżnia się także: czystość roboty, dokładność, ścisłość, poprawność, bezbłędność, udatność, wzorowość, prostotę, niezawodność, naprawialność, solidność, szczegółowość, doskonałość, operatywność, racjonalność, efektywność, wydajność (kolejność zgodna z: Piłejko, 1976, s. 196-199). Później uzupełniono powyższy katalog cech o zręczność (sprawność manipulacyjną), komponuje się ona bowiem najlepiej z wymienionymi cechami. Cecha skoordynowania w zasadzie mogłaby tutaj także uzupełnić powyższy katalog cech dystrybutywnych.

Sprawność nierozerwalnie łączy się z działaniem, nie tylko na gruncie prakseologii, ale także teorii organizacji. Jest kategorią rozumianą atrybutowo w trzech perspektywach - jako własność sprawcy, działania (czynności) oraz rezultatu (efektu) działania ${ }^{23}$. Żadna postać sprawności nie jest cechą przynależną narzędziom lub jakimkolwiek rzeczom. Zieleniewski zapożycza z nauk technicznych pojęcie sprawności jako cechy funkcjonowania rzeczy. Zwraca jednak uwagę, że określenia typu sprawność turbiny - czyli właśnie sprawność rzeczy - jest wyłącznie uproszczeniem językowym, jakie technicy wprowadzają dla ułatwienia, nie stanowi jednak osobnej kategorii sprawności. Sprawność dotyczy w tym przypadku funkcjonowania (działania) rzeczy albo człowieka (Zieleniewski, 1969, s. 268). Rzecz może także uzyskać cechę skuteczności w wyniku trafnego zastosowania środków działania przez sprawcę.

Sprawność jako cecha sprawcy ${ }^{24}$ rozpatrywana jest przez prakseologów (sic!) z perspektywy psychicznej i fizycznej. Pszczołowski podejmuje także zagadnienie sprawności psychicznej. Pisze on, że „Ostatnio coraz częściej wymagamy

dobrze. Oba terminy domagają się tego samego, żądają, by działanie osiągało cel, dla którego zostało przedsięwzięte. Należy jednak wyłączyć powodzenia przypadkowe, gdyż nie ma powodu uważać za sprawne takich działań, które doprowadziły do zamierzonego wyniku tylko dzięki nieprzewidzianemu korzystnemu zbiegowi okoliczności”. Natomiast „przez energię działania rozumiemy tę jego właściwość, że działający zużytkował ze swych zasobów wszystko, co było niezbędne do osiągnięcia celu" (Kotarbiński, 1966, s. 145).

23 Kotarbiński przedstawia pojęcia prakseologiczne, które „bierze do użytku jako dobra gotowe" z dyscypliny ekonomii. Są to pojęcia celu, środka, sposobu, tworzywa, wytworu oraz działania (Kotarbiński, 1966, s. 88). Spośród tych podstawowych pojęć cechą sprawności mogą być obdarzone środki i sposoby reprezentowane przez posługującego się nimi człowieka (niesamoistnie), wytwór i działanie. Jest to podstawą do określania podmiotu i przedmiotów o walorach sprawności.

24 Prakseologowie używają takiego właśnie sformułowania, jednak należy mieć na względzie, że jako sprawne lub niesprawne oceniane jest działanie osoby, a nie osoba jako taka. 
od naszego organizmu, by był sprawny i wydajny na zawołanie [...]" (Pszczołowski, 1982, s. 132). Zwraca on uwagę w tym zakresie na „warunki podmiotowe, znajomość własnych sił i umiejętności, na biocykle i biorytmy, na wynikające z nich wahania poziomu aktywności" (Pszczołowski, 1982, s. 132). Sprawny człowiek, który jest „Wyspany [...], dobrze odżywiony [...] i zrelaksowany [...] działa lepiej niż inny sprawca, nie dbający o dobre warunki podmiotowe działania albo troszczący się tylko o pewną ich część” (Pszczołowski, 1982, s. 132). Pszczołowski podkreśla także - na co po trzydziestu pięciu latach należy położyć jeszcze większy nacisk - że:

Człowiek najlepiej pracuje, gdy się nie napina, bo nie znajduje się w sytuacji stresowej [...] Trzeba mieć odporność psychiczną, która wyraża się właśnie nieobniżeniem się sprawności w warunkach napięcia emocjonalnego, stresu, zagrożenia (Pszczołowski, 1982, s. 133 - podkr. M.Z.-T.).

Sprawność z perspektywy fizycznej to przede wszystkim zręczność, wprawa, czyli sprawność manipulacyjna:

Postęp sprawności tak pojętej polega na tym, że się pewne ruchy wykonywa w sposób bardziej wdrożony, ale analogicznie można powiedzieć tak samo i o pewnych czynnościach czysto umysłowych, np. rachunkowych odbywanych w myśli (Kotarbiński, 1966, s. 96).

Sprawność w tym znaczeniu polega na tym, że człowiek wykonuje działanie szybciej, z mniejszym wysiłkiem, mniejszym nakładem uwagi, a części składowe wykonywanych czynności lepiej łączą się w całość (są lepiej koordynowane). Stąd o sprawcy mówi się, że jest wprawny, zręczny, w swoim zakresie wytrawny (Kotarbiński, 1966, s. 97).

Stawia się także pytania, co robić z osobami niesprawnymi, jak się wobec nich zachowywać - „Co robić z niesprawnym »ogonem«? Obcinać czy ciągnąć?” (Pszczołowski, 1982, s. 208). Wykonujący działania pracownicy nie są jednakowo zręczni, zdolni i nie wykazują się jednakowymi umiejętnościami. W takiej sytuacji postuluje się danie im szansy (nauki, nabrania wprawy), a po wykorzystaniu wszystkich prób prakseolog radzi pozbycie się takich pracowników (Pszczołowski, 1982, s. 208). Widzi jednak problem moralny w takim działaniu i poucza, aby nie osądzać pochopnie. Zwraca także uwagę na działania pozorne, które wydają się sprawne, a takie nie są (Pszczołowski, 1982, s. 209).

Sprawność jako cecha czynności, czyli działania, rozpatrywana jest przez prakseologów najczęściej, o czym świadczy choćby tytuł podstawowego dzieła 
prakseologii - Traktat o dobrej robocie. „Działanie było rzeczywiście sprawne, gdy w rzeczywistości odpowiadało właściwym w danej sytuacji kryteriom sprawności” (Zieleniewski, 1969, s. 275). Do tego typu sprawności głównie odnoszą się definicje przytoczone na wstępie - w sensie kumulatywnym i dystrybutywnym. Stąd też określenia, że działanie jest sprawne w sensie dystrybutywnym, gdy jest proste, dokładne, racjonalne albo udatne. Działanie jest tym sprawniejsze w sensie kumulatywnym, im zawiera w sobie więcej kryteriów i to w możliwie najwyższym stopniu. Warunkiem koniecznym sprawności działania w sensie kumulatywnym jest zatem choćby minimalna skuteczność tego działania. Działanie sprawne w sensie dystrybutywnym nie jest automatycznie sprawne w sensie syntetycznym, ale jest sprawne w sensie kumulatywnym, jeśli jest chociaż minimalnie skuteczne.

Sprawność rozumiana jest także jako cecha rezultatu ${ }^{25}$, efekt działania, wynik pracy sprawcy i „skutek czyjegoś działania” (Kotarbiński, 1982, s. 46). Nie chodzi tu o rzecz, lecz o zdarzenie:

Ilekroć powstaje zdarzenie, czyli zmiana czegoś, [...] tylekroć zaczyna istnieć ów przedmiot o właściwościach tak właśnie zmienionych. Nazywamy taki przedmiot wytworem. A przyda się też informacja, że skutek działania i wynik działania to to samo, a „wynik” i „wytwór” łącznie próbuje się objąć wspólnym mianem „rezultatu”. Rzecz jasna, że pośród olbrzymiej liczby rezultatów działań danego sprawcy nieliczne tylko bywają zamierzone, a najprawdopodobniej pośród niezamierzonych znajdują się zawsze rezultaty niezgodne z jakimś zamierzeniem tegoż sprawcy (Kotarbiński, 1982, s. 505).

\section{W koncepcjach prakseologicznych koordynowanie stanowi jedną z dyrek-} tyw sprawnego działania. To znaczy, że koordynacja traktowana jest jako sprawność w sensie dystrybutywnym. Kotarbiński uznaje optymalną koordynację, czyli uzgodnienie, za istotny warunek racjonalnej integracji działań. Integracja jest w tym przypadku pojęciem ogólniejszym niż koordynacja, oznaczającym scalanie czynności składowych w całość jak najprzydatniejszą do celu (Kotarbiński, 1982, s. 186). Koordynacja występuje w postaci negatywnej, polegającej na tym, aby składniki całości nie przeszkadzały sobie, oraz pozytywnej, polegającej na wzajemnym wspomaganiu się czynników (Kotarbiński, 1982, s. 191). Przeciwieństwem koordynacji jest dyskoordynacja - brak „zgodności ruchów elementów składowych kompleksu” 26 (Kotarbiński, 1982, s. 191). Dla Kotarbińskiego „Pozytywna strona koordynacji - to nic innego, jak tylko koncentracja” (Kotarbiński, 1982,

25 „Rezultat - to zdarzenie, wytwór - to rzecz temu zdarzeniu podległa” (Kotarbiński, 1982, s. 384). Dlatego cechę sprawności nosi wynik, a nie wytwór (rzecz).

26 Słowo kompleks oznacza organizację i jest zapożyczeniem od A.A. Bogdanowa (1968). 
s. 192) (jest to jednak definicja cząstkowa). Zastrzega on, aby nie utożsamiać koncentracji z kumulacją ${ }^{27}$, gdyż „Koncentracja jest kumulacją działań w odniesieniu do wspólnego celu. Pojęcie kumulacji - to pojęcie ogólniejsze” (Kotarbiński, 1982, s. 192). Za najbliższe pojęciu koordynacji uznaje koncentrację i organizację - „założenie intensywności prowadzi do postulatu koncentracji, ten zaś do postulatu koordynacji, a ów ostatni do postulatu organizacji” (Kotarbiński, 1999, s. 160). Stąd osiąganie celu podzielone zostało na szczegółowe działania wykonywane tak, aby zespół mógł wspólnie wykonać pracę. Członkowie zespołu wykonują czynności zgodnie z podziałem pracy i specjalizacjami, koncentrując swoje wysiłki wokół wspólnego celu. Ich praca cząstkowa jest następnie integrowana, scalana ${ }^{28} \mathrm{w}$ procesie koordynacji. Prowadzi to do możliwości korzystania z efektu organizacyjnego działania.

Efekt $^{29}$ działania to potocznie wynik, rezultat działania. Jest to określenie ugruntowane w języku potocznym, wieloznaczne i pojawiające się w rozmaitych kontekstach językowych (Skudrzykowa, Urban, 2000, s. 94), jednocześnie w nauce jest ono właśnie z tego względu kłopotliwe.

Badanie efektu pociąga za sobą trzy odrębne perspektywy badawcze (podobnie jak w przypadku sprawności). Przedmiotem badania może być (Sobczyk, 2010, s. 337):

1) cecha działania, czyniąca to działanie efektywnym (bo działanie daje skutek, nawet skutek oceniany pozytywnie);

2) rezultat działania (wynik przez działanie wytworzony, o różnym stopniu realizowanej skuteczności);

3) taki rezultat działania, który kumuluje cechy zamierzone i niezamierzone, wyznaczone celem działania (czasem bada się efekt w wąskim znaczeniu, utożsamiając go z niezamierzonymi konsekwencjami).

27 Podaje przykład kumulacji ziemniaków w rowie (Kotarbiński, 1982, s. 192).

28 „Cóż to jest organizacja? To scalanie czynności lub elementów czynności tak, aby lepiej - w poszczególnym przypadku jak najlepiej - współdziałały dla wspólnego celu” (Kotarbiński, 1966, s. 73).

29 Na gruncie prakseologii pojęcie efektywność jest związane z pojęciem sprawności, jednak niekoniecznie jest ono sprecyzowane - „między tak pojmowaną efektywnością a sprawnością w sensie uniwersalnym nie ma istotnej różnicy" (Zieleniewski, 1966, s. 24), jednocześnie „efektywność nie jest poszczególnym przypadkiem skuteczności” (Pszczołowski, 1978, s. 60), dlatego „Termin efektywność - jeśli kto woli - sprawność działania użyty bez dodatków objaśniających [...] jest [...] niejako «ograniczenie» wieloznaczny, dlatego w praktyce konieczny staje się wymóg [...] każdorazowego porozumiewania się, w jakim znaczeniu stosuje się ten termin” (Zieleniewski, 1966, s. 23). „[...] tatwo poddać się wrażeniu, ze pojęcie «efektywności» w prakseologii należy do jednych z najsłabiej ugruntowanych poznawczo. Jest oto bowiem - słowo. Jest ono intuicyjnie dobrze rozumiane, użyteczne w mowie potocznej i komunikatywnie nośne, ale teraz dopiero w języku prakseologii poszukuje się dlań adekwatnego znaczenia, gdy «pola semantyczne» pojęć innych [...], bliskich mu co do znaczenia - zostały już zaanektowane i zakresowo znaczenia lepiej określone” (Sobczyk, 2010, s. 336). 
W niniejszym opracowaniu przyjęto trzecią perspektywę - ujęcie rezultatowe, które wprawdzie także służy ocenie działania, ale w sposób pośredni - za pomocą wyniku wraz z nieplanowaną nadwyżką. Tak rozumiane pojęcie efektu stanowi podstawę do definiowania pojęcia efektu organizacyjnego, jest to „efekt współdziałania grupy ludzi zorganizowanej w zespół [...] większy niż suma efektów działań pojedynczych" (Zieleniewski, 1964, s. 78). Jednocześnie Zieleniewski (1964, s. 78) stwierdza także, że efekt organizacyjny wzrasta ${ }^{30}$ dzięki ciągłości pracy, wprawnemu działaniu, posługiwaniu się wydajnymi, wyspecjalizowanymi narzędziami, koncentracją sił i środków w czasie i przestrzeni, wzajemnemu motywowaniu się uczestników organizacji. Jak widać, zakresu pojęcia efektu organizacyjnego nie powinno się ograniczać wyłącznie do współdziałania ludzi, bo obejmuje także dzielenie się zasobami (wiedzą, maszynami, komputerami). Dlatego na potrzeby pracy poszerza się rozumienie pojęcia efektu organizacyjnego i definiuje się je w następujący sposób: efekt organizacyjny jest to nadwyżka wartości rezultatu, która pojawia się jako wynik działania zorganizowanego, wielopodmiotowego w porównaniu $\mathrm{z}$ działaniem realizowanym przez każdy z tych podmiotów oddzielnie.

Tak sformułowana definicja prowadzi do dwóch zasadniczych konsekwencji. Po pierwsze, efekt organizacyjny traktowany jest jako wynik równoważny sprawności rezultatowej i jednocześnie jako mierzalne kryterium oceny sprawności funkcjonowania organizacji. Rezultat potwierdza bowiem skuteczność przeprowadzonego działania. Ma jednak charakter statyczny w tym sensie, że cel, który został osiągnięty, już się nie zmienia. Rezultat może być jednak dowodem sprawności działania podjętego dla realizacji jego osiągnięcia. Oceniając rezultat, można ocenić, czy sprawca działał sprawnie. Po drugie, efekt organizacyjny można osiągnąć w zasadzie wyłącznie dzięki koordynacji działań. Co najważniejsze, jest to bezwzględnie podstawowy powód, dla którego powstają i funkcjonują współczesne organizacje biznesowe.

W naukowym zarządzaniu wyznaczono trzy składniki przyczyniające się do wzrostu efektu organizacyjnego ${ }^{31}$ (Martyniak, 2002, s. 10):

30 W praktyce można wyróżnić trzy podstawowe podejścia do poprawy efektywności całego tańcucha wartości danego przedsiębiorstwa. Pierwsze polega na optymalizacji poszczególnych podstawowych i pomocniczych funkcji przedsiębiorstwa (np. przez doskonalenie strategii marketingowej). Drugie przewiduje lepszą koordynację funkcji podstawowych i pomocniczych [podkr. M.Z.-T.]. Trzecie wreszcie zakłada poprawę koordynacji zewnętrznej, czyli lepsze powiązania łańcucha wartości swoich dostawców czy nabywców, a nawet konkurentów (np. wspólne sterowanie zapasami) (Czekaj, 2000, s. 65-66).

31 „Wielki wzrost produkcji, który w przypadku zastosowania podziału pracy może być osiągnięty przez tę samą liczbę ludzi, zawdzięczamy trzem różnym okolicznościom: po pierwsze, zwiększeniu sprawności każdego robotnika; po drugie, ograniczeniu strat czasu powstających przy przechodzeniu od jednego rodzaju pracy do drugiego; i wreszcie po trzecie, 
1) podział pracy, który pozwalał na to, aby ta sama liczba ludzi wykonała znacznie większą ilość pracy przez wzrost sprawności każdego robotnika;

2) oszczędność czasu, „który się zwykle traci, gdy się przechodzi od jednego rodzaju pracy do drugiego" (Smith, 1954, s. 13);

3) wynalezieniu maszyn, które ułatwiają i skracają pracę.

Wówczas postulowano podział pracy jako czynnik sprawności funkcjonowania organizacji, stąd konieczność koordynowania pracy rozczłonkowanej.

Obecnie wydaje się, że potrzeba koordynacji dla osiągania efektu organizacyjnego przybiera na sile w sposób wykładniczy. O ile nie zawsze stosowany jest podział pracy w tradycyjnym rozumieniu, to chęć lub konieczność oszczędności czasu (Dille, Söderlund, 2011) i korzystanie z komputerów stanowi podstawę działania każdej firmy. „Technologie cyfrowe są kluczem do koordynacji globalnych operacji” (Setia, Venkatesh, Joglekar, 2013, s. 567). Ułatwiają koordynację i mogą wpływać na strukturę działalności organizacji (Malone, Crowston, 1994). Powstają nawet modele oprogramowania wydajności zespołu (Software Team Performance Model) (Dingsøyr i in., 2016).

Liczne sposoby określania koordynacji i koordynowania prowadzą do konieczności ustalenia typów i rodzajów koordynacji (rezultatu) i procesów koordynowania wewnątrzorganizacyjnego (działania). Niejednolitość płaszczyzn określania koordynacji zaczęto zauważać dość wcześnie. Koordynacja jako „syntetyczna dyrektywa sprawnego działania” zaleca koordynowanie poszczególnych elementów działania pod względem jakościowym, ilościowym i czasowym ${ }^{32}$ (Zieleniewski, 1969, s. 262), pomija jednak koordynację przestrzenną. Zieleniewski, rozważając dyrektywę koordynacji, wskazuje na bliskie jej pokrewieństwo $\mathrm{z}$ „prawem harmonii” Adamieckiego (Adamiecki, 1924, s. 24-25; Zieleniewski, 1976, s. 360; Zieleniewski, 1969, s. 262) oraz z „postulatem integracji” Kotarbińskiego - „scalać czynności składowe w całość jak najprzydatniejszą do celu" (Zieleniewski, 1969, s. 262). Rozumie on koordynację:

[...] jako włączanie do działania wszystkich i tylko tych elementów (ludzi wykonujących określone czynności i innych zasobów spełniających określone funkcje), które są niezbędne do zapewnienia powodzenia i to włączanie ich tak, aby elementy te maksymalnie przyczyniały się do powodzenia całości (instytucji, zespołu, lub

wynalezieniu wielkiej liczby maszyn, które ułatwiają i skracają pracę, pozwalając jednemu człowiekowi na wykonanie zadań spełnianych przez wielu ludzi" (Martyniak, 2002, s. 10).

32 Zieleniewski w wydanej w 1964 roku książce Organizacja zespołów ludzkich podaje koordynację w wymiarach ilościowym i czasowym. Wymiar jakościowy, który wtedy jeszcze pomija (s. 320), uzupełnia w 1969 roku. 
ich fragmentów) - a więc włączanie ich we właściwej jakości i ilości i we właściwej chwili (Zieleniewski, 1969, s. 262-263).

Koordynowanie jest więc ciągłym „doregulowywaniem” działania organizacji, które chroni ją przed stratami. Warunkiem koniecznym koordynowania jest informacja wzajemna -

[...] scentralizowana lub w pewnej mierze zdecentralizowana [...] o tym jak postępuje realizacja splecionych wzajemnie funkcji, wiążąca poszczególnych członków zespołu w instytucjach za pomocą sprzężeń zwrotnych (Zieleniewski, 1969, s. 263).

Działanie ludzi w organizacji nie może być od siebie oderwane, są to działania lub wiązki działań wzajemnie zależne, powiązane ze sobą, następujące po sobie w określonej kolejności, w określonym porządku czasowym. Te wiązki działań wykonywane są przez różne podmioty. Jeśli działania ulegną zakłóceniu (zakłócenia mogą powodować różne względy - braki surowca, opóźnienia, niewłaściwe miejsce lub czas dostawy, sposób wykonania, osoba wykonawcy itp.), są mniej sprawne. Stąd widać wyraźnie, że potrzeba koordynacji rośnie wprost proporcjonalnie do wzrostu skomplikowania (złożoności) struktury organizacyjnej jednostki organizacyjnej, a także wzrostu zależności części od całości. Struktura organizacyjna jednostki oraz czas, miejsce i sposób wykonania zadania prowadzą do określenia czterech wymiarów koordynacji - strukturalnego (rozumianego statycznie), czasowego, przestrzennego oraz funkcjonalnego. Ten katalog należy uzupełnić określonym przez Crowstona (1997, s. 160) wymiarem zasobowym. W ten sposób konstytuuje się pięciopłaszczyznowy wskaźnik koordynacji organizacyjnej.

W tym miejscu należy przedstawić - wprowadzone na potrzeby pracy - określenie efektu koordynacji oraz efektu koordynacyjnego. Efektem koordynacji uprzednio podjętego działania jest skoordynowanie jako rezultat działania. Jest to pewien stan, który gwarantuje efekt organizacyjny, tym większy, im większy jest uzyskany stopień skoordynowania.

Natomiast efekt koordynowania to cecha działania. Działanie może być mniej lub bardziej skoordynowane. Koordynuje się przez relacje komunikacyjne, uzgadnianie więzi relacji komunikowania między podsystemami.

Efektem koordynacyjnym należałoby zatem nazwać nadwyżkę korzyści przypadającą na jednego członka zespołu, współdziałającego z innymi współpracownikami, w porównaniu z korzyścią możliwą do osiągnięcia w działaniu indywidualnym. Nie każdy zespół przejawiający cechę koordynowania jest organizacją. Zespół koordynowany, w odróżnieniu od organizacji, ma charakter tymczasowy, jest rozwiązywany po wykonaniu zadania, nie jest powoływany do realizacji celów w dłuższym horyzoncie czasowym. 


\subsection{Model koordynacji: sprawne komunikowanie - efekt organizacyjny}

Wszelkie działanie wewnątrzorganizacyjne jest związane z komunikowaniem. Niezależnie od tego, czy jest ono jedno-, czy wielopodmiotowe, każde działanie w organizacji poprzedzone jest jakimś komunikatem-inicjatorem - na przykład umową zlecenia, poleceniem lub prośbą o wykonanie zadania. W trakcie realizacji zadań zespoły komunikują się, aby koordynować swoje działania, minimalizować wysiłek i maksymalizować efekt. I wreszcie komunikowane jest zakończenie procesu, rezultat odbierany jest także za pomocą komunikowania (podziękowania, przelewu).

Realizacja celów organizacji (w postaci określonych działań) bezwzględnie wymaga komunikowania się, a komunikacja w organizacji musi być sprawna. Konieczne jest zatem zapewnienie sprawnych zachowań werbalnych i pozawerbalnych w sytuacjach organizacyjnych. Oznacza to jednocześnie sprawne realizowanie procesu komunikacji oraz sprawność poszczególnych elementów procesu.

Sprawność procesów komunikowania i komunikacji wewnątrzorganizacyjnej jest podstawą realizacji procesów podstawowych (i pobocznych) organizacji ${ }^{33}$. I konsekwentnie, wzrost sprawności komunikowania się między współpracownikami przyczynia się do wzrostu poziomu efektu koordynacji. Sprawność komunikacji w organizacji polega zatem przede wszystkim na tym, aby właściwy komunikat dotarł do właściwego adresata we właściwym czasie (na czas). Chodzi o to, aby odbiorca był wyposażony w wiadomości właściwe co do treści (te, które dotyczą jego i zadań przez niego wykonywanych), zakresu, obszerności (problem stanowią komunikaty zbyt wąskie i zbyt szerokie ${ }^{34}$ ) i czasu ${ }^{35}$ (na kiedy jest potrzebny).

33 Na potwierdzenie powszechności procesów komunikowania można przytoczyć następujące słowa: „Zarządzanie informacją przenika przez wszystkie wyróżnione w łańcuchu rodzaje działalności (funkcje), zarówno podstawowej, jak i pomocniczej” (Czekaj, 2000, s. 66). Mimo iż odnoszą się one do zarządzania informacją, to należy pamiętać, że ludzie przekazują sobie informacje w relacjach wzajemnych.

34 Oba typy komunikatów powodują opóźnienia w rozpoczęciu działania. Komunikaty zbyt wąskie pociągają za sobą konieczność dalszego prowadzenia komunikacji, na przykład w postaci dopytania rozmówcy o brakujące elementy komunikatu lub poszukiwania dodatkowych źródeł informacji. Komunikaty nadmiarowe wymagają analizy wiadomości i określenia, co jest potrzebne, a co zbędne dla danego działania.

35 Komunikaty spóźnione nie spełniają swojej roli. Komunikaty dostarczone przedwcześnie mogą być - zależnie od formy (np. pisemna, ustna) i elementów zawartości (element informacyjny w postaci określenia, jakiej sprawy komunikat dotyczy) - zapomniane („mówiłem ci przecież”), przechowane („to było w mailach z ubiegłego miesiąca, trzeba poszukać”), zapamiętane („tak, wiem o co chodzi”) lub traktowane jako uprzedzanie, a zatem przygotowane do wykorzystania w odpowiednim czasie. Jednak nie jest pewne, która z wymienionych sytuacji będzie zachodzić $w$ danym przypadku. 
Sprawny przekaz to również taki, który dociera bez zbędnych zatrzymań i zniekształceń. Nie jest przetrzymywany, zapomniany lub zaniechany do przekazania i w trakcie „podróży” po szczeblach hierarchii organizacyjnej nie ulega zmianom treści.

Istotne w sprawnym porozumiewaniu się są właściwie sformułowane komunikaty niosące określone cechy. Powinny one być: adekwatne, aktualne, bezbłędne, celowe, czyste, dokładne, wystarczalne, jednoznaczne, kompatybilne, kompletne, konkretne, konsesyjne (rzetelne), odpowiednie, operatybilne, pełne, proste i wiarygodne (więcej o tym por. Zalewska-Turzyńska, 2012, s. 139-176).

Przyjmuje się tu zatem rolę komunikacji jako narzędzia do uzyskania efektu koordynacyjnego. Sprawność narzędzia, jakim jest komunikowanie, jest widoczna podczas działania (przebiega harmonijnie) i przez rezultaty działania (są skoordynowane).

Koordynacja działania wymaga ustaleń między współpracownikami, na przykład w zakresie kolejności wykonywanych zadań, osób odpowiedzialnych za ich wykonanie, sposobów i metod wykorzystywanych w realizacji zadań przez poszczególne osoby, a także uzgodnień w zakresie rodzaju wykorzystywanych maszyn (komputerów) do realizacji zadań przez kolejne osoby i wreszcie tego, w jaki sposób współpracownicy będą się dzielić czasem pracy maszyny, przeznaczonym na wykonanie zadania (jedna maszyna, wielu pracowników). Bez komunikowania nie uda się koordynowanie działań ludzi.

Sprawna koordynacja zapewniona za pomocą sprawnej komunikacji prowadzi do osiągnięci efektu organizacyjnego.

Efekt organizacyjny ujawnia się we wspólnym, skoordynowanym wykorzystaniu technologii i urządzeń. Jednak ważniejszym jeszcze powodem powstawania efektu synergicznego jest przede wszystkim współpraca ${ }^{36}$. Współdziałanie grupy ludzi zorganizowanej w zespół daje efekt większy niż suma efektów działań jednostkowych, jednocześnie to współdziałanie musi być koordynowane. Jeśli współpraca jest nieskoordynowana, może prowadzić do jeszcze gorszych efektów niż działania jednostkowe brane sumarycznie.

Sprawność mierzona jest na kilka sposobów - celowościowo, gdy miarą jest osiągnięty cel. Zgodnie z wartościami dla interesariuszy nie można jednak mówić o jednym, uniwersalnym kryterium oceny sprawności, różni interesariusze stosują bowiem odmienne kryteria sprawności. Zgodnie z modelem konkurencyjnych wartości stosowane są oceny wartości i preferencji podmiotów oceniających. Układają się one (preferencje i wartości) w dwie dychotomie, które dotyczą struktury organizacyjnej (elastyczność - kontrola) oraz realizacji celów osób albo organizacji jako całości (ludzie - organizacja).

36 „[...] w porównaniu z rozmaitymi wzorcowo pracującymi społeczeństwami nie pracujemy dość sprawnie, a w szczególności nie umiemy współpracować dość sprawnie" (Kotarbiński, 1966, s. 92). 
W kontekście niniejszej pracy efekt organizacyjny jest podstawą mierzenia sprawności organizacji, jest bowiem głównym powodem powoływania jej do życia. Funkcjonowanie organizacji i jej rozwój ma sens, gdy występuje efekt organizacyjny, w innym przypadku, jeśli działania jednostkowe przynoszą więcej korzyści niż zespołowe, nie ma podstaw do utworzenia organizacji. Natomiast jeśli $\mathrm{w}$ istniejącej organizacji efekt ten nie pojawia się, wówczas organizacja powinna przestać istnieć, generuje bowiem wyłącznie koszty (nie tylko finansowe).

O poziomie efektu koordynacyjnego świadczyć będzie stopień wzajemnego uzgodnienia działań przez elementy zespołu (np. uzgodnienie kolejności wykonywania zadań, tak aby kolejny nie wyprzedzał uprzedniego, kolejności korzystania z maszyn i urządzeń itp.) - zarówno podmiotowe, jak i rzeczowe. Tak określony efekt koordynacyjny jest stopniowalny, może przybierać różne poziomy lub stopnie nasilenia cechy - może być całkowity, częściowy (silniejszy, słabszy).

Powyżej uzasadniono, jak efekt koordynowania wpływa na efekt organizacyjny. W dalszej części przedstawiono sposób, w jaki ustalono mierniki tego wpływu. W niniejszej pracy wyróżnia się koordynowanie in statu (jest to koordynowanie „wejściowe” w organizacji poddawanej badaniu, zastane) oraz koordynowanie in tractu (jest to koordynowanie interwencyjne, doraźne). Składają się one z szeregu dość szczegółowych wskaźników pozwalających na ich pomiar, pogrupowanych w pięć wyżej zasygnalizowanych kategorii: wskaźniki strukturalne (koordynacji strukturalnej - $\left.K O_{S}\right)$, funkcjonalne $\left(K O_{F}\right)$, zasobowe $\left(K O_{Z}\right)$, czasowe $\left(K O_{C Z}\right)$ i przestrzenne $\left(K O_{P}\right)$.

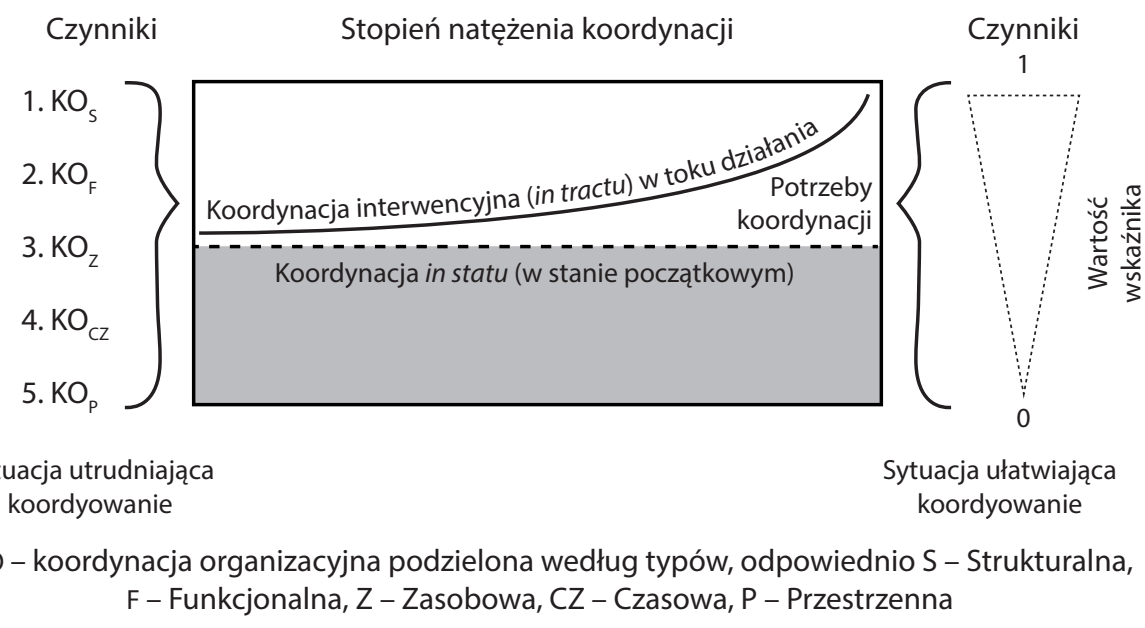

Rysunek 23. Model koordynacji organizacyjnej

Źródto: opracowanie własne. 
Koordynacja in statu wskazuje, jaki poziom koordynowania osiąga organizacja, jeśli brać pod uwagę szczegółowe wskaźniki koordynacji, przedstawione w następnym podrozdziale. Wskaźnik może przybrać dowolną wartość osiągania pełni natężenia cechy koordynowania in statu - od 0, sugerującego działanie chaotyczne, do 1, czyli działania w pełni skoordynowanego (maksimum osiągalne). Na rysunku 23 linia przerywana wskazuje poziom koordynacji in statu. Obszar powyżej linii przerywanej wskazuje możliwości do osiągnięcia przez koordynację interwencyjną in tractu. Wszelkie niedostatki koordynacji in statu mogą być uzupełnione w wyniku poprawy interwencyjnej, doraźnej, przez wdrożenie koordynowania in tractu już w trakcie działania, wykonywania zadania. Koordynacja in tractu, realizowana w toku działania, powinna być traktowana jako „doregulowanie” systemu organizacji. Natomiast poszczególne cechy koordynowania, a w konsekwencji także wskaźniki koordynowania, należy wykorzystywać do określania czynników ułatwiających albo utrudniających koordynację.

Wysoka sprawność funkcji koordynowania (efekt koordynowania) przekłada się bezpośrednio na wysoką sprawność organizacyjną. Natomiast komunikacja pełni rolę służebną wobec koordynowania, im lepsze jest bowiem narzędzie (komunikacja), tym lepszy efekt koordynowania. Jeśli nie można poprawić efektu koordynowania przez zwiększanie sprawności komunikowania, to trzeba poprawiać natężenie poszczególnych cech (wskaźników) z osobna, czyli zmniejszać poziom tych, które wpływają niekorzystnie na proces koordynowania.

Reasumując, dobra (sprawna) koordynacja prowadzi do wyższego stopnia zorganizowania, czyli wyższy stopień natężenia cechy koordynacji przekłada się na wyższy stopień natężenia cechy sprawności pojmowanej syntetycznie ${ }^{37}$. Sprawność organizacji należy mierzyć maksymalizacją efektu organizacyjnego, natomiast efekt organizacyjny zależy wprost proporcjonalnie od efektu koordynacyjnego.

\subsection{Wskaźniki koordynowania wedtug rodzajów}

Klasyczne i jednocześnie uniwersalne podejście do koordynowania pracy oraz wcześniej sygnalizowane perspektywy koordynowania stały się inspiracją do ustalenia katalogu jej wymiarów, sformułowanego na potrzeby podnoszenia sprawności systemu organizacja (efektu organizacyjnego) za pomocą systemu sieci relacji komunikowania. System wskaźników koordynacji pozwoli na mierzenie i zarządzanie sprawnością organizacji jako systemu sieci relacji komunikowania. Stworzenie

37 Efekt organizacyjny może być w organizacjach społecznych wyższy od jedności (co nie może się zdarzyć w naukach technicznych, gdzie nie można uzyskać więcej energii niż się dostarczyło) (Zieleniewski, 1964, s. 269). 
takiego katalogu stanowi bowiem ostatni z kroków prowadzących do uzasadnienia tezy pracy. Stąd, jak wyjaśniono w poprzednim podrozdziale, konsekwentnie powstało pięć typów koordynacji organizacyjnej, określonych w pracy jako kompleksowy aparat wskaźnikowych mierników badawczych (Indicative Research Meters Aparatus - IRMA), na który składają się - wymiar strukturalny, funkcjonalny ${ }^{38}$, zasobowy oraz związany z czasem i przestrzenią. Każda z prezentowanych poniżej grup wskaźników i każdy ze wskaźników wewnątrz wymiarów zostały zaprojektowane w taki sposób, aby ich wartość mieściła się w przedziale od 0 do 1 - im bliżej wartości 0, tym wpływ na koordynowanie jest słabszy, a koordynacja trudniejsza, natomiast im bliżej wartości 1 , tym jest ona łatwiejsza.

Optymalny, a właściwie referencyjny ${ }^{39}$ poziom poszczególnych wskaźników należy ustalić w drodze badań empirycznych ${ }^{40}$ dla każdego typu organizacji z osobna (produkcja usługi, handel). Mogą się one różnić także ze względu na typ architektury organizacji (Czarnecki, 2012).

Pierwszy z typów koordynacji - strukturalny wymiar koordynacji organizacyjnej - przedstawiony jest w światle cech budowy struktury organizacyjnej i ich wpływu na przebieg procesów koordynowania wewnątrzorganizacyjnego (przy zastosowaniu metody wskaźnikowej).

Obecnie stałym elementem w podejściu do struktur organizacyjnych jest ich zmienność, elastyczność i kształtowanie ad hoc, co wynika ze zmian w otoczeniu organizacji (Nalepka, Kozina, 2007; Zakrzewska-Bielawska, 2015, s. 105-111). Część jednostek nadal jednak charakteryzuje się względnie trwałą strukturą - wtedy oznaką nowoczesnego podejścia jest nakładanie na struktury klasyczne różnych rodzajów pracy zespołowej (Hopej, 2017, s. 99-109). Systemy organizacyjne mają

38 Ackoff (1969, s. 197) rozróżnia własności strukturalne i własności funkcjonalne. Pierwsze pochodzą od rzeczy (materiału - w tym przypadku organizacji jako rzeczy) lub też formy opisywanych obiektów, mają na ogół postać rzeczową. Drugie są pochodną właściwości użytkowych obiektów i mają charakter procesualny, zdarzeniowy.

39 Określenie przedziału stanowiącego normę - wartość referencyjna zamiast jednej wartości - optymalnej.

40 Określenie poziomu optymalnego lub referencyjnego wskaźników jest możliwe w wyniku badań empirycznych, nie ma tu bowiem zastosowania ani prawo Goodharta, ani wątpliwości, jakie wyrastają na gruncie badań etnograficznych. Prawo Goodharta, stwierdzające, że „Każda obserwowana statystycznie zależność ma skłonność do zawodzenia w momencie, w którym zaczyna być wykorzystywana do celów regulacyjnych" (Goodhart, 1984, s. 91), nie ma zastosowania do prezentowanej tutaj metody wskaźnikowej, ponieważ badaniem objęte jest pełne spektrum zagadnień organizacyjnych, a nie zagadnienie pojedyncze, charakteryzowane jednym wskaźnikiem. Natomiast badania etnograficzne polegają na tym, że badacz staje się częścią badanej grupy w jej naturalnym środowisku (Czarniawska, 2011 s. 11-29), zatraca obiektywizm i wpływa na zachowanie badanego środowiska. Tymczasem badań systemowych dokonuje się z „zewnątrz” systemu. 
swoją strukturęe1, czy architekturę (Simon, 1962, s. 467-482). Niezależnie od formy budowy wewnętrznej czy jej ogromnej zmienności, jest to cecha opisu systemu, której nie można pominąć w przypadku korzystania z systemowych metod badawczych organizacji. Struktura organizacyjna to - w tym kontekście - „zbiór metod dzielących zadanie na określone czynności i koordynujących je” (Ahmady, Mehrpour, Nikooravesh, 2016, s. 455) albo „sposób, w jaki działania organizacyjne są podzielone, zorganizowane i skoordynowane. Organizacje tworzą struktury, aby koordynować działania czynników pracy i kontrolować czynności członków” (Rezayian, 2005, w: Ahmady, Mehrpour, Nikooravesh, 2016, s. 455-456). Struktura organizacyjna jest rozumiana statycznie, pozwala dokonać pomiaru poniższych wskaźników na podstawie analizy schematu organizacyjnego.

Bezpośrednio z pojęciem struktury wiąże się także pojęcie wielkości organizacji $^{42}$, które jest intuicyjnie rozpoznawane - mówi się o organizacjach mikro, małych, średnich i dużych. Określenie wielkości organizacji nie jest zadaniem łatwym, wybór miary wielkości organizacji zależy bowiem od jej charakteru i specyfiki. Zieleniewski proponuje miarę „stanowiącą kombinację liczby zatrudnionych z wartością aparatury (np. iloczyn tych dwu wielkości)” (Zieleniewski, 1976, s. 149). Opinie różnych autorów na temat elementów, które powinny składać się na miernik wielkości organizacji są rozmaite ${ }^{43}$ - brane są pod uwagę wielkości

41 Wąska perspektywa prowadzi do wielu ograniczeń, do uznania jej za przestarzały szkielet organizacji - „Struktury organizacyjne są z definicji przestarzałe” (Clawson, 2001, s. 4). Perspektywa szersza, bardziej nowoczesna, rozumie strukturę organizacyjną równoznacznie z pojęciem organizacji: „wiele osób na stanowiskach patrzy na strukturę organizacyjną. Czy to na papierze, czy po prostu układa sobie w umysłach tę sieć zamierzonych relacji w organizacji, która koordynuje podejmowanie decyzji w ramach wielu funkcji" (Clawson, 2001, s. 4).

42 Wielkość fizyczna to „wielkość mierzalna, fizyczna właściwość zjawiska lub ciała, którą można odróżnić jakościowo (od innych właściwości) i wyznaczyć ilościowo” (Encyklopedia Powszechna PWN, 1987, t. 4, s. 709). Definicja wielkości organizacji nie występuje w popularnych encyklopediach i słownikach dotyczących teorii organizacji. W literaturze z tego zakresu odnajduje się jednak liczne „obserwowane zależności między wielkością (rozmiarami) organizacji a pozostałymi cechami jej budowy i funkcjonowania” (Sobczyk, 1981, s. 155).

43 „[...] liczba zatrudnionych, liczba robotniko-godzin/miesiąc i średni poziom wykształcenia załogi, jakkolwiek uznane za mierniki wielkości organizacji, mogą charakteryzować jedynie jej wielkość kadrową, a nie inną. Podobnie takie mierniki, jak: wartość pieniężna zasobów trwałych i obrotowych, wartość aparatury, obroty pieniężne/miesiąc lub rok, wartość towarów sprzedanych w określonym czasie, suma zaliczonej marży handlowej lub zyski/miesiąc, charakteryzują - ale wyłącznie - wielkość finansową. Również wielkość powierzchni lub przestrzeni roboczej tak samo jak liczba sklepów wchodzących w skład przedsiębiorstwa i łączna wielkość ich powierzchni stanowią tylko fizyczną (terytorialną) miarę wielkości instytucji (przedsiębiorstwa), nie mówiąc nic o jej wielkości w rozumieniu ściśle organizacyjnym" (Sobczyk, 1981, s. 159). 
kadrowe (liczba zatrudnionych to podstawowy miernik), liczba jednostek organizacyjnych, zdolności produkcyjne lub obroty (Hopej, 1994, s. 15), także wielkości finansowe, fizyczne (terytorialne) (Stabryła, 2009; 2011). Sobczyk (1981, s. 159) postuluje poszukiwanie obiektywnego kryterium wielkości organizacji na płaszczyźnie formalnej, a ściślej na podstawie struktury organizacyjnej ${ }^{44}$. Jest to bez wątpienia idealizacja miernika wielkości organizacyjnej.

Dla ułatwienia funkcjonowania praktyka gospodarcza wypracowała własne dyspozycje w zakresie określania wielkości organizacji. Ustawa o rachunkowości wśród ogółu jednostek objętych jej przepisami wyróżnia jednostki mikro, małe oraz domyślnie pozostałe (średnie i duże przedsiębiorstwa) na podstawie kryteriów sumy aktywów bilansu na koniec roku obrotowego (mikro do $1500000 \mathrm{zł}$, małe 4000000 euro), przychodów netto ze sprzedaży towarów i produktów za rok obrotowy (3000 000 zł i 8000000 euro) oraz średniorocznego zatrudnienia w przeliczeniu na pełne etaty (10 i 50 etatów). Zgodnie z tymi kryteriami przedsiębiorstwa zaliczają się do określonej kategorii, jeśli „w danym roku obrotowym i w roku go poprzedzającym nie przekroczyły dwóch z trzech wielkości" (ustawa o rachunkowości). W praktyce organizacyjnej wielkość, jako cecha organizacji empirycznie istniejącej, nie jest obiektywna, powstają pewne nieścisłości między wartościami teoretycznymi a faktycznie istniejącymi, w określonym $\mathrm{z}$ nazwy, konkretnym przedsiębiorstwie.

W niniejszej pracy pomocną wartością przy określaniu wielkości organizacji i dla potrzeb budowy strukturalnych wskaźników koordynacji organizacyjnej stał się miernik liczby elementów $(N)$ występujących w organizacji, określający - jak wskazano - tylko częściowo jej wielkość za pomocą liczby zatrudnionych w niej osób (im więcej zatrudnionych osób w organizacji, tym trudniej jest je koordynować). Jednakże ogólne określenie elementów w organizacji wydaje się być kategorią niewystarczająco szczegółową, stąd propozycja uszczegółowienia liczby elementów w określonych kategoriach: pracowników, kierowników, działów, jednostek - im większe rozdrobnienie, tym trudniejsza jest koordynacja.

Przedstawione poniżej wskaźniki strukturalne ${ }^{45}$ odniesione są do statycznie rozumianej struktury organizacyjnej. Wielkości, takie jak liczba elementów

44 Sobczyk zaproponował spójny model do określania wielkości badanej struktury organizacyjnej, złożony z czterech cech (i wskaźników) - cechy dezagregacji (DA), dyferencjacji (DF), zorganizowania $(\mathrm{O})$ i hierarchizacji (H). Wartości cech umieszcza w układzie współrzędnych, dla których dane wartości wskaźnika tworzą czworobok o określonym polu powierzchni, który wskazuje wielkość struktury. Model ten stał się niekwestionowaną inspiracją dla strukturalnych wskaźników koordynacji organizacyjnej.

45 Inspiracją i podstawą do ich budowy są wskaźniki budowy struktur organizacyjnych (klasycznych) opracowane przez Sobczyka w 1977 roku (Nalepka, Kozina, 2007). Stanowią one bazę dla przedstawionych tutaj strukturalnych wskaźników koordynowania, wymagają zmian, ponieważ w międzyczasie wyewoluowały kolejne typy struktur organizacyjnych, 
w kategorii, prowadzą do określenia cech złożoności ${ }^{46}$ organizacyjnej, na którą składają się łącznie cechy ilościowe (dezagregacji, rozczłonkowania, określające liczbę elementów) i jakościowe (dyferencjacji, zróżnicowania, wskazujące rodzaj elementów), wskazane poniżej.

Cecha dezagregacji (rozczłonkowania ${ }^{47}$ ) $W_{D A}{ }^{48}$ (por. Sobczyk, 1977 s. 60) organizacji jest to wielkość wyrażona przez stosunek liczby zespołów (lub komórek organizacyjnych), wyróżnionych w budowie danej organizacji, do ogólnej liczby pracowników tej organizacji, powiązanych z organizacją przez dowolny rodzaj umowy, na podstawie której otrzymują oni wynagrodzenie.

Dezagregację określa się za pomocą wzoru:

$$
W_{D A}=\frac{2 N_{k}}{N}
$$

gdzie:

$W_{D A}$ - wskaźnik dezagregacji (przy tak sformułowanym wzorze maksymalny stopień nasilenia dezagregacji, $W_{D A \max }=1$ przy najmniejszych, dwuosobowych komórkach organizacyjnych),

$N_{k}$ - liczba elementów struktury,

$N$ - liczba wszystkich pracowników opłacanych przez organizację na podstawie dowolnego rodzaju umowy.

Ponieważ zakłada się, że im wyższa wartość wskaźnika rozczłonkowania, tym trudniejsze koordynowanie, to - aby zachować spójność miar - należy stosownie przeformułować równanie do postaci:

zmienit się język opisu organizacji. Pozostała zależność między typem struktury organizacyjnej i procesem koordynowania (zarówno in statu, jak i in tractu).

46 Złożony to „składający się przynajmniej z dwóch elementów. Im więcej części posiada dany przedmiot na poziomie złożoności makroskopowej, tym bardziej jest złożony (skomplikowany)" (Pszczołowski, 1978, s. 298).

47 Oryginalny opis cechy rozczłonkowania ,jest to wielkość wyrażona przez stosunek liczby komórek organizacyjnych, wyróżnionych w budowie danej organizacji, do liczby osób obsady etatowej organizacji” (Sobczyk, 1977, s. 60). Warunki i tryb pracy zmieniły się w ciągu czterdziestu lat, „obsada etatowa” jest już anachronizmem. Pracownicy związani z organizacją mogą być zatrudnieni na etacie, na umowę o dzieło, umowę zlecenie, na kontrakcie, mogą świadczyć usługi na zasadzie samozatrudnienia itp. - dlatego w mianowniku wskaźnika wybrano: „powiązanie z organizacją przez dowolny rodzaj umowy, na podstawie której otrzymują wynagrodzenie", brane są bowiem pod uwagę organizacje biznesowe typu profit. W przypadku organizacji non-profit warunek wynagrodzenia jest bezzasadny, wystarcza wówczas warunek umowy.

48 Oryginalne oznaczenia literowe i reprezentacje matematyczne zostały zmienione w celu dostosowania ich do pozostałych wskaźników umieszczonych w tej pracy. 


$$
W_{D A}=\frac{N-2 N_{k}}{N} .
$$

Cecha dyferencjacji (zróżnicowania) $W_{D F}$ organizacji:

[...] jest to wielkość wyrażona przez stosunek liczby wyróżnionych w danej organizacji rodzajów poszczególnych komórek organizacyjnych do liczby wszystkich komórek organizacyjnych wyróżnionych w budowie tej organizacji (Sobczyk, 1977 s. 61).

Chodzi tutaj o zróżnicowanie funkcjonalne.

Dyferencjację określa się za pomocą wzoru:

$$
W_{D F}=\frac{N_{r e}}{N_{k}},
$$

gdzie:

$W_{D F}$ - wskaźnik dyferencjacji,

$N_{r e}$ - liczba rodzajów elementów,

$N_{k}$ - liczba wszystkich rodzajów elementów.

Podstawę wyróżnienia poszczególnych rodzajów elementów w budowie struktur stanowi ich specjalizacja w zakresie realizowania odmiennych, a zatem różnych od siebie funkcji, zadań itp. Każda struktura składa się zawsze z określonej i sobie właściwej liczby rodzajów jej elementów, reprezentując określony stopień dyferencjacji (Ashby, 1991, s. 405-417; Ashby, Goldstein, 2011, s. 190).

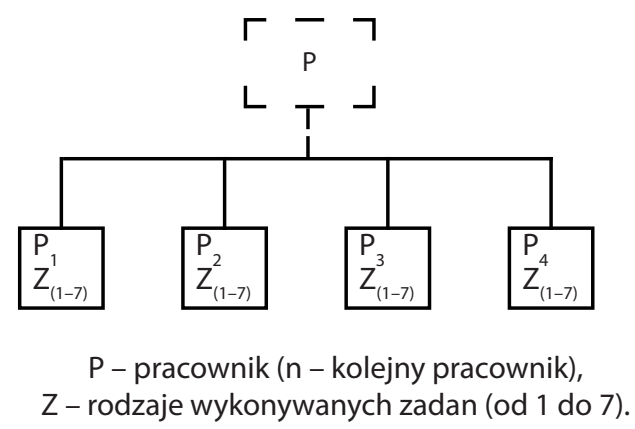

Rysunek 24. Praca grupowa

Źródto: opracowanie własne.

W tym miejscu należy wyjaśnić przyjętą w niniejszej pracy różnicę między pracą grupową i pracą zespołową, wyjaśniającą różnicowanie rodzajów elementów. Rozgraniczenie to jest stosowane w dalszej części tego rozdziału. Na obu rysunkach linią 
przerywaną zaznaczono pozycję osoby koordynującej (lub przełożonego), nie jest on jednak niezbędny i niekoniecznie musi zajmować miejsce nadrzędne. Pozostawienie jednak rysunku bez elementu koordynacyjnego wskazywałoby na brak potrzeby ogniwa koordynującego pracę grupową i zespołową, co wprowadzałoby w błąd.

W przypadku pracy grupowej każdy z członków grupy, pracowników wykonuje na stanowisku pracy w zasadzie „zestaw” tych samych lub bardzo podobnych co do treści zadań. Na rysunku 24 oznaczono siedem rodzajów zadań (1-7) - każdy z członków grupy może zatem wykonywać dowolnie siedem zadań, zależnie od wyznaczonych potrzeb (proces koordynacji).

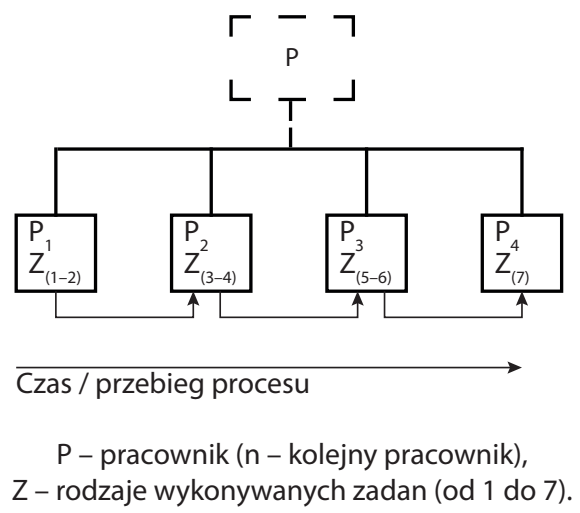

Rysunek 25. Praca zespołowa

Źródto: opracowanie własne.

W przypadku pracy zespołowej zadania, jakie wykonują pracownicy, mają wyraźnie określone miejsce w procesie. W zasadzie każdy pracownik wykonuje swoje zadanie po otrzymaniu efektów pracy swojego poprzednika i przekazuje efekt swojej pracy kolejnemu pracownikowi. Wyjątek stanowią osoby pierwsza i ostatnia w kolejności przebiegu procesu.

Cecha zorganizowania $\left(W_{O}\right)$ struktury organizacyjnej:

[...] jest to wielkość wyrażona przez stosunek liczby rzeczywiście wykorzystywanych powiązań, wyróżnionych między poszczególnymi komórkami organizacyjnymi danej organizacji, do liczby wszystkich powiązań możliwych do wyróżnienia w budowie tej organizacji ze względu na liczbę wszystkich jej komórek organizacyjnych (Sobczyk, 1977, s. 61).

Liczba powiązań w strukturze jest decydująca dla stopnia jej zorganizowania i przynajmniej teoretycznie będzie zwiększać się wraz z liczbą elementów. 
Zorganizowanie określa się za pomocą wzoru:

gdzie:

$$
W_{O}=\frac{N_{R}}{\left(N_{E-R}\right)^{2}}
$$

$W_{O}$ - wskaźnik organizacyjności,

$N_{R}$ - liczba faktycznie wykorzystywanych powiązań (relacji) między elementami struktury,

$\left(N_{E-R}\right)^{2}$ - liczba wszystkich powiązań typu elementy-relacje, możliwych do wyodrębnienia ze względu na liczbę elementów struktury, ale niekoniecznie wykorzystywanych ze względu na typ organizacji.

$\left(N_{E-R}\right)=N(N-1) / 2$ - liczba relacji dwustronnych,

$\left(N_{E-R}\right)=N(N-1)$ - liczba relacji jednostronnych.

W tej postaci wskaźnik organizacyjności jest tożsamy z niespecyficznym wskaźnikiem koordynacji opisanym w poprzednim podrozdziale.

Cecha hierarchizacji $\left(W_{H}\right)$ struktury organizacyjnej:

[...] jest to wielkość wyrażona przez stosunek liczby szczebli organizacyjnych, wyróżnionych w budowie danej organizacji, do liczby wszystkich komórek organizacyjnych tej organizacji (Sobczyk, 1977, s. 61).

Hierarchizację określa się za pomocą wzoru:

gdzie:

$$
W_{H}=\frac{N_{s z}}{N},
$$

$N_{S Z}$ - liczba szczebli organizacyjnych struktury (Sobczyk, 1977, s. 61), $N$ - liczba elementów ogółem.

Wysoka wartość wskaźnika hierarchizacji wskazuje na większe uporządkowanie organizacji, zwłaszcza jeśli rozpatrywać na przykład strukturę liniową w kontraście do dowolnej innej realizującej kontakty na podstawie relacji „każdy z każdym” (np. zadaniowa, sieciowa). Uporządkowanie struktury liniowej pozwala na skierowanie informacji precyzyjnie przeznaczonej dla zespołu, działu lub adresata. Jednak, zależnie od sytuacji, droga służbowa w strukturze liniowej jest wówczas zwykle dłuższa, dlatego koordynowanie jest trudniejsze. Trudność polega na tym, że komunikat może wówczas nie nadążyć za potrzebą zmiany (korekty) - jest to szczególny przypadek koordynowania in tractu (szczegóły w kolejnym podrozdziale).

Do przedstawionych wskaźników z grupy strukturalnych należy wprowadzić ograniczenia ich stosowalności do struktur tradycyjnych. W przedstawianych 
w sposób statyczny strukturach wskaźnik osiąga wartość z przedziału 0-1. W strukturach innych niż tradycyjne nie można przedstawić wartości wskaźnika dla organizacji, ze względu na jej dynamiczność i zmienność w czasie. Dlatego - aby nie pozbawiać się pewnej orientacji dotyczącej warunków strukturalnych na przebieg procesu koordynowania - nie odrzucono wskaźników całkowicie, ale proponuje się dynamiczne ujęcie wartości wskaźnika w postaci funkcji zależnej od czasu. Wskaźnik będzie zależał od momentu czasowego, w którym uchwycone są dane. Miarodajność takiego wyniku badania jest ograniczona, dany poziom wskaźnika jest aktualny przez określony czas związany z etapem procesu - gdy zmienia się etap pracy, a wraz z nim liczba osób zaangażowanych i sposób ich zaangażowania, wówczas konsekwentnie zmienia się także wartość wskaźnika. Takie dynamiczne ujęcie wskaźnika nie kwestionuje potrzeby orientacji odnośnie rozpoznania stanu organizacji - podczas realizacji jakiegoś projektu stopień koordynacji będzie odmienny niż przy innym, realizowanym w tej samej organizacji, ze względu na inną liczbę więzi (i inną liczbę zaangażowanych osób).

Drugi z typów koordynacji - funkcjonalny wymiar koordynacji organizacyjnej - przedstawiony jest w świetle cech funkcjonowania organizacji i ich wpływu na przebieg procesów koordynowania wewnątrzorganizacyjnego (przy zastosowaniu metody wskaźnikowej).

Cechy funkcjonalne opracowane zostały przez autorkę na potrzeby tej pracy dla opisania sposobu funkcjonowania różnych typów organizacji, który można koordynować przez proces komunikacji. Dotyczą przebiegu procesu głównego organizacji (niekiedy także procesów pobocznych). Obejmują takie obszary zainteresowań jak na przykład rozwiązywanie problemów w organizacji, realizowanie zadań prostych i złożonych, wykonywanie produktów lub usług w sposób zindywidualizowany lub zautomatyzowany czy skomputeryzowany. Chodzi tutaj o sposób ${ }^{49}$, w jaki organizacja realizuje rozmaite zadania własne, bo sposoby funkcjonowania organizacji podlegają koordynacji wewnątrzorganizacyjnej realizowanej przez komunikację i porozumienie. Podmiotem realizacji zadań jest człowiek - jego funkcjonowanie w przestrzeni pracy znalazło tu także swoje miejsce, on również jest bowiem podmiotem koordynowania organizacyjnego.

Cecha liczby zadań (por. wydajność50) przepadających na pracownika $(Z L)$ mówi, że im więcej pracownik wykonuje zadań w określonym czasie, tym trudniej

49 Niektórzy mogą się w tym miejscu dopatrzeć analogii „sposobu funkcjonowania” z „dynamicznie" rozumianą strukturą organizacyjną, która koncentruje uwagę na strukturze procesów (Bielski, 1973, s. 15; Nalepka, 2001, s. 17). Będzie to analogia jak najbardziej uzasadniona.

50 Jest to wskaźnik porównywalny do zdolności produkcyjnej maszyny, oznaczającą maksymalną ilość produktu, jaka może być wytworzona w określonym czasie (Waters, 2001, s. 278). 
jest koordynować zadania ${ }^{51}$. Intuicyjnie wydaje się, że wskaźnik liczby zadań powinien osiągać wysoką wartość przy dużej liczbie zadań, jednak wówczas koordynacja staje się trudniejsza. Ponieważ - jak zadeklarowano na początku tego podrozdziału - im łatwiejsza koordynacja, tym wyższy poziom wskaźnika, pierwotną, intuicyjną proporcję należy zatem odwrócić w taki sposób, aby wysoki poziom wskaźnika informował o małej liczbie zadań i ułatwionym koordynowaniu. Ostatecznie zatem wzór dla wskaźnika liczby zadań przyjmuje postać:

$$
Z L=1-\frac{L}{T}
$$

gdzie:

$Z L$ - wskaźnik liczby zadań,

$L$ - maksymalna liczba zadań, jaką faktycznie wykonuje pracownik,

$T$ - określona jednostka czasu (spójna, zawsze ta sama, zależna od typu pracy, np. godzina, dzień pracy, tydzień, miesiąc, nawet rok).

Pochodną wskaźnika liczby zadań jest tempo ich wykonywania - jego szybkość, a ten wskaźnik umieszczono wśród wskaźników w wymiarze czasowym.

Cecha złożoności zadań $(Z Z)$ mówi, że im bardziej zadania są złożone, tym trudniej jest je koordynować. Wskaźnik określa, z ilu czynności składa się dane zadanie $^{52}$. Zadanie uważane jest za złożone, jeśli wymaga wykonania wielu czynności. Często złożoność produktu gotowego (lub usługi) przekłada się na złożoność zadań prowadzących do jego wykonania. W zasadzie każda organizacja wykonuje zadania złożone, chodzi tu jednak o sposób obchodzenia się z nimi, o to, czy zadania złożone są rozkładane na czynności i po rozłożeniu przydzielane pracownikom, czy też w podstawowej swojej postaci są przekazywane pracownikom do realizacji. Wówczas pracownik sam decyduje, jak się z nim obchodzić. Jest to kolejny wskaźnik „odwrócony”, czyli zadania złożone są trudniejsze w koordynacji, zadania proste łatwiej koordynować - tu jednak wysoka wartość wskaźnika świadczy o łatwiejszej koordynacji, a więc o mniejszej złożoności zadań.

51 Istotnym elementem obciążenia pracownika zadaniami jest jego stopień przemęczenia. Trudniej jest koordynować pracę zmęczonego pracownika, częściej zapomina on o czynnościach do wykonania, pracuje wolniej itp. Niestety, trudno jest zoperacjonalizować miernik zmęczenia pracownika, dlatego nie wprowadzono go do listy proponowanych wskaźników koordynacyjnych, jeśli jednak jego operacjonalizacja będzie możliwa, należy dołączyć go do tego zbioru.

52 Czynności wyodrębnia się zgodnie z metodą sieciową analizy ścieżki krytycznej (Critical Path Method - CPM). Po wyróżnieniu listy zadań grupuje się je według rodzajów, aby określić kolejny wskaźnik - różnorodności zadań. 
Złożoność zadań określa się za pomocą wzoru:

$$
Z Z=1-\frac{L C}{100}
$$

gdzie:

ZZ - wskaźnik złożoności zadań,

LC - maksymalna liczba czynności składających się na zadanie.

Cecha różnorodności zadań $(Z R)$ i prac do wykonania mówi, że im większa różnorodność, tym trudniej koordynować pracę. Zadanie uważane jest za różnorodne, jeśli wymaga odmiennych metod, narzędzi i środków do jego realizacji w porównaniu $\mathrm{z}$ innymi zadaniami.

Różnorodność zadań określa się za pomocą wzoru:

$$
Z R=1-\frac{R}{100}
$$

gdzie:

$Z R$ - wskaźnik różnorodności zadań,

$R$ - rodzaj zadań.

Cecha zastępowalności $(Z)$ dotyczy łańcucha wykonywanych zadań na stanowiskach pracy (w perspektywie strukturalnej). Obejmuje sposób wyznaczenia zadań na stanowiskach pracy ${ }^{53}$ - czy wyznaczone zadania na stanowiskach uzupełniają się, czy nakładają. Stanowi jednak cechę funkcjonalną, jej podstawą jest bowiem przebieg procesu (np. wytwórczego, administracyjnego lub usługi). Wskaźnik ma za zadanie określenie, czy krótkotrwała nieobecność pracownika ogranicza lub w skrajnych przypadkach uniemożliwia płynną pracę i osiąganie celu organizacji ${ }^{54}$. Pomiar wskaźnika dokonywany jest na podstawie zakresu obowiązków pracownika na stanowisku pracy.

Istnieją organizacje o niskiej różnorodności elementów (zatrudnia się wielu pracowników na takie same stanowiska pracy - wyżej określona praca grupowa), w takim przypadku nieobecność jednego z nich w niskim stopniu wpływa na możliwość wykonywania zadania, chociaż wpływa na wydajność (obniża ją). W takim przypadku wskaźnik zastępowalności jest wysoki (wiele osób może zastąpić osobę nieobecną). Dla pracy grupowej wskaźnik zastępowalności przyjmuje postać:

53 Stanowisko nie jest jednoznaczne z zadaniem. Istnieją stanowiska jednoosobowe i wieloosobowe. Istnieje także praca wielostanowiskowa.

54 Klasyczne zasady budowania stanowisk pracy przewidywały korzystanie z zasady automatycznego zastępstwa nieobecnych. Skrajnym przypadkiem realizowania tej zasady jest „maksymalna uniwersalność pracowników”. Obie zasady są kosztowne z punktu widzenia finansów organizacji, dlatego często stosowane są jako wyjątek, a nie reguła, albo po prostu nie są stosowane. Co ważne, stosowanie wskazanych zasad lub ich niestosowanie ma bezpośredni wpływ na koordynowanie. 


$$
\vee N_{k} \in\{0,5: 1\} \quad Z=1
$$

W organizacjach o wysokiej różnorodności, gdzie stanowiska pracy nie są multiplikowane, zastępowanie osoby nieobecnej musi być przemyślane i zaplanowane. Taki sposób zatrudnienia występuje zwykle w niedużych organizacjach. Jeśli każde stanowisko jest inne, należy porównać zakres obowiązków pracowników odnośnie powtarzalności istotnych czynności (kluczowych) dla osiągania celu organizacji. Jeśli obowiązki nakładają się przynajmniej u dwóch pracowników, wówczas istnieje możliwość zastępstwa i koordynacji działań. Jeśli czynności się nie pokrywają w zakresie obowiązków pracowników, to okresowo koordynacja jest ograniczona (elementy z łańcucha czynności są niemożliwe do realizacji przy krótkoterminowej nieobecności pracownika, spowodowanej np. urlopem, chorobą). Dla pracy zespołowej wskaźnik zastępowalności przyjmuje postać:

$$
\vee N_{k} \in\{0: 0,5\} \quad Z=\frac{P}{N_{K}},
$$

gdzie:

$P$ - krotność powtarzalności obowiązków (ile razy ten sam obowiązek jest określany dla różnych typów stanowisk), $N_{K}$ - liczba rodzajów stanowisk.

Niski wskaźnik różnorodności w zasadzie powinien pociągać za sobą wysoki wskaźnik zastępowalności (wiele osób może wykonać to samo zadanie) i odwrotnie.

Cecha fluktuacji $(F)$ członków zespołu wskazuje stan zmiennej stałości zatrudnienia, inaczej mówiąc - jest to wskaźnik zastępowania pracowników, jednak chodzi o zastępstwa długoterminowe (np. urlopy macierzyńskie, długie leczenie itp.) i naturalną w organizacjach wymianę kadr. Im wskaźnik fluktuacji jest wyższy, tym trudniej jest koordynować zespół i jego pracę, ponieważ nowi pracownicy, zastępujący dotychczasowych, potrzebują czasu, aby wprawić się w ich obowiązki. Doraźne i niewłaściwe zastępstwa często skutkują potrzebą kolejnej zmiany pracowników (koniecznością napraw, stratami czasu i środków).

Fluktuację określa się za pomocą wzoru:

$$
F=\frac{Z}{N},
$$

gdzie:

$F$ - wskaźnik fluktuacji,

$Z$ - liczba zastępstw,

$N$ - liczba pracowników. 
W tym miejscu pojawia się także kwestia stopnia opanowania wiedzy potrzebnej na stanowisku pracy. Zostanie ona określona przez cechę kwalifikacji pracowniczych, omówioną dalej.

Cecha stylu kierowania (SK) określa rodzaj stylu kierowania, jaki prezentuje kierownik. Styl autokratyczny realizuje koordynację łatwiej niż styl demokratyczny w instytucjach władzy, takich jak sąd, policja, kościół. Tam inny styl kierowania nie jest możliwy lub jest nieefektywny. Z drugiej strony uzgadnianie stanowisk pracowników utrudnia koordynację ich działań, zajmuje czas i często odwleka podejmowanie decyzji.

Wskaźnik przyjmuje wartości 0, 1/2 i 1 w zależności od stosowanego w organizacji stylu zarządzania, i tak:

- $S K=0$ - dla stylu demokratycznego (wyrażanego komunikatami zawierającymi słowa typu: czy moglibyśmy, jak uważasz/cie, może moglibyśmy),

- $S K=0,5$ - dla stylu mieszanego demokratyczno-autokratycznego (zawierającego jednocześnie oba typy komunikatów),

- $S K=1$ - dla stylu autokratycznego (w którym komunikaty są sformułowane przy użyciu słów: trzeba, należy, koniecznie, obowiązkowo, prosze wykonać/zrobić).

Cecha kwalifikacji pracowniczych $(K w P)$ określa poziom kwalifikacji pracowniczych w odniesieniu do potrzebnych i koniecznych kwalifikacji na stanowisku (wystarczające i konieczne). Kwalifikacje pracownicze wpływają na proces koordynacji - im wyższe kwalifikacje pracownicze, tym łatwiejsza koordynacja.

Optymalna sytuacja występuje, gdy oczekiwania i faktyczne kwalifikacje pracownika są tożsame. Często zdarza się jednak, że pracownik dysponuje kwalifikacjami większymi, niż są potrzebne na danym stanowisku ${ }^{55}$ - może wówczas traktować pracę jako tymczasową (widoczny wpływ na wskaźnik zastępowalności i fluktuacji). I odwrotnie, pracownik może także charakteryzować się kwalifikacjami niższymi niż oczekiwane - $\mathrm{z}$ rozmaitych powodów, zależnych zarówno od organizacji, jak i od niego samego.

55 Ten element jest tożsamy co do zawartości rzeczowej z zasadą przystosowalności Kowalewskiego (1982, s. 31-33). Realizacja obowiązków na określonym stanowisku wymaga specjalistycznej wiedzy oraz (w równym stopniu) podstawowych umiejętności czytania i pisania, „Wtedy [...] znaczna część jego specjalistycznej wiedzy zostanie zmarnowana, i to dokładnie w takiej proporcji, w jakiej zużywa on czas na czynności kancelaryjne, do wykonywania których wystarczy aż nadto szkoła podstawowa" (Kowalewski, 1982, s. 32). Problem ten był widoczny w latach siedemdziesiątych ubiegłego wieku: badania przeprowadzone „w 1974 r. wykazały, że roboty kancelaryjne wykonywane przez pracowników przystosowanych do prac merytorycznych (prawników, inżynierów, lekarzy itp.) kosztowały w ciągu roku 16,8 mln zł. Suma ta wynikła z różnic w wysokości wynagrodzenia kancelistów i specjalistów" (Kowalewski, 1982, s. 32). Od tamtego czasu niewiele zmieniono w zakresie wypełniania dokumentacji medycznej, prawnej, edukacyjnej itp. Autorka, mimo starań, nie dotarła do wyników bieżących badań w tym zakresie, spodziewa się wyników nieodbiegających od wskazanych. 
Przyczyny zewnętrzne mogą być na przykład ekonomiczne (rynek pracownika), społeczne (wyjątkowo niszowy zawód, którego nie naucza się w szkołach) oraz wewnątrzorganizacyjne (natychmiastowa potrzeba zastąpienia innego pracownika, potrzeba wyszkolenia pracownika zgodnie z własnymi normami - wtedy będzie przyjęty z zamiarem dokształcenia go, pracownik może również sam chcieć zbierać szerokie doświadczenie).

Koordynowanie pracy pracownika o niewystarczających kwalifikacjach, do przyuczenia jest trudniejsze niż pracownika dostosowanego do stanowiska pod względem kwalifikacji. Jeśli jednak kwalifikacje pracownika są wyższe niż potrzebne, organizacja może wykorzystać taki potencjał w innym obszarze i zakresie.

Powyższe wyjaśnienie prowadzi do stwierdzenia, że wskaźnik na poziomie $100 \%$ (=1) miałby oznaczać tożsamość kwalifikacji rzeczywistych i potrzebnych (wymaganych) na określonym stanowisku. Jednak przyjęte wcześniej założenie o wartości wskaźnika w przedziale 0-1 zmusza do zmiany jego konstrukcji. Przybiera on zatem następująca postać:

$$
K w P=\frac{K f}{K p},
$$

gdzie:

$K f$ - faktyczny poziom kwalifikacji posiadany przez pracownika, przyjmujący każdą dowolną wartość między 0 a 100\%, w taki sposób, że:

- 0 - (czysto teoretycznie) poziom kwalifikacji dla pracowników nieprzygotowanych do stanowiska pracy („surowych”),

- 100 - poziom kwalifikacji adekwatny do stanowiska oraz poziom kwalifikacji przekraczający potrzeby,

$K p$ - poziom kwalifikacji pracownika potrzebny $\mathrm{w}$ organizacji $=100 \%$.

Wskaźnik poziomu dokumentyzacji (B) dotyczy przesycenia formalizacją, która utrudnia koordynację organizacją. Im wyższy poziom biurokracji, tym trudniej koordynować działania w organizacji (kolejny wskaźnik odwrócony). Działanie i praca w organizacji zależą od ilości zadań do wykonania i czasu oczekiwania na ich wykonanie oraz kolejności wypełniania dokumentów związanych z wymaganiami formalnymi. W zasadzie przełożeni odpowiadają za poziom biurokracji w organizacji, mają zatem główny wpływ na wartość tego wskaźnika. Jednak część organizacji jest zobowiązana prawnie do wykonywania określonych czynności biurokratycznych, uznawanych za nadmierne obciążenie, jednak niemożliwych (np. $\mathrm{z}$ mocy ustawy) do pominięcia.

Poziom dokumentyzacji określa się za pomocą wzoru:

$$
B=\frac{D f}{D p},
$$


gdzie:

Df - liczba dokumentów faktycznie używanych w danej organizacji, koniecznych do wykonania zadania z sukcesem,

$D p$ - liczba dokumentów formalnych koniecznych i potrzebnych do wykonania zadania (wynikająca z ustaw wyższego rzędu i innych regulacji prawnych oraz zdrowego rozsądku).

Wskaźnik ma optymalną wartość, gdy liczba dokumentów potrzebnych i rzeczywistych jest tożsama (=1). Istnieją jednak sytuacje, gdy dokumentów faktycznie używanych jest znacznie więcej niż wymaga tego konieczność. Odwrotna wersja występuje niezwykle rzadko i także świadczy o błędach w koordynacji. Tak więc w przypadku gdy wartość $B \leq 1$, taką się przyjmuje, natomiast jeśli $B>1$, należy zastosować następujący wzór:

$$
B=\frac{D p}{D f} .
$$

Przebiurokratyzowanie powoduje, że wartość wskaźnika maleje, a koordynacja jest utrudniona.

W kontekście biurokratyzacji i formalizacji, na którą przełożeni mają wpływ, znajduje się wskaźnik kadry wykonawczej $(K W)$, który określa liczbę pracowników administracji w stosunku do pracowników wykonawczych (usługowych, produkcyjnych). Brak równowagi i przerost (nadmiar) kadry administracyjnej prowadzi do utrudnień w koordynacji w organizacji. W celu przeprowadzenia obliczeń wprowadza się pomocniczy wskaźnik $k w$, przedstawiony poniżej:

$$
k w=\frac{P W}{P A},
$$

gdzie:

$k w$ - pomocniczy wskaźnik kadrowy,

$K W$ - wskaźnik kadry wykonawczej,

$P W$ - liczba pracowników wykonawczych,

$P A$ - liczba pracowników administracyjnych.

Wartość kw jest zależna od branży - szczegółowe badania empiryczne pozwolą oszacować jego referencyjną wartość dla poszczególnych sektorów. Co do zasady należy stwierdzić, że $k w$ równy około $10 \%$ ułatwia koordynowanie - wówczas $K W=1$. Każde odchylenie od wzorca o 1\% oznacza obniżenie wartości wskaźnika $K W$ o 0,01, niezależnie, czy odchylenie oznacza wzrost, czy spadek wartości wskaźnika pomocniczego $k w$.

Wskaźnik jakości produktów $(J)$ jest to wskaźnik wskazujący liczbę prawidłowo wykonanych produktów lub usług w stosunku do wszystkich wykonanych 
zamówień. Im gorsza koordynacja, tym gorsza jakość produktu (mierzona reklamacjami, zwrotami, niezadowoleniem wyrażanym publicznie, np. na stronach internetowych organizacji).

Jakość produktów określa się za pomocą wzoru:

$$
J=\frac{Q}{Q+n Q},
$$

gdzie:

$Q$ - liczba produktów lub usług spełniających kryteria jakościowe, $n Q$ - liczba produktów lub usług niespełniających kryteriów jakościowych.

Wskaźnik empowermentu $(E)$ wskazuje poziom wzmocnienia i usamodzielnienia pracowników ${ }^{56}$. Składa się ze wskaźników: decyzyjności, odpowiedzialności i samodzielności opisanych poniżej. Im wyższy poziom wskaźnika empowermentu, tym łatwiejsze jest koordynowanie. Przyjmuje on postać:

$$
E=D+O+S
$$

Wskaźnik ten jest uzależniony od rodzaju wykonywanej pracy, poziomu kompetencji pracowników i zakresu obowiązków na stanowisku pracy.

Wskaźnik decyzyjności $(D)$ jest to wskaźnik określający liczbę decyzji podejmowanych przez pracownika na jego stanowisku pracy w stosunku do wszystkich decyzji możliwych do podjęcia w określonej jednostce czasu. Im więcej decyzji pracownik może podejmować samodzielnie ${ }^{57}$ na stanowisku pracy, tym łatwiej jest koordynować jego pracę. Ciąg wykonywanych przez niego zadań nie jest przerywany nieustanną potrzebą (własną pracownika) lub koniecznością (narzuconą przez szefa) uzgodnień z przełożonym. Istotne założenie jest jednak takie, że poziom kompetencji pracownika dorównuje poziomowi jego decyzyjności.

56 Obejmuje proces angażowania pracowników w podejmowanie decyzji dotyczących organizacji i umożliwienie im brania odpowiedzialności za swoje działania (Blanchard, 2007).

57 Spotkać można także odmienne poglądy. Jeśli pracownik podejmuje mało samodzielnych decyzji, oznacza to, że większość decyzji jest podejmowana przez przełożonego/koordynatora, co jednocześnie - jak się może wydawać - ułatwia koordynowanie, bo koordynujący skupia wszelkie informacje. Staje się on najlepszym źródłem informacji o procesach pracy i funkcjonowaniu organizacji. Problem pojawia się, gdy pracownicy muszą czekać na komunikaty od koordynatora, na podjęcie decyzji i niezbędne do pracy informacje. Jeśli wątpliwości musi rozstrzygać przełożony, pracownik nie ma możliwości samodzielnego podjęcia większości decyzji, wówczas skutkiem może być „zatkanie” kanału komunikacyjnego i długie oczekiwanie na niezbędny komunikat. Z tego względu w niniejszej pracy uznaje się, że koordynacji sprzyja szeroko określony zakres decyzyjności i konsekwentnie także odpowiedzialności za podjęte decyzje i działania. 
Decyzyjność określa się za pomocą wzoru:

$$
D=\frac{D_{P}}{D_{P}+D_{K}},
$$

gdzie:

$D_{P}-$ decyzje podejmowane przez pracownika,

$D_{K}$ - decyzje podejmowane przez kierownika.

Cecha odpowiedzialności $(O)$ jest to wskaźnik określający liczbę „odpowiedzialności” (responsibilities) za wykonywane przez siebie zadania. Wymaga on wyjaśnienia, dotyczy bowiem formalnego zakresu odpowiedzialności pracownika. Nie odnosi się do cech podmiotowych pracownika (np. poziomu jego rzetelności, solidności czy obowiązkowości), nie jest to również cecha związana z dyspozycją psychiczną człowieka (nie chodzi tutaj o „bycie człowiekiem odpowiedzialnym”). Cecha ta dotyczy liczby zadań, za które odpowiedzialny jest pracownik - uprawnień będących zarazem obowiązkami. Kontekst i znaczenie cechy odpowiedzialności związane są z zasadą zgodności podstawowych elementów stanowiska pracy - określeniem zadań, uprawnień do ich wykonania i właśnie odpowiedzialności za ich wykonanie.

Wskaźnik przedstawiony jest za pomocą liczby zadań, za które odpowiada (odpowiedzialny jest) pracownik na swoim stanowisku pracy, w stosunku do wszystkich zadań (za które odpowiedzialni są pracownicy i kierownicy).

Odpowiedzialność określa się za pomocą wzoru:

$$
O=\frac{O_{P}}{O_{P}+O_{K}},
$$

gdzie:

$O_{P}$ - liczba zadań, za które odpowiedzialny jest pracownik, $O_{K}$ - liczba zadań, za które odpowiedzialny jest kierownik.

W zasadzie wskaźnik nigdy nie osiąga wartości 1, choć zbliża się dostatecznie blisko, aby w zaokrągleniu uznać jego wartość za 1. Takim przypadkiem jest w zasadzie tylko grupa samosterująca, która nie posiada kierownika (w znaczeniu przełożonego), jednak zawsze posiada koordynatora, którego odpowiedzialnością jest pośredniczenie w płynnym przekazywaniu informacji, jego wskaźnik odpowiedzialności wynosi $O_{K}=1$. Wówczas $\mathrm{O}=O_{P} /\left(O_{P}+1\right) \approx 1$.

W przypadku gdy połowa decyzji jest podejmowana przez przełożonego, a połowa przez wykonawców, wskaźnik przyjmuje wartość 0,5.

Cecha samodzielności $(S)$ określa zakres swobody pracowników w obszarze wykonywanej pracy (dotyczy wyboru wykorzystywanych do zadania materiałów i metod). Koordynowanie pracy samodzielnych pracowników jest łatwiejsze. 
Samodzielność określa się za pomocą wzoru:

$$
S=\frac{S_{P}}{S_{P}+S_{K}},
$$

gdzie:

$S_{P}$ - liczba zadań, dla których materiały i/lub metody dobrał pracownik, bo nie

były one nakazane instrukcją lub innym zapisem formalnym, $S_{K}$ - liczba zadań, dla których materiały i/lub metody dobrał kierownik.

Podobnie jak w przypadku odpowiedzialności, samodzielność zupełna nie występuje (wówczas nie można by mówić o organizacji w sensie harmonizacji pracy), możliwa jest jednak wysoka samodzielność wsparta przez koordynatora - jak we wskaźniku powyżej.

Trzeci z typów koordynacji - zasobowy wymiar koordynacji organizacyjnej - przedstawiony jest w świetle zasobów organizacji i ich wpływu na przebieg procesów koordynowania wewnątrzorganizacyjnego (przy zastosowaniu metody wskaźnikowej).

Podczas realizacji podstawowych procesów organizacja używa się różnych dostępnych zasobów, których poziom i sposób wykorzystania podlega koordynacji wewnątrzorganizacyjnej. Zasoby organizacji wspomagają lub ograniczają możliwości jej działania (korzysta się z innych zasobów, gdy realizuje się np. produkcję masową lub wykonuje produkty unikatowe). Ponieważ człowiek jest traktowany jako „najważniejszy zasób organizacji” 58 , został on w tym miejscu potraktowany w sposób nieco przedmiotowy. Poniżej przedstawiono także wskaźniki „wydajnościowe” zasobów organizacji.

Wskaźnik liczba pracowników w zespole $\left(N_{K}\right)$ jest to wielkość komórki organizacyjnej. Zespoły mniejsze są łatwiejsze do koordynacji niż zespoły bardziej liczne. Uznaje się, że efektywne zespoły nie mogą przekraczać dwunastu członków (Robbins, 2000, s. 121). Wartość ta nie może być jednak przyjmowana bezkrytycznie, zależy bowiem od rodzaju wykonywanej pracy (charakterystyki opisywane przez kolejne wskaźniki obejmujące prace powtarzalne, mechaniczne versus praca koncepcyjna, unikatowa).

Wskaźnik stopnia wykorzystania pracowników w zespole $\left(N_{S W}\right)$ określa liczbę osób realnie zaangażowanych $\left(N_{Z}\right)$, potrzebną do ukończenia zadania, w stosunku do liczby osób wchodzących w skład zespołu (komórki organizacyjnej). Wskaźnik pozwala określić liczbę „zbędnych” osób, które mogłyby być

58 Jakkolwiek mało podmiotowo to brzmi. Nazywanie człowieka zasobem budzi sprzeciw, przestaje on bowiem być podmiotem, a staje się narzędziem. Niemniej w literaturze przedmiotu na stałe zakorzeniło się wyrażenie zarzq̨dzanie zasobami ludzkimi, co odpowiedzialne jest za degradację ludzkiej podmiotowości. 
wykorzystane do realizacji innych działań. Wskaźnik nie obejmuje osób uczących się, podlegających szkoleniu, których umiejętności będą wykorzystane później.

Stopień wykorzystania pracowników w zespole określa się za pomocą wzoru:

$$
N_{S W}=\frac{N_{Z}}{N_{K}},
$$

gdzie:

$N_{S W}$ - wskaźnik stopnia wykorzystania pracowników w zespole,

$N_{Z}$ - liczba osób zaangażowanych w pracę (określana na podstawie wskaźnika $Z I$

dla pracownika),

$N_{K}$ - liczba osób w zespole/komórce organizacyjnej.

Jeśli wartość wskaźnika spada poniżej 0,8, należy zastanowić się nad niewykorzystanymi siłami w zespole. Spadek wskaźnika do poziomu 0,5 oznacza niewykorzystanie sił i środków w zespole i sugeruje nadmierne zatrudnienie.

Wskaźnik stopnia standaryzacji zadań (St) określa odsetek zadań standardowych ${ }^{59}$ w stosunku do wszystkich wykonywanych przez pracownika zadań.

Konieczne jest w tym miejscu wyjaśnienie dotyczące przyjętej tu różnicy w rozumieniu pojęć: wykonywane $w$ organizacji zadanie a podstawowy proces organizacji (mierzony efektem działalności organizacji - podstawowym wytworem lub usługą, jakie oferuje organizacja). Organizacje mogą realizować niestandardowe, unikatowe procesy przez rozkładanie ich na zadania, a te mogą już podlegać zestandaryzowaniu, a następnie koordynacji.

Jeśli liczba standardowych zadań $S t_{Z}$ wynosi do $10 \%$ w stosunku do wszystkich zadań $Z$, uważa się, że praca jest skrajnie niestandardowa, wówczas $S t=0,1$ - trudno jest wtedy koordynować pracę zespołu, bo wykonuje się wiele zadań unikatowych. Im więcej jest zadań standardowych w stosunku do wszystkich zadań, tym wyższa jest wartość wskaźnika standaryzacji. Koordynowanie jest więc łatwiejsze, gdy poziom standaryzacji jest wyższy. Wyższe wartości $S t_{Z}$, około 0,75, uznaje się normalne, zakładając, że każda organizacja musi się uczyć, tak samo jak jej pracownicy. Wskaźnik St powyżej 0,9 wskazuje na pewną „ospałość” organizacji i brak działań innowacyjnych. Sugeruje się wówczas dokonanie analizy organizacji i jej głównych procesów z szerszej perspektywy, mającej na celu ustalenie adekwatności rynkowej. Reasumując, wskaźnik standaryzacji przyjmuje postać:

59 Zadania standardowe są tu rozumiane jako zadania typowe co do rodzaju. Istnieje także zbiór zadań powtarzalnych, czyli identycznych względem siebie, które mogą, ale nie muszą być zadaniami standardowymi. 


$$
S t=\frac{S t_{Z}}{Z}
$$

gdzie:

St - wskaźnik standaryzacji zadań,

$S t_{Z}-$ liczba standardowych zadań wykonanych w jednostce czasu,

$Z$ - liczba wszystkich zadań koniecznych do wykonania w (tej samej) jednostce czasu.

Koncepcyjnie zadania standardowe są związane z powtarzalnością, różnica polega jednak na częstotliwości ich wykonywania. Standard określa sposób wykonania zadania (zgodny ze standardem lub nie), ale krotność powtórzeń jest już definiowana przez ich powtarzalność, dlatego kolejny wskaźnik, który niejako automatycznie nasuwa się na myśl w tym miejscu, to wskaźnik powtarzalności.

Cecha powtarzalności $(P)$ zadań określa stopień powtarzalności zadań na sto zadań kolejno wykonanych. Określa się ją za pomocą wzoru:

$$
P=\frac{P_{Z}}{100}
$$

gdzie:

$P_{Z}$ - liczba powtórzeń określonego, tego samego zadania.

Powtarzalność $P$ w przedziale $(0,5: 0,8)$ uznaje się jako wysoką. $P=0,8$ stanowi wartość graniczną, powyżej której organizacji grożą szeroko opisane w literaturze przedmiotu negatywne skutki związane z monotonią wykonywanej pracy (niekoniecznie tylko fizycznej, częściej nawet biurowej lub „klawiaturowej”). Jednocześnie łatwiej jest koordynować pracę powtarzalną niż unikatową.

Wskaźnik automatyzacji $(A)$ zadań na stanowisku pracy ${ }^{60}$ jest określany przez stopień „niepewności realizacji zadań” (Galbraith, 1974, s. 28). Określa się go za pomocą wzoru:

$$
A=\frac{A_{Z}}{Z}
$$

gdzie:

$A_{Z}$ - liczba konkretnych, określonych i wyznaczonych zadań do wykonania w jednostce czasu,

60 Jay R. Galbraith formułuje hipotezę, „że im większa jest niepewność zadania, tym większa ilość informacji, które muszą być przetwarzane między decydentami podczas realizacji zadania. Jeśli zadanie jest przejrzyste i klarowne przed jego wykonaniem, wiele czynności z nim związanych można zaplanować wcześniej. Jeśli jest niezrozumiałe, w trakcie realizacji jest potrzeba gromadzenia wiedzy w trakcie rzeczywistego wykonywania zadań, co prowadzi do zmian przydziału zasobów, harmonogramów i priorytetów. Wszystkie te zmiany wymagają przetwarzania informacji w czasie wykonywania zadań” (Galbraith, 1974, s. 28). 
$Z$ - liczba wszystkich zadań koniecznych do wykonania w jednostce czasu $(=A+n A)$ $n A$ - zadania, o których wiadomo, że należy je wykonać, brak jednak specyfikacji dotyczącej szczegółów wykonania (kto, kiedy, w jakim czasie itp.).

Łatwiej jest koordynować pracę pewną, przewidywalną, konkretną i określoną. Wskaźnik stopnia mechanizacji pracy $(M P)$ mówi, że im wyższy stopień mechanizacji pracy, tym możliwe są bardziej liczne, większe zespoły i łatwiejsza jest ich koordynacja ze względu na fakt, że pracownicy wykonują mniej więcej takie same lub podobne działania (Sikorski, 2002). Dla potrzeb pracy ustala się trzy wartości wskaźnika:

$M P=0,1$ - praca koncepcyjna, bez elementów mechaniczności,

$M P=0,5$ - wersja mieszana, praca częściowo mechaniczna, częściowo koncepcyjna,

$M P=1$ - praca mechaniczna.

Łatwiej jest koordynować pracę mechaniczną. Nie oznacza to oczywiście w żaden sposób mechanizacji wykonania zadań, a wyłącznie stopień zaangażowania wysiłku umysłowego w kształtowanie wyniku pracy. Co więcej, nawet najbardziej spektakularny koncepcyjnie przedmiot, najnowszej generacji, powstaje przez sekwencję kolejnych, następujących po sobie działań (procesu produkcyjnego), które można określić właśnie jako mechaniczne (odruchowe). Stąd nie wynik działania jest tu oceniany, ale zasób (umysłowy), jaki pracownik dostarcza w wyniku procesu pracy.

Wskaźnik zróżnicowania wytworów pracy $(Z W P)$ jest to wskaźnik określający typ wytworu - wytwór masowy, krótkoseryjny, unikatowy (zindywidualizowany) (Woodward, 1965; Sikorski, 1998). Wytwory masowe pozwalają sprawnie kierować dużym zespołem, praca jest bowiem powtarzalna, możliwa jest zatem większa rozpiętość kierowania. Wytwory unikatowe wymagają znacznie więcej koordynacji. Wskaźnik przyjmuje wartości $0,1 / 2$ i $1 \mathrm{w}$ zależności od stosowanego przez organizację stylu produkcji, i tak:

- $Z W P=0,1$ - wytwór unikatowy, zindywidualizowany,

- $Z W P=0,5$ - wytwór krótkoseryjny,

- $Z W P=1-$ wytwór masowy.

Wskaźnik zaangażowania w budowanie zespołu $(T B)^{61}$ określa zaangażowanie przełożonych i pracowników w budowanie zespołu - łatwiej jest koordynować

61 Przy ocenianiu wartości wskaźnika TB należy także mieć na względzie koszt budowania zespołu i jego zaangażowania. Stwierdza się bowiem zależność, o bliżej nieokreślonym jeszcze charakterze, między atrakcyjnym geograficznie miejscem, na przykład szkolenia, a przywiązaniem do organizacji (może także do zespołu). Skonstruowano zatem wskaźnik kosztu budowania zespołu $(T B C)$ w postaci: $T B C=\frac{D S \times D K}{R S \times R K}$, gdzie: $D K-$ koszty poniesione 
„zgrany” zespół. W przypadku tego wskaźnika przyjęto założenie, że wzorcem w codziennej pracy jest większa liczba spotkań „zadaniowych” niż spotkań służących wyłącznie budowaniu zespołu. W przypadku odmiennego założenia należy przeformułować postać wskaźnika. Prawdopodobnie mogą istnieć organizacje - na przykład typu non-profit - w których proporcja spotkań jest odwrotna. Dla organizacji nastawionych na zysk wskaźnik przyjmuje jednak postać:

$$
T B=\frac{D S}{R S},
$$

gdzie:

$R S$ - liczba regularnych spotkań „zadaniowych” zespołu w jednostce czasu (dziennie, tygodniowo, miesięcznie), z założenia odbywających się w miejscu pracy lub przez techniczne środki łączności, $D S$ - liczba dodatkowych spotkań pozazadaniowych, zorientowanych na budowanie zespołu (w tej samej jednostce czasu), odbywających się jak regularne lub na przykład „wyjazdowych”.

Czwarty z typów koordynacji - czasowy wymiar koordynacji organizacyjnej - przedstawiony jest w świetle czasu pracy organizacji i jego wpływu na przebieg procesów koordynowania wewnątrzorganizacyjnego (przy zastosowaniu metody wskaźnikowej).

Czas jest specyficznym zasobem organizacji - nie można go magazynować, cofnąć, powtórzyć. Organizacje mogą starać się równoważyć niedostatki czasu na wykonanie zadania (np. zgodnie z trójkątem zarządzania projektami), zatrudniając więcej pracowników lub obniżając jakość wykonania. Prawidłowa koordynacja wewnątrzorganizacyjna w wymiarze czasu pozwala na uniknięcie rozrzutnego, marnotrawnego gospodarowania czasem, który opłacany przez organizację może generować nieuzasadnione koszty. Koordynacja zajmuje się także prawidłową kolejnością wykonywania działań, aby zadania wzajemnie sobie nie przeszkadzały, nie wykluczały się i aby nie było konieczności powtórnego ich wykonywania.

Wydajność czasowa pracownika $(W C P)$ to cecha określająca, ile sztuk produktu wytworzył, obsłużył pracownik w określonym czasie. Ma ona wskazać, czy dostępny czas wykorzystano w sposób maksymalny. Być może słowo wydajność sugeruje, że wskaźnik powinien znajdować się w grupie wskaźników funkcjonalnych, jednak

na spotkania pozazadaniowe, zorientowane na budowanie spójności zespołu (wyjazdy, szkolenia z dodatkowych umiejętności społecznych); RK - koszty poniesione na spotkania zadaniowe zorientowane na wykonanie podstawowych procesów organizacji. Wartość wskaźnika może znacznie przekraczać wartość 1 w przypadku zasobnej organizacji, która przeznacza znaczne środki finansowe na szkolenia typu team building w porównaniu ze środkami przeznaczonymi na spotkania zadaniowe. Pozostaje jednak kwestia interpretacji takiego wskaźnika, czyli wpływu TBC na poziom koordynacji organizacyjnej. 
należy zwrócić uwagę, że jest to rodzaj wydajności częściowej w odniesieniu tylko do czasu, dlatego znajduje się w tym miejscu.

Wydajność czasową pracownika określa się za pomocą wzoru:

$$
W C P=\frac{i}{T}
$$

gdzie:

WCP - wskaźnik wydajności czasowej pracownika,

$i$ - liczba poprawnie wykonanych zadań,

$T$ - określony czas pracy.

Zadań prostych można wykonać więcej niż złożonych, automatycznych i mechanicznych więcej niż koncepcyjnych - rodzaj zadań determinuje zatem liczbę możliwych poprawnie wykonanych zadań.

Ze wskaźnikiem wydajności czasowej pracownika nierozerwalnie związana jest szybkość jego pracy i poprawność wygenerowanych przez niego wyników. Należy unikać sytuacji, w której pracownik wykonuje dużą liczbę niepoprawnych zadań. Jednocześnie także nie jest satysfakcjonujący przypadek, gdy pracownik wykonuje zadanie poprawnie, ale w znacznie dłuższym czasie, niż jest na zadanie przeznaczony. Biorąc pod uwagę te parametry proponuje się następującą cechę koordynacji czasowej: tempo wykonywania zadań (TZ), czyli tempo, w jakim pracownik wykonuje zadania (jak szybko). Cecha ta wskazuje w zasadzie dwa parametry:

1) ile czasu (w czasie rzeczywistym) zajmuje pracownikowi poprawne wykonanie zadania w stosunku do wzorca czasu przewidzianego na wykonanie tego zadania;

2) ile zadań wykonuje pracownik (poprawnie) w stosunku do wzorca (np. w dniu pracy).

Określanie wartości wskaźnika TZ polega na pomiarze faktycznego czasu trwania wykonywania zadania lub ewidencjonowania czasu rozpoczęcia i zakończenia zadania, a następnie porównaniu tych wartości ze wzorcem.

Jeśli czynności są typowe i powtarzalne, łatwo jest określić zarówno wzorzec, jak i czas wykonania zadania przez określoną osobę. Jednak w przypadku unikatowych i nietypowych zadań pierwszy z wykonawców niejako ustala wzorzec czasu trwania zadania, który przy kolejnej próbie, zgodnie z krzywą doświadczenia, z pewnością zostanie skrócony. Dla ułatwienia wprowadzono wskaźnik pomocniczy $t z$ w postaci:

$$
t z=\frac{W_{T}-T_{P}}{W_{T}},
$$

gdzie:

tz- wskaźnik pomocniczy szybkości pracy, 
TZ - wskaźnik szybkości pracy,

$T_{P}$ - czas wykonywania czynności przez pracownika,

$W_{T}$ - wzorzec określający czas przeznaczony na wykonanie czynność.

Interpretacja relacji wzajemnej $t z$ i $T Z$ znajduje się poniżej.

Jeśli $t z \in\langle-0,5: 0,5\rangle$, to przyjmuje się, że wzorzec czasu trwania zadania jest w organizacji ustalony na takim poziomie, że można czynność wykonać krócej lub dłużej, jednak różnica nie może przekraczać 10\% czasu określonego jako wzorzec. Przekroczenie oznacza, że wzorzec został nieprawidłowo wyznaczony (np. jak szybko przebiega fakturowanie, pakowanie produktu).

Jeżeli $t z=0$, to $T Z=1$ - pracownik wykonuje czynność/zadanie dokładnie w czasie określonym we wzorcu. Im wartość wskaźnika $t z$ jest bliższa 0 , tym mniejsze odchylenie od wzorca, co wskazuje na realne ustalenie poziomu wzorca.

Jeżeli $t z>0$, to $T Z=1$ - wartości dodatnie wskaźnika pokazują, że pracownik wykonuje zadanie w czasie krótszym niż ustalony we wzorcu. Należy przyjrzeć się bliżej realności poziomu wzorca, czy od czasu ustalenia wzorca nie wprowadzono udogodnienia (np. komputera, programu) redukującego czas wykonania zadania - należy wówczas zmienić poziom wzorca.

Jeżeli $t z<0$, to $T Z=|t z|-$ pracownik wykonuje zadanie w czasie dłuższym niż ustalony we wzorcu. Należy przyjrzeć się bliżej realności poziomu wzorca, czy nie została w zadaniu dołożona czynność, która wydłuża pracę - należy wówczas zrewidować poziom wzorca.

Im wskaźnik $T Z$ jest bliższy 1, tym łatwiejsze jest koordynowanie, bo czas pracy jest bardziej przewidywalny.

Wskaźnik czasu przekazywania komunikatów $(P K)$ określa czas, w jakim komunikat (np. polecenie, wiadomość o stanie zaopatrzenia itp.) dociera do bezpośredniego wykonawcy, inaczej mówiąc - ile czasu pochłania przekazanie wiadomości. Wskaźnik jest liczony w minutach. Im czas jest krótszy ${ }^{62}$, tym wyższa wartość wskaźnika i tym łatwiejsze koordynowanie. Urządzenia elektroniczne znacznie ułatwiają możliwość przekazania poleceń, a tym samym koordynację. Wskaźnik przyjmuje następującą postać:

$$
P P=\frac{100-T_{P P}}{100},
$$

gdzie:

$P P$ - przekazywanie komunikatów,

$T_{P P}$ - czas na przekazanie polecenia (od nadawcy do finalnego odbiorcy).

62 Jeśli współpracownicy zlokalizowani są w różnych strefach czasowych, mogą wystąpić skrajne różnice w wysyłaniu komunikatów i ich odbiorze z powodu odmiennego czasu funkcjonowania. Przesunięcia te mogą osiągać różnicę nawet dwunastu godzin. Są to jednak sytuacje skrajne, które rzadko występują w badanych zespołach. 
Cecha terminowości ( $T$ ) przekazu określa, czy przyszedł on w porę, aby wykonać zadanie. Wskaźnik terminowości jest również liczony w minutach, alternatywnie obserwowana jest data i godzina jego dotarcia do odbiorcy w stosunku do zadania, którego dotyczy. Chodzi tutaj o określenie interwału czasowego, jaki pozostaje pracownikowi na wykonanie działania - czy zwykle brakuje mu czasu na wykonanie zleconych działań, czy polecenia przychodzą z należytym wyprzedzeniem (rozumianym jako wzorzec).

Terminowość określa się za pomocą wzoru:

$$
T=\frac{W_{T}-T_{K}}{W_{T}},
$$

gdzie:

$T_{K}$ - czas pozostały między nadejściem wiadomości (komunikatu) dotyczącej po-

trzeby wykonywania czynności a terminem oddania pracy,

$W_{T}$ - wzorzec określający czas przeznaczony na wykonanie czynności.

Jeśli pojawia się ujemna wartość wskaźnika, należy wtedy przyjąć $W=0$, co wskazuje, że przekazy są nieterminowe, a właściwie przeterminowane.

Cecha uporządkowania ${ }^{63}(U)$ określa czas, w jakim odnajdowane są określone rzeczy - dokumenty w miejscu pracy, surowce w magazynie. Konsekwencją braku porządku na stanowiskach pracy jest potrzeba wyszukiwania lub poszukiwania ${ }^{64}$ niezbędnych elementów rzeczowych, co wydłuża czas wykonania zadania, powodując tym samym trudności w koordynacji pracy. Brak porządku przedłuża poszukiwania i opóźnia realizację zadań.

Uporządkowanie określa się za pomocą wzoru:

$$
U=\frac{1}{T_{P}},
$$

gdzie:

$T_{P}$ - czas wyszukiwania lub poszukiwania potrzebnej rzeczy lub informacji.

63 Wskaźnik uporządkowania intuicyjnie wydaje się być wskaźnikiem z grupy przestrzennych, bo niska jego wartość oznacza bałagan na stanowisku pracy, który utrudnia odnalezienie niezbędnych rzeczy i dokumentów, co wydłuża czas pracy i utrudnia koordynację. Sposób pomiaru tego wskaźnika - czas, o jaki wydłuża się wykonywanie zadania - decyduje o zakwalifikowaniu go do kategorii wskaźników czasowych koordynacji organizacyjnej.

64 Rozróżnić należy dwa procesy - wyszukiwania i poszukiwania. Wyszukiwanie następuje wtedy, gdy człowiek wie, gdzie znajduje się dana rzecz lub informacja i musi fizycznie dokonać określonych czynności, aby tę rzecz przedstawić. W przypadku poszukiwań człowiek nie wie, gdzie znajduje się potrzebna rzecz lub informacja. Być może jest to podstawa do wygenerowania dwóch różnych wskaźników, jednak obecnie autorka nie znajduje uzasadnienia do ich multiplikacji. 
Przyjmuje się tu następujące założenie: czas wyszukiwania nie wynosi 0, nawet u najlepiej zorganizowanej osoby 65 - potrzebuje ona kilku sekund na wyszukanie potrzebnych rzeczy lub informacji, na przykład na otwarcie pliku, dysku, szuflady czy segregatora. Tym niemniej jeśli $T_{P} \rightarrow 0$, to przyjmuje się wartość $U=1$.

Piąty, ostatni z typów koordynacji - przestrzenny wymiar koordynacji organizacyjnej - przedstawiony jest w świetle przestrzeni organizacji i jej wpływu na przebieg procesów koordynowania wewnątrzorganizacyjnego (przy zastosowaniu metody wskaźnikowej).

Właściwą koordynację w organizacji dostrzec można także w postaci odpowiednio zaaranżowanej przestrzeni rzeczywistej (głównie w organizacjach produkcyjnych), tak aby pracownicy współpracujący ze sobą (przenoszący dokumenty, surowce, wyroby gotowe) nie byli zmuszeni do odległych (tym samym czasochłonnych) wędrówek po obiekcie.

Cecha rozmieszczenia przestrzennego $(R P)$ określa odległość fizyczną między stanowiskami pracy. Sposób rozmieszczenia przestrzennego stanowisk pracy określa, czy komórki są umieszczone blisko siebie, we właściwej kolejności i w wygodny sposób. Jest ono mierzone w metrach odległości między stanowiskami (ewentualnie może być mierzone czasem ${ }^{66}$ dostępu od poprzedzającego do następującego stanowiska pracy). Im większa odległość lub dłuższy czas dostępu i niższy wskaźnik rozmieszczenia przestrzennego, tym trudniejsza koordynacja między oddalonymi od siebie elementami. Jeśli odległość między stanowiskami jest duża (stanowiska są oddalone), jednak czas dostępu jest krótki (np. dzięki technologii komunikacyjnej), wówczas uznaje się, że wskaźnik jest wysoki.

Z powodu wskazanej tutaj niejednoznaczności miana wskaźnika postanowiono nie komplikować jego postaci matematycznej i tymczasowo pozostawić go bez niej.

65 Autorka zdaje sobie sprawę z ważnego w tym miejscu elementu wpływającego na wartość wskaźnika, wymaga on jednak pogłębionej wiedzy psychologicznej, którą nie dysponuje. Mianowicie rodzaj charakteru osoby wpływa na tempo jej prac i sposób zorganizowania własnej przestrzeni pracy - inaczej w tym względzie zachowuje się flegmatyk, inaczej choleryk, ktoś może szukać rzeczy długo, mimo że jest ona na swoim miejscu. Byłoby korzystne w jakiś sposób uwzględnić ten element we wskaźniku uporządkowania.

66 Wskaźnik ten, mimo propozycji operacjonalizacji przez wymiar czasu, został zakwalifikowany jako przestrzenny z powodu odniesienia go do drogi, jaką fizycznie musi przebyć pracownik w przypadku potrzeby bezpośredniej rozmowy ze współpracownikiem. Istnieją przypadki organizacji posiadających oddalone oddziały - gdy odmiana kilometrowa wskaźnika jest wysoka (np. inny kraj, kontynent), ale odmiana czasowa wskaźnika jest stosunkowo niska (np. przelot samolotowy, rozmowa przez Skype'a), i odwrotnie - gdy odległość jest stosunkowo nieduża (ten sam kraj), ale brak dogodnych połączeń wydłuża znacznie czas dotarcia na miejsce. 
Cecha pracy zdalnej, rozumianej jako praca na odległość $(P n O)$, określająca liczbę pracowników wykonujących swoje zadania typu stacjonarnego ${ }^{67}$ poza firmą ( $n R$ - np. w domu) w stosunku do liczby wszystkich pracowników zespołu (czyli tych, którzy świadczą pracę w miejscu pracy, rezydentów $(R)$ i poza nią łącznie). Wskaźnik przyjmuje postać:

$$
P n O=\frac{R}{R+n R}=\frac{R}{N_{K}},
$$

gdzie:

$R$ - liczba pracowników wykonujących pracę w budynku organizacji, $n R$ - liczba pracowników wykonujących pracę poza firmą,

$N k$ - liczba pracowników w zespole $(=R+n R)$.

Niski poziom wskaźnika wskazuje na dużą liczbę pracowników przebywających poza firmą. Uznaje się, że łatwiej koordynować pracę pracowników przebywających na terenie organizacji ${ }^{68}$. Można się wówczas skomunikować z nimi w dowolnej chwili, zawsze gdy zajdzie taka potrzeba, odpowiedź jest w zasadzie natychmiastowa - co niekoniecznie występuje przy komunikacji asynchronicznej. Wadą „bycia na miejscu” jest często dokładanie pracownikowi kolejnych zadań.

W skład zagadnień związanych z rozmieszczeniem przestrzennym wchodzi także kwestia osobnych pokoi dla pracowników lub przestrzeni typu open-space. Wydaje się, że łatwiej jest koordynować pracownikami w „odkrytej” przestrzeni, gdy widać poszczególne stanowiska robocze. Jednak pracownikowi w takiej przestrzeni trudniej jest się koncentrować - zwłaszcza jeśli wykonuje pracę koncepcyjną (ze względu na destruktory, elementy rozpraszające w otoczeniu pracy). Ze względu na niejasność interpretacji takiej cechy zdecydowano się nie włączać jej do dalszych rozważań, należy ją uzupełnić, jeśli powstanie taka możliwość.

67 Nie chodzi tutaj na przykład o przedstawiciela handlowego, którego istotą pracy jest przebywanie poza siedzibą firmy, ale o taki typ zadań, który jest niejednoznaczny, może być wykonywany zarówno w siedzibie firmy, jak i poza nią (np. wszelkie rozliczenia rachunkowe).

68 Coraz częściej organizacje decydują się na pracę zdalną pracownika, uznając całe spektrum argumentów. Pracownik pracuje w czasie, gdy jest najbardziej wydajny, liczy się efekt, a nie godziny spędzone przy biurku. Elastyczny czas pracy docenia wiele osób, jest on jednocześnie dowodem zaufania do pracownika. Z drugiej strony pracownik, pracując poza biurem, pracuje stale, a na pewno ma być „,komunikacyjnie dostępny”, zachwiana jest więc równowaga podziału czasu na dom i pracę, poczucie przynależności do organizacji, następuje spadek umiejętności społecznych i ,zamykanie się w pudełkach” (komputerach). O ile menedżerowie doceniają elastyczność pracy zdalnej, o tyle psychologowie biją na alarm z powodu długofalowych efektów takiej zmiany sposobu pracy (Hochschild, 1997; Zużewicz, Konarska, 2005; Naus, van Iterson, Roe, 2007; Bolton, Houlihan, 2009; Doherty, 2009; Carter i in., 2011; Brown, Charlwood, Spencer, 2012; Cushen, Thompson, 2012; Felstead i in., 2013; Olszewski, 2013; BIS, 2014; Strzemińska, Bednarski, 2014; Angrave, Charlwood, 2015; Srnicek, Williams, 2015; Gallie, Felstead, Inanc, 2016). 


\section{Sumaryczny wskaźnik koordynacji organizacyjnej}

Poniżej przedstawiono sumaryczny wskaźnik koordynacji organizacyjnej. Czynnikami, które wzmacniają sprawność i koordynację są: zorganizowanie, zastępowalność, styl kierowania, kwalifikacje pracownicze, wysoka jakość produktów (usług), empowerment, wykorzystanie pracowników w zespole, stopień automatyzacji i mechanizacji pracy, zróżnicowanie wytworów pracy, zaangażowanie w budowanie zespołu, szybkość pracy, właściwe przekazywanie poleceń i uporządkowanie, a także właściwe rozmieszczenie przestrzenne.

Koordynacje osłabiają takie czynniki jak: dezagregacja, dyferencjacja, hierarchizacja, liczba zadań, złożoność zadań, różnorodność zadań, fluktuacja, biurokracja, duża liczba pracowników w zespole.

Ponieważ wskaźniki ustalone są w przedziale wartości $0-1$, ich niski poziom wskazuje na utrudnioną koordynację, a wysoki na koordynację sprawną. Poniżej przedstawiono grupy wskaźników w podziale na strukturalne, funkcjonalne, zasobowe, czasowe i przestrzenne, wraz z ich wskaźnikami składowymi w postaci równań:

\section{$\mathrm{KO}_{S}$ - wskaźnik koordynacji organizacyjnej w wymiarze struktury $K O_{S}=f\left(W_{D A}, W_{D F}, W_{O}, W_{H}\right)$,}

gdzie:

$W_{D A}$ - wskaźnik dezagregacji,

$W_{D F}-$ wskaźnik dyferencjacji,

$W_{O}$ - wskaźnik zorganizowania,

$W_{H}$ - wskaźnik hierarchizacji.

$$
\begin{gathered}
\mathrm{KO}_{F} \text { - wskaźnik koordynacji organizacyjnej } \\
\mathbf{w} \text { wymiarze funkcjonalnym } \\
K O_{F}=f(Z L, Z Z, Z R, Z, F, S K, K w P, B, K W, J, E),
\end{gathered}
$$

gdzie odpowiednie skróty literowe odnoszone są do wskaźników:

$Z L$ - liczby zadań,

$Z Z$ - złożoności zadań,

$Z R$ - różnorodności zadań,

$Z$ - zastępowalności,

$F$ - fluktuacji,

$S K$ - stylu kierowania,

$K w P$ - kwalifikacji pracowniczych,

$B$ - dokumentyzacji, 
$K W$ - kadry wykonawczej,

$J$ - jakości produktów,

$E$ - empowermentu (czyli $D$ - decyzyjności, $O$ - odpowiedzialności, $S$ - samodzielności).

$$
\begin{gathered}
\mathrm{KO}_{Z} \text { - wskaźnik koordynacji organizacyjnej } \\
\text { w wymiarze zasobowym } \\
K O_{Z}=f\left(N_{K}, N_{S W}, S t, P, A, M P, Z W P, T B\right),
\end{gathered}
$$

gdzie:

$N_{K}$ - liczby pracowników w zespole,

$N_{S W}$ - stopnia wykorzystania pracowników w zespole,

St - stopnia standaryzacji zadań,

$P$ - powtarzalności,

$A$ - automatyzacji,

$M P$ - stopnia mechanizacji pracy,

$Z W P$ - zróżnicowania wytworów pracy,

$T B$ - zaangażowania w budowanie zespołu.

$$
\begin{gathered}
\mathrm{KO}_{C Z}-\text { wskaźnik koordynacji organizacyjnej } \\
\text { w wymiarze czasu } \\
K O_{C Z}=\mathrm{f}(W C P, T Z, P K, T, U),
\end{gathered}
$$

gdzie:

WCP - wydajności czasowej pracownika,

$T Z$ - tempa wykonywania zadań,

$P K$ - czasu przekazywania komunikatów,

$T$ - cechy terminowości,

$U$ - cechy uporządkowania.

$$
\begin{gathered}
\mathrm{KO}_{P} \text { - wskaźnik koordynacji organizacyjnej } \\
\text { w wymiarze przestrzennym } \\
K O_{P}=f(R P, P n O),
\end{gathered}
$$

gdzie:

$R P$ - rozmieszczenia przestrzennego,

$\mathrm{PnO}$ - pracy zdalnej.

Wskaźniki obszarowe stanowią elementy składowe wskaźnika ogólnego koordynacji. W badaniach empirycznych należy ustalić ich udziały procentowe 
we wskaźniku ogólnym. Wskaźnika ogólnego nie powinno się jednak przedstawiać w postaci prostej sumy arytmetycznej - taki wskaźnik będzie zbyt prosty i niekoniecznie miarodajny. Propozycja przedstawienia go jako średniej arytmetycznej ważonej nie pozwoli na uchwycenie, które czynniki i zagadnienia są najważniejsze dla koordynacji, a które z nich mają mniejszą wagę. Taką możliwość daje wprowadzenie wag dla określonych zagadnień. Wagi nadaje się zatem ze względu na stopień trudności koordynacji poszczególnych obszarów tematycznych w organizacji, przedstawionych za pomocą wskaźników. Sposób funkcjonowania wydaje się zatem najtrudniejszy do koordynowania, $\mathrm{w}$ drugiej kolejności będą to zagadnienia związane z czasem, przestrzenią i zasobami. Koordynowanie zagadnień struktury w obszarze organizacji wydaje się najłatwiejsze ze względu na ukonstytuowany porządek, dlatego funkcja:

$$
f(K O)=\frac{K O_{S}+K O_{F}+K O_{Z}+K O_{C Z}+K O_{P}}{5},
$$

gdzie:

KO - ogólny wskaźnik koordynacji organizacyjnej,

przyjmuje wskaźnikową postać:

$$
f(K O)=\frac{10 \% K O_{S}+30 \% K O_{F}+30 \% K O_{Z}+15 \% K O_{C Z}+15 \% K O_{P}}{5} .
$$

Wskaźnik koordynacji organizacyjnej jest przedstawiony w formule prostej addytwności, wszelkie miary wchodzące w jego skład skonstruowane są bowiem na podstawie różnych zmiennych. Jednak badacz musi zdawać sobie sprawę, że między poszczególnymi wartościami wskaźników szczegółowych mogą zachodzić istotne współzależności (korelacji, asocjacji, odległości) (Pułaska-Turyna, 2011).

Zgodnie z przyjętą $\mathrm{w}$ pracy zasadą wartość wskaźnika mieści się w przedziale od 0 do 1 - im wskaźnik koordynacji organizacyjnej jest bliższy wartości 1, tym wyższy jest poziom koordynacji organizacyjnej.

Wysoka sprawność funkcji koordynowania (efekt koordynacyjny) przekłada się bezpośrednio na wysoką sprawność organizacyjną. Natomiast komunikacja pełni rolę służebną wobec koordynacji, im lepsze jest bowiem narzędzie (komunikacja), tym lepszy efekt koordynacyjny. 


\section{Zakończenie}

Zainteresowanie komunikacją i sprawnością organizacji oraz wzajemnymi relacjami komunikacji i sprawności, a także zamiłowanie do teorii systemów w służbie organizacji stały się główną inspiracją powstania niniejszej książki. Dlatego rozważania w przedstawionym tekście prowadzą do skonstruowania systemowego modelu organizacji za pomocą metody analizy systemowej ${ }^{1}$ i syntezy systemowej (jako metody badawczej), przez pryzmat komunikowania dla potrzeb osiągania optymalnej sprawności.

Przedstawiona praca jest w założeniu teoretyczna ${ }^{2}$. Jej celem jest wypracowanie modelu organizacji z perspektywy komunikacyjnej dla potrzeb osiągania sprawności organizacji oraz metody badawczej w postaci analizy systemów złożonych. Przy tworzeniu tej pracy korzystano - w miarę wiedzy i możliwości - z literatury pierwotnej - wyszukiwano prace prekursorów i docierano do źródeł. Stąd najstarsze pozycje literaturowa występujące w przypisach do niniejszego opracowania datowana jest na rok 1904 (Haeckel) i 1909 (Adamiecki). Literatura w naukach humanistycznych ma wartość bez względu na datę publikacji - nadal czyta się i cytuje Arystotelesa (1990), jednak wydaje się, że w naukach technicznych, biologii i medycynie najważniejsze są prace najnowsze. W naukach humanistycznych prace prekursorów rozmaitych koncepcji mają jednak nieocenioną wartość, ogromny potencjał intelektualny i dają pewną „wolność pracy umysłowej”, nienarzuconą przez ich interpretatorów - pozwalają na swobodę formułowania własnych konstrukcji myślowych.

W niniejszym opracowaniu uznaje się, że dotychczasowe podejścia do komunikowania w organizacji i sprawności organizacyjnej są niezadowalające, dotyczą fragmentów rzeczywistości organizacyjnej. Wykazano, że związek między komunikacją a sprawnością organizacji, uznawany za pewnik, rozumiany był

1 Część systemowców unika posługiwania się terminem analiza systemowa, aby nie budzić niepożądanych skojarzeń z metodologia podejścia analitycznego, w opozycji do którego powstało podejście systemowe i metodologia badań systemowych. W zamian stosują określenie dekompozycja systemowa.

2 „Dobra teoria jest praktyczna, ponieważ rozwija wiedzę w dyscyplinie naukowej, prowadzi badania w kierunku kluczowych kwestii i oświeca zawód zarządzania. [...] skupia się na kryteriach i metodach tworzenia dobrej teorii. Jej celem jest zaproponowanie sposobów wzmocnienia możliwości rozwoju teorii i lepszego powiązania teorii z dyscyplinami i profesjami reprezentowanymi w Akademii” [tłum. M.Z.-T.] (Van De Ven, 1989, s. 486). 
intuicyjnie, w zasadzie bez większej refleksji naukowej3. Menedżerowie (Giganci biznesu, 2007) twierdzą na przykład, że dobra komunikacja zwiększa produktywność firmy. Twierdzenie to z pewnością odzwierciedla ich doświadczenie lub przekonania. Nie jest to jednak podejście naukowe, ponieważ problem nie był przez nich poddany procedurze badania naukowego.

Dotychczas nie przeprowadzono badań analitycznych, aby określić, jakie cechy sprawnego komunikowania można zoperacjonalizować, przełożyć na jednoimienne wskaźniki sprawności koordynacji w organizacji jako systemu działania. Brakuje także zadowalających koncepcji objaśniających funkcjonowanie całej organizacji przez pryzmat komunikacji i w konsekwencji możliwości sprawnego zarządzania nią (z perspektywy komunikacyjnej). Proponowane ujęcie powstało na gruncie teorii systemów, z tego powodu dotyczy całości organizacji, nie jej fragmentów, jest zintegrowane i kompletne. Ponadto obecnie na proces komunikowania w organizacji często patrzy się przez pryzmat możliwości informatycznych - ilości danych, możliwości ich przekazywania, przetwarzania, składowania. Taka perspektywa marginalizuje istotę procesu komunikowania się, za to podkreśla parametry stosowanego narzędzia i sposób komunikowania się (a nie treść).

Niedostatki dotychczasowego podejścia do komunikowania się w organizacji z perspektywy teorii systemów obserwuje się w tym, że wprawdzie von Bertalanffy wypracował kompletną koncepcję podejścia systemowego na gruncie teoretycznym, ale jej nie zoperacjonalizował i nigdy, w żadnej ze swoich prac, nie odnosił do komunikowania. Propagatorzy podejścia systemowego zajmujący się komunikacją często odwoływali się do jego spuścizny (np. Mazur, Flakiewicz). Wówczas jednak komunikacja nie była rozpatrywana jako system społeczny, ale jako system informatyczny przeznaczony do komunikacji w organizacji.

Takie podejście doprowadziło do wyznaczenia celu pracy w postaci systematycznego wskazania sposobu (metody), w jaki komunikowanie w organizacji prowadzi do poprawy jej sprawności (integrowanie komunikatów - organizowanie - koordynacja - sprawność).

3 Istnieje wiele interesujących prac naukowo-badawczych podejmowanych w tym obszarze, które jednak koncentrują się wokół zagadnień bardziej szczegółowych niż wzajemny wpływ komunikacji i produktywności - na przykład wpływ technologii komunikowania (w tym informacji marketingowych) na produktywność (Ogutu, Okello, Otieno, 2014, s. 311-321; Grazzi, Jung, 2016, s. 103-135; Bashir, Mahmood, 2018, s. 77-87; Wagner, Ruhe, 2018), wpływ stylu komunikacji przywódczej (albo osobowości) na produktywność (Solaja, Idowu, James, 2016, s. 99-117). Interesującą grupą prac są te z zakresu Software Engineering - tam jednak komunikacja sprowadzana jest do postaci interfejsu (np. Henley i in., 2018, s. 157-170). Istnieją także badania dotyczące komunikacji i produktywności rozważane z perspektywy zmian organizacyjnych (Singh, Goel, 2018, s. 27-35). 
Realizacja celu głównego obejmowała w części naukowej opracowanie systemowego modelu sieci zintegrowanych relacji komunikowania (SMSZRK), naukowej metody analizy systemów złożonych oraz systemu wskaźników koordynacji systemowego modelu sieci relacji komunikowania w kierunku sprawności. Wszystkie cele naukowe osiągnięto $\mathrm{w}$ toku prac.

Cel aplikacyjny wyrażono możliwością posługiwania się modelem, aby doskonalić zarządzanie (koordynowanie) organizacją i podnosić jej sprawność przez komunikację oraz w przypadku tworzenia nowej firmy, zbudowania organizacji optymalnej od strony komunikacyjnej. Cel aplikacyjny osiągnięto w znacznej części, okazało się bowiem, że wartości referencyjne wskaźników należy ustalić w toku badań empirycznych - będą one przyjmować inne wartości w zależności od branży i typu organizacji. Wskaźniki mogą być stosowane w sposób dynamiczny - zmiana wartości wskaźnika w czasie dla tej samej firmy określa zmianę stopnia koordynacji, jaka zachodzi w firmie.

Z powyżej wskazanych względów można uznać, że cel pracy został osiągnięty, co wymagało prac teoretycznych i metodycznych. W części teoretycznej dokonano interpretacji dotychczasowego dorobku w dziedzinie komunikacji wewnątrzorganizacyjnej, oceny dorobku teorii systemów w zakresie wykorzystywania w organizacji i zarządzaniu, krytycznej oceny opisanych w literaturze przedmiotu systemów społecznych (organizacji) ujmowanych systemowo oraz metod analizy systemowej. W części metodycznej wypracowano metodykę analizy systemów złożonych (ASZ) organizacji i stworzono narzędzie badawcze, skonstruowano model organizacji z perspektywy komunikacyjnej, ustalono wskaźniki koordynacji organizacyjnej podnoszące sprawność działania organizacji i zbudowano model systemu organizacji osadzonego na idei komunikowania się - tak zwany model koordynacji organizacyjnej (KO).

W konsekwencji przyjętego toku prac można uznać tezę badawczą, zgodnie z którą podnoszenie sprawności organizacyjnej można osiągać przez poprawę komunikacji wewnątrzorganizacyjnej, za uzasadnioną.

Istnieją pewne typy działań, które - stosowane w określonej kolejności - decydują o sprawności funkcjonowania organizacji. Należą do nich komunikacja, integracja, koordynacja i organizacja.

W celu uzasadnienia tezy ogólnej kolejno uzasadniano tezy szczegółowe - należało zatem zintegrować komunikację w taki sposób, aby tworzyła organizację (ujęcie modelowe), wskazać możliwości koordynowania takiej organizacji i dokonać operacjonalizacji narzędzi koordynowania (za pomocą komunikacji) w kierunku sprawności organizacji.

Konstrukcja monografii jest ściśle powiązana z tezą pracy. Przyjęty cel pracy w postaci systematycznego wskazania sposobu (metody), w jaki komunikowanie 
w organizacji prowadzi do poprawy jej sprawności (integrowanie komunikatów - organizowanie - koordynacja - sprawność), narzuca kolejność rozważań, a tym samym strukturę pracy. Typ prowadzonych w pracy rozważań ma charakter diagnostyczny (od rozważań szczegółowych do ogólnych) i znajduje odzwierciedlenie w konstrukcji opracowania. Składa się ono z trzech części - teoretycznej, metodologiczno-badawczej i konstrukcyjnej. W celu dowiedzenia tezy ogólnej kolejno uzasadniono tezy szczegółowe: zintegrowanie komunikacji w taki sposób, aby tworzyła organizację (ujęcie modelowe), wskazanie możliwości koordynowania takiej organizacji i dokonanie operacjonalizacji narzędzi koordynowania (za pomocą komunikacji) w kierunku sprawności organizacji.

Pracę rozpoczęto przeglądem dotychczasowych ujęć i podejść do zagadnienia komunikowania wewnątrz organizacji - wyodrębniono dwie zasadnicze perspektywy: punkt widzenia na komunikację społeczną w środowisku organizacji oraz punkt widzenia na proces konstytuujący istnienie organizacji, promowany na gruncie nauk socjologicznych. Zaprezentowany przegląd dotychczasowych dokonań w tym zakresie jest z natury rzeczy wycinkiem z obszernej literatury przedmiotu. Nie chodziło tu o skatalogowanie kompletnego dorobku z zakresu komunikowania się w organizacji, ale o zaznaczenie dwoistości natury komunikacji wewnętrznej jako procesu służebnego dla organizacji, mającego charakter transmisyjny oraz jako podstawy jej istnienia, procesu ją konstytuującego. Obie przedstawione w rozdziale pierwszym perspektywy wypracowane zostały w oderwaniu od teorii organizacji, a następnie zaadaptowane do jej potrzeb. Są one zatem niespecyficzne dla dyscypliny, ale uprawomocniają konstytutywna rolę komunikacji dla organizacji. Niestety, nie pozwalają - z powodów metodologicznych - na operacjonalizację w kierunku sprawności organizacji. Przedstawienie organizacji jako komunikacji, za pomocą innej metody pozwalającej na taką operacjonalizację umożliwiłoby podniesienie sprawności organizacji przez komunikację wewnątrzorganizacyjną.

W naukach o zarządzaniu w początkowych podejściach do organizacji nie zauważano potrzeby badań nad komunikacją, wówczas naukowymi metodami badano tylko wzrost wydajności. W podejściu „stosunków międzyludzkich” badano komunikację jako element społecznego porozumiewania się ludzi, a efektywność procesu komunikowania zależała w zasadzie wyłącznie od kompetencji jednostki (nadawca, odbiorca). Dlatego w następnej kolejności przeanalizowano fragmentaryczne podejścia (wyniki przedstawiono w tabeli 2) do komunikowania wewnątrzorganizacyjnego według następujących po sobie paradygmatów organizacji, jakie powstały w latach dziewięćdziesiątych ubiegłego wieku, uwidaczniając tym samym rosnącą wagę procesu komunikowania w funkcjonowaniu i zarządzaniu organizacjami na przestrzeni lat. Nie tylko autorka zauważyła potrzebę integracji tak obficie 
występujących koncepcji i podejść do komunikowania wewnątrzorganizacyjnego, dlatego przedstawione zostały prace „integrujące” proces komunikowania dla potrzeb organizacji. Ujęto także opracowania autorów, którzy badali kwestię oceny efektywności organizacji przez pryzmat komunikacji lub oceniali skuteczność komunikacji wewnętrznej. Daty publikacji przytoczonych prac wskazują, że obecnie ma miejsce rozkwit zainteresowań naukowo-badawczych i praktycznych dotyczących tych zagadnień.

Zebrane informacje wskazały na możliwość „integracji” komunikowania wewnątrzorganizacyjnego na płaszczyźnie teorii systemów, zgodnie z perspektywą komunikacji konstytuującej organizację, ale wypracowaną na gruncie teorii organizacji. Istnieje także pole do przygotowania mierników sprawności tak modelowanej organizacji jako komunikacji, co uzasadnia możliwość podjęcia dalszych badań w tym zakresie.

W efekcie konceptualizacji problemu badawczego skonkretyzowano tezę: „Komunikowanie warunkuje integrowanie, integrowanie warunkuje koordynowanie, koordynowanie warunkuje zorganizowanie, zorganizowanie warunkuje sprawność".

Rozważania w pracy zostały systematycznie ukierunkowane na uzasadnienie tak sformułowanej tezy. Praca ma zatem charakter sekwencyjny - polega na następującym po sobie stawianiu problemów i ich sukcesywnym rozwiązywaniu. W punkcie wyjścia problemem stała się kategoria systemowości. O systemach (ogólnie) w literaturze naukowej napisano wiele, powstałe prace przygotowali socjologowie, cybernetycy, matematycy i systemowcy.

Systemy jako podstawa rozważań dotyczą obiektu jako całości. W rozumieniu, w którym traktuje się całość jako pierwotną, powstaje ona przez nawiązanie wzajemnych relacji między częściami. Intuicyjne wyobrażenie o złożonej całości przystaje do zagadnień komunikowania, ponieważ pozwala traktować komunikowanie jako najważniejszą z relacji w organizacjach. Co więcej, taka konstrukcja pozwala przypuszczać, że w miejscu relacji musi bezwzględnie zachodzić komunikacja, bo jeśli więzi znikają, to całość dezintegruje się. Ta perspektywa inspiruje do podjęcia próby budowy modelu organizacji na gruncie teorii organizacji, ze szczególnym ukierunkowaniem na rolę i znaczenie relacji jako kategorii systemotwórczej. Teoria systemów prezentowana przez Bertalanffy’ego jako OTS - ogólna teoria systemów (General Systems Theory - GST) daje podstawy do badań całościowych oraz pozwala określić koncepcje szeroko rozumianych relacji - jest bowiem nie tylko filozofią, lecz także daje możliwości badawcze, zapewniając własną metodę badań - analizę i syntezę systemową.

W pracy przyjęto podejście systemowe jako zasadę prowadzonego badania. Konsekwencją stała się konieczność wykorzystania w jej toku analizy i syntezy 
systemowej. Tego typu analiza stosowana była w badaniach organizacji między innymi przez specjalistów z zakresu teorii organizacji, a także w obszarze nauk społecznych, ekonomicznych i technicznych. Obiekt badany z punktu widzenia rozmaitych nauk jest przecież tym samym obiektem, jednak rozmaicie definiowanym.

Z tego względu część metodologiczną rozpoczęto od uporządkowania i wyraźnego zidentyfikowania miejsca analizy systemowej jako metody badawczej w ogólniejszym kontekście systemowym - obok filozofii i teorii. Przedstawiono także przewagę analizy systemowej nad innymi stosowanymi metodami badawczymi dla potrzeb organizacji. W wyniku przeprowadzonego przeglądu uznano, że analiza systemowa jako metoda badawcza odpowiada potrzebom badawczym zamierzonej pracy.

W wyniku wyboru analizy systemowej jako metody badawczej w niniejszej pracy dokonano porównania metod podejścia systemowego z klasycznym podejściem analitycznym, co wyraźnie uwydatniło przewagę teoriopoznawczą metodologii systemowej. Dokonano także porównania metody systemowej ze stosowaną empirycznie metodą analizy sieci społecznych. Wyniki szczegółowe porównania przedstawiono syntetycznie w tabeli 6.

Kolejna wątpliwość, jaką należało rozważyć, dotyczyła toku postępowania $\mathrm{w}$ trakcie prowadzonej analizy systemowej. Występujące w literaturze metody badawcze określane mianem analiza systemowa, mimo że powstały na gruncie tej samej teorii systemowej, odniesione były do obiektu organizacja i występowały w obszarze nauk o organizacji i zarządzaniu oraz przyjmowały rozmaite postacie. Dokonano zatem ich porównania, do analizy wybierając tylko te, które wykazywały podejście systemowe (całościowe). Problemem, jaki napotkano w tym miejscu, była rozpiętość nazewnicza procedur - z natury systemowych, a rozmaitych z nazwy. Analizowano ich przebieg, kolejność etapów, a także - jeśli występowały - ich niedostatki lub niekonsekwencje z punktu widzenia metody systemowej. Przedstawiony w tym miejscu przekrój wypracowanych procedur analizy systemowej jako metody badawczej stanowi inspirujące kompendium wiedzy w tym zakresie, które wykorzystano później do budowy procedury autorskiej. W efekcie prac zaobserwowano znaczną rozbieżność w postaci określeń tego, czym jest analiza systemowa i w jaki sposób należy dokonywać analizy i syntezy, posługując się tą metodą.

Po takim rozpoznaniu sytuacji należało zdecydować się na konstrukcję własnej, autorskiej propozycji procedury analizy systemów złożonych (ASZ, Complex Systems Analysis) jako metody badawczej do projektowania i doskonalenia organizacji w rozumieniu zintegrowanego systemu sieci relacji komunikowania.

Przedstawione szczegółowo etapy procedury ASZ jako metody badawczej do projektowania i doskonalenia organizacji poprzedzono określeniem założeń 
w niej stosowanych - procedura może być stosowana zarówno do organizacji istniejącej, jak i do tworzonej od nowa. Należy jednocześnie rozróżnić komunikację w obu typach organizacji - inaczej postępuje się w dopiero projektowanej organizacji, gdzie komunikacja jest pierwotna w stosunku do jej struktury, a odwrotnie rzecz wygląda w organizacji działającej, gdzie struktura już istnieje, a komunikacja jest wobec niej wtórna.

Autorska wersja przebiegu ASZ jako metody badawczej przedstawiona została przez charakterystykę kolejnych etapów prac konstrukcyjnych i badawczych wraz z ich opisem i wytycznymi, obejmując:

1) określenie systemu na obiekcie i jego przedstawianie:

a) sprawdzenie prawidłowości sformułowania celu systemu,

b) identyfikację podsystemów systemu,

c) identyfikację istotnych sprzężeń (relacji) między podsystemami systemu,

d) grupowanie relacji wokół celu organizacji,

e) graficzną postać systemu,

2) analizę struktury organizacji i zachowania komunikacyjnego w systemie,

3) projekt udoskonalenia lub poprawy systemu - etap tożsamy z budowaniem systemu.

Do potrzeb opisu procedury ASZ jako metody badawczej do projektowania i doskonalenia organizacji wprowadzono autorskie pojęcie systent, oznaczające najmniejszy, graniczny składnik dekompozycji (system/podsystem) składający się co najmniej z dwóch elementów i relacji między nimi, przyjęty umownie ze względu na cel pracy jako granica rozważań (w przypadku organizacji jest to podsystem złożony z koordynującego, np. przełożonego, i koordynowanego, np. podwładnego, oraz relacji między nimi).

W wyniku prac własnych ustalono zapis matematyczny procedury analizy systemów złożonych dla kolejnych rzędów analizy oraz przedstawiono tę procedurę w sposób graficzny, poglądowy. Zaproponowano także synkretyczny model cyklu zarządzania (SMCZ, Syncretic Model of Management Cycle-SMMC) w postaci zintegrowanych elementów koncepcji cyklu działania zorganizowanego Le Chateliera oraz funkcji zarządzania Fayola z opisem jego konstrukcji. Posłużył on w dalszej części pracy jako integrator, grupujący w odpowiednie wiązki i sieci komunikaty i kanały komunikowania, jako podstawowe elementy konstrukcyjne w budowie modelu systemu sieci zintegrowanych relacji komunikowania (SSZRK, System of Integrated Relations of Communication Networks - SIRCN).

W literaturze przedmiotu występuje kilka modeli organizacji, które są nazywane systemowymi albo przez ich twórców, albo przez propagatorów. Jeśli chodzi o cel pracy, interesujący jest sposób, w jaki one powstały - czy powstały wskutek przeprowadzenia badania systemowego, czyli czy wypracowano je przez syntezę 
systemową poprzedzoną kompleksową analizą systemową odniesioną do rzeczywistego, treściowego i formalnego opisu obiektu badania. Dokonano w tym zakresie systematycznego przeglądu i stwierdzono, że żadnego ze zbadanych modeli nie można uznać w pełni za systemowy - niektóre z nich być może powstały w sposób systemowy, jednak ich autorzy nie pokazują sposobu wypracowania modelu, a w przypadkach, w których droga badacza jest znana, nie spełnia ona kryterium badania systemowego w postaci analizy i syntezy systemowej (szczegóły znajdują się w rozdziale 4 ).

Prace nad własnym projektem budowy systemowego modelu organizacji, po wcześniej przeprowadzonej analizie procedury analizy systemów złożonych jako metody badawczej do budowy i doskonalenia organizacji, rozpoczęto od ogólnych przesłanek do budowy modelu. Badanie organizacji jako przedmiotu skonceptualizowanego opisu obiektu empirycznego przeprowadzono na trzech poziomach metodologicznych:

1) rzeczowym, dotyczącym określenia rzeczy i przedmiotów, w tym człowieka (zgodnie z przyjętą zasadą reizmu), wchodzących w skład systemu organizacji, a także sposobu ich uporządkowania, czyli wewnętrznej struktury systemu;

2) czynnościowym, ze względu na wyodrębnienie przebiegów komunikacji między podsystemami - miejsc ich występowania (są one „zawieszone” na strukturze); relacje w modelu wyodrębnione będą w ujęciu przedmiotowym - ze względu na treść relacji komunikacyjnej zachodzącej między określonymi podsystemami;

3) atrybutowym, pozwalającym określić typy wcześniej wyodrębnionych relacji, tak aby modelować przebiegi komunikacyjne w kierunku sprawności.

Model ten - jako systemowy - z założenia ma za zadanie odnosić się do wszystkich typów organizacji, dlatego żadna konkretna organizacja ani grupa organizacji tożsamych co do typu działalności nie służy za podstawę do badań. Jest nią obraz pojęciowy organizacji (termin wyjaśniony w pracy w podrozdziałach 2.1 oraz 4.1), integrujący wszystkie jej typy i rodzaje - w zakresie rzeczowym.

W konsekwencji rozważania szerokiego materiału empirycznego praca przebiegała wieloetapowo - najpierw powstał (1) model opisowy organizacji, a na jego podstawie (2) model formalny. Model opisowy sam w sobie stanowi badanie systemowe, ale jest nieoperacyjny, natomiast model formalny może posłużyć do dalszych badań.

Konkretyzację, czyli budowę relacyjnego modelu organizacji z perspektywy komunikacji, rozpoczęto - zgodnie z procedurą - od ustalenia celu systemu, zidentyfikowania problemu i identyfikacji systemu. Kolejne etapy budowy modelu, najpierw opisowego, przedstawiono, rozpoczynając od identyfikacji elementów 
systemu, które wyodrębniono z całości systemu organizacja, zgodnie z systemową zasadą ontycznego pierwszeństwa całości wobec jej elementów. Wyodrębniono zatem realnie występujące części, mające odniesienie ontyczne do realnych składników bytu w rzeczywistości organizacyjnej, wchodzące w skład obiektu organizacja. Rozpoznano i określono cechy części, w efekcie czego powstał niezamknięty katalog właściwości, który uporządkowano w kategorie tożsame z podsystemami - antropologicznym, społecznym, technicznym (techniczno-technologicznym) i ekonomicznym. Te podsystemy były dalej nazywane autonomicznymi. Dostrzegając różnice między wyodrębnionymi właśnie podsystemami autonomicznymi tworzonego na potrzeby pracy modelu a elementami istniejących modeli systemowych (opisanych i zanalizowanych wcześniej), ustosunkowano się do nich w sposób szczegółowy.

Praca badawcza doprowadziła do uporządkowania elementów rzeczowych zaobserwowanych w organizacjach i utworzenia wstępnej konstrukcji modelowej możliwej do przedstawienia graficznego, zaprezentowanego na rysunku 19. Wymieniono przykładowe cechy wewnątrzpodsystemowe podsystemów autonomicznych (relacje pierwszego rzędu). Konieczny jest tu komentarz, że niektóre elementy składowe podsystemów autonomicznych charakteryzują więcej niż jeden podsystem, dlatego nazwy składowych powtarzają się, ale nie powtarzają się własności je opisujące.

W następnej kolejności w modelu systemu wyróżniono podsystemy drugiego rzędu, nazywane podsystemami skojarzonymi: antropo-społeczny, antropo-techniczny, antropo-ekonomiczny, społeczno-techniczny, społeczno-ekonomiczny oraz techniczno-ekonomiczny. Konsekwentnie rozpoznano także podsystemy trzeciego i czwartego rzędu, w których występują relacje między trzema i czterema podsystemami. Relacje zachodzące w podsystemach kolejnych rzędów nazwano relacjami organizacyjnymi, w odróżnieniu od relacji komunikacyjnych, które omówiono w dalszej części pracy. W tym miejscu wskazano także przykładowe typy relacji organizacyjnych kolejnych rzędów, charakteryzujące poszczególne podsystemy kolejnych rzędów - katalog ograniczono do relacji wiążących system (systemotwórczych), przedstawionych w tabelach w załączniku. Dla zwiększenia czytelności i ułatwienia rozpoznania omawianych subsystemów kolejnych rzędów (wyodrębniono bowiem piętnaście podsystemów czterech kolejnych rzędów) wprowadzono oznaczenia graficzne. Konstrukcję zamyka opis relacji samozwrotnych z podsystemem zarządzania - drugiego, trzeciego, czwartego i piątego rzędu, które z racji nadrzędnej roli podsystemu zarządzania mają odmienną od pozostałych charakterystykę (funkcjonalną). Trafiające do podsystemu zarządzania relacje zostały pogrupowane zgodnie z funkcjami wprowadzonego wcześniej synkretycznego modelu cyklu zarządzania (SMCZ). Przedstawiono przykładowe relacje organizowania, zaadresowane do poszczególnych funkcji. Relacje organizacyjne kolejnych stopni 
mają swoje izomorficzne odzwierciedlenie w relacjach komunikacyjnych tych samych stopni - co przedstawiono w dwóch kolejnych podrozdziałach (4.1 oraz 4.2), a przykłady relacji komunikacyjnych w układzie tabelarycznym z ich odniesieniem do funkcji SMCZ - w załącznikach.

Okazało się, że model organizacji jako systemu sieci zintegrowanych relacji komunikowania może w dalszej części pracy posłużyć jako podstawa do optymalizowania sprawności organizacji przez koordynację. W tym celu podjęto kolejne systematyczne kroki - przeprowadzono szczegółowe rozważania dotyczące koordynacji na potrzeby konstrukcji autorskiego systemu wskaźników koordynacji organizacyjnej do osiągania sprawności organizacyjnej.

Koordynacja w naukach o zarządzaniu rozumiana jest głównie na dwa sposoby - jako etap działania zorganizowanego (etap niewyróżniony z nazwy u Le Chateliera) i jako funkcja zarządzania (określona z nazwy przez Fayola). Dla autorki jest ona pierwszą i najważniejszą zasadą organizacji. Od początków istnienia dyscypliny zarządzanie koordynacja i jej waga rosną. Nie zmienił tego ani upływ lat, ani pojawienie się nowych form organizacji przedsiębiorstw i sposobów zarządzania nimi. Hiperturbulentne otoczenie organizacyjne i związana z nim transformacja typów organizacji i procesów organizacyjnych jeszcze bardziej wzmagają potrzebę koordynacji. Tymczasem istnieje wiele rozmaitych cząstkowych ujęć procesu koordynacji. W literaturze z zakresu teorii systemów zasada koordynacji doczekała się reprezentacji matematycznej w postaci funkcji matematycznej, którą przytoczono w podrozdziale 5.1 i omówiono jej ograniczenia. Dla potrzeb dalszej części pracy wyodrębniono także koordynację ex ante, in tractu i ex post, dotyczące odpowiednio fazy i funkcji planowania, realizowanej przez funkcję organizowania oraz funkcję kontrolowania. Ponieważ szczegółowa analiza rozmaitych ujęć koordynacji wykazała rozproszenie płaszczyzn definicyjnych, zdecydowano się przyjąć prakseologię jako płaszczyznę porządkującą i perspektywę badawczą. Głównym powodem tego wyboru była przyświecająca w badaniach w niniejszej pracy chęć doskonalenia sprawności organizacyjnej - zadecydowały więc możliwości, jakie daje prakseologiczna teoria organizacji, która pozwala nie tylko na opis czy operacjonalizację zjawiska, ale i na jego pomiar.

Przyjęcie takiej perspektywy rozwiązało problem nadmiernej różnorodności stanowisk i podejść do koordynacji organizacyjnej, dało w perspektywie możliwość operacjonalizacji pojęcia koordynacji, a także narzuciło kolejność następnych rozważań - powstała potrzeba odróżnienia sprawności działania i sprawności rezultatu. W niniejszej książce przyjęto perspektywę rezultatową. W koncepcjach prakseologicznych koordynowanie stanowi jedną z dyrektyw sprawnego działania - praca wykonana zgodnie z podziałem pracy ma być scalana w procesie koordynacji, co prowadzi do osiągania efektu organizacyjnego. Koncepcja efektu 
organizacyjnego została zatem uzupełniona koncepcją własną efektu koordynacyjnego, definiowanego konsekwentnie jako efekt działania i rezultatu. Po takim przygotowaniu, przypisując komunikacji w organizacji rolę narzędzia, można było uzależnić osiąganie efektu koordynacyjnego od sprawnego przebiegu procesu komunikowania, co przyniosło rezultat w postaci efektu organizacyjnego, będącego wskaźnikiem sprawności funkcjonowania całej organizacji.

W pracy szczegółowo uzasadniono wpływ efektu koordynowania na efekt organizacyjny oraz przedstawiono sposób, w jaki ustalono mierniki tego wpływu. Wprowadzono pojęcia koordynowania in statu - jako zastanego poziomu koordynowania (na wejściu) oraz koordynowania in tractu - jako koordynowania interwencyjnego (doraźnego). Przedstawiono ogólną koncepcję mierników i mierzenia efektu koordynacyjnego, z zaznaczeniem pięciu wyodrębnionych typów koordynacji szczegółowych - koordynacji strukturalnej, funkcjonalnej, zasobowej, czasowej i przestrzennej. Każdy wskaźnik może przybrać dowolną wartość od 0, sugerującego działanie chaotyczne, do 1 - działania w pełni skoordynowanego (maksimum osiągalne). Co więcej, koordynacja in statu wskazuje poziom koordynowania jako sumę szczegółowych wskaźników koordynacji (zostało to przedstawione w podrozdziale 5.5 z podziałem na kategorie). Wartości wskaźników poziomu koordynacji in statu dają obraz początkowego stanu koordynowania - jeśli nie osiąga wartości 1, to oznacza, że istnieją niedostatki w zakresie koordynowania, które mogą być zmniejszone w wyniku koordynacji interwencyjnej, doraźnej, przez wdrożenie koordynowania in tractu w czasie wykonywania zadań. Opis koordynacji organizacyjnej uzupełniono modelem przedstawionym na rysunku 23.

Rozdział zwieńczył model organizacji jako systemu sieci zintegrowanych relacji komunikowania w postaci opisowej i graficznej. Organizacja w ten sposób modelowana podlega koordynacji przez narzędzie komunikowania dla osiągnięcia efektu organizacyjnego i sprawności. Wymiernym rezultatem pracy jest również konstrukcja kompleksowego aparatu wskaźnikowych mierników badawczych przebiegu procesów komunikowania wewnątrzorganizacyjnego i ich efektów.

Wskaźniki koordynacji w układzie wymiarów szczegółowych - strukturalnej, funkcjonalnej, zasobowej, czasowej i przestrzennej - przygotowano w świetle cech wpływu na przebieg procesów koordynowania wewnątrzorganizacyjnego i budowy struktury organizacyjnej. Każdy ze wskaźników otrzymał swoją nazwę, skrót literowy, definicję operacyjną, wzór i interpretację wartości. Wszystkie wskaźniki zostały zaprojektowane w taki sposób, aby przyjmowały wartości z przedziału od 0 do 1, gdzie 0 wskazuje niski poziom koordynacji, a 1 najwyższy możliwy do osiągnięcia poziom sprawności koordynacji. W rezultacie szeroko zakrojonych prac powstał zestaw trzydziestu jeden wskaźników, w których koordynację strukturalną opisują wskaźniki dezagregacji (WDA), dyferencjacji (WDF), zorganizowania 
$(W O)$ i hierarchizacji $(W H)$, koordynację funkcjonalną opisują wskaźniki: liczby zadań $(Z L)$ złożoności zadań $(Z Z)$, różnorodności zadań $(Z R)$, zastępowalności $(Z)$, fluktuacji (F), stylu kierowania $(S K)$, kwalifikacji pracowniczych $(K w P)$, dokumentyzacji $(B)$, kadry wykonawczej $(K W)$, jakości produktów $(J)$, empowermentu ( $E$, na który składają wskaźniki decyzyjności $(D)$, odpowiedzialności $(O)$ i samodzielności $(S))$. W grupie zasobowych wskaźników koordynacji występują wskaźniki: liczby pracowników w zespole $\left(N_{K}\right)$, stopnia wykorzystania pracowników w zespole $\left(N_{S W}\right)$, standaryzacji zadań $(S t)$, powtarzalności zadań $(P)$, automatyzacji zadań $(A)$, stopnia mechanizacji pracy $(M P)$, zróżnicowania wytworów pracy $(Z W P)$ oraz zaangażowania w budowanie zespołu $(T B)$. Koordynację czasową określają wskaźniki: wydajności czasowej pracownika (WCP), tempa wykonywania zadań $(T Z)$, czasu przekazywania komunikatów $(P K)$, terminowości pracy pracownika $(T)$ i uporządkowania $(U)$. Wreszcie koordynację przestrzenną wyznaczają wskaźniki rozmieszczenia przestrzennego $(R P)$ i pracy zdalnej $(P n O)$. Jako podsumowanie wypracowanego katalogu wskaźników przedstawiono sumaryczny wskaźnik koordynacji organizacyjnej.

Ten etap prac okazał się wyjątkowo trudny, ponieważ mierniki konstruowane na podstawie organizacji in abstracto można odnosić do typów organizacji, ustalając wyłącznie zakresy ich wartości (wartość referencyjną), a nie konkretną wartość. Wskaźniki określonego typu koordynacji dają wynik liczbowy w przypadku ich odniesienia do konkretnej, realnej organizacji, charakteryzującej się określoną liczbą pracowników i zadań, określonym typem zadań, rodzajem pracy itp.

Wykonane działania pozwalają na osiągnięcie celu pracy i uzasadnienie postawionej tezy.

Wszystkie czynności, jakie realizowane są w organizacji, mają w tle proces komunikowania, ponieważ zespół w organizacjach we współdziałaniu wiążą właśnie relacje komunikacyjne różnego typu. Koordynacja natomiast „konsumuje” pozytywne właściwości tych relacji (powstaje sumowana efektywność komunikowania) i pozwala na uporządkowanie współdziałań. Przedstawiona praca nie jest renowacją pięknej starej fasady i nie stanowi uzupełnienia czy korekty pomysłu z lat pięćdziesiątych ubiegłego wieku, jest budową postawioną od nowa po systematycznej i gruntownej analizie luk i niedostatków poprzedniego projektu. Dziś w nauce potrzeba systemowej analizy.

W niniejszej pracy zaproponowano pierwsze i - w intencji autorki - w całości systemowo ugruntowane badanie organizacji. Jest to badanie naukowe, przeprowadzone metodą analizy systemów złożonych, wskazujące na zależność między komunikacją wewnątrzorganizacyjną a sprawnością działania organizacji. Istotą pracy nie jest określenie optymalnego poziomu wskaźników komunikacji, ale ścisłe wyodrębnienie i zdefiniowanie tego, co powinno być mierzone. 
Optymalizacja cząstkowych funkcji przedsiębiorstwa lub części procesów produkcyjnych nie musi prowadzić do optymalizacji działania przedsiębiorstwa jako całości. Co więcej, doskonalenie tylko jednej funkcji może doprowadzić do zmniejszenia sprawności funkcjonowania całości (Lis, 1984, s 59).

Optymalny lub referencyjny poziom wskaźnika będzie inny dla każdego z przedsiębiorstw, należy go określić w drodze weryfikacji empirycznej.

W tej sytuacji trudność stanowi liczbowe określenie optymalnej czy referencyjnej wartości wskaźników i poziomu wskaźnika syntetycznego najlepszego dla każdej organizacji. Jest to jednak model wypracowany naukowo, przybliżający do wyjaśnienia wpływu komunikacji na koordynowanie organizacji i podnoszenie jej sprawności. Model może zostać - w toku dalszych prac - ulepszony lub poprawiony. Nie aspiruje on do miana jedynej i najlepszej recepty na sprawne komunikowanie w organizacji, natomiast jest syntezą zjawiska. Przedstawione narzędzie wykorzystywać można do określenia odpowiedniego lub zadowalającego poziomu komunikacji w celu osiągnięcia określonej sprawności realizacji działań organizacyjnych.

Dla każdego z wypracowanych trzydziestu jeden szczegółowych wskaźników koordynacji organizacyjnej należy ustalić empirycznie jego optymalny lub referencyjny poziom. Przewiduje się, że wartości poziomu optymalnego będą różne dla poszczególnych wskaźników (każdy wskaźnik będzie miał inną wartość dla przedziału referencyjnego lub optimum). Co więcej, ten sam wskaźnik może przyjmować inny poziom optymalny dla określonego typu organizacji (np. inny w przypadku struktury liniowej, inny zadaniowej). Ta zmienność może być także uzależniona od branży (np. produkcja, usługi, nowe technologie). Takie badania muszą być zakrojone na szeroką skalę, w wersji podstawowej powinny obejmować: trzydzieści jeden wskaźników dla pięciu typów organizacji tylko dla trzech sektorów - co daje 465 pozycji wskaźnikowych do ewentualnego przebadania w przyszłości. Jest to z pewnością kierunek dalszych badań w tym zakresie. Obecnie, zanim uda się ustalić poziomy optymalne i referencyjne poszczególnych wskaźników, można korzystać z nich do określania zmian w poziomie koordynacji w ramach tego samego przedsiębiorstwa. Należy mierzyć koordynację organizacyjną tej samej firmy w regularnych odstępach czasowych, aby ustalić $\Delta-$ zmianę poziomu koordynacji w czasie.

Zebranie informacji potrzebnych do weryfikacji wskaźników wymaga korzystania równocześnie $z$ wielu różnorodnych metod badawczych. W celu pozyskania wszystkich potrzebnych danych należy zastosować wiele szczegółowych źródeł danych - wywiad, analizę dokumentów, kwestionariusz oceny itp.

Przeprowadzenie badań wiąże się także ze szczegółową analizą tego, kto konkretnie (personalnie) z kim w danej organizacji się komunikuje (identyfikacja 
i analiza relacji), ale także tego, jaka jest zawartość merytoryczna komunikatu (o czym do siebie mówią lub piszą). Są to elementy, których możliwość badania jest utrudniona ze względu na utrudniony dostęp do takich informacji - przełożeni odmawiają możliwości przeprowadzenia badań, powołując się na wrażliwość przekazywanych informacji, a pracownicy unikają ujawnienia prawdziwych treści prowadzonych rozmów, przyznając, że część z wymienianych przez nich wzajemnie komunikatów nie dotyczy spraw organizacji bezpośrednio lub pośrednio i obawiając się konsekwencji wyników przeprowadzonych badań. Pracownicy dokonują oceny własnej i często uznają proporcje komunikatów za niewłaściwe (pomijają np. zalety budowania relacji w zespole), w związku z czym ukrywają prawdziwe proporcje komunikatów organizacyjnych i pozaorganizacyjnych. $Z$ tych przyczyn badanie organizacji przez osobę z zewnątrz jest zdecydowanie utrudnione.

Reasumując, kierunki dalszych badań zarysować można w czterech podstawowych nurtach:

1) weryfikacja modelu organizacji,

2) weryfikacja metody systemowej dla innej niż komunikacyjna perspektywy badawczej (np. zarządzanie konfliktem),

3) ustalenie optymalnych poziomów wskaźników, specyficznych dla konkretnych organizacji i wreszcie

4) badanie relacji system-otoczenie - przygotowanie modelu, metody, a następnie przeprowadzenie badań.

Każda z wymienionych dróg zasługuje na osobne opracowanie.

Zasadne w naukach są „różnorodne podejścia, polegające nie tylko na podejmowaniu nowych problemów badawczych, ale także analizie już istniejących, dokonywanej z innej perspektywy" (Lisiński, 2011, s. 9). 


\section{Bibliografia}

2014 MIT SDM Conference on Systems Thinking for Contemporary Challenges (2014), Massachusetts Institute of Technology, October 8, http://sdm.mit.edu/systemsthinkingconference/2014/agenda.html (dostęp: 4.06.2018).

Abdelkafi N., Täuscher K. (2016), Business models for sustainability from a system dynamics perspective, „Organization \& Environment”, vol. 29(1), s. 74-96.

Ackoff R.L. (1969), Decyzje optymalne w badaniach stosowanych, Państwowe Wydawnictwo Naukowe, Warszawa.

Ackoff R.L. (1973), O system pojęć systemowych, „Prakseologia”, nr 2(46), s. 143-160.

Adamiecki K. (1909), Metoda wykreślna organizowania pracy zbiorowej w walcowniach, „Przegląd Techniczny”, nr 17, 18, 19, 20, przedruk w: Adamiecki K. (1970), O nauce organizacji. Wybór pism, Państwowe Wydawnictwo Ekonomiczne, Warszawa (oraz TNOiK - PWE, Warszawa 1985).

Adamiecki K. (1924), Harmonizacja jako jedna z głównych podstaw organizacji naukowej, „Przegląd Techniczni”, nr 49, 5253, przedruk w: J. Kurnal (red.) (1972), Twórcy naukowych podstaw organizacji, Państwowe Wydawnictwo Ekonomiczne, Warszawa.

Adamiecki K. (1926), Przedmowa tłumacza, [w:] H. Le Chatelier, Filozofja systemu Taylora, Nakładem Instytutu Naukowej Organizacji, Warszawa.

Adamkiewicz-Drwiłło H.G. (2008), Współczesna metodologia nauk ekonomicznych, Dom Organizatora, Toruń.

Adams K.M., Mun J.H. (2005), Towards a system of systems methodologies, once again, Proceedings of the $26^{\text {th }}$ National ASEM Conference: Organizational Transformation: Opportunities and Challenges, American Society for Engineering Management, Virginia Beach.

Afoutni Z., Martin-Clouaire R., Courdier R., Guerrin F. (2010), Coordination of activities: application of some concepts and formalizations to agricultural systems simulation, The $9^{\text {th }}$ International Conference on Modeling \& Applied Simulation October 13-152010, Fes.

Aghion P., Akcigit U., Bergeaud A., Blundell R., Hémous D. (2015), Innovation and top income inequality, NBER Working Papers no. 21247, National Bureau of Economic Research.

Aguinis H. (2018), Applied Psychology in Talent Management, $8^{\text {th }}$ edition, Sage Publications, Thousand Oaks. Ahmady G.A., Mehrpour M., Nikooravesh A. (2016), Organizational structure, „Procedia-Social and Behavioral Sciences”, no. 230, s. 455-462.

Ahmed P.K., Rafiq M. (2002), Internal marketing: Tools and concepts for customer-focused management, Butterworth-Heinemann, Oxford.

Akkirman A.D., Harris D.L. (2004), Organizational communication satisfaction in the virtual workplace, „Journal of Management Development”, vol. 24(5), s. 397-409.

Aldag R.J., Stearns T. M. (1987), Management, South-Western Publishing Co., Cincinnati.

Allen L.A., Terry G.R. (1958), Management and Organization, McGraw-Hill, Tokyo.

Alter S. (2007), Could the work system method embrace systems concepts more fully?, „Information Resource Management Journal”, vol. 20(2), s. 33-43.

Altınöz M. (2008), An overall approach to the communication of organizations in conventional and virtual offices, „World Academy of Science, Engineering and Technology International Journal of Information and Communication Engineering", vol. 2, no. 5, s. 627-633. 
Alwzinani F. (2017), A method to disseminate and communicate IS research outputs beyond academia, doctoral dissertation, Brunel University, London.

Amagoh F. (2008), Perspectives on organizational change: systems and complexity theories, „The Innovation Journal: The Public Sector Innovation Journal", vol. 13(3), s. 1-14.

Ancona D.G., Goodman P.S., Lawrence B.S., Tushman M.L. (2001), Time: a new research lens, „Academy of Management Review", vol. 26(4), s. 645-663.

Angrave D., Charlwood A. (2015), What is the relationship between long working hours, over-employment, under-employment and the subjective well-being of workers? Longitudinal evidence from the UK, „Human Relations”, vol. 68(9), s. 1491-1515.

Arystoteles (1990), Kategorie i hermeneutyka, Państwowe Wydawnictwo Naukowe, Warszawa.

Ashby W.R. (1976), Systemy i ich miary informacyjne, [w:] G.J. Klir (red.), Ogólna teoria systemów, Wydawnictwa Naukowo-Techniczne, Warszawa.

Ashby W.R. (1991), Requisite variety and its implications for the control of complex systems, [w:] G.J. Klir (red.), Facets of systems science, Springer, Boston.

Ashby W.R., Goldstein J. (2011), Variety, constraint, and the law of requisite variety, „Emergence: Complexity and Organization", vol. 13(1/2), s. 190-207.

Ashcraft K.L., Kuhn T.R., Cooren F. (2009), Constitutional amendments: "Materializing" organizational communication, „Academy of Management Annals”, vol. 3(1), s. 1-64.

Ashmos D., Huber G. (1987), The Systems paradigm in organization theory: correcting the record and suggesting the future, „Academy of Management Review”, vol. 12(4), s. 607-621.

Argenti P.A. (1996), Corporate communication as a discipline, „Management Communication Quarterly", vol. 10, no. 1, s. 73-97.

Argenti P.A. (2003), Corporate communication, $3^{\text {rd }}$ ed., McGraw-Hill, New York.

Argenti P.A., Forman J. (2002), The Power of Corporate Communication: Crafting the Voice and Image of Your Business, McGraw-Hill, New York.

Austin J.L. (1993), Mówienie i poznawanie: rozprawy i wykłady filozoficzne, PWN, Warszawa.

Babbie E. (2004), Badania spoteczne w praktyce, Wydawnictwo Naukowe PWN, Warszawa.

Bakken T., Hernes T. (red.) (2003), Autopoietic organization theory: Drawing on Niklas Luhmann's social systems perspective, Copenhagen Business School Press, Oslo.

Bales R. (1970), Personality and Interpersonal Behavior, Rinehart \& Winston, New York.

Banajski R. (2015), Jak uobecnia się prakseologia w Polsce?, „Prakseologia”, nr 157, s. 5-22.

Bandura A. (1986), Fearful expectations and avoidant actions as coeffects of perceived self-inefficacy, „American Psychologist”, no. 41, s. 1389-1391.

Bandura A. (1993), Perceived Self-Efficacy in Cognitive Development and Functioning, „Educational Psychologist", no. 28, s. 117-148.

Barabási A.L. (2007), The architecture of complexity. From network structure to human dynamics, „IEEE Control Systems”, vol. 27(4), s. 33-42.

Baran S.J., Davis D.K. (2007), Teorie komunikowania masowego, Wydawnictwo Uniwersytetu Jagiellońskiego, Kraków.

Barnard C. (1938), The functions of the executive, Harvard University Press, Cambridge.

Baron R.A. (1998), Cognitive mechanisms in entrepreneurship: Why and when entrepreneurs think differently than other people, „Journal of Business Venturing”, vol. 13(4), s. 275-294.

Bartlett C.A., Ghoshal S. (1988), Organizing for worldwide effectiveness: The transnational solution, „California Management Review”, vol. 31(1), s, 54-74.

Bartoo H., Sias P. M. (2004), When enough is too much: Communication apprehension and employee information experiences, „Communication Quarterly”, vol. 52(1), s. 15-26.

Bashir S., Mahmood T. (2018), Impact of Information and Communication Technology on the Productivity of South Asian Economies, „NICE Research Journal of Social Science”, no. 10, s. 77-87. 
Basu A., Blanning R.W. (2000), A formal approach to workflow analysis, „Information Systems Research", vol. 11(1), s. 17-36.

Bausch K. (2002), Roots and branches: a brief, picaresque, personal history of systems theory, „Systems Research and Behavioral Science", vol. 19(5), s. 417-428.

Bavelas A. (1950), Communication patterns in task-oriented groups, „The Journal of the Acoustical Society of America", vol. 22(6), s. 725-730.

Beath C.M., Orlikowski W.J. (1994), The contradictory structure of systems development methodologies: Deconstructing the IS-user relationship in information engineering, „Information Systems Research", vol. 5(4), s. 350-377.

Becker G.S., Murphy K.J. (1992), The division of labor and coordination, „Quarterly Journal of Economics", no. 107, s. 1137-1160.

Bednar D.A. (1982), Relationships between communicator style and managerial performance in complex organizations: A field study, „The Journal of Business Communication”, vol. 19(4), s. 51-76.

Beer S. (1972), Brain of the Firm, Allen Lane, London (wyd. 2, John Wiley \& Sons, Chichester 1981).

Beer S. (1974), Designing Freedom, CBC Publications, Toronto.

Beer S. (1979), The Heart of Enterprise, John Wiley \& Sons, Chichester.

Beer S. (1985), Diagnosing the System for Organizations, John Wiley \& Sons, Chichester.

Beeson I., Davis C. (2000), Emergence and accomplishment in organizational change, „Journal of Organizational Change Management", vol. 13(2), s. 178-189.

Belohlavek R. (2017), Systems, uncertainty, and information: A legacy of George J. Klir, „International Journal of General Systems", vol. 46(8), s. 792-823.

Bennett J., Owers M., Pitt M., Tucker M. (2010), Workplace impact of social networking, „Property Management", vol. 28(3), s. 138-148.

Benschop Y., Holgersson C., Van den Brink M., Wahl A. (2015), Future challenges for practices of diversity management in organizations, [w:] R. Bendl, I.L. Bleijenbergh, E. Henttonen, A.J. Mills (red.), Handbook for Diversity in Organizations, Oxford University Press, Oxford.

Berkel F.J. van, Ferguson J.E., Groenewegen P. (2016), Speedy Delivery Versus Long-term Objectives: How Time Pressure Affects Coordination between Temporary Projects and Permanent Organizations, „Long Range Planning”, vol. 49(6), s. 661-673.

Berko R. (1996), SCA issues speaking, listening, and media literacy standards, „SPECTRA”, vol. 32(6), s. 1-5.

Bernard Ch.I. (1958), The Functions of the Executive, Harvard University Press, Cambridge.

Berne E. (2013), W co graja ludzie, Wydawnictwo Naukowe PWN, Warszawa.

Berninghaus S., Vogt B. (2006), Network Formation in Symmetric 22 Games, „Homo Oeconomicus", vol. 23(3/4), s. 421-466.

Bertalanffy L. von (1951), Problems of general system theory, „Human Biology”, vol. 23(4), s. 302-361.

Bertalanffy L. von (1968), General System Theory, https://pl.scribd.com/doc/234768936/Ludwig-Von-Bertalanffy-General-System-Theory-1968 (dostęp: 21.06.2015).

Bertalanffy L. von (1976), Historia rozwoju i status ogólnej teorii systemów, [w:] G.J. Klir (red.), Ogólna teoria systemów, Wydawnictwa Naukowo-Techniczne, Warszawa.

Bertalanffy L. von (1984), Ogólna teoria systemów, Państwowe Wydawnictwo Naukowe, Warszawa.

Besio C., Pronzini A. (2010), Inside organizations and out: Methodological tenets for empirical research Inspired by systems theory, „Qualitative Social Research”, vol. 11(3), s. 1-22.

Bielecka-Prus J. (2012), Problem kontekstu w teoriach komunikowania społecznego, „Studia Socjologiczne", nr 1, s. 19-38.

Bielski M. (1973), Formalna i rzeczywista struktura organizacyjna, Państwowe Wydawnictwo Ekonomiczne, Warszawa. 
Bielski M. (2001), Organizacje. Istota, struktury, procesy, Wydawnictwo Uniwersytetu Łódzkiego, Łódź.

Bielski M. (2002), Podstawy teorii organizacji i zarzadzania, Wydawnictwo C.H. Beck, Warszawa. BIS (2014), Work Life Balance Employer Survey. Department of Business and Skills, London: HMSO, https://assets.publishing.service.gov.uk/government/uploads/system/uploads/attachment_data/file/398557/bis-14-1027-fourth-work-life-balance-employer-survey-2013. pdf (dostęp: 15.05.2018).

Bisel R.S. (2010), A communicative ontology of organization? A description, history, and critique of CCO theories for organization science, „Management Communication Quarterly”, vol. 23(1), s. 124-131.

Blake R.R., Mouton J.S., Barnes L.B., Greiner L.E. (1964), Breakthrough in organization development, „Harvard Business Review”, vol. 42(6), s. 133-155.

Blanchard K. (2007), Przywództwo wyższego stopnia, Wydawnictwo Naukowe PWN, Warszawa.

Blauberg I.W., Sadowski W.N., Judin E.G. (1973), Koncepcje systemowe we współczesnej nauce, [w:] S. May (red.), Problemy metodologii badań systemowych, Wydawnictwa Naukowo-Techniczne, Warszawa.

Bobrowski F. (1905), Lexicon Latino-Polonicum. Słownik tacińsko-polski, nakładem i drukiem Józefa Zawadzkiego, Wilno.

Boder D.P. (1927), The adjective-verb-quotient: a contribution to the psychology of language, „Psychological Record", no. 3, s. 310-343.

Bogdanow A. (1968), Uniwersalna nauka o organizacji (tektologia), „Studia Ekonomiczne”, z. 20, s. $123-140$.

Bohm F., Laurell S. (2009), Rozwiq̨zywanie konfliktów. Praktyczny przewodnik dla pracodawców i menedżerów, BL Info Polska, Gdańsk.

Bolman L.G., Deal T.E. (2017), Reframing organizations: Artistry, choice, and leadership, John Wiley \& Sons, San Francisco.

Bolton S., Houlihan M. (red.) (2009), Work Matters: Critical Reflections on Contemporary Work, Palgrave, Basingstoke.

Borowiecki R., Rojek T. (red.) (2012), Współpraca międzyorganizacyjna w działalności przedsiębiorstw. Klastry-alianse - sieci, Uniwersytet Ekonomiczny w Krakowie, Fundacja UE w Krakowie, Kraków.

Boulding K. (1953), Toward a general theory of growth, „Canadian Journal of Economics and Political Science/Revue Canadienne de Economiques et Science Politique”, vol. 19(3), s. 326-340.

Boulding K. (1956), General system theory - the skeleton of science, „Management Science”, April, s. $197-208$.

Bovée C.L. Thill J.V. (2000), Business Communication Today, $6^{\text {th }}$ ed., Prentice-Hall, Upper Saddle River.

Bowles S., Kirman A., Sethi R. (2017), Retrospectives: Friedrich Hayek and the Market Algorithm, „Journal of Economic Perspectives”, vol. 31(3), s. 215-230.

Braa J., Hanseth O., Heywood A., Mohammed W., Shaw V. (2007), Developing health information systems in developing countries: The flexible standards strategy, „MIS Quarterly”, no. 31, s. 381-402.

Bradley P.H., Baird Jr J.E. (1977), Management and communicator style: A correlational analysis, „Communication Studies”, vol. 28(3), s. 194-203.

Bradshaw J. (1994), Zrozumieć rodzinę, Instytut Psychologii Zdrowia i Trzeźwości, Warszawa.

Brocklesby J., Cummings S. (1996), Foucault plays Habermas: An alternative philosophical underpinning for critical systems thinking, „Journal of the Operational Research Society”, no. 47, s. $741-754$.

Brodbeck P.W. (2002), Complexity theory and organization procedure design, „Business Process Management Journal", vol. 8(4), s. 377-402. 
Brown A., Starkey K. (1994), The effect of organizational culture on communication and information, „Journal of Management Studies”, vol. 31(6), s. 807-828.

Brown A., Charlwood A., Spencer D.A. (2012), Not all that it might seem: why job satisfaction is worth studying despite it being a poor summary measure of job quality, „Work, Employment \& Society", vol. 26(6), s. 1007-1018.

Brown A., Colville I., Pye A. (2015), Making sense of sensemaking in organization studies, „Organization Studies", vol. 36(2), s. 265-277.

Browning T.R. (2001), Applying the design structure matrix to system decomposition and integration problems: a review and new directions, „IEEE Transactions on Engineering Management", vol. 48(3), s. 292-306.

Brummans B.H.J.M., Cooren F., Robichaud D., Taylor J.R. (2014), Approaches to the communicative constitution of organizations, [w:] L.L. Putnam, D.K. Mumby (red.), Sage handbook of organizational communication, 3rd ed., Sage, Thousand Oaks. Brzeziński J. (2007), Metodologia badań psychologicznych, Wydawnictwo Naukowe PWN, Warszawa.

Bunge M. (1979), A systems concept of society: Beyond individualism and holism, „Theory and Decision", vol. 10(1-4), s. 13-30.

Bunge M. (2000), Ten modes of individualism - none of which works - and their alternatives, „Philosophy of the Social Sciences", vol. 30(3), s. 384-406.

Burgess D. (2005), What motivates employees to Transfer Knowledge Outside Their Work Unit?, „Journal of Business Communication”, no. 42, s. 324-348.

Burlita A. (2015), Zarządzanie budżetem czasu jako determinanta rozwoju kapitału ludzkiego, „Zeszyty Naukowe Uniwersytetu Szczecińskiego. Studia i Prace Wydziału Nauk Ekonomicznych i Zarządzania", nr 39, s. 25-37.

Buskens V. Snijders Ch. (2005), Effects of Network Characteristics on Reaching the Payoff-Dominant Equilibrium in Coordination Games: A Simulation Study, ISCORE paper, Utrecht University, Utrecht.

Buskens V., Corten R., Weesie J. (2008), Consent or conflict: Coevolution of coordination and networks, „Journal of Peace Research”, vol. 45(2), s. 205-222.

Butler A. (1990), A methodological approach to chaos: Are economists missing the point?, „Federal Reserve Banks of St. Louis", vol. 72(13), s. 36-48.

Cackowski Z. (1979), Człowiekjako podmiot działania praktycznego i poznawczego, Wydawnictwo Książka i Wiedza, Warszawa.

Cameron K.S., Dutton J.E., Quinn R.E., Wrzesniewski A. (2003), Developing a discipline of positive organizational scholarship, [w:] K. Cameron, J. Dutton (red.), Positive organizational scholarship: Foundations of a new discipline, Berrett-Koehler Publishers, San Francisco.

Campbell D., Fiske D. (1959), Convergent and discriminant validation by the multitrait-multimethod matrix, „Psychological Bulletin”, no. 56(2), s. 81-105.

Capps C., Hazen S.E. (2002), Applying general systems theory to the strategic scanning of the environment from 2015 to 2050, „International Journal of Management”, vol. 19(2), s. 308-314.

Carter B., Danford A., Howcroft D., Richardson H., Smith A., Taylor P. (2011), 'All they lack is a chain': lean and the new performance management in the British civil service, „New Technology, Work and Employment", vol. 26(2), s. 83-97.

Casidy R., Nyadzayo M. (2017), Drivers and outcomes of relationship quality with professional service firms: An SME owner-manager perspective, „Industrial Marketing Management”, article in press, s. 1-16.

Castells M. (1996), The network enterprise: the culture, institutions, and organizations of the informational economy, [w:] M. Castells (red.), The Rise of the Network Society, Blackwell, Oxford.

Castells M. (2007), Społeczeństwo sieci, Wydawnictwo Naukowe PWN, Warszawa. 
Castor T.R. (2005), Constructing social reality in organizational decision making: Account vocabularies in a diversity discussion, „Management Communication Quarterly”, vol. 18(4), s. 479-508.

Cavaleri S., Obloj K. (1993), Management Systems: A Global Perspective, Wadsworth, Belmont.

Cerdin J.L., Brewster C. (2018), Management of People in Mission-Driven Organizations: Current State and Future Directions, [w:] C. Brewster, J.L. Cerdin (red.), HRM in Mission Driven Organizations, Palgrave Macmillan, Cham.

Charles M. (2007), Language matters in global communication: Article based on ORA lecture, October 2006, „The Journal of Business Communication”, vol. 44(3), s. 260-282.

Checkland P. (1981), Systems Thinking, Systems Practice, John Wiley \& Sons, Chichester.

Checkland P. (1990), Systemy jako rzeczy i jako idee, [w:] W. Gasparski, D. Miller (red.), Projektowanie i systemy. Zagadnienia metodologiczne dyscyplin praktycznych, t. 12, Wydawnictwo Państwowej Akademii Nauk, Wrocław-Warszawa-Kraków-Gdańsk-Łódź.

Checkland P. (1999), Systems Thinking, Systems Practice, John Wiley \& Sons, Chichester.

Checkland P. (2000), Soft systems methodology: A thirty year retrospective, „Systems Research and Behavioral Science", no. 17, s.11-58.

Checkland P.B., Scholes P. (1990), Soft Systems Methodology in Action, John Wiley \& Sons, Chichester.

Chełpa S. (2002), Metody badań problematyki kadrowej, [w:] T. Listwan (red.), Zarzqdzanie kadrami, Wydawnictwo C.H. Beck, Warszawa.

Chen R., Liao L., Fang Z. (2012), A Virtual Organization Model Based on Semantic Web Services and Its Application in Supply Chain for Agricultural Product, Advances in Control and Communication, Springer, Berlin-Heidelberg.

Cheney G., Christensen L. (2001), Organizational Identity Linkages between Internal and External Communication, [w:] F.M. Jablin, L.L. Putnam (red.), The New Handbook of Organizational Communication, Sage, Thousand Oaks. Chikere C.C., Nwoka J. (2015), The Systems Theory of Management in Modern Day Organizations - A Study of Aldgate Congress Resort Limited Port Harcourt, „International Journal of Scientific and Research Publications”, vol. 5(9), s. 1-7.

Chisholm D. (1989), Coordination without hierarchy: Informal structures in multiorganizational systems, University of California Press, Berkeley.

Cho J. (2017), Communication Load, [w:] C. Scott, L. Lewis (red.), The International Encyclopedia of Organizational Communication, John Wiley \& Sons, New York.

Church A.H., Burke W.W. (2017), Four trends shaping the future of organizations and organization development, „OD Practitioner”, vol. 49(3), s. 14-22.

Churchmann C.W. (1968), The Systems Approach, Dell Publishing, New York.

Clampitt P.G. (2009), The questionnaire approach, [w:] O. Hargie, D. Tourish (red.), Auditing Organizational Communication, Routledge, London.

Clampitt P.G., Downs C.W. (1993), Employee perceptions of the relationship between communication and productivity: A field study, ,The Journal of Business Communication”, vol. 30(1), s. $5-28$.

Clarke B., Crossland R. (2002), The Leader's Voice: How Your Communication Can Inspire Action and Get Results!, Select Books Inc., New York.

Clarke L. (1994), The essence of change, Prentice Hall, New York.

Clawson J.G. (2001), Leading Organizational Design, Darden School of Business, University of Virginia, Virginia.

Clippinger J. III. (1999), Order from the bottom up: complex adaptive systems and their management, [w:] tenże (red.), The Biology of Business: Decoding the Natural Laws of Enterprise, Jossey Bass, San Francisco. 
Cooper R., Burrell G. (1988), Modernism, postmodernism and organizational analysis: An introduction, „Organizational Studies”, no. 9, s. 91-112.

Cooper R., John A. (1988), Coordinating coordination failures in Keynesian models, „Quarterly Journal of Economics", no. 103, s. 441-464.

Cooren F. (2004), Textual agency: How texts do things in organizational settings, „Organization”, vol. 11(3), s. 373-394.

Cooren F. (2006), The organizational world as a plenum of agencies, [w:] F. Cooren, J.R. Taylor, E.J. van Every (red.), Communication as organizing. Empirical and theoretical explorations in the dynamic of text and conversations, Lawrence Erlbaum, Mahwah.

Cooren F. (2012), Communication theory at the center: Ventriloquism and the communicative constitution of reality, „Journal of Communication”, vol. 62(1), s. 1-20.

Cooren F., Fairhurst G.T. (2008), Dislocation and stabilization: How to scale up from interactions to organization, [w:] L.L. Putnam, A.M. Nicotera (red.), Building theories of organization: the constitutive role of communication, Routledge, New York.

Cooren F., Taylor J.R. (1997), Organization as an effect of mediation: Redefining the link between organization and communication, „Communication Theory”, vol. 7(3), s. 219-260.

Cooren F., Taylor J.R., Van Every E.J. (red.) (2006), Communication as organizing: Empirical and theoretical explorations in the dynamic of text and conversations, Lawrence Erlbaum, Mahwah.

Cooren F., Kuhn T.R., Cornelissen J.P., Clark T. (2011), Communication, organizing, and organization: An overview and introduction to the special issue, „Organization Studies”, vol. 32(9), s. $1149-1170$.

Cornelissen J.P. (2004), Corporate Communication: A Guide to Theory and Practice, Sage, London.

Cornelissen J.P., Oswick C., Christensen L.T., Phillips N. (2008), Metaphor in organizational research: context, modalities and implications for research - introduction, „Organization Studies", no. 29, s. 7-22.

Cowan D. (2017), Strategic internal communication: how to build employee engagement and performance, Kogan Page Publishers, New York.

Cragan J.F., Wright D.W. (1991), Communication in small group discussions: An integrated approach, $3^{\text {rd }}$ ed., West, St. Paul. Craig R.T. (1999), Communication theory as a field, „Communication Theory", vol. 9(2), s. 119-161.

Crowston K. (1997), A Coordination Theory Approach to Organizational Process Design, „Organization Design", vol. 8(2), s. 157-175.

Cummings T.G. (1978), Self-regulating work groups: A socio-technical synthesis, „Academy of Management Review", vol. 3(3), s. 625-634.

Cummings T.G., Worley C.G. (2009), Organizational development and change, $9^{\text {th }}$ ed., Thomson Southwestern, Mason.

Cushen J., Thompson P. (2012), Doing the right thing? HRM and the angry knowledge worker, „New Technology, Work and Employment”, vol. 27(2), s. 79-92.

Cutlip S.M., Center A.H., Broom G.M. (2006), Effective public relations, $9^{\text {th }}$ ed., Pearson Prentice Hall, Upper Saddle River.

Cyfert S. (2012), Granice organizacji, Wydawnictwo Uniwersytetu Ekonomicznego w Poznaniu, Poznań.

Cyfert Sz., Krzakiewicz K. (2006), Organizacja i zarządzanie - przegląd podstawowych pojęć, [w:] K. Krzakiewicz (red.), Teoretyczne podstawy organizacji i zarządzania, Wydawnictwo Akademii Ekonomicznej w Poznaniu, Poznań.

Czakon W. (2009), Mity o badaniach jakościowych w naukach o zarządzaniu, „Przegląd Organizacji", $\mathrm{nr}$ 9, s. 13-15.

Czakon W. (2011), Paradygmat sieciowy w naukach o zarządzaniu, „Przegląd Organizacji”, nr 11, s. 5-8. 
Czakon W. (2017), Tworzenie teorii w naukach o zarządzaniu, [w:] A. Sopińska, P. Wachowiak (red.), Wyzwania wspótczesnego zarządzania strategicznego, Oficyna Wydawnicza SGH, Szkoła Główna Handlowa w Warszawie, Warszawa.

Czapla T.P. (2011), Modelowanie kompetencji pracowniczych w organizacji, Wydawnictwo Uniwersytetu Łódzkiego, Łódź.

Czarnecki J.S. (2012), Architektura korporacji. Analiza teoretyczna i metodologiczna, Wydawnictwo Uniwersytetu Łódzkiego, Łódź.

Czarniawska B. (2010), Trochę inna teoria organizacji: organizowanie jako konstrukcja sieci dziatań, Wydawnictwo Poltext, Warszawa.

Czarniawska B. (2011), Antropologia i teoria organizacji. Wczoraj i dziś, „Problemy Zarządzania”, vol. 2(32), s. 11-29.

Czekaj J. (2000), Metody zarzq̨dzania informacja w przedsiębiorstwie, Wydawnictwo Akademii Ekonomicznej w Krakowie, Kraków.

Czekaj J., Ziębicki B. (2006), Audyt komunikacyjny w organizacji, [w:] A. Stabryła (red.), Doskonalenie systemów zarządzania w społeczeństwie informacyjnym, t. 1, Wydawnictwo Akademii Ekonomicznej w Krakowie, Kraków.

Czekaj J., Ziębicki B. (2008), Metodyczne aspekty audytu systemu komunikacji w organizacji, „Zeszyty Naukowe Uniwersytetu Ekonomicznego w Krakowie", nr 775, s. 5-22.

Czekaj J., Ziębicki B. (2013), Pozytywna nauka o organizacji na tle ewolucji teorii i koncepcji zarzadzania, „Organizacja i Kierowanie”, nr 3(156), s. 45-56.

Czerniak J. (1978), Informacja i zarządzanie, Państwowe Wydawnictwo Ekonomiczne, Warszawa.

Ćwiklicki M. (2010), Koordynacja organizacji metodq Hoshin Kanri, [w:] A. Stabryła (red.), Koncepcje zarządzania wspótczesnym przedsiębiorstwem, Mfiles, Kraków.

D’Aprix R. (1996), Communicating for change: Connecting the workplace with the marketplace, Jossey-Bass, San Francisco.

D'Aprix R. (2006), Throwing rocks at the corporate rhinoceros: The challenges of employee engagement, [w:] T.L. Gillis (red.), The IABC handbook of organizational communication, Jossey-Bass, San Francisco.

Daft R.L. (2016), Organization Theory and Design, South-Western, Cengage Learning, Boston.

Dance F.E.X., Larson C.E. (1976), Communication, Holt, Rinehart and Winston, New York.

Davenport Th.H. (1993), Process Innovation: Reengineering Work through Information Technology, Harvard Business School Press, Boston.

Davis K. (1953a), Management communication and the grapevine, „Harvard Business Review”, September-October, s. 84-90.

Davis K. (1953b), A method of studying communication patterns in organizations, „Personnel Psychology", vol. 6(3), s. 301-312.

Davis K. (1969), Grapevine communication among lower and middle managers, „Personnel Journal", vol. 48(4), s. 269-272.

De Dreu C.K., Weingart L.R. (2003), Task versus relationship conflict, team performance, and team member satisfaction: a meta-analysis, „Journal of Applied Psychology”, vol. 88(4), s. 741-749.

De Roo G., Hillier J. (2016), Complexity and planning: Systems, assemblages and simulations, Routledge, London.

deCharms R. (1976), Enhancing Motivation, Irvington, New York.

deCharms R. (1983), Intrinsic Motivation, Peer Tutoring, and Cooperative Learning: Practical Maxims, [w:] J. Levine, M. Wang (red.), Teacher and Student Perceptions: Implications for Learning, Erlbaum, Hillsdale.

Deetz S.A. (2005), Critical theory, [w:] S. May, D.K. Mumby (red.), Engaging organizational communication theory and research: Multiple perspectives, Sage, Thousand Oaks. Deetz S.A., Tracey S., Simpson J. (2000), Leading organizations through transitions: Communication and 
cultural change, Sage, Thousand Oaks. Dekkers R. (2017), Applied systems theory, Springer, University of Glasgow, Glasgow.

DeMaria K. (2016), Evaluating the Internal Communications of the Triangle's 'Best Places to Work', „Elon Journal of Undergraduate Research in Communications”, vol. 7(1), s. 70-78.

Demetis D.S., Lee A.S. (2016), Crafting theory to satisfy the requirements of systems science, „Information and Organization", vol. 26(4), s. 116-126.

Demetis D.S., Lee A.S. (2017), Taking the first step with systems theorizing in information systems: A response, „Information and Organization”, vol. 27(4), s. 163-170.

Denzin N.K., Lincoln Y.S. (1994), Handbook of qualitative research, Sage Publications Inc., Thousand Oaks.

Derks D., Bakker A.B. (2010), The impact of e-mail communication on organizational life. Cyberpsychology, „Journal of Psychosocial Research on Cyberspace”, vol. 4(1), https://cyberpsychology.eu/article/view/4233/3277 (dostęp: 21.06.2018).

Derrida J. (1993), Structure, sign, and play in the discourse of the human sciences, [w:] J. Natoli, L. Hutcheon (red.), A postmodern reader, State University of New York Press, New York.

DeSanctis G. (1993), Shifting foundations in group support systems research, [w:] L. M. Jessup, J.S. Valacich (red.), Group Support Systems: New Perspectives, Macmillan, New York.

Deutsch M., Coleman P.T., Marcus E. (red.) (2014), The Handbook of Conflict Resolution: Theory and Practice, Jossey-Bass, San Francisco.

Dickson D., Rainey S., Hargie O. (2003), Communication sensitive business issues. Part 1, „Corporate Communications: An International Journal”, vol. 8(1), s. 35-43, https://doi. org/10.1108/13563280310458902.

Dille T., Söderlund J. (2011), Managing inter-institutional projects: the significance of isochronism, timing norms and temporal misfits, „International Journal of Project Management”, vol. 29(4), s. 480-490.

Dingsøyr T., Fægri T.E., Dybå T., Haugset B., Lindsjørn Y. (2016), Team performance in software development: research results versus agile principles, „IEEE Software”, vol. 33(4), s. 106-110.

Dobek-Ostrowska B. (2004), Podstawy komunikowania społecznego, Wydawnictwo Astrum, Wrocław.

Dobija M. (2014), Teoretyczne podstawy integracyjnego obszaru walutowego. Dylematy przystapienia Polski do strefy euro, „Nierówności Społeczne a Wzrost Gospodarczy”, nr 39, s. 110-133.

Doherty M. (2009), When the Working Day is Through: The End Of Work as Identity?, „Work, Employment and Society", vol. 23(1), s. 84-101.

Dorosiński W.C., Gasparski W., Wrona S. (1981), Zarys metodyki projektowania, Wydawnictwo Arkady, Warszawa.

Dunmore M. (2002), Inside-out Marketing: How to Create an Internal Marketing Strategy, Kogan Page Ltd, Londyn.

Dutta B., Jackson M.O. (2003), On the formation of networks and groups, [w:] B. Dutta, M.O. Jackson (red.), Networks and Groups. Models of Strategic Formation, Springer, Berlin-Heidelberg.

Dürig U.M., Sriramesh K. (2004), Public relations and change management: The case of a multinational company, „Journal of Communication Management”, vol. 8(4), s. 372-383.

Dwojacki P., Nogalski B. (1998), Tworzenie struktur sieciowych jako wynik restrukturyzacji scentralizowanego przedsiębiorstwa, „Przegląd Organizacji”, nr 4, s. 8-11.

Edmunds A., Morris A. (2000), The problem of information overloading business organisations: a review of the literature, „International Journal of Information Management”, no. 20, s. 17-28.

Eijnatten F.M. van (2004), Chaordic systems thinking: Some suggestions for a complexity framework to inform a learning organization, „The Learning Organization”, vol. 11(6), s. 430-449.

Eisenberg E.M., Goodall H.L. Jr (2004), Organizational Communication: Balancing Creativity and Constraint, $4^{\text {th }}$ ed., Bedford/St Martin's, Boston. 
El-Gazzar R., Hustad E., Olsen D.H. (2016), Understanding cluod computing adoption issues: A Delphi study approach, „The Journal of Systems and Software”, no. 118, s. 64-84.

Ellis C.A., Gibbs S.J., Rein G. (1991), Groupware: some issues and experiences, „Communications of the ACM", vol. 34(1), s. 39-58.

Emery F.E. (1959), Characteristics of socio-technical systems, document no. 527, Tavistock Institute of Human Relations, London.

Emery F.E. (1997), The next thirty years: Concepts, methods and anticipations, „Human Relations”, vol. 50(8), s. 885-931.

Emery M. (2000), The current version of Emery's open systems theory, „Systemic Practice and Action Research", vol. 13(5), s. 623-643.

Emery F.E., Trist E.L. (1981), Socio-technical Systems, [w:] F.E. Emery, Management Science Models and Techniques, vol. 1, Pergamon, London.

Encyklopedii organizacji i zarządzania (1981), Państwowe Wydawnictwo Ekonomiczne, Warszawa.

Encyklopedia powszechna PWN (1987), t. 1-4, Państwowe Wydawnictwo Naukowe, Warszawa.

Encyklopedia PWN (2013), http://encyklopedia.pwn.pl/haslo/3865767/addytywnosc.html (dostęp: 25.03.2016).

Enthoven A.C. (1963), Decision Theory and Systems Analysis, „The Armed Forces Comptroller”, vol. 9, no. 1, March, s. 34-44.

Eppink J. (2014), A brief history of the GIF (so far), „Journal of Visual Culture”, vol. 13(3), s. 298-306.

Ertel S. (1986), Language, thought, and culture: toward a mergence of diverging problem fields, „Advances in Psychology”, no. 39, s. 139-163.

Espejo R., Harnden R.J. (red.) (1989), The Viable System Model: Interpretations and Applications of Staford Beer's VSM, John Wiley \& Sons, Chichester.

Espejo R., Schwaninger M. (red.) (1993), Organizational Fitness: Corporate Effectiveness through Management Cybernetics, Campus Verlag, New York.

Espinosa A. (2002), Proyecto Consolidacion del Sistema de Informacion Ambiental Colombiano (SIAC), Working Paper, United Nations Development Program, United Nations, Bogota.

Fayol H. (1947), Administracja przemysłowa i ogólna oraz nauka o administracji w zastosowaniu do państwa, WINOiK, Księgarnia Wt. Wilak, Poznań.

Feely A.J., Harzing A.W. (2003), Language management in multinational companies, „Cross Cultural Management: An International Journal”, vol. 10(2), s. 37-52.

Felstead A., Gallie D., Green F., Inanc H. (2013), Work Intensification in Britain: First Findings from the Skills and Employment Survey 2012, Centre for Learning and Life Chances in Knowledge Economies and Societies, Institute of Education, London.

Fiedler F.E. (1965), Engineer the job to fit the manager, „Harvard Business Review”, SeptemberOctober, vol. 43, no. 5, s. 115-122.

Fiedler F.E., Chemers M.M. (1974), Leadership and effective management, Scott, Foresman, Glenview.

Field J. (2005), Psycholinguistics: The Key Concepts, Taylor and Francis, New York.

Findeisen W., Quade E.S. (1985), Metodologia analizy systemowej, [w:] W. Findeisen (red.), Analiza systemowa - podstawy i metodologia, Państwowe Wydawnictwo Naukowe, Warszawa.

Fioretti G., Visser B. (2004), A cognitive interpretation of organizational complexity, „Emergence: Complexity \& Organizations", Special Double Issue 6(1-2), s. 11-23.

Fioretti G., Visser B. (2006), A cognitive approach to organizational complexity, [w:] G. Minati, E. Pessa, M. Abram (red.), Systemics of emergence: research and development, Springer, Boston.

Fiske J. (2003), Wprowadzenie do badań nad komunikowaniem, Wydawnictwo Astrum, Warszawa. Fisher B.A. (1978), Perspectives on Human Communication, Macmillan, New York.

Fitz-enz J. (1990), Human value management: The value adding human resources management strategy for the 1990, Jossey-Bass, San Francisco. 
Flap H. (2004), Creation and Returns of Social Capital: A New Research Program, [w:] H. Flap, B. Völker (red.), Creation and Returns of Social Capital: A New Research Program, Routledge, London.

Flood R.L., Jackson M.C. (1991), Creative Problem Solving: Total Systems Intervention, John Wiley \& Sons, Chichester.

Ford M.E. (1992), Motivating humans: Goals, emotions, and personal agency beliefs, Sage, Newbury Park-London.

Foreman J., Argenti P.A. (2005), How corporate communication influences strategy implementation, reputation and the corporate brand: an exploratory qualitative study, "Corporate Reputation Review", vol. 8(3), s. 245-264.

Forrester J.W. (1958), Industrial dynamics: A major breakthrough for decision makers, „Harvard Business Review", no. 36, s. 37-48.

Forrester J.W. (1961), Industrial Dynamics, Productivity Press, Portland.

Forrester J.W. (1968), Industrial dynamics - After the first decade, „Manager Science”, no. 14, s. 398-415.

Forrester J.W. (1971), World Dynamics, Productivity Press, Portland.

Forrester J.W. (1993), System Dynamics and the Lessons of 35 Years, [w:] K. B. De Greene, The Systemic Basis of Policy Making in the 1990s, Springer, Boston.

Forrester J.W. (1994), System dynamics, systems thinking, and soft OR, „System Dynamics Review", vol. 10(2-3), s. 245-256.

Forrester J.W. (2007), System dynamics - A personal view of the first fifty years, „System Dynamic Review", vol. 23(2/3), s. 345-358.

Fortuin L., Beek P. van, Wassenhove L. van (red.) (1996), OR at Work, Taylor \& Francis, London.

Foucault M. (2002), Archeologia wiedzy, Wydawnictwo De Agostini Polska, Warszawa.

Foucault M. (2009), Nadzorować i karać, Wydawnictwo Aletheia, Warszawa.

Fredriksson R., Barner-Rasmussen W., Piekkari R. (2006), The multinational corporation as a multilingual organization: The notion of common corporate language, „Corporate Communications: An International Journal", vol. 11(4), s. 406-423.

Fried Y., Slowik L.H. (2004), Enriching Goal Setting Theory with Time: An Integrated Approach, „Academy of Management Review”, no. 29, s. 404-422.

Frontczak A., Struktura sieci społecznych, www.if.pw.edu.pl/ agatka/moodle/spoleczne.html (dostęp: 4.07.2018).

Fuks K., Kawa A., Pierański B. (2014), Zastosowanie mierników SNA w analizie sieci przedsiębiorstw, „Marketing i Rynek”, nr 5, s. 47-53.

Fuller L.L. (1969), The Morality of Law, Yale University Press, Revised Edition.

Furmanek W. (2017), Konsekwencje metodologiczne ujmowania pracy jako wartości, „Annales Universitatis Mariae Curie-Skłodowska. Sectio J - Paedagogia-Psychologia”, vol. 29(4), s. 23-42.

Galbraith J.R. (1974), Organization design: An information processing view, „Interfaces”, vol. 4(3), S. $28-36$.

Gallie D., Felstead A., Inanc H. (2016), The hidden face of job insecurity, „Work, Employment and Society", vol. 31(1), s. 36-53.

Galton F. (1883/2004), Inquires into human faculty and its development, http://www.galton.org/ books/human-faculty/text/galton-1883-human-faculty-v4.pdf (dostęp: 28.10.2016).

Gare A. (2000), Systems Theory and Compexity, „Editorial of Special Edition of Democracy and Nature", vol. 6(3), s. 327-339.

Gasparski W. (1978), Projektowanie. Koncepcyjne przygotowanie działań, Państwowe Wydawnictwo Naukowe - Polska Akademia Nauk, Warszawa.

Gasparski W. (1988), Projektoznawstwo. Elementy wiedzy o projektowaniu, Wydawnictwo Naukowo-Techniczne, Warszawa. 
Gasparski W., Kieżun W. (1973), O niektórych wspólnych zagadnieniach metodologicznych teorii organizacji i zarządzania oraz teorii systemów technicznych i ich sterowania, „Prakseologia", nr 2, s. 163-174.

Gasparski W., Lewicka A. (1973), Problematyka badań systemowych - próba charakterystyki, „Prakseologia”, nr 2, s. 5-21.

Gasparski W., Miller D. (1990), Projektowanie i systemy. Zagadnienia metodologiczne, t. 12, Ossolineum, Wrocław-Warszawa-Kraków-Gdańsk-Łódź.

Gersick C.J. (1988), Time and transition in work teams: Toward a new model of group development, „Academy of Management Journal”, vol. 31(1), s. 9-41.

Ghoshal S., Bartlett C.A. (1990), The multinational corporation as an interorganizational network, „Academy of Management Review”, vol. 15(4), s. 603-626.

Ghoshal S., Korine H., Szulanski G. (1994), Interunit communication in multinational corporations, „Management Science”, vol. 40(1), s. 96-110.

Gibson D.E., Callister R.R. (2010), Anger in organizations: review and integration, „Journal of Management", no. 36, s. 66-93.

Giddens A. (1984), The constitution of society: Outline of the theory of structuration, University of California Press, Berkeley.

Giddens A. (2003), Stanowienie społeczeństwa. Zarys teorii strukturacji, Zysk i S-ka, Poznań.

Giganci biznesu (2007), Biblioteka Gazety Wyborczej, Biznes, t. 8, Wydawnictwo Naukowe PWN, Warszawa.

Gilin-Oore D., Leiter M.P., LeBlanc D.E. (2015), Individual and organizational factors promoting successful responses to workplace conflict, „Canadian Psychology/Psychologie Canadienne", vol. 56(3), s. 301-310.

Gist M.E. (1987), Self-efficacy: Implications for organizational behavior and human resource management, „Academy of Management Review”, vol. 12(3), s. 472-485.

Gleick J. (1987), Chaos: The Making of a New Science, Abacus, London.

Gleick J. (2003), Szybciej. Przyspieszenie niemal wszystkiego, Wydawnictwo Zysk i S-ka, Poznań.

Goban-Klas T. (1999), Media i komunikowanie masowe. Teorie i analizy prasy, radia, telewizji i Internetu, Wydawnictwo Naukowe PWN, Warszawa-Kraków.

Goldhaber G. (1993), Organizational Communication, Brown \& Benchman, Madison.

Goodhart Ch. (1984), Problems of Monetary Management: The UK Experience, Palgrave, London. Goyal S., Vega-Redondo F. (2005), Network Formation and Social Coordination, „Games and Economic Behavior", vol. 50(2), s. 178-207.

Graham S. (1991), A Review of Attribution Theory in Achievement Contexts, „Educational Psychology Review", vol. 3(1), s. 5-39.

Grazzi M., Jung J. (2016), Information and Communication technologies, Innovation, and productivity: evidence from Firms in Latin America and the Caribbean, [w:] M. Grazzi, C. Pietrobelli (red.), Firm Innovation and Productivity in Latin America and the Caribbean, Palgrave Macmillan, New York.

Greenhaus J.H., Powell G.N. (2006), When work and family allies: A theory of work-family enrichment, „Academy of Management Review”, no. 31, s. 72-92.

Griffin E. (2003), Podstawy komunikacji społecznej, Gdańskie Wydawnictwo Psychologiczne, Gdańsk.

Griffin R.W. (2002), Podstawy zarzq̨dzania organizacjami, Wydawnictwo Naukowe PWN, Warszawa.

Groddeck V. von (2011), Rethinking the Role of Value Communication in Business Corporations from a Sociological Perspective - Why Organisations Need Value-Based Semantics to Cope with Societal and Organisational Fuzziness, „Journal of Business Ethics”, no. 100, s. 69-84.

Gronbeck B.E., German K., Ehninger D., Monroe A.H. (2001), Zasady komunikacji werbalnej, Wydawnictwo Zysk i S-ka, Poznań. 
Gronn P. C. (1983), Talk as the work: The accomplishment of school administration, „Administrative Science Quarterly", vol. 28, no. 1, s. 1-21.

Gros U. (1993), Analiza systemu porozumiewania się w organizacji, „Przegląd Organizacji”, nr 3, s. $11-12$.

Gros U. (1994), Organizacyjne aspekty zachowania się ludzi w procesach pracy, „Prace Naukowe Akademii Ekonomicznej w Katowicach", nr 131.

Gros U. (2003), Zachowania organizacyjne w teorii i praktyce zarzadzania, Wydawnictwo Naukowe PWN, Warszawa.

Grunig J.E. (1978), Defining publics in public relations: The case of a suburban hospital, „Journalism Quarterly", vol. 55(1), s. 109-124.

Grunig J.E. (1992), Symmetrical system of internal communication, [w:] tenże (red.), Excellence in public relations and communication management, Lawrence Erlbaum Associates, Hillsdale.

Grunig J.E., Hunt T. (1984), Managing Public Relations, Harcourt Brace Jovanovich College Publishers, New York.

Grzesiuk L. (1979), Style komunikacji interpersonalnej, Wydawnictwo Uniwersytetu Warszawskiego, Warszawa.

Grzesiuk L. (red.) (1988), Zaburzenia komunikowania się neurotyków. Osobowościowe wyznaczniki nerwicy i psychoterapia, Wydawnictwo Uniwersytetu Warszawskiego, Warszawa.

Grzesiuk L., Korpolewska K. (1988), Zaburzenia komunikowania się neurotyków, ich poznawcze uwarunkowania i psychoterapia, [w:] L. Grzesiuk (red.), Zaburzenia komunikowania się neurotyków. Osobowościowe wyznaczniki nerwicy i psychoterapia, Wydawnictwo Uniwersytetu Warszawskiego, Warszawa.

Grzesiuk L., Trzebińska E. (1978), Jak ludzie porozumiewają się, Instytut Wydawniczy „Nasza Księgarnia", Warszawa.

Gummesson G. (2002), Internal marketing in the light of relationship marketing and network organizations, [w:] R.J. Varey, B.R. Lewis (red.), Internal marketing: Directions for management, Routledge, London-New York.

Guzicki W., Zakrzewski P. (2007), Wykłady ze wstępu do matematyki. Wprowadzenie do teorii mnogości, Wydawnictwo Naukowe PWN, Warszawa.

Haas J.W. (2007), A Communication Meta-myth Revisited: Is More Communication in the Workplace Better?, International Communication Association, San Francisco.

Habr J., Veprek J. (1976), Systemowa analiza i synteza. Nowoczesne podejście do zarządzania i podejmowania decyzji, Państwowe Wydawnictwo Ekonomiczne, Warszawa.

Haeckel E. (1904), Wonders of Life: A Popular Study of Biological Philosophy, Harper \& Brothers, London.

Hall A.D. (1968), Podstawy techniki systemów (Ogólne zasady projektowania), Państwowe Wydawnictwo Naukowe, Warszawa.

Hall C.S., Lindzey G. (1998), Teorie osobowości, Wydawnictwo Naukowe PWN, Warszawa.

Hall J.A., Roter D.L., Rand C.S. (1981), Communication of affect between patient and physician, „Journal of Health and Social Behavior”, vol. 22(1), s. 18-30.

Hammer M., Champy J. (1996), Reengineering w przedsiębiorstwie, Neuman Management Institute, Warszawa.

Hammond D. (2010), The Science of Synthesis: Exploring the Social Implications of General Systems Theory, University Press of Colorado, Boulder.

Hargie O.D., Tourish D. (1993), Assessing the effectiveness of communication in organisations: the communication audit approach, „Health Services Management Research”, vol. 6(4), S. $276-285$.

Harris T.E., Nelson M.D. (2008), Applied organizational communication: Theory and practice in a global environment, Lawrence Erlbaum, New York. 
Harris T.E., Sherblom J.C. (2005), Small group and team communication, $3^{\text {rd }}$ ed., Allyn \& Bacon, Boston.

Hartano E., Li X., Na K.-S., Simpson J.T. (2010), The role of the quality of shared information in interorganizational system use, „International Journal of Information Management”, vol. 30, s. 399-407.

Hawkins J.L., Weisberg C., Ray D.W. (1980), Spouse differences in communication style: Preference, perception, behavior, „Journal of Marriage and Family”, vol. 42(3), s. 585-593.

Henley A.Z., Muçlu K., Christakis M., Fleming S. D., Bird C. (2018), CFar: A Tool to Increase Communication, Productivity, and Review Quality in Collaborative Code Reviews, [w:] Proceedings of the 2018 CHI Conference on Human Factors in Computing Systems, ACM, Montreal. Herbsleb J. (2016), Building a socio-technical theory of coordination: why and how (outstanding research award), [w:] Proceedings of the 201624th ACM SIGSOFT International Symposium on Foundations of Software Engineering, November, ACM, Seattle.

Herbst Ph.G. (1974), Socio-technical design, Tavistock Institute of Human Relations, London.

Hernes T., Bakken T. (2003), Implications of self-reference: Niklas Luhmann's autopoiesis and organization theory, „Organization Studies”, vol. 24(9), s. 1511-1535.

Heron A.R. (1942), Sharing information with employees, Stanford University Press, Stanford.

Hersey P., Blanchard K.H., Johnson D.E. (2007), Management of organizational behavior, vol. 9, Prentice Hall, Upper Saddle River.

Herzberg F.I. (1982), The managerial choice: To be efficient and to be human, $2^{\text {nd }}$ ed., Olympus, Salt Lake City.

Hitch C. (1955), An appreciation of systems analysis, „Journal of the Operations Research Society of America", vol. 3(4), s. 466-481.

Hochschild A. (1997), The time bind: When work becomes home and home becomes work, Horton Metropolitan Books, New York.

Hogan R., Hogan J. (2001), Assessing leadership: A view from the dark side, „International Journal of Selection and Assessment", vol. 9(1-2), s. 40-51.

Honeycutt J.M., Wilson C., Parker C. (1982), Effects of sex and degrees of happiness on perceived styles of communicating in and out of the marital relationship, „Journal of Marriage and the Family", vol. 44, no. 2, s. 395-406.

Hopej M. (1994), Dokonywanie zmian w strukturze organizacyjnej, Wydawnictwo Politechniki Wroctawskiej, Wroctaw.

Hopej M. (2017), Kształtowanie struktur organizacyjnych zgodnie z zasada prostoty, „Zeszyty Naukowe. Organizacja i Zarządzanie/Politechnika Śląska”, z. 102, s. 99-109.

Hornowska E. (2009), Testy psychologiczne. Teoria i praktyka, Wydawnictwo Naukowe Scholar, Warszawa.

Hornowska E., Brzezińska A.I., Kaliszewska-Czeremska K., Appelt K., Rawecka J., Bujacz A. (2012), Paradoksalny efekt triangulacji, „Edukacja”, vol. 120(4), s. 72-83.

Hovorka D., Larsen K. (2017), Modes of theory integration, Proceedings of the $50^{\text {th }}$ Hawaii International Conference on System Sciences, Hawaii.

Howison J., Crowston K. (2014), Collaboration Through Open Superposition: A Theory of the Open Source Way, „MIS Quarterly”, vol. 38(1), s. 29-50.

Hsiao J.P.H., Jaw C., Huan T. C., Woodside A.G. (2015), Applying complexity theory to solve hospitality contrarian case conundrums: Illuminating happy-low and unhappy-high performing frontline service employees, „International Journal of Contemporary Hospitality Management", vol. 27(4), s. 608-647.

Husserl E. (1964), The idea of phenomenology, transl. W.P. Alston, G. Nakhnikian, Martinus-Nijhoff, The Hague. 
Ihlen Ø.V., Van Ruler B. (2009), Introduction: Applying social theory to public relations, [w:] Ø. Ihlen, B. van Ruler, M. Fredriksson (red.), Public Relations and Social Theory: Key Figures and Concepts, Routledge, New York.

Infante D.A., Gorden W.I. (1991), How employees see the boss: Test of an argumentativeness and affirming model of supervisors' communicative behavior, „Western Journal of Speech Communication", no. 55, s. 294-304

Ingarden R. (1960, 1961), Spór o istnienie świata, t. 1-2, Państwowe Wydawnictwo Naukowe, Warszawa.

Ioannides Y.M. (2012), Complexity and organizational architecture, „Mathematical Social Sciences", vol. 64(2), s. 93-202.

ISO 9000: 2000 PN-EN ISO 9000, Systemy zarządzania jakością - podstawy i terminologia (2002), PKN, Warszawa.

Jablin F.M. (2004), Organizational entry, assimilation, and disengagement/exit, [w:] F.M. Jablin, L.L. Putnam (red.), The new handbook of organizational communication, Sage Publications Inc., Thousand Oaks. Jabłonowska L. (2012), Style komunikacyjne w budowaniu zaufania w organizacji, „Studia i Prace Kolegium Zarządzania. Zeszyty Naukowe SGH w Warszawie”, nr 116, s. 70-80.

Jackson M. (1991), The origins and nature of critical systems thinking, „Systems Practice”, no. 4, s. $131-149$.

Jackson M. (2000), Systems Approaches to Management, Kluwer/Plenum, New York.

Jackson M. (2003), Systems Thinking: Creative Holism for Managers, John Wiley \& Sons Ltd, Chichester.

Jackson M., Keys P. (1984), Towards a system of systems methodologies, „Journal of the Operational Research Society", vol. 35(6), s. 473-486.

Jackson M., Watts A. (2002), On the Formation of Interaction Networks in Social Coordination Games, „Games and Economic Behavior”, vol. 41(2), s. 265-291.

Janicik G.A., Bartel C.A. (2003), Talking about time: effects of temporal planning and time awareness norms on group coordination and performance, „Group Dynamics: Theory, Research Practice", vol. 7(2), s. 122-134.

Jarzębowski W. (1981), Koordynacja, [w:] Encyklopedia organizacji i zarządzania, Państwowe Wydawnictwo Ekonomiczne, Warszawa.

Jastrzębowski W. (1997), Rys ergonomii, czyli nauki o pracy, opartej na prawach zaczerpniętych z nauki przyrody, CIOP, Warszawa.

Jefkins F. (1988), Public Relations Techniques, Heinemann Professional Publishing, London.

Jemielniak D., Latusek D. (2005), Zarzadzanie: teoria i praktyka od podstaw. Ćwiczenia, Wydawnictwo WSPiZ, Warszawa.

Jessop B. (2007), Promowanie dobrego rządzenia i ukrywanie jego słabości: refleksja nad politycznymi paradygmatami i politycznymi narracjami, „Zarządzanie Publiczne”, vol. 2(2), s. 5-25.

Jędrych E. (2016), Zarządzanie wiedzą pracowników 65 plus w organizacji, „Zeszyty Naukowe Uczelni Vistula”, vol. 46(1), „Ekonomia X”, s. 12-27.

Jo S., Shim S.W. (2005), Paradigm Shift of Employee Communication: The Effect of Management Communication on Trusting Relationship, „Public Relations Review”, vol. 31(2), s. 277-280.

Johnson R.A., Kast F.E., Rosenzweig J.E. (1967), The Theory and Management of Systems, $2^{\text {nd }}$ edition, McGraw-Hill Book Company, New York.

Jones E., Watson B., Gardner J., Gallois C. (2004), Organizational communication: Challenges for the new century, „Journal of Communication”, vol. 54(4), s. 722-750.

Jones M.R., Karsten H. (2008), Giddens's structuration theory and information systems research, „MIS Quarterly”, no. 32, s. 127-157. 
Jørgensen L., Jordan S., Mitterhofer H. (2012), Sensemaking and discourse analyses in inter-organizational research: A review and suggested advances, „Scandinavian Journal of Management", vol. 28(2), s. 107-120.

Jougan A. (1958), Stownik kościelny łacińsko-polski, Księgarnia Św. Wojciecha, Poznań.

Jowett G., O’Donnell V. (1989), Propaganda and Persuasion, Stage, Beverly Hills.

Kalla H.K. (2005), Integrated internal communications: a multidisciplinary perspective, „Corporate Communications: An International Journal”, vol. 10(4), s. 302-314.

Kałuski J. (2012), Logika podejmowania decyzji (podejmowanie decyzji w aspektach logiki klasycznej i logiki kwantowej), „Zeszyty Naukowe Politechniki Śląskiej”, seria „Organizacja i Zarządzanie", nr 1873, s. 191-219.

Kanfer R. (1990), Motivation Theory and Industrial Organizational Psychology, [w:] M.D. Dunnette, L.M. Hough (red.), Handbook of Industrial and Organizational Psychology, Consulting Psychologists Press, Palo Alto.

Kant E. (1957), Krytyka czystego rozumu, t. 1, Państwowe Wydawnictwo Naukowe, Warszawa.

Kanter R.M., Stein B.A., Jick T. D. (1992), The challenge of organizational change: How companies experience it and leaders guide it, The Free Press, New York.

Kaplan R., Norton D. (2001), Strategiczna karta wyników - jak przełożyć strategię na działanie, Wydawnictwo Naukowe PWN, Warszawa.

Kast F.E., Rosenzweig J.E. (1972), General systems theory: Applications for organization and management, „Academy of Management Journal”, vol. 15(4), s. 447-465.

Kast F.E., Rosenzweig J.E. (1973), Contingency Views of organization and Management, Science Research Associates Inc., Chicago.

Katz D., Kahn R.L. (1979), Społeczna psychologia organizacji, Państwowe Wydawnictwo Naukowe, Warszawa.

Kauffman S. (1995), At Home in the Universe, Oxford University Press, New York.

Kawa A. (2013), Analiza sieci przedsiębiorstw z wykorzystaniem metody SNA, „Przedsiębiorczość i Zarządzanie", nr 14(13), cz. 1: Zarządzanie organizacjami sieciowymi, s. 77-87.

Kawa A. (2014), Analiza sieciowa jako metoda badawcza w naukach o zarzadzaniu, „Prace Naukowe Uniwersytetu Ekonomicznego we Wrocławiu", nr 356, s. 40-49.

Kelliher C., Anderson D. (2008), For better or for worse? Analysis of how flexible working practices influence employees perceptions of job quality, „The International Journal of Human Resource Management", no. 19, s. 419-431.

Kempisty M. (red.) (1973), Mały słownik cybernetyczny, Wiedza Powszechna, Warszawa.

Kennan W.R., Hazleton V. (2006), Internal public relations, social capital, and the role of effective organizational communication, [w:] C.H. Botan, V. Hazleton (red.), Public relations theory II, Lawrence Erlbaum, Mahwah.

Keys P. (1991), Operational Research and Systems: The Systemic Nature of Operational Research, Plenum, New York.

Khoshafian S., Buckiewicz M. (1995), Introduction to Groupware, Work-flow, and Workgroup Computing, Wiley, New York.

Kisielnicki J. (1986), Metody systemowe, Państwowe Wydawnictwo Ekonomiczne, Warszawa.

Kisielnicki J. (2001), Zarządzanie organizacją. Zarządzanie nie musi być trudne, Oficyna Wydawnicza Wyższej Szkoły Handlu i Prawa im. Ryszarda Łazarskiego, Warszawa.

Kitchen P.J. (1997), Public Relations: Principles and Practice, International Thomson Business Press, London.

Kitchen P.J., Daly F. (2002), Internal communication during change management, „Corporate Communications: an International Journal", vol. 7(1), s. 46-53.

Klir G.J. (1981), Podstawy pojęciowe do rozwiqzzywania problemów systemowych, [w:] W. Gasparski, D. Miller, Nauka, technika, systemy, Ossolineum PAN, Wrocław-Warszawa-KrakówGdańsk-Łódź. 
Klir G.J. (red.) (1976), Ogólna teoria systemów, Wydawnictwa Naukowo-Techniczne, Warszawa.

Knapp M.L., Hall J.A. (2000), Komunikacja niewerbalna w interakcjach międzyludzkich, Wydawnictwo Astrum, Wrocław.

Koffka K. (1935/2013), Principles of Gestalt psychology, vol. 44, Routledge, Oxon.

Kolman R. (1992), Inżynieria jakości, Państwowe Wydawnictwo Ekonomiczne, Warszawa.

Kołodziejczak M. (2016), Organizacje w Polsce, [w:] K. Januszkiewicz i in., Wielowymiarowa Analiza Zachowań Organizacyjnych (WAZO) w polskich przedsiębiorstwach, Wydawnictwo Uniwersytetu Łódzkiego, Łódź.

Kołodziejczak M., Zalewska M. (2006), Komunikowanie się w organizacjach sieciowych. Wybrane aspekty, [w:] M. Lisiecki (red.), Organizacje przedsiębiorstwa i rynki kapitałowe w otoczeniu globalnym, t. 7, Wydawnictwo KUL, Lublin, s. 27-36.

Komunikacja wewnętrzna, http://www.episteme.com.pl/uslugi/media-i-komunikacja/komunikacja-wewnetrzna (dostęp: 21.06.2018).

Konchitchki Y., Luo Y., Ma M.L., Wu F. (2016), Accounting-based downside risk, cost of capital, and the macroeconomy, „Review of Accounting Studies”, vol. 21(1), s. 1-36.

Konecki K. (2000), Studia z metodologii badań jakościowych. Teoria ugruntowana, Wydawnictwo Naukowe PWN, Warszawa.

Koontz H., O’Donnell C. (1969), Zasady zarzq̨dzania. Analiza funkcji kierowniczych, Państwowe Wydawnictwo Naukowe, Warszawa.

Kopczyński J., Siciński A. (red.) (1990), Człowiek-środowisko-zdrowie, Wydawnictwo PAN, Wroctaw-Warszawa-Kraków.

Kotarbiński T. (1955, 1969, 1982), Traktat o dobrej robocie, Zakład Narodowy im. Ossolińskich, Wrocław-Warszawa-Kraków-Gdańsk.

Kotarbiński T. (1961), Elementy teorii poznania, logiki formalnej i metodologii nauk, wydanie II, Zakład Narodowy im. Ossolińskich, Wrocław-Warszawa-Kraków.

Kotarbiński T. (1966), Sprawność i błąd (Z myślą o dobrej robocie nauczyciela), PZWS, Warszawa.

Kotarbiński T. (1968), Tektologia A. Bogdanowa, „Studia Ekonomiczne”, z. 20, s. 141-145.

Kotarbiński T. (1999), Prakseologia, t. 1, Zakład Narodowy im. Ossolińskich, Wrocław-Warszawa.

Kotey B., Meredith G.G. (1997), Relationships among owner/manager personal values, business strategies, and enterprise performance, „Journal of Small Business Management”, vol. 35(2), s. 37-64.

Kowalewski S. (1982), Przełożony - podwładny w świetle teorii organizacji, Państwowe Wydawnictwo Ekonomiczne, Warszawa.

Kozielecki J. (1970), Konflikt, teoria gier i psychologia, Państwowe Wydawnictwo Naukowe, Warszawa.

Kozyra B. (2008), Komunikowanie bez barier, Wydawnictwo MT Biznes, Warszawa.

Koźmiński A.K. (1979), Analiza systemowa organizacji, Państwowe Wydawnictwo Ekonomiczne, Warszawa.

Koźmiński A.K. (1984), Przedmowa do wydania polskiego, [w:] L. von Bertalanffy, Ogólna teoria systemów. Podstawy, rozwój, zastosowania, tłum. E. Woydyłto-Woźniak, Państwowe Wydawnictwo Naukowe, Warszawa.

Koźmiński A.K. (1987), Wspótczesne koncepcje zarządzania, Państwowe Wydawnictwo Naukowe, Warszawa.

Koźmiński A.K. (red.) (1983), Współczesne teorie organizacji, Państwowe Wydawnictwo Naukowe, Warszawa.

Koźmiński A.K., Latusek-Jurczak D. (2011), Rozwój teorii organizacji, Wolters Kluwer Polska, Warszawa.

Koźmiński A.K., Zawiślak A. (1982), Pewność i gra: wstęp do teorii zachowań organizacyjnych, Państwowe Wydawnictwo Ekonomiczne, Warszawa. 
Kraut R.E. (2016), The Relationship between Facebook Use and Well-Being Depends on Communication Type and Tie Strength, „Journal of Computer-Mediated Communication”, vol. 21(4), S. $265-281$.

Kreps G.L. (1989), Reflexivity and internal public relations: The role of information in directing organizational development, [w:] C.H. Botan, V. Hazleton Jr, Public relations theory, Lawrence Erlbaum, Hillsdale.

Krishnamurthy S. (2002), Cave or community: An empirical examination of 100 mature Open Source projects, „First Monday”, vol. 7(6), http://firstmonday.org/issues/issue7_6/krishnamurthy/ index.html (dostęp: 25.03.2016).

Krone K.J., Jablin F.M., Putnam L.L. (1987), Communication theory and organizational communication: Multiple perspectives, [w:] F.M. Jablin, L.L. Putnam, K.H. Roberts, L.W. Porter (red.), Handbook of organizational communication: An interdisciplinary perspective, Sage, Newbury Park.

Krugman P. (1979), A model of innovation, technology transfer, and the world distribution of income, „The Journal of Political Economy”, vol. 87(2), s. 253-266.

Krupski R. (red.) (2005), Zarzq̨dzanie przedsiębiorstwem w turbulentnym otoczeniu, Polskie Wydawnictwo Ekonomiczne, Warszawa.

Krzakiewicz K. (2013), Zastosowanie podejścia sieciowego w zarzq̨dzaniu strategicznym, „Organizacja i Zarządzanie", no. 109, s. 109-117.

Krzeszowski T.P. (2010), Wstęp do wydania polskiego, [w:] G. Lakoff, M. Johnson, Metafory w naszym życiu, Wydawnictwo Aletheia, Warszawa.

Krzyżanowski L.J. (1999), O podstawach kierowania organizacjami inaczej: Paradygmaty, modele, metafory, filozofia, metodologia, dylematy, trendy, Wydawnictwo Naukowe PWN, Warszawa.

Kubik K. (2012), Profesjonalizm menedżera determinantą sukcesu organizacji, „Zeszyty Naukowe Uniwersytetu Przyrodniczo-Humanistycznego w Siedlcach”, nr 93, seria: „Administracja i Zarządzanie", s. 21-33.

Kuc B.R., Moczydłowska J. (2009), Zachowania organizacyjne: podręcznik akademicki, Wydawnictwo Difin, Warszawa.

Kuhn H. (1962), Ordnung im Werden und Zerfall, [w:] H. Kuhn, F. Wiedmann (red.), Das Problem der Ordnung, Meisenheim am Glan.

Kuhn T. (2008), A communicative theory of the firm: Developing an alternative perspective on intra-organizational power and stakeholder relationships, „Organization Studies”, vol. 29(89), S. $1227-1254$.

Kulczycki E. (2011), Kulturowo-obiektywne istnienie procesu komunikacji jako warunek projektowania autonomicznej dyscypliny komunikacji, https://repozytorium.amu.edu.pl/bitstream/10593/1449/1/Kulturowo-obiektywne_istnienie_procesu_komunikacji_jako_warunek_projektowania_autonomicznej_dyscypli.pdf (dostęp: 15.12.2018).

Kuratowski K., Mostowski A. (1978), Teoria mnogości wraz ze wstępem do opisowej teorii mnogości, seria „Monografie Matematyczne”, t. 27, Państwowe Wydawnictwo Naukowe, Warszawa.

Kurnal J. (1970), Zarys teorii organizacji i zarządzania, Państwowe Wydawnictwo Ekonomiczne, Warszawa.

Lachotzki F., Noteboom R. (2005), Beyond control: Managing strategic Alignment through corporate dialogue, John Wiley \& Sons, Chichester.

Laeven L., Levine R., Michalopoulos S. (2015), Financial innovation and endogenous growth, „Journal of Financial Intermediation", vol. 24(1), s. 1-24.

Lakoff G. (2014), The All New Don't Think of an Elephant!: Know Your Values and Frame the Debate, Chelsea Green Publishing, Vermont.

Lakoff G., Johnson M. (2010), Metafory w naszym życiu, Wydawnictwo Aletheia, Warszawa.

Laloux F. (2015), Pracować inaczej, Studio Emka, Warszawa. 
Lamoreaux N., Raff D. (1995), Coordination and information: Historical perspective on the organization of enterprise, University of Chicago Press, Chicago.

Langton C.G. (1990), Computation at the edge of chaos: phase transitions and emergent computation, „Physica D: Nonlinear Phenomena”, vol. 42(1-3), s. 12-37.

Larkin T.J., Larkin S. (1996), Reaching and changing frontline employees, „Harvard Business Review", vol. 74(3), s. 95-104.

Lasswell H. (1948), The Structure and Function of Communication in Society, [w:] tenże, The Communication of Ideas, Institute for Religious Studies, New York.

Laszlo E. (1978), Systemowa wizja świata, Państwowy Instytut Wydawniczy, Warszawa.

Latham G.P. (2000), Motivate Employee Performance through Goal-Setting, [w:] E.A. Locke (red.), Handbook of Principles of Organizational Behavior, Blackwell, Malden.

Latour B. (1994), On technical mediation: Philosophy, sociology, genealogy, „Common Knowledge”, vol. 3(2), s. 29-64.

Le Chatelier H. (1926), Filozofja systemu Taylora, Nakładem Instytutu Naukowej Organizacji przy Muzeum Przemysłu i Rolnictwa, Warszawa.

Leary T. (1957), Interpersonal Diagnosis of Personality, Ronald New, York.

Leavitt H.J. (1965/2013), Applied organizational change in industry: structural, technical and humanistic approaches, [w:] J.G. March (red.), Handbook of Organizations, Rand McNally \& Company/Routledge, London.

Lengel R.H., Daft R.L. (1984), An exploratory analysis of the relationship between media richness and managerial information processing, no. TR-DG-08-ONR, Texas A\&M University, College Station Deptartment of Management, Texas.

Leonardi P.M. (2013), Theoretical foundations for the study of sociomateriality, „Information and Organization", no. 23, s. 59-76.

LeRoy S.F., Sonstelie J. (1983), Paradise lost and regained: Transportation innovation, income, and residential location, „Journal of Urban Economics”, vol. 13(1), s. 67-89.

Lewin K. (1945), The research center for group dynamics at Massachusetts Institute of Technology, „Sociometry”, vol. 8(2), s. 126-136.

Liao S., Cheng C.C. (2014), Brand equity and the exacerbating factors of product innovation failure evaluations: A communication effect perspective, „Journal of Business Research”, vol. 67(1), s. 2919-2925.

Lieberman M.A., Yalom I.D., Miles M.B. (1973), Encounter groups: First facts, Basic Books, New York.

Likely F. (2008), Securing the function the greatest protection, „Strategic Communication Management", vol. 12(3), s. 15.

Likert R. (1979), From production-and employee-centeredness to systems 1-4, „Journal of Management", vol. 5(2), s. 147-156.

Lim S.G.S., Murnighan J.K. (1994), Phases, deadlines, and the bargaining process, „Organizational Behavior and Human Decision Processes", vol. 58(2), s. 153-171.

Lingard L., Espin S., Whyte S., Regehr, G., Baker, G.R., Reznick R., Bohnen J., Orser B., Doran D., Grober E. (2004), Communication failures in the operating room: an observational classification of recurrent types and effects, „Quality and Safety in Health Care”, vol. 13(5), s. 330-334.

Lipiec J. (1972), Podstawy ontologii społeczeństwa, Państwowe Wydawnictwo Naukowe, Warszawa.

Lipiec J. (1979), Ontologia świata realnego, Państwowe Wydawnictwo Naukowe, Warszawa.

Liptak F. (1980), Program usprawnienia organizacji przedsiębiorstwa, Państwowe Wydawnictwo Naukowe, Warszawa.

Lis S. (1984), Organizacja i ekonomika procesów produkcyjnych w przemyśle maszynowym, Państwowe Wydawnictwo Naukowe, Warszawa.

Lisiński M. (2011), Przegląd paradygmatów zarządzania strategicznego, „Zeszyty Naukowe Uniwersytetu Ekonomicznego w Krakowie", nr 856, s. 5-21. 
Listwan T., Menedżer i kierowanie zespołem w warunkach nowej gospodarki, „Przedsiębiorczość i Zarządzanie" 2017, vol. 18(3), cz. 2, s. 115-126.

Littlejohn S.W. (1992), Theories of human communication, Wadsworth, Belmont.

Liu Y., Alsaadi F.E., Yin X., Wang Y. (2015), Robust Ho filtering for discrete nonlinear delayed stochastic systems with missing measurements and randomly occurring nonlinearities, „International Journal of General Systems", vol. 44(2), s. 169-181.

Locke E.A. (1968), Toward a Theory of Task Motivation and Incentives, „Organizational Behavior and Human Performance", May, s. 157-189.

Locke E.A. (1991), The Motivation Sequence, the Motivation Hub, and the Motivation Core, „Organizational Behavior and Human Decision Processes", no. 50, s. 288-299.

Locke E.A., Latham G.P. (1990), A Theory of Goal Setting and Task Performance, Prentice Hall, Englewood Cliffs.

Locke E.A., Latham G.P. (2002), Building a Practically Oriented Theory of Goal Setting and Task Motivation: A 35-Year Odyssey, „American Psychologist”, no. 57, s. 705-717.

Locke E.A., Latham G.P. (2005), Goal Setting Theory: Theory Building by Induction, [w:] K. Smith, M.A. Hitt (red.), Great Minds in Management: The Process of Theory Development, Oxford University Press, Oxford.

Locke E.A., Latham G.P. (2009), Has Goal Setting Gone Wild or Have Its Attackers Abandoned Good Scholarship?, „Academy of Management Perspectives”, no. 18, s. 17-23.

Lorenz E.N. (1963), Deterministic non-periodic flow, „Journal of the Atmospheric Sciences”, no. 20, s. $130-141$.

Lorr M., Strack S. (1990), Wiggins interpersonal adjective scales: A dimensional view, „Personality and Individual Differences", vol. 11, issue 4, s. 423-425.

Louhiala-Salminen L., Kankaanranta A. (2012), Language as an issue in international internal communication: English or local language? If English, what English?, „Public Relations Review", vol. 38(2), s. 262-269.

Löfgren L. (1988), Towards system: from computation to the phenomenon of language, [w:] E.M. Carvallo (red.), Nature, Cognition and System, vol. 1, Springer, Dordrecht.

Luhmann N. (1986), The autopoiesis of social systems, [w:] F. Geyer, J. van der Zouwen (red.), Sociocybernetic paradoxes: Observation, control and evolution of self-steering systems, Sage, London.

Luhmann N. (1989), Law as a social system, „Northwestern University Law Review”, vol. 83(1-2), s. $136-150$.

Luhmann N. (1992), What is communication? „Communication Theory”, vol. 2(3), s. 251-259.

Luhmann N. (1995), Social systems, Stanford University Press, Stanford.

Luhmann N. (2000), Organisation und Entscheidung, Westdeutscher Verlag, Opladen.

Luhmann N. (2003), Organization, [w:] T. Bakken, T. Hernes (red.), Autopoietic organization theory: Drawing on Niklas Luhmann's social systems perspective, Copenhagen Business School Press, Oslo.

Luo Y., Shenkar O. (2006), The multinational corporation as a multilingual community: Language and organization in a global context, „Journal of International Business Studies”, no. 37, s. 321-339.

Lyneis J.M., Cooper K.G., Els S.A. (2001), Strategic management of complex projects: a case study using system dynamics, „System Dynamics Review”, vol. 17(3), s. 237-260.

Lyotard J.-F. (1984), The Postmodern Condition: A Report on Knowledge, Manchester University Press, Manchester.

Maani K.E., Cavana R.Y. (2000), Systems Thinking and Modelling, Pearson Education, New Zealand. Mackey J.D., Perrewé P.L., McAllister C.P. (2017), Do I fit in? Perceptions of organizational fit as a resource in the workplace stress process, „Group \& Organization Management”, vol. 42(4), s. 455-486. 
Maclean D. (2006), Beyond English: Transnational corporations and the strategic management of language in a complex multilingual business environment, „Management Decision”, vol. 44(10), s. 1377-1390.

Malone T.W., Crowston K. (1994), The interdisciplinary study of coordination, „ACM Computing Surveys (CSUR)", vol. 26(1), s. 87-119.

Manifesto for Agile Software Development (2017), http://agilemanifesto.org/ (dostęp: 29.06.2017).

Mann R., Gibbard G., Hartman J. (1967), Interpersonal Styles and Group Development, John Wiley, New York.

Maslach C., Leiter M.P. (2016), Pokonać wypalenie zawodowe: sześć strategii poprawienia relacji z praca, Wolters Kluwer, Warszawa.

March J.G., Simon H. (1974), Teoria organizacji, Państwowe Wydawnictwo Ekonomiczne, Warszawa

Marschak R.T. (1995), Workflow: Applying automation to group processes, [w:] D. Coleman, R. Khanna (red.), Groupware: Technologies and Applications, Prentice-Hall, Upper Saddle River.

Martinelli D.P. (2001), Systems hierarchies and management, „Systems Research and Behavioral Science", vol. 18(1), s. 69-82.

Martyniak Z. (1976), Elementy metodologii organizowania, Państwowe Wydawnictwo Naukowe, Warszawa.

Martyniak Z. (1979), Organizacja i zarządzanie. 42 problemy teorii i praktyki, Książka i Wiedza, Warszawa.

Martyniak Z. (1982), Metodologiczne podstawy doskonalenia organizacji przedsiębiorstwa, Instytut Wydawniczy Związków Zawodowych, Warszawa.

Martyniak Z. (1993), Prekursorzy nauki organizacji i zarzq̨dzania, Państwowe Wydawnictwo Ekonomiczne, Warszawa.

Martyniak Z. (1995), Karol Adamiecki - prekursor wspótczesnych nauk o zarządzaniu, „Przegląd Organizacji”, nr 6, s. 29-32.

Martyniak Z. (2002), Historia myśli organizatorskiej. Wybitni autorzy z zakresu organizacji i zarzqdzania w pierwszej połowie XX w., Akademia Ekonomiczna, Kraków.

Maryniarczyk A. (1989-1990), O autonomiczne pojęcie systemu metafizyki (cz. 1), „Roczniki Filozoficzne", t. XXXVII-XXXVIII, z. 1, s. 291-309.

Maslow A. (1970/1990), Motywacja i osobowość, PAX, Warszawa.

Matejun M. (2011), Metoda badania przypadków w naukach o zarządzaniu, „Ekonomika i Organizacja Przedsiębiorstwa", nr 10, s. 93-102.

Matthews L. (2010), Social Media and the Evolution of Corporate Communications, „The Elon Journal of Undergraduate Research in Communications”, Winter, vol. 1(1), s. 17-23.

Maturana H.R., Varela F.J. (1980), Autopoiesis and Cognition: The Realization of the Living, D. Reidel, Dordrecht.

Mayo E. (1933), The Human Problems of an Industrial Civilization, Mac Millan, New York.

Mazanowska E. (2015), Konflikt jako etiologia powstawania patologii w organizacji, „Współczesna Gospodarka", vol. 6(1), s. 53-65.

Mazmanian M.A., Orlikowski W.J., Yates J. (2005), Crackberries: The social implications of ubiquitous wireless e-mail devices, [w:] C. Sorensen, K. Lyytinen, J.I. DeGross (red.), Designing ubiquitous information environments: Socio-technical issues and challenges, Springer, New York.

Mazur M. (1976), Cybernetyka i charakter, Państwowy Instytut Wydawniczy, Warszawa.

Mazzei A. (2010), Promoting Active Communication Behaviours Through Internal Communication, „Corporate Communications: An International Journal”, vol. 15, no. 3, s. 221-234.

McClelland D.C. (1965), Toward a Theory of Motive Acquisition, „American Psychologist”, vol. 20(5), s. 321-333.

McClelland D.C. (1985), Human Motivation, Scott, Foresman, Glenview. 
McPhee R.D., Poole M.S. (2001), Organizational structures and configurations, [w:] F.M. Jablin, L.L. Putnam (red.), The new handbook of organizational communication: Advances in theory, research and methods, Sage, Thousand Oaks. McPhee R.D., Zaug P. (2000), The communicative constitution of organizations: A framework for explanation, „Electronic Journal of Communication", vol. 10(1-2), s. 1-17.

McPhee R.D., Zaug P. (2008), The communicative constitution of organizations: A framework for explanation, [w:] L.L. Putnam, A.M. Nicotera (red.), Building theories of organization: The constitutive role of communication, Routledge, New York.

McShane S.L., Von Glinow M.A. (2000), Organizational behavior, Irwin McGraw-Hill, Boston.

Mehralizadeh Y., Shahi S., Sharify A. (2014), Effectiveness of organizational Communication (organizational structure and technology) in education system of Iran, https://rms.scu.ac.ir/ Files/Articles/Journals/Abstract/Effectiveness\%20of\%200rganizational\%20Communication\%20(Organizational\%20Structure\%20and\%20Technology)\%20in\%20Education $\% 20$ System\%20of\%20Iran.pdf201076237815.pdf (dostęp: 10.10.2017).

Mento A.J., Locke E.A., Klein H.J. (1992), Relationship of Goal Level to Valence and Instrumentality, „Journal of Applied Psychology”, no. 77, s. 395-405.

Mesarović M.D. (1973), Rozwój matematycznej teorii systemów ogólnych, „Prakseologia”, nr 2(46), S. 47-69.

Mesarović M.D. (1976), Matematyczna teoria systemów ogólnych, [w:] G.J. Klir (red.), Ogólna teoria systemów, Wydawnictwa Naukowo-Techniczne, Warszawa, s. 246-262.

Mesarović M.D., Takahara Y. (1975), General systems theory: mathematical foundations, Academic Press, Ohio.

Mesarović M.D., Maćko D., Takahara Y. (2000), Theory of hierarchical, multilevel, systems, vol. 68, Elsevier, Ohio.

Mesjasz Cz. (2004), Organizacja jako system złożony, „Zeszyty Naukowe Akademii Ekonomicznej w Krakowie", nr 652, s. 58-59.

Midgley G. (red.) (2003), Systems thinking, Sage, London.

Mikołajczyk Z. (1997), Techniki organizatorskie w rozwiazywaniu problemów zarzq̨dzania, Wydawnictwo Naukowe PWN, Warszawa.

Mikołajczyk Z., Zimniewicz K. (2001), Informacja i komunikowanie, [w:] B. Piasecki (red.), Ekonomika i zarządzanie mata firma, Wydawnictwo Naukowe PWN, Warszawa.

Mikuła B. (2006), Organizacje oparte na wiedzy, „Zeszyty Naukowe/Akademia Ekonomiczna w Krakowie. Seria Specjalna, Monografie”, nr 173.

Miles J.A. (2012), Management and organization theory, A Jossey-Bass Reader, Jossey-Bass, San Francisco.

Milgrom P., Roberts J. (1992), Economics, organization, and management, Prentice Hall, Englewood Cliffs.

Miller K. (1996), Who are we and what are we doing?, „Management Communication Quarterly”, vol. 10, no. 1, s. 3-4.

Miller K. (2005), Communication theories: Perspectives, processes, and contexts, McGraw-Hill, New York.

Miller K. (2012), Organizational communication. Approaches and processes, Wadsworth, Boston.

Milmoe S., Rosenthal R., Blane H.T., Chafetz M.E., Wolf I. (1967), The Doctor's Voice: Postdictor of Successful Referral of Alcoholic Patients, „Journal of Abnormal Psychology”, vol. 72, s. $78-84$.

Mingers J. (2014), Systems thinking, critical realism and philosophy: A confluence of ideas, Routledge, London.

Mingers J. (2017), Back to the future: A critique of Demetis and Lee's "Crafting theory to satisfy the requirements of systems science”, ,Information and Organization”, vol. 27(1), s. 67-71. 
Mingers J., White L. (2010), A review of the recent contribution of systems thinking to operational research and management science, „European Journal of Operational Research”, vol. 207(3), s. $1147-1161$.

Mintzberg H. (1979), The Structuring of Organizations, Prentice-Hall, Englewood Cliffs.

Mintzberg H. (1981), Organization Design: Fashion or Fit?, „Harvard Business Review”, January - February, no. 59, s. 103-116.

Miotto R., Li L., Kidd B.A., Dudley J.T. (2016), Deep patient: An unsupervised representation to predict the future of patients from the electronic health records, „Scientific Reports”, vol. 6 , article number: 26094, https://www.nature.com/articles/srep26094 (dostęp: 26.03.2017).

Miron-Spektor E., Gino F., Argote L. (2011), Paradoxical frames and creative sparks: enhancing individual reativity through conflict and integration, „Organizational Behavior and Human Decision Processes", vol. 116(2), s. 229-240.

Mishra J. (1990), Managing the grapevine, „Public Personnel Management”, vol. 19(2), s. 213-228.

Modaff D., DeWine S., Butler J. (2008), Organizational Communication. Foundations, Challenges and Misunderstandings, Pearson, Sydney.

Monge P., Contractor N.S. (2003), Theories of communication networks, Oxford University Press, New York.

Montuori L.A. (2000), Organizational longevity. Integrating systems thinking, learning and conceptual complexity, „Journal of Organizational Change Management”, vol. 13(1), s. 61-73.

Mooney J. (1947), Principles of organization, Harper \& Brothers, New York.

Morel B., Ramanujam R. (1999), Through the looking glass of complexity: the dynamics of organizations as adaptive and evolving systems, „Organization Science”, vol. 10(3), s. 278-293.

Morgan G. (1997), Obrazy organizacji, Wydawnictwo Naukowe PWN, Warszawa.

Morley D., Shockley-Zalabak P., Cesaria R. (2002), Organizational influence processes: Perceptions of values, communication and effectiveness, „Studies in Communication Sciences”, vol. 2(1), s. 69-104.

Morreale S.P., Spitzberg B.H., Barge J.K. (2007), Komunikacja między ludźmi. Motywacja, wiedza i umiejętności, Wydawnictwo Naukowe PWN, Warszawa.

Mreła H. (1968), Technika organizowania pracy, Wiedza Powszechna, Warszawa.

Mruk H. (2004), Komunikowanie się w marketingu, Polskie Towarzystwo Ekonomiczne, Warszawa.

Muk A., Chung C. (2015), Applying the technology acceptance model in a two-country study of SMS advertising, „Journal of Business Research”, vol. 68(1), s. 1-6.

Myers S.A., Rocca K.A. (2000), The relationship between perceived instructor communicator style, argumentativeness, and verbal aggressiveness, "Communication Research Reports”, vol. 17(1), s. 1-12.

Mynarski S. (1981), Elementy teorii systemów i cybernetyki, Państwowe Wydawnictwo Naukowe, Warszawa.

Nadolna B. (2017), Triangulacja w badaniach rachunkowości zarządczej, „Ekonomiczne Problemy Usług", nr 127, s. 173-185.

Nalepka A. (2001), Struktura organizacyjna, Wydawnictwo Antykwa, Kraków.

Nalepka S., Kozina A. (2007), Podstawy badania struktury organizacyjnej, Wydawnictwo Akademii Ekonomicznej w Krakowie, Kraków.

Napoli P.M. (2006), The marketplace of ideas metaphor in communications regulation, „Journal of Communication", vol. 49(4), s. 151-169.

Nash D., Hann D. (2017), Organisational innovators: A study of workplace intra-employee conflict management strategies, Paper presented at Conflict and its Resolution in the Changing World of Work: A Conference and Special Issue Honoring David B. Lipsky, November, Ithaca.

Nassehi A. (2005), Organizations as Decision Machines: Niklas Luhmann's Theory of Organized Social Systems, [w:] C. Jones, R. Munro (red.), Contemporary Organization Theory, Blackwell, Oxford. 
Naus F., Iterson A. van, Roe R. (2007), Organizational cynicism: Extending the exit, voice, loyalty, and neglect model of employees' responses to adverse conditions in the workplace, „Human Relations", no. 60, s. 683-718.

Nazareth D.L., Choi J. (2015), A system dynamics model for information security management, „Information \& Management", vol. 52(1), s. 123-134.

Nespor J. (1987), The Role of Beliefs in the Practice of Teaching, „Journal of Curriculum Studies”, no. 19 , s. 317-328.

Newman M., Barabási A.L., Watts D. (2006), The structure and dynamics of networks, Princeton University Press, Princeton.

Nęcki Z. (1996), Komunikacja międzyludzka, Wydawnictwo Profesjonalnej Szkoły Biznesu, Kraków.

Nęcki Z. (2000), Komunikacja międzyludzka, Wydawnictwo Antykwa, Kraków.

Nonaka I., Takeuchi H. (1995), The Knowledge Creating, Oxford University Press, Oxford.

Norton R.W. (1977), Teacher effectiveness as a function of communicator style, „Annals of the International Communication Association", vol. 1(1), s. 525-542.

Norton R.W. (1978), Foundation of a communicator style construct, „Human Communication Research", no. 4, s. 99-112.

Norton R.W. (1983), Communication Style: Theory, Applications and Measure, Sage, Beverly Hills.

Norton R.W., Nussbaum J. (1980), Dramatic behaviors of the effective teacher, „Annals of the International Communication Association", vol. 4(1), s. 565-579.

Nowak S. (red.) (1984), Wizje człowieka i społeczeństwa w teoriach i badaniach naukowych, Państwowe Wydawnictwo Naukowe, Warszawa.

Nydhal S. (2011), W'́lepej uliczce pośpiechu, „Forum”, nr 1, s. 36.

Ober J. (2013), Funkcja i rola efektywnej komunikacji w zarzq̨dzaniu, „Zeszyty Naukowe Politechniki Śląskiej", nr 65, s. 257-266.

Obrębska M., Obrębski T. (2011), Style mówienia w schizofrenii. Analiza porównawcza z wykorzystaniem Wskaźników Stylów Mówienia Suitberta Ertela, „Czasopismo Psychologiczne”, vol. 17(2), s. 189-198.

Ogutu S.O., Okello J.J., Otieno D.J. (2014), Impact of information and communication technology-based market information services on smallholder farm input use and productivity: The case of Kenya, „World Development”, no. 64, s. 311-321.

Olesen K., Myers M.D. (1999), Trying to improve communication and collaboration with information technology: an action research project which failed, „Information Technology \& People", vol. 12(4), s. 317-332.

Oliver C. (1997), Sustainable competitive advantage: combining institutional and resource-based views, „Strategic Management Journal”, vol. 18(9), s. 697-713.

Oliver S. (1997), Corporate communication: Principles, techniques and strategies, Kogan Page Publishers, https://books.google.pl/books?hl=pl\&lr=\&id=BM230IRdB7IC\&oi=fnd\&pg=PA 11\&dq=Oliver,+S.+(1997),+Corporate+Communication:+Principles, + Techniques + and+Str ategie\&ots=K_3bZvL7ql\&sig=oGLOY-UmRljS54tGvms-HRsLRh8\&redir_esc=y\#v=onepage \&q=Oliver\%2C\%20S.\%20(1997)\%2C\%20Corporate\%20Communication\%3A\%20Principles \%2C\%20Techniques\%20and\%20Strategie\&f=false (dostęp: 21.06.2018).

Olszewski J. (2013), System pracy w warunkach globalnego społeczeństwa informacyjnego, Wydawnictwo Uniwersytetu Ekonomicznego, Poznań.

O metodzie (Social Network Analysis), http://www.episteme.com.pl/obszary-wiedzy/SNA/o-metodzie (dostęp: 4.07.2018).

Orchard R.A. (1976), o pewnym ujęciu ogólnej teorii systemów, [w:] G.J. Klir (red.), Ogólna teoria systemów, Wydawnictwa Naukowo-Techniczne, Warszawa.

Ordonez L., Schweltzer M., Galinsky A., Bazerman M. (2009), On Good Scholarship, Goal Setting, and Scholars Gone Wild, „Academy of Management Perspectives”, no. 18, s. 82-87. 
Orlikowski W.J. (2007), Sociomaterial practices: Exploring technology at work, „Organization Studies", vol. 28(9), s. 1435-1448.

Orlikowski W.J., Robey D. (1991), Information technology and the structuring of organizations, „Information Systems Research”, no. 2, s. 143-169.

Orlikowski W.J., Yates J., Okamura K., Fujimoto M. (1995), Shaping electronic communication: the metastructuring of technology in the context of use, „Organization Science”, vol. 6(4), s. 423-444.

Ormerod R.J. (2003), Taket's suggestions for the OR toolkit, „Journal of the Operational Research Society", no. 54, s. 322-323.

Ostwald M. (2009), Inżynieria systemów, Politechnika Poznańska, Poznań.

Packard N. (1988), Adaptation towards the edge of chaos, [w:] J.A.S. Kelso, A.J. Mandell, M.F. Shlesinger (red.), Dynamic patterns in complex systems, World Scientific, Singapore.

Paluchowski W.J. (2010), Komputerowa analiza narracyjności. Wybrane problemy metodologiczne, [w:] M. Straś-Romanowska, B. Bartosz, M. Żurko (red.), Badania narracyjne w psychologii, ENETEIA Wydawnictwo Psychologii i Kultury, Warszawa.

Pankiewicz M. (2007), Style komunikacji a preferencje wartości uczniów zdolnych, „Studia z Psychologii w Katolickim Uniwersytecie Lubelskim", vol. 14, s. 39-56.

Parsons T. (1972), Szkice z teorii socjologicznej, Państwowe Wydawnictwo Naukowe, Warszawa.

Pasieczny J. (2015), Obszary i źródła patologii organizacyjnych, „Zeszyty Naukowe. Organizacja i Zarządzanie/Politechnika Śląska”, nr 83, s. 529-538.

Pava C. (1986), Redesigning sociotechnical systems design: Concepts and methods for the 1990s, „Journal of Applied Behavioral Science”, no. 22, s. 201-221.

Pawłowski T. (1978), Tworzenie pojęć i definiowanie w naukach humanistycznych, Państwowe Wydawnictwo Naukowe, Warszawa.

Pekalis W. (1974), Maleńka encyklopedia wielkiej cybernetyki, Wydawnictwo Szkolne i Pedagogiczne, Warszawa.

Penman R. (2000), Reconstructing communicating: Looking to a future, Routledge, New York.

Perechuda K. (1984), Rekonstrukcja tektologicznej teorii organizacji A. Bogdanowa, „Prakseologia”, nr 3-4(91-92), s. 7-102.

Perechuda K. (2000a), Zarządzanie przedsiębiorstwem przyszłości. Koncepcje, modele, metody, Agencja Wydawnicza Placet, Warszawa.

Perechuda K. (2000b), Kod genetyczny menedżera, [w:] A. Potocki (red.), Wspótczesne tendencje w zarządzaniu - teoria i praktyka, Wydawnictwo Wyższej Szkoły Przedsiębiorczości i Marketingu, Chrzanów.

Perechuda K. (2007), Dyfuzja wiedzy w przedsiębiorstwie sieciowym, Wydawnictwo Uniwersytetu Ekonomicznego we Wrocławiu, Wrocław.

Peters P., Van der Lippe T. (2007), The time-pressure reducing potential of telehomeworking: The Dutch case, „International Journal of Human Resource Management”, no. 18, s. 430-447.

Peters T., Waterman R. (2011), W poszukiwaniu doskonałości w biznesie: doświadczenia najlepiej zarzq̨dzanych firm Ameryki, Wydawnictwo MT Biznes, Warszawa.

Peters T., Waterman R., Phillips J. (1980), Structure is not organization, „Business Horizons”, vol. 23(3), s. 14-26.

Peterson C., Seligman M.E. (2004), Character strengths and virtues: A handbook and classification, vol. 1, Oxford University Press, Oxford.

Pettegrew L.S. (1977), Psychoanalytic theory: A neglected rhetorical dimension, „Philosophy \& Rhetoric", vol. 10, no. 1 (Winter), s. 46-59.

Piłejko K. (1976), Prakseologia - nauka o sprawnym działaniu, Państwowe Wydawnictwo Naukowe, Warszawa.

Pinder C.C. (1998), Motivation in work organizations, Prentice Hall, Upper Saddle River. 
Pocztowski A. (2008), Zarządzanie zasobami ludzkimi. Strategie - procesy - metody, Polskie Wydawnictwo Ekonomiczne, Warszawa.

Podsiad A., Więckowski Z. (1983), Mały słownik terminów i pojęć filozoficznych, Instytut Wydawniczy PAX, Warszawa.

Porter M. (1985), Competitive Adventage, Free Pres, New York.

Potocki A. (2001), Komunikacja wewnętrzna w przedsiębiorstwie, Wydawnictwo Akademii Ekonomicznej w Krakowie, Kraków.

Potocki A., Winkler R., Żbikowska A. (2003), Techniki komunikacji w organizacjach gospodarczych, Wydawnictwo Difin, Warszawa.

Price I. (2004), Complexity, complicatedness and complexity: a new science behind organizational intervention?, „Emergence: Complexity \& Organizations”, Special Double Issue 6(1-2), s. $40-48$.

Prigogine I., Stengers I. (1990), Z chaosu ku porządkowi. Nowy dialog człowieka z przyroda, Państwowy Instytut Wydawniczy, Warszawa.

Przelaskowski W. (1968), Ekonomiczne problemy tektologii A. Bogdanowa, „Studia Ekonomiczne", z. 20, s. 147-166.

Pszczołowski T. (1978), Mała encyklopedia prakseologii i teorii organizacji, Zakład Narodowy im. Ossolińskich, Wrocław-Warszawa-Kraków-Gdańsk.

Pszczołowski T. (1982), Dylematy sprawnego działania, Wiedza Powszechna, Warszawa.

Pułaska-Turyna B. (2011), Statystyka dla ekonomistów, Wydawnictwo Difin, Warszawa.

Putnam L.L., Nicotera A.M. (2008), Building Theories of Organization: Centering Organizational Communication, Taylor \& Francis, New York.

Putnam L.L., Nicotera A.M. (2009), Building theories of organization: The constitutive role of communication, Routledge, New York.

Putnam L.L., Nicotera A.M. (2010), Communicative constitution of organization is a question: Critical issues for addressing it, „Management Communication Quarterly”, vol. 24(1), s. 158-165.

Putnam L.L., Phillips N., Chapman P. (1996), Metaphors of communication and organizations, [w:] S.R. Clegg, W. R. Nord (red.), Handbook of organization studies, Sage, Thousand Oaks. Pytkowski W. (1985), Organizacja badań i ocena prac naukowych, Państwowe Wydawnictwo Naukowe, Warszawa.

Quade E.S. (1963), Military Systems Analysis, RAND, Santa Monica.

Quinn D., Hargie O. (2004), Internal communication audits: A case study, „Corporate Communications: An International Journal”, vol. 9(2), s. 146-158, https://doi.org/10.1108/135632804105 34348.

Rahim M.A. (2017), Managing conflict in organizations, Routledge, New York.

Ramage M., Shipp K. (2009), Systems Thinkers, Springer, London-New York.

Rapoport A. (1983), Rozmaite podejścia do budowy ogólnej teorii systemów: elementarystyczny iorganizmistyczny, seria „Problemy Metodologiczne”, Państwowy Komitet do spraw Nauki i Techniki, Akademia Nauk ZSRR, Ogólnozwiązkowy Instytut Naukowo-Badawczy, Moskwa.

Reinsch N.L. Jr, Beswick R.W. (1990), Voice mail versus conventional channels: A cost minimization analysis of individuals' preferences, „Academy of Management Journal”, vol. 33(4), s. 801-816.

Rennecker J., Godwin L. (2005), Delays and interruptions: A self-perpetuating paradox of communication technology use, „Information and Organization”, no. 15, s. 247-266.

Repper F.C. (2013), How Communication Managers Can Apply the Theories of Excellence and Effectiveness, [w:] J.E. Grunig (red.), Excellence in public relations and communication management, Routledge, New York.

Reynolds M., Holwell S. (red.) (2010), Systems Approaches to Managing Change: A Practical Guide, Springer, London.

Robbins S.P. (2000), Zachowania w organizacji, Polskie Wydawnictwo Ekonomiczne, Warszawa. 
Robbins S.P., Judge T.A. (2011), Zachowania w organizacji, Polskie Wydawnictwo Ekonomiczne, Warszawa.

Robertson B. (2015), Holacracy: The New Management System for a Rapidly Changing World, Henry Holt and Company LLC, New York.

Robertson J., Robertson S. (1994), Pełna analiza systemowa, Wydawnictwo Naukowo-Techniczne, Warszawa.

Robey D., Mikhaeil C.A. (2016), Déjà Vu or Art Nouveau? A comment on Demetis and Lee's "Crafting theory to satisfy the requirements of systems science”, ,Information and Organization", vol. 26(4), s. 127-130.

Robichaud D., Giroux H., Taylor J.R. (2004), The metaconversation: The recursive property of language as a key to organizing, „Academy of Management Review”, vol. 29(4), s. 617-634.

Robson P., Tourish D. (2005), Managing internal communication: An organizational case study, „Corporate Communications: An International Journal”, vol. 10(3), s. 213-222.

Rokita J. (2003), Organizacja ucząca się, „Prace Naukowe/Akademia Ekonomiczna w Katowicach”.

Rokita J. (2011), Myślenie systemowe w zarządzaniu organizacjami, „Prace Naukowe/Uniwersytet Ekonomiczny w Katowicach".

Romero D., Vernadat F. (2016), Enterprise information systems state of the art: Past, present and future trends, „Computers in Industry”, no. 79, s. 3-13.

Rosenfeld L.B., Richman J.M., May S.K. (2004), Information adequacy, job satisfaction and organizational culture in a dispersed network organization, „Journal of Applied Communication Research", no. 32, s. 28-54

Rosenhead J., Mingers J. (red.) (2001), Rational Analysis for a Problematic World Revisited, John Wiley \& Sons, Chichester.

Rowe A.J., Boulgarides J.D. (1992), Managerial Decision Making, Prentice Hall, Upper Saddle River.

Rozwadowska B. (2011), Public Relations. Teoria, praktyka, perspektywy, Wydawnictwo Studio EMKA, Warszawa.

Ruck K., Welch M. (2012), Valuing internal communication; management and employee perspectives, „Public Relations Review”, vol. 38(2), s. 294-302.

Rumel-Syska Z. (1990), Konflikty organizacyjne. Ujęcie mikrospołeczne, Państwowe Wydawnictwo Naukowe, Warszawa.

Rummler G., Brache A. (2000), Podnoszenie efektywności organizacji, Polskie Wydawnictwo Ekonomiczne, Warszawa.

Ryś M. (1993), Psychologia małżeństwa w zarysie, Centrum Metodyczne Pomocy Psychologiczno-Pedagogicznej Ministerstwa Edukacji Narodowej, Warszawa.

Sadowski W. (1966), O matematycznej teorii organizacji, „Problemy Organizacji”, nr 5, s. 5-19.

Sadowski W. (1978), Podstawy ogólnej teorii systemów, Państwowe Wydawnictwo Naukowe, Warszawa.

Sadowski W.N. (1981), Metodologia nauki a ujęcie systemowe, [w:] W. Gasparski, D. Miller, Nauka, technika, systemy, Ossolineum, Wrocław-Warszawa-Kraków-Gdańska-Łódź.

Sadowskij W.N. (1973), Ogólna teoria systemów jako metateoria, „Prakseologia”, nr 2, s. 23-46.

Samborski A. (2012), Governance w przedsiębiorstwie w kontekście społecznej odpowiedzialności, „Przegląd Organizacji”, vol. 1, s. 14-17.

Samul J. (2017), Stan badań nad metodami naukowymi w zarządzaniu zasobami ludzkimi - systematyczny przegląd literatury, „Human Resource Management/Zarządzanie Zasobami Ludzkimi", vol. 115(2), s. 51-61.

Sanchez A.M., Pérez M., De Luis Carnicer P., Vela Jiménez M.J. (2007), Teleworking and workplace fexibility: A study of impact on firm performance, „Personnel Review”, no. 36, s. 42-64.

Satir V., Banmen J. (1991), The Satir model: Family therapy and beyond, Science \& Behavior Books, Palo Alto.

Schein E. (1985), Organizational culture and leadership, Jossey-Bass, San Francisco. 
Schein E. (1996), Culture: The missing concept in organization studies, „Administrative Science Quarterly", vol. 41, no. 2, 40th Anniversary Issue, s. 229-240.

Schoeneborn D. (2011), Organization as communication: A Luhmannian perspective, „Management Communication Quarterly", no. 25, s. 663-689.

Schoeneborn D., Blaschke S., Cooren F., McPhee R.D., Seidl D., Taylor J.R. (2014), The three schools of CCO thinking: Interactive dialogue and systematic comparison, „Management Communication Quarterly", vol. 28(2), s. 285-316.

Scholes E. (red.) (1997), Gower Handbook of Internal Communication, Gower Publishing Limited, Aldershot, https://books.google.pl/books?hl=pl\&lr=\&id=jJRcdNis_OIC\&oi $=$ fnd \&pg $=$ PR11\&dq=Scholes, + E.+(red.)+(1997).+Gower+Handbook+of+Internal+C ommunication\&ots=73mnIPIADL\&sig=BLA7B2tLFGuJ75urFSUYmHQ7VMI\&redir_ esc=y\#v=onepage \&q=Scholes\%2C\%20E.\%20(red.)\%20(1997).\%20Gower\%20Handbook\%20of\%20Internal\%20Communication\&f=false (dostęp: 21.06.2018).

Schotter A., Beamish P.W. (2011), Performance effects of MNC headquarters - subsidiary conflict and the role of boundary spanners: the case of headquarter initiative rejection, „Journal of International Management", vol. 17(3), s. 243-259.

Schultze U. (2017), What kind of world do we want to help make with our theories?, „Information and Organization", vol. 27(1), s. 60-66.

Schulz von Thun F. (2001), Sztuka rozmawiania. Analiza zaburzeń, t. 1, Wydawnictwo WAM, Kraków.

Schulz von Thun F., Ruppel J., Stratmann R. (2004), Sztuka zarządzania. Psychologia komunikacji dla szefów i liderów, Wydawnictwo WAM, Kraków.

Schunk D.H., Pintrich P.R., Meece J.L. (2008), Motivation in education: Theory, research, and applications, $3^{\text {rd }}$ ed., Pearson Education, Upper Saddle River.

Schutz W.F. (1958), A Three-Dimensional Theory of Interpersonal Behavior, Holt, Rinehart \& Winston, New York.

Schwertner K. (2017), Analysis and Visualization of Marketing, Statistical and Macroeconomic Data with GIS, „Economics”, vol. 5(5), s. 389-398.

Searle J.R. (1987), Czynności mowy, Instytut Wydawniczy PAX, Warszawa.

Seidl D. (2005a), The basic concepts of Luhmann's theory of social systems, [w:] D. Seidl, K.H. Becker (red.), Niklas Luhmann and organization studies, Copenhagen Business School Press, Oslo.

Seidl D. (2005b), Organization and interaction, [w:] D. Seidl, K. H. Becker (red.), Niklas Luhmann and organization studies, Copenhagen Business School Press, Oslo.

Seidl D., Becker K.H. (2006), Organizations as distinction generating and processing systems: Niklas Luhmann's contribution to organization studies, „Organization”, vol. 13(1), s. 9-35.

Seidl D., Becker K.H. (red.) (2005), Niklas Luhmann and organization studies, Copenhagen Business School Press, Oslo.

Seligman M.E., Csikszentmihalyi M. (2000), Positive psychology: An introduction, „American Psychologist", vol. 55, no. 1, s. 5-14.

Senge P. (2014), Piąta dyscyplina. Teoria i praktyka organizacji uczących się, Oficyna Ekonomiczna, Kraków.

Senge P., Sterman J.D. (1994), Systems thinking and organizational learning: Acting locally and thinking globally in the organization of the future, [w:] J.D.W. Morecroft, J.D. Sterman (red.), Modelling for Learning Organizations, Productivity Press, Portland.

Senge P., Kleiner A., Roberts C., Ross R., Smith B. (1994), The Fifth Discipline Fieldbook, Century, London.

Setia P., Venkatesh V., Joglekar S. (2013), Leveraging digital technologies: How information quality leads to localized capabilities and customer service performance, „MIS Quarterly”, vol. 37(2), June, s. 565-590.

Sharma V. (2015), Ways of Effective Internal Communication, „Biz and Bytes”, vol. 6(2), s. 91-96. 
Shockley-Zalabak P. (1995), Fundamentals of organizational communication: Knowledge, sensitivity, skills, values, $3^{\text {rd }}$ ed., Longman, New York.

Short J., Williams E., Christie B. (1976), The social psychology of telecommunications, John Wiley \& Sons Ltd, Hoboken.

Sienkiewicz P. (1988), Inżynieria systemów kierowania, Państwowe Wydawnictwo Ekonomiczne, Warszawa.

Sillince J.A.A. (2010), Can CCO theory tell us how organizing is distinct from markets, networking, belonging to a community, or supporting a social movement?, „Management Communication Quarterly", no. 24, s. 132-138.

Silvert W. (2001), Modelling as a discipline, „International Journal of General System”, vol. 30(3), s. 261-282.

Sikorski Cz. (1998), Ludzie nowej organizacji - Wzory kultury organizacyjnej wysokiej tolerancji niepewności, Wydawnictwo Uniwersytetu Łódzkiego, Łódź.

Sikorski Cz. (2002), Zachowania ludzi w organizacji, Wydawnictwo Naukowe PWN, Warszawa.

Sikorski Cz. (2005), Język konfliktu. Kultura komunikacji społecznej w organizacji, Wydawnictwo C.H. Beck, Warszawa.

Simon H.A. (1962), The Architecture of Complexity, „Proceedings of the American Philosophical Society", vol. 106, no. 6, s. 467-482.

Simon H.A., March J.G. (1958), Organizations, Wiley, Oxford.

Simpson C.W., Prusak L. (1995), Troubles with information overload - Moving from quantity to quality in information provision, „International Journal of Information Management”, vol. 15(6), s. 413-425.

Singh A., Goel V. (2018), Impact of communication on emploees' productivity at the time of change, „NOLEGEIN - Journal of Organizational Behavior Management”, vol. 1, issue 1, s. 27-35, http://www.mbajournals.in/index.php/JoOBM/article/view/130 (dostęp: 8.04.2018).

Singh I.A.K. (2014), Role of Interpersonal Communication in Organizational Effectiveness, ,International Journal of Research in Management \& Business Studies”, vol. 1(4), s. 36-39.

Skrzypek A. (2013), Zarządzanie wiedza w organizacjach zorientowanych projakościowo w spoteczeństwie informacyjnym - aspekty teoretyczne i praktyczne, „Nierówności Społeczne a Wzrost Gospodarczy", nr 32, s. 368-381.

Skrzypek E. (2002), Jakość i efektywność, Wydawnictwo Uniwersytetu Marii Curie-Skłodowskiej, Lublin.

Skrzypek E., Hofman M. (2010), Zarządzanie procesami w przedsiębiorstwie. Identyfikowanie, pomiar, usprawnienia, Wolters Kluwer, Warszawa.

Skudrzykowa A., Urban K. (2000), Mały słownik terminów z zakresu socjolingwistyki i pragmatyki językowej, Wydawnictwo Towarzystwa Miłośników Języka Polskiego, Kraków-Warszawa.

Skyrms B., Pemantle R. (2009), A dynamic model of social network formation, [w:] T. Gross, H. Sayama (red.), Adaptive networks, Springer, Berlin-Heidelberg.

Słownik języka polskiego PWN, http://sjp.pwn.pl/ (dostęp: 8.04.2015).

Smidts A., Pruyn A.T.H., Riel C.B.M. van (2001), The impact of employee communication and perceived external prestige on organizational identification, „The Academy of Management Journal", vol. 44(5), s. 1051-1062.

Smith A. (1954), Badania nad natura i przyczynami bogactwa narodów, t. 1, Państwowe Wydawnictwo Naukowe, Warszawa.

Smith A. (2005), Complexity theory for organisational futures studies, „Foresight”, vol. 7(3), s. $22-30$.

Smith J.K.A. (2006), Who's Afraid of Postmodernism? (The Church and Postmodern Culture): Taking Derrida, Lyotard, and Foucault to Church, Baker Academic, Michigan. 
Snell S.A., Shadur M., Wright P. M. (2001), Human resources strategy: the era of our ways, [w:] M.A. Hitt, R.E. Freeman, J.S. Harrison (red.), Handbook of Strategic Management, Blackwell, Oxford.

Sobczyk J.R. (1977), Analiza wskaźnikowa cech podstawowych budowy struktur organizacyjnych, "Organizacja i Kierowanie”, nr 3-4(9-10), s. 57-67.

Sobczyk J.R. (1981), „Wielkość” organizacji jako cecha budowy struktury organizacyjnej (zasady pomiaru, sposób wyrażania wartości, porównywalność), „Organizacja i Kierowanie”, nr 3-4(25-26), s. 155-170.

Sobczyk J.R. (2007), Koordynacja - semantyczny i terminologiczny rozbiór językowy kluczowego pojęcia teorii organizacji i zarządzania, „Współczesne Zarządzanie”, nr 4, s. 153-163.

Sobczyk J.R. (2010), Człowiek jako a ksjologiczna determinanta rozważań - o wartościowaniu efektywności w kontekście pragmatologicznym, „Przedsiębiorczość i Zarządzanie”, t. XI, z. 10, s. 333-345.

Sobkowiak B. (2005), Interpersonalne igrupowe komunikowanie się w organizacji, Wydawnictwo Forum Naukowe, Poznań-Wrocław.

Sobolewska S. (2016), Opinie klientów jako czynnik wpływający na zaufanie do podmiotów branży e-handlu, [w:] E. Gołębiowska (red.), Zarządzanie w dobie ograniczonego zaufania, „Przedsiębiorczość i Zarządzanie", t. XVII, z. 2, cz. III, s. 127-141.

Solaja M.O., Idowu E.F., James E.A. (2016), Exploring the relationship between leadership communication style, personality trait and organizational productivity, „Serbian Journal of Management", vol. 11(1), s. 99-117.

Sowa B.C. (2005), Internal communication, [w:] R.L. Heath (red.), Encyclopedia of public relations, vol. 1, Sage, Thousand Oaks. Spence W.R. (1994), Innovation: The Communication of Change in Ideas, Practices and Products, Chapman \& Hall, London.

Spiegelman J., Detsky A.S. (2008), Instant mobile communication, efficiency and quality of life, „Journal of the American Medical Association”, no. 299, s. 1179-1181.

Srnicek N., Williams A. (2015), Inventing the future: Postcapitalism and a world without work, Verso Books, London.

Stabryła A. (1983), Funkcje zarządzania, Ossolineum oddział w Krakowie, Wydawnictwo PAN, seria „Nauka dla wszystkich”, nr 370, Kraków.

Stabryła A. (2011), Problemy doskonalenia i rozwoju struktur organizacyjnych, „Prace Naukowe Uniwersytetu Ekonomicznego we Wrocławiu. Nauki o Zarządzaniu”, nr 216.

Stabryła A. (red.) (2009), Doskonalenie struktur organizacyjnych przedsiębiorstw w gospodarce opartej na wiedzy, Wydawnictwo C.H. Beck, Warszawa.

Stacey R.D. (2007), Strategic management and organisational dynamics: The challenge of complexity to ways of thinking about organisations, Prentice Hall, Pearson education, London.

Stankiewicz J. (2006), Komunikowanie się w organizacji, Wydawnictwo Astrum, Wrocław.

Stephens K.K., Mandhana D.M., Kim J.J., Li X., Glowacki E.M., Cruz I. (2017), Reconceptualizing Communication Overload and Building a Theoretical Foundation, "Communication Theory", no. 27, s. 269-289.

Stewart J., Ayres R. (2001), Systems theory and policy practice: an exploration, „Policy Sciences”, vol. 34(1), s. 79-88.

Stępka P., Subda K. (2009) Wykorzystanie analizy sieci społecznych (SNA) do budowy organizacji opartej na wiedzy, „E-mentor”, vol. 1(28), http://www.e-mentor.edu.pl/artykul/index/numer/28/id/618 (dostęp: 8.08.2018).

Stipek D.J. (1993), Motivation to learn: From theory to practice, Allyn \& Bacon, Boston.

Stone N. (1995), The Management and Practice of Public Relations, Macmillan Press, London.

Straub D., Karahanna E. (1998), Knowledge worker communications and recipient availability: Toward a task closure explanation of media choice, „Organization Science”, vol. 9(2), s. 160-175. 
Strelau J. (2004a), Różnice indywidualne: opis determinanty i aspekt społeczny, [w:] tenże (red.), Psychologia. Podręcznik akademicki, t. 2, Gdańskie Wydawnictwo Psychologiczne, Gdańsk.

Strelau J. (2004b), Wpływ społeczny, [w:] tenże (red.), Psychologia. Podręcznik akademicki, t. 3, Gdańskie Wydawnictwo Psychologiczne, Gdańsk.

Strzemińska H., Bednarski M. (red.) (2014), Czynnik czasu w nowej gospodarce. Wjakim kierunku zmierzamy?, IPiSS, Warszawa.

Styczyński M. (1990), Filozofia społeczne Aleksandra Bogdanowa, Wydawnictwo Uniwersytetu Łódzkiego, Łódź.

Styhre A. (2002), Non-linear change in organizations: organization change management informed by complexity theory, „Leadership \& Organization Development Journal”, vol. 23(6), s. 343-351.

Sugianto D., Abdullah A.G., Elvyanti S., Muladi Y. (2017), Modul Virtual: Multimedia Flipbook Dasar Teknik Digital, „Innovation of Vocational Technology Education”, vol. 9(2), s. 101-116.

Sullivan H.S. (2013), The interpersonal theory of psychiatry, Routledge, New York.

Sullivan T. (2004), The viability of using various system theories to describe organizational change, „Journal of Educational Administration”, vol. 42(1), s. 43-54.

Suter E., Arndt J., Arthur N., Parboosingh J., Taylor E., Deutschlander S. (2009), Role understanding and effective communication as core competencies for collaborative practice, „Journal of Interprofessional Care", vol. 23(1), s. 41-51.

Sydow J., Lindkvist L., DeFillippi R. (2004), Project-based organizations, embeddedness and repositories of knowledge: editorial, „Organization Studies”, vol. 25(9), s. 1475-1489.

Szczerski K. (2005), Administracja publiczna w modelu zarządzania wielopasmowego, Centrum Europejskie Natolin, Warszawa.

Szymanek K. (2004), Sztuka argumentacji. Słownik terminologiczny, Wydawnictwo Naukowe PWN, Warszawa.

Šmite D., Moe N.B., Šāblis A., Wohlin C. (2017), Software teams and their knowledge networks in large-scale software development, „Information and Software Technology”, no. 86, s. 71-86.

Świątek-Barylska I. (2017a), Core Values and Formalization as Determinants of Individual Behavior in an Organization A Managerial Perspective, [w:] Z. Nedelko, M. Brzozowski (red.), Exploring the Influence of Personal Values and Cultures in the Workplace, Wydawnictwo IGI Global, Hershey.

Świątek-Barylska I. (2017b), Images of Person-Organization Fit: Elements Affecting Employee Organizational Bahavior, „Kelaniya Journal of Management”, vol. 5(2), s. 17-31.

Taket A. (2002), Facilitation: Some contributions to theorising the practice of operational research, „Journal of the Operational Research Society”, no. 53, s. 126-136.

Taket A.R., White L.A. (2000), Partnership and Participation: Decision-making in the Multiagency Setting, John Wiley \& Sons, Chichester.

Taliferro J.D., Baumgartel H. (1970), Organization and Management: A Systems Approach (Book Review), „Personnel Psychology”, Winter, vol. 23(4), s. 614-618.

Tannenbaum R., Schmidt W.H. (1958), How to choose a leadership pattern, Harvard Business School, Boston (reprint).

Tariszka-Semegine E. (2012), Organizational internal communication as a means of improving efficiency, „European Scientific Journal”, vol. 8(15), s. 86-96.

Taylor J.R. (1993), Rethinking the theory of organizational communication: How to read an organization, Ablex, Norwood.

Taylor J.R. (1995), Shifting from a heteronomous to an autonomous worldview of organizational communication: Communication theory on the cusp, „Communication Theory”, no. 5, s. 1-35.

Taylor J.R. (2000), What is an organization?, „Electronic Journal of Communication”, http://www. cios.org/www/ejc/v10n1200.htm (dostęp: 5.03.2016). 
Taylor J.R., Cooren F. (1997), What makes communication 'organizational'? How the many voices of a collectivity become the one voice of an organization, „Journal of Pragmatics”, vol. 27(4), s. 409-438.

Taylor J.R., Van Every E.J. (2000), The emergent organization: Communication as its site and surface, Lawrence Erlbaum, Mahwah.

Taylor J.R., Van Every E.J. (2011), The situated organization: Case studies in the pragmatics of communication research, Routledge, New York.

Te'eni D. (2001), Review: A cognitive-affective model of organizational communication for designing IT, „MIS Quarterly”, vol. 25(2), s. 251-312.

Ten Brummelhuis L.L., Bakker A.B., Hetland J., Keulemans L. (2012), Do new ways of working foster work engagement?, „Psicothema”, vol. 24(1), s. 113-120.

Thietart R.A., Forgues B. (1995), Chaos Theory and Organization, „Organization Science”, vol. 6(1), s. $19-31$.

Thomas G.F., Stephens K.J. (2015), An introduction to strategic communication, „International Journal of Business Communication", vol. 52(1), s. 3-11.

Thompson J.D. (1967), Organizations in action: social science bases in administrative behavior, McGraw-Hill, New York.

Thomson V.J. (1995), Process monitoring for continuous improvement, [w:] J. Browne, D. O'Sullivan (red.), Reengineering the Enterprise, Chapman and Hall, London.

Tien J.M., Berg D. (2003), A case for service systems engineering, „Journal of Systems Science and Systems Engineering", vol. 12(1), s. 13-38.

Tjosvold D. (2007), The conflict-positive organization: It depends upon us, „Journal of Organizational Behavior", no. 29, s. 19-28.

Tjosvold D., Wong A.S., Feng Chen N.Y. (2014), Constructively managing conflicts in organizations, „The Annual Review of Organizational Psychology and Organizational Behavior”, vol. 1(1), S. 545-568.

Tokarczyk P. (1980), Prawa wierne naturze. Krytyka doktryny Lona Luvois Fullera, Wydawnictwo Lubelskie, Lublin.

Tompkins P.K. (1984), The functions of communication in organizations, [w:] C. Arnold, J. Bowers (red.), Handbook of Rhetorical and Communication Theory, Allyn \& Bacon, New York.

Tompkins P.K., Wanca-Thibault M. (2001), Organizational communication: Preludes and prospects, [w:] F.M. Jablin, L.L. Putnam (red.), The New Handbook of Organizational Communication: Advances in Theory, Research, and Methods, Sage Publications, Thousand Oaks. Topp W.K. (1999), Towards heuristic systems methods for generating new knowledge in post-industrial business, Doctoral dissertation, University of Cape Town, Cape Town.

Tourish D., Hargie O. (red.) (2004), Key Issues in Organizational Communication, Routledge, London.

Trist E. (1981), The evolution of socio-technical systems, Occasional paper, no. 2.

Trist E., Bamforth K.W. (1951), Some Social and Psychological Consequences of the Longwall Method of Coal-Getting, „Human Relations”, no. 4, s. 3-38.

Trist E., Murray H., Trist B., Cytrynbaum S. (1995), The Social Engagement of Social Science: A Tavistock Anthology. Vol. II: The Socio-Technical Perspective, „International Journal of Group Psychotherapy", vol. 45(4), s. 567-569.

Turzyński A. (2003), Elementy matematyki wyższej dla wydziałów ekonomicznych, Mazowiecka Wyższa Szkoła Humanistyczno-Pedagogiczna w Łowiczu, Łowicz.

Ujemow A.I. (1973a), Metody budowy i rozwoju ogólnej teorii systemów, „Prakseologia”, nr 2(46), s. $91-102$.

Ujemow A.I. (1973b), Systemy i badania systemowe, [w:] Problemy metodologii badań systemowych, Wydawnictwa Naukowo-Techniczne, Warszawa.

Ustawa z dnia 29 września 1994 r. o rachunkowości (Dz.U. z 2018 r., poz. 395). 
Ustawa z dnia 14 lutego 2003 r. o zmianie ustawy kodeks cywilny oraz niektórych innych ustaw (Dz.U. z 2003 r. Nr 49, poz. 408).

Van de Ven A.H. (1989), Nothing is quite so practical as a good theory, „Academy of Management Review", vol. 14(4), s. 486-489.

Van Gramberg B., Teicher J., Bamber G.J., Cooper B. (2017), A Changing World of Workplace Conflict Resolution and Employee Voice: An Australian Perspective, https://digitalcommons. ilr.cornell.edu/cgi/viewcontent.cgi?article=1016\&context=lipskycrconference (dostęp: 15.12.2018).

Van Riel C.B., Blackburn C. (1995), Principles of corporate communication, vol. 111, Prentice Hall, London, http://getbookreal.com/principles-of-corporate-communication-c-b-m-van-riel-new-digital-library-program.pdf (dostęp: 13.12.2018).

Vandermeeren S. (1999), English as a lingua franca in written corporate communication: findings from a European survey, [w:] F. Bargiela-Chiappini, C. Nickerson (red.), Writing business: genres, media and discourses, Longman, London.

Verčič A.T., Verčič D., Sriramesh K. (2012), Internal communication: Definition, parameters, and the future, „Public Relations Review”, vol. 38(2), s. 223-230.

Vickers G. (1965), The Art of Judgement, Chapman \& Hall, London.

Vickers G. (1970), Freedom in a Rocking Boat, Allen Lane, London.

Vollstedt M. (2002), English as a language for internal company communications, [w:] K. Knapp, C. Meierkord (red.), Lingua Franca Communication, Peter Lang, Frankfurt am Main.

Wagner S., Ruhe M. (2018), A systematic review of productivity factors in software development, preprint arXiv: 1801.06475 .

Walentynowicz B. (1979), Przedmowa do wyd. polskiego ksiq̨żki G. M. Weinberga „Myślenie systemowe", Wydawnictwa Naukowo-Techniczne, Warszawa.

Waller M.J., Zellmer-Bruhn M.E., Giambatista R.C. (2002), Watching the clock: group pacing behavior under dynamic deadlines, „Academy of Management Journal”, vol. 45(5), s. 1046-1055.

Wang T. (2004), From general system theory to total quality management, „Journal of American Academy of Business", vol. 4(1/2), s. 394-400.

Waszczyk M., Szczerbicki E. (2003), Metodologiczne aspekty opisowego modelowania w naukach ekonomicznych, „Zeszyty Naukowe Politechniki Gdańskiej. Filozofia”, nr 7, s. 3-20.

Waters D. (2001), Zarządzanie operacyjne: towary i ustugi, Wydawnictwo Naukowe PWN, Warszawa.

Watzlawick P., Beavin J., Jackson D. (1967), Pragmatics of human communication, Norton, New York.

Weaver W. (1948), Science and Complexity, „American Scientist”, no. 36, s. 536-544.

Webster J. (1998), Desktop Videoconferencing: Experiences of Complete Users, Wary Users, and Non-users, „MIS Quarterly”, vol. 22(3), s. 257-286.

Wei L., Lin H.H. (2017), Not a One-Size-Fits-All Methodology: A Survey of Mixed Methods, „Journal of Advances in Education Research", vol. 2(2), s. 97-102.

Weick K.E. (1979a), Cognitive processes in organizations, „Research in Organizational Behavior”, vol. 1(1), s. 41-74.

Weick K.E. (1979b), The Social Psychology of Organizing, Addison-Wesley, Reading.

Weick K.E. (1995), Sensemaking in organizations, Sage, London-New Delhi.

Weick K.E. (2016), Tworzenie sensu w organizacjach, Wydawnictwo Uniwersytetu Jagiellońskiego, Kraków.

Weinberg G.M. (1976), Ogólna teoria systemów w ujęciu informatyki, [w:] G.J. Klir (red.), Ogólna teoria systemów, Wydawnictwa Naukowo-Techniczne, Warszawa.

Weinberg G.M. (1979), Myślenie systemowe, Wydawnictwo Naukowo-Techniczne, Warszawa.

Weiner B. (1986), An Attributional Theory of Motivation and Emotion, Springer Verlag, New York.

Weiner B. (1994a), Ability versus Effort Revisited: The Moral Determinants of Achievement Evaluation and Achievement as a Moral System, „Educational Psychologist”, no. 29, s. 163-172. 
Weiner B. (1994b), Integrating Social and Persons Theories of Achievement Striving, „Review of Educational Research", no. 64, s. 557-575.

Weiner B. (2010), The Development of an Attribution-Based Theory of Motivation: A History of Ideas, „Educational Psychologist”, no. 45, s. 28-36.

Welch M. (2011), The evolution of the employee engagement concept: communication implications, „Corporate Communications: An International Journal”, vol. 16(4), s. 328-346.

Welch M., Jackson P.R. (2007), Rethinking internal communication: a stakeholder approach, „Corporate Communications: An International Journal", vol. 12(2), s. 177-198.

Wendland M. (2012), Działanie komunikacyjne a przekazywanie informacji, [w:] E. Kulczycki, Wendland M., Komunikologia. Teoria i praktyka komunikacji, Wydawnictwo Naukowe IF UAM, Poznań.

Wężyk K. (2014), Prawica wojuje na słoniach. Wywiad z George'em Lakoffem, http://www.if.pwr. edu.pl/ wsalejda/pwn.pdf (dostęp: 23.08.2014) lub wyborcza.pl/magazyn/1,124059,1651 0015,Prawica_wojuje_na_sloniach.html (dostęp: 8.01.2018).

White C., Vanc A., Stafford G. (2010), Internal communication, information satisfaction, and sense of community: The effect of personal influence, „Journal of Public Relations Research”, vol. 22(1), s. 65-84.

Wielki słownik języka polskiego, http://www.wsjp.pl/ (dostęp: 21.06.2017).

Wieman H.N. (1958), Man's ultimate commitment, Southern Illinois University, Carbondale.

Wiener N. (1948), Cybernetics, „Scientific American”, vol. 179(5), s. 14-19.

Wiener N. (1961), Cybernetyka i społeczeństwo, Książka i Wiedza, Warszawa.

Wiener N. (1971), Cybernetyka, czyli komunikacja i sterowanie w zwierzęciu i maszynie, Państwowe Wydawnictwo Naukowe, Warszawa.

Wiener N., Schade J.P. (1965), Cybernetics of the nervous system, vol. 17, Elsevier, AmsterdamLondon-New York.

Wilmot W.W. (1987), Dyadic communication, $3^{\text {rd }}$ ed., Random House, New York.

Witczak H. (2018), O systemowości zarządzania, [w:] M. Budzanowska-Drzewiecka, K. Czernek (red.), Kierunki ewolucji nauk o zarządzaniu, Wydawnictwo Uniwersytetu Jagiellońskiego, Kraków.

Wojciechowski E. (2013), Ontologia elementarna i klasyczny rachunek relacji, „Roczniki Filozoficzne", t. LXI, nr 2, s. 27-38.

Wolstenholme E.F. (1990), Systems Enquiry: A System Dynamics Approach, John Wiley \& Sons, Chichester.

Wood A.M., Linley P.A., Maltby J., Kashdan T.B., Hurling R. (2011), Using personal and psychological strengths leads to increases in well-being over time: A longitudinal study and the development of the strengths use questionnaire, „Personality and Individual Differences”, vol. 50(1), s. 15-19.

Wood R., Bandura A. (1989)., Social cognitive theory of organizational management, „Academy of Management Review", vol. 14(3), s. 361-384.

Woodside A.G. (2014), Embrace perform model: Complexity theory, contrarian case analysis, and multiple realities, „Journal of Business Research”, vol. 67(12), s. 2495-2503.

Woodward J. (1965), Industrial Organization: Theory and Practice, Oxford University Press, London.

Wright D. (1995), The role of corporate public relations executives in the future of employee communications, „Public Relations Review”, vol. 21, no. 3, s. 181-198.

Wright P. M., O'Leary-Kelly A.M., Cortinak J.M., Klein H.J., Hollenbeck J.R. (1994), On the Meaning and Measurement of Goal Commitment, „Journal of Applied Psychology”, no. 79, s. 795-803.

Wymore A.W (1967), A mathematical theory of Systems Engineering. The Elements, John Wiley \& Sons, New York.

Yarnold P.R., Grimm L.G., Lyons J.S. (1987), The Wiggins Interpersonal Behavior Circle and the Type A behavior pattern, „Journal of Research in Personality”, vol. 21, issue 2, s. 185-196. 
Yassa M.M., Hassan H.A., Omara F.A. (2012), New Federated Collaborative Networked Organization Model (FCNOM), „International Journal of Cloud Computing and Services Science”, no. 1, s. $1-10$.

Yates J., Orlikowski W.J. (1992), Genres of organizational communication: A structurational approach to studying communication and media, „Academy of Management Review”, vol. 17(2), s. 299-326.

Yoon S., Kuchinke K.P. (2005), Systems theory and technology. Lenses to analyze an organization, „Performance Improvement”, vol. 44(4), s. 15-20.

Zakrzewska-Bielawska A. (2015), Struktury organizacyjne sprzyjajq̨ce odnowie organizacyjnej przedsiębiorstw: ambidextrous approach, „Management Forum”, vol. 1(3), s. 105-111.

Zalewska-Turzyńska M. (2012), Komunikowanie się w organizacji - studium prakseologiczne, Wydawnictwo Uniwersytetu Łódzkiego, Łódź.

Zalewska-Turzyńska M. (2013), Jak organizacja steruje komunikacyjnymi zachowaniami (e-)klientów, [w:] M. Czajkowska, J. Januszkiewicz, M. Kołodziejczak, M. Zalewska-Turzyńska, Uwarunkowania zachowań ludzi w organizacji, „Acta Universitatis Lodziensis. Folia Oeconomica", nr 282, s. 295-304.

Zalewska-Turzyńska M. (2016a), Teorie systemowe w służbie badania organizacji - Ludwik von Bertalanffy, Talcott Parsons i Florian Znaniecki, [w:] Lisiński M., Ziębicki B. (red.), Wspótczesne problemy rozwoju metodologii zarządzania, Wydawnictwo Fundacji Uniwersytetu Ekonomicznego w Krakowie, Kraków.

Zalewska-Turzyńska M. (2016b), Wymiar komunikacja, [w:] K. Januszkiewicz i in., Wielowymiarowa Analiza Zachowań Organizacyjnych (WAZO) w polskich przedsiębiorstwach, Wydawnictwo Uniwersytetu Łódzkiego, Łódź.

Zhang Y., Dilts D. (2004), System dynamics of supply chain network organization structure, „Information Systems and E-Business Management", vol. 2(2-3), s. 187-206.

Zieleniewski J. (1964, 1976), Organizacja zespołów ludzkich. Wstęp do teorii organizacji i kierowania, Państwowe Wydawnictwo Naukowe, Warszawa.

Zieleniewski J. (1966), Efektywność badań naukowych, Pracownia Ogólnych Problemów Organizacji Pracy Polskiej Akademii Nauk, Państwowe Wydawnictwo Naukowe, Warszawa.

Zieleniewski J. (1969), Organizacja i zarzq̨dzanie, Państwowe Wydawnictwo Naukowe, Warszawa.

Ziemba S., Jarominek W., Staniszewski R. (1980), Problemy teorii systemów, Zakład Narodowy im. Ossolińskich, Wydawnictwo Polskiej Akademii Nauk, Wrocław-Warszawa-KrakówGdańsk.

Ziębicki B. (2017), Organizacje bez „szefów” - współczesna moda czy nowy paradygmat zarządzania, [w:] D. Walczak-Duraj, M. Kołodziejczak, M. Zalewska-Turzyńska (red.), Humanizacja pracy - Heterogeniczność czy unifikacja - zachowania organizacyjne w XXI wieku, Wyższa szkoła im. Pawła Włodkowica w Płocku, Płock.

Zimniewicz K. (2003), PM Senge i jego „Piąta dyscyplina”, „Zeszyty Naukowe/Akademia Ekonomiczna w Poznaniu", nr 33, s. 117-128.

Zimniewicz K. (2014), Nauka o zarzqdzaniu wobec potrzeb praktyki, „Research Papers of the Wroclaw University of Economics/Prace Naukowe Uniwersytetu Ekonomicznego we Wrocławiu", nr 340, s. 199-205.

Zimniewicz K. (2015), Praktyczna użyteczność wiedzy o zarządzaniu w dobie globalizacji, „Kwartalnik Nauk o Przedsiębiorstwie", nr 2, s. 101-104.

Zimniewicz K. (2016), W poszukiwaniu metodologicznego modelu dla nauk o zarządzaniu, „Przegląd Organizacji”, nr 2, s. 6-7.

Zużewicz K., Konarska M. (2005), Czas - czwarty wymiar pracy, „Bezpieczeństwo Pracy: Nauka i Praktyka", nr 9, s. 2-4. 



\section{Załączniki}





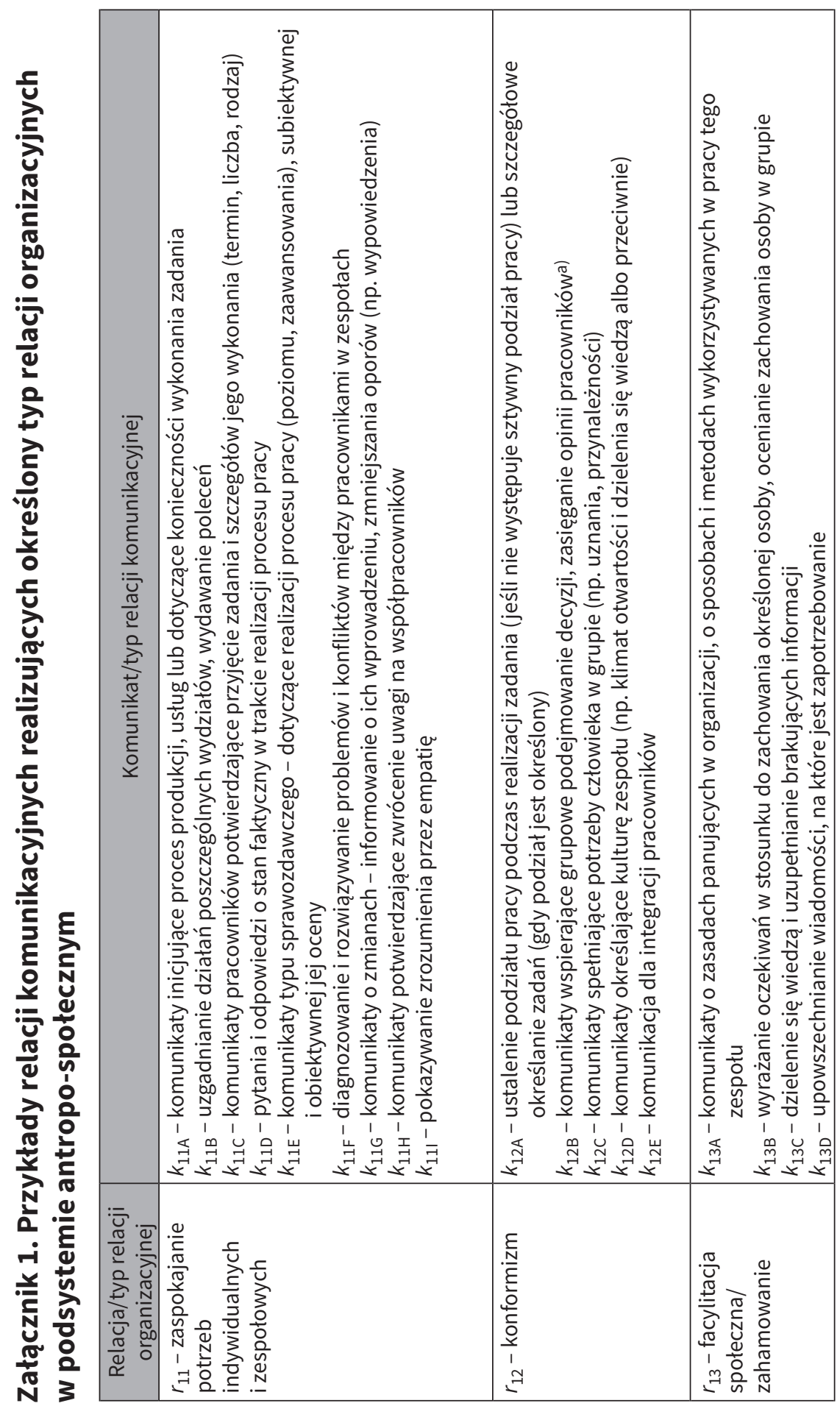




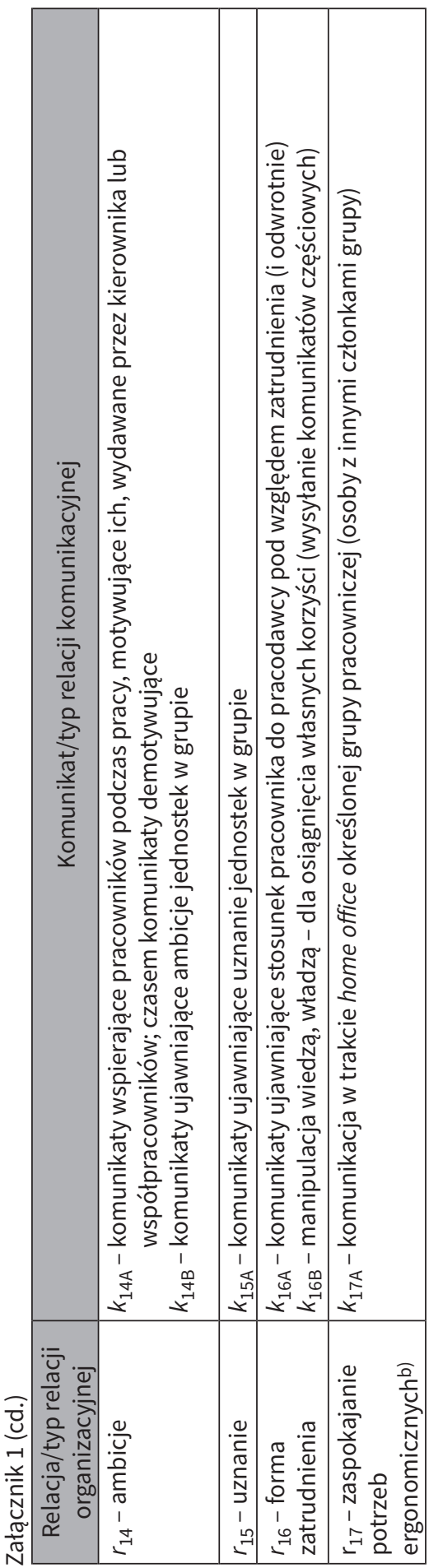

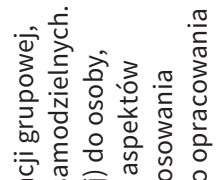
可

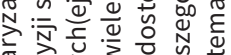

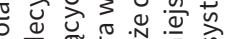

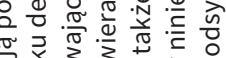

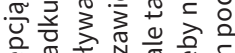

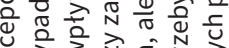

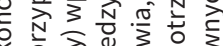
各合. N 3030

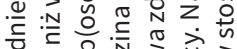

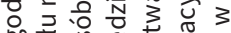

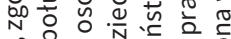

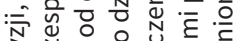

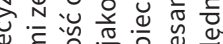

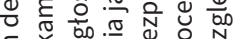

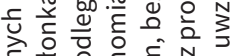

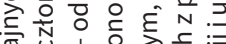

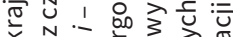
帘 N .

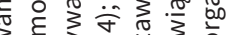
उत्रा $N$ 旅 ำ 궁

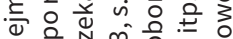

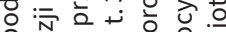
권단

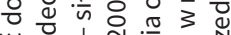

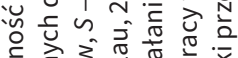

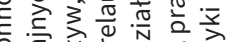

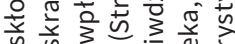
U.

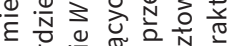

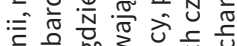
응 중

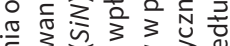

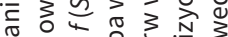
o

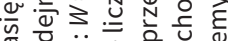
N 응 임

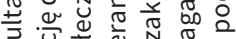
N

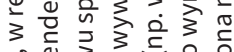

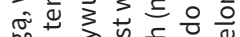
品 0 중.

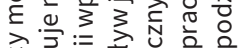

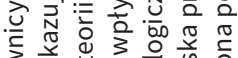

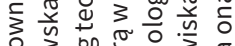

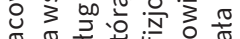

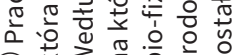


Załączniki

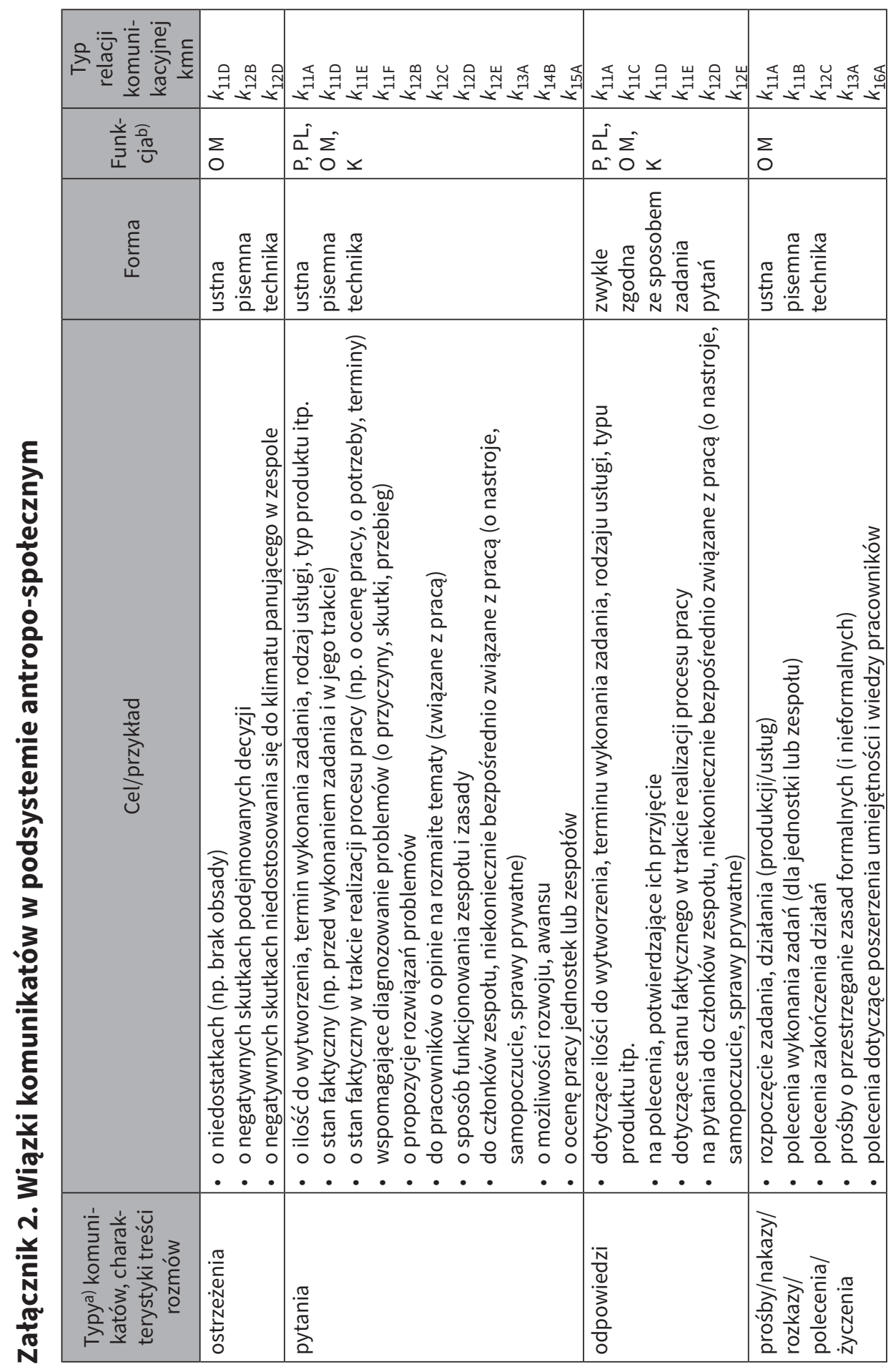




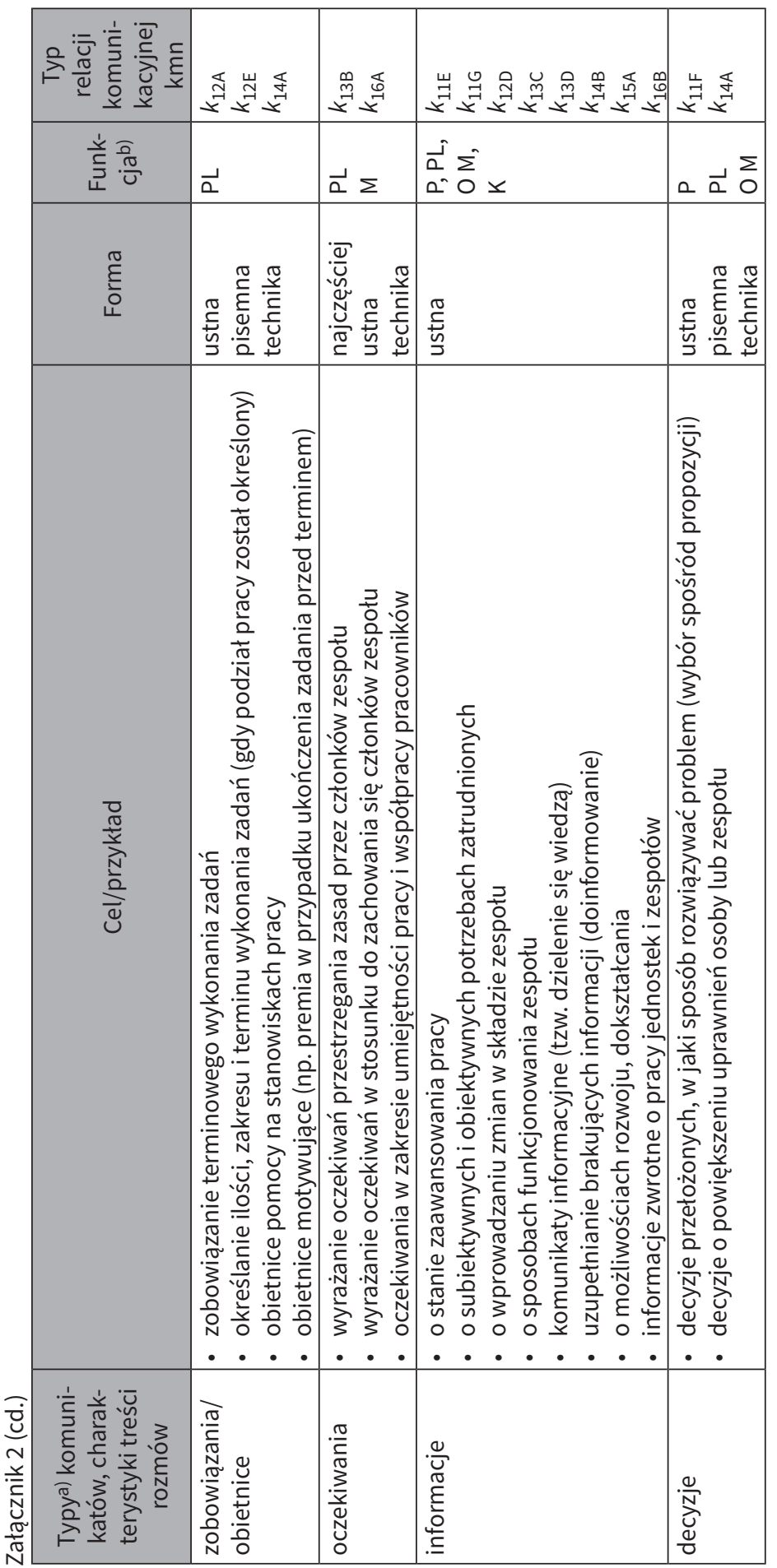




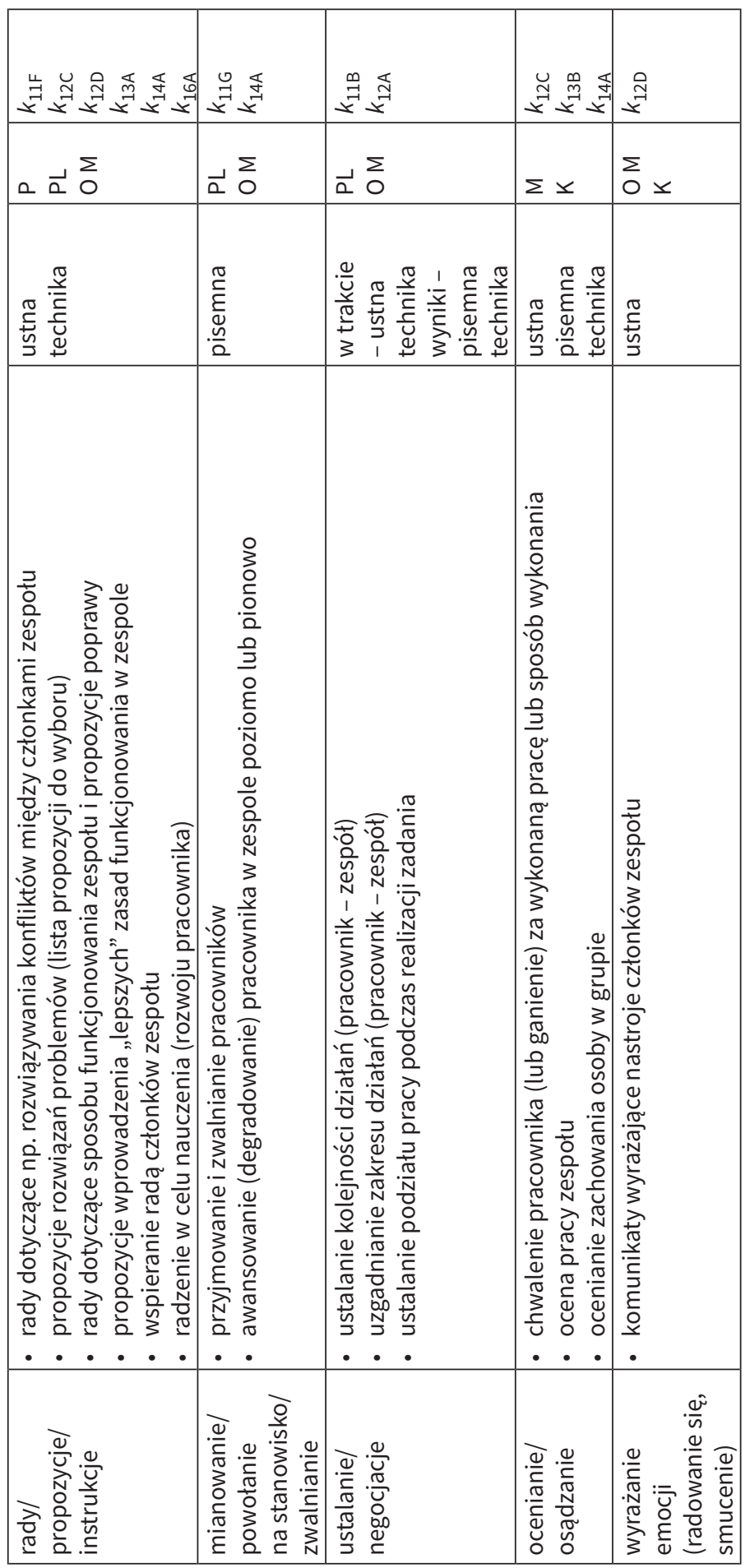

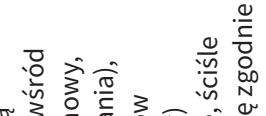
『̛⿱

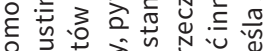

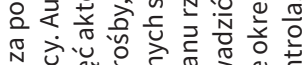
N

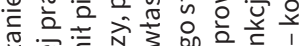

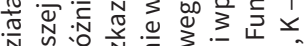

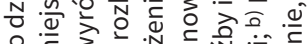

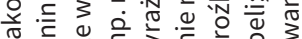

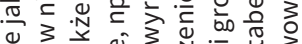
焉

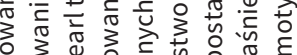
o w

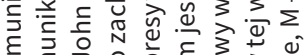

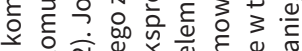

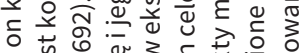

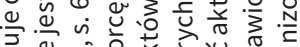
ㅍำ

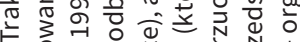

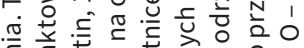
ब

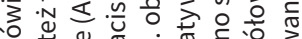

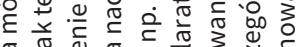
눈

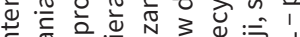

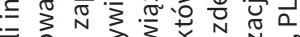

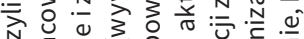
U

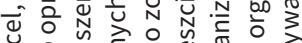
药

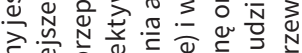

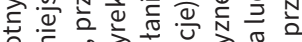
을 क्षे :

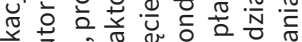

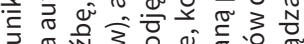

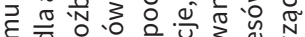

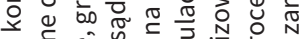

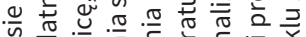

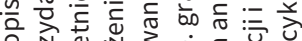

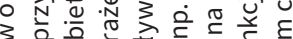

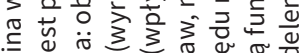

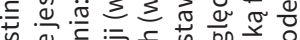

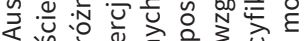

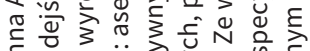

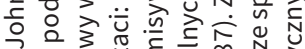

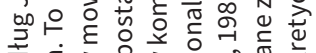

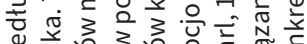

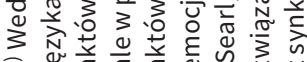




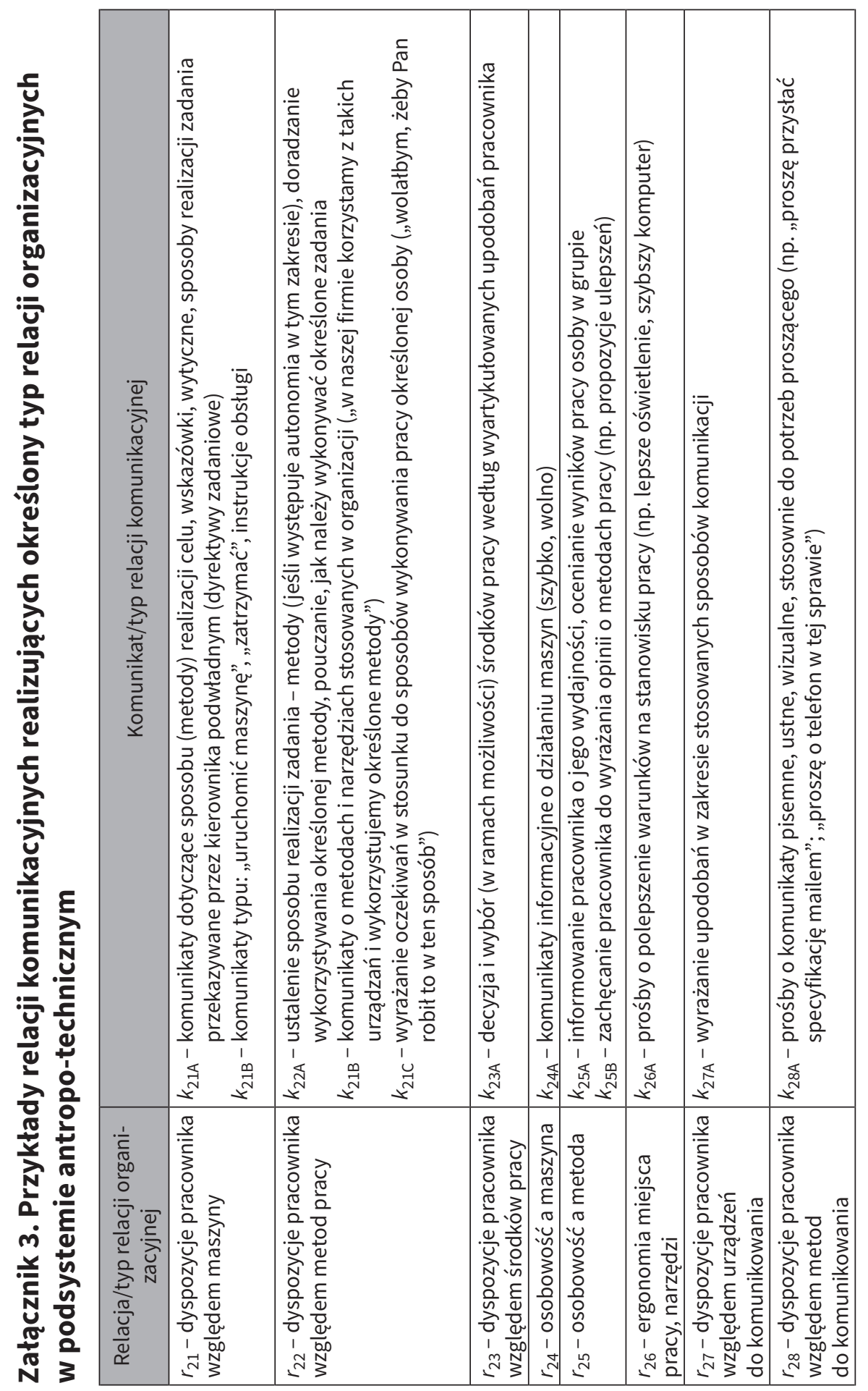


Załączniki

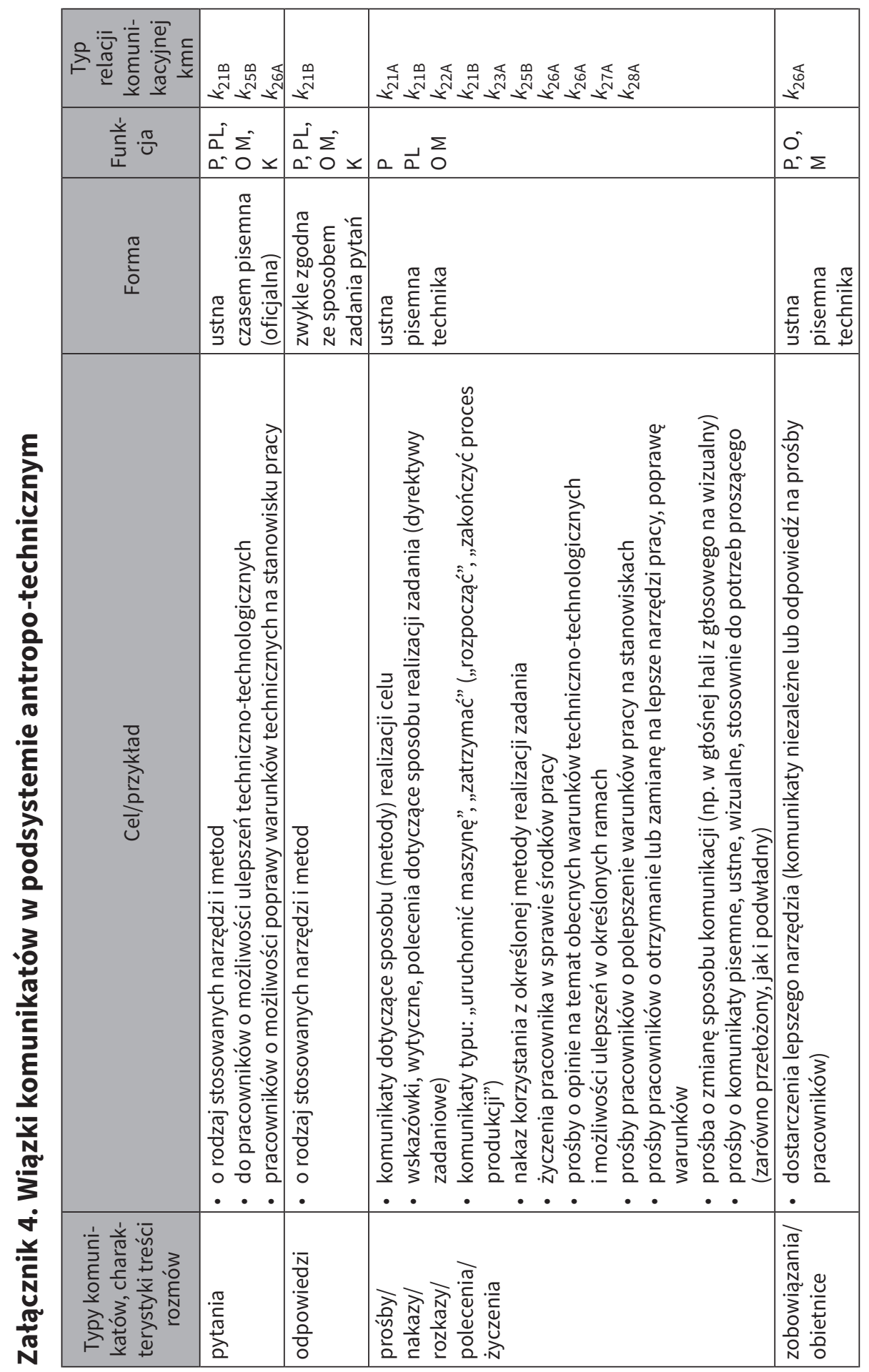




\begin{tabular}{|c|c|c|c|c|c|c|}
\hline 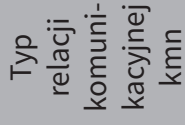 & 胥岕孞 & 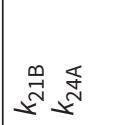 & 帝 & $\stackrel{\infty}{\sim}$ & 疍孞岕 & 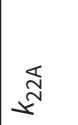 \\
\hline$\underset{⿱ 亠 䒑}{\frac{1}{5}} \cdot \frac{\sigma}{\sigma}$ & $\Delta_{\alpha} \sum_{0}$ & $\vec{\alpha} \circ$ & $\sum_{0}$ & $a \sum_{0}$ & a & $\sum_{0}$ \\
\hline $\begin{array}{l}\text { है } \\
\text { రิ } \\
\end{array}$ & 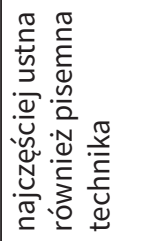 & 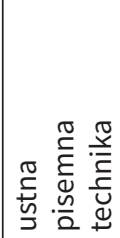 & 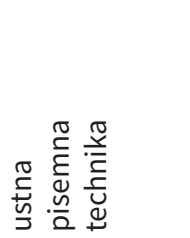 & 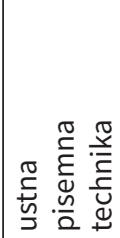 & 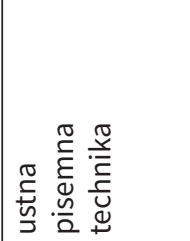 & 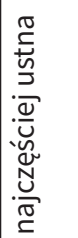 \\
\hline 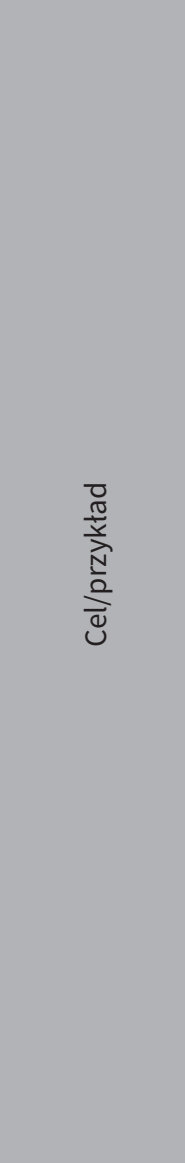 & 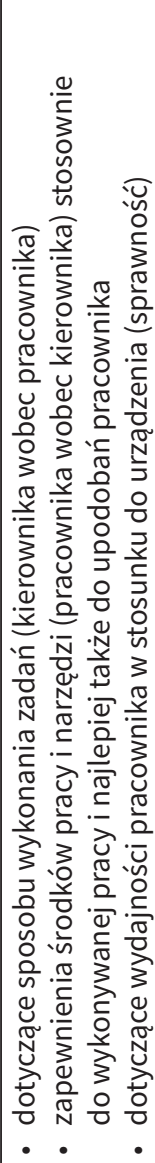 & 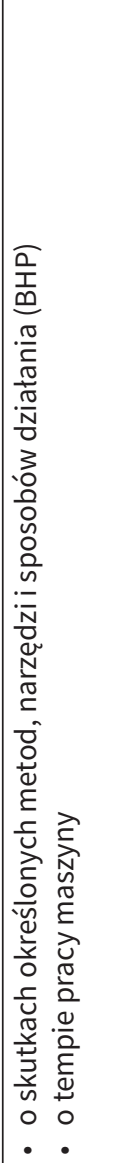 & 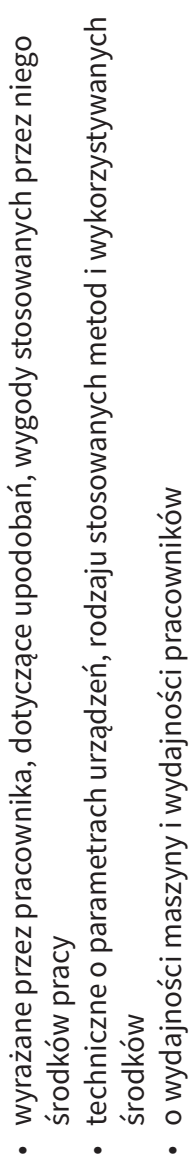 & 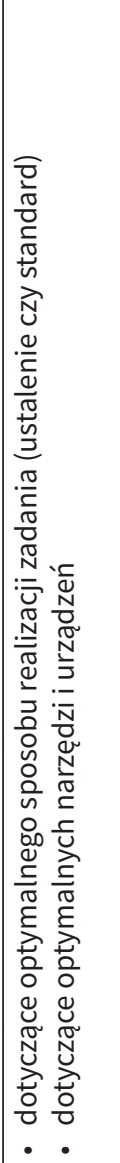 & 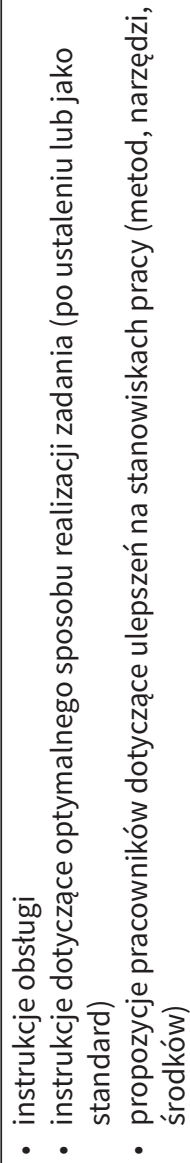 & 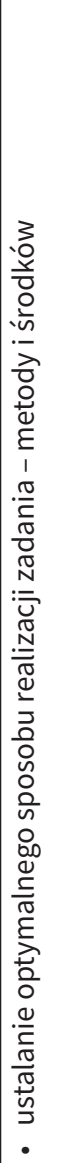 \\
\hline 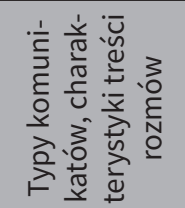 & 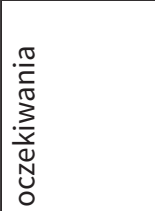 & 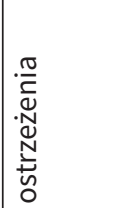 & 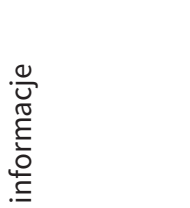 & $\begin{array}{l}\frac{d}{N} \\
\frac{d}{0} \\
\frac{d}{0}\end{array}$ & 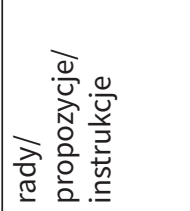 & 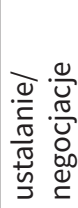 \\
\hline
\end{tabular}




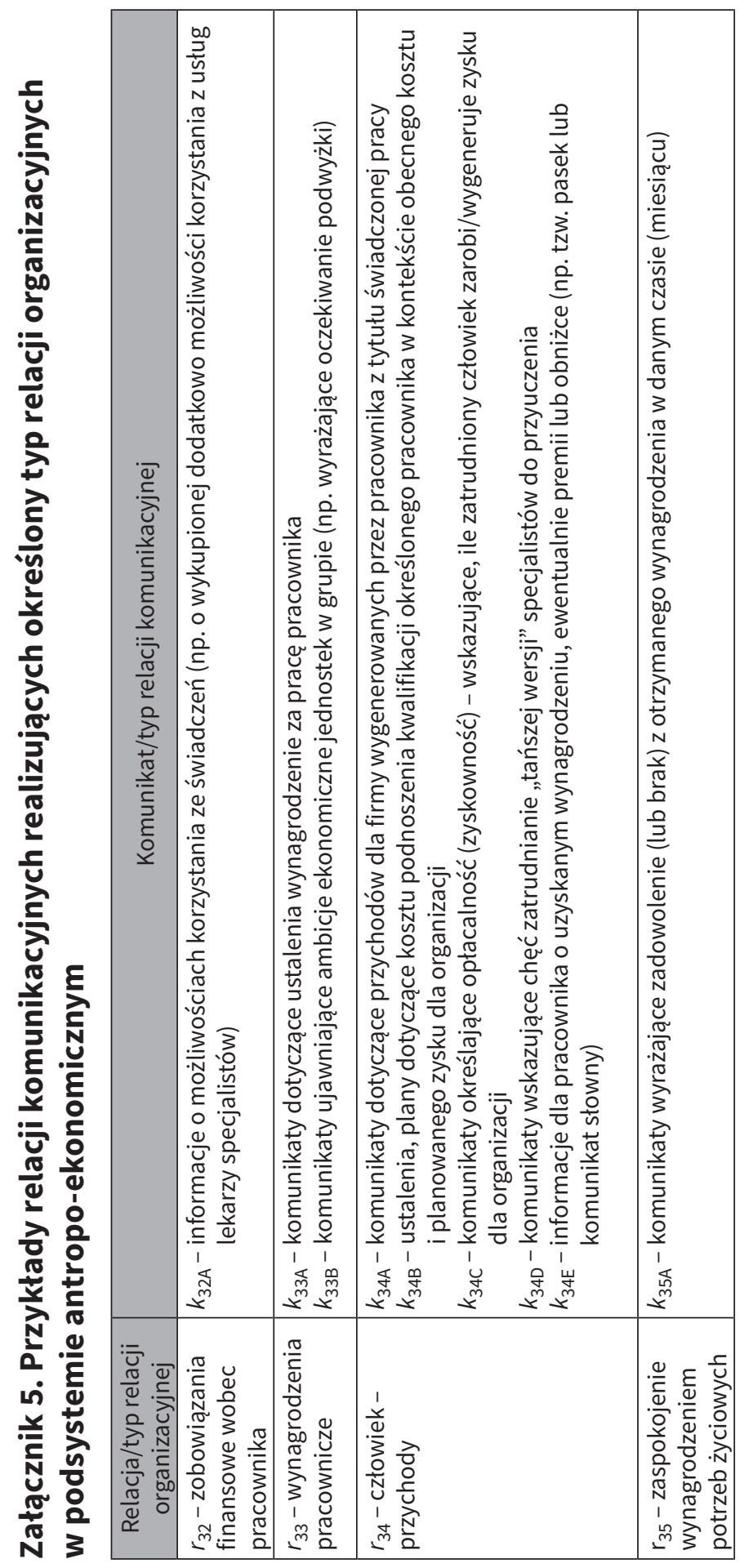




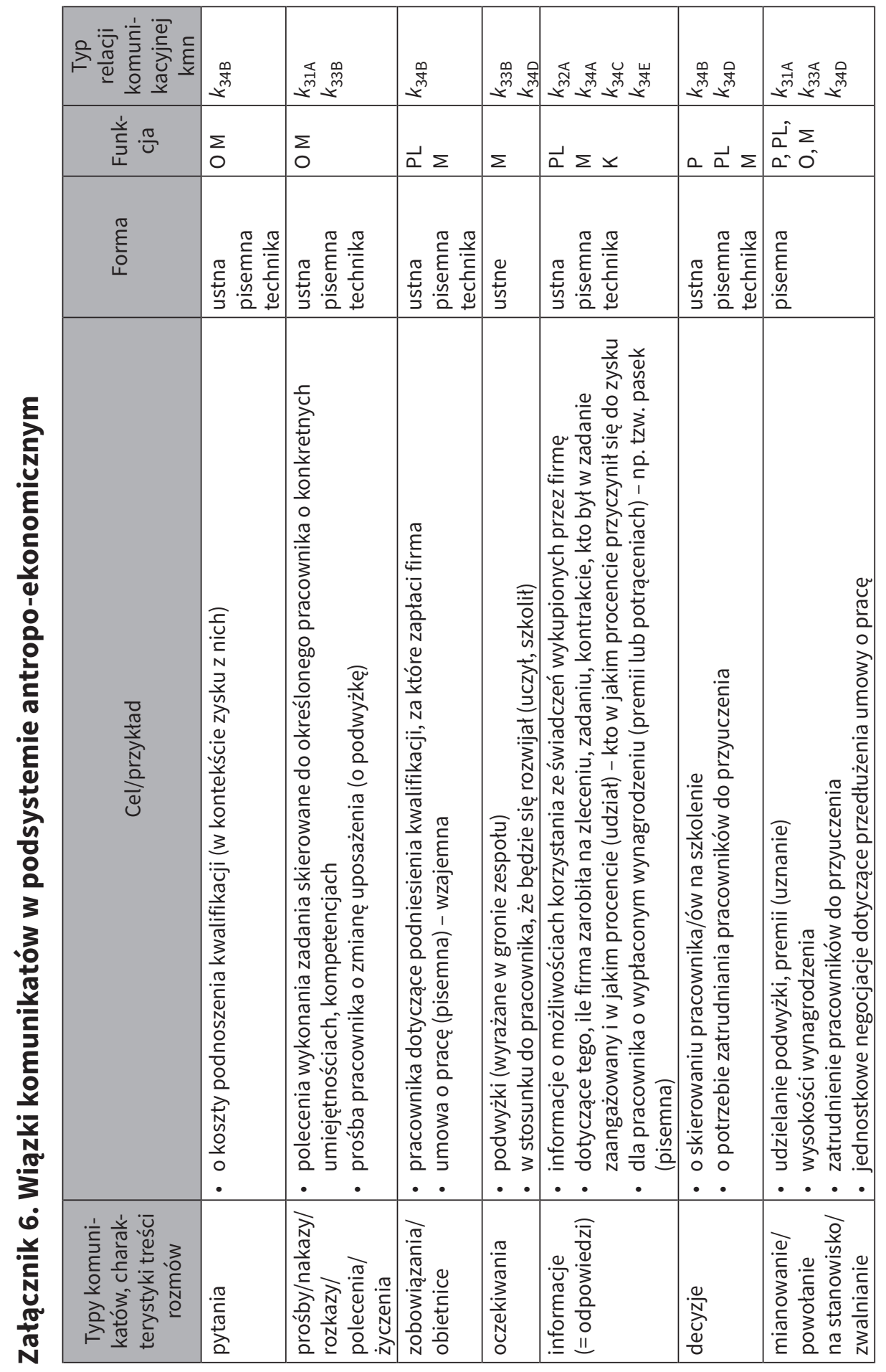




\begin{tabular}{|c|c|c|}
\hline 离 & 趈 & 怘 \\
\hline 0 & $\frac{Y}{\Sigma}$ & $\begin{array}{l}x \\
\Sigma\end{array}$ \\
\hline 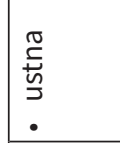 & 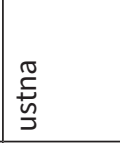 & $\begin{array}{l}\stackrel{0}{ \pm} \\
\stackrel{ \pm}{J}\end{array}$ \\
\hline 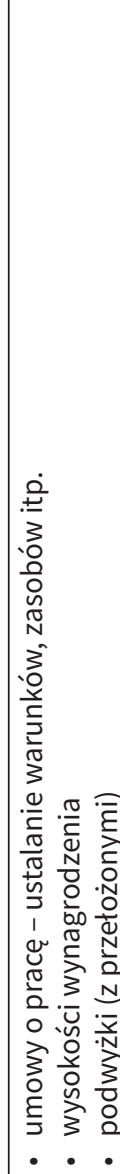 & 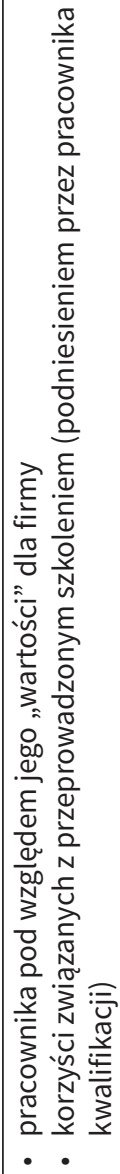 & 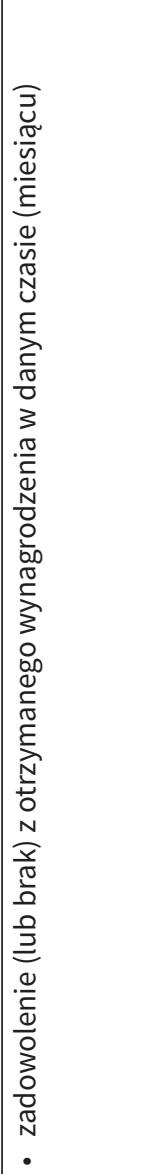 \\
\hline 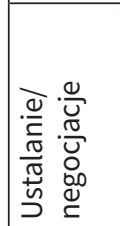 & 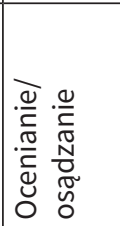 & 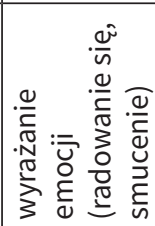 \\
\hline
\end{tabular}




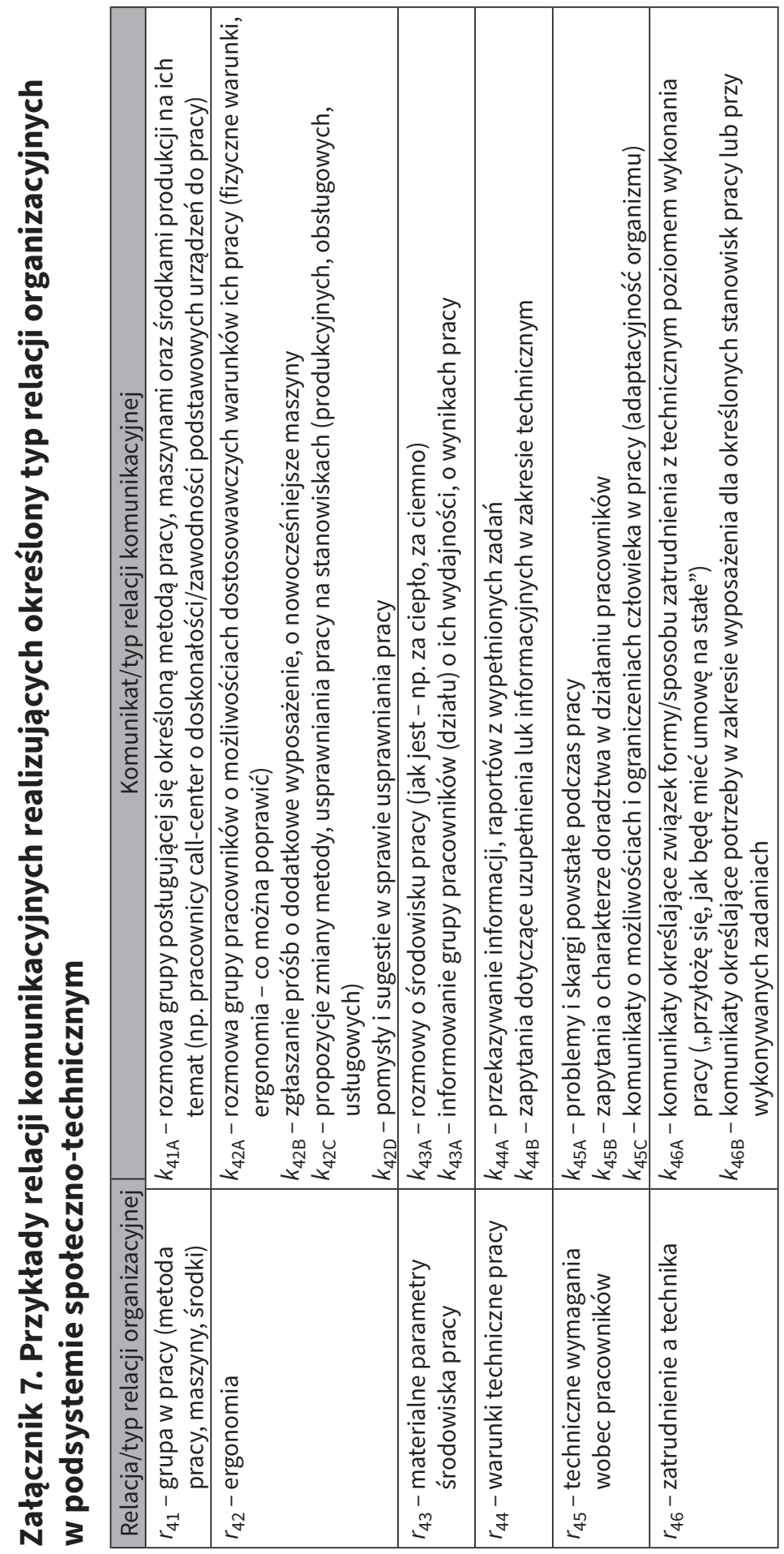


Załączniki

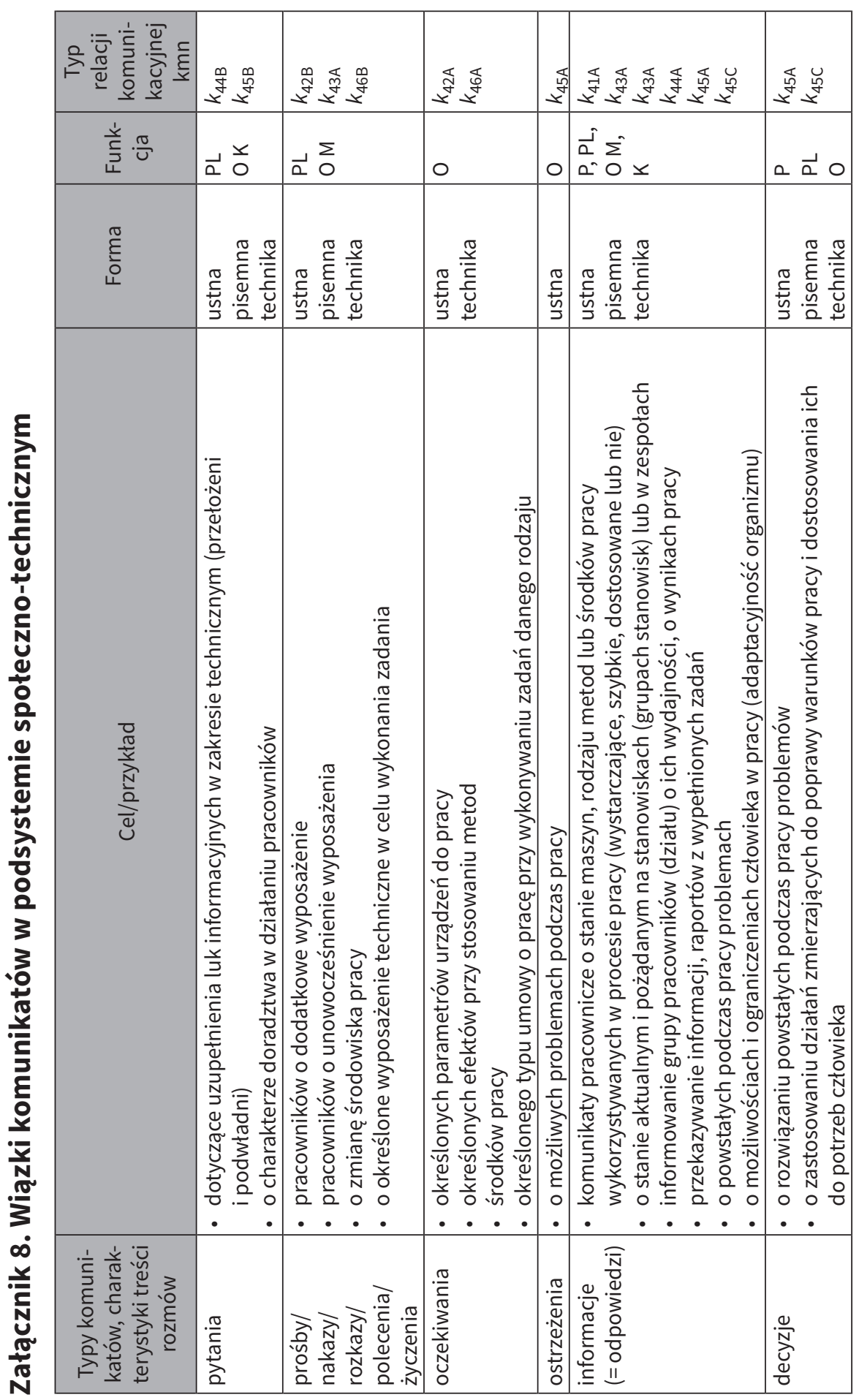




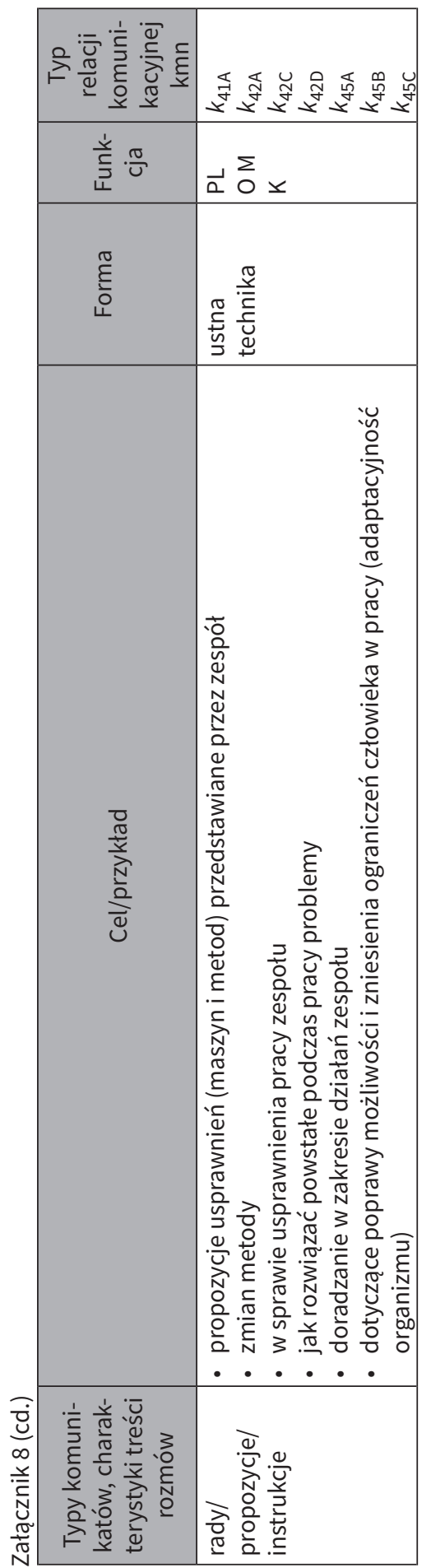




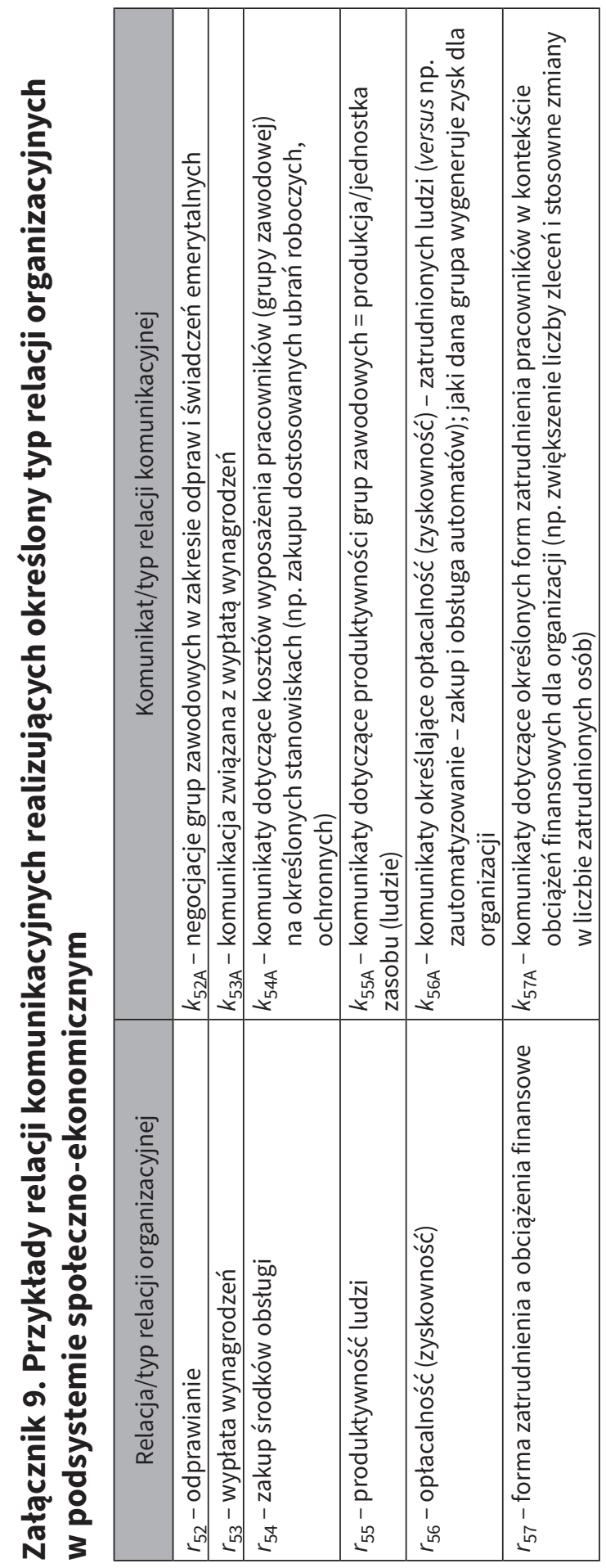




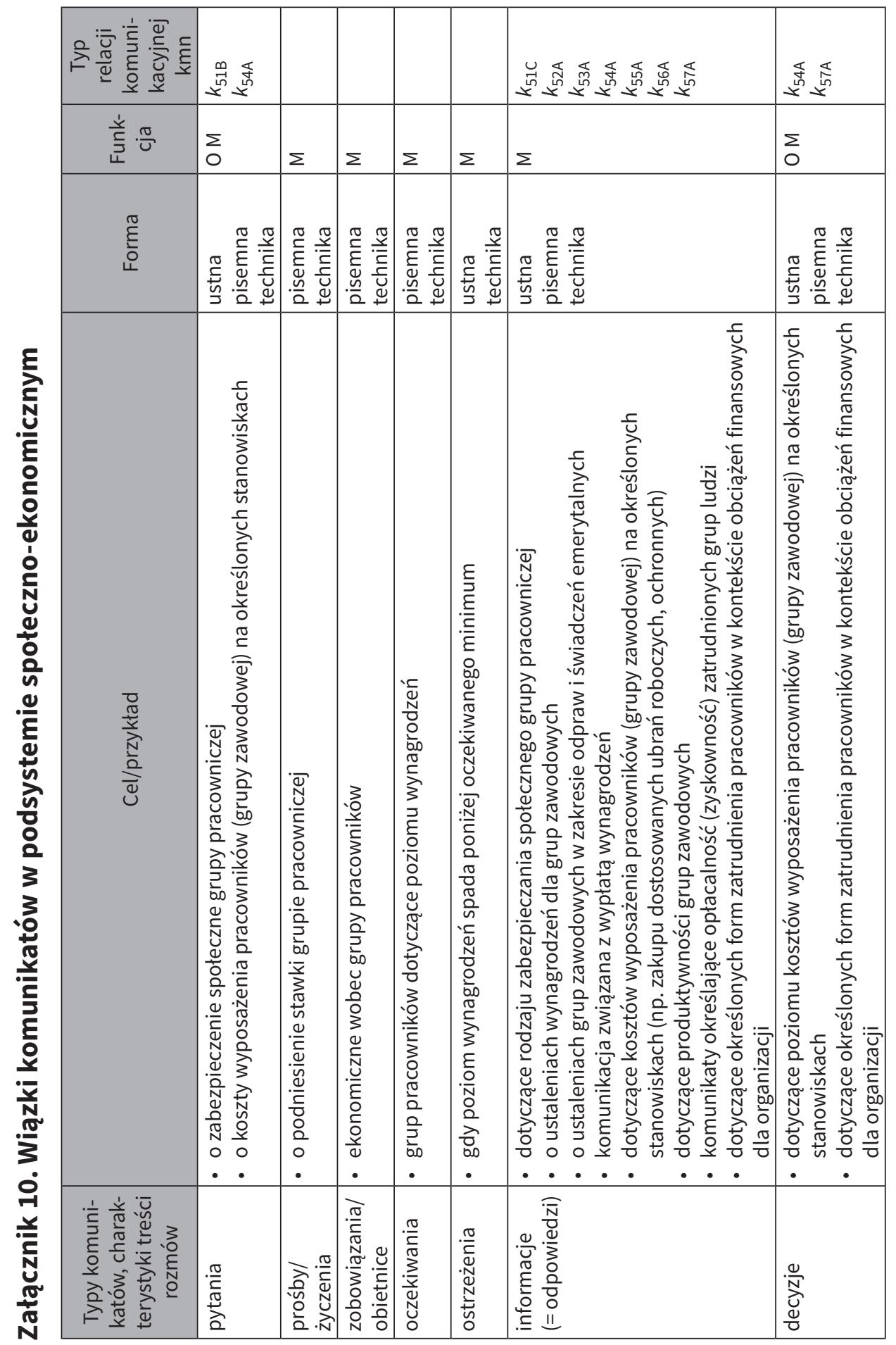




\begin{tabular}{|c|c|}
\hline$\underset{n}{\mathbb{N}}$ & 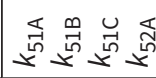 \\
\hline $\begin{array}{l}\hat{a} \\
a^{n} \sum_{0}^{n}\end{array}$ & $\vec{a} \Sigma x$ \\
\hline 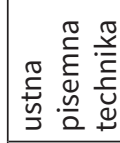 & 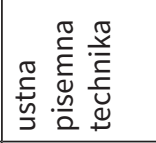 \\
\hline 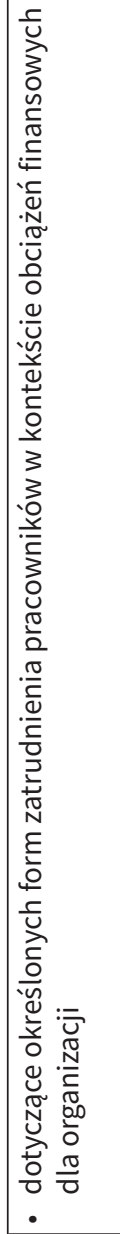 & 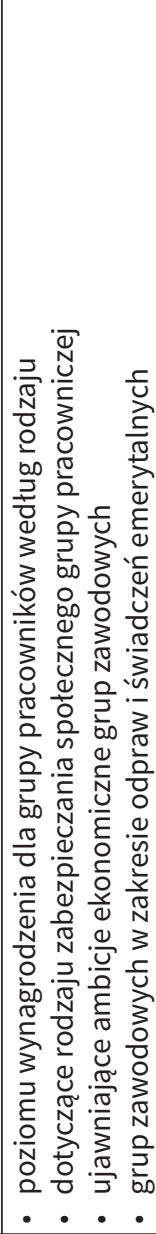 \\
\hline 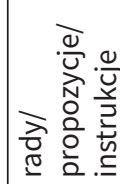 & 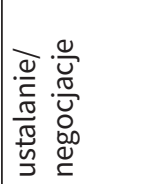 \\
\hline
\end{tabular}




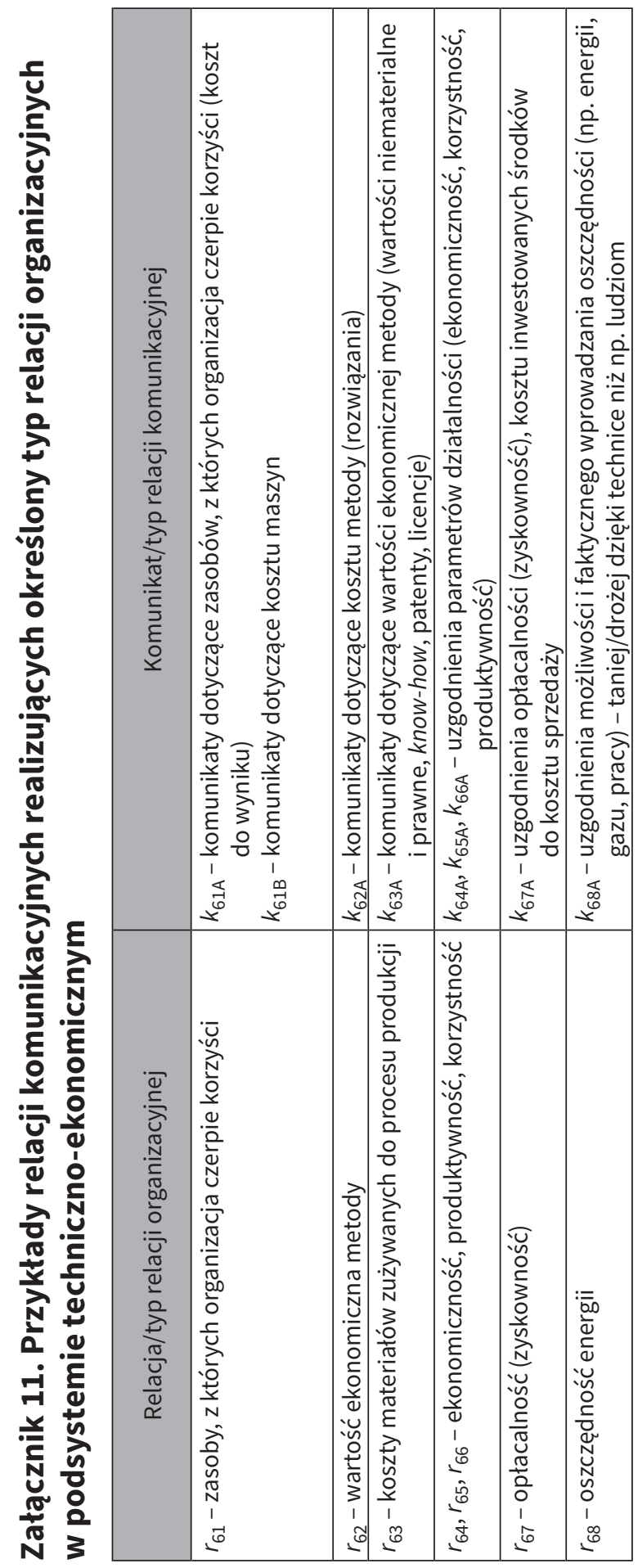


Załączniki

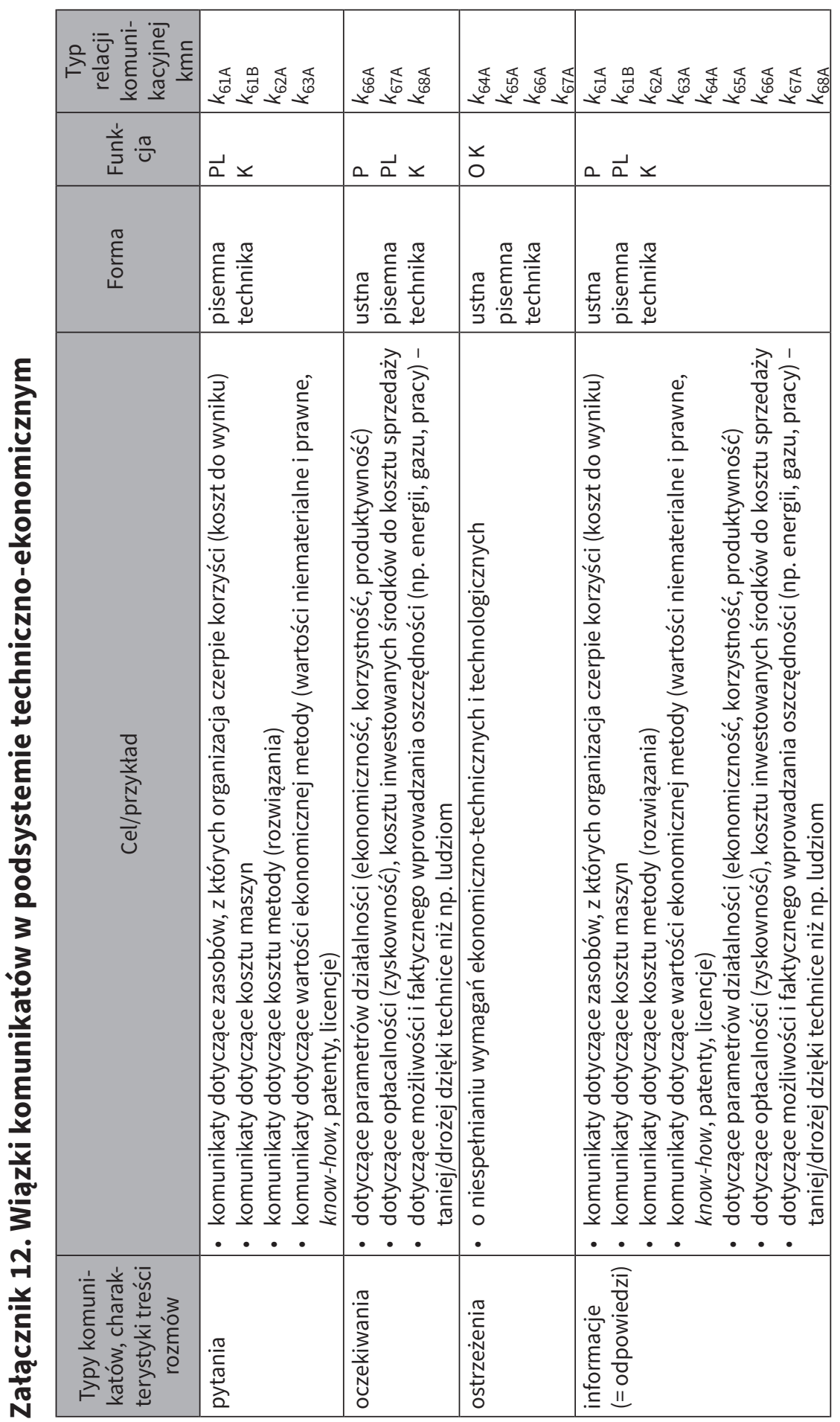


Załączniki

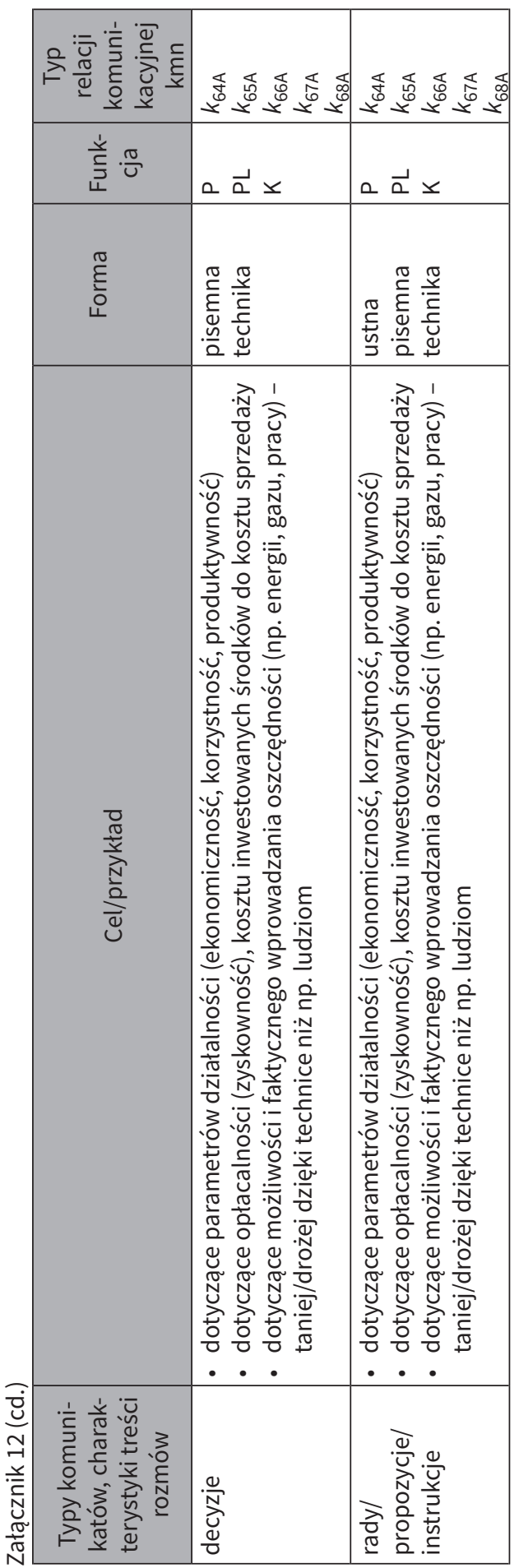




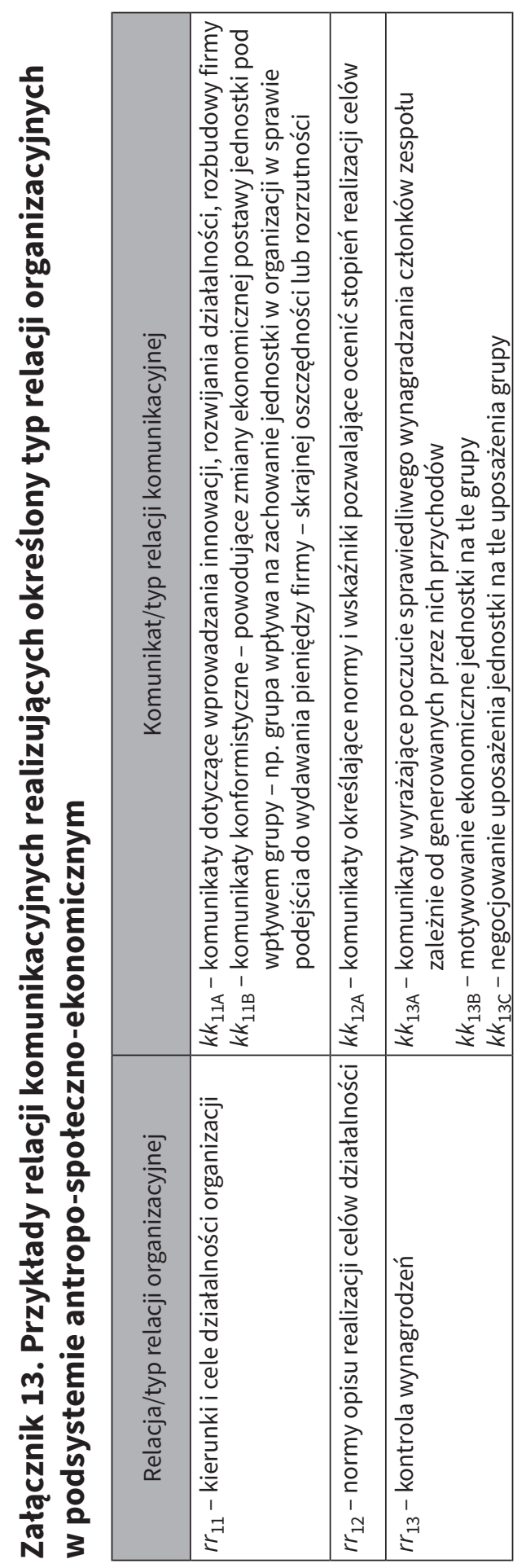




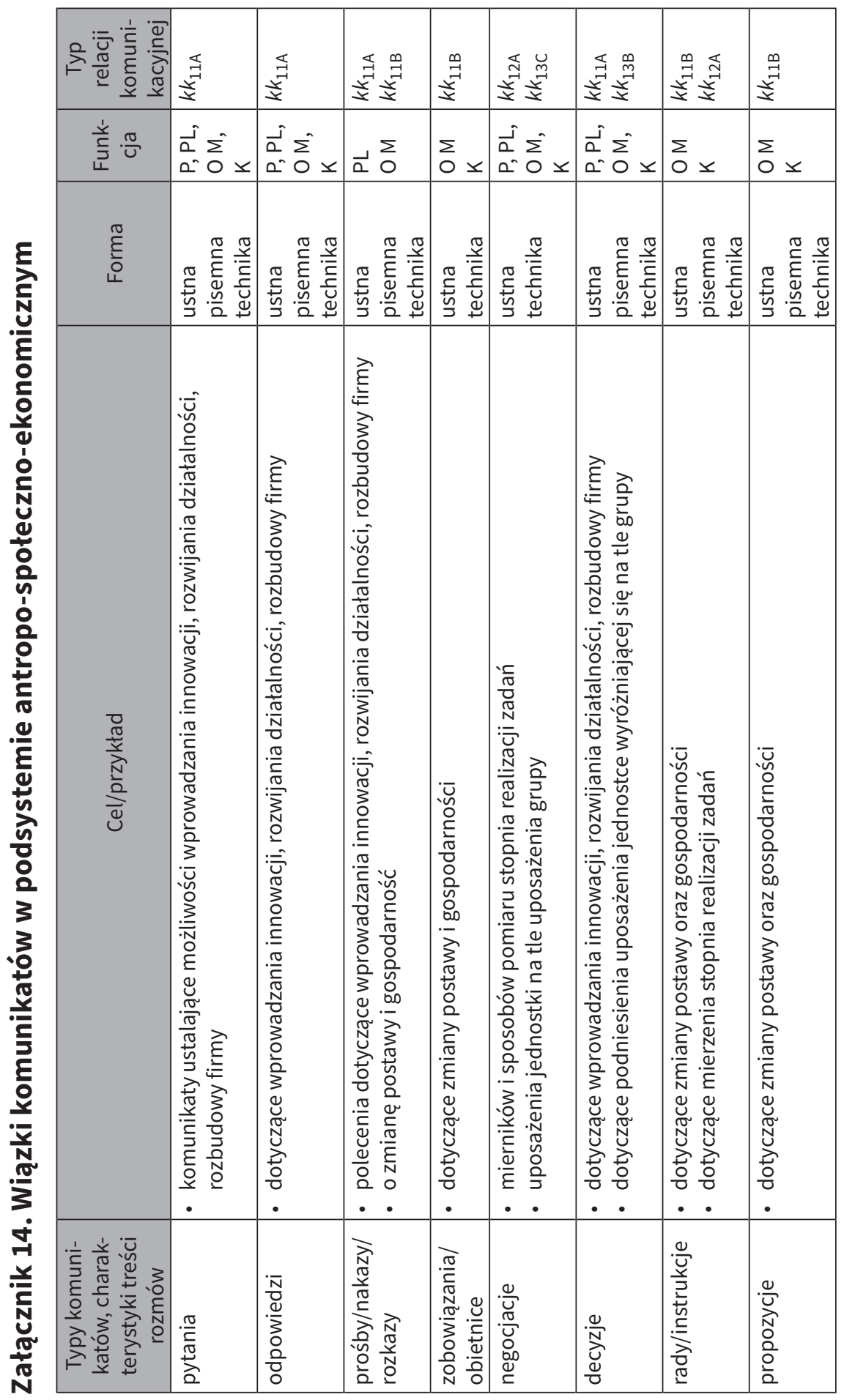




\begin{tabular}{|c|c|c|c|}
\hline 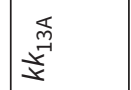 & 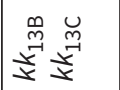 & 高旁 & 豙 \\
\hline$\sum_{0}$ & $\Sigma$ & $a \not \sum_{0}$ & \\
\hline 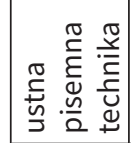 & 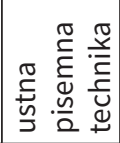 & 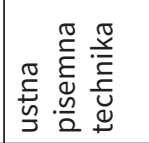 & 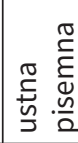 \\
\hline 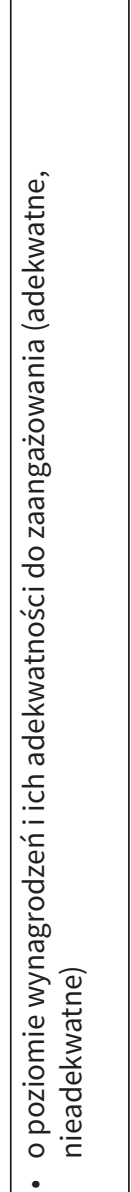 & 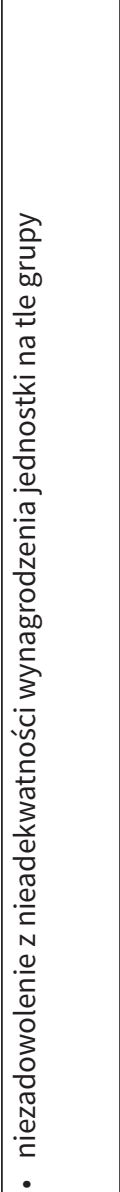 & 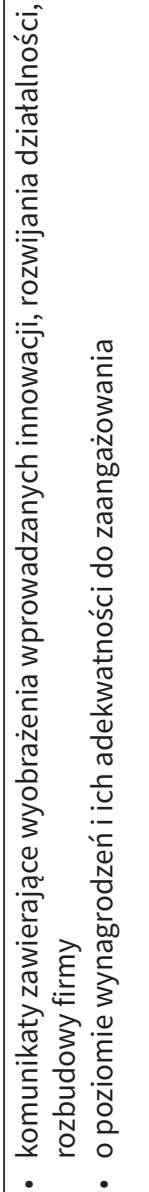 & 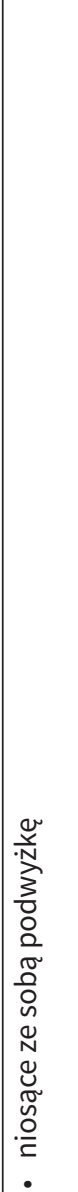 \\
\hline 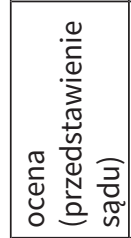 & 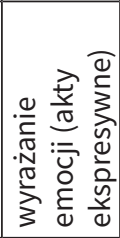 & 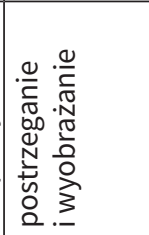 & 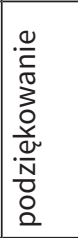 \\
\hline
\end{tabular}




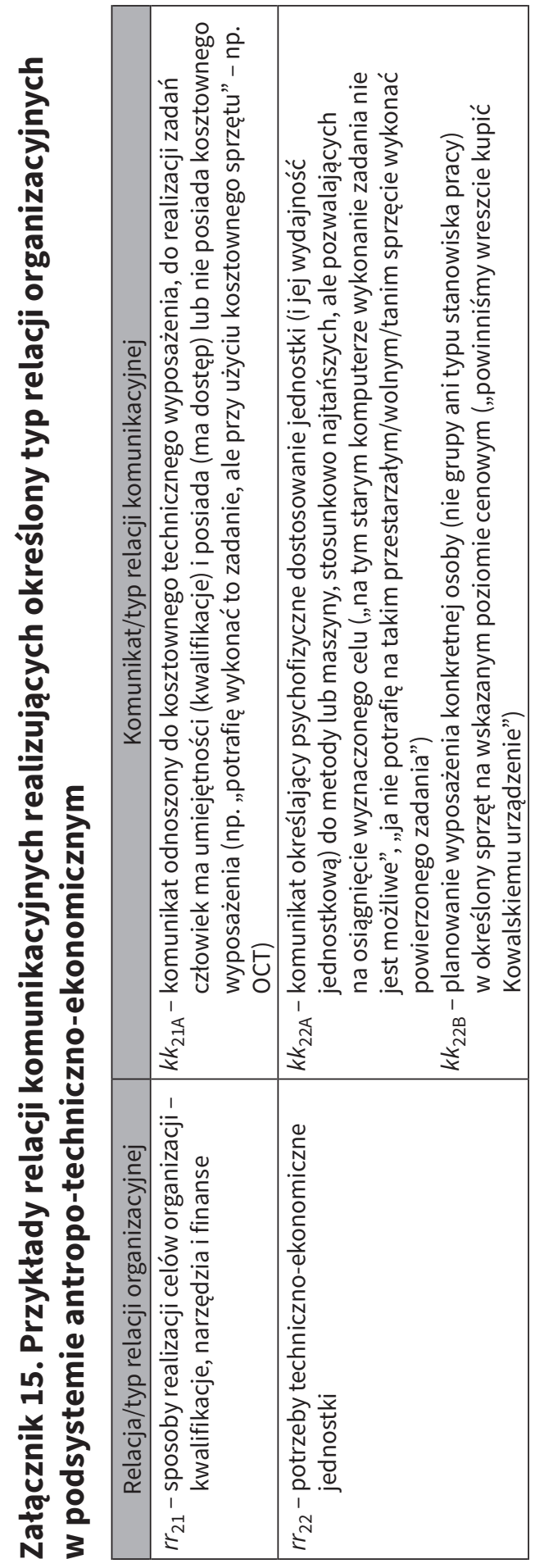


Załączniki

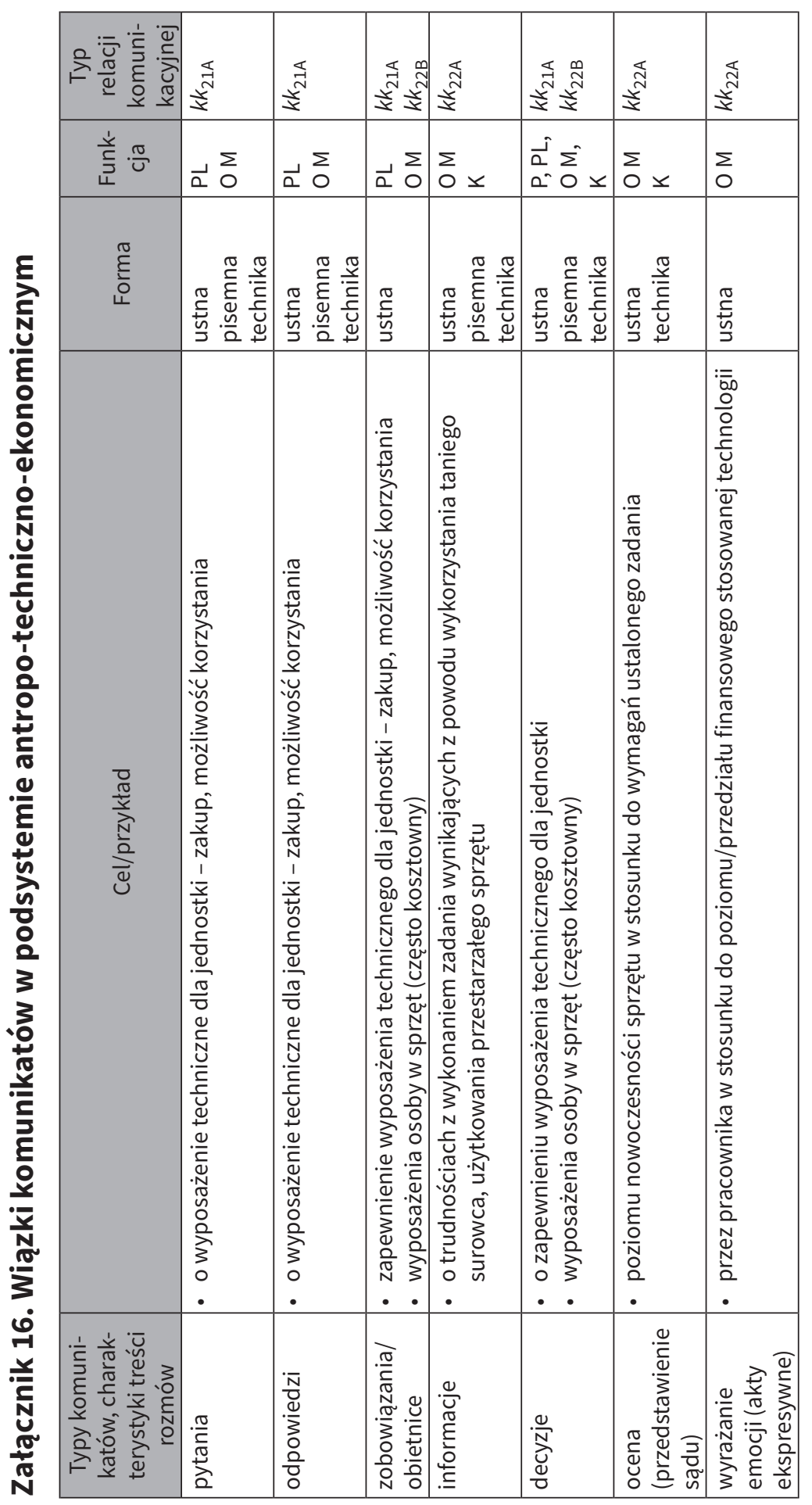




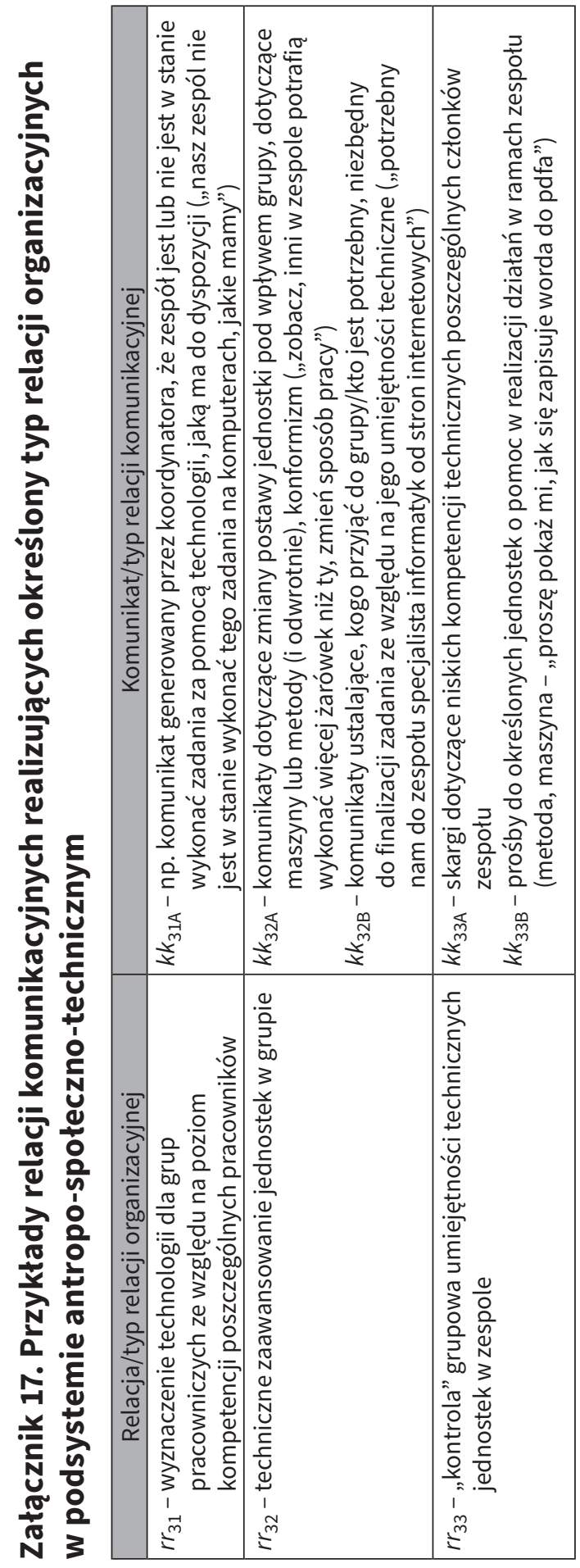




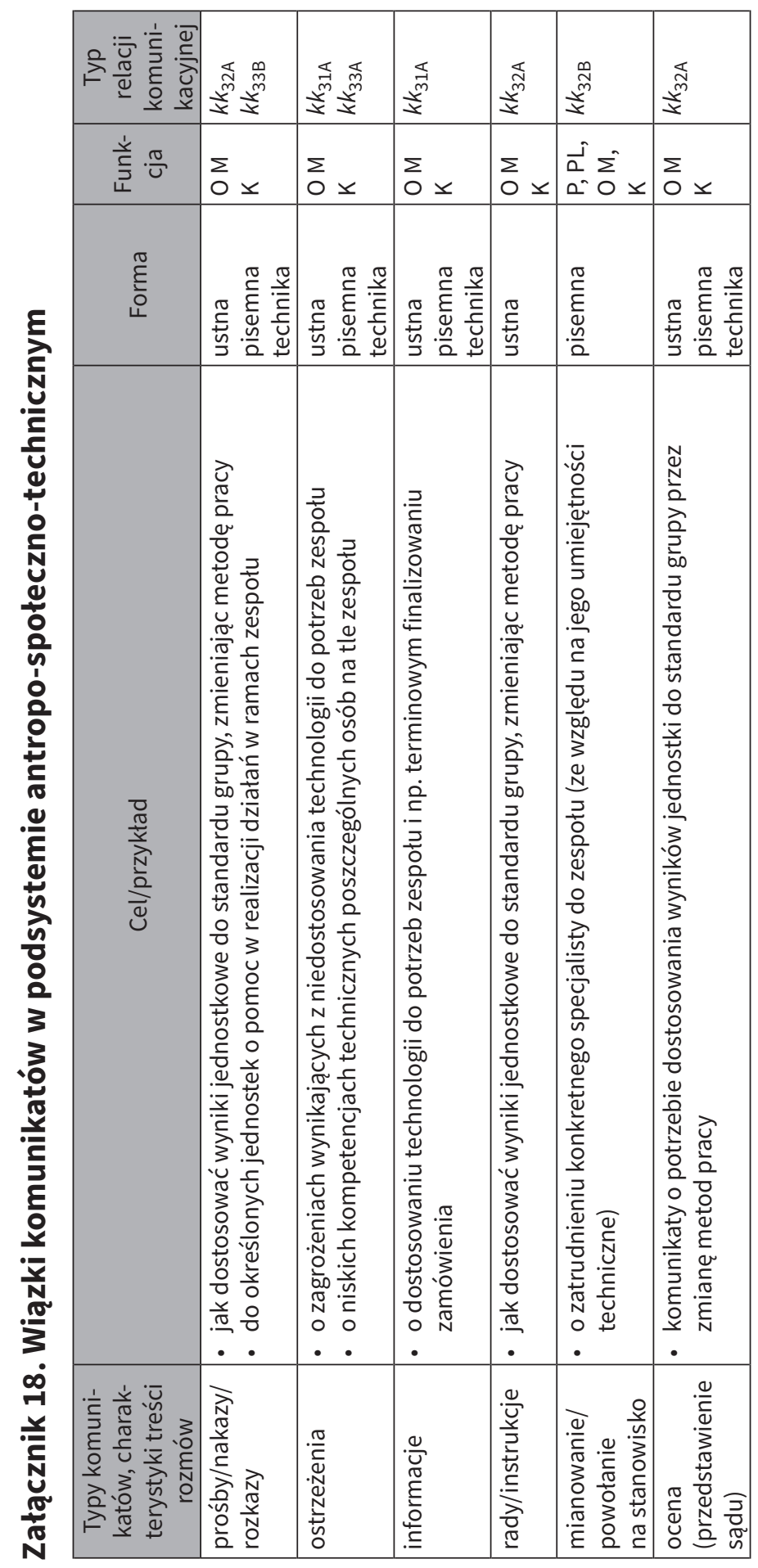




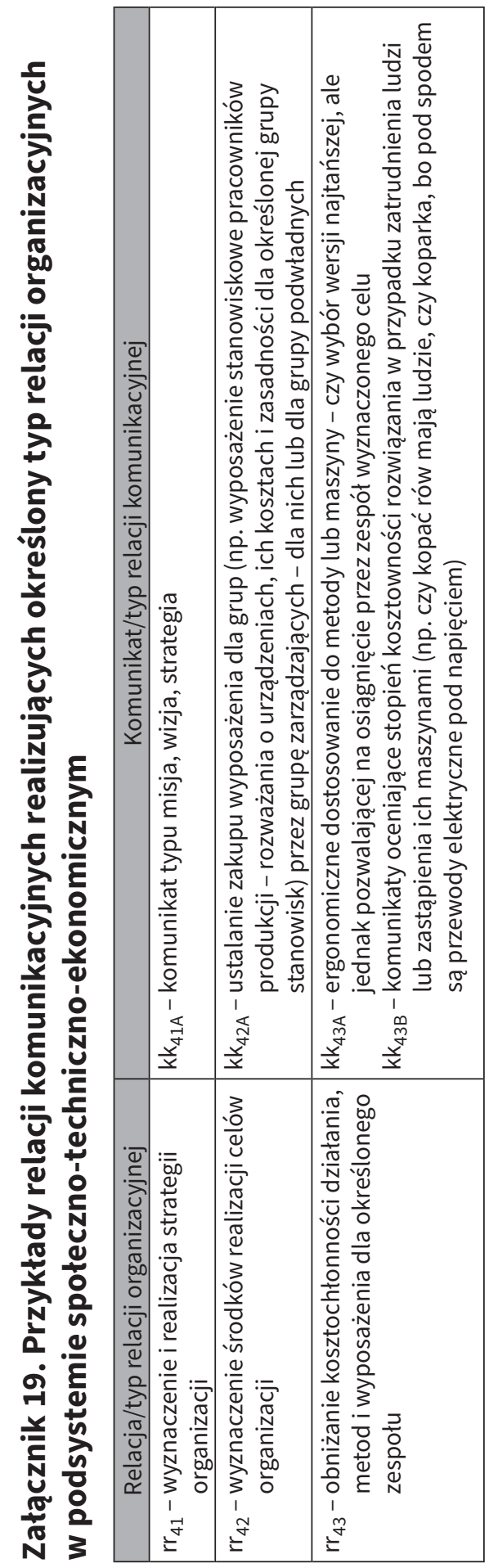


Załączniki

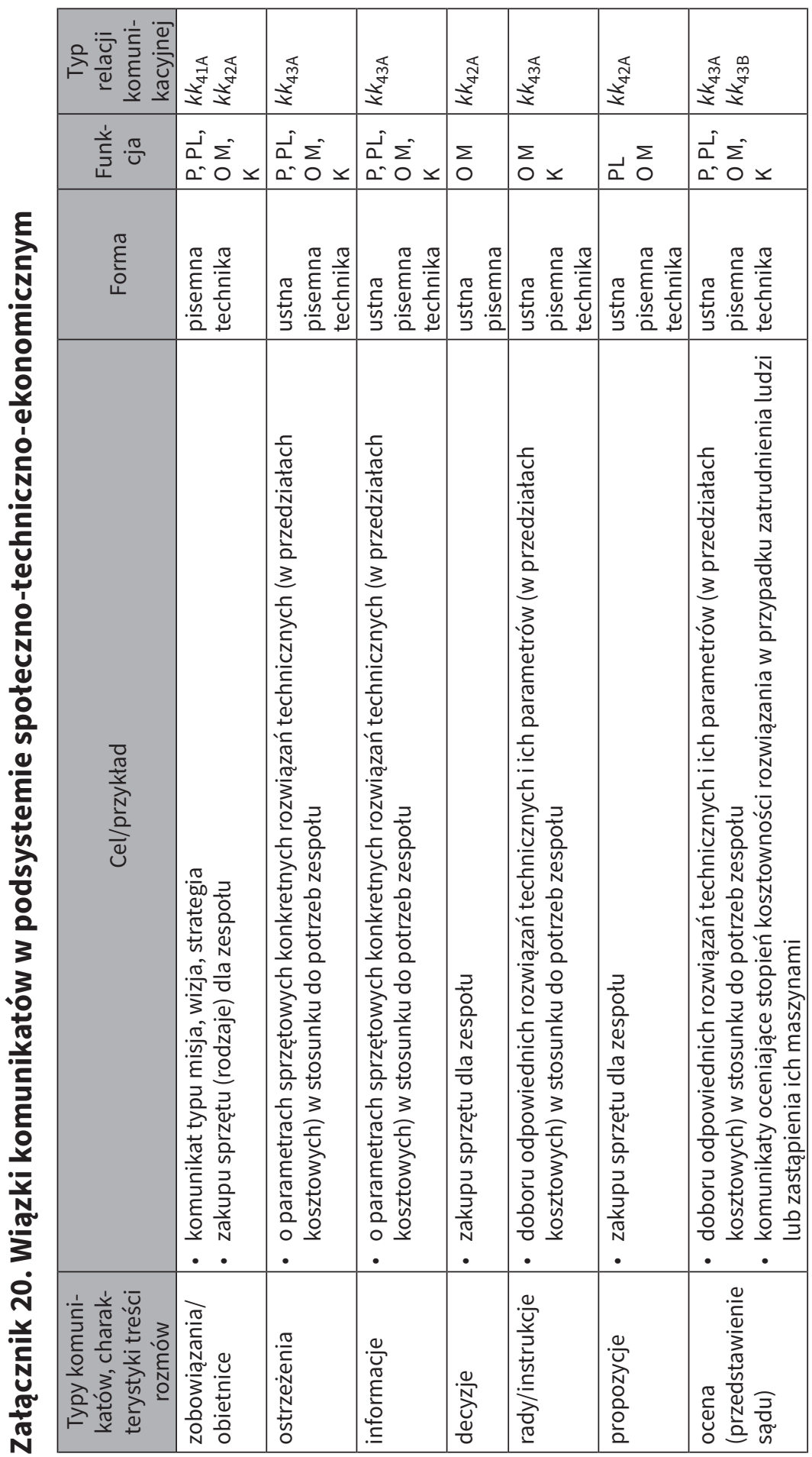


Załączniki

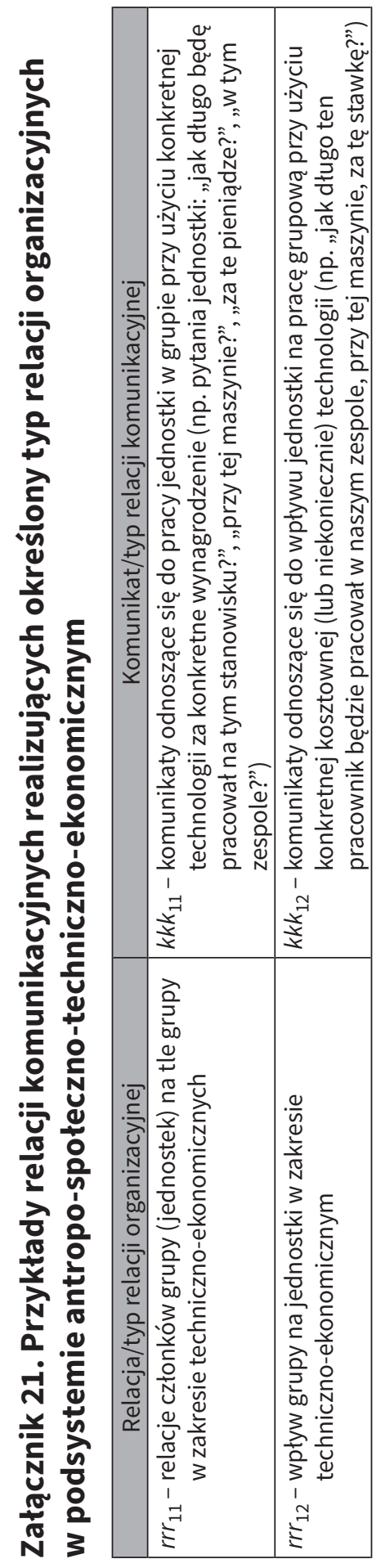




\section{Abstract}

\section{Organization as a system of the network of integrated communication relations}

Keywords: communication, coordination, efficiency, relations, systems

In economic life and in the organization's operations, important, if not the most important, is its efficiency. It decides about the success of the organization, customer satisfaction and the overall success of the company. Inefficiency is, therefore, a problem. Communication is the most important social process, and in the organization, it allows for coordinating collective actions. A significant number of detailed causes of different scales were identified among the sources of the organization's inefficiency. In this work, it was assumed that the basic problem in achieving organizational efficiency is ineffective communication disturbing the coordination of employee activities. Here, therefore, lies a cognitive gap that the author tries to answer in the course of her work, and her goal is to show the relationship between organizational efficiency and communication.

On the basis of the theory of organization, the understanding of communication relations in companies is still largely intuitive, not subjected to rigours posed to theories (description, explanation, and utilitarian guidelines). Scientific and application goals were formulated in the work - the scientific goal is to develop a systemic model of integrated communication relations in the organization and a scientific method of system analysis leading to the improvement of organizational efficiency through intra-organizational communication. The application goal is to create the possibility of using this model in the process of improving the organization management and increasing its efficiency through communication.

The author separates the main thesis of the study that there are certain types of activities which, when used in a specific order, determine the efficiency of the organization - these include communication, integration, coordination and organizing (in a functional sense) - into the following detailed theses:

1) Communication conditions integration,

2) Integration conditions coordination, 
3) Coordination conditions the organization,

4) Organizing determines efficiency.

The result of the work is a model of the organization for improving the organization's efficiency through communication. Communication is treated here as a tool, and the model and the accompanying system theory used as a tool allow for a systemic explanation of the phenomenon of raising the efficiency of the organization by improving communication.

The first part of the work presents the achievements in the field of intra-organizational communication from two perspectives - when "social" communication takes place in the organization's environment and when communication constitutes the organization. Both approaches emerged from the social sciences and were adapted to organizational sciences, but their method does not allow for operationalization towards organizational efficiency. For a change, the systemic approach offers the possibility to see the organization from the perspective of subsystems and relations between them - identical to the characteristics of the communication process. In addition, the methods of analysis (and synthesis) of complex systems enable the operationalization and enhancement of organizational efficiency through internal communication. This method was chosen to achieve the goals of the work. For this reason, the further part of the first chapter refers to the output of the science of systems and presents an analysis of its content and critical evaluation, which also constitutes a detailed analysis of the cognitive gap in this respect. The focus was on the systemic concept of relations, because communication in this work is treated in a relational way, and the theory of systems has developed a formal form of recording intra-system relations. When constructing the model of the organization as communication, the form of this record was referred to.

The second part has a methodological and research character; it begins with an explanation of the extent to which system analysis in this work is a methodical advantage over classical analysis and analysis of social networks. Further, it was shown that it is not possible to adapt the functioning organizational model as the basic system for further work and that it is necessary to build a model based on the method of system analysis as a research method. Assuming that the effect of the work may be similar to the existing ones, for the sake of methodical correctness, the construction of the systemic model was undertaken using the system method. Subsequently, this chapter presents previously developed for the organization's purposes research methods of system analysis and detailed procedures within the method, which, however, were limited to decision-making methodologies or corrective methodologies for specific functions - the wider context of system analysis procedures was not found in the literature. For this reason, the author broadly sought inspiration for building her own proposal for a method of analyzing complex systems, going beyond the discipline 
and directing her interest at the general theory of systems. She found such inspiration in Jaroslav Habr and Jaromir Veprek (1976), Peter Checkland (2000) and John Mingers $(2014 ; 2017)$. At the end of this chapter, she presented her own modification of the system analysis method as a research method.

The fourth chapter presents the application of the designed method of analysis of complex systems. The separated real elements of the system were incisively sorted into first-order subsystems and the relations between them were distinguished. Next, the second-, third- and fourth-degree subsystems and their mutual relations have been consistently separated. The communication relations have been mapped on separate relations of the organizational subsystems - specific relations are realized in the organization by means of specific messages. These messages were separated and tied in content beams that were functionally connected in the network, thus the basis of the organization model was created - a network of communication relations (of first-, second-, third- and fourth degree). The messages are then sorted and integrated due to the syncretic model of the management cycle. The result of the work presented in the third chapter is the model of the network of integrated communication relations, which is the basis for further work on building a model of organizational coordination for efficiency.

In the fifth chapter, in the construction part, a model of communication coordination for the needs of organizational efficiency was created as a system of the network of integrated communication relations, previously prepared. In this study, the coordination function was recognized as a superior management function, therefore the relations of communication are integrated precisely because of this function; this assumption was justified. In classical theories, coordination was understood more broadly than among contemporary authors. Current approaches to coordination are indicated by the range of detailed approaches used in this work to develop five groups of indicators for organizational coordination (through communication). The need for the operationalization of coordination indicators has initiated the need to turn to the praxeological level, which allows for measuring the efficiency of the organization and achieving the organizational effect (through communication coordination).

These explanations lead to the presentation of 31 indicators of organizational coordination for the efficiency of communication, divided into five generic groups - structural, functional, resource, time and spatial. The indicators have been designed consistently, in such a way that their value is always between 0 and 1 , with the increase in the indicator being the same as the increase in organizational efficiency. The work ends with the conclusion which indicates the directions for further research and the possibilities of using the method and model proposed in this work. 



\section{Spis rysunków}

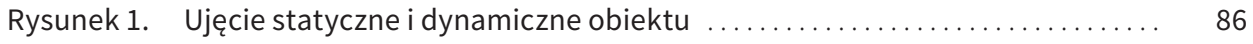

Rysunek 2. Model układu .......................................... 102

Rysunek 3. Model systemu ............................................ 102

Rysunek 4. Procedura analizy systemowej wedtug Quade'a $\ldots \ldots \ldots \ldots \ldots \ldots \ldots \ldots . \ldots 11$

Rysunek 5. System idealny wedtug Geralda Nadlera ........................ 112

Rysunek 6. Procedura analizy systemowej Findeisena i Quade'a . . . . . . . . . . . . . 115

Rysunek 7. Procedura analizy systemowej z pętlami iteracyjnymi Findeisena i Quade'a .............................................. 115

Rysunek 8. Algorytm systemowego opracowania organizacji .................. 117

Rysunek 9. Relacje pierwszego stopnia .............................. 132

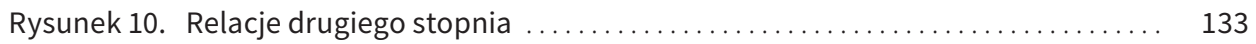

Rysunek 11. Wybrane relacje trzeciego stopnia ........................... 134

Rysunek 12. Synkretyczny model cyklu zarządzania ........................ 143

Rysunek 13. Grupy relacji ......................................... 145

Rysunek 14. Schematyczna przykładowa struktura systemu jako całości ........... 146

Rysunek 15. Wstępny model organizacji na etapie uporządkowania elementów (wersja przestrzenna na płaszczyźnie i uproszczona wersja „płaska”) .......... 167

Rysunek 16. Podsystemy modelu społeczno-technicznego organizacji ............. 171

Rysunek 17. Przykład relacji zarządzania zakwalifikowanych według synkretycznego modelu cyklu zarządzania ................................... 178

Rysunek 18. Hierarchia komunikacyjnych potrzeb pracowników ................. 191

Rysunek 19. Model organizacji jako system sieci zintegrowanych relacji komu-

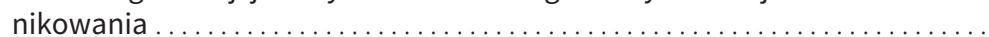

Rysunek 20. Szczegółowe poziomy modelu organizacji jako systemu sieci zintegrowa-

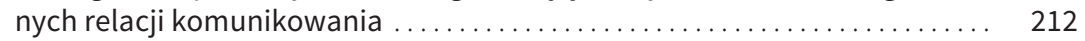

Rysunek 21. Model zarządzania (z selektywną eksplikacją jego funkcji i procesów) - w roli integratora relacji komunikowania wewnątrzorganizacyjnego .....

Rysunek 22. Schemat „obszaru pojęciowego” pojęcia koordynacji i koordynowania zakreślonego siecią relacji wokół wyodrębnionego centrum „koordynacja - organizacja" ........................................ 227

Rysunek 23. Model koordynacji organizacyjnej .......................... 240

Rysunek 24. Praca grupowa ........................................ 246

Rysunek 25. Praca zespołowa ..................................... 247 



\section{Spis tabel}

Tabela 1. Sposoby definiowania komunikacji wewnętrznej. ...

Tabela 2. Przegląd nurtów myślowych w kontekście ich zainteresowania komunikowaniem w organizacji................................ 33

Tabela 3. Systematyczne porównanie trzech szkół myślenia CCO .............. 49

Tabela 4. Podejścia systemowe związane z kontekstami problemowymi w systemie metodologii systemów

Tabela 5. Klasyfikacja systemów.

Tabela 6. Porównanie metod analizy klasycznej i systemowej.

Tabela 7. Porównanie analizy systemowej i analizy systemów społecznych w obszarze modelowania organizacji.................................. 105

Tabela 8. Przyczyny „niesystemowości” modeli systemowych

Tabela 9. Zachowania charakterystyczne dla stylów komunikacyjnych według Lidii Jabłonowskiej. 



\section{Od Redakcji}

Dr inż. Magdalena Zalewska-Turzyńska ukończyła studia inżynierskie na International Faculty of Engineering na Politechnice Łódzkiej na kierunku Business and Technology, studia licencjackie w Salezjańskiej Wyższej Szkole Ekonomii i Zarządzania na kierunku rachunkowość oraz studia magisterskie na Wydziale Organizacji i Zarządzania Politechniki Łódzkiej na kierunku zarządzanie i marketing.

W 2001 roku podjęła pracę na Uniwersytecie Łódzkim. Tytuł doktora uzyskała w roku 2008 na podstawie rozprawy pt. Komunikowanie się w organizacji -studium prakseologiczne (promotor - prof. UŁ, dr hab. Wanda Błaszczyk).

W swojej pracy naukowej koncentruje się na następujących zagadnieniach: metodologia organizacji i zarządzania, prakseologia i prakseologiczne podstawy ogólnej teorii organizacji, komunikowanie się w organizacji oraz zarządzanie operacyjne.

Dr inż. Magdalena Zalewska-Turzyńska prowadziła badania naukowe z zakresu komunikowania wewnątrzorganizacyjnego na reprezentatywnej próbce polskich przedsiębiorstw (zgodnie z kodami PKD) i uzyskała informacje od 2274 osób. Wyniki tych badań przedstawiła w zwartych publikacjach oraz artykułach naukowych. Ponadto prowadziła badania w polskich przedsiębiorstwach produkcyjnych na temat ich komunikacji i absorbcji rozwiązań chmurowych (dane z 400 firm również opublikowała w postaci artykułów naukowych). Jest autorem i współautorem 75 publikacji oraz autorem lub współautorem 6 pozycji książkowych.

Uczestniczyła w 37 konferencjach krajowych i 10 międzynarodowych, w tym w Oxfordzie, Berlinie, Brnie i Wiedniu, prezentując wyniki swoich prac badawczych oraz opracowań teoretycznych.

Prowadziła zajęcia $\mathrm{z}$ komunikowania wewnątrzorganizacyjnego jako visiting professor na Polytechnic Institute of Beja (Portugalia) oraz University of Primorska, Koper (Słowenia).

W latach 2011-2013 była członkiem Rady Programowej Wydziału Zarządzania Uniwersytetu Łódzkiego. Tworzy programy przedmiotów, prowadzi zajęcia w języku polskim i angielskim. 
